Louisiana State University

LSU Digital Commons

1962

\title{
A Distributional Study of the Birds of British Honduras.
}

Stephen Mims Russell

Louisiana State University and Agricultural \& Mechanical College

Follow this and additional works at: https://digitalcommons.Isu.edu/gradschool_disstheses

\section{Recommended Citation}

Russell, Stephen Mims, "A Distributional Study of the Birds of British Honduras." (1962). LSU Historical Dissertations and Theses. 740.

https://digitalcommons.Isu.edu/gradschool_disstheses/740

This Dissertation is brought to you for free and open access by the Graduate School at LSU Digital Commons. It has been accepted for inclusion in LSU Historical Dissertations and Theses by an authorized administrator of LSU Digital Commons. For more information, please contact gradetd@lsu.edu. 
This dissertation has been $\quad 62-3666$ microfilmed exactly as received

RUSSELL, Stephen Mims, 1931A DISTRIBUTIONAL STUDY OF THE BIRDS OF BRITISH HONDURAS.

Louisiana State University, Ph.D., 1962

Zoology

University Microfilms, Inc., Ann Arbor, Michigan 
A DISTRIBUTIONAI STUDY OF THE BIRDS

OF BRITISH HONDURAS

A Dissertation

Submitted to the Graduate Faculty of the

Louisiana State University and Agricultural and Mechanical College in partial fulfillment of the requirements for the degree of Doctor of Philosophy

in

The Department of Zoology

\footnotetext{
by

Stephen Mims Russell

B.S., Virginia Polyteohnic Institute, 1953 January, 1962
} 


\section{ACKNOWLEDGMENTS}

Innumerable persons make contributions to a field study such as the present report. I wish to express my thanks to all who have contributed in any way to this work.

In British Honduras, the Belize Estate and Produce Company, Limited, and the Forest Department put their facilities at my disposal on numerous occasions. The late A. E. Prince and David Prince contributed much toward making my work more nearly complete and to making my stay in the Colony more pleasant. Many other people in British Honduras aided in connection with this study: A. H. Anderson, A. P. Bellhouse, D. R. Bradley, C. E. Burne, W. E. Christie, D. D'Silva, A. Felix, F. J. Fogg, B. Foggie, A. Frith, H. Grant, A. Gutierrez, L. Habet, W. Habet, A. H. Harrison, R. K. Masson, Sr., O. Phillips, J. A. Waight, D. Webb, and A. N. Wolffsohn. Paul scott acted as my field assistant on the difficult trip into the Cockscomb Mountains in 1959, and E. Barahona, G. Cardenez, O. Escalante, and J. M. Guy assisted me on other trips in the Colony.

Several of my associates at the Louisiana State University Museum of Zoology have worked in British 
Honduras. I was accompanied by D. A. Lancaster in 1955 and by D. Dennett, Jr., in the spring of 1956. Each took time from his own project to further my work. J. Verner and E. Willis each spent several months in the Colony and placed their field notes at my disposal. D. Lay and G. F. van. Tets also made their notes available to me. G. N. Ross obtained some weather records for me.

The United Fruit Company provided transportation to Belize on three occasions. H. A. J. Evans generously contributed financial assistance. A Summer Fellowship from the National Science Foundation made possible my visit to other museums. I have been dependent upon the Louisiana State University Museum of Zoology for material support on each of my trips to the Colony.

Foremost among persons in this country, I wish to thank W. E. Clyde Todd, who generously made available to me many notes that he had prepared on the birds of British Honduras.

Several persons allowed me to make use of material entrusted to their care: J. Bond of the Philadelphia Academy of Sciences, H. Friedmann and A. Wetmore of the United States rational Museum, K. E. Goellner of coe College, K. C. Parkes of the Carnegie Museum, R. A. Paynter, Jr., of the Museum of Comparative Zoology, and R. W. Storer and the late J. Van Tyne of the University of Michigan Museum of Zoology. K. C. Parkes, 
R. A. Paynter, Jr., R. W. Storer, J. D. Webster, and A. Wetmore critically examined specimens for me. E. Eisenmann answered many of my questions concerning Middle American birds. Velva E. Rudd identified the plants. C. T. Agostini gave me helpful suggestions for my trips into the Cockscomb Mountains. Thanks are especially due G. H. Lowery, Jr., who directed the study and extended advice and encouragement throughout. R. J. Newman offered many helpful suggestions during the preparation of the manuscript. I am greatful for the advice of J. H. Roberts, especially during the final stages of the preparation of this report. Professors H. J. Bennett, H. B. Boudreaux, C. A. Brown, and G. C. Kent, Jr., critically examined the manuscript and offered council.

My wife, Dorothy M. Russell, assisted in the preparation of the map and the bibliography and extended patience and encouragement when I most needed it. 


\section{TABLE OF CONTENTS}

PAGE

TITLE PAGE.......................... i

ACKNOWLEDGMENTS. .................... ii

TABLE OF CONTENTS.................... v

IIST OF TABLES...................... viii

LIST OF FIGURES..................... ix

ABSTRACT $\ldots \ldots \ldots \ldots \ldots \ldots \ldots \ldots \ldots \ldots \ldots \ldots \ldots \ldots \ldots \ldots \ldots$

INTRODUCTION........................ I

RESUMÉ OF ORNITHOLOGICAI INVESTIGATIONS IN

BRITISH HONDURAS................... 4

TOPOGRAPHY AND GEOLOGY................. 12

CIIMATE AND VEGETATION................. Is

PLAN OF THE SPECIES ACCOUNTS.............. 25

ACCOUNTS OF THE SFECIES................. 31

Tinamidae........................... 31

Podicipedidae......................... 37

Felecanidae........................ 38

Sulidae.......................... 40

Phalacrocoracidae.................... 42

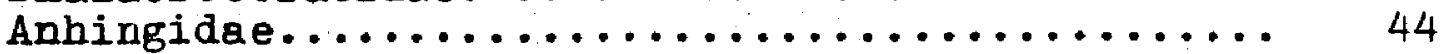

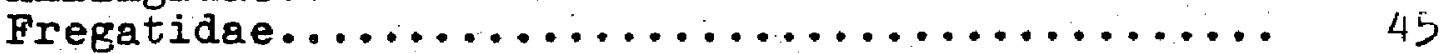

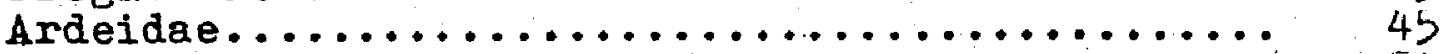

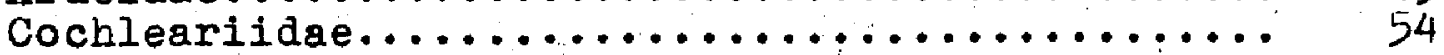

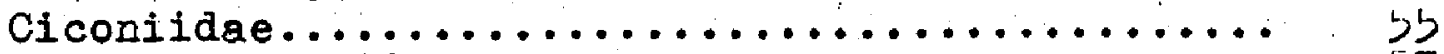

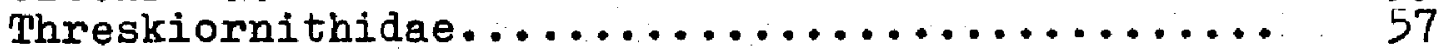

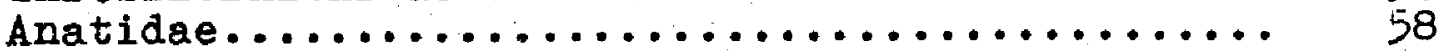

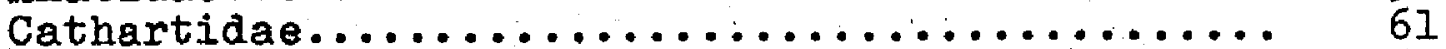

Accipitridae.......................... 63

Pandionidae......................... 78

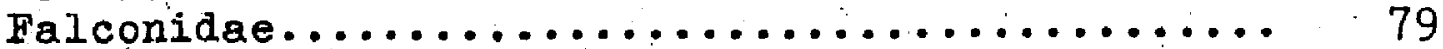

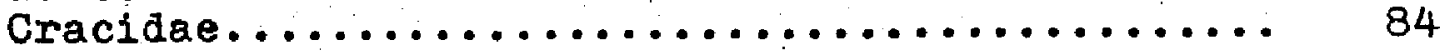




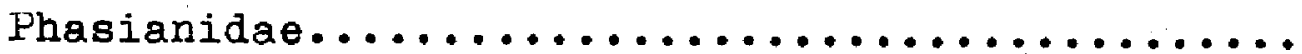

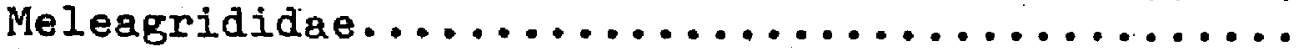

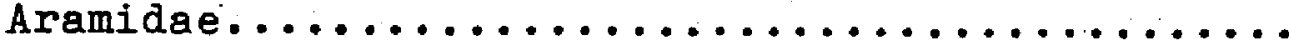

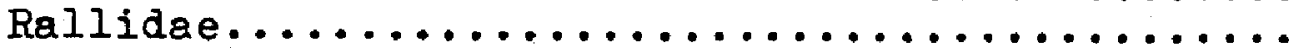

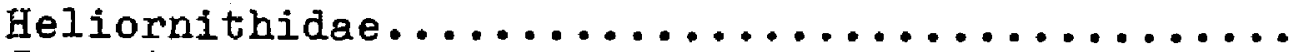

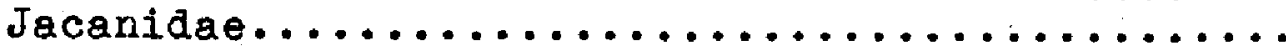

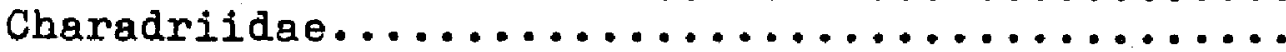

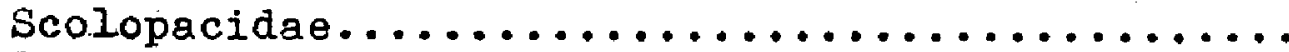

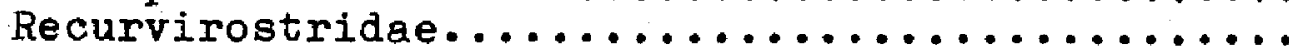

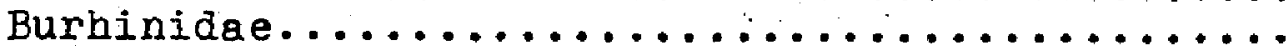

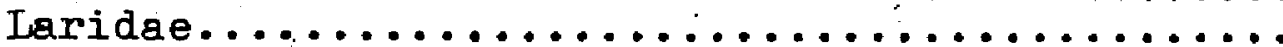

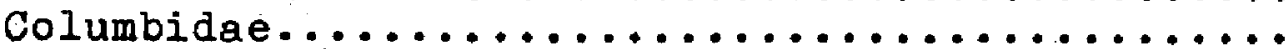

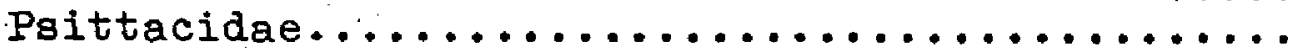

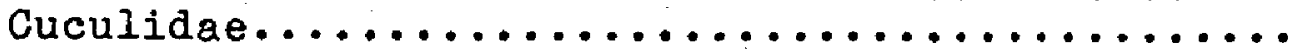

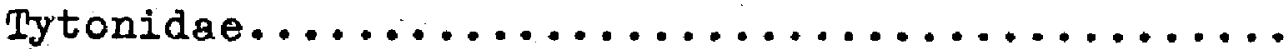

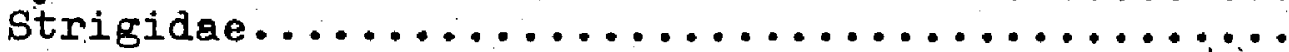

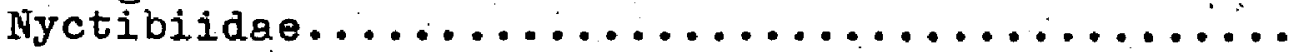

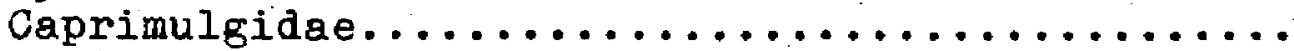

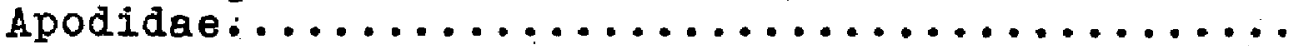

Trochilidae.

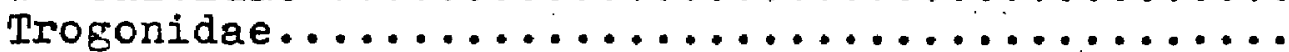

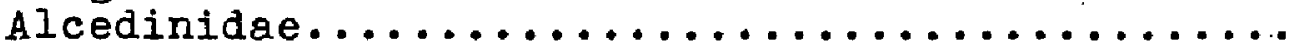

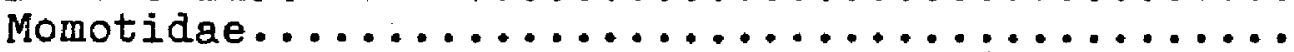

Galbulidae.

138

141

142

147

148

152

158

171

174

178

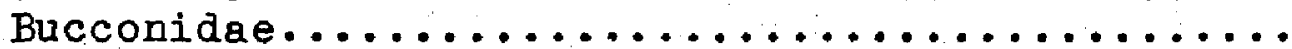

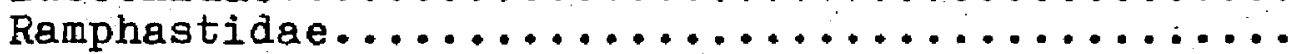

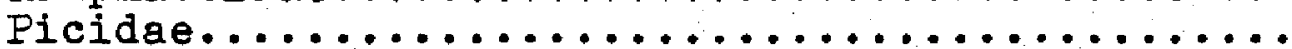

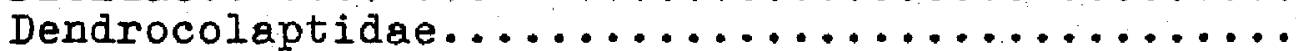

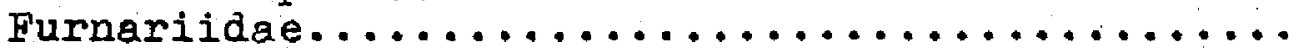

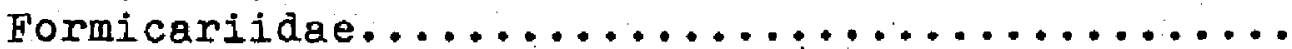

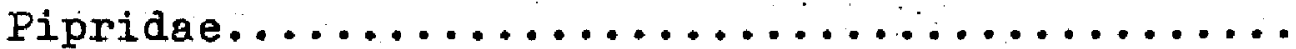

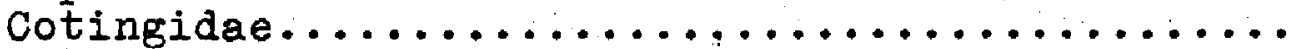

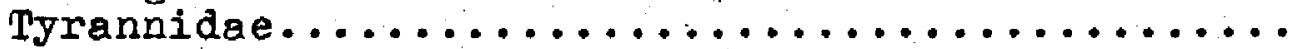

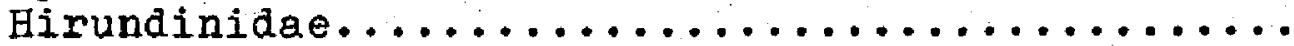

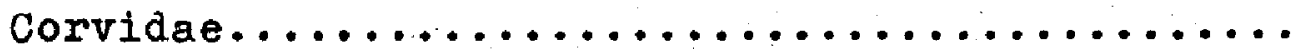

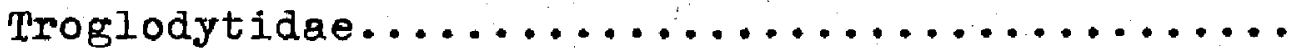

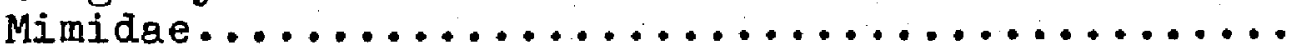

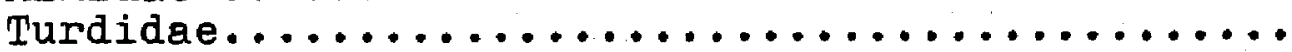

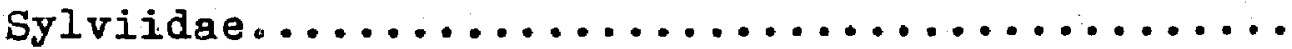

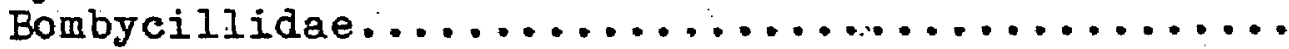

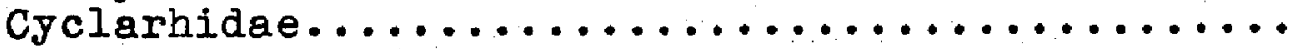

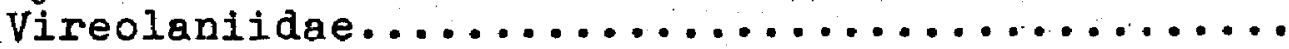

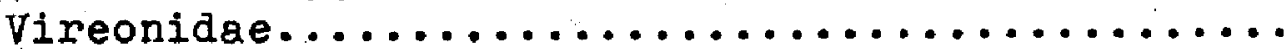

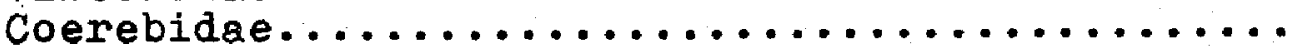

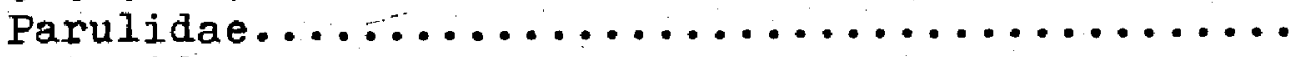

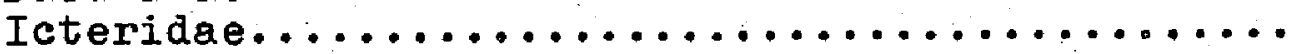

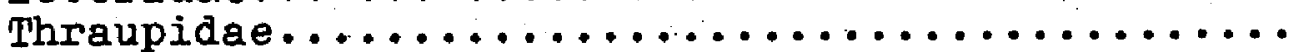

Fringillidae.

180

181

182

186

196

204

208

214

217

$22 b$ 
Appendix A, Primary Citations Mentioned in

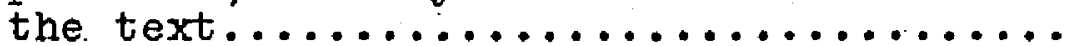

Appendix B, Gazetteer of Localities............ 444 LITERATURE CITED ...................... 456 AUTOBIOGRAPHY .......................... 466 


\section{IIST OF TABLES}

\section{TABLE}

1. Species recorded in rainforest or associated habitats.................. 397

2. Species endemic to the Yucatán Pentnsula that occur in British Honduras or whose characteristics are approached by British Honduran

birds................................ 399

3. Species breeding on the keys.............. 400

4. Species occurring in pinelands but not in other habitats in British Honduras......... 403 


\section{IIST OF FIGURES}

FIGURE

PAGE

1. Map of British Honduras showing the localities that are numbered in the Gazetteer..................... 443 


\section{ABSTRACT}

This study is the first comprehensive report on the birds of British Honduras. It deals with the composition and distribution of the avifauna.

A preliminary examination of 4400 specimens collected over the last one hundred years in British Honduras and a review of all published and several unpublished reports made by collectors in British Honduras revealed localities requiring additional investigation. An itinerary was prepared in order to distribute wisely the additional necessary field work carried out by the author. Specimens selectively collected in 11 months in the field provided additional distributional records and supplemented existing specimens as a basis for taxonomic considerations. Published references, field notes compiled by the author, and records made by others were considered in preparing statements regarding each species.

All ornithological investigations in British Honduras are outlined. A gazetteer and map identify collecting localities. Accounts of each of the 463 species definitely recorded in British Honduras present 
the critical data. Over 6100 specimens of 437 species are listed in the species accounts with the collecting locality, date of collection, and an indication of the present repository. Sex and weight are recorded for 1600 of the birds collected by the author or his field associates. Seasonal and geographic distribution, habitat preferences, and breeding season are briefly stated for each species. Data pertinent to other phases of natural history are given in cases where the information is not generally available. Specimens of polytypic species are identified to race. Nomenclatorial and taxonomic comments are included where significant.

Three hundred and eight species, some definitely, others presumably, nest in British Honduras. Transients and winter visitants that do not breed in British Honduras total 126 species. The largest element in the avifauna is neotropical in origin and occurs in the tall forests. The composition of this group varies little from the southern to the northern portion of British Honduras, although the precipitation declines by twothirds from south to north. Only four species have named races endemic to British Honduras; one of these races is of doubtful validity and the other three are confined to the pinelands. The pinelands contain 24 species not also found in other habitats in British Honduras, most of which are characteristic of highlands in Guatemala and Honduras. 
The islands, although numerous, are small and support only a depauperate fauna, consisting of waterdependent birds and species also found in coastal regions of the mainland.

Four of the seven species endemic to the Yucatán Peninsula range into northern British Honduras. Two other species occurring in British Honduras are present elsewhere only in the northeastern sector of the Yucatán Peninsula and in the West Indies.

Only four species resident on the upper slopes of the highest mountains (elevation 3700 feet) are not also widely distributed at lower elevations in British Honduras. 


\section{INTRODUCTION}

British Honduras is a Crown Colony of about 8600 square miles situated at the southern base of the Yucatán Peninsula. The Colony lies between $15^{\circ} 54^{\prime}$ and $18^{\circ} 29^{\prime}$ north latitude and between $87^{\circ} 28^{\prime}$ and $88^{\circ} 11^{\prime}$ west longitude. It is bounded on the north by Mexico, on the west and south by Guatemala, and on the east by the Caribbean Sea. It includes numerous small keys. Tall tropical forests predominate on the mainiand, which is low in comparison with most of Middle America. The only mountainous area has maximum elevations of 3700 feet. The Colony is entirely within the Neotropical Region.

About 75,000 people live in British Honduras. Most of them reside in the lowlands, particularly in the drainage of the Belize River. The northwestern and southwestern parts of the Colong are practically uninhabited. According to Anderson (1954), Negroes and individuals of Negro extraction form the largest proportion of the population, followed by Maya Indians and Hispano-Indians, Caribs, Europeans, and Asiatics. Forest and citrus products are the principal exports.

In comparison with other areas of Central America, 
British Honduras has been relatively ignored by ornithologists. Collectors interested in obtaining skins for future sale in Europe or America bypassed the Colony in favor of nearby Guatemala and Honduras, where the more varied topography proferred a greater variety of birds. The more northern part of the Yucatán Peningula received its share of collectors, who were interested in the endemic subspecies found there.

Only three papers (Salvin, 1864; Austin, 1929; Bond, 1954) have dealt with all the birds of a specific part of British Honduras. The only list of the birds of the Colony as a whole appeared in tabular form in 1904 as a part of Volume I of the Biologia Centrali-Americana: Aves. R. P. Devas (1953) informally described some of the birds he saw or heard about in a six weeks stay at Belize and Stann Creek.

W. E. Clyde Todd began to assemble material on the birds of British Honduras in 1910. with the intention of publishing a report on the entire avifauna. He was joined by J. Van Tyne on this project in 1932. The many other projects carried out by each of these ornithologists prevented completion of their work.

I began my study of the avifauna of British Honduras in 1954. Both Todd and Van Tyne encouraged me and made available to me many of the data they have accumulated in their preliminary study. Todd's notes were espectalIy helpful, since they contained comments on specimens 
in several museums, including the British Museum, that I personally have not been able to visit. Before I initiated my own field work, I obtained data on 4400 specimens from British Honduras, most of which I personally examined; otherwise I utilized notes made: by Todd or Van Tyne. With knowledge of these specimens and the areas from which they came, I planned my work in the Colony to supplement the existing material. My 11 months study in the Colony was carried out in 1955, 1956, 1958, and 1959. Other personnel of the Louisiana State University Museum of Zoology conducted field studies in British Honduras. They collected a number of specimens, usually as an incidental part of their own work. Nearly 1700 specimens were obtained by the various field parties from this institution. Field notes of many persons who collected in British Honduras in this century were also available to me.

This study is the first to assemble all available data on the birds of British Honduras. I base this report on the birds of British Honduras on information in the literature, on over 6100 specimens, on the unpublished notes of many individuals, and on my own experiences in the Colony. 
RÉSUMÉ OF ORNITHOLOGICAI INVESTIGATIONS IN BRITISH HONDURAS

The first birds to be taken in British Honduras were obtained by David Dyson in 1845. Presumably the object of his trip was to capture living birds for the menagerie of the Earl of Derby. Dyson did prepare some skins, which went to the British Museum and the Derby Museum, now a part of the Liverpool Museums. In 1856, Thomas J. Leyland, a dealer in skins from Liverpool, collected a few birds near Belize. Some of Leyland's specimens from British Honduras were included in a report by Moore (1859). However, Forbes and Robinson (1889: 63) expressed the opinion that localities on labels of specimens taken by Leyland were unreliable. Osbert Salvin passed through British Honduras in December 1887, April 1860, August 1861, and May 1862. The report (Salvin, 1864) of his trip among the keys in May 1862 contains a greater wealth of unique information than any other paper in the past. Salvin obtained many specimens and eggs on the keys-but only a few specimens on other stops in British Honduras.

Dr. Carl H. Berendt arrived in Belize in December 1865 en route to the Peten and southern Mexico. Christopher Wood accompanied Berendt. About 50 specimens that they collected near Belize are now either in 
the Museum of Comparative Zoology or the United States National Museum.

Col. N. S. Goss of Kansas collected a few birds near Belize in February 1886 and near Cayo in February 1887. Specimens collected by Goss are included in a report by Lantz (1899).

Many specimens were sent to Salvin and Godman by F. Blancaneaux, a Frenchman who collected in the vicinities of Belize, Cayo, and the Mountain Pine Ridge in the period of 1870 to 1890. Blancaneaux, a chicle and mahogany contractor, was an amateur naturalist.

George F. Gaumer collected extensively in the Yucatán Peninsula. Presumably he collected a few birds in British Honduras about 1887, since Salvin and Godman (1874-1904) list specimens from Orange Walk with Gaumer credited as the collector.

Several hundred specimens were obtained in the vicinities of Toledo Settlement, Ycacos Lagoon, and Manatee Lagoon by Morton E. Peck from November 1900 to July 1901, and from June 1905 to June 1907. Peck also collected birds along the Sibun, Mullens, Sittee, Monkey, Moho, and Temash Rivers. Specimens that he collected are now widely distributed among collections in this country, notably those at the Museum of Comparative Zoölogy, Carnegie Museum, and Willamette University. Peck was a trained biologist and published three ornithological papers (1908, 1910, 1921) and was 
co-author of another (Bangs and Peck; 1908). I have. been fortunate in having access to many of his unpublished notes on the birds of British Honduras, and I have referred to them often in the species accounts. J. D. Johnson was with Peck in parts of 1905 and 1906 and collected a few birds, many of which were deposited at Pomona College. Gerald B. Thomas spent two months with Peck in the spring of 1906. About 30 of his specimens are now in the Museum of Comparative Zoölogy. B. H. Bailey joined Peck in May, June, and July, 1905. Specimens obtained by Bailey were deposited at Coe College. A number of other specimens collected from November 1906 to May 1907 and labeled "Berry" were also deposited at Coe College. Many of the specimens that were at Coe College are no longer extant. James I. Peters collected only one bird (Ciccaba virgata) in British Honduras, although in 1912 he worked several weeks on the Mexican side of the Rio Hondo, which is a part of the northern border of British Honduras. Early in 1923, Karl P. Schmidt collected about 20 birds in the vicinity of Middlesex. The specimens are in the Chicago Natural History Museum. In late March of 1923, Harry Malleis obtained about 40 specimens at Cayo, which were deposited in the United States National Museum. Ludlow Griscom passed through British Honduras en route to Quintana Roo and Yucatán in January 1926. He did not collect in the Colony, but 
he did record some of his observations (Griscom, 1926). On behalf of the Carnegie Museum, Ernest G. Holt collected from March 10 to April 20 and April 29 to May 5, 1926, in British Honduras. The period of March 14 to 24 was spent on Half Moon Cay where he obtained materials for a habitat group of the booby colony. In late March, April, and May, Holt worked near Cayo, Duck Run, and the Belize River. His specimens were accompanied by notes.

Oliver 0. Austin, Jr., was in the Colony from March 15 to about May 1, 1928, and collected near Cayo, Camp.6, Mountain Cow, and Augustine. The results of his work constitute one of the major papers on British Honduran birds (Austin, 1929). The nearly 300 specimens that he collected are in the Museum of Comparative Zoölogy •

An expedition of the University of Michigan Museum of Zoology, consisting of $\mathrm{H}$. H. Bartlett as botanist, Adolf Murie as mammalogist, and Josselyn Van Tyne as ornithologist, arrived in Belize on January 26, 1931. Their destination was Uaxactun, Feten, Guatemala, but because of delays, they collected in British Honduras before they reached Guatemala. From January 27 to February 8 they worked near Belize, from February 14 to March 9 they were in the Mountain Pine Ridge, and from March 10 to 24 they operated near Cayo. Van Tyne collected most of the birds, but Murie did obtain few 
bird specimens. Mammals collected on this expedition were reported upon (Murie, 1935), as were the birds taken in the Fetén (Van Tyne, 1935).

Percy w. Shufeldt collected 649 specimens in the vicinity of Belize, most of them between November 6 , 1930 and April 10, 1931, although he obtained a few later in 1931 and in 1932. Many of Shufeldt's notes were lost in the hurricane of September 1931, but some of his notes on specimens that he collected in British Honduras remain intact and have been considered in my study. The specimens are now a part of the bird collection of the University of Michigan Museum of Zoology.

Emmet R. Blake and Charles T. Agostini collected 801 birds in British Honduras for the Carnegie Museum in 1935. From March 8 to April 1 they worked in the Cockscomb Mountains. There they collected up to an elevation of 1850 feet. All Pines was their base of operations in the period April 9 to 27. On April 30 they moved a few miles to freetown, where they collected until May 24. Blake and Agostini visited South West Cay, May 29 to June 1. I have utilized the field notes of Agostini.

The Turneffe Islands and Northern Two Cays were visited by James Bond in the period of January 20 to 24 , 1954. He collected about a dozen specimens. The report (Bond, 1954) on this trip includes several important 
sight records.

Field parties of the Louisiana State University Museum of Zoology began work in British Honduras in. 1955. Douglas A. Lancaster and I collected at Hill Bank, Gallon Jug, Augustine, and Ballerina Camp from February 18 to May 5. The following year I was accompanied by Dan Dennett, Jr., who was primarily interested in trapping mammals but did obtain many birds. From February 16 to June 8 we collected at many localities. Most important were Hill Bank, Calabash Cay, the Mountain Pine Ridge, the North Stann Creek valley, and the vicinity of San. Pedro Columbia. From October 21 to December 18, 1956, I worked at Hill Bank, Gallon Jug, and Augustine.

Lancaster and Edwin 0 . Willis arrived at Gallon Jug on February 15, 1957. Lancaster remained only until June but Willis stayed until August 1. Willis then spent the first week in August at Hill Bank. Both investigators were primarily interested in life history studies (Iancaster, 1960; Willis, 1958, 1960a, b, c, and 1961), but they did collect some birds of special significance, and their field notes have been of great importance. Willis took careful notes on all nests that he found and recorded daily counts of the number of individuals of each species that he saw.

In the period of February to June 1958, Lancaster resumed his studies at Gallon Jug. Jared Verner, also 
from the Louisiana State University Museum of Zoology, studied the nesting activities of the boobies on Half Moon Cay from February 14 to May 9, 1958. Verner collected a number of specimens, and his records of transients on the key are extremely valuable. At the conclusion of his work on Half Moon Cay, Verner made a short trip among the keys in the barrier reef in an effort to record nesting gulls and terns. In the period of April 24 to May 9, I worked in the upper drainage of South Stann Creek, and on the southern slope of the Cockscomb Mountains. On this trip I reached an elevation of about 2700 feet on the summit of a minor peak to the east of Victoria Peak. In 1959, I made a second trip into the Cockscomb Mountains in the period of May. 23 to June 3 , and collected up to an elevation of 3400 feet on Victoria Peak.

Douglas M. Lay shot a few birds of species previously unrecorded in the colony between August 11 and 26, 1960, at Corozal and Belize. The specimens are in the Louisiana State University Museum of Zoology.

Although he collected few specimens, Gerrard F. van Tets kept useful records of the birds that he saw from December 21, 1960, to January 3,1961, at Belize and Half Moon Cay.

In the period of August 15 to September 2, 1961, Michael J. Fogarty obtained 39 specimens at Augustine and in the North Stann Creek valley. His specimens are 
also in the museum at Louisiana State University.

In April 1961, I. Irbj Davis and Bill Guion made three breeding bird censuses in British Honduras: one in the Mountain Pine Ridge, another about 35 miles west of Belize, and the third in forest along the Humingbird Highway. Their reports (Davis and Guion, 1961) were published too late to be included in my study. 


\section{TOPOGRAPHY AND GEOLOGY}

British Honduras occupies a rectangular mainland area measuring about 170 miles from north to south and about 60 miles from east to west. The northern boundäry with Quintana Roo, Mexico, is formed by the Rio Hondo, a rather sluggish river of moderate size. The boundary with Guatemala on the west is approximately a northsouth line. The southern end of the colony borders Guatemala at the Sarstoon River. The Caribbean Sea lies to the east of the mainland.

Most of the northern half of the Colony is low and rather flat, although a few hills near the western boundary exceed 500 feet. The rocks of this half of the Colony are Cretaceous to Eocene Iimestones overlaid in many places with white marls of Miocene age (Dixon, 1956). Most of the large streams in this area flow north or north-northeast into the Bahía de Chetumal.

Flat lowlands form a narrow strip about ten miles wide along the coast from the center of the Colony south to the Guatemalan border. Many swamps and coastal lagoons abound in this area. A considerable portion of the lowland is formed of rather typical alluvial deposits of the sort associated with river valleys. Alluvial deposits are also found in much of 
the lowlands of the Belize River in the central part of the Colony. At many points a terrace at about 40 to 50 feet elevation marks the inland limit of the coastal swamps.

Inland from the coastal lowlands and south of the Belize River are the Maya Mountains, a crescentic shaped range with the highest elevations only about twenty miles from the coast. The northern and southern ends of this range extend westward. In parts of these mountains, ridges and peaks reach elevations slightly in excess of 3000 feet. Victoria Peak, the highest point in the Colony, is nearly 3700 feet elevation and is a part of a conspicuous ridge called the Cockscomb Mountains. The eastern, northern, and southern slopes of the Maya Mountains are steep, and the rivers draining these slopes are straight and usually flow through narrow, steep valleys. The western slope of the Maya Mountains is very gradual and forms a considerable area above an elevation of 1600 feet. The drainage is into tributaries of the Belize River, except for a small stream that flows into the Río de la Paisón in Guatemala. The rocks of the higher ridges of the Maye Mountains are Paleozoic and include granite, quartzites, slates, and shales. These old rocks dip beneath more recent limestones toward the west. The Mountain Pine Ridge, covering about 125 square miles, is a part of the northwestern portion of the Maya Mountains. 
A barrier reef extends the length of British Honduras. In most places it is about 15 miles from the coast. Many tiny mangrove-covered keys dot the reef. A number of coral reefs lie outside of the barrier reef. Among these are Iighthouse Reef, Glover's Reef, and the Turneffe Islands. The latter is often shown on maps as a single land mass, but Turneffe actually consists of many small islands. 


\section{CLIMATE AND VEGETATION}

Rather uniform year round temperatures and seasonal rainfall characterize the climate of British Honduras. Easterly breezes from the Caribbean blow throughout much of the year. Winter storms or "northers," which bring cooler temperatures in winter and early spring, are usually weak by the time they reach the Colony. Hurricanes, which approach from the east, are a constant threat from June to the end of October, but severe ones strike only every few years.

The annual mean shade temperature (Fahrenheit) in Belize is about 79 degrees, the mean daily maximum is about 86 degrees, and the mean daily minimum is about 71 degrees. The lowest temperature ever recorded at Belize was 49 degrees; and the maximum was 96 degrees. Temperatures vary little throughout the lowlands. No data are available on temperatures at high elevations in the Mountain Pine Ridge or the Cockscomb Mountains, but I suspect the winter months there are slightly cooler. Frost is unknown in the Colony.

Rainfall varies considerably from one part of the Colony to another. It is greatest in the south, where Punta Gorda normally receives over 175 inches per Jear. 
Precipitation declines toward the north. As illustration, annual rainfall at Belize averages 73 inches; at Orange Walk, 61 inches; and at Corozal, 51 inches. At the inland localities of Augustine (in the Mountain Pine. Ridge at on elevation of 1600 feet) and Cayo, the annual mean is about 65 inches. Gallon Jug, in the midst of a tall, luxuriant forest, receives only about 59 inches per year. Reputedly, but without accurately determined meteorological data for support, the southern portions of the Maya Mountains receive 200 inches of rain per year.

The seasonal distribution of the rainfall is rather uniform throughout British Honduras. February, March, April, and May are the "dry" months; the remaining months are the "wet" months. At Belize, Augustine, and Galion Jug, the four driest months receive only about 10 per cent of the annual rainfall; data for this comparison are not available for other localities:

The life zones of British Honduras are best described in terms of the classification scheme of Holdridge (1947). Slud (1961) has applied this system to zoogeography and compared its usefulness with other methods of classifying vegetation. Holdridge limits the use of the term "tropical" to land areas bounded by the isotherm of mean annual temperature of 24 degrees Centigrade (75.2 degrees Fahrenheit). The tropical region includes all sea level land masses bounded by 
this isotherm. Other regions toward the poles are defined by specific isotherms, e.s., warm temperate region by the 12 degree isotherm, cool temperate region by the 6 degree isotherm, etc. In regions where mountains are present, the same respective isotherms delimit belts. The lowest belt in the tropics is the tropical belt and at greater elevations are found the subtropical belt; lower montane belt, montane belt, etc. Rainfall is the criterion used by Holdridge to define the life zones present within the respective belts. Most of the southern half of British Honduras is within the Tropical Moist Forest Iife Zone of the Holdridge scheme. This life zone is defined as having an annual mean rainfall of 2000 to $4000 \mathrm{~mm}$. and as lying within the 24 degree isotherm, both in respect to latitude and altitude. Northern British Honduras is situated within the Tropical Dry Forest Life Zone, bounded by the same isotherms but by definition receiving only 1000 to $2000 \mathrm{~mm}$. rainfall annually. The local areas in the Colony that receive rainfall in excess of $4000 \mathrm{~mm}$. are within the Tropical Wet Forest Life Zone. According to the Holdridge system, Troplcal Rain Forest occurs only in those areas in the tropical belt that receive over $8000 \mathrm{~mm}$. precipitation annually, and no areas in British Honduras do so.

Because British Honduras lacks high mountains, the forest types are rather undiversified.. Mangroves, 
savannas, pinelands, and "rain forests" are the principal forest categories in the Colony. The "rain forest" is not true rain forest, if judged by the Holdridge system, or by many of the strict definitions of rain forest. "Since the expression "rain forest" does convey the impression of a tall canopied forest with scattered emergient trees, numerous epiphytes, lianas, and buttressed trunks (which are characteristics of tall forests in the Colony), I have used the term in describing general habitat preferences of birds. British Honduran forests are subjected to a long ( 4 months) dry season, and some trees are deciduous (e.g., mahogany), as is not usually the case with true rain forest. In this study", rain forest, tall humid forest, or tall moist forest are intended to imply the general impression of a luxurious tropical growth of large trees.

Tall forests of the sort occurring in the colony have been subdivided by various authors, including Standley and Record (1936), Bartlett (1935), and Iundell (1940). In the limestone-capped area to the west of the Maya Mountains, there are numerous terraces faced with rough limestone blocks. The terraces are remnants of an extensive Mayan civilization, and one in which agricultural practices were well developed. Most archaeologists and botanists believe that the Mayan peoples have at one time or another had all British Honduras under cultivation. Presumably the forests 
have been undisturbed for at least the last 500 years; with the exception of recent forestry and agricultural practices. The milpa system of planting crops, a system presumably less advanced than terrace agriculture, is the most common procedure in the Colony today. Many square miles of forest have disappeared in the vicinity of San Pedro Columbia and San Antonio in the southern section of the Colony, and the original tall forest has shown no signs of returning. In other areas the forest has rapidly replaced the milpas. Since forest products are the main exports, much of the accessible region of the Colony has been logged. Mahogany (Swietenia macrophylia) is the species most sought, but only one tree of useful size is usually found per acre. The tractor trails formed to extract these trees grow over rapidly, so that logging operations rarely cause lasting damage to the forests. The most common forest trees (though not all may occur in the same forest association) are mahogany (Swietenia macrophylla), santa maria (Calophyllum brasiliense), nargusta (Terminalia obovata), timber sweet (Nectandra globösa), mamey cerilla (Lucuma campechiana), negrito (Simaruba glauca), yemeri (Vochysia hondurensis), polewood (Xylopia frutescens), waika chewstick (Symphonia globulifera), mylady (Aspidosperma megalocarpon), sapodilla (Achras zapota), cohune palm (Orbigyna cohune), and Ironwood (Dialium guianense). Second-growth successions pose considerable 
difficulty to the phytogeographer in British Honduras, as in other tropical areas. Technically, all of the Colony - even where the tallest forests are present is covered by second growth, because Indian agriculture at one time or another presumably has included all of the arable mainland. Since a milpa is used for agri- * cultural purposes only for one or two growing seasons and then abandoned, much of the Colony is covered with second growth. I have made a rather artificial distinction between second growth (or huamil) and tall forest. Second growth in the sense that I employ it, includes those stages of forest regeneration that succeed a milpa (or other artificial clearing) until the growth reaches 40 to 50 feet. Above these limits I utilize the term forest, modified by the adjectives tall or low as the case may be. The following trees are characteristic of tall sëcond growth in most regions of the Colony (Standiey and Record, 1936): trumpet (Cecropia mexicana), moho (Belotia campbellii), salmwood ( polak (Ochroma bicolor), and quamwood (Schizolobium parahybum).

Pinelands are characteristic of the sandy soils between rivers in much of the lowlands and of a considerable area in the Maya Mountains known as the Mountain Pine Ridge. I shall describe lowland pine areas first. The most extensive pinelands (locally 
called "pine ridges," although they may be flat) lie between the Rio Hondo and the New River, between the New and Belize Rivers, between the Belize and Sibun Rivers, and in coastal areas south to Deep River. The pine is Pinus caribaea and the lowland pine areas resemble regions in the southeastern United States where the closely related slash pine predominates. The pinelands may be either wet or dry. Clusters of palmettos (Acoelorraphe Wrightii) are frequent in wetter areas. Oaks (Quercus oleoides and others), Jaha (Curatella americana), and craboo (Byrsonima crassifolia) are characteristic of better drained areas. Other typical plants are sedges (Rhynchospora barbata and $\underline{R}$. intermixta), sundew (Drosera), and species of the genera Polygala, Utricularia, Panicum, and Paspalum.

"Broken pine ridge" is a term applied to the scrubby marginal growth that borders the lowland pine ridges. Again the word ridge is a misnomer, for no noticeable slope is apparent. The "broken pine ridge" is characterized by low forest, including many thorny species, and dense undergrowth. The common small trees and shrubs that I collected in this habitat near Hill Bank included Acacia riparioides, Parathesis obovata, Eugenia winzerlingi1 (?), Miconia pteropoda, Calliandra houstoniana, and Xylosoma anisophylla. Other conspicuous flowering plants were Metastelma pedunculare, 
Scleria bractea, and Bauhinia tormentosa. The "broken pine ridge" is a marginal growth and is not identical to "broken ridge," which may be a tall mahoganysapodilla forest.

The pine forests of the Mountain Pine Ridge form one of the most beautiful areas in the Colony. Lundell (1940: 36-54) has described the botany of this area in some detail. Pinelands cover the areas of the Mountain Pine Ridge where the limestones have been eroded away and exposed the underlying granites. Where limestones remain, tall rain forest is often present. The topography of the Mountain Pine Ridge is highly irregular. Its elevations range from 1000 to 3000 feet, and numerous creeks arise in its uplands. Fires frequently sweep through the pinelands and prevent the accumulation of undergrowth. Thus the rolling pinelands are open and grassy. Pines are by far the most characteristic trees, but oaks (Quercus barbeyana and $Q$. hondurensis), and such trees as Clethre hondurensis, Leucothoe mexicana, nanze or craboo (Byrsonima crassifolia) also occur. Vegetation in the ravines and creek valleys is dense and often forms forest limited in extent and variety of trees. Where the headwaters of a stream are in broad flat valley, marshes often occur.

Brackish and fresh-water savannas cover only about 3 per cent of the Colony. Brackish savannas. occur above the tidal limits and are characterized by 
sedges of the genera Fuirena and Mariscus (Standley and Record, 1936:19). Fresh-water savannas are often burned or flooded. They are characterized by the grass Panicum barbinode, which forms conspicuous tussocks. Red Mangrove (Rhizophora mangle ) dominates the vegetation on most of the keys, the coastal areas, tidal lagoons, and brackish canals.

Small areas in various parts of the Colony support distinctive habitats not included in the preceding general descriptions. Many of the keys rise a few feet above sea level and are sandy. Often the higher portions of the sandy keys are planted with coconut palms (Cocos nucifera). The larger "coconut walks" are kept cleared of undergrowth, since the harvesting of the fruit is a major occupation on the keys. Several broadleaved trees occur in the booby colony on Half Moon Cay. The principal tree utilized as a nest support by the boobies is Cordia sebestena, but Bursere simaruba and Bumelia retusa are also of general occurrence (Verner, 1959). Many of the larger keys support a limited woodland dominated by sapodilla (sp.?) trees.

The upper slopes of the Cockscomb Mountein support a distinctive habitat, but it is one extremely limited in extent. The highest siopes are steep - precipitous in many places. Rainfall is probably greater there than in the lowlands, and the mountains are frequently enveloped in clouds. The resulting formations are 
similar to those called "Palm Brake" and "Elfin Woodland" by Beard (1944: 146).. On the windswept uppermost slopes, the dominant tree is a species (Clusia sp.?) about 20 feet tall with slightly stilted roots. Practically every twig, limb, and tree trunk is covered with a mass of mosses and ferns. The spaces between the stilt roots are filled with moss, humus, and other vegetative material, to the extent that they are concealed. Surface rocks are covered with sphagnum moss, ferns, selaginellas, lycopodiums, and lichens. This habitat has a vertical distribution of a few hundred feet near the summit of Victoria Peak. On one of the lower peaks to the east, the habitat is present as low as 2600 feet.

Below this moss covered area, palms become more abundant and the slopes less steep. A vertical range of perhaps 300 feet is dominated by palms. Fallen palm leaves litter the ground. Unfortunately, the plant specimens that I collected in the Cockscombs were lost and no plants were identified.

I have used the term "semi-open" in the manner. first applied by Darlington (1931) and later extensively employed by Slud (1961). Semi-open should imply cleared areas with scattered trees (such as pastures, and fields) and clearings containing small patches of woodland. 
PLAN OF THE SPECIES ACCOUNTS

The sequence of families, genera, and species follows Eisenmann's The Species of Middle American Birds. His arrangement was derived primarily from Helimayr's volumes of the Catalogue of Birds of the Americas, Peter's Check-list of Birds of the World, and Friedmann's volumes of Birds of North and Middle America. Eisenmann's (1955) work includes all species found in British Honduras except Oporornis agilis. No other list is nearly so complete.

Fach species account is introduced by the scientific name of the species. The names of birds of doubtful occurrence in British Honduras are placed within brackets. The common name, which follows the sclentific name in the heading of each species account, is the English name that I prefer to use. In keeping with the current trend to standardize vernacular names, I have not created any new names. If the species is included in the 5th edition of the Check-list of North American Birds (1957), I have used the name that appears there. Otherwise, I have drawn heavily upon the common names recommended by Eisenmann in his Species of Middle American Birds. In a few instances I have selected 
names that I feel are more satisfactory than those used by Eisenmann. But in all cases, I have employed names that have been previously used in various publications. In instances where the local English names are unique, I have included them in the text in quotation marks. Since the majority of the inhabitants of British Honduras are English speaking people, I have not provided special Spanish or Indian names.

At the beginning of each species account (under the heading SPECIMEN or SPECIMENS) I have summarized information regarding specimens collected in British Honduras. In most cases this section consists of three parts. The first part includes specimens in the ISUMZ (Louisiana State Umiversity Museum of Zoology). A summary of specimens in OTHER MUSEUMS follows. CRITICAL PUBLISHED REFERENCES to specimens constitute the final part. The year in which specimens were collected is given when fewer than five specimens have. been taken in British Honduras. Within all three parts specimens axe listed by localities arranged in order from north to south.

All specimens from British Honduras in the LSUMZ (except Mycteria americana and Anous tenuirostris) were obtained by personnel of the museum since the beginning of my study. Data for each specimen include locality, sex, weight in grams, and day and month of collection. In cases where several specimens of the species were collected on 
the same day, the sex and weights respectively are provided. Persounel of the ISUMZ weighed specimens upon return from the field each day, using an Ohaus Triple-beam Balance with a sensitivity of 0.1 gram. Weights would be more useful if supplemented by some indication of the size of the specimen (such as a wing measurement) and an evaluation of the extent of fat deposition in the bird. However, I feel the weights may be useful even without the additional data. All interrogation points in the specimen section indicate unsexed specimens.

Specimens in museums other than the ISUMZ are listed collectively and follow the abbreviations of their repositories. Although $I$ have personally examined the majority of the specimens listed, I am grateful to W. E. Clyde Todd for permission to include his notes on specimens in the British Museum, Coe College, Pomona College, and Willamette University. I am indebted to the late J. Van Tyne for information regarding 20 specimens from British Honduras in the Chicago Natural History Museum. The months of collection are stated whenever given on the specimen labels. Abbreviations employed for the various collections are as follows: BM British Museum (Natural History); CC - Coe College; CM - Carnegie Museum; CNHM - Chicago Natural History Museum; LSUMZ - Louisiana State University Museum of Zoology; MCZ - Museum of Comparative Zoölogy; 
PANS - Philadelphia Academy Natural Sciences; PC Pomona College; UMMZ - University of Michigan Museum of Zoology; USNM - United States National Museum; WU - Willamette University. CRITICAL PUBLISHED RECORDS include references to specimens taken at localities not represented in either of the first two headings.

The first paragraph of each species account includes a summary statement of the distribution and seasonal occurrence of the species within British Honduras. A brief description of the major habitat preferences is provided. Data concerning the reproductive season were obtained from examination of the gonads of the birds collected and from observation of nests. Remarks on other phases of natural history are included when they represent observations supplementary or contradictory to general information published by other authors. In the case of polytypic species, specimens are referred to subspecies in the final part of each species account. If the nature of the geographic variation requires discussion, this information is also included at the end of the account. Citations of all the original descriptions of each subspecies are included in Appendix $A$ and are identified by the superscript number following the first appearance of the trinomial in the text. The majority of the primary citations were compared with the original source. I have not included primary citations of 
monotypic species. Unless otherwise stated, wing measurements are of the chord, and bill measurements are of the exposed culmen. The standard deviation is preceded by a plus and minus sign following the mean in each group of measurements. Capitalized names of. colors are used only in a few cases in which specimens have been compared with a well preserved copy of the color key of Ridgway (1912). Terms expressing true relative abundance are especially difficult to standardize when used to describe birds of the tropics. A shy, inconspicuous species residing in the canopy of tall forest may be actually abundant but rarely noted by the ornithologist. My evaluation of the numerical occurrence of a species is an estimate of its abundance in its preferred general habitat. I would consider a species seen every day in the field to be common, or if many individuals were normally noted every day, then abundant. Species called moderately common are ones noted nearly every day, sometimes in numbers, whereas uncommon species are those recorded only at intervals of one or more weeks. When a species has been recorded only a few times, all records are cited. Unpublished notes made by Peck, Holt, Van Tyne, Agostini, Lancaster, Willis, Verner, Lay, and van Tets have been available to me in this study. The absence of a bibliographic reference, when the observations of these ornithologists are cited in a species account, 
indicates that the information was obtained from the unpublished data. 
ACCOUNTS OF THE SPECIES

Family PINAMIDAE

Tinamus major (Gmelin)

Great Tinamou

SPEC IMENS. LSUMZ: Gallon Jug - $\sigma$, $9(1171,1175 \mathrm{~g}$.$) ,$ Jan. 28; $\sigma$ (1148), Mar. 3; $\sigma^{\prime}(824.0)$, Mar. 18; $\sigma(874.1)$, Mar. 20; 9 (1337), May 2; $9(917.0)$, May $3 ; \%(937.2)$, May 10; $\sigma(1025)$, May 24; $Q$ (III3), May 26. Twenty-two mi. SW Stann Creek on South Stann Creek - P, Apr. 24. OTHER MUSEUMS (CC, CM, ICZ, PC): Fifteen specimens from the Manatee Lagoon area, E slope Cockscomb ints. (600750'), Toledo settlement. CRITICAI PUBLISHED RECORDS: Belize, Cayo District (Hellmayr and Conover, 1942: 12).

The Great Tinamou is a common resident of the floor of tall rain forests, and I recorded it wherever I found suitable hobitat in the colony. In many areas, especially where the forest is undisturbed, the species is the most numerous tinamou. The cockscomb Basin is such an area, and there in April and May I frequently noted 12 or more individuals daily, al though I did not find it above 2500 feet elevation. The gonads of most specimens collected in the period from late January through May were enlarged, but the peak of reproductive activity occurs in April and May. of the ten specimens for which weights are listed, the three heaviest males and three heaviest females were in breeding condition. British Hondurans have named this tinamou "blue-footed partridge." 
Specimens from the base of the Yucatán Peninsula are generally paler, grayer, and less olive than birds from other localities in southern Mexico and Guatemala. Van Tyne (1935: 8-9) named the peninsular birds T. ‥ percautus. His type series consisted of eight specimens from Uaxactun, Petén, Guatemala. I refer specimens from British Honduras to $\underline{\text {. }}$. - percautus, but the specimens from the Colony are not typical of the race and, they differ from the type series in an interesting manner. I have examined 19 specimens from British Honduras, ten of them from Gallon Jug, a locality situated only 40 miles east of Uaxactun. Some specimens from Gallon Jug are rather gray and are practically identical to the type of I. I. percautus. Other Gallon Jug birds are comparatively olive-brow and are unlike any specimens in the Uaxactun series. Between the extreme brown and gray birds are various intermediates. Most striking are birds exhibiting patches of gray on the breast, sides of breast, wing coverts, or back. In some cases the gray is bilaterally distributed; in other specimens only asymetrical patches of gray occur. Individual feathers may be partially gray, the remainder of the feather olive-brown. The Uaxactun series is a homogeneous group and does not include any specimens having gray splotches.

A critical examination of the molts and plumages of specimens referable to $\underline{\text { T. }}$. percautus indicates the characteristic paleness and grayness of that race is not 
acquired until the bird is a year or more old. A halfgrown specimen taken at Manatee Lagoon on July 12, 190b, is in what I presume is the juvenal plumage. It is decidedly dark brown above, has a dark gray pileum, and has much light buffy spotting on the edges of the grayish secondaries and their coverts. The primaries are uniformly dark slate. A specimen collected in December was in the process of replacing most, if not all, of the juvenal plumage. The new primaries are not different in appearance from the juvenal primarles. The new secondaries have deep rich chestnut outer webs with some rather inconspicuous light buffy marks toward the outer edges. Ragged black marks cross the chestnut vanes. The coverts and rectrices are also new, the latter chestnut. The greater coverts are slightly chestnut and the median and minor coverte are more olive. The upper parts are dominantly brown. Many feathers of the pileum are tipped faintly with rufous. Neither of the two Individuals described here have the grayness characteristic of $\underline{\text { T. }}$. percautus. Grayness is acquired in subsequent molts, but I have been unable to determine which molts are involved. Since the sequence of molt has not been followed further, the possibility exists that color phases are involved. This hypothesis is supported by the observation that some breeding birds are gray like $\underline{\text {. }}$. . percautus, while other breeding individuals are predominantly brown or olivebrown. However, I have a suspicion that the brown breeding birds are "young adults" that will eventually become gray. 


\section{Crypturellus soui (Hermann)}

\section{Little Tinamou}

SPECIMENS. ISUMZ: Gallon Jug - o, Feb. 26; $q(268.0$ g.), Mar. 1; o, o (165.4, 235.2), Mar. 5; 9 (239.5), Mar. 7; $\$(225.5), \operatorname{Mar} .18 ; 5, \%(178.7,212.8), \operatorname{Mar} .21$; $q(227.4)$, Apr: $9 ; \%(204.0)$, Apr. $10 ; ?(212.0)$, May 15. Ballerina Camp - $\sigma$ (244.2), Apr. 23. Two mi. W San Pedro Columb1a - o $(194.4)$, May 4; $9(238.5)$, May $7 ;$ of (199.8), May 19. OTHER MUSBUMS (CM, MCZ):.. Five specimens from the Manatee Lagoon area; Mar., Apr., Aug., Oct.

\section{This small tinamou, locally known as "bawley," is} a moderately common resident in British Honduras. Moderately tall and tall, second growth is its preferred habitat, but the Jittle Tinamou also frequents the forest edge and brushy areas within the forest.. I found the species in the forested ravines in the Mountain Pine Ridge but not in the Cockscomb Mountains. Three-fourths of the specimens collected from late February to mid-May were in breeding condition.

British. Honduran specimens of the Little Tinamou are referable to $\underline{\text { C. }}$. meserythrus.

\section{Crypturellus boucardi (Sclater)}

Boucard's Tinamou

SPECIMENS. ISUMZ: Hill Bank - \& (430.I g.), Gallon Jug - $9(413.3)$, Jan. $30 ;$ o $(414.5)$, Feb. $7 ;$ o $(435.0)$, Feb. 8; o (406.5), Mar. 7; 9 (433.2), Mar. 9; 2 o's (40.9.3, 423.8), Mar. 22; $20^{\prime \prime} \mathrm{s}(415.0,432.2)$, Mar. 23; ó (429.9), Mar. 29; of (392.0), Apr. 6; $9(508.4)$, Apr. 10; 2 o's, 9 $(429.3,436.5,510.0)$, Apr. $11 ; 30^{\prime} s, 2$, $s(414.0,426.0$, $434.0,374.0,452.0)$, May 2; ? chick, of (26.0, 435.0), May 4; $(460.7)$; May $5 ;$ of $(400.0)$, May $6 ; 0(429.0)$, May $7 ; 20^{\prime \prime} \mathrm{s}(374.9,390.4)$, May $9 ; \%(438.9)$, May $10 ; \sigma$, \& $(425.0,417.4)$, May $15 ; 0 " 3$ \%'s $(-, 460.2,508.4,526.0)$, May 20 ; 0,3 ' $3, i m n .9(463.6,466.2,491.8,497.4,155.4)$, 
May 21; o (386.7), May 23. Ballerina Camp - 8 (525.7), Apr. 23; $?$ (503.4), Apr. 28. Two mi. NE Millionario Q (398.1), Mar. 13. Two mi. W San Pedro Columbia - \& (394.9), May 9. OTHER MUSEUMS (CM, MCZ, UMMU): Three specimens from $12 \mathrm{mi}$. S Cayo, Camp VI, E slope Cockscomb Mts. (600'); Feb., Mar.

Boucard's Tinamou is a moderately common resident of tall second growth and rain forest in most parts of mainland British Honduras. The "red-footed partridge," as it is called by the people of the colony, is difficult to observe, and the fine series in the ISUM2 is to the credit of Lancaster, who collected most of the specimens. He spent several seasons at Gallon Jug engaged in a study of the life history of this tinamou (Lancaster, 1960). Breeding specimens were collected from early february to late May. Each of the three adult females taken on May 21 contained eggs with shells.

I refer the specimens from British Honduras to $\underline{\text {. }} \underline{\mathrm{b}}$. boucardi.

\section{Crypturellus cinnamomeus (Iesson)}

Rufescent Tinamou

SPECIMENS. LSUMZ: Hill Bank - $\sigma(434.4 \mathrm{~g}$.$) , Apr. 2,$ 1955. Gallon Jug - o (448.3), Feb. 27, 1958.

The Rufescent Tinamou is a moderately common resident at Hill Bank, where it frequents the dense second growth surrounding the village. It is rare at Gallon Jug but has been recorded there several times in woodlands also occupied by Boucard's Tinamou. The Rufescent 
Tinamou has not been recorded at any other localities in British Honduras. 'the testes of the male collected February 27 at Gallon Jug were fully enlarged.

The two specimens are dissimilar and are also unlike all specimens in an extensive series from Mexico, Guatemala, and Honduras. I am unable to refer them to any of the races occurring in northern Central America. Individual variation is exceptionally pronounced in the species, especially in the males, and the two birds under consideration must approach the extremes in the population.

Van Tyne (1935: 10) collected two Rufescent Tinamous at Uaxactun, Petén, and referred them to $\underline{c}$.. goldmani. I have examined his two specimens and agree with his identification. Paynter (1955: 18) assigns specimens from southern Quintana Roo to this race also. On a geographical basis, the British Honduran birds would be expected to resemble $\underline{\text { c. }}$. goldmani of the Yucatán Peninsula. In comparison with four topotypical specimens of this race from Chichén Itzá, Yucatán, the Hill Bank bird is much deeper red-brown above, its pileum is darker, and its nape is redder. Its under parts are also more red-brown, especially on the upper breast. The upper parts of the Gallon Jug individual are unbarred and uniformly dark brown from the nape to the upper tail coverts. Its tail and wings are barred in the same manner as females of $\underline{C}$. boucardi, quite 
unlike $\underline{\mathrm{C}}$. cimnamomeus. The upper breast of the Galion Jug bird is dark slate, but the lower breast is redish as in the Chichén Itzá specimens. The sides of the neck are darker than in any $\underline{\underline{C}}$. cinnamoneus examined. Additional specirnens from the Colony are required for adequate study of the geographic variation involved.

Family PODICIPIDIDAE

\section{Podiceps dominicus (Iinnaeus)}

\section{Least Grebe}

SPECIMENS, LSUMZ: Ballerina Camp - $q(104.4 \mathrm{~g}$.$) ,$ Apr. 24, 1955; ऽ, Apr. 26, 1956. OTHFR MUSEUM (BM) : Upper Makal [= Eastern Branch Belize River], undated.

The Least Grebe is local and uncommon in British Honduras, where it is called "diving dabbler." Presumably pairs nested on two small ponds near Gallon Jug where they were seen in several years from February to late July. I saw them occasionally at Hill Bank in spring and daily at Ballerina Camp in late April. Peck saw the species only once, near Ycacos Lagoon on March 6. There are no additional records from the Colony. There are no records from August to January, inclusive, but the species is normally resident in its range.

I refer the two specimens from Ballerina Camp to P. d. brachypterus. 
Podilymbus podiceps (Linnaeus)

Pied-billed Grebe

SPECIMENS. ISUMZ: Hill Bank - 0, Mar. 22, 1955. OTHER MUSEUM (MCZ): Ycacos Lagoon - 9, Mar. 6, 1907.

The species is a moderately common winter visitant and possibly a rare breeding bird in British Honduras. From October to mid-March Pied-billed Grebes can be seen in small numbers (1-6) on ponds, lagoons, and streams. On May 15, 1907, Peck saw one bird near Ycacos Lagoon; and on May 26, 19>6, I saw a pair on the New River. The lateness of the last two dates is the only indication this grebe may breed in the colony.

The wing of the specimen from Hill Bank measures $135 \mathrm{~mm}$. This measurement is well within the range of P. p. podiceps. I have not identified the specimen collected at Ycacos Lagoon to subspecies.

\author{
Family PTLECANIDAE \\ Pelecanus erythrorhynchus Gmelin \\ White Pelican
}

Peck's notes include a record of two White Pelicans that he observed on the beach near the mouth of the Manatee River on April 1, 1901. The species is rare so far south, but I have no reason to question Peck's identification. 
Pelecanus occidentalis Linndeus

Brown Pelican

SPECIMENS. ISUMZ: Hill Bank - (2077 g.), Feb. 21. Calabash Cay - $\$$ (2130), Apr. 11. O'IHER MUSEUM (CC): Six specimens from the Manatee Iagoon area; June, Deo. CRITICAI PUBLISHED RECORD: Glover's Reef' (OgilvieGrant, 1898: 478).

Small numbers of Brown Pelicans are resident along the cosst and among the islands of British Honduras. Daily counts exceeding 20 individuals are unusual except in the Belize harbor or in the vicinity of a nesting colony. The species rarely occurs inland, although I have recorded it twice at. Hill Bank (February 21, November 29). About 15 pelican nests were present in the mangroves on Man-of-war Cay at the time of my visit on April 12, 1956. Some nests contained eggs and others held young birds. It is probable that the Brown Pelican nests on other keys in British Honduras.

The specimen collected on Calabash Cay on April 11, 1956, contained ova as large as $18 \mathrm{~mm}$. The wing of this bird measures 465, the tail 127, and the culmen $252 \mathrm{~mm}$., and on the basis of these measurements I refer it to the small West Indian race, $\underline{P}$. o. occidentalis. pelicans definitely known to be incubating have not been collected in British Honduras, but it appears highly probable that this female would have nested in the area where it was collected, possibly on Man-of-war Cay, 
which is only five miles from Calabash cay. ㅁ․ ㅇ.. occidentalis has not previously been recorded as breeding in Central America. The Check-list of North American Birds (1957: 30) includes the coasts of the Gulf of Mexico, Cuba, and Panamá, as a part of the breeding range of $\underline{p}$. 0 . carolinensig. The bird shot at Hili. Bank is large and I assign it to $\underline{P}$. o. carolinensis.

\section{Family SULIDAE}

Sula dactylatra Lesson

Blue-faced Booby

I saw two Blue-faced Boobies several miles east of Belize on February 15, 1955. This observation constitutes the only record of the species in Eritish Honduras. Red-footed Boobies are not uncommon in the coastal waters of the Colony, and it is probable that Blue-faced Boobies are often overlooked.

\section{Sula sula Iinnaeus \\ Red-footed Booby}

SPECIMENS. ISUMZ: Half Moon Cay - $20^{\prime} \mathrm{g}(696.0,735.0$ g.), Apr. 25; downy young $\sigma(540.0)$, Feb. 24. OTHLR MUSEUMS (CM, UMMZ): About twenty-five specimens (most mounted) from Half Moon Cay; Jan., Mar.

A colony of Red-footed Boobies has been established on Half Moon Cay for over a hundred years, and individuals 
of this species are often seen among the keys and occasionally along the coast of British Honduras. The number of birds in the colony has undoubtedly varied considerably. Salvin (1864: 379) thought there were "several thousands" in May 1862. A study of this booby on Half Moon Cay in 1958 (Verner, 1959) revealed 1389 nests and an estimated 3500 individuals exclugive of nestlings. The hurricane in september 1931 reportedly killed many boobies and it may be assumed the powerful hurricane of late October 1961 also reduced the size of the colony. Nesting activity on Half Moon Cay begins in November and continues for nearly eleven months. In late December 1960, van Tets. found most birds were courting, but about 20 per cent of the birds were incubating. January is probably the month in which most pairs lay (fide van Tets, Verner). Flight and nesting behavior of the Red-footed Booby has been described by Verner (1959, 1961). I assign the specimens from Half Moon Cay to S. S. sula.

\section{Sula leucogester Linnaeus}

Brown Booby

SPECIMENS. CC, MCZ, UMMZ: Belize - ?, Dec., 1928. Manatee Bar - ?, Jan., 1907. Mouth of Rio Grande - 0 , Mar. 5, 1907.

A few Brown Boobies are present among the keys and off the coast of British Honduras throughout the 
year, but the species is not known to breed in the Colony. Salvin (1864: 385) published a secondhand report that the species bred on Mauger Cay, but no boobies were nesting there at the time of my visit in April 1956. Brown Boobies sometimes roost at the edge of the Red-footed Booby colony on Half moon Cay (maximum 15, Verner notes).

I refer the specinens from. British Honduras to S. I. Ieucogaster.

Family PHALACROCOPACIDAE

\section{Phalacrocorax auritus (Lesson)}

Double-crested Cormorant

SPECIMENS. CRITICAL PUPLISHED RECORD: Man-of-war Cay (Salvin, 1864: 374 ).

Salvin (1864: 374) collected specimens and eggs of the Double-crested Cormorant on May 8 , 1862, on Man-of-war Cay. The species has not been recorded again in British Honduras. Olivaceous Cormorants are not uncommon on fresh water of the mainland, and it is possible that some cormorants not identified to species may have been Double-crested Cormorants. However, I know of no cormorants recorded off the coast of British Honduras except those described and collected by Salvin. I visited Man-ol-war Cay in mid-April 1956, and the only nesting birds were Brown Pelicans and 
Magnificent Frigatebirds. The pelicans were not present on this tiny key at the time of Salvin's visit, but cormorants and Snowy Egrets shared the mangroves with Magnificent Frigatebirds.

At least two British Honduran specimens are in the British Museum. I have not critically examined these specimens but it is probable they are referable to $\underline{\mathrm{P}}$. $\mathrm{a}$. floridanus, the race breeding in the southeastern United States, the Bahamas, and Cuba.

\section{Phalacrocorax olivaceous (Humboldt)}

\section{Olivaceous Cormorant}

SPECIMENS. LSUMZ: Hill Bank Lagoon - $\sigma^{\prime}$ (ll79 g.), Feb. 25, 1956; $\sigma$, March 24, $1955 ; 2$ 's $(98, .5,1031)$, Nov. $24,1956$.

Olivaceous Cormorants are common throughout the year on the New River and on Hill Bank Lagoon. I also noted several individuals daily at Ballerina Camp in late April and twice on the Columbia River near San Pedro Columbia in late May. Holt saw one bird on the Belize River in March 1926, and Peck saw about six on a small pond near Ycacos Iagoon on March 6, 1907. The species has not been recorded elsewhere in British Honduras. The male collected in November and the two females taken in February were in breeding condition. Olivaceous Cormorants undoubtedly breed in the vicinity of the New River and probably also in other fresh water areas of the Colony. 
I refer the specimens from British Honduras to P. ‥ mexicanus.

Family ANHINGIDAE

Anhinga anhinga (Linnaeus)

Anhinga

SPECIMEN. PC: Near Manatee Iagoon - 9 , Mar. 28, 1906.

The Anhinga is a rarely recorded resident of freshwater ponds and streams. One or two, and once six, individuals have been recorded on 12 dates on the New River, Wanatee Lagoon, Stann Creek, Monkey River, Ycacos Lagoon, and Deep River (Peck, Russell, Willis). On May 15, 1907, Peck found a nest holding two or three downy young in a tree overhanging a pond near Ycacos Lagoon.

Anhingas from the southeastern United States, Mexico, Central America, and Colombia are referred to A. a. leucogaster by most authorities. 
Family FREGA'PIDAE

Fregata magnificens Mathews

Magnificent Frigatebird

SPECIMENS. ISUMZ: Calabash Cay - $\$$ (1419 g.), Apr. 8; \%" (1061), Apr. 9. OTHER MUSEUMS (CC, CM): Ten specimens from the Manatee Lagoon area; June, Dec. CRITICAI PUBLISHED RECORDS: "Belize "coast," Man-of-war Cay (Salvin, 1864: 372, 374).

Several. "man-o'-war birds" can be seen daily at almost any coastal or insular locality in British Honduras. Nesting colonies have been in existence on Half Moon and Man-of-war Cays at least since Salvin's visit to them in 1862. On Half Moon Cay in late December 1960, van lets noted about 20 pairs courting and nest building. Verner saw an average of 25 individuals daily during his three months on the island in the spring of 1958. On April 12, 1956, I found 60 occupied nests on Man-of-war Cay.

I refer the British Honduran specimens to $\underline{F}$. rothschildi.

Family ARDEIDAE

Ardea herodias Iinnaeus

Great Blue Heron

I have seen Great Blue Herons in small numbers from November to late May at many insular localities and on 
ponds and lagoons on the mainland. No evidence suggests that the species breeds in British Honduras, and it is unrecorded from June to November.

Great Blue Herons collected in the Colony have-not been preserved as specimens. Four individuals banded as young birds in Illinois, Wisconsin, and Michigan have been recovered in British Honduras (Cooke, 1938b: 184; I946: 254); The birds were banded in the range of $\underline{A}$. $\underline{\text { h. }}$ herodias.

\section{Butorides virescens (Iinnaeus)}

Green Heron

SPICIMENS. ISUMZ: Hill Bank - $\sigma(196.1$ g.), Feb. 26; ? $(171.3)$, Nov. $22 ; q$, Nov. $24 ; \sigma(194.8)$, Nov. $28 ; \sigma$ ( 184.6 ), Nov. 29. OTHER MUSSTUMS (CM, UMMZ): Seven specimens from Belize, Manatee Lagoon, Cayo; Feb., Mar., Aug., Oct., Dec.

June and July are the only months in which this species, the "poor Joe" to local residents, has not been recorded in British Honduras. Observations of Green Herons in late May and early August indicate that some individuals are probably resident. The species is not uncommon near rivers and lagoons and on the keyss. I have counted as many as 40 in a few hours near Hill Bank in late March, but six was the maximum in the same area in late November. The wing of the female collected November 22 at Hill Bank neasures $167 \mathrm{~mm}$, and that of another female 
taken December 19 at Manatee Lagoon measures $166 \mathrm{mm.;}$ consequently, I refer these specimens to the small race, B. v. maculatus. All other specimens from the Colory - 1 . 17 are larger and within the size range of $\underline{B}$. $\underline{v}$ : viresce $\overline{n s}$. There are no definite breeding records of the species from British Honduras; although I presume that it does nest there. Without specimens of birds known to breed in British Honduras, it is not possible to determine which race is the breeding form. Two specimens collected by Paynter (1955: 31) in Hay at Laguna Chacanbacab, : Quintana Roo, were in full breeding condition and were typical of the nominate race. Van Tyne (1935: 15) listed a specimen of $\mathrm{B}$. $\mathrm{V}$. maculatus that was collected at Pacomón, Petén, Guatemala, in June.

\section{Florida caerulea (Iinnaeus)}

\section{Little Blue Heron}

SPECIMENS, ISUMZ: Gallon Jug - $q(308.2$ g.), Mar. 5. Hunting Cay - 9 (210.7), Apr. 27. OTHER MUSEUMS (CC, CM, PC, UMMZ, USMM): Ten specimens from Belize, Manatee Lagoon area; Mar., Sept., Nov., Dec.

Iittle Blue Herons are common transients and winter. visitants at many insular and mainland localities in British Honduras and have been recorded throughout the year, with the exception of a few weeks in early summer (May 15-July 19). Most northbound migrants pass through the Colony between March 20 and April 15. Birds banded 
in South Carolina and Mississippi have been recovered in British Honduras (Cooke, 1938a: 83). I do not believe the species nests in the Colony.

I am unable to detect any difference between specimens from British Honduras and those from the United States, and, consequently, I refer specimens from the colony to $F$. . caerulea. The race F. caerulescens, which is supposed to breed from Mexico or Central America to South America according to some authors, may not be valid. In that case, the species is monotypic.

\section{Dichromanassa rufescens (Gmelin) \\ Reddish tigret}

On August 7, 1957, Willis saw a Reddish. Egret in the vicinity of mud flats and mangroves near the mouth of the Belize River. Although the species is not uncommon at many coastal and insular localities in Quintana Roo, there are no other records from British Honduras.

\section{Casmerodias albus (Iinnaeus)}

Common Egret

SPECIMENS. ISUMZ: Hill Bank - q (810.1 g.), Nov. 23. OIHER MUSEUMS (CM, PC, UMMZ): Four specimens from Belize, Manatee Lagoon area; Mar., Sept., Nov.

The species is moderately common near rivers, lagoons, ponds, and the coast and is less numerous at 
ingular localities. Common Egrets have not been recorded in the Colony in June or July, and they have not been found breeding there. Salvin (1864: 387) attributed old nests found near Grasgy Cay about May 20, 1862, to this species, but the record does not appear positive enough to provide definite evidence of breeding. Individuals from the United States migrate to or through British

- Honduras, as two birds banded in Misstssippi were shot in the Colony (Iincoln, 1936: 141; Cooke, 1938b: 184). c. a. egretta is the race occurring in the Western Hemisphere.

Leucophoyx thula (Molina)

Snowy Egret

SPECIMENS. UMMZ, USNM: Five specimens from Belize, Sibun River; Apr.

Snowy sigrets are moderately common in the Colony during most of the year, but like many other species of herons they have not been recorded in June and July. The species inhabits river, pond, and lagoon borders, mangrove swamps, and, to a lesser extent, beaches. Salvin (1864: 374) records this egret nesting on Man-of-war Cay on May 8 , 1862, but I did not find it there in 1956, and there are no additional breeding records. According to Peck's notes, all egrets were rare in British Honduras early in this century, presumably as a result of excessive killing by plume hunters. 
I refer specimens of the snowy Egret from the Colony to I. $t$. thula.

\section{Bubulcus ibis (Iinnaeus)}

Cattle Egret

SPECIMENS. LSUMZ: GalIon Jug - 7 (226.6 g.), Oct. 25, 1956. Stann Creek - j(351.0 g.), Mar. 24, 1956.

I saw a maximum of four Cattle eigrets in a pasture at Stann ureek during the last week of March 1956, and one individual at Gallon Jug on October 25 of the same year. Lancaster's observation of one in a pasture at Gallon Jug on May 1,1958 , is the only other record of the species in the Colony. Ihis egret is spreading rapidly through the New World and will undoubtedly become established as a breeding species in British Honduras.

I assign the two specimens to B. $\underline{i}$ ibis.

Hydranassa tricolor (Meller)

Louisiana Heron

SPECIMENS. CC: Morgan Cay - J, Apr. 20, 1907. Manatee Lagoon - ?, Nov. 30, 1906 . CRITICAI PUBLISHED RECORD: Turneffe (Sharpe, 1898: 130).

The species is uncommon in the colony but has been observed in all months except January, June, July, and september. A young bird banded in July in North Carolina was recovered four months later near Belize (Cooke, 
1938a: 82); consequently many of the Louisiana Herons recorded in British Honduras could be transients or winter visitants. No breeding record from the Colony is known to me. This heron occurs in suitable wet places on both the islands and mainland.

The British Honduran specimens are referable to H. t. ruficollis.

Agamia agami (Gmelin)

Agami Heron

SPECIMENS. LSUMZ: Gallon Jug - $\sigma(759.3 \mathrm{g.})$, Nar. 28, 195ל. OTHER MUSEUMS ( $\mathrm{CM}, \mathrm{MCZ}, \mathrm{PC})$ : near Manatee Lagoon -,+ Dec. 2, 1905; \%, 9 , Dec. 11, 1905. Toledo Settlement - $9, \operatorname{Jan} .23,1907$.

The specimen collected at Galion Jug was found by a local hunter on a small stream in the forest. The species was not recorded in British. Honduras by any field parties of the ISUMZ, and I consider it now a local or rare resident. Peck, who was in British Honduras from 1900 to 1907, found the Agami Heron in "considerable numbers," and in "great abundance" near the Manatee and Ycacos Lagoons and Toledo Settlement. Peck's notes also indicate this heron frequents streams and ponds in heavy forest, and usualiy it is solitary or occurs in twos. Peck found many Agami Herons about a small pond in the vicinity of Yoacos Lagoon on May 15, 1907. On the basis of the birds' behavior, Peck assumed "that the nesting season was at hand." But he found no nests. 
Nycticorax nycticorax (Iinnaeus)

Black-crowned Night Heron

SPECIMEN. LSUMZ: Hill Bank - $\gamma(827.2$ g.), Nov. 2l, 1956.

Peck collected a Black-crowned Night Heron at Toledo Settlement in April 1907, but did not preserve the specimen. A bird shot at Belize in October 1943 had been bended as a young bird four months previously in Illinois (Cooke, 1950: 12). At Hill Bank I saw two Black-crowned Night Herons on November 21, 1956, and one on November 29, 1956. I believe that this species is both a rare transient and rare winter visitant in the colony, but there are no additional records to substantiate this assumption.

I refer the specinen to N. n. hoactli.

Nyctanassa violacea (Linnaeus)

Yellow-crowned Night Heron

SPECIMENS. LSUMZ: Six mi. NNE Hill Bank - 6 (5ל2.) g.), Mar. 31. OTHER MUSEUMS (CC, CM, MCZ): Six specimens from Belize, Manatee Lagoon area; Oct., Nov., Dec.

Yellow-crowned Night Herons are common at many insular and mainland localities as transients and winter visitants, and they also nest locally in smali numbers on the mainland near fresh water. Verner saw one to five individuals on 14 dates from March 2 to April 16 on Half Moon Cay in 19.58 but no night herons 
before or after these dates. The birds recorded by verner were probably migrants. Peck found young birds just leaving the nest near Ycacos Lagoon on May 22, 1907 .

The specimens collected in British Fonduras are referable to $\underline{\mathbb{H}}$. $\mathrm{v}$. Violacea.

\section{5}

Heterocnus mexicanus (Swainson)

Bare-throated Tiger Heron

SPECIMENS. LSUMZ: Cockscomb Br. of South Stann Creek 6 , May 4. OTHER MUSEUMS (BIh, MCZ): Four specimens from Hakal [= Eastern Branch Belize River], Ycacos Lagoon, Deep River; Mar., May. CRITICAL PUBLISHED RECORD: Belize (Sharpe, 1898: 200).

The species is an uncomnon and secretive resident along smaller watercourses in forested areas of the mainland. Peck found it in mangroves and the pine ridges near the coast, as well as in the forest. There are sight records of the Bare-throated Tiger Heron from Hill Baink, the Rio Grande, Toledo Settlement, and the Temash River. The gonads of the male that I collected on May 4 were slightly enlarged.

I refer the specimens to H. m. mexicanus.

Ixobrychus exilis (Gmelin)

Least Bittern

SPECIMEN. ISUMZ: Half Moon Cay - ${ }^{\circ}(55.4 \mathrm{~g}$.$) , Apr. 17,$ 1958. 
I flushed a least Bittern from the marsh at Hill. Bank on November 22, 1956. This observation and the specimen collected by Verner on Half Moon Cay constitute the only known occurrence of the species in the Colony. The specimen undoubtedly represents a transient, and the bird that I saw at Hill Bank was probably a winter visitant, although this bittern does breed locally in Central America.

I refer the specimen to I. e. exilis.

Botaurus lentiginosus (Rackett)

American Bittern

On March 22, 1955, and November 23, 1956, I noted single American Bitterns in the marsh near Hill Bank. I checked the identification of these bitterns carefully, as Paynter (1955: 40) had found Botaurus pinnatus in a marsh in southern Quintana Roo, Iess than 60 miles from Hill Bank.

Family COCHLEARIIDA.

Cochlearius cochlearius (Iinnaeus)

Boat-billed Heron

SPECIMENS. ISUMZ: Six mi. NNE Hill Bank - o, Mar. 24. OTHER MUSEUMS (CM, PC, UMMZ): Six.specimens from the Manatee Iagoon area, Cayo; Mar., Nov. CRITICAI PUBIISHED RECORD: Grassy Cay (Salvin, 1864: 387). 
In regions undisturbed by man on the mainland and keys, Boat-billed Herons are moderately common local residents of wooded areas in the vicinity of water. Additional points of record are the Sibun River, Ycacos Lagoon, and Soldier Cay. The "cooper," as the species is best known to the residents of the colony, is shy and nocturnal, and is responsible for many of the wierd sounds that may be heard in swamps at night. Peck noted nests on April 29 near Ycacos Lagoon; some nests contained eggs and others large young. A female collected by Murie near Cayo on March 17, 1931, weighed 577.5 grams.

I refer Boat-billed Herons from British Honduras to $\underline{\text { c. }}$ c. zeledoni.

\section{Family CICONIIDAE}

\section{Mycteria americana Iinnaeus \\ Wood Ibis}

SPECIMEN. LSUMZ: near Manatee Lagoon - imm., June 1905.

I have seen small flocks (10 - 32 birds) of Wood Ibis on two dates (February 16, 1955; May 26, 1956) soaring over the New River, and on March 14, 1958, Lancaster noted three individuals perched in a treetop in his study area in the rain forest at Galion Jug 
immediately before a storm. Peck saw Wood Ibis occasionally near Manatee Lagoon and lroledo Settlement in 1906 and 1907, but he did not record dates.

\section{Jabiru mycteria (Iichtenstein)}

Jabiru

SPECIMENS. LSUHZ: Hill Bank - $\sigma(6400$ g. $)$, Feb. 27, 1956. O'IHER MUSEUM (UMMZ): Sibun River near Belize o, Feb. 5, 1931.

The Jabiru is an uncommon resident in the Colony. Single birds, or more rarely pairs, regularly feed near marshes and ponds in the pinelands from Manatee Iagoon to Hill Bank. Both "turk" and "fillymingo" are used by local people as names for the species. Individuals are conspicuous because of their great size, white appearance, and tendency to forage in open situations, but they are shy and are easily alarmed. My observations of the species at Hill Bank indicate that it has regular roosting and feeding areas several miles apart. A nest found by Peck on May 23, 1906, was situated in a pine tree 50 feet above the ground in a remote section of the pine ridge. Coarse marsh grasses, palmetto leaves, and large sticks were incorporated into the platform-type nest measuring 6 by 8 feet. Peck noted that the nest material had been recently collected and surmised that the nest was in use for the first time. The three-foot thickness of the nest prevented him from seeing its contents. 
Dennett and I collected the specimen at Hill Bank early in the morning as it flew toward its feeding area. The bird was initially injured and attempted to protect itself by biting motions with its sharp, serrated bill. Jabbing movements were not employed. Its crop was empty, but its large gizzard contained some vegetable matter, bivalves, and a coleopteran exoskeleton. "The testes were enlarged.

\section{Family THRESKIORNITHIDAE}

Fudocimus albus (Iinnaeus)

White Ibis

SPECIMENS. CRITICAL PUBLISHED RECORD: Gragsy Cay, Turneffe Islands, May 20, 1862 (Sharpe, 1898: 41).

There are no recent records of the Write Ibis in British Honduras. Salvin (Salvin and Sclater, 1860: 402) found two birds on Golden Stream Cays in April 1860. In 1862 Salvin (1864: 387) found empty nests, which he attributed to this species, on a key adjacent to Grassy Cay. Peck saw a few individuals near Manatee Lagoon in January 1901 and at Ycacos Lagoon on March 2, 1907. 


\section{Ajaia ajaja (Linnaeus)}

Roseate Spoonbill

SPEGIMEN. UMIZ: Sibun River near Belize - ₹, Apr. 2,1932 .

The specimen listed above and the one individual. that Dennett and I saw on the dock at Punta Gorda constitute the only records of the species from British Honduras.

\section{Famijy ANATIDAE}

Dendrocygna autumnalis (Iinnaeus)

Black-bellied Tree Duck

SPECIMENS. BM, CC: Spanish Creek - two unsexed specimens, June 4, 1887. Manatee Lagoon - ?, Mar., 1907.

The species is rare in British Honduras and is known there only from the specimens listed above. and two observations made by the H. A. J. Evanses and by A. P. Bellhouse in the ricefields near Boom. Possibly this duck is becoming more numerous in the Colony. The specimens have not been critically examined. $29 /$

D. a- fulgens is the race recognized in the check-list of North American Birds (1957: 69) as occurring from southern Texas to Panamá. 
Cairina moschata (Iinnaeus)

Muscovy

SPECIMENS. CRITICAL PUBLISHED RECORD: Belize (Salvin and Godman, Biologia, iii, 1902: 198).

The Muscovy is an uncommon resident of lagoons, ponds, and streams in British Honduras. It is most often found in uninhabited or sparsely populated regions. Undoubtedly extensive hunting has driven it from inhabited areas, for it is much desired as game. The species is exceedingly wary and flushes readily. The Muscovy probably breeds in the Colony, but no nests have been found.

\section{Anas carolinensis Gmelin}

Green-winged Teal

The inclusion of British Honduras in the winter range of this species in the Check-list of North American Birds (1957: 76) is apparently based on a record published by Goss (1891: 62). Goss reported that he encountered a small flock of Green-winged Teal on March 23, 1887, on the Belize River near Orange Walk. Presumably no specimens were collected.

Anas acuta Iinnaeus

Pintail

SPECIMEN. CRITICAL PUBLISHED RECORD: Belize (Salvin and Godman, Biologia, iii, 1902: 214). 
The Pintail is a rare winter visitant on lagoons in British Honduras. I saw half a dozen individuals on two dates at Hill Bank in November 1956. A male banded in Oregon in September 1927 was recovered near Belize in December of the same year (Iincoln, 1928: 359).

\section{Anas discors Linnaeus}

\section{Blue-winged Teal}

SPICIMENS, ISUMZ: Gallon Jug - $9(263.0 \mathrm{g.})$, 0ct: 22 , 1956. Belize - J'(349.8), Apr. 6, 1956.

North American ducks do not winter in British Honduras in great numbers. Flocks of Blue-winged Teal consisting of fewer than two dozen individuals are widely distributed on the ponds and lagoons of the mainland of the Colony from september into April. In comparison with other ducks, this teal is the nost common species. August 7 is the date of the earliest record of a visitant from the north and May 19 is the latest date in spring on which they have been observed.

I refer the British Honduran specimens to the nominate race, $\underline{A}$. $\underline{\text {. discors}}$.

Aythya affinis (Eyton)

Lesser Scaup

SPECIMENS. LSUMZ: Hill Bank - q (626.0 g.), Feb. 22, $1956 ; 0$ ( Manatee Lagoon - 3 , Dec. 11, 1905. 
Lesser Scaup are present in the Colony from

November into April in small numbers, usually on lagoons or ponds. On. Half Moon Cay in 1958, Verner saw one individual on April 4 and 5, the only record not from the mainland.

\section{[0xyura jamaicensis (Gmelin)] \\ Ruddy Duck}

Eisenmann (1955a: 19) specifically includes British Honduras within the range of the species. I can find no basis for this inclusion. Mr. Tisenmann (in litt) does not have the source of this record; consequently, the species should not be included on the list of British Honduran birds.

Family CATHARTIDAE

Sarcoramphus papa Linnaeus

King Vulture

SPECINENS. ISUMZ: Nine mi. N Gallon Jug - ?, Mar. 22. OTHER MUSEUMS (CC, MCZ): Four specimens from the Manatee Lagoon area, Toledo Settlement; Feb., Nov.

King Vultures, or "King John Crows" as they are called locally, are distributed over all regions of the mainland of British Honduras, except along the coast. They are generally uncommon and are most often 
seen feeding on carrion or soaring over or near rain forest. I have seen individuals soaring high over Victoria Peak, as well as over many lowland localities. The species is more wary than other vultures in the colony and rarely approaches viliages or towns.

Coragyps atratus (Bechstein)

Black Vulture

This vulture is abundant in the vicinity of human settlements on the mainland of British Honduras and often roosts in trees in towns. In soite of its ubiquitousness, it has been shunned by collectors and no specimens have been taken in the Colony. The number of Black Vultures roosting at Gallon Jug declined in March, April, and inay, possibly because some birds left the village in order to nest. The species is well known to residents of British Honduras as the "John Crow."

\section{Cathartes burrovianus Cassin}

Yellow-headed vuiture

SPECIMEN. LSUMZ: One mi. S Belize - ?, Aug. 24, 1960.

Lay saw several individuals of this species in the lowlands near Belize in August 1960. Undoubtedly Yellow-headed Vultures are often incorrectly identified in the field as Turkey VuItures. There are no other records of the species from the colony. 


\section{Cathartes aura (Iinnaeus)}

Turkey Vulture

SPECIMENS. ISUMZ: Gallon Jug - ?, Feb. 13, 1957.

The species is common in the colony but it is more numerous than the Black Vulture only in the Mountain Pine Ridge. Turkey Vultures are widespread residents in the open regions of the mainland but are seldom found in settlements. I have no data indica-. ting the presence of transients in British Honduras. Both the Turkey Vulture and Black Vulture are called "John crow" by British Hondurans, but the Turkey Vulture is sometimes distinguished from other valtures as "doctor John crow."

I am unable to identify the only specimen of this species to race. Resident birds of Central America are referable to $\underline{C}$. a. aura.

\section{Family ACCIPITRIDAE}

Elanus caeruleus (Desfontaines)

White-tailed Kite

SPECIMENS. CM, MCZ: All Pines - ?, Apr. 24, 193b. Toledo Settlement $-s$, Nov. $27,1906$.

The species is uncommon in British Honduras. One or two individuals at a time have been noted by many observers in the lowland pinelands and semi-open in 
all months except May and June. On the basis of the distribution of these records, I suspect the species is resident in the colony. The ovary of the bird collected April 24 by Blake and Agostini was much enlarged. I refer the two specimens to $\underline{\text { E. }}$ c. majusculus.

\section{Elanoides forficatus (Linnaeus)}

Swallow-tailed Kite

SPECIMENS. ISUMZ: Gallon Jug - 3 , JuIy 2. OTHER MUSDUMS (CM, MCZ): Freetown - \$, May 14, 1935; ?, May 23, 1935. Sittee River - 0 , Apr. 27, 1907. CRITICAL PUBIISHED RECORD: Belize (Salvin and Godman, Blologia, iii, 1901: 96).

This kite is an uncommon breeding bird and rare transient in British Honduras and has been recorded only from mid-February to late July. Almost all individuals that I have seen were soaring over tall rain forest. It is virtually impossible to see soaring species from within the forest, and since the Swallowtailed Kite rarely flies through the canopy, it may be more common than my records indicate. Peck found an unoccupied nest in a tree on the bank of the Rio Grande on May 7, 1907. I have never seen more than six birds at once, but Peck noted a flock of about 200 individuals near Manatee Lagoon on April 16, 1907, which he thought was probably migrating. "Scissor-tailed hawk" is the name applied to this species by the residents of the. Colony. 
The specimen from Gallon Jug is referable to E.. f. yetapa, the breeding race ranging from Mexico to Argentina.

\section{Leptodon cayanensis (Latham)}

Gray-headed Kite

SPECIMENS. CC, CM, PC, UMMZ: Vicinity of Manatee Lagoon - 8, Jan. 30, 1906; 8, Sept. 11, 1905; 3', Dec. 2, 1906. Cayo - $\%(475$ g.), Mar. 10, 1931. CRITICAL PUBLISHED RECORD: Orange Walk (Salvin and Godman, Biologia, iit, 1901: 101).

The five specimens constitute the only records of this species from British Honduras. No data pertaining to the breeding condition of the birds were recorded by the collectors.

\section{Chondrohierax uncinatus (Temminck) \\ Hook-billed Kite}

SPRCIMEN. BM: One specimen, undated and without a specific locality.

Mr. Todd examined the specimen in the British lifuseum several years ago. Lancaster observed one Hookbilled Kite at Gallon Jug on March 6, 1957, and Willis saw single individuals there on July 12 and 21, 1957. There are no additional records from the colony.

The specimen has not been critically examined, and consequently cannot be referred to race. It is probably

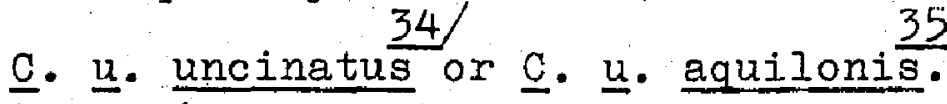


Ictinia plumbea (Gmelin)

Plumbeous Kite

SPECIMENS. ISUMZ: Gallon Jug - $\sigma$ (282.4 g.), Mar. 1; of, $9(250.5,301.5)$, Mar. 29. Ballerina Camp - 6 $(-260.8)$, Apr. 25. OTHER MUSEUIAS (BM, CM, MCZ, PC, UMMZ): Twenty-one specimens from the Manatee Lagoon area, Duck Run, vicinity of Cayo, $12 \mathrm{mi}$. S Cayo, Augustine, Mountain Cow, Freetown, Toledo Settlement; Feb. - Aug.

The Plumbeous Kite is moderately common in the Colony from late Fe bruary into August. It prefers the forest border and the semi-open tall forest, but it frequently enters pinelands. Breeding, as indicated by the condition of the gonads of collected specimens or by presence of occupied nests, begins in early March and continues into June. I have not seen this kite in the period of August to February; however, Peck noted that some individuals were present at all seasons at Toledo settlement. He did not record it at more northerly localities in winter. The data do not indicate whether the breeding birds in the extreme southern portion of the colony are resident there or whether they migrate and are replaced in winter by birds from the north. Some individuals observed in spring are doubtless transients, and Peck further noted that in autumn he often saw this .. kite in "immense flocks." 


\section{Rostrhamus sociabilis(Vieillot)}

Snail Kite

SPECIMENS. ISUMZ: Hill Bank - 9, Mar. 23, 1955. Galion Jug - $\$(437.5 \mathrm{g.})$, June 4, 1956.

Marshes along the New River and the Hill Bank Iagoon provide the only areas where this resident species is common. It is present locally in small numbers south from Hill Bank to Stann Creek. Both specimens are in juvenal plumage, but the bird collected in June had a slightly enlarged ovary.

The exposed culmens of the two specimens measure 28.7 and $30.7 \mathrm{~mm}$, and the tails 196 and $200 \mathrm{~mm}$. On the basis of their large size, I refer the specinens to R. . major.

Accipiter bicolor (Vieillot)

Bicolored Hawk

SPECIMENS. BH, CN: Near Hanatee Lagoon - 5 , Aug. 3, 1905. Cayo - ?, undated. .

The specimen from the vicinity of Manatee Lagoon vas collected by Peck in tall rain forest. At Gallon Jug in 1957 Willis saw this rare hawk on two occasions. On April 25 he noted an immature bird in the undergrowth of tall forest and on July 21 he saw an adult perched in a tree in a cutover area. The specimen from Cayo constitutes the only adoitional record from the Colony. 
I refer the specimen from Manatee Lagoon, which $I$ 37 have exarnined, to $\underline{A}$. $\underline{b}$. bicolor. The specirnen in the British Museum has not been critically examined in the course of this study, but is presumably referable to. this race also.

\section{Buteo albicaudatus Vieillot}

White-tailed. Hawk

SPECIMEN. MCZ: Ycacos Ligoon - o, Mar. 8, 1907.

This hawk is uncommon in. British Honduras. There are about a dozen sight records of the species, all made in March, April, and early May except for the observation of a single individual on August 25. Most birds were in pinelands, savanna, or the semi-open when observed, but on two occasions White-tailed Hawks were noted in tall forest. It is possible that some, if not all, individuals of this species recorded from the colony. were transients, since there is no direct evidence that it breeds there.

The race ranging from the United States to Venezuela is B. a. hypospodius.

\section{$38 /$}

Buteo jamaicensis (Gmelin)

Red-tailed Hawk

SPECIMEN. BM: Southern [= Mountain] Pine Ridge $-\sigma$, Jan. $10,1888$. 
I have seen Red-tailed Hawks in the Mountain Pine Ridge on several dates in March and April. Mr. J. H. Fleming critically examined the specimen in the British Museum about 1930 at the request of Mr. Todd and found it referable to B. $j$. costaricens $\frac{39}{i s}$, the resident race in much of Central America. Possibly the species is resident in British Honduras.

\section{Buteo platypterus (Vieillot) \\ Broad-winged Hawk}

SPECIMEN. CM: Toledo Settlement - ९, Oct. 22, 1906.

Peck collected the specimen, which represents the only record of the species from the Colony. The specimen is referable to the nominate race, B. p. platypterus:

Buteo magnirostris (Gmelin)

Roadside Hawk

SPECIMENS. ISUMZ: Hill Bank - 9 (303.3 g.), Feb. 20; o, Mar. 22; $\$(284.4)$, Apr. I; o (244.9), Nov. 25. Gallon Jug - o (248.5), Feb. 21; $\$(293.5)$, Mar. 2. Belize - O, Aug. 31. OTHER MUSEUMS (CC, CM, CNFM, MCZ, PC, UMMZ): Forty specimens from Belize, Manatee Lagoon area, Duck Run, Cayo, Middlesex, Freetown, All PInes, Toledo Settlment; ali months except Oct. Nov. CRITICAL PUBIISHED RECORD: Orange Walk (Salvin and Godman, Biologia, iii, 1900: 77).

The species is the commonest hawk in most parts of the mainland of British Fonduras, occurring in pinelands, low woodlands, and the semi-open. It frequents exposed 
perches, flies reluctantly, and moves sluggishly. Stomach contents have included grasshoppers, beetles, scorpions, spiders, and lizards. Roadside Hawks in breeding condition have been collected in March, April, and May; and Peck found a nest holding a halfgrown young bird on May 17, 1906. Other adult birds collected in spring were not in breeding condition. Specimens from Cayo, Belize, and the area to the north of these two localities exhibit characteristics of B. m. conspectus and B. $\underline{\text {. direptor. }}$. The latter race is dark plumaged and has a considerable amount of rufous in the basal half of the rectrices; whereas,

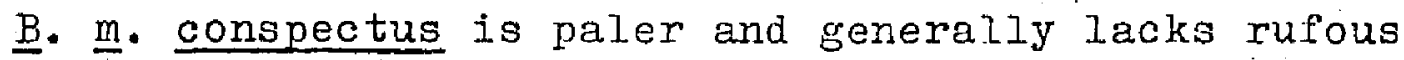
in the tail. Some specimens from this region are decidedly nearer one race or the other, but most specimens show a combination of racial characters. The population of this species in northern British Honduras is similar taxonomically in this respect to the population in southern Quintana Roo described by Paynter (195: 60). I refer specimens from Manatee Lagoon and localities in the southern two-thirds of the Colony to $\underline{B}$. conspectus. No size differences are demonstrable in the specimens from different areas of British Honduras.

\section{Buteo brachyurus vieillot}

Short-tailed Hawk

SPECIMEN. CM: Manatee Lagoon - 0, Aug. 6, 1905. 
Peck collected the only specimen, a melanistic adult, from the Colony. Single individuals were seen in $19>7$ by Willis at Hill Bank on August $b$ and between Belize and Cayo on August 9.

In a recent study of this species, Rand (1960: 448 - 459) referred North and Central American populations to $\underline{B}$. b. fuliginosus.

Buteo nitidus (Latham)

Gray Hawk

SPECIMENS. ISUMZ: Gallon Jug - $\$(387.6 \mathrm{~g}$.$) , Mar. 2l,$ 1955; ? (649.0), Mar. 31, 1955. OTHER MUSEUM (CM): roledo settlement - of, June 21, 1907.

The Gray Hawk is an uncommon to moderately common resident of the semi-open and has been recorded at many localities in the colony. The species occupies much the same habitat as $\underline{B}$. magnirostris but is more often found in the border between tall forest and clearings. the male collected March 2l was not in breeding condition, and no data concerning the reproductive condition of the other two specimens were recorded.

I follow Hellmayr and Conover (1949: 157) in referring all Gray Hawks north of Costa Rica to $\underline{b}$. $\underline{\text { n. plagi- }}$ atus. 
Leucopternis albicollis (Latham)

White Hawk

SPECIMENS. LSUMZ: Gallon Jug - ? (708.7 g.), Apr. 4, 1955. OTHER MUSEUM (MCZ): Toledo Settlement- $-\sigma$, Sept. 12, 1906; 7 , Dec. I5, 1906. CRITICAI PUBIISHED RECORD: Cayo (Salvin and Godman, Biologia, iii, 1900: 83).

Tall rain forest is the customary habitat of this uncommon resident, but occasionally it is found in tall second growth and the semi-open. Peck saw the spectes in the vicinity of Manatee Lagoon and of the Moho River, the only additional points of record. No data are available to indicate the breeding season of the White Hawk in British Honduras.

I refer the specimen from Gallon Jug to $\underline{\underline{I}}$. ghiesbreghti. Peters (1929: 418) noted that one of the two Toledo setllement specimens was referable to $\underline{I}$. ghiesbreghti but the other approached $\underline{I}$. a. costaricensis in "having the secondaries and inner primaries invaded with black."

\section{Busarellus nigricolizis (Latham)}

Fishing Hawk

SPECIMENS, LSUMZ: HiIl Bank - ? (11ל7 g.), Nov. 26, 1956. Two mi. W Gallon Jug - 9 (1195), Mar. 2, 1956. OTHER MUSEUM (MCZ): Sibun River -, , May I, 1906. Manatee River - 0', \$, May 12, 1906.

I have seen this uncommon resident at Stann Creek, at several localities on the New River, and near Hill 
Bank and Gallon Jug. Lagoons, rivers, and small ponds provide it with a suitable habitat. Landlocked ponds containing many small fish exposed in shallow water in the spring dry season are especially favored by the Fishing Hawk. The species often soars in wide circles over its feeding area. Ihe female that I collected near Gallon Jug contained an ovum $14 \mathrm{~mm}$. in diameter. Peck noted a nest about 40 feet above the ground in a pine tree near the Sibun River in April 1906. He did not determine the contents.

I refer British Honduran specimens to B. $\underline{\text { n. nigri- }}$ coliis, which ranges from Mexico to southern Brazil.

Buteogallus anthracinus (W. Deppe)

Common Black Hawk

SPEC IMENS. ISUMZ: Half Moon Cay - $\$(686.7$ g. ), May 7. OTHER MUSIUMS (CC, CM, PC, UMMZ): Thirteen specimens from the Manatee Lagoon area, is slope Cockscomb iits. $\left(750^{\circ}\right)$, Freetown; Feb., Mar., May, July, Sept., Dec.

The Common Black. Hawk is common locally in coastal British Honduras but is uncommon inland, al though it has been recorded several times at Gallon Jug, Habitats occupied by this species include the coastal beaches, mangrove swamps, pinelands, and less often, forests. The specimen from Half Moon Gay constitutes the only insular record. Nests axe usually placed in pine trees and the eggs laid in mid-April (Peck; Thomas, 1908: 116-118). I refer the specimens to $\underline{B}$. a. anthracinus. 


\section{Buteogallus urubitinga (Gmelin)}

Great Black Hawk

SPECIMENS. LSUMZ: Gallon Jug - ? (1I97 g.), Mar: 7; o, $9(996.0,1156)$, Nov. 7. OTHER MUSEUMS (CC, CM, IMCZ, UMMZ): Five specimens from the Manatee Lagoon area, 12 mi. S Cayo, Toledo Settlement; Feb., Mar., May, Oct. CRTTICAL PUBLISHED RECORD: Cayo (Salvin and Godman, Biologia, iii, 1900: 80).

The species is an uncommon resident in British Honduras; only a few observations from Galion Jug and one from Kendal supplement the specimen record. The pair of adult Great Black Hawks collected at Gallon Jug in November were taken in the edge of tall rain forest at a plantation clearing. Two collected by Van Tyne south of Cayo were on pine ridges. B. u. ridgway $\frac{49}{i}$, to which I refer the British Honduran specimens, ranges from Mexico to Panamá.

Harpia harpyja (Iinnaeus)

Harpy Hagle

Lancaster saw one individual of this rare species in tall rain forest at Gallon Jug on March II, 1958. The bird dropped to the ground, seized a snake, and flew to a low limb of a tree, where it proceeded to devour its prey. 


\section{Spizastur melanoleucus (Vieillot)}

Black and White lagle-Hawk

SPECIMENS. JMMZ: Cayo - $₫$, Mar. 21, 1931. Twelve mi. S Cayo - $\sigma$, Mar. 4, 1931.

The specimen from cayo, a male in breeding condition, held an adult Pteroglossus torquatus in its claws when it was shot by a native. Van Tyne examined the toucan and established that it had been killed by the hawk and not by the shot. South of Cayo, Murie collected a nonbreeding adult in the pine ridge. He found the remains of an adult Columba speciosa in its stomach. There are no other records of this hawk from British Honduras.

\section{Spizae"tus ornatus (Daudin)}

Crested Eagle-Ilawk

SPECIMENS. LSUNI: Eighteen mi. NW Gallon Jug - $\sigma$ $(840.5 \mathrm{~g}$.$) , Mar 24,1955$. Balierina Camp - o (1)42), Apr. 21, 19ל5. Two mi. W San Pedro Columbia - \$ (1760), May 6, 1956. OTHER MUSNUMS (BM, CM): Manatee Lagoon 9, July 5, 1905. Upper Makal [ = Lastern Branch Belize River] - undated specimen. CRITICAL PUBLISHED RECORD: Belize (Salvin and Godman, Biologia, iii, 1901: 92).

The Crested Eagle-Hawk is an uncommon resident in. British Honduras. It normally occurs in tall rain forest but at least occasionally leaves the forest to forage in pinelands. Near the Cockscomb Branch of South Stann Creek on May 6, 1958, I heard a female Crax rubra clucking a few yards away. I located the bird and shot 
it after it flew into a Trumpet Tree. As I picked up the fallen curassow, two large birds dropped from another tree 30 feet away. One was a $\mathbf{S}$. ornatus and

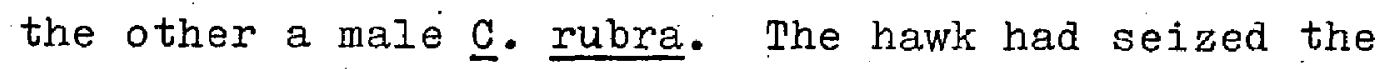
curassow in the tree, and it retained possession on the ground until my investigation caused it to release Its prey. The curassow fled, but the hawk flew to a low branch and remained there until I approached to within 25 feet. The local name, "curessow hawk," appears to be well founded, if the activity I witnessed is typical of the hawk. However, the crest of the eaglehawk may be the reason for its name. The eagle-hawk from Ballerina Camp was collected as it attempted to catch a snake in the water of the Eastern. Branch of the Belize River. None of the three birds now in the LSUMz was in breeding condition. In April 1907 Peck found a pair of $\mathrm{S}$. ornatus in possession of a nest that had been occupied only a few days earlier by Buteogallus urubitinga. The nest was situated 60 feet above the ground in a tall tree in the vicinity of Toledo Settlement.

Specimens from Central America and northwestern South America are referable to S. ㅇ. vicarius. The type of this race was collected by Peck in the pine ridge near Hanatee Lagoon. 


\section{Spizaetus tyrannus (Wied)}

Tyrant Eagle-Hawk

SPECIMEN. CNHM: Middlesex - ?, Feb. 9, 1923.

The specimén collected by Schmidt and Walters represents the orly record of the species from the Colony.

Friedmann (1950b: 3) examined the Tyrant EagleHawk from Pritish Honduras and referred it to $\underline{S}$. $\underline{t}$. serus.

\section{$51 /$}

Circus cyaneus (Linnaeus)

Marsh Hawk

I saw a female Marsh Hawk gliding over the mangroves on the outskirts of Belize on March 14, 1956. This observation of the species is the only one in British Honduras.

\section{Geranospiza nigra (DuBus) Blackish Crane Hawk}

SPECIMEN. CRITICAL PUBLISHED RECORD: Orange WaIk (Salvin and Godman, Biologia, iii, 1899: 53 ).

The published reference to a specimen collected by Gaumer is the only record from British Honduras.

G. n. nigra, which ranges from Mexico to Panamá, is undoubtedly the race to which the specimen is referable. 
The only other race occurring north of Panama is known onIy from Sonora, Mexico.

\section{Family PAIDIONIDAE}

Pandion haliaetus (Iinnaeus).

Osprey

SPECIMENS. ISUIRZ Calabash Cay - $\sigma$ (1340 g.), Apr. 10, 1956. OTHER MUSTUM (CM): Manatee Lagoon - ó, oct. 20 , 1905. CRITICAI PUBIISHED RECORDS: Belize, Half Moon Cay, Middle Cay of Glover's Reef (Hellmayr and Conover, 1949: 236, 237).

Ospreys, or "billy hawks". as British. Hondurans called them, are present in small numbers throughout the year at many coastal and insular localities and. occur sparingly on rivers and inland lagoons inf fall and winter. Griscom (1926: 13) found a pair of Ospreys with a nest containing eggs on Hick's Cay in January 1926, and Bond (1954: 4) saw a nest that he believed to be occupied on one of the Turneffe Islands in January 1954.

The specimen from Calabash vay is referable to $23 /$ P. $\underline{\text { h. }}$ ridgwayi and is representative of the resident breeding race. Specimens of $\underline{p}$. $h$. carolinensis have been collected in October at Manatee Lagoon and at: Belize in December. All the individuals that I have observed on rivers have been dark-headed and referable to the latter race. Thus, $\underline{P}$. $\underline{h}$ - carolinensis occurs 
at inland, coastal, and insular localities, whereas the breeding race is perhaps restricted to coastal and insular areas.

\section{Family FALCONIDAE}

\section{Herpetotheres cachinnans (Iinnaeus)}

Laughing Falcon

SPECIIAENS. LSUMZ: Gallon Jug - of (589.0 g.), Mar. 2; Q $(732.0)$, Nov. 7 ; $9(702.7)$, Nov. 18. Stann Creek o (582.7), Mar. 28. OTHER MUSEUMS (CC, CM, PC, MCZ): Eight specimens from the Manatee Lagoon area, Freetown, and Toledo Settlement; Jan., May, June, Sept., Oct., NOV. CRITICAI PUBIISHED RFCORD: Western $\dot{i}=$ Cayo] District (Salvin and Godman, Biologia, iii, 1901: 112).

The species is a moderately common resident of the semi-open throughout most parts of the mainland of British Honduras. Tall, isolated trees in pastures or second growth provide suitable perches for this noisy falcon. Its sustained calling, most frequently heard in early morning and late afternoon, may be distinguished at distances exceeding one-half mile. None of the four specimens that I collected was in breeding condition, and the size of the gonads was not recorded by the other collectors of Laughing Falcons.

The three specimens from Gallon Jug were obtained a few miles south of the type locality of 1 . c. chapmani. However, there is considerable individual variation among specimens from Mexico, British Honduras, and other parts 
of Central America that I have examined, and I refer the British Honduran birds to $\underline{H}$. $\underline{\text {. cachinnans. }}$

\section{Micrastur semitorquatus (Vieillot)}

Collared Forest Falcon

SPECIMENS. LSUMZ: Galion Jug - ' $\sigma$ (646.1), Nov. 12; $\sigma(479.0)$, NOv. 19. OTHER MUSTUMS (CM, MCZ): Four specimens from Manatee Lagoon, Freetown, Toledo Settlement, Woho River; May, Sept., Oct., Nov.

Four observations of this species at Gallon Jug in May and July by Lancaster and Fillis supplement the specimen data. Thelack of additional records suggests that the species is rare, but it is a shy species and frequents tall second growth and forest edges, where it is difficult to observe. It may also occur in the heart of rain forest, though $I$ have not seen it there. The specimens taken at Galion Jug were not in breeding condition, and there is no information indicating the reproductive condition of the gonads of the remaining specimens. naso:

The only race recognized north of Panamá is $\underline{\text { II. }}$. 57

\section{Micrastur ruficollis (Vieillot)}

Barred Forest Falcon

SPECIMENS. ISURZ: Ballerina Camp - $\sigma(174.0 \mathrm{~g} \cdot)$,

Apr. 30. Two mi. NE Millionario - o (235.9), Mar. 15. O'THER MUSEUMS (BM, CM, MCZ): Four specimens from Manatee Lagoon, Duck Run, Cayo; Apr., Oct. 
The Barred Forest Falcon is en uncommon inhabitant of the lower level of tall rain forest and has been recorded only at Gallon. Jug and at the collecting localities. On several occasions this small hawk abruptiy approached me as I attempted to imitate the high-pitched alarm call of a small bird. The female collected March 15 had a slightly enlarged ovary. I refer specimens from British Honduras to $\underline{M}$. $\underline{I}$. guerilla:

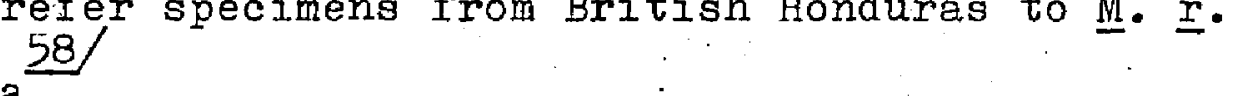

SPECIMENS. LSUMZ: HaIf Moon Cay - ( $(973.5 \mathrm{~g}$.$) , Mar.$ 25, 1958. OTHER MUSEUM (PC): Manatee Bar - ?, Nov. 10, 1905.

The Peregrine. Falcon is an uncommon winter visitant and transient in British Honduras. Willis saw one individual at Galion Jug on May 5, 1957; of 13 sight records, his is the only one that is not from an insular locality. On Half Moon Cay during the spring of 1958, Verner observed 12 birds on elght dates from March 20 to April 19, including four individuals on April 16. I refer the British Honduran specimens to $\underline{F} \cdot \mathrm{p}$. anatum. 59 
Falco albigularis Daudin

Bat Falcon

SPECIMENS. LSUMZ: Gallon Jug - o (128.9 g.), Feb. 28; $\sigma(141.2)$, Mar. 15; $\%(195.0)$, Apr. 5. OTHER MUSEUMS (BM, CC, CM, PC, UMMM): Fifteen specimens from the Belize River near Belize, Manatee Lagoon area, Cayo, $12 \mathrm{mi}$. S Cayo, Freetown, All Pines; all months except June, Oct., Dec.

The Bat fialcon is a common resident of the pine ridges and of clearings in the vicinity of woodlands in most regions of the mainland of the Colony. The species has not been recorded south of Ycacos Lagoon, although it is to be expected there. Insects and small birds make up a considerable part of the diet of this swiftly flying hawk, but its cominon name is not without justification. Murie (1935: 20) found the remains of the bat Molossus aztecus in a Bat Falcon he collected on the Mountain Pine Ridge in webruary. Some of the Bat Falcons taken in the period of February to May had enlarged gonads.

I refer the specimens from British Honduras to the nominate race, $\underline{F}$. a. albigularis.

\section{Falco femoralis Temminck}

$$
\text { Aplomado Falcon }
$$

SPECIMENS. ISUMZ: Hill Bank - $\checkmark$ (235.I g.), Feb. 18, 1956: OTHER MUSEUM (MCZ): Ycacos Lagoon - $\sigma$, Mar. 8, 1907 .

The Aplomado Falcon is rare or local in British Honduras. The half dozen records from the Colony were 
obtained in February, March, April, May, November; and Decernber in coastal scrub, lowland pinelands, and the Mountain Pine Ridge. There are no breeding data from British Honduras, but I presume the Aplomado Falcon is a resident, although some northerm individuals may winter as far south as the Colony.

Friedmann (1950a: 687) referred the specimen from Ycacos Lagoon to F. $f$. femoralis. ${ }^{61}$ The male from $\mathrm{Hill}$ Bank has the following measurements: wing 244.0, tail 160.0, and culmen from cere $16.0 \mathrm{~mm}$. On the basis of its small size, I refer. It also to the nominate form.

\section{Falco columbarius Linnaeus}

Pigeon Hawk

No specimens of this small falcon have been collected in British Honduras, but in 1958 Verner saw single bixds at Half Moon Cay on seven dates from April 7 to May 6 and 20 individuals on April 16.

\section{Falco sparverius Linnaeus}

\section{Sparrow Hawk}

SPECIMENS. ISUMZ: Gallon Jug - ?, Feb. 17 ; o (90.2 g.), Mar. 1; 8 (108.7), Nov. 17. OTHER MUSEUMS (BM, CM, MOZ)! Seven specimens from Belize, Manatee Lagoon area, Cayo, $12 \mathrm{mi}$. S Cayo; Feb., Mar., Oct., Nov., Dec. CRITICAL PUBIISHED RECORD: Órange Walk (Salvin and Godman, Biologia, iii, 1901: 123). 
The Sparrow Hawk is a moderately common winter visitant and has been recorded from october 18 to April 9 in the Colony. The species frequents pinelands and the semi-open at all elevations. At Gallon Jug, presumably the same individual perched daily on the flag pole at the landing field from the time of its arrival in the fall until its departure in the following spring.

All specimens from British Honduras are referable to $\mathrm{F}$. $\mathrm{B}$. sparverius. $62 /$

Pamily CRACIDAE

\section{Crax rubra Iinnaeus}

Great Curassow

SPECIMENS. ISUMZ: Galion Jug area - ?; Mar. 16; 9 $(4120 \mathrm{~g}$.$) , Mar. 26; o (4060), Mar. 27; of (4230), Mar.$ 28; $\sigma$ chick (160.I), May 30. OTHER MUSEUM (CM): Two specimens from Manatee Lagoon, I slope Cockscomb Mts. $\left(750^{\circ}\right)$; Mar., Sept.

The Great Curassow is resident in tall rain forest and is common where it is not extensively hunted. It ranges throughout the mainland where suitable habitat exists; and $I$ have seen it from near sea level to about 3000 feet elevation. On May 4, 1956, on a trail beside Cockscomb Branch, I disturbed a female curassow, which feigned injury and attempted to lead me away. When I turned opposite to the direction in which she apparently wished to lead me, she uttered a threatening, 
mammallike snarl, similar to that of an angry dog. I then sat motionless for several minutes and the curassow circled clockwise about me nany-tines at a half-run, half-walk. The radius of these circles varied from 10 to 30 feet. Presumably a nest or young birds were in the vicinity. She ran ahead of me as I departed and after a hundred feet she. whirred high into the air and disappeared. Normaliy curassows run away when alarmed or fly into the treetops and continue to move away by many short flights.

I refer the British Honduran specimens to the nominate race, $\underline{\underline{C}} \underline{\underline{r}}$. rubra.

\section{Penelope purpurascens Wagler}

Crested Guan.

SPECIMENS. ISUMZ: Gallon Jug - ?, Jan. 23. OTHER MUSEUMS (CM, MCZ, UMRZ): Five specimens from the Manatee Lagoon area, $12 \mathrm{mi}$. S Cayo, E slope Cockscomb Mts. (750.); Feb., Mar., Aug., Oct.

The arboreal Crested Guan is a moderately common resident of tall, undisturbed rain forest and ranges from forests near sea level to above 3200 feet in the Cockscomb Mountains. Along with other game species, the guan, or "quam" as it is called locally, is least numerous where extensively hunted. The specimen collected in February was an adult male weighing about 2.1 kilograms and was one of a pair found near the edge of the pines in the Mountain Pine Ridge. 
I refer the specimens to the nominate race, $\underline{P} . \underline{p}$.
purpurascens.

Ortalis vetula (Wagler)

Plain Chachalaca

SPICIMENS.' LSUNZ: GalIon Jug - P (408.9 g.), Mar. 2I; 5'(487.0), June 4. Ballerina Camp - $9(414.6)$, Mar. 9. Two mi. W San Pedro Columbia $-\sigma ; q(384.6,401.6)$, May 6; $7(345.5)$, May 11. OTHER MUSEUMS (CC, CM, CNHM, MCZ): Thirteen specimens from the Manatee Lagoon area, Duck Run, Middlesex, 22 Mile Station, Mountain Cow, Freetown, Sittee River; Jan., Feb., Apr., May, June, Sept. CRI'PICAI PUBLISHED RECORD: Vicinity of Belize (Ogilvie-Grant, 1893: 514).

The "cockrico" is a common resident throughout the mainland of British Honduras, and is found in thickets, dense second growth, and the border of rain forest. Willis saw a short-tailed young bird clambering about the low branches of a tree accompanied by its parents on February 27 -- evidence that breeding begins at least as early as January. I have collected individuals in breeding condition in March and May.

The specimens from Gallon Jug are clearly referable 65 to . . $v$. intermedia. I assign specimens from the other British Honduran localities to $\underline{\underline{O}}$. $\underline{\mathrm{v}}$. plumbiceps on the basis of the bicolored tips of the rectrices and the color of the under parts. Some specimens from the central part of the Colony are intermediate in these characters, as would be expected in a region of overlap between the races. 


\section{Colinus nigrogularis. (Gould)}

Black-throated Bobwhite

SPECIMENS. BM, CC, CM, MCZ, UMMZ: Twenty-five specimens from the vicinity of Belize, Manatee Lagoon area, Freetown, All Pines, Ycacos Lagoon, Toledo Dist.; all months except Jan., Aug., Sept., Oct.

The species is a moderately common resident of lowland pine ridges from the vicinity of Hill Bank south to Ycacos Lagoon. A mixture of oak, pine, and palmetto overgrown with high grasses provides its preferred habitat. Coveys are difficult to flush since the birds prefer to run if the cover is adequate. Each of the 13 specimens collected by Blake and Agostini at Freetown and All Pines in April and May had enlarged gonads.

I refer specimens of the Black-throated Bobwhite from British Honduras to $\underline{\mathrm{C}}$. $\underline{\mathrm{n}}$. nigrogularis.

\section{Odontophorus guttatus (Gould)}

Spotted Wood-Quail

SPECIMENS. ISUMZ: Gallon Jug - $-6(356.9$ g.), Mar. 19. Augustine - 7 , Dec. 13. OIHER MUSEUMS (CM, MCZ): Five specimens from Augustine, Camp VI, N slope Cockscomb Mts. (1300'), Freetown; Mar., Apr., May . CRITICAI PUBIISHED RECORDS: Rio Hondo (Salvin and Godman, Biologia, iii, 1903: 312); Belize, San Felipe (Ogilvie-Grant, 1893: 440,441$)$.

The Spotted Wood-Quail, which is called the "congo bird" by inhabitants of the Colony, is a moderately common resident of tall rain forest and high second 
growth in British Honduras. Although the species is predominantly terrestrial and usually runs when alarmed by humans, it can be flushed by dogs. The birds fly onto low limbs and remain motionless; I have been told by natives that the birds can then be struck with a stick. I collected a male in March that had fuliy enlarged testes and a female in December that possessed many follicles $3 \mathrm{~mm}$. in diameter.

FamiIy MELEAGRIDIDAE

Meleagris ocellata Cuvier.

Ocellated Turkey

SPECIMENS. ISUMZ: GaIIon Jug - o; Feb, 22, 1953; (5530 g.), Mar. 25, 3.955; ? chick (45.3), June 6; 1956.

The Ocellated Turkey is a moderately common resident from the Bastern Branch of the Belize River on the southern edge of the Mountain Pine Ridge through the northwestern sector of the Colony. Forest borders and low and moderately tall second growth provide the turkeys' favored habitats. Probably the vast regions of rain forest limit its southern distribution, since it does not penetrate the forest. There are a number of - published records of the Ocellated Turkey from British Honduras dating back into the last century, but specific localities are not stated. Lancaster found a nest and eggs of this species on April 27, 1957, near Gallon Jug. 


\section{Farnily ARAMIDAE}

\section{Aramus guarauna (Linnaeus)}

\section{Limpkin}

SPACTMENS. LSUMZ: HiIl Bank - $\sigma$ (1480 g.), Mar. 24; 5. (1120), Nov. 23. Four mi. NGalion Jug - o" (1294), Feb. 29. OTHER MUSWUMS (PC, UMIRZ): Three specimens from Belize, Manatee Lagoon; Apr., Nov.

In the northern third of the Colony, Limpkins are common residents of marshy river banks, and lagoon and pond edges. They have been recorded in the eastern lowlands as far south as the Sittee River. The testes of the rale collected March 24 were only slightly enlarged; those of the male coliected November 23 were moderately enlarged, and those of: the male obtained in February were fully enlarged. Undoubtedly the variety of sounds produced by this species have led to its. local name, "clucking hen."

I refer British Honduran specimens to the Central American race A. $g$. dolosus:

$$
68
$$

\section{Family RALIIDAE}

Rallus longirostris Boddaert Clapper Rail

SPECIMEN. MCZ: Ycacos Lagoon - ?, May 14, 1907.

The Clapper Rail frequents coastal and insular mangrove swamps in British Honduras. It is common 
locally but its elusiveness, in such an impenetrable habitat makes it exceedingly difficult to collect. Peck obtained a nest and five eggs along with the brooding female at.Ycacos Lagoon. The nest was situated about 5 feet above the water in the branch of a mangrove. The species is familiar to coastal and. insular inhabitants, who call it "top-na-chick" or "chink-topnah."

The one specimen from British Honduras is the. type of R. I. belizensis $\frac{69}{}$ No additional specimens have been collected of this race. Clapper Rails exhibit much individual variation and a series will be necessary to establish the taxonomic position of coastal and insular birds in the Colony. However, I have no other basis on which to doubt the validity of the race belizensis.

\section{Pardirallus maculatus (Boddaert) \\ Spotted Rail}

SPRCIMEN. HCL: Ycacos Lagoon - ?, June, 1907.

Peck obtained this specimen from Hubert Payne, a local collector. Nothing was recorded concerning the habitat in which the bird was found.

The specimen is the type of $\underline{P}$. m. insolitus. The only additional specimen of this race known to me is one taken near Tuxtla Gutierrez, Chiapas, in 1946 (Friedmann, 1949: 86). 


\section{Amaurolimnas concolor (Gosse) \\ Uniform Crake}

SPECIMEN. CHI Freetown - $\sigma$, Apr. 30, 1935.

The specimen was collected by Blake and Agostini near the sittee River and was in breeding condition. Peck states in his notes that he collected a Uniform Crake on high ground in tall rain forest near Manatee Lagoon in January 1907. Apparently the specimen was not preserved.

The extant British Honduran specimen is referable to A. c. guatemalensis.

$$
71 \%
$$

Aramides cajanea (P. I. S. Mulier)

Gray-necked Wood Rail

SPECIMENS. ISUMZ: Six mi. NNE Hill Bank - q (475.0 g.), Mar. 31. Ballerina vamp - $x$ (454.8), Apr. 21. OTHER MUSEUMS (CM, MCZ): Fifteen specimens from the belize River, Manatee Lagoon area, Mountain Cow, Freetown, Sitte River; Mar., Apr., May, Aug., Sept., Nov. CRITICAI IUBJISHED RECORD: Belize (Sharpe, 1894: 60).

This wood rail is a moderately common resident and has been recorded in all sections of the mainland. It is most numerous in the swampy woodlands in the northern two-thirds of the Colony, but it also inhabits mangrove swamps and well-drained tall forests in the vicinity of streams and ponds. I have recorded it up to an elevation of 1600 feet in forested valleys in the Mountain Pine Ridge. The Gray-necked Wood Rail, or 
"top-na-chick" as it is more frequently called in British Honduras, is shy and is most frequently seen walking on branches overhanging waterways or on exposed regions of stream banks. Half the adult specimens collected in March, April, and May were in breeding condition. Specimens from British Honduras are topotypes of A. c. albiventris.

\section{Aramides axillaris Lawrence}

Rufous-necked Wood Rail

SPECIMEN. CRITICAI PUBLISHED RECORD: Belize (Sclater. and Salvin, 1868: 449).

A specimen, probably now lost, was collected in the mangroves near the mouth of the Manatee River in March, 1901, by Peck. This is the only record supplementing the specimen reported by Sclater and Salvin.

\section{Porzana carolina (Iinnaeus)}

\section{Sora}

SPECIMENS, LSUMZ: Hill Bank - $\sigma(81.4$ g.), Mar. 24, 1955. Galion Jug - $5(67.9)$, Nov. 7 , 1956. OTHER MUSEUM (CM): Manatee Lagoon area - Q, Sept. 27, i905. CRITICAL PUBLISHED RECORD: Belize (Sharpe, 1894: 100).

The Sora is an uncommon by recorded transient and winter visitant. Two or three individuals wintered in a wet grassy area at Gallon Jug and were recorded there 
from 0ctober 22 to March 13. I observed this rail at Hill Bank in November, and Peck shot one at Toledo Settlement in February but did not preserve it. Verner saw one migrant on Half Woon Cay on April 11, the only other individual recorded from the Colony. I suspect the species is more common than these records indicate.

Laterallus ruber (Sclater and Salvin) Ruddy Crake

SPECIMANS. LSUMZ: Hill Bank - 7 , $q(48.9,41.6$ g.), $\mathrm{Feb} .25 ; \zeta$, $(48.5,42.5)$, Nov. 29 . Pomona - o $(44.0)$, Mar. 28. Two mi. W'San Pedro Columbia - 2 's (42.7, 47.6), May 4. OTHIR MUSEUMS (MCZ, UMMIZ): Hive specimens from Belize; Manatee Lagoon area, Toledo Settlement; Jan., Feb., Apr., Dec.

The Ruddy Crake is Iocally common in British Honduras. The only points of record not listed in the record of specimens are Gallon Jug, Kendal, and Ycacos Lagoon. The species occupies a variety of grassy habitats: tall sawgrass, low grasses growing in water, and grass in fields, pastures, ditches, and citrus groves. Near San Pedro Columbia, I found crakes in the dense grass of low huamil on hillsides with Thamnophilus doliatus and Arremonops conirostris. A mousetrap baited with peanut butter and oats and set in the grass near a citrus grove at Pomona captured an individual at noon. The long, drawn-out, descending trill or whinny of this crake is distinctive and is heard most frequently at sunrise and about two hours before sunset. The specimens that I collected in spring 
at Hill Bank and San Pedro Columbia had slightly enlarged gonads but were probably not yet breeding. Peck found three spherical nests of this species constructed in tussocks of orass; two were incomplete on Niriy 21 and $M a y$ 23, and the third contained an ege on June 6 .

Both Brodkorb (1943: 35) and Paynter (1955: 90) examined Mexican and Central Amexican specimens of Laterallus ruber and concluded that on the basis of their material they were unable to recognize any geographic variation. The species is not common in colleotions and in the seven recent specimens from the Colony, I find individual variation exceeding that ascribed to geographic variation in the species. Consequently, I concur in considering the species monotypic.

\section{Gallinula chloropus (Linnaeus)}

\section{Common Gallinule}

Iwo to four Common Gallinules were seen at a marshy pond near Gallon Jug in February, March, and October 1956 (Russell), March 1957 (Willis), and February 1958 (Lancaster). I saw one individual in a marsh at Stann Creek on Warch 23, 1956. These observations, the only records of the species from the Colony, do not indicate whether the birds were residents, winter visitants, or migrants. 


\section{Porpilyrula martinica (Linnaeus)}

Purple Gallinule

SPECIMENS. LSUIV: Two mi. W Gallon Jug - (218.8 g.), Mar. I, 1956. OTHER MUSDUM (BM): Three undated specimens from Crooked Tree Lagoon. CRITICAI PUBLISHED RICORD: Orange Walk, Dec. (Sharne, 1894: 191).

Willis noted a pair of Purple Gallinules at a marshy pond near Gallon. Jug on July 7 and $21,1957$. The lateness of these dates indicates that the species may breed there. The only additional sight records from the Colony are from the same pond in February and harch. The individual collected there March 1 , 1956, had a slightly enlarged ovary.

Fulica americana Gmelin

$$
\text { American Coot }
$$

SPECIMTHS. ISUMZ: Hill Bank - ? (402.4 g.), Nov. 29, 1956.

This species winters in small numbers on streams and fresh-water ponds in British Honduras and has been observed on a total of only nine dates near Orange Walk, Hill Bank, Maskalls, and Stann Creek. Thirty individuals at the latter locality on March 23, 1956, had dwindled to two birds on March 30 .

American Coot in North and Central America are referabie to $\underline{\mathrm{F}}$. a. americana. 
Family HEIIORNITHIDAE

\section{Heliornis fulica (Boddaert)}

Sun Grebe

SPECIUENS. ISUMZ: Three mi. SW Hill Bank - ‘' ( 139.6 g.), Nov. 30. OTHER MUSWUMS (CC, CM, MCZ, PC, UTHZ): I'welve specimens from the Belize River near Belize, Sibun River, Manatee Lagoon area, Duck Run, Freetown, Rio Grande; Jan., Feb., Mar., Apr., Nay, Nov., Dec. CRITICAI PUBIISHED RECORD: Rio Makal [= wastén Branch Belize River] (Sharpe, 1894: 235).

The Sun Grebe is a moderately common resident of rivers and streams in the colony. I have seen it at elevations from near sea level to ls00 feet. Quiet sections of waterways flowing through woodlands provide its preferred habitat. Normally sun Grebes seek shelter by swimming away from the cause of alarm or by darting swiftly into the vegetation on the banks. If sufficiently alamed, they fly rapidly to cover. The specimen taken near Hill Bank was collected at night by a netive hunting in his dory by carbide light. He struck the swimming bird with his boat paddle. The specimen was an adult with much fat, but it was not in breeding condition.

Family JACANIDAE

Jacana spinosa (Iinnaeus)

Jacana

SPECIMENS. ISUMZ: Gallon Jug - $-(86.3 \mathrm{g.})$, Oct. 26. Stann Creek - $\sigma(86.4)$, Mar. 24. OTHER MUSEUMS (BM, CM, MCZ, UMMZ, USNWI): Fourteen specimens from Crooked Pree 
Iagoon, Belize, Sibun River, Freetown, Sittee River; Jan., Feb., Apr., May. CRITICAL PUBLISHED RECORDS: Orange Walk, Belize River (Sharpe, 1896: 88).

The Jacana or "Georgia bull," as it is called locally, is a common resident of ponds and slowly flowing rivers where mats of floating aquatic vegetation are abundant. Breeding apperently reaches a peak in April and May. The gonads of individuals collected. by Blake and Agostini in late April and early May were enlarged and on May 26 I saw adults and chicks along the New River.

I refer British Honduran specimens to J. s. spinosa.

Family CHARADRIIDAE

Squatarola squatarola (Iinnaeus)

Black-bellied Plover

SPECIMEN. ISUMZ: Calabash Cay - o(169.4 g.), Apr. 14, 1956.

The Black-bellied Plover is an uncommon winter visitant on the sand beaches of the islands of the colony. It has been recorded only on Half Moon Cay in February (Lencaster and Verner), on Calabash Cay in April (Russell), and Long Cay in December (van Tets). Fewer than seven individuals were noted on each occasion. 
Charadrius semipalmatus Bonaparte

Semipalmated Plover

SPECIMENS. LSUMZ: Half Moon Cay - P, Apr. 23, $19>8$. OPHER IMUSEUAS (CH, PC): Near Manatee Lagoon - $\checkmark$, Oct. 6, 1905; . Nov. 14, 190b.

Verner saw this species almost daily on Half

Moon Cay in 1958 (February 1ל - May 8). Ilarked

increases in his daily counts of individuals on several dates in late February, March, and early April undoubtedly are attributable to migration. His maximum oneday count was 24 individuals. Some semipalmated Plovers winter on the keys, as indicated by birds seen on Half Moon and Long Cays in December by van l'ets. Ithe species is known from the mainland only from the two Manatee Lagoon specimens and "one Ione bird on the Belize River, March 17" (Austin, 1929: 371). There are no additional records from the Colony.

\section{[Charadrius melodus ord]}

Piping Plover

Peck states in his notes that he collected a: Piping Plover in March 1901 at Manatee Lagoon, but I do not know the present location of the specimen. This record must be considered hypothetical, because the species has not otherwise been recorded from Central America, and the identity of Peck's specimen has" not been confirmed. 
Charadrius collaris vieiliot

Collared Plover.

SPECIMEN. LSUMZ: Stann Creek - $\sigma^{*}(30.0$ g.), Mar. 28, 1956.

One individual at Stann Creek on March 28, 1 yb6 (Kussell), six on valabash vay on April 11, 1956 (Kussell), and Iive on Halit jioon lay on jebruary 14 , 1958 (Iancaster), cunstitute the only records of this species from British Honduras.

\section{Gharadrius vociferus Iinnaeus}

\section{Killdeer}

SPECIMENS. ISUMZ: Gallon Jug - q (86.0 g.), Mar. 29. OTHER MUSTUIS (CM, UIMZ): Inree specimens from $8 \mathrm{mi}$. NW Belize, Manatee Lagoon, 12 mi. S Cayo; H'eb., Mar., Nov. CRITICAI PUBIISHPD RECORD: vayo (Sharpe, 1896: 246).

Whe Killdeer is moderately common in British Honduras from October to late March, the extreme dates being October 23 and Aprit 1. It occurs from the coast to 2,500 feet in the hountain Pine kidge wherever exposed ground or short grass tielus are present. Most wintering birds have been seen on the mainland, but some individuals were noted on Halt Moon Cay in Lecember and early January (van Tets). Undoubtedly, some birds are transients in tall and spring, but it is not possible to distinguish between migrants and winter visitants. During his three months stay on 
Half Moon Cay in the spring of 1958, Verner saw ondy two Killdeer, one on March 2 and the other on March 31. I'his would indicate that the migratory route of transient individuals either does not pass over the island or that the Killdeer is not afrected by the same con- .. ditions that caused other migrants to stop on the island. I'he specimens are reterable to the nominate race o. v. vociterus. 75

\section{Uharadrius wilsonia ord}

$$
\text { Wilson's Plover }
$$

SPECINENS. LSUMZ: Belize - $\checkmark$, Aug. 31, 1460. URIIICAL PUBLISHED RECORD: Grassy Cay (Salvin, 1864: 387).

salvin collected two adults and found two nests of the Wilson's Plover on Grassy Cay on or about May 20, 1862. sxcept for a few individuals seen on the Hanatee beach and on keys north of Belize by Peck in liarch and April 1901, the species has been recorded subsequently only by Lay, who collected a specimen at Belize. The testes of this bird were not enlarged.

I refer the specimen from Belize to $\underline{c}$. w. wilsonia. The Check-list of North American Birds (1957: 169) cites Grassy vay as the southernmost breeding locality of the norinate race in ventral America. 
Family SCOLOPACIDAE

Bartramia Iongicauda (Bechstein)

Upland Plover

SPICIMENS. BM: Two specimens from Cayo, Apr. 8 and 26 , 1889. CRITICAI PUBIISHED RECORD: Turneffe Islands (Salvin, 1864: 385).

The specimens represent the only records of the species from British Honduras. The bird from the Turneffe Islands was collected by Salvin on or about. May 18, 1862.

Numenius phreopus (Iinnaeus)

Whimbre1

SPECIMEN. CRITICAI PUBIISHED RECORD: Belize (Forbes and Robinson, 1899: 69).

The only record of the Whimbrel in British

Honduras is cited above. The specimen is probably referable to N. $\mathrm{g}$. hudsonicus, as no other races have been recorded from Central America.

\section{Iimosa fedoa (Iinnaeus)}

Marbled Godwit SPECIMENS CRITICAL PUBLISHED RECORD. Belize (Moore,
1859: 64 .

British Honduras is often included within the winter range of the Marbled Godwit, presumably on the basis of a specimen collected by Ieyland, who considered 
it "common" (Moore, 1859: 64) at Belize. The specimen is listed by Forbes and Robinson (1899: 70), but without the date on which it was collected. 'There are no additional records of the species. from the Colony.

\section{Totanus flavipes (Gmelin)}

Lesser Yellowlegs

SPECIMENS. ISUMZ: Stann Creek - $\sigma(63.9 \mathrm{~g} \cdot)$, Mar. 28, 1956. OTHER MUSEUM (UMMZ): Belize - $\%$, Feb. 17, 1931.

I. saw one Lesser Yellowlegs at Hill. Bank on February 19, 1956, and one or two almost daily from March 23 to 30, 1956, at Stann Ureek. Peck observed a few individuals in the Manatee Lagoon area in spring but mentioned no specific dates in his notes. The specimen from Belize, collected by Shufeldt, provides the only additional British Honduran record.

Totanus melanoleucus (Gmelin)

Greater Yellowlegs

SPECIMENS. ISUMZ: Stann Creek - o, Mar. 24, 1956. OTHER MUSEUMS (BM, USNM): One specimen labeled "British Honduras," another from Belize; without dates.

verner observed three Greater Yellowlegs on Half Moon Cay on March 26, 1958, following a storm the preceding night. On August 24, 1960, Lay saw an individual on the coast at Belize. lhere are no additional sight records. 


\section{Tringa solitaria Wilson}

\section{Solitary Sandpiper}

SPICIMENS, IISUNZ: Gallon Jug - q, ? (40.2, $37.0 \mathrm{g.})$, Mar. 3, 1956. OTHER MUSEUMS (BH, MCZ): Sibun River - i, May 2,1906 . Cayo - ?, Apr. 5, 1889.

The Solitary Sandpiper is a rare winter visitant and a moderately comon spring and fali transient through British Honduras, found usually near freshwater ponds. The earliest recorded southbound migrant was seen by ifillis at GaIlon Jug on July 30, 1957. In spring, individuals have Iingered as late as May 2. There are no Novenber or December records, but Iancaster and Peck each saw Solitary Sandpipers once in January.

The two birds collected in march are referable to the nominate form, $\underline{\text { T. s. solitaria. }}$

\section{Actitis macularia (Iinnaeus)}

Spotted Sandpiper

SPECIMENS. ISUMZ: Ballerina Camp - o (4l.b g.), Apr. 27. OTHER MUSEUMO (BM, CM, JMMZ): Nine specimens from Manatee Lagoon, Cayo, Eastern Branch Belize River, 12 mi. S Cayo, Freetown, All Pines; Mar., Apr., May, Aug. CRITICAL PUBIISHED RTCORD: Belize' (Forbes and Robinson, 1899: 71).

The species is a common spring and fell migrant and winter visitant on lagoon, pond, and river banks, on beaches, and in rocky streams. Spotted sandpipers have been observed at many insular, coastal, and inland 
localities in British Honduras and in all months of the year, but they have not been recorded in a short period in early summer (June 2 - July 30). Although most records are of single individuals, Blake and. Agostini saw flocks of as many as 25 birds on May $1<$, 13 , and 14, 1935 .

\section{Catoptrophorus semipalmatus (Gmelin) \\ Willet}

SPECIMENS. LSUMZ: Hill Bank $-\sigma(261.0 \mathrm{~g}$.$) , Mar. 30$, 1955.

The Willet has been recorded in British Honduras only a few times. Peck observed the species in April 1901 on the beach near Manatee Lagoon, but he was not specific in recording numbers of individuals or dates. Läncaster noted two birds on Northern Iwo Cays on February 15, 1958. Verner saw one on Half moon Cay on April 23, 1958. And on August 24, 1960, Lay recorded an individual on the coast at Belize.

I refer the specimen to $\mathrm{C}$. $\underline{\mathrm{s}}$. inornatus, but $\mathrm{C}$. . semipalmatus probably also occurs in the colony.

\section{Arenaria interpres (Iinnaeus)}

Ruddy Turnstone

SPECIMENS, LSUMZ: Calabash Gay - o, o (112.2, 123.2 g.), Apr. 15, 1956. Stann Creek - $(96.6)$, War. 28, 
1956. CRITICAI PUBIISHED RICORD: Turneffe Islands (Salvin, 1864: 385 ).

Ruddy Turnstones have been observed on the beach at Stann Creek and many insular locklities. Harly and late dates of record for this moderately common visitant are in mid-December and mid-May, but turnstones undoubtedly could be recorded in other months also. I saw flocks of 20 and 22 but most records were of fewer individuals. Verner saw turnstones alrnost every day on Half roon Cay in the spring of 1958. Salvin (1864: 385) recorded this species on sillen and Curlew Cays and implied that he collected it on "Turneffe" on May 18, 1862. Sharpe (1896: I02) Iists specimens collected by Salvin on Saw pit Key and "Turneff Land." The species is so widespread on the keys that the specific locality is inconsequential; all the keys mentioned are part of the Turneffe Islands.

The British Honduran specimens in the ISUMZ are referable to $\underline{A}$. $\underline{\text { i. morinella. }}$.

\section{Capella gallinago (Linnaeus)}

Common Snipe

SPECIMENS. LSUMZ: Gallon Jug - $\sigma(73.8 \mathrm{g.})$, Oct. 27. OTHER MUSIUMS (CM, UIMZ): Five specimens from Belize, Manatee Lagoon; Feb., Nov. CRITICAL PUBIISHED RECORD: Cayo (Sharpe, 1896: 646).

Snipe are moderately common in wet grassy areas of the mainland from mid-November to late March. The 
earliest fall arrivals were noted on 0ctober 27, and the latest spring birds were seen by Peck on an unspecified date in April. Only one common snipe has been recorded on the keys, a bird seen by Verner on Half Moon Cay on March 31, 1958. I believe snipe are more numerous in November, February, and March than in other months, but my data are not adequate for quantitative analysis. delicata. I refer the specimens from the colony to $\underline{\mathrm{g}} \mathrm{g}$.

Crocethia alba (Pallas)

Sanderling

SPECIIENS. LSUMZ: Stann Creek - $\sigma(58.2 \mathrm{g.})$, Mar. 28, 1956. CRITICAI PUBIISHED RECORD: Northern Two Cays (SaIvin, 1864: 386).

The individual collected at Stann Creek was very fat. It was one of four birds that I saw there on the sand beach. Salvin presumably optained only one specimen. There are no additional observations of the Sanderling in British Honduras.

Ereunetes pusillus (Linnaeus)

Semipalmated Sandpiper

SPECINEN, CM: South West Cay in Glover's Reef - 9 , Niay $31,1935$. 
Verner saw one Semipalmated Sandpiper on Half Moon Cay on April 5, 1958. This is the only other record of the species from the Colony.

\section{Ereunetes mauri Cabanis}

Western Sandpiper

verner carefully studied one Western Sandpiper on Half Moon Cay on March 20, 1958. This is the only record of the species in British Honduras.

\section{Erolia minutilla (Vieillot)}

Least Sandpipex

SPECIMENS, ISUMZ: Belize - $\gamma$, $q(18.2,18.8 \mathrm{~g}$.$) ,$ Mar. 7. Half Moon Cay - z (20.9), Mar. 9. Stann Creek - 2 ' 's $(18.7,21.5)$, Mar. 23. OTHER MUSIUUS (BM, MCZ, UMMZ): Five specimens from Belize, Cayo, Toledo District; Apr., May., Oct., Nov.

The species is a moderately common transient and winter visitant at coastal and insular localities and has been recorded from October 9 to May 8. It undoubtedly arrives earlier in the fall than the october date indicates. On Half Moon Cay in the spring of 19ל8, Verner saw Least Sandpipers almost every day, but usually fewer than eight individuals. There were no marked fluctuations in his daily total counts of individuals that suggested the passage of transients from the south. 


\section{Erolia fuscicollis (Vieillot)}

White-rumped Sandpiper

SPECIMEN. CH: North East Cay in Glover's Reef - $?$, May $30,1905$.

The specimen collected by Blake and Agostini and a. flock of 40 individuals seen on the Belize River on March 20, 1928, by Austin (1929: 371) constitute the only records of this species from the colony.

\section{Erolia melanotos (Vieillot)}

Pectoral Sandpiper

SPECIMENS. LSUMZ: Gallon Jug - o (60.4 g.), Mar. 14, 1957. OTHER MUSEUMS (CM, MCZ): Belize - 2 '́'s, Apr. 3, 1931. Ycacos Lagoon - 9, May 22, 1907.

Shufeldt indicates in his notes that Pectoral Sandpipers vere numerous in the vicinity of Belize in freshwater ponds on April 3, 1931. One adiitional observation of the species in British Honduras was made by Peck, who saw two individuals in company with a flock of Jacanas on the Sittee River on April 29 , 1907.

\section{Tryngites subruficollis (Vieillot)}

Buff-breasted Sandpiper

SPECIMEN. BM: One specimen, without specific locality or date.

This specimen, examined by Todd, represents the only record of the species in British Honduras. 
Family RECURVIROSTRIDAE

Himantopus mexicanus (Müller)

Black-necked stilt

SPECIMENS. ISUMZ: Hill Bank - o (205.0 g.), Mar. 30, 1955. OTHER INUSEUM (BM): Two specimens without specific locality or date.

The specimen collected at Hill Bank, a male with enlarged testes, was one of a pair of stilts seen on the edge of the Hill Bank Lagoon. Col. A. Belihouse informed me (in litt.) that he saw a "small party" of stilts at the Rice Station at Boom on March 17, 1927. The birds involved in these records could be either migrants or individuals about to nest in the colony. The species does nest locally in Central America, and there are many suitable breeding areas in British Honduras.

Recurvirostra anericana Grnelin

American Avocet

Peck recorded in his notes that he saw American Avocets twice: a few birds "flying past the nouth of the Manatee River near the end of March, 1901, and two individuals at Belize on April 18, 1901.: Avocets are. rare south of Mexico, but it doubtful that Peck could have mistaken such a distinctive species. 
Family BURHINIDAE

Burhinus bistriatus (Wagler)

Mexican Thick-knee

Lancaster and Verner studied a bird walking in the yard of the Fort George Hotel in Belize on the evening of February 11, 1958, that they identified beyond doubt as a thick-knee. The area was lighted, and they could examine the bird at very close range. Lancaster was familiar with the species and its nocturnal habits from experience in Mexico. It is possible that the thick-knee is a local resident in the Colony, since it has been overlooked by other ornithologists. The species has been recorded in the Caribbean drainage of Guatemala.

\section{Family IARIDAE}

[Larus delawarensis ord] Ring-billed Gull

On August 1b, 1960, Lay identified five gulls in the bay at Corozal as Ring-billed Gulls. The species was previously unrecorded south of Veracruz on the Atlantic side of Mexico, but it has been seen as far south as thl Salvador on the Pacific coast. I do not include this species as one identified beyond doubt in British Honduras. 
Larus argentetus Pontoppidan

Herring Gull

SPECIMENS. UMAZ: Belize - 7, Jan. 19, 1931.

The Herring Gull is an uncommon winter visitant along the coast of British Honduras. Present records snow the occurrence of this guil only from mid-Decenber to late March, but it is to be expected much earlier in the autumn. A bird banded by wr. Walter Nickell on. June $1 \perp, \perp 9>7$, at Roger's lity, lichigan, was recovered on the Hill Bank Lagoon on January 6, 1 yb8.

I refer the specimen to $\mathrm{L}$. a. smithsonianus.

\section{Larus atricilla Linnaeus}

Laughing Gull

SPECIMENS, ISUHZ: singlish Cay - $\sigma$, May 16, 1958. URITICAL PUBLISHED RECORDS: Belize (Saunders, 1896: 197); saddle cay (Salvin, 1864: 381 ).

The species is present in small numbers on the coast and among the islands of british Honduras, probably throughout the yoar, although not yet recorded in June, JuLy, or September. I saw one Laughing lill on the Hill bank Lagoon on May 26, 1966 , the only inland record tor the Colony. I'he only breeding record ascribed to British Honduras apparently dates back to sclater and Salvin (1859: 230), who publisned the intormation that it was "said to breed in the keys along the coast." No nests have been found in British Honduras. the male 
collected by Verner on English Cay did not have enlarged testes.

Larus pipixcan Wagler

Franklin's Gull

SPECIMEN. PC: One specimen without a specific locality; December 2, 1905.

Todd examined the specimen a number of years ago. It represents the only record of the species from British Honduras.

\section{Chlidonias niger (Linnaeus)}

Black Tern

SPECIMENS. CM, USNM: Hanatee Lagoon - o, Oct. 20, 1905. Southern Water Cay - $\sigma$, May 16, 1862. CRITICAI PUBLISHED RECORD: Near Tobacco Cay (Salvin, 1864: 385).

In May 1862, Salvin (1864: 385) saw a large flock of Black Terns near Tobacco Cay and secured "several specimens in all stages of plumage." The localities where the birds were observed or collected appeared subsequently in print as Southern Water Cay (Coues, 1864: 391), Cay Dolores Channel (Saunders, 1896: 23), and Curlew Cay (Salvin and Godman, Biologia, 1903: 399). Consequently, there is some question as to the precise. locality (or localities) where the birds were collected. Since all these points of record are within a small area east of Stann Creek and AlI Pines, the problem is not 
critical. I saw $j 0$ Black Terns between Belize and Stann Creek on May 2, 1956, and 6) at the Hill Bank Lagoon on may 26 of the same year. Willis observed single birds on the New River on August $6,195 \%$, and at. Belize the next day.

Specimens trom the Colony are reterable to $\underline{\underline{u}} \underline{\mathrm{n}}$.
surinamensis. Gelochelidon nilotica (Gmelin) Gull-billed Tern

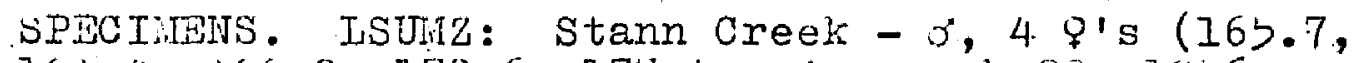
$161.4,166.9,170.6,177.4 \mathrm{~g}$.$) , warch 28,1956$.

The five specimens were obtained from a flock of ten individuals standing on the beach at Stann Creek. ithe five birds collected were rather fat, and the largest ova in each female were about $3 \mathrm{~mm}$. in diameter. Willis saw one Gull-billed Tern in selize on August?, and two on August $9,195 \%$.

I assign the specimens to $\underline{\dot{L}} \underline{\underline{m}}$ : aranea.

\section{Hydroprogne caspia (Pallas) \\ Caspian Tern}

A Caspian Tern shot at Belize on November 28, 1935, had been banded by Mr. W. I. Lyon at shoe Island, Hichigan, on July 18, 1951 (Lincoln, 1936: 148). Lay identified this species near Sergeant's Cay and liclvabb's Water 
Cay on August. 11 and 12, 1960.. I. know of no other records of this tern from. British Honduras.

\section{Sterna hirundo Iinnaeus}

Common Tern

The only record of the Common Tern from British Honduras is of a bird banded in the Great Lakes region and recovered at Belize (Austin, 1953: 46, 52).

\section{Sterna dougallii Montagu}

Rogeate Tern

SPECIMEN. CRITICAT PUBLISHED RECORD: Grassy cay in Turneffe Islands (Salvin, 1864: 387).

On May 20, 1862, Salvin collected a male Roseate Tern from three or four that he saw on Grassy Cay. He also commented (1866: 199) that he thought they were "preparing to breed on that igland." Griscom (1926: 7) recorded the species, in Chetumal Bay on January 17, 1926. If the birds seen by Griscom were in british Honduran waters, they represent the only point of record, except for Belize, other than Salvin's. Belize is included with Grassy Cay as a British Honduran locality by Salvin and Godman (Biologia, 1903: 404), but.I suspect this was a lapsus, for Belize was not included in earlier reports by Salvin. 


\section{Sterna anaethetus Scopoli}

Bridled Tern

SPECIMENS. USNM: One specimen from Saddle Cay in Iighthouse Reef; May 10, 1862. CRITICAL PUBIISHED RECORD: Southern Watex Cay (Saunders, 1896: 106).

Bridled Terns have been recorded in British Honduras only in May, 1862, by Salvin who collected them on Saddle and Southern Water Cays. He found nesting colonies on saddle, Ellen, and Curlew Cays (Salvin, 1864: 385) and possibly also Southern Water Cay.

Specimens from British Honduras are generally assigned to $\underline{S}$ : ․ㅡ. recognita.

Sterna fuscata Iinnaeus

Sooty Tern

SPECIMENS. ISUMZ: Round Cay - 9, May 15, 1958. URITICAI PUBIISHED RECORD: "Curlew Cay (Salvin, 1864: 385$)$.

In the first account of his two weeks trip among the keys of British Honduras, Salvin states (1864: 385) that he saw this species on Ellen and Curlew Cays and collected one bird. Coues (1864: 392) mentions "one specimen only, from Curlew Cay" with reference to the Sooty Tern collected by Salvin in 1862. Salvin (1866: 200) again writes of this species, "I only met with a few solitary birds of this species about the 
Cays of the Belize Coast." In the Catalogue of the Birds of the British Museum (Saunders, 1896: 110), there is a Salvin specimen listed from Southern Water Cay. I assume that the specimen from Southern Water Cay is the same specimen as the one Salvin and Coues reported from Curlew Cay; the two islands are less than three miles apart and the localities could have inadvertantly been exchanged. Salvin and Godman (1903: 409) writing in the Biologia include a nesting record of the Sooty Tern from Saddle Cay. This may be an error, as it is the first mention of nesting, and Salvin (1866: 200) earlier stated he encountered only "a few solitary birds." The species was not recorded again until the spring of 1958, when Verner made a search for nesting terns. On that trip, Verner found a colony with nests containing eggs on Round Cay.

British Honduran Sooty Terns are referable to s. I. fuscata.

\section{Sterna albifrons Pallas}

\section{Least Tern}

SPECIMENS. USNM: One specimen from Long Cay in Glover's Reef; May 14, 1862 .

The Least Terns that Salvin found on long Cay on May 14, 1862, were about to lay (Salvin, 1864: 384), and on Grassy Cay on May 19, he found eggs of this 
species (Oates, 1901: 195). This tern has not been recorded in British Honduras since Salvin's trip. Least Tern's breeding in the Caribbean area, are 88

representative of $\underline{S}$. a. antillarum.

\section{Thalasseus maximus (Boddaert)}

Royal Tern

SPEC IMINS : ISUMZ: Stann Creek - ? (380.6 g.), Mar. 28, i956. OTHER MUSTUMS (CC, CM, MCZ): Pive specimens from the mouth of the Manatee River, Wild Cane Cay; Mar., Dec. CRITICAL PUBLISHED RECORD: Iong Cay in Glover's Reef (Salvin, 1864: 385).

Royal Terns are moderately common winter visitants and have been recorded at many coastal and insular localities between extreme dates of November 20 and May 2. I expect some individuals will eventually be recorded in the summer and early autumn. On July 24 , 1935, Mr. E. M. Burton banded a Royal Tern in Charleston County, South Carolina, which was recovered at Corozal on April 1, 1936 (Lineoln, 1936: 148).

I assign the specimens from the colony to $\underline{\underline{T}}$. $\mathrm{m}$. maximus. $89 \%$

\section{Thalasseus sandvicensis (Latham)}

Sandwich Tern

SPECIMENS. UMMZ: One specimen from Belize; liov: II, $1927 .$. CRITICAI PUBIISHED RECORD: Saddle cay in

Lighthouse Reef (Salvin, 1864: 381). 
Salvin found the species nesting on Northern Two Cays, for eggs collected by Salvin are listed from that locality in the Catalogue of the Collection of Birds' Eggs in the British Museum (Oates, 1901: 187). On January 17, 1926, Griscom (1926: 7) saw 20 Sandwich Terns in Chetumal Bay. The only additional records from the Colony consist of six and twelve individuals that van Tets saw feeding in the Belize harbor on December 21, 1960, and January 3, 1961, respectively.

I refer the British Honduran specimens to $\underline{T}$. $\underline{s}$. $90 /$ acuflavidus, which is the only race recorded in North and Central American waters.

\section{Anơus stolidus (Iinnaeus)}

Brown Noddy

SPECIMENS. LSUMZ: South West Cay in Glover's Reef 3 's (185.5, 185.7, 203.2), Apr. 25; 2 o's (164.4, 167.0), Apr. 26, 1956. OTHER MUSEUMS (CC, CM, UMMZ, USNM): Thirty specimens from South West Cay collected in April and May; one specimen from Sergeant's Cay collected June 23, 1930. CRIPICAT PUBLISHED RECORD: Cay Dolores Channel (Saunders, 1896: 140).

Salvin (1864: 383-385) found eggs and nestlings about Way 12 to 17 , 1862, on South West, Ellen, Curlew, and Southern Water Cays. He collected specimens on South West Cay and in Cay Dolores Channe1. On April 17 and 21, 1907, Berry obtained a series of Noddy Perns, also on South West Cay. Blake and Agostini collected a number of specimens on this same key on May 29, 1935, 
and noted young birds in the nests. Dennett and $I$ collected on South lest Cay on April 25 and 26, 19>6, and found a colony of 300 to 400 Noddy lerns. These birds were in the process of building their nests 60 feet above the ground in the axils of leaves of the coconut palms. Salvin (1864: 383) also indicated that this tern was nesting in the tops of coconut palms. Noddy Terns once nested on Round and Pompion Cays, according to ilr. Austin Garbutt, lightkeeper on English Cay. In 1958, Verner searched for Noddies on these two keys but found none.

Noddy Terns from Britisj Honduras are referable to A. s. stolidus.

\section{1}

Anots tenuirostris Temminick

Black Noddy

$\triangle P$ ICIMLNS. LSUMZ: "British Honduras" - $\sigma$, LApr. 13, 1907. OTHER MUSEUMS (CC, USNM): Thirteen specinens from South West Cay in Glover's Reef, Morgan Cay; May, 1862: Apr., 1907.

OnIy two collectors have recorded Black Noddies in British Honduran waters. Salvin (1864: 383-384) found the species nesting, with eggs on "point of hatching," on South West Cay on May 12, 1862. On ApriI i3 and 17, 1907, on the same key and on Morgan Cay, Berry collected this tern and found it breeding in considerable numbers. Although South West Cay and other islands in the vicinity have been searched for the Black Noddy since 
1907, it has not been found again. I do not think it likely that the species still breeds on South West Cay, although there may be other small keys that have a nesting colony. Hr. R. K. Masson, Sr., who was Comptroller of customs and Iighthouse Inspector in British Honduras for many years, knew that two "kinds" of. noddies once nested on South Fest Cay and had seen the "small noddy" nesting on Torn Owens Cay about 1950. A systematic search of the nany small keys off British Honduras will be required to determine the definite status of this and several other species of Iaridae. Mathews (1912: 423) described a new subspecies 92) A. t. americanus on the basis of specimens from British Honduras. Until recently, when the Black Noddy was found on several islands off the northern coast of South America, the British Honduran colony was the only known population of the race. Unfortunately, only one of the series of $1<$ skins that was in the Coe College collection is now extant. I recognize A. t. americanus, but I do feel that Wathew's race needs critical review with the aid of recently collected specimens from the Caribbean area. 
Family COLUIBBIDAE

\section{Columba leucocephala Linnaeus}

White-crowned Pigeon

SPECIMINS, LSUAZ: Calabash Cay $-\sigma(240 . \mathrm{b}$. .), Apr. 11. Half Moon Cay - ₹, Apr. 7. OTHER IIUSHUMS (CO, UVIIZ): Four specimens frorn Cay Corker, Manatee River; Aug., Dec. CRITICAL PUBIISHED RECORD: Middle Cay of Glover's Reef (Salvin, 1864: 383).

I know of no records of the White-crowned Pigeon in British Honduras during July, september, october, or November. In the remaining months, it has been seen frequently but in small numbers on many of the mangrove covered keys, but only once on the mainland (December, Manatee River). Practically no field work has been done on the islands in sumer and fall; consequently, the lack of records at these seasons is perhaps not significant. Verner noted one to seven individuals nearly every day in his three months stay on Half Moon Cay in the spring of 19>8. There is no information concerning breeding except that the female collected April 7 had a slightly enlarged ovary and that the testes of the male taken April 11 were not enlarged:

Columba flavirostris Wagler

Red-billed Pigeon

SPECIMEN... ISUMZ: Corozal - ?, Aug. 19, 1960.

Lay saw two Red-billed Pigeons and collected one of them in tall woods on the outskirts of Corozal. The 
bird had a fully enlarged ovary. There are no other records of the species from the Colony.

I refer the specinen to $\underline{C}$. f. Plavirostris.

Columba cayennensis Bonnaterre

Pale-vented Pigeon

SPECIMFNS, LSUMZ: Hill Bank - $f(238.1 \mathrm{~g}$.$) , Feb. 24$. OTHER WUSEUIMS (CC, CM, MCZ): Fleven specimens from the Manatee laagoon area, Freetown; Mar., Apr., May, June, July, Aug.

Pale-vented Pigeons are moderately common residents from Orange Walk, Hill Bank, and Gallon Jug south through the coastal plain to the Toledo District. The species is unrecorded above an elevation of 400 feet in the Colony and $I$ did not find it in the vicinity of San Pedro Columbia. The species is shy and arboreal and is most numerous in open woodlands, at the edge of pinelands, and in the tops of tall trees near lagoons. Peck found seven nests between May 3 and May 31, and one on July 22, each with only one egg. In his notes, Peck indicates that some nests were situated in low bushes, mangroves, and tufts of grass, but others were placed as high as bo feet in pine trees.

The race to which I refer the British Honduran specimens is C. c. pallidicrissa. 


\section{Columba speciosa Gmelin}

Scaled Pigeon

SPEC IMENS. LSUMZ: Hill Bank - $\}$ (274.b g.), Nov. 26. Gallon Jug - $(272.8)$, Mar. 21; $\sigma$ (256.1), Mar. 26; $\sigma(271.7)$, Way $31 ; \sigma(267.8)$, June 2 . OTHER MUSEUMS (Ch, UIMMZ): Four specimens from the Manatee Iagoon area, IL mi. S Cayo; Feb., Mar., Aug., Dec.

The species is a moderately common resident of heavy rain forest, the forest borders, and tall second growth, and it is not infrequently found in pinelands. I normally recorded fewer than four individuals in a day in the field, but in late November in a very heavily overgrown "broken pine ridge" near Hill Bank I counted 50 scaled Pigeons. Possibly this species wanders in the winter. I attribute the paucity of localities of record (Sittee River, South Stann Creek, the San Pedro Columbia area, and Toledo settlement are the only additional localities) "to the "inconspicuousness of the birds. Ihe "mountain pigeon", as many people call the species, is difficult to detect, especially when perched high in a forest tree. Peck found two nests of The scaled Pigeon, each containing one egg, one on April 22 and the other on September 2. The nests were situated about 12 feet above the ground in small vine-entangled trees in huamil of medium height. A male collected by van tyne in the Mountain Pine Ridge on February 27 weighed 313 grams including 35 grams of food (mostly palm seeds) in the crop. The bird had enlarged testes and was presumably breeding. 
Specimens collected in March, May, and June at Gallon Jug also had enlarged gonads.

Columba nigrirostris Sclater

Short-billed Pigeon

SPECIMENS. ISUMZ: Gallon Jug - హ (159.1 g.), Mar. Il; ? (124.8), Mar. 20; $\sigma(156.4)$, Apr. 5. Two mi. W San Pedro Columbia - ? (145.5), May $13 ; \%$ (154.7), May 18. OTHFR MUSTUMS (BM, CH, CIHM, MCZ): Ten specimens from the Manatee Lagoon area, Cayo, San Felipe, Augustine, Pomona; Feb., Mar., Apr., June, July, Sept., Nov. CRITICAL PUBLISHED RECORD: Vicinity of Belize (SaIvadori, 1893: 323).

Short-billed Pigeons are common residents of the vast regions of tall humid forests and are moderately common in high second growth. The species apparently does not flock, for I have seen only pairs or single individuals. As with other members of the genus that perch high in the forest trees, it is very likely to be overlooked unless it is calling. In April and May, I found it the most abundant pigeon in the cockscomb Basin. Locally its song is expressed as "Tres pe-sos son." All the individuals collected in March, April, or May at Gallon Jug and San Pedro Columbia were breeding.

Zenaidura macroura (Jinnaeus)

Mourning Dove

SPECIMENS. ISUMZ: Hill Bank - $\sigma(98.7 \mathrm{~g}$.$) , Nov. 26,$ 1956. Augustine - $\sigma$, Dec. 8, 1956. OTHER MUSWUH (MCZ): Toledo Settlement - 8 , October 17, 1906. 
The Mourning Dove is a moderately common winter visitant and presumably also a transient. Pine ridges and cultivated land, especially cane fields, are its preferred habitats while in the Colony. On December 4, 1956, I counted over 100 doves along the highway rightof-way between-Orange Walk and Corozal. The specimen collected by Peck on October 17 represents the earliest fall date in. British Honduras, and an unspecified date in March (Peck notes) is the latest spring record. Ridgway (1916: 341) referred the bird from Toledo Settlement to the West Indian race, $\underline{z}$. $\underline{m}$. macroura. I was unable to identify the two specimens in the ISUMZ to subspecies.

\section{Columbina passerina (Iinnaeus)}

Common Ground Dove

SPECIMINS. CH, IHCZ, UMIMZ Seven specimens from eight mi. NW Belize, Manatee Lagoon area, Toledo Settlement; Jan., Feb., Apr., May, June. CRIqICAI PUTLISHED RECORD: orange Walk (Salvadori, 1893: 479).

This resident dove is local in British Honduras. Cayo (Holt, notes) and Camp VI (Austin, 1929: 370) are the only points of record not listed above. Field parties from the ISUMZ have not recorded the species, but the field notes of Holt, Peck, and Shufeldt indicate that it is found in pinelands, brushy pastures, and clearings. Peck found nests and eggs in late May and June in the pine ridges. 
I refer the British Honduran specimens to $\underline{\text { C. }}$ p. pallescens.

\section{6}

Columbina minuta (Iinnaeus)

Plain-breasted Ground Dove

DPECIMENS. ISUMZ: Three mi. NE Hill Bank - 9 , Mar. $23 ; \sigma(34.0 \mathrm{~g} \cdot)$, Apr. 1. OTHRR MUSEUMS (CM, MCZ, UMMZ): Thirteen specimens from pine ridges $N$ and $W$ of Belize, the Mianatee Lagoon area, All Pines, Toledo Settlement; Jan., Feb., Mar., Apr.

This small ground dove is an uncommon resident of the pinelends of the coastal areas of the northern twothirds of the Colony. I did not see it in the extreme southern third, but Peck noted it in cultivated fields at Toledo settlement and found it breeding there in May. Two birds collected at the Belize airfield on February 28 by Shufeldt were breeding, as were the four individuals taken by Blake and Agostini in April at All Pines. 97

C. - interrupta is the rrce to which I assign the specimens from British Honduras.

Columbina talpacoti (Temminck)

Ruddy Ground Dove

SPECIMINS. LSUMZ: Gallon Jug - $\sigma(49.2 \mathrm{~g} \cdot)$, Feb. 22; ( 44.2$)$, Mar. 14; $s(56.3)$, Nov. 16. OTHER MUSEUMS (CM, CNHM, UVMZ): Three specimens from Belize, Cayo, IHidlesex; Feb., Apr.

The Ruddy Ground Dove is a locally common resident and has been recorded in the vicinity of corozal, orange 
Walk, Hill Bank, Gallon Jug, Belize, Cayo, Stann Creek Valley, and san Pedro Columbia. The species is most frequently seen in snall flocks on the ground on the roadsides or in cleared areas. At Gallon Jug I captured several individuals in mist nets suspended in low dense second growth near plantations. Birds collected in February and April were breeding, and the testes of the male taken in October were slichtly enlarged. British Honduran specimens are typical of the race c. t. rufipennis. 98

\section{Claravis pretiosa (Ferrari-Perez)}

Blue Ground Dove

SPECIIMENS. LSUMZ: Gallon Jug - 9 (68.5 g. ), Feb. 18; $\checkmark(76.6)$, Mar. 21. Two mi. W San Pedro Columbia - 6 $(71.4)$, May 3. OTHER MUSTUMS (CM, USNM): Five specimens from the Manatee Lagoon area, Cayo; Mar., Aug., Sept. CRITICAL PUBLISHED RECORDS: Orange Walk, Belize (Salvadori, 1893: 493).

Rain forest clearings and tall second growth provide the habitat in British Honduras for this largely terrestrial species. Along with many other resident doves, it is somewhat local in its distribution and does not occur in every locality where the habitat appears suitable. Yet in some places, for example, Gallon Jug and the Stann Creek Valley; it is common. Peck recorded it in the pine ridges near Manatee Lagoon, but I fajled to find it in pinelands in any region. Additional points of record are provided by Austin (1929: 371) who saw it "in small flocks 
in the roads and clearings all through the rain forest" in the Camp VI to Mountain Cow area. The birds taken at Gallon Jug and San Pedro Columbia had fully enlarged gonads.

\section{Leptotila verreauxi (Bonaparte) \\ White-fronted Dove}

SPECIMENS. ISUMZ: Corozal - 9, Aug. 16, 1960. OTHER MUSEUM (CM): Manatee Lagoon - o, June 22, 1905.

Species of Ieptotila are notoriously difficult to. identify in the field. The observer rarely has more than a monentary glimpse of a dark terrestrial dove as it disappears behind a tree trunk or fallen log. Lay collected a female Wite-fronted Dove in breeding condition at Corozal. in tall second growth, and Peck obtained a specimen in the forest near Manatee Lagoon. In tall second growth at Galion Jug and Hill Bank in the spring and summer of 1957, Willis several times recorded a dove he believed to be of this species. There is a possibility the dove noted by Willis was I. jamaicensis, a species never reported from the Colony. At Agua Blanca, Quintana Roo, a locality on the Rio Hondo less than 35 miles from Gallon Jug and Hill Bank, Paynter (1955: 122) found I. plumbeiceps, numerous examples of $\underline{L}$. jamaicensis, but no $\underline{L}$. verreauxi.

The two specimens from British Honduras are referable to I. I. fulviventris. 
Leptotila plumbeiceps Sclater and Salvin

$$
\text { Gray-headed Dove }
$$

SPECIMENS. ISUMZ: Gallon Jug -0 , o (139.4, 163.5 g•), Mar. 5; $\sigma$ (162.1) Mar. 20; $\sigma^{\prime \prime}(161.0)$, June 2; $q(163.2)$, Nov. $10 ; \sigma(165.2)$, Nov. 12; $q(205.0)$, Nov. $13 ; 2$ \% (161.8, 191.8), Nov. 16: Two mi. NW Augustine - o, Dec. 12. Ballerina Camp - $\sigma(192.4)$, Apr. 30. OTHER MUSEUMS (CC, CM, UMMZ): Ten specimens from Belize, Manatee Lagoon area, Duck Run, Cayo, Freetown; Jan., Apr., May, June, July, Dec. CRITICAL PUBLISHED RECORD: Orange Walk (Salvadori, 1893: 551).

The Gray-headed Dove is a common resident in the northern two-thirds of the Colony on the floor of tall, wet forest and high second growth. It is unrecorded from Toledo District. Willis found six nests in the period of February to June at Gallon Jug. The gonads of half the specimens collected in the fall were enlarged; some contained ova about $2 \mathrm{~mm}$. in diameter. Several individuals were extremely fat.

The specimens are typical of L. $\mathrm{p}$. plumbeiceps.

\section{Leptotila cassinii (Iawrence)}

Cassin's Dove

SPECIMENS. LSUMZ: Four mi. W Stann Creek - of (162.2 g.), Mar. 28. Bailerina Camp - o (173.4), Apr. 24; ó (163.4), Apr. 30. Two m1. W San Pedro Columbia - Q (142.7), May 3; $\oint(158.9)$, May 4; $\sigma(163.0)$, May $11 ; 2 \sigma^{\prime} s, q(149.2$, 131.6, 179.4), May 21. OTHER MUSEUMS (BM, CC, CM, MCZ): Eleven specimens from the Manatee. Lagoon area, Cayo, Freetown, Toledo Settlement; Apr., May, June, July, oct.

Cassin's Dove is common in the vicinity of Ballerina Camp, San Pedro Columbia, and Manatee Lagoon, where 
collecting has confirmed field indentifications. Its preferred habitat aprears to be the ground in medium and high second growth where the vegetation is rather dense but the floor is relatively open. I have not recorded this species in the heart of rain forest, although it does occur within the forest border. The habitats of $\mathrm{I}$. cassinii and I. RIumbeiceps rarely overlap; in general, the former species is one of second growth, the latter of heavy forest. I have collected breeding birds in March, April, and May, and Blancaneaux obtained eggs at Cayo in June (Oates, 1901: 105).. I do not have data to indicate whether the species breeds in other months also.

I. c. cerviniventris ranges from hexico to Panama. Geotrygon montana (Iinnaeus)

Ruddy Quail-Dove

SPECIMENS. ISUMZ: Gallon Jug - $\sigma$ (143.0 g.), Feb. 6 . Two mi. SSE Victoria Peak - $\sigma$, May 8. OTHER MUSEUNS (CH, MCZ): Eleven specimens from the Manatee Lagoon area, Augustine, Toledo Settlement; Feb., Mar., Apr., Sept., Oct., Dec. CRITICAI PUBLISHED RECORD: Orange Walk (Salvadori, 1893: 569).

The species is an extremely inconspicuous terrestrial resident of heavy rain forests. Although it has been recorded only at the localities where it was collected, it is probably moderately common in all undisturbed rain forest areas. Both Lancaster and Willis found the Ruddy Quail-Dove frequently during the course of their field 
work in limited study areas at Gallon Jug. Peck thought the species "plentiful" at Manatee Lagoon. In April and May at Gallon Jug Willis found four nests constructed on brushpiles or stumps, within 6 feet of the ground. Only two nests contained eggs. montana.

The race of this species in British Honduras is G. m. 102/:

Family PSITIACIDAE

Ara macao (Linnaeus)

Scarlet Macaw

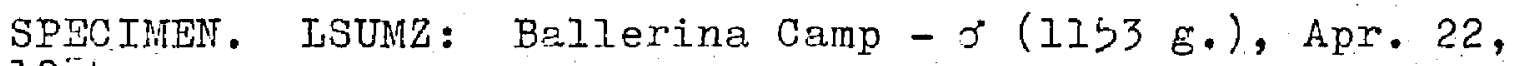
1955.

Flocks of a few to 30 macaws frequent the uninhabited headwaters of many of the larger streams in the central part of British Honduras. I have seen "guacamayas", as they are called locally, in the Hountain Pine Ridge, along the Eastern Branch of the Belize River, near the Hummingbird Highway, and in the upper parts of South Stann Creek. They ascend to 3000 feet or more in the Cockscomb Mountains; and in late May 1959, I saw a pair of macaws attending what I suspect was an occupied nest in a tall tree on the crest of a narrow ridge south of Victoria Peak. In the Mountain Pine Rldge, flocks are sometimes observed in pine trees a short distance from the rain forest. Macaws, to 
my knowledge, do not enter the coastal plain in British Honduras, although escaped cage birds have been seen near Belize.

\section{Aratinga astec (Sovancé)}

\section{Aztec Parakeet}

SPECIMENS. LSUAZ: Gallon Jug - - $(73.3 \mathrm{~g}$.$) , Mar. 2$. Augustine - 9 , Aug. 23. Two mi. W San Pedro Columbia 7. (79.7), May 20. OMHER MUSEUMS (CC, CM, MOZ, PC, UWHZ): Twenty-five specimens from Belize, Manatee Lagoon area, Duck Run, $12 \mathrm{mi}$. S Cayo, Camp VI, jiountain Cow; all months except May, June, Sept., Oct. CRITICAI FUBIISHID RICORD: Orange Halk (Salvadori, 1891: 193).

The Aztec Parakeet is widely distributed in the mainland of the colony and has been observed in pairs or small flocks at nearly every collecting station. It occurs in all wooded habitats and in the semi-open but is least comon in the heart of rain forest. I have seen this resident often in the pine ridges, and Peck noted it on the beach at the mouth of the Manatee River. Al though Aratinga astec is moderately comnon and enjoys the greatest habitat range of the British Honduran parrots, other forest parrots are recorded more frequently and in greater numbers. At Galion Jug, for example, Pionus serilis, Pionopsitta haematotis, smazona kutumnalis, and Amazona farinosa are more common. Breeding in April and Nay is indicated by the enlarged gonads of Aztec Parakeets collected in those months.

$$
103 /
$$

A. a. astec ranges from southern hexico to western Panamá. 
Pionopsitta haematotis (Sclater and Salvin)

Brown-hooded Parrot

SPECIMENS. ISUMZ: Gallon Jug - 9 , Feb. 17. B:Llerina Camp - $\}$ (I3l.7 g.), Apr. 30. .0THRR MUSTUMS (BM, CC, CM, PC): Eighteen specimens from the Manatee Iagoon area, Duck Run, San Antonio, is slope Cockscomb Mts. (1500.), Freetown, Toledo Settlement; Jan., Mar., Apr., May, July, Oct., Dec. CRITICAL PUBLISHED RlCORD: Orange Walk (Salvadori, 1891: 344).

This species is an inconspicuous but common resident of the tail forests of the Colony. Small flocks of Brownhooded Parrots may feed unnoticed high in the treetops until their presence is made known by an occasional warbling call or a falling fruit. They remain quiet and still when alarmed. Only three of ten birds shot in April and ihay had enlarged gonads. Specimens collected at other seasons are without breeding data or were not breeding. The Central American race is $\underline{P}$. h. hematotis.

\section{Pionus senilis (Spix)}

White-crowned Parrot

SPECIMLNS, LSUNZ: Gallon Jug - P (193.2 g.), Mar. I; \% (203.6), Mar. 9; $\sigma(198.6)$, May 29. Sibun River at Hummingbird Hwy. $-\sigma(21 b .1)$, Mar. 26. Augustine - $\sigma$ (228.8), May 5. Two mi. NE Millionario - 9 (209.7), Mar. 15. OTHER MUSEUMS (BM, CC, CM, MCZ, PC, UMMZ): Twenty-nine specimens from the Manatee Lagoon area, Duck Run, Cayo, $12 \mathrm{mi}$. S Cayo, Camp VI, Freetown; all roonths except June, Sept., Nov., Dec. CRITICAI PUBLISHED RECORDS: Orange Walk, vicinity of Belize (Salvadori, 1891: 332 ).

In nearly every part of the Colony, White-crowned Parrots are noisy and conspicuous residents of forests 
(especially near their borders), the semi-open, and pinelands. Willis noted aduits of this comnon species occupying nesting cavities in late February and March, and Peck found a nest containing three eggs in mid-April. The three holes were about ID, 24, and $2>$ feet above the ground. The testes of the specimen collected at Augustine in May were enlarged.

I refer British Honduran specimens to $\underline{\underline{p}}$ s. senilis. Adults from the Colony are not distinguishable from san Luis Potosi specimens in the ISUMz. On the basis of the few Costa. Rican specimens that I have examined, I agree with Brodkorb $(1943: 41)$ in doubting the validity of P. S. decoloratus.

\section{Amazona xantholora (Gray)}

Yellow-lored Parrot

SPECIMINS. CC, CM, MOZ, UMII: Twelve specimens from Belize, Manatee Lagoon area, Duck Run; Apr., May, June, Nov. CRITICAL PUBLISHED RECORD: Orange Walk (Salvadori, 1891: 314 ).

Peck observed this parrot "in considerable numbers" in the pine ridges near the sibun River and Manatee Lagoon, and Holt collected two from oak trees in the pine ridge near Duck Run. It is probable that the Belize specimen was taken in the pinelands near the city. Young birds occupied each of the four nests found by Peck in April and May. Amazona albifrons also enters the pine 
ridges, and it is probable that the two sibling species have often been misidentified in the field.

\section{Amazona albifrons (Sparrmann) \\ White-fronted Parrot}

SPECIMINS. LSUI:L Hill Bank - ? (205.7 g.), Nov. 26. Gallon Jug - $\sigma$ (198.6), Mar. 22. OTHER MUSEUMS (BII, CM, UMMZ): Five specimens from the Manatee Lagoon area, Cayo; Mar., June.

Lay saw this uncominon species at Corozal and I recorded it near Pomona; these are the only localities where it has been observed with certainty but not collected. The White-fronted Parrot inhabits high second Erowth, the edge of rain forest, pinelands, and areas with scattered tall trees. The female collected in November at Hill Bank had a slightly erlarged ovary.

The British Honduran specimens are typical of the small Yucatén Peninsula race, $\underline{A}$. a. nana.

Amazong autumnalis (Iinnaeus)

Yellow-cheeked Parrot

SPECIMENS. ISUMZ: Gallon Jug - Q (332.6 g.), Peb. 24; \%, $9(336.1,376.5)$, Mar. 16; ?, June 1b. OTHER MUSEUMS (BM, CC, CM, MCZ, PC, UMMZ): Twenty-one specimens from Belize, Manatee Lagoon area, Cayo, $12 \mathrm{mi}$. Sayo, pine ridge near Camp VI, Freetown, All Pines, loledo Settlement; all months except Jan., June, JuIy, Sept:

Yellow-cheeked Parrots are common and widely distributed residents of most parts of British Honduras. In the extreme southern region of the colony, this parrot is 
present but it seemed less numerous to me than in the north. Plantation clearings and second frowth in the immediate vicinity of tall rain forest are its usual habitats, but the species also penetrates the forests and is not uncommon in the pine ridges. Yellow-cheeked Parrots frequently raid ripening citrus and mango fruits, along with other parrot species. I have collected birds in breeding condition in February and March; Peck found a nest containing two eggs on larch 16 and holes presumably occupied by nesting individuals as late as May 20 . A. a. autumnalis is the subspecies to which I assign the British Honduran specimens. $\cdot \cdot$

Amazona ochrocephala (Gmelin)

Yellow-headed Parrot

SPECIMENS. ISUMZ: Hill Bank - O (410.0 g.), Feb. 21; $\checkmark(460.8)$, Nov. 20. Galion Jug - $\sigma$, May 5 . OIHTIR MUSEUMS (BM, CH, MCZ): Four specimens from Crooked Tree Lagoon, All Pines, Ycacos Lagoon; Mar., Apr. CRIIICAI PUBLISHED RECORD: Belize (Salvin, 1866: 195).

The personable "yellow-head," as it is called in British Honduras, is local in its distribution in the Colony and is common only in the vicinity of the Hill Bank and Ycacos Lagoons and the lower sections of the Sibun and Sittee Rivers. The species roosts and nests in the pine ridges but flies daily into nearby tall, humid forests in order to feed. At twilight, pairs or loose groups of several pairs of loudly calling Yellowheaded Parrots regularly flew east across the Hill Bark 
Lagoon to the pine ridges. yellow-heads usually roost in the highest branches of tali pines, one or two pairs to a tree. Peck found nest cavities containing esgs in pine trees in Iharch and April, and in llay he found a nest holding a young bird. The female that I collected in February contained an ovum $>\mathrm{mm}$. in diameter, and the male collected by Lancaster in May had enlarged testes. I refer specimens from the colony to A. o. oratrix.

\section{Amazona farinosa (Boddaert) \\ Blue-crowned Parrot}

SPECIMENS. ISUMZ: Galion Jü - o, lifar. 29, 1955. OTHER MUSEUMS (CM, PC): Near Manatee Lagoon - 9 , Oct. 17, 1905; O, Oct. 19, 2905. N slope Cockscomb Mts. $\left(1600^{\prime}\right)-\infty$, Mar. 25, 1935.

The raucous cry of this large parrot sounds to local people like the words of warning "watch out!", and they therefore call it the "watch-out parrot." It is a moderately common resident in or close to. tall, humid forests, and I have seen it near Hill Bank, the edge of the Mountain Pine Ridge, Millionario, and San Pedro Columbia in aduition to the collecting localities. I have no evidence indicating the breeding season. The race occupying northern Central America is A. 1 . suatemalae. 


\section{[Coccyzus erythropthalmus (Wilson)]}

Black-billed cuckoo

In his notes, Peck recorded seeing one Blackbilled Cuckoo at Toledo Settlement on November 15; 1906. Peck included no qualifying comments in his notes. Since the species is rare in Central America, it should not be considered a species recorded without question in British Honduras.

\section{Family CUCULIDAE}

\section{Coccyzus americanus (Iinnaeus)}

Yellow-billed Cuckoo

SPECIMENS. LSUMZ: Half Hoon Cay 6,1958 .

Verner collected the specimen listed, a female with a slightly enlarged ovary. He observed others on the island on March 26, April 17 and 18, and May $\zeta$, 6,7 , and 8 . On most dates, only one cuckoo was seen, but on May 7 Verner counted 12. I watched one Yellowbilled Uuckoo at Ballerina Camp on hpril 26, 19bs, the only additional record from the Colony.

The wing of the specimen measures 149.5, the tail 148.b, and the exposed culmen $27.0 \mathrm{~mm}$. These measurements are near the mean for $\underline{c}$. a. occidentalis but still within the upper limits of $\mathrm{C}$. a. americanus. Use of a trinomial is not advisable in this case. 


\section{Coccyzus minor (Gmelin)}

Miangrove vückoo

SPUCINENS. CN, UMMZ: BeIize - 9, Oct. 23, 1931. Wanatee Legoon - 7 , Dec. I0, 190\%. Uayo - 5, Apr. $8,1926$.

Whe three specimens were obtained by whufeldt, Peck, and lolt, respectively. line bird collected by Holt at vayo had enlarged testes and ras iaken from Low growth on the riverbank. Peck stetes in ins notes that he saw three liangrove cuckoos (including the one he collected) in the edge of the pineland near the Manatee Iagoon. ' $\perp$ have not seen this species and presume that it is rare, although it is to be expected in the extensive coestal mangrove swamps.

lhe specinens are refereblo to $\mathrm{C}$. m. continentalis.

\section{Piaye cayana (Iinneeus)}

squirrel unckoo

SPECIMENS. LSUMZ: Hill Bask - o $(96.1 \mathrm{~g}$.$) , Feb. 18$. Galıon Jug - P, Feb. 18;? (103.1), 5 eb. 26; o (89.2), Mar. 16; o $(90,0)$, Apr. S; $\sigma(110 . \zeta)$, Oct. 26; $\sigma$ (105.2), Nov. 6. Augustine - 9, Aug. 16. '1'wo mi. W san Pedro columbia - o $(110.8)$, May 8. OPHIR INUSEUHS (CC, CW, MCZ, PC, UNML): Nineteen spicimens from Belize, Hanatee Iagoon area, Juck kun, vayo, Uamp vI, Mountain Cow, l'oledo settlement; Jan., Feb., Mír., Apr., July, Aug., Dec.

The resident Squirrel vuckoo is found in forests of: all heights, tall second growth, and the scatiered trees of the semi-open. Its explosive call, resembling its local name, "pe-quam," may be heard in almost all parts of the mainland of the Colony. More than four individuals 
are rarely recorded in a day of field work but the species is seen with great regularity in suitable habitats. The gonads of most of the cuckoos dissected in February, March, April, and May were slightly enlarged. Considerable fat was present on the two birds collected in October and Novernber.

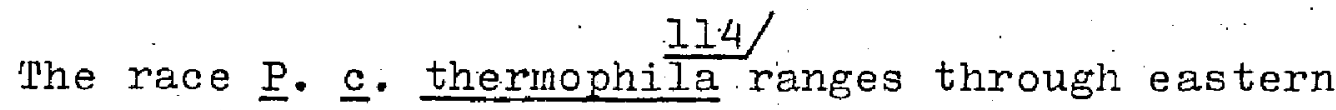
Mexico and south to Panamá.

\section{Crotophaga ani Iinnaeus \\ Smooth-billed Ani}

SPECIMEN. CC: Middle Long Cay - Q, Anr. 23, 1907.

The sole specimen from British. Honduras was examined some years ago by Todd. However, in a recent check of the British Honduran skins in the Coe College collection, Dr. Karl E. Goellner was unable to find this ani.

Crotophaga sulcirostris Swainson

Groove-billed Ani

SPECIMENS. ISUMZ: Gallon Jug - 9 (66.6 g.), Mar. 27; $\sigma^{\prime}(82.7)$, May 9 . OTHER MUSTUMS (BM, CC, CM, MCZ, PC, UMM : Twenty-three specimens from Belize, the Manatee Lagoon area, Cayo, Freetown, All Pines; all months except June, Aug., Sept. CRITICAL PUBLISHED RECORD: Orange Walk (Sheliy, 1891: 433).

Pastures, thickets, second growth, riverbanks, and forest borders provide habitats for this common resident throughout most parts of mainland British Honduras. It 
is less common in the vicinity of extensive rain forest and in the Mountain Pine Ridge. Half Moon Cay is the only key on which the species has been seen. 'There Holt in 1926 and verner in 1958 saw it almost daily. 'l'wo birds collected April 25 and May 9 had slightly enlerged gonads. The only occupied nest found by Peck held one egg on June 3.

The nominate form, $\underline{\text { c. }}$. sulcirostris, ranges from Mexico to South America.

Tapera naevia (Iinnaeus)

Striped Cuckoo

On Novernber 24, 1956, I saw a striped Cuckoo in low, dense second gro:th at Hill Bank. There are no other records of the species from British Honduras. Paynter (1955: 131) collected one of these cuckoos in a similar habitat at ohetumal, Quintana Roo. .

Tamily TYSONIDAE

Tyto alba (scopoli)

Barn OwI

This owl has not been collected in British Honduras; but Dennett, Lancaster, and $I$ have seen it in April and May at Cayo, and Willis recorded it at Gallon Jug in June. 
Paul Scott, my local field assistant in 1959, described a Barn OWI to me and noted that one or more had resided in a building at hiddlesex for some time.

British Honduras would presumably be included in the range of $\underline{\text { T. }}$. pratincola.

\section{Family STRIGIDAE}

\section{Otus guatemalae (Sharpe)}

Vermiculated Screech Owl.

Lancaster saw and heard a vermiculated Screech Owl in the daytime at Galion Jug on February $b$ and 6 and on Irarch 6, 1958. Also at Gallon Jug, Willis noted an individual of an unidentified species of otus on July $10,1937$.

o. E. Euatemalae has been collected about 75 miles west of Gallon Jug at Chuntuqui, Petén, Guatemala (Van Tyne, 1935: 18).

\section{Bubo virginianus (Gmelin)}

Great Horned Owl

SPICIMEN, MCZ: near Manatee Lagoon - 6, May 20, 1906.

The specimen listed above was collected in the open pine ridge near Manatee Lagoon by Peck. The bird retains soine of its down plumage; consequently. it was probably reared in the area. 
I have not critically examined the specimen, but Nelson (Bangs and Peck, 1908: 44) referred it to $\underline{B} \cdot \underline{V}$. 118 mayensis, which he described. Webster and $\operatorname{Orr}$ (19.58: 141) in their study of the Middle American populations of the species also examined the Manatee Lagoon bird and referred it to this race.

\section{Pulsatrix perspicillata (Latham)}

Spectacled Owl

SPEC IMINS. ISUMZ: Gallon Jug - q (981.5 g.), Mar. 12; $\checkmark(816.0)$, June 5 . OTHER MUSEUTS (BM, CM, MCZ): Six specimens from Western Dist. [= Cayo Dist.], E slope. Cockscomb Mts: (750'), Freetown, Toledo Settlement; Har., May, Nov.

This species is an uncommon or inconspicuous resident of tall: second growth and heavy forest in British Honduras: In addition to the two specimens that I collected at Gallon Jug, I saw one individual about 15 miles southeast of Cayo on December 7, 1956. Two specimens in the British Museum examined by Todd and noted by him as from "Western District" are probably birds obtained by Blanceneaux and listed in Part III of the Biologia by Salvin and Godman (1897: 28) as collected at "Cayo in the Western District." The only recognized race of the spectacled Owl in Central America is $\underline{P}$. $p$. saturata. 


\section{Glaucidium minutissimum (Wied)}

Least Pygrmy Ow1

SPIGIMENS. BM: Southern [= Mountain] Pine Ridge sex ?, Jari. 12, 1888 .

In 1934 Todd examined the specimen, which was collected by Blancaneaux, and referred it to $\underline{G} . \underline{m}$. griseiceps. 120 . Tod describes the bird in hị notes as follows: "extreme rufescent phase, head almost as deep brown as back, browner than in any . . skin from Guatemala, but [is] approachea by one."

\section{Glaucidium brasilianum (Gmelin) \\ Ferruginous Pygmy Owl}

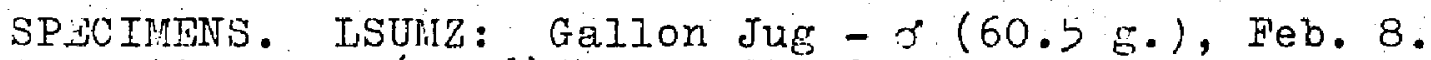
Augustine - ? (74.6), Mar. 20; ?, Aug. 13. Five mi. S Augustine - o (77.7), Mar. 10. Ballerina Camp - o (94.8), Mar. 9; $6(62.6)$, Apr. 23. OTHFR MUSEUMS (INCZ, UNIZ): Six specimens from $12 \mathrm{mi}$. S Cayo, Augustine; Feb., Mar., Apr.

The Herruginous Pygmy Owl is a moderately common resident of the Mountain Pine Ridge, where it usually frequents the narrow transisional area between open pineland and rain forest. The only additional point of record is Galion Jug, where it is uncommon but presumably resident in the second growth at the forest edge. Individuals of this species are active and usually forage within 15 feet of the ground. The female collected March 9 was breeding, but the gonads of four 
other specinens collected in rebruary, March, and April were only slightly enlarged.

ispecimens of this owl from British Honduras are reterabie to $\underline{G}$. $\underline{\text { r }}$ ridgivay $\underline{i}$.

\section{Dpeotyto cunicularia (Molina)}

Burrowing Owl

According to his notes, peck collected two indiviauals of this species on the beach at the noutin of the Manatee River in january 1901. The present location of the specimens is unknom to me; and there are no other records from the colony. It is not inprobable that the Burrowing OwI occurs in british Hondures as a regular but rare winter visitant.

specimens from the colony would presumably be referable to $\underline{\dot{I}}$. c. hypugaea

\section{Ciccaba virgata (Cassin)}

Mottled nood OwI

SPECINENS. LSUMZ: Gallon Jug - f (250.7 g.), Feb. 23; $3(177.4)$, Mar. 2; ?, may 2 . Ballerina Carnp - ? (344.9), Apr. 2b. Two mi. Ne Millionario - s (242.1), Mar. 12. 'L'wo mi. W San Pedro Columbia - o (229.8), May 9. OTHER MUSEUMS (CM, MCZ, UMWZ, USHM): whirteen specimens from Belize, Manatee Lagoon area, Toledo Settlement; Jan., inay, June, Oct., IVov., Dec. CRITICAI PUBIISHED RECORDS: Orange Walk, San Felipe (Salvin and Godman, Biologia, iii, 1897: 29); Cayo (Lantz, 1899: 219).

The species is a moderately common resident of heavy forest and medium to tall second growth throughout the 
mainland of the Colony. It occasionally enters pinelands, since Peck collected one bird in the pine ridge near Hanatee Lagoon in October. Peck noted a nest near Ycacos Lagoon on March 16, 1907, which contained two eggs. A male collected near Millionario in Warch was in breeding condition, but four February, April, and way birds were not. At Gallon Jug on June 6, 19b6; I saw a fledgling with an adult nearby.

I refer the British Honduran specimens to $\underline{\mathrm{C}}$. $\underline{\mathrm{V}}$. centralis.

Ciccaba nigrolineata sclater

Black-and-white 0 w

SPECIMENS LSUMZ: Ballerina Camp - $\sigma(402.5 \mathrm{g.})$, Apr. 28, 1955. CRITICAL PUBLISHTD RECORD: Cayo' (SaIvin and Godman, Biologia, iii, 1897: 27).

At Ballerina Camp, I lured an adult male about 200 yards to a nearby tree by imitating its loud, highpitched call - a who-ah, uttered almost as one note. I collected the bird. Its testes were not fully enlarged. Both this individual and another that I saw near Millionario on March 12, 1956, were in heavy forest. I presume the Blackand-white Owl is a rare resident in British Honduras.

Blake (1958:514) considered . nigrolineata and

C. huhula conspecific primarily on the basis of two specimens from Columbia that exhibit a combination of the characters of the two owls. Until the relationship between 
these two species is further studied, I prefer to consider them monotypic species.

\section{Asio stycius (Wagler) \\ Stygian $0 w 1$}

SPECIMEN. ISUMZ: Five mi. W Baldy Beacon (about 2200') - J (390.7.g.), Apr. 21, 1956.

The only Stygian Owl ever recorded in British

Honduras flew into a pine tree in my lighted camp shortly after dark and perched on a limb so feet overhead from which I shot it. Open pineland surrounded the camp, although there was heavy forest in a ravine a mile distant. The bird was an adult but not in breeding condition.

I refer the specimen to $A$. s. robustus.

Family NYCTIBIIDAS

Nyctibius griseus (Gmelin)

Common Potoo

SPECIMENS. ISUMZ: Gallon Jug - q (250.4 g.), Feb. 7 , 1958; o (252.6), Mar. 7, 1935. OTHER MUSEUM (BM): One undated specimen from the Eastern Branch of the Belize River.

The two specimens from Galion Jug were collected from the edge of the rain forest, one of them from the top of a telephone pole along a railroad track. The Common Potoo is an uncommon resident in British Honduras, 
as indicated by the-lack of additional records by museum personnel. It is known to some residents of the Colony as the "six-months bird," presumably because it habitually returns to the same perch month after month. The gonads of the Gallon Jug specimens were slightly enlarged.

British Honduras lies well within the range attributed to $\underline{N}$. $\mathrm{g}$. mexicanus.

$$
125
$$

Family GAPRIMULGIDAE

Chordeiles acutipennis (Hermann)

Lesser Nighthawk

SPECTHENS, LSUMZ: Half Woon Cay - $\sigma(5.5 .6 \mathrm{~g} \cdot)$, Apr. 8, 1958. Calabash Cay - $\sigma(49.1), \Lambda p r .9,1956$. OTHER MUSTUM (CM): All Pines - o, Apr. 17, 1935.

The Lesser Nighthawk has been observed regularly on the keys in spring (March 30 - May 8), presumably as a transient. It is unlikely that this nighthawk. winters on the keys, for in the course of daily observations on Half Woon Cay in the spring of 1958, Verner did not see the species until Harch 30. Two individuals noted at Gallon Jug by Willis on f'ebruary 28, 1957, and one on the following day, may have been winter visitants.

I refer the three specimens to $\underline{C}$. a - texensis. The specimen from Calabash Cay is the smallest of the three specimens (wing 177, tail $104 \mathrm{~mm}$.) but indistinguishable from birds from Texas. Oberholser (1914: 101) 
includes British Honduras in the breeding range of the small race, $\underline{c}$. a. micromeris, but he did not examine any specimens from the Colony. I found no evidence indicating that the species breeds in British Honduras, although the breeding range of $\mathrm{C}$. a. micromeris allegedly extends from southern Mexico to Nicaragua.

\section{Chordeiles minor (Forster)}

Common Nighthawk

SPECIMENS. ISUMZ: Augustine - q, Aug. 24, 1961. OTIRR MUSEUM (MCZ): Augustine -, , Apr. 26, 1928. CRIPICAI PUBIISHED RECORD: Southern [= Mountain] Pine Ridge (Hartert, 1892: 613).

I have seen and heard one to four individuals of this species migrating over the wountain Pine Ridge from April 24 to Hay 5 and over the forest at South stann Creek on April 24 and 25. Lancaster noted one Common Nighthawk at Gallon Jug on April 23, and at the same locality. Willis saw one on April 12 and others from May 4 to May 1l, including a flock of 20 on May 9 . Willis recorded one bird at Gallon Jug on the very late date of June 5. Another at Hill Bank on August I was probably an early migrant.

I refer the specimen collected at Augustine in August to $\mathrm{C}$. m. minor. Austin (1929: 375 ) identified the bird he collected at Augustine in April as $\mathrm{C}$. henryi. The three specimens in the British Museum were 
listed as $\underline{\mathrm{C}}$. $\mathrm{m}$. henryi by Hartert in 1892, but several other races have been named subsequently.

\section{Nyctidromus albicollis (Gmelin)}

Paurague

SPECIMENS. LSUMZ: Hill Bank - ?, Feb. 24. Gallon Jug - o (46.9 g.), Treb. 21; o (57.0), Feb. 23; 9 , $(69.6,66.6)$, Mar. 17; $\checkmark(84.8)$, oct. 22. Two mi. W San Pedro Columbia - $\}(72.9)$, May 7 . OTHER MUSEUTS (Bli, CC, CM, CNHA, MCZ, UMMZ): Thirty-seven specimens from Belize, Manatee Lagoon area, Duck Run, Cayo, Midalesex, $12 \mathrm{mi}$. S Cayo, Augustine, Camp VI, Freetown, Toledo Settlenent; all months except June, July, Sept., Nov. CRITICAI PUBLISHED RECORD: Orange Valk (Hartert, 1892: 589).

The Pauraque; better known as "hoo-yoo" in British Honduras, is a common resident of the open areas of the mainland of the colony and is especially abundant in the clearings bordering tall forest or second growth. The call of the Pauraque may be heard throughout the year, although it is very characteristic of the months from January to July. Like other caprimulegids, this species is crepuscular and nocturnal. Half a dozen individuals may occasionally be found in a small clearing, probably because such an area represents the most suitable habitat for the species in an othervise overgrown region. Nests containing one or two eggs were found in April, May, and June; and I collected birds in breeding condition in mid-March.

I refer all British Honduran specimens to N. a. 130

vucatanensis. I do not note any significant differences 
between birds from the coastal areas and those from the more humid interior of the colony. Weights vary considerably among the Galion Jug specimens and can be correlated with the amount of fat stored by the bird.

\section{Otophanes yucatanicus (Hartert)}

\section{Yucatán Poor-will}

SPECIMEN. LSUMZ: Gallon Jug-q.(27.7.g.), Mar. 28, 1955.

The specimen; a female with a moderately enlarged ovary, was collected by Lancaster. Willis saw one or two individuals of this rare arboreal species on 19 dates in the period of February 16 to July 31 at Gallon Jug in 1958. He found four Yucatán Poor-wills at Hill Bank on August 3, 1958.

\section{Caprimulgus salvini (Bangs and Peck)}

$$
\text { Tawny-collared Nightjar }
$$

SPECIMENS. LSUMZ: Half Moon Cay - o $(64.38$.$) , Feb. 28,$ 1958. OTHER MUSDUM (MCZ): Toledo Settlement - $\sigma$, Jan. $2,1907$.

verner collected this species on Half loon Cay, and also saw one bird there on March 1 and 26. The only additional record from the colony is the type of the race $\underline{\text {. S. }}$ badius, collected by M. E. Peck. The presence of this nightjar on one of the small outer keys in late February and March suggests that the species is migratory. 
However, specimens have been obtained in November in vampeche (Storer, 1961: 8) and in January in Yucatán (Paynter, 1955: 143). Paynter also recorded it on Cozumel Island on February 3 and found it nesting there on June 5. It is possible this species is resident on some of the wooded keys off British Honduras but wanders locally in winter and spring.

The Half lioon Cay specinen is assignable to $\underline{\text { S. }}$. badius.

Caprimulgus vociferus Wilson

Whip-poor-will

SPECIMEN. MCZ: Toledo Settlement - 9, Nov. 3, 1906.

The specinen, collected by Peck, is referable to C. $\underline{v}$ vociferug.

\section{Family APODIDAE}

\section{Streptoprocne zonaris (Shaw)}

White-collared swift

SPECIMENS. CM, MCZ, UMMZ: Seven specimens from Manatee Lagoon, Toledo Settlement; Feb., Aug., Sept.

The White-collared Swift was first recorded from British Honduras by Peck, who saw them almost daily in large flocks in September and October of 1906 at Toledo Settlement. From November into the following June, Peck 
continued to see flocks at irregular intervals. On August 9, 1931, Shufeldt collected four birds from a large flock in the vicinity of Hanatee Lagoon. I have seen the species at Gallon Jug in November, Augustine in December, Cubetas in March, and San Pedro Columbia in May. There are no other records from British Honduras and $I$ do not know whether this swift nests in the Colony. I have not critically exarnined the three specimens from Toledo Settlement, but Ridgway (1911: 701) referred them to $\underline{\mathrm{S}}$. $\underline{\mathrm{z}}$. mexicana. A first year nale from Manatee Lagoon has a distinct, bluish gloss on the upper parts, and its forehead is the same sooty-black as the pileum. Its wing measures $194.5 \mathrm{~mm}$. The specimen resembles S. z. albicincta from southern Central America, and $I$ refer it to that race. A first-year female from Manatee Lagoon (wing $191.5 \mathrm{~mm}$.) has a dark forehead that is barely lighter than the pileum and this specimen is probably referable to $\underline{S}$. $\underline{z}$. albicincta. The upper parts of an adult male from the same locality are not decidedly sooty black and its forehead is paler than its pileum; I refer this specimen to $\underline{\text { S. }}$. mexicana. The fourth bird from Manatee Lagoon, a juvenile male, is probably $\underline{\mathrm{S}}$. $\underline{\mathbf{z}}$. mexicana. 


\section{[Chaetura pelasica (Iinnaeus)]}

Chimney Swift

Bent (1940: 293) listed British Honduras among the localities where the chimney Swift had been recorded. He commented, "A specimen was taken (accidentally destroyed) in March 1905." A reference to British Honduras is also included in the account of this species in the Check-list of North American Birds (1957: 298). I know of no evidence that substantiates these two records. ConsequentIy, I do not consider the Chimney Swift a species definitely recorded in the Colony.

Verner noted a single swift belonging to the genus Chaetura on Half Moon Cay on April 22, 1957. It is possible this bird was $\underline{G}$. pelagica. Chimney Swifts were collected by Gaumer on Isla Cozumel in April (Salvin, $1889: 367)$.

\section{Chaetura vauxi. (J.K. Townsend) Vaux's Swift}

SPECIMENS. ISUMZ: Corozal - ?, Aug. $15 ; 2 \sigma^{\prime \prime} \mathrm{s}$, Aug. 17. Gallox Jug - ? (14.3 g.), Nov. 12. Belize - , Apr. 6.

Vaux's Swifts have been observed in the Colony in every month except September and october, but only the presence of the birds in spring and summer suggests that they may breed there. Willis noted five to ten individuals almost daily at Galion Jug from March to July and 
flocks of 30 to 40 birds in February, early March, and late July. I have seen small flocks at ilill Bank, Belize, the fountain Pire Ridge, Cockscomb Mountains, and San Pedro Colunbia. Almost without exception the birds were flying high. In August 1960, Lay found an old water tank about nine feet high and six feet in diameter in the center of Corozal that was used as a roost by approximately 700 swifts. Lay examined 254 of the birds in the tank and found that all were Vaux's Swifts. He preserved two as skins.

Alexander Wetmore has examined the three specimens collected by Lay at jorozal and identified thern as $\underline{\mathrm{C}}$. richmondi. I refer the two specimens from Gallon Jug and Belize to the same race.

\section{Cypseloides cryptus Zirnmer}

White-chinned swift

SPECIMENS. UWMZ: Four specimens from Manatee Iagoon; Aug. 9, 1931.

The four specimens of this species listed above were collected by Shufeldt at the same time that he obtained four White-collared Swifts. Unfortunately, Shufeldt's notes do not describe the conditions associated with the capture of these eight swifts on the same day.

Zimmer (1945: 588) described this species from four specimens from Perú, British Guiana, Venezuela, 
and Costa Rica. Howell (1957: 82) collected one in Nicaragua and a specimen frow Panamá reported by Rogers (1939: 83) is presumably this swift. The shufeldt series from Manatee Lagoon consists of an adult nale and female and an immature male and female. The maturity of the bixds was determined by the degree of skeletal ossification (Shufeldt notes). The wing and tail feathers of the adult male were being replaced, but the other three birds were in fresh plumage. Measurements in millimeters of the four British Honduran specimens follow.

Measurements in millimeters of four specimens of Cypseloides cryptus from British Honduras

$\begin{array}{lrrrr} & \text { ad. } 0 & \text { imm. } 0 & \text { ad. } & \text { imm. } \\ \text { wing } & 131 * & 135 & 135 & 134 \\ \text { tail } & 48 & 52 & 47.5 & 48.5 \\ \text { exposed culmen } & 5.1 & 5.2 & 5.1 & 5.0 \\ \text { culmen from base } 9.1 & 10.1 & 9.2 & 9.1 \\ \text { tarsus } & 16.1 & 17.1 & 17.1 & 16.5\end{array}$

* worn

The adult male agrees very well with the description of the type of $\underline{C}$. cryptus. The adult female from Hanatee Lagoon is similar to the female from Costa Rica described by zimmer; the adult female differs from the adult male primarily in having white tips to the feathers of the belly and under tail-coverts and in having very little white on the chin. The two immature birds are very similar to the adult female but have no white at all on the sides of the head. The white is replaced by a buffy brown that 
causes the head to anpear darker than that of the female. The shafts of the feathers of the under parts are dark in the four British Honduran specimens and in this respect differ from those of all $\underline{C}$. niger that I have examined.

\section{Aeronautes saxatalis (Woodhouse) \\ White-throated Swift}

Lancaster saw two White-throated Swifts at Gallon Jug on February 6 and 8 and larch 8, 1958, and Peck believed that he saw many individuals of this srecies at pianatee lagoon in ilebruary and March 1906. Bent (1940: 313) described a nest of this species in the collection of the Wuseum of Comparative Zo8logy that was coliected lifay 27 , 1906, in the Cockscomb hountains by Gerald B. Thomas.

Presumably breeding birds from British Honduras would be referable to A. s. nigrior, the roce present in the mountains of EI Salvador, Guatenala, and southern Mexico.

\section{Panyptila cayennensis (Gmelin)}

Svallow-tailed swift

Duxing the period from February 16, 1957, to August 1, 19>7, Willis carried out ornithological field studies at Galion Jug. In the course of his field work, he observed one to five Swallow-tailed swifts on 24. dates. Most observations were in February, March, and July, but 
he did see one or two birds three times in April, once in May, and twice in June. Usually these swifts were. circling high in wheeling blocks of vaux's Swifts. Willis wrote (in litt.), "The Panyptila had distinctly white throats; the abdomen, and rest of the body was black, except for whitish patches on the flanks. The Panyptila rarely showed their forked tails, keeping them closed much of the time; but I distinctly saw the forked tails on several occasions when birds turned sharply." The species probably, nests in the area, since Edwards (19>9: 358) recently found it nesting in Petén, Guatemala.

Family TROCHILIDAE

Phaethornis superciliosus (Linnaeus) Long-tailed Hermit

SPECIMENS. ISUHZ: Humningbird Gap - $\sigma$ (6.1 g.), Mar. 26. OTHER MUSEUMS (BM, CC, MOZ): Eight specimens from the Manatee Jagoon area, Cayo, Mountain Pine Ridge, Mountain Cow, Toledo District; Mar., Apr., Oct., Dec. CRITICAI PUBIISHED RECORD: San Felipe (Sálvin, 1892: 272).

The species is moderately common in the understory of tall, wet forest of the central and southern regions of the colony but is rare in the drier northern third. I saw it only twice at Gallon Jug (Oct., Nov.) and Willis noted it there once in August. It ranges from near sea level to at least 2700 feet in the lookscomb Mountains. The gonads of a male I collected on March 26 were only 
slightly enlarged. Peck (1910: 55-56) found a nest and two eggs on April 20, 1907, at Toledo Settlement. Specimens of the Long-tailed Hermit from British Honduras are referable to $\underline{\underline{p}}$. $\mathrm{s}$. Iongirostris.

\section{Phaethornis Ionguemareus (Lesson) \\ Iittle Hermit}

SPECIMENS. LSUMZ: Hummingbird Gap - $\sigma\left(2.8 \mathrm{~g}_{.}\right)$, Mar. 26. Ballerina Camp - P (2.5), Apr. 26. Two mi. W San Pedro Columbia - ? (2.0), May 12. OTHER MUSBUMS (CM, MCZ, USNM): Five specimens from Manatee Lagoon, Cayo, Freetown; Mar., May, July, Nov.

This tiny hermit is the most comnon humningbird of the understory of heavy forests throughout mainland British Honduras. It is frequently noted in the forest border and within the forest where the undergrowth is exceptionally dense. Although this species occupies almost the same habitat as the Iong-tailed Hermit, it is much more common than its Iarger relative. At Gallon Jug Willis noted nests under construction on May 30 and June 27, 1957, and at Toledo Settlement Peck found a nest containing eggs on May 26, 1907.

I have compared British Honduran specimers with ' $138 /$

the type of $\underline{\text { P. }}$ 1. Saturatus from Costa Rica and with specimens of $\underline{\underline{P}}$ l. adolphi from Veracruz. Birds from the Colony are intermediate between the two races. The specimen from Freetown is closer to $\underline{\text { P. }}$ l. saturatus than to P. 1. adolphi; specimens from other localities in 
the Colony are paler and could be referred to either race.

Phaeochroa cuvierii (DeLattre and Bourcier)"

Cuvier's Hunmingbird

SPECIMENS. ISUMZ: Gallon Jug $-\sigma(8.6 \mathrm{~g} \cdot)$, Feb. 6 ; q(8.0), Oct. 25 ; $q(8.2)$, Nov. 13. OTHER MUSEUMS (BM): Two specimens from Cayo; undated. CRITICAL PUBLISH RECORDS: Belize River, San Felipe; Feb., Mar., Dec. (Salvin, 1892: 300).

Cuvier's Hummingbird is an uncommon species in British Honduras. Personnel of the ISUHZ recorded it only at Gallon Jug, where they found it in the forest edge. The species is presumably resident since Willis saw half a dozen individuals in as many days in July and early August near Gallon Jug, but there are no additional summer records from the Colony. The testes of a bird collected by Verner at Gallon Jug on February 6 , 19>8, were slightly enlarged.

I refer specimens from British Honduras to $\underline{P}$. $\underline{\text { c. }}$ roberti.

Campylopterus curvipennis (Iichtenstein)

Wedge-tailed Sabrewing

SPECIMENS. ISUMZ: Gallon Jug - $\sigma(6.6 \mathrm{~g}$.$) , Mar. 29;$ $\sigma(6.7)$, June $6 ; \sigma(5.4)$, Nov 1 ... Ballerina Camp - $\sigma$ (7.4), May 1. Two mi. Ne Milizonario - $9(6.7)$, Mar. 1b. Two mi. W San Pedro Columbia - $5(7.1)$, hay 13. 
This humingbird is a moderately common resident of tall forest and the forest edge, and it sometimes visits flowering.trees in open areas outside the forest. I have seen it in the North Stann Creek valiey, the only additional point of record. It is perhaps local in its distribution since I found it at only four localities and none of the other ornithologists who have visited the Colony reported it at ali. The bird collected May I had only slightly enlarged gonads, but the other four specimens, taken in March, May, and Tune, were in breeding condition. The male obtained in November was an immature bird.

The specimens are typical of $\mathrm{C}$. c. pampa.

Campylopterus hemileucurus (Iichtenstein)

Violet Sabrewing

SPECIMENS. ISUMZ: Ballerina lamp - ? (8.4), May 1 . Two mi. W San Pedro Colunbia $-\sigma(12.5)$, May 5 . OTHSR MUSHUM (CM): Three specimens from the hanatee Lagoon area (July, Aug., 1905), N slope Cockscomb Mts. (1200', Mar., 1935$).$

During late April and early May, 1958, and in late Way and early June, 1959, I found the Violet sabrewing to be the most common hummingbird from an elevation of about 400 feet along South Stann creek to about 2400 feet in the Cockscomb Mountains. Above the latter elevation only exupherusa eximia was more common. I saw the present species several times at Gallon Jug in October 
and November and once at Augustine in December. The specimen collected by Arostini in the Cockscomb Mountains on March Is was in breeding condition. The birds collected at Ballerina Camp (1500') and west of San Pedro columbia (250') in thay were not in breeding condition. These data suggest that this hummingbird breeds in the Tropical "let porest life zone of the Maya and Cockscomb Hountain area, perhaps descending to as low as 400 feet above sea level, and randers to the north and east after the nesting season. There is no clinatological information from these mountains; thus there is the possibility that their upper slopes are transitional into the subtropical belt'. Nevertheless, $\underline{\text { C. hemileucurus }}$ does presumably nest in the tropical zone, at least in British Honduras. Todd (1942: 289) suggested that the species is limited to the subtropics, but tris statement was questioned by Blake (1950: 403):

\section{Florisuga mellivora (Iinnaeus)}

White-necked Jacobin

SPECIIENS. ISUMZ: Hill Bank - 2 :s $(7.1,8.1 \mathrm{g.})$, Nov. 26. Two mi. s Pomona - $7(7.0)$, Mar. 31. OTHER MUSEUMS (BM, CM, UNHZ): Wight specimens from the Belize River, Manatee Lagoon; July, Nov. CRITICAI PUBIISHID RECORD: Western [= Cayo] District, Nov. (Salvin, 1892: 330).

On November 26,1956 , I observed nine individuals of this species in the "broken" pine ridge near Hill Bank and I saw three near Pomona on March 31, 1956. At 
the latter locality, Dennett collected one of a pair of birds hovering about 40 feet over a small stream in tall second growth. Shufeldt collected one specimen on November 6, 1930, in the pine ridge near Manatee Iagoon, but the five specimens peck collected in July, 190ל, near, the same lagoon were "about openings in the forest" (Peck notes). There are no additional records from British Honduras; consequently my knowledge of its status and distribution is meager. None of the Hill Bank or Pomona specimens was in breeding condition. hiexican and Central American specimens of this species are generally referred to $\underline{\underline{F}}$. m. mellivora.

\section{Colibri delphinae (Lesson)}

Brown Violet-ear

SPECIMENS. LSUMZ: Hill Bank - $\$(5.6 \mathrm{g.})$, Nov. 2), 1956.: One and one-half mi. B Victoria Peak (2600')' 9, May 8, 1958. OTHER MUSEUM (CM): One specimen from the Manatee Lagoon area, July. 28, 1905.

I collected the specimen taken at Hill. Bank as it perched silently about ten feet above the ground in. extremely dense second growth that was 30 feet high. The bird from the Cockscomb Mountains was one of two or three I saw on the crest of the mountain in. low growth that was heavily laden with epiphytes. The gonads of the Hill Bank and Cockscomb Mountain specimens were only slightly enlarged. Peck's notes contain no additional 
information concerning the specimen that he collected near Manatee Lagroon.

\section{Anthracothorax prevostii (Lesson) \\ Green-breasted Mango}

SPECIMTNS. ISUMZ: Four mi. HE Hill Bank Apr. 1. Calabash Cay - $(6.6)$, Anr. 13; $3^{\prime} 29^{\prime}(6.5$, $6.4,7.0)$, Apr. 14; $5(6.7)$, Apr. 15. Hunting vay - 3 (6.7), Apr. 27. OTHER MUSJUIS (CM, UMMZ): Twenty-two specimens from Belize, Wanatee Lagoon area, Half moon Cay, Freetown, Northeast and Middle Cays in Glover's Reef; Feb., Mar., Apr., May, JuIy, Dec. URILICAI PUBLISHED RECORD: Isabella (Jaintz, 1899: 221).

The Green-breasted Iifango is a moderately common resident of keys and coastal lowlands from Corozal south at least to Freetown. I believe individuals move about between islands or between islands and the mainland. Two birds were noted on Hunting Cay on fipil 27, 1956, an island that seemed too small to support many breeding birds. It is normally found in scrub growth, especially where Hibiscus or other flowering plants are in bloom, and in small numbers in tine pinelands. In Belize it is one of the comnonest hummingbirds. The species is rare inland but has been recorded at HilI Bank, Gallon Jug (twice), and Ballerina Camp. Breeding begins in early April and continues through May and possibly longer.

I refer British Honduran specimens to A. p. prevosti $\frac{14}{1}$ No specimens from the Colony approach $\underline{A}$. p. nigrilineatus of the Bay Islands, Honduras. 
Paphosia helenae (Delattre)

Black-crested Coquette

SPECIMEN. BM: Cayo, undated.

This specimen, examined by Todd in the British Miuseum, constitutes the only record of the species from the Colony.

\section{Chlorostilbon canivetii (Lesson)}

Fork-tailed Emerald

SPECIMISN. CM, MC2, UH:1Z: Nine specimens from Belize and the Manatee Lagoon area; Jan., Feb., July, Aug., Wov. CRITICAL PUBLISHEI) RECORD: Orange Walk (Salvin, 1892: 48).

The species is an uncominon resident of coastal scrub and pine ridge thickets in the northeastern. lowlands south to the Manatee Iagoon area. There is no information concerning the breeding season of this hummingbird in British Honduras, but farther north in the Yucatán Peninsula tt treeds from February at least to May (Paynter, 1955: 147). Specimens from the Colony are referable to $\subseteq . c$.
canivetii

Thalurania furcata (Gmelin)

Common Woodnymph

SPECIMEN. ISUMZ: Seven mi. NW San Pedro Columbia - $\sigma$ (5.8 g.), May 18, 1956. 
This specimen, a male with slightly enlarged testes, was collected by Dennett in heavy forest and constitutes the only record of the species from the Colony •

I refer the specinen to I. f. townsendi.

Hylocharis eliciae (Bourcier and Mulsant) Elicia Goldentail

Disenmann (19b5a: 48) implied that this species has been recorded from British Honduras but I have been unable to confirm its presence there. It should be omitted from the list of birds known to occur in the Colony.

Amazilia candida (Bourcier and Mulsant)

White-bellied Imerald

SPECIMDNS. LSUMZ: Gallon Jug - $\sigma(3.5 \mathrm{~g} \cdot), \Lambda \mathrm{pr} .7 \%$ $(3.9)$, oct. $27 ; \sigma(3.6)$, Nov 6 . Augustine - $\sigma$, Augr. 13. Seven mi. NW San Pedro Columbia - P (3.9), May 18. OTHER MUSEUMS (CM, MCZ, UMYI, USMM): Eight specimens from Belize, Manatee Lagoon area, Cayo, Mountain Cow; Jan., Feb., Mar., Apr., June, July. CRIIICAI PUBLISHED RECORDS: Corozal, Southern [= Mountain] Pine Ridge (Salvin, 1892: 190).

Semi-open, moderately tall and tall second growth, the forest edge, and sometimes the interior of heavy. forest provide habitats for this moderately common resident. It is distributed throughout the mainland of British Honduras. And additional points of record are 
Hill Bank, Ballerina Camp, Ycacos Lagoon, and Toledo Settlement. I collected a male on April 5 that had enlarged testes and a female on way 18 that had an enlarged ovary. A nest with eggs found by Peck on May 5 was built about 12 feet above the ground in a snall tree. Specimens from the Colony are assignable to A. C.
candida.

\section{Amazilia cyanocephala (Lesson)}

Red-billed Azurecrown

SPECTMENS. LSUMZ: Three mi. WN HiIl Bank - $2 \mathrm{q}^{\prime} \mathrm{s}$ $(4.7,6.3 \mathrm{~g})$, Apr. $1 ; 7 ?$ ? $(4.4)$, Nov. 29. Augustine ? (5.8), Mar. 19; o, $9(6.1,4.9)$, Apr. 20. Ballerina Camp - ? (5.6), Apr. 26. OTHER MUSEUMS (CC, CM, MCZ, UNMZ): Highteen specimens from $8 \mathrm{mi}$. NW Belize, the itanatee Lagoon area, $12 \mathrm{mi}$. s Cayo, Augustine, Freetown, All Pines; Feb., Mar., Apr., May, June, July.

The Red-billed Azurecrown is the nost common and characteristic hummingbird of the pinelands at all. elevations in British Honduras, and it frequently enters other open habitats in the vicinity of the pine ridges. shufeldt collected a female containing an egg almost ready for laying on February 20 , the earliest indication of breeding. The nesting season continues at least to July 30 , when a nest containing eggs was noted by Peck. Specimens from British Honduras are referable to A. c. guaterialensis $148 /$. 


\section{Amazilia 'rutila (DeLattre)}

Cinnamon Humingbird

SPECIMENS. LSUMZ: Calabash Cay - o (4.9 E.), Apr. 9; of (4.2), Apr. 16. OTHER MUSDUM (MCZ): Two specimens from Wild Cane Cay; Dec. 3I. CRITIC $\Lambda$ I PUBLISHED RECORDS: Orange Walk, Belize (Salvin, 1892: 208); Turneffe (Bond, 1954: 8).

The species is an abundant resident of the larger keys but is rare on the mainland. Specimens collected by Gaumer at Orange Walk and by Blancaneaux at Belize are the only records from the mainland. It has been observed on Noxthern Two Cays (Bond, 1954: 6), Half Hoon Cay (Salvin: 1864: 380; Verner; van Tets), and lifrabb's Water Cay (Iay) in addition to the keys on which it was collected. On the keys the Cinnamon fummingioird is found in low scrub growth and coconut groves but not in the mangroves.

I refer British Honduran specimens to $\underline{A}$. $\underline{r}$ rutila.

\section{Amezilia Zucatanensis (Cabot)}

Buff-bellied Humingbird

SPECIMPNS, LSUMZ: Hill Bank - $9(3.7 \mathrm{g.})$, Nov. 25, 1956. OTHER MUSBUHS (CM, MCZ): Two specimens from the Manatee Lagoon area; Aug. 2 and Nov. II, 1905.

The three specimens were collected in thickets in the pine ridge. Peck, who collected the birds near Manatee Lagoon, also saw the species north of Belize and at Point Placentia. On April 10 and June 23, 1906, he located nests of the Buff-beliied Hummingbird situated 
about 4 feet above the ground in open thickets in the pine ridge near. Manatee Lagoon. There are no other records of the species from the colony.

I refer the specimens from British Honduras to the nominate form, A. $y$. yucatanensis.

\section{0}

Amazilia tzacatl (De la Llave)

Rief'er's Humingbird

SPECIIIENS. LSUMZ: Hill Bank - $\gamma(5.5 \mathrm{~g} \cdot)$, Nov. 25. Gallon Jug - 2 ?'s, Jan. 15; ?, Feb. 18; $\sigma(5.2)$, Feb. 25 ; 8 (5.4), Mar. 9; $x^{\prime}(5.4)$, oct. 30 . Aupustine - 5 , Aug. 13. Two mi. W San Pedro Columbia - 5 (5.3), May 3; (4.1), WIay 12. OTHRR MUSEUMS (CC, CM, CNHM, MCZ, UNMZ, USIMM): Fifty-two specimens from $8 \mathrm{mi}$. IN Belize, Belize, Belize River, Manatee Lagoon area, Duck Run, Cayo, Middlesex, Pomona, Freetown, All Pines, Toledo Settlement; all months except Aug., Sept., Nov. CRITICAI PUBLISHID RECOPDS: Corozal, Orange Walk (Salvin, 1892: 218):

Rieffer's Humingbird is a common to abundant resident of the mainland of the Colony, where it inhabits the semi-open and most wooded areas except the pine ridges. Although the species does occur in heavy rain forest, it is less common within the forest than at its edges. I did not see it in the heavily forested Cockscomb Mountains, nor did Blake and Agostini collect it there. Peck found occupied nests in January, February, May, August, and september, and males that I collected in october and November had slightly enlarged Eonads. The subspecies in Middle America is A. t. tzacatl. 
Eupherusa eximia (DeJattre)

Stripe-tailed Hummingbird

SPECIMENS. LSUMZ: S slope Victoria Peak (3400'), May 29. ORHER MUSEUM (CM): Seven specimens from the $N$ slope Cockscomb Mts. (1300'-1500'); March, 1935.

The species has been recorded only from the Cockscomb Mountains above an elevation of about 1000 feet. On the steep slopes above 2400 feet, I found it the most common hummingbird in April and May. Presumably it is resident there, but the mountains have not been visited by ornithologists at other seasons.

The specimens from British Honduras are similar to Guatemalan specimens. I refer them to E. e. eximia.

\section{Heliothryx barroti (Bourcier)}

\section{Purple-crowned Fairy}

SPECIMENS. BH: Two specimens from Cayo; no date. CRITICAI PUBLTSHDD RECORDS: Belize, San Felipe (Salvin, 1892: 33 ).

Toda examined the two specimens from cayo in the British Museum, and Salvin (1892: 33) lists specimens collected by Blancaneaux at Belize, Cayo, and San Telipe. Lantz (1899: 220) records a male collected at Cayo by Goss. There are no other records of the species from British Honduras. 


\section{Archilochus colubris (Linnaeus)}

Ruby-throated Hummingbird

SPICIMINS, ISUMZ: Gallon Jug $-\gamma(2.9 \mathrm{~g} \cdot)$, Mar. 2 . Half Hoon Cay - ? $(3.4)$, Apr. 8. OMHER GUSBUMS (BR, CC, ON, UMYZ: Five specimens from Belize, Manatee River, Cayo; Feb., llar., Apr.

Ruby-throated Hummingrirds are uncommon in British Honduras and have been collected only in the period of February 7 to April 8. A few individuals seen in midwinter and early spring by Peck at Manatee Lagoon and Toledo Settlenent and one bird noted at Gallon Jug on February 8, 1958, by Lancaster supply the only aditional records. The bird collected on Half Moon Cay by Verner was certainly a migrant, as it was the only one observed during the three months verner spent on the island. The remaining records could presunably be of migrants or winter visitants.

Fanily TROGONIDAT

Trogon massena Gould

Massiena Trogon

SPECIMENS. ISUMZ: Sixteen mi. N Gallon JuE - Q ( 148.5 g.), Mar. 4. Gallon Jug - $\$$ (143.9), Mar. 11; (162.1), Nov. 14: Seven mi. IN: San Pedro Columbia - o (163.3), May 19. OTHER IMUSEUMS (BM, CC, CM, MCZ, UMHZ): Twentyone specimens from Belize, Manatee Lagoon area, Duck Run, San Antonio, $12 \mathrm{mi}$. S Augustine, Augustine, Freetown, S slope Cockscomb ints. (I650'); all months ercept Aug. Nov, inclusive, CRITICAI PUBLISHED RECORDS: CaJo, San Felipe (Grant, 1892: 475). 
The Massena Trozon is a mọderately common resident of heavy forest and tall second growth throughout most parts of mainland British Honduras. I have seen it at elevations ranging from sea level near stann creek up to at least 2700 feet in the Cockscomb Mountains. It has a wide vertical distribution within the forest but is most often observed perched motionless in the middle level. Nests made in aerial termite houses were noted by Peck in way and June, but the enlarged gonads of specimens that I collected in March indicate that breeaing begins earlier. Van Tyne collected a feriale south of Cayo on Tiebruary 19, 1931, which weighed 147 grams.

The race occurring in northern Central America is $\underline{\mathrm{T}} \cdot \underline{\mathrm{m}} \cdot \underline{\operatorname{massen}} \underline{\underline{I}}$

\section{3}

Trogon citreolus (Gould)

Citreoline Trogon

SPICIMENS. ISUMZ: GaIlon Jug - $\sigma$ (48.2 g.), Feb. 25; $\sigma$ $(71.5)$, Feb. 28. Two mi. W San Pedro Colunbia - 9 (74.7), May 11. OTHER MUSEUMS (BM, CC, CM, MCZ, UMTZ, USTM): Thirty specimens from Belize, Manatee Lagoon area, Cayo, San Antonio, Mountain Cow, Freetown, All pines; Jan., Feb., Mar., Apr., May, June. URITICAI PUBIISHED RFCORDS: Corozal, Orange Walk, San Felipe (Grant, 1892: 464).

This resident species is the most common trogon in British Honduras and is found throughout the mainland. It is most frequently seen in medium to tall second growth and the forest border, but it also occurs in pinelands and areas where trees are scattered. Rarely is it found 
in heavy forest. Peck collected six sets of eggs from nests in the pine ridge near Manatee Lagoon from May. 14 to June 16, 1906. All the nests were in termite houses less than $2 b$ feet above the ground.

The race of the Citreoline Progon in british Fonduras is $\underline{\text { I. }}$. nelanocephala.

Progon collaris (Vieillot)

Collared Trogon

SPECIMENS. ISURZ: Three-fourths mi. SE Victoria Peak (2700') - $?$, May 30, 1959. OTHER MUS\$UM (MCZ): One Ecimen from Mountain Cow; Apr. 7, 1928. CRITICAL FUBLISHED RECORD: Western [= Cayo] Dist. (Grant, 1892: 4万4).

On April 14, 19b7, Lancaster found a nest and two eggs of this rare species in a moho stub in high second growth at Gallon Jug. A predator took the eggs and killed the female a few days later. In the same area, Willis saw a single individual on five dates during the three months following the death of the female. There are no other sight records of the collared Trogon from the colony. The bird that I collected near Victoria Peak was calling from a linb about 40 feet above the ground in tall undisturbed forest. Its ovary was slightly enlarged.

The specimens are referable to $\underline{\text { T. }}$. . puella. 
Trogon violaceus (Gmelin).

Violaceus Trogon

SPECIIENS. LSUMZ: Gallon Jug - 7 ( >.$^{7} \mathrm{~g} \cdot$ ), Mar. 3. "'wo mi. W San Pedro Columbia - $\sigma(37.2)$, May $8 ; .5$ ( $(28.8)$, May 17. OTHER MUSEUMS (CM, IRC): Four specimens from Cajo, Camp VI, Freetown; Mar., Apr.

The Violaceus Trogon is a moderately commor resident of tall second growth, the forest edge, and heavy forest. Sight observations of this species at Hill Bank, Duck Run, Fummingbird Gap, Augustine, Ballerina Camp, Kendal, and South Stann Creek supplenent the specimen records. I collected a female at Gallon eTug on March 3 that had a slightly enlarged gonad, but two males taken in May near San Pedro Columbia were not in breeding condition. Willis noted an adult with a short-tailed juvenile at Gallon Jug on July 4.

The race of this trogon in British Honduras is $\underline{I}$. braccatus. $1>6$

Family ALCEDINIDAE

Ceryle torquata (Linnaeus)

Ringed Kingfisher

SPECIMTNS. BN, CC, CIN, UMHZ: Nine specimens from Belize, Manatee Lagoon area, Cayo, Freetown; Feb., May, Aug., Nov, CRITICAL PUBLISHED RECORD: Belize River (Sharpe, i892: 1<2).

This kingfisher is a common resident along inland lagoors and larger waterways, and it is sometimes seen 
along the coastal beaches. Occasionally I saw one or two birds flying very high over the lowland pinelands from one body of water to another. Peck found eight occupied nesting cavities from April 26 to May 2b. Iwo burrows that he excavated on May 8 were complete but contained no eggs.

I refer specimens from the Colony to the widely ranging $\mathrm{C}$. $t$. torquata.

\section{Ceryle alcyon (Iinnaeus)}

Belted Kingfisher

SPECIMENS. ISUMZ: IIII Bank - ? (I42.0 g.), Feb. 26. OTHER MUSGUMS (CM, UMMZ): Three specimens from Belize, Manatee Lagoon; Jan., Sept.

Among the keys, flong coastal beaches, and in the larger lagouns, the Belted Kingfisher is moderately common from early september (Peck) to late hpril. The latest individual recorded in spring was seen by Verner at Half Moon Cay on May 8, 1958. Daily counts of individuals are so inconsistent during the nine months ceryle alcyon is in the colony that migrating birds are difficult to detect. The species is very uncommon inlend; so perhaps 12 individuals that I observed in three days in late March at Hill Bank Lagoon were migrants. The specimens are referable to $\underline{\mathrm{c}}$. a. alcyon. 


\section{Chloroceryle amazona (Latham) \\ Amazon Kingfisher}

SPICIMENS. ISUMz: Two mi. W San Pedro Columbia - 2 \%'s (129.0, 143.4), hay 16. OTHER MUSEUTS (BM, CC, CM, U:MZ): Six specimens from the Manatee Iagoon area, Cayo, Eastern Branch Belize River; Mar., May.

The Anazon Kingfisher is a modertely common resident of the laxger lagoons and rivers from the coast inland. In April 1975, I saw this species daily at Ballerina Canp at an elvation of 1400 feet, which is the highest point from which I recorded it. There the Eastern Branch of the Belize River is still a sigable stream with many large deep pools interspersed between the ranids. 'the two males collected near san Pedro Columbia had only slightly enlarged gonads.

The Central American race is $\underline{C}$. a- mexicana.

\section{Chloroceryle americana (Gmelin)}

Little Green Kingfisher

SPECIMINS. LSUMZ: Six mi. NNE Hill Bank Feb. 2). Gallon Jug - ? (49.3), Mar. 28. OTHER MUSEUMS (CC, CH, CNHM, HCZ, UMT): Twenty opecimens fron the Belize River, Manatee Lagoon area, $12 \mathrm{mi}$. S Cayo, lifdde. sex, Camp VI, Freetown; Feb., Jiar., Apr., Jiay, Aug., Sept., Dec. CRITICAI PUBLISHED RECORD: Cayo (Sharpe, 1892: 135).

The species is a moderately common resident of the colony and is found on nearly all streams and lagoons. of the seven specimens collected in February, March, April, and May for which there is information, five had at least slightly erlarged gonads. Two males and a female 
collected by van Tyne in February and INarch south of layo weighed $32.7,38.3$, and 40.0 grams, respectively. In sone specimens from several areas in British Honduras, the extent of the submalar line, the amount of spotting on the under parts, and the extent of white on the throat approach the characters of $\mathrm{C}$. ‥ isthmica, but I refer all specimens from the colony to $\underline{c}$. a. septentrionalis.

\section{Chloroceryle aenea (Pallas)}

Pygmy Kingfisher

SPECIMENS. ISUMZ: Four mi. NE HiIl Bnk - o, Har. 23. OTHER MUSEUMS (BM, $C C$, CH, UNZ): Twenty specimens from Belize, Belize River, Manatee Lagoon area, Benque Viejo, Eastern Branch Belize River, San Felipe, Freetowr; all months except Feb., June, Oct., Nov.

Pygmy Kingfishers are common residents of small streams in forested areas at all altitudes and are moderately comon along lowland streams and lagoons lined with woods or mangrove thickets. The only indication of breeding was provided by the enlarged gonads of two specimens collected in May by Mlake and Agostini.

British Honduran specimens are referable to $\underline{\mathrm{C}}$. $\underline{\text { a }}$ stictoptera. 162/ 


\section{Hylomanes momotula (Lichtenstein)}

Tody Motmot

SPECIMENS. LSUMZ: GaIIon Jug - $q$ Jan. 7; $f(29.2$ g.), Feb. 29; ?.(25.2), Mar. 7; ? (20.3), Mar. 14; 6 (28.2), Mar. 21; $\sigma(31.6)$, Nov. 17. OTHER MUS SUMS (BM, CH, MCZ): Six specimens from Eastern Branch Belize River, Toledo Settlement; Feb., Nov., Dec. CRITICAL PUBLISHED RECORD: Cayo (Sharpe, i892: 332 ).

This small motmot is a quiet and retiring resident of the understory in heavy forest. Whe only point of record in addition to the collecting localities is ballerina Camp. The species is uncommon and individuals are nearly always solitary. Willis noted adults carrying food near Gallon Jug on June 21 and saw a grown young bird with an adult on July 3 in the same vicinity. Specimens from the Colony are assignable to $\underline{H}$. $\underline{\text {. }}$ momotula.

\section{Electron carinatum (DuBus) \\ Keel-billed inotmot}

SPECIMENS. BM, CN: Belize and San Felipe - one undated specimen from each locality. N slope Cockscomb Mts. 7, March 1ל, 1935.

Two undated specimens in the British Museum and a specimen collected by Blake in the Cockscomb lifountains constitute the only records from the colony.

I have examined the specimen from the cockscomb Mountains and $I$ refer it to E. c. carinatum. The other 
two specimens are probably referable to this race also.

\section{Nomotus momota (Iinnaeus)}

Blue-crowned irotmot

SPECIMINS. ISUMZ: Gallon Jug - \%, Ifar. 16; \& (136.5

g.), Nov: 6. 'Iwo mi. Nif Augustine - 3 ", Dec. 13. Ballerina Camp - P. (148.2), Apr. 27; (113.0), Apr. 29. Two mi. W San Pedro Columbia - 3 (125.0), May 7; \& (129.1), May 8. OTHER MUSTUMS. (BH, CC, CH, MCZ, UMMZ): Twenty-one specimens from the lanatee Iagoon area, Cayo, San Felipe, Mountain Cow, N slope Cockscombints. (1300, - $\left.1500^{\prime}\right)$, Freetown, Ioledo Settlenent; Nlar., Apr., Nay, June, Sept., Oct., Dec.

Blue-crowned thotmous are common but inconspicuous residents of the tall forests of British Honduras. In the heavy forests of the hilly and mountainous western and southern sections of the Colony, where banks suitable for nesting are plentiful, the species is especially. abundant. The species is well known to rural residents as. "good cook," a name dexived from the phonetic expression of its call. I have noted nests or collected breeding birds from late April to early June, and Villis sav a pair feeding young in a hole near Gallon Jug on June 28 . The females weighing 129.1 and 148.2 grams were in breeding condition, and the lighter bird contained a fully developed egg in the oviduct. The least heavy bird of each sex from British Honduras weighed more than the heaviest bird of the same sex recorded by Paynter (1955: 160) from quintana Roo or by van Tyne (1935: 19) from the Petén. 
I refer British Honduran specinens to $\underline{M}$. lessoni. 165

Family GALBULIDAE

Galbula ruficauda (Cuvier)

Rufous-tailed Jacarnar

SPEOIMINS. LSUMZ: GaIIon Jug - $q$, Jan. $8 ; q(28.9$

g.), Mar. 4; 9 (19.3), Mar. 7; $(28.1)$, Oct. 21. Two mi. W San Pedro Columbia - 2 o's $(27.6,28.9)$, lifay 7. OTHER MUSEUMS (BR, MCZ): Two specimens from San Antonio, Rio Grande; NOv. CRITICAI PUBIISHED RICORD: Belize (Sclater, 1891: 167).

Jacamars are moderately coinmon birds in British Honduras and have been observed in a number of localities not represented by specimens. I have seen them near Hill Bank, along sections of the Hunmingbird Highway, in the Stann Creek Valley, and at Guecanallo, Ballerina Camp, Cubetas, Kendall, and South Stann Creek. The preferred habitats of this species in the Colony are the forest edge and second growth, but it does occur in the lower level of heavy forest. Jacamars are conspicuous and noisy birds and are prone to use the same few exposed perches over and over agein as base stations for their insect catching activity. West of San Pedro Columbia on May 7, 1956, I watched a female Rufous-tailed Jacamar enter a circular hole in a hard dirt bank about two feet above a dry stream bed.. Although she carried a hymenopteron about an inch and one-half long; I could" 
hear no young in the nest. On May 21 and 22 young were calling from this nest.

The race of this species present in Central America is $\underline{G}$. $r$. melanogenia.

\section{Family BUCCONIDAE}

Notharcus macrorhynchus (Gmelin)

White-necked Puffbird

SPECIHZNS. ISUMZ: Gallon Jug - $q(84.4 \mathrm{~g}$.$) , Mar. 2$. Seven mi. NW San Pedro Columbia - 5 , $9(102.8,112.7)$, May 14; 7 (109.9), May 19. OTHER MUSBUN (CC): One specimen from the Ifanatee Lagoon area; Jan. 22, 1907. CRITICAI PUBLISHED RECORD: Cayo (Sclater, 1891: 182).

Although ISUMZ field parties have worked many months in British Honduras, only one additional observation supplements the specimen records: one individual was observed at Gallon Jug the day after a specimen was collected. Ihe Gallon Jug and San Pedro Columbia birds were collected from perches 20 to 40 feet high in open areas along roads through tall rain forest. The females taken. in May contained many 3 and $4 \mathrm{~mm}$. ova, and the male had slightly enlarged testes.

I refer the British Honduran birds to the widely ranging race $\underline{N}$. $\underline{m}$. hyperrhynchus. 


\title{
Walacoptila panamensis (Lafresnaye)
}

White-whiskered Puffbird

SPICIMENS, ISIMZ: Gallon Jug - o (33.4 g.), Feb. 7 . Ten mi. NW Middlesex on Hummingbird Hwy - $-3(33.8)$, Mar. 26. OTHRR MUSEUNS (CM, MCZ): Seven specimens from Augustine, $\mathbb{N}$ slope Cockscomb Mts. (1300'), upper Moho River, Toledo Settlement; Jan., JTar., Apr., Dec.

Solitary White-wisisked Fuffbirds were seen at Gallon Jug on Pebruary 17 and 26 and March 12 in different years and five individuals were noted near the Humningbird Highway on March 26 in addition to the one collected that day. I do not know the precise status of this species in British Honduras, except that it is rare. There are no records from May to mid-December. No data indicate nesting; furthermore, the males collected February 7 and Narch 26 did not have enlarged testes. The field notes of persons who have seen or collected this snecies in the Colony indicate tiat they found it in the lower level of tall forest and high second growth.

I refer the British Honduran specimens to $\mathrm{H}$. $\mathrm{p}$.
inornata.

\author{
Tamily RALPHASTIDAE
}

Aulacorhynchus prasinus (Gould)

Emerald Toucanet

SPECTIIENS. LSUMZ: GaJIon Jug - Q (144.I g.), Mar. ?; \%. (113.0), May 8; $\sigma$, June 15. Augustine - $\%$, Aug. 16. 
Seven mi. ITW San Ledro volumbia - j.(1b3.6), May 19. OTHER MUSBUMS (BM, MCZ): Three specimens from Cayo and liountain Cow; Apr.

This spevies is very uncommon in British Honduras, where it inhabits heavy forest and tall second Erovth in the vicinity of rain forest. It has been seen but not collected near Hill Bank and Humingbird Gap. I presume that the tmerald Toucanet is a resident, but I know of no records in the colony from early september through Jamury. Specimens collected in ilarch, Hay; and June had slightly enlarged gonads.

The British Ilonduran specimens are assimnable to A. . virescens. 169/.

\section{Pteroglossus torquatus (Gmelin)}

$$
\text { Collared Arecari }
$$

SPECIMTHS. LSUMZ: Gallon Jug - $\sigma(197.7$ g.), Mar. I; (186.8), Mar. 21; o (179.1), Mar. 26;?, fpr. 1; (174.ל), Nov. $1 ; 3(194.6)$, Nov. $13 ; 2$ 's (171.1, 180.5), Nov. 12. Augustine - ?, Aug. 13. Wwo mi. W San Pedro Columbia - $\zeta \cdot(211.1)$, May 3 . OTHER MUSTUAS (BM, CC, CH, MCZ, PC, UIMZ, WU): Twenty-seven specimens from Belize, Sibun River near Uhurchyard, Manatee Lagoon area, Cayo, Lamp VI, Freetown, All Pines; all months except Aug., Oct., NOV. CRITICAI PUPIISHED RECOFD: Orange Walk (Șclater, 1891: 142).

The "Phyliis," as it is usually called in the Colony, is a common resident throughout the mainland of British Honduras. It is found in clearings where tall scattered trees are present, in tall second growth, and in high rain forest although most frequently rear its borders. 
Aragaris forage in pairs or small groups usually well above the ground. The species may be inclined to wander extensively in minter since Peck collected a specimen on the beach at the mouth of the rianatee River in December. In spite of the frequency with which these birds are seen, no nests have been reported. Some but not all the individuals collected in April and May had enlarged gonads.

I refer the specinen from San Pedro Columbia to $\underline{p}$. $\underline{t}$. 170

torquatus and specimens from all other localities in the Colony to the snalier Yucatán race, $\underline{P}$. $t$. erytinozonas. The bird from the extrene southern portion of the colony that I refer to the nominate forn is the largest and heaviest (wing $141 \mathrm{~mm}$, tail $152 \mathrm{~mm}$, culmen $105 \mathrm{~mm}$, weight $211.1 \mathrm{~g}$.$) and possesses a distinctly bluish tinire on the$ back. Brodkorb (1943: 20) has discussed the intermediate characters of British Honduran specimens in respect to the two races, and his observations are substantiated by the larger series that I have examined. The measurements in millimeters of seven males and seven females, respectively, that I assigned to $\underline{P}$. $\underline{t}$. erythrozonas are as follows: wing, 131-140 (135) and 127-140 (133); tail, 13b-152 (144) and 139-149 (144); culmen, 85-97 (90) and 77-90 (83).

\section{Ramphastos sulphuratus (Lesson)}

Keel-billed Ioucan

SPECIMENS. ISUMZ: Gallon Jug - $\sigma(443.7)$, Mar. 28; $\sigma$ (412.2), Apr. 6; ? (366.3), Hay $27 ; 3$ (408.1), Nov. 13; 
or (466.4), Nov. 15; $23^{\prime} \mathrm{s}(418.0,550.9)$, Nov. 16; 6 (380.9), Nov. 17. OTHER MUSEUMS (BN, CC, CM, MCZ, PC,

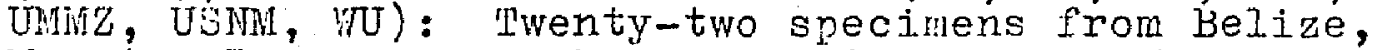
Manatee Lagoon area, Duck Run, Cayo, Camp VI, Freetown, Toledo Settlement; all months except Apr., Nov. CRITICAL PUBLISHED RECORD: Urange Walk (Sclater, 1891: 126).

Keel-billed Toucans, or "bill-birds," are a common and conspicuous element of the avifauna of British Honduras. The species is present in open areas where large trees are present and in the taller second growth and rain forest. A tree in the middle of the village of Gallon Jug was used by one pair for roosting or nesting purnoses. Peck found that this toucan is nore abundant in coastal lcoalities in winter and believed that breeding individuals retire to more inland forests. There are no nesting records from the colony and of the relatively few specimens for which the condition of the fonads is known, only two birds had enlarged conads, both collected in Hilay.

Todd (1943: 157) referred the extensive series of British Honduran birds in the Carnegie Iuseum to $\underline{R}$. . sulfuratus. I refer the additional specimens that $I$ have examined to the same form. For the most part, all specimens from the volony have very inconspicuous red borders along the yellow of the throat. Although one of the males collected Novernber 16 was exceptionally heavy $(550.9 \mathrm{g.})$, it was not fat." It was the largest of the Gallon Jug specimens (wing $206 \mathrm{~mm}$, tail $168 \mathrm{~mm}$., culmen $149 \mathrm{~mm}$.) 
Family PICIDAE

Piculus rubiginosus (swainson)

Golden-olive Woodpecker

SFICIMINS. ISUMZ: Gallon Jug - q (77.8 g.), Mar. 4; $\checkmark(84.7)$, oct. $22 ; \sigma(85 . b)$, Oct. 29 . Humingbird Gap 0 (87.5), war. 26. Augustine - 7 (79.0), Hay $\%$ OHFR MUSEUMS (BM, CM, IMCZ, UiTMZ, WU): Mineteen specimens from Belize, Manatee Lagoon area, Cayo, 12 mi. S Cayo, Mountain Pine Ridge, Freetom, All Pines; Jan., Heb., Mar., Apr., May, Dec. CRITICAL PUBIISHSD RECOPD: Orange Walk (Hargitt; 1890: 85).

The species is a moderately common and widely distributed resident in British Honduras. Individuals have been seen or collected in all types of mainland wooded habitats from coastal mangroves and scrub to pineland and high forest. Although it is not really numerous in any area, it is perhaps nost frequently seen in the semi-open and second growth in the vicinity of tall forest. I noted that it was decidediy less comon near San Pedro Columbia in Way than in other areas to the north. Specimens collected in March, April, and may were in breeding condition.

I assign the British Honduran specimens to $\underline{\underline{P}}$. $\underline{\text {. }}$ 173

yucatarensis. Six birds collected in the wountain

Pine Ridge are decidedly paler and grayer than specimens from the lowlands. Yet all birds examined from the Colony fall within the range of variability exhibited by specimens from Yucatán. 


\section{- Celeus castaneus (Wagler)}

Chestnut-collared moodpecker

SPECIMENS. LSUMZ: Gallon Jug - $6(90.4 \mathrm{~g}$.$) , Mar. 4$. (8).1), Mar. II; ?, May 31; $\%(97.4)$, June $1 ; 2$ s's $(85.1,86.4)$, NOV . 13. OTHBR MUSEUNS (BIT, CC, CM, LICZ, PC, UlMIZ, UU ): Whirty-eight specimens from Belize, Manatee Lagoon area, $5 \mathrm{mi}$. N Cayo, Cayo, Mountain Pine Ridge, Mountain Cow, $\mathbb{N}$ and $E$ slopes Cockscomb Mts. (750'-1500'), Freetown, All Pines, Toledo Settlement; ali months except JuIy. CRI'lICAI PUPIISHID RECORD: Orange Walk (Hargitt, 1890: 434 ).

Chestnut-collared woodpeckers are moderately common to common residents of tall second growth and heavy forest throughout the mainland of the Colony. In winter it wanders into the coastal scrub and mangroves along the beach (Peck). Gonads enlarge in naroh; and among the specinens with gonadal date, those collected in April, May, and June were in breeding condition. Willis noted noisy young in two different nests in mid-itay and late July, and Peck examined a nest containing four eggs in an advanced stage of incubation on June IO. The three nests were in dead trees and were 3 feet, 3 reet, and "high" above the ground. The lowest was in a sabal palm.

\section{Dryocopus Iineatus (Iinnaeus)}

Lineated Woodpecker

SPECIMENS. LSUMZ: Gallon Jug - $\sigma(163.7 \mathrm{~g}$.), Feb. 19; \%, Mar. 18; o (157.2), Nov. 16. Augustine- ?, Aug. 15. Eight mi. NW San Pedro Columbia - $\gamma$ (149.9), May 16. OTHER MUSEUMS (BM, CC, CM, MCZ, PC, UMMZ)! Twenty-five specimens from Belize, Manatee Lagoon area, Duck Run; Cayo, 12 mi. S Cayo, All Pines; Jan., Feb., Mar., Apr., June, JuIy. 
This large resident woodpecker is a moderately common inhabitant of tine semi-open, second growth, forest border, and tall rain forest. It is least common in the latter habitat, where the similar Phloeoceastes guatemalensis is more abundant. But tine two species do share habitats; in a clerring at Gallon Jug. I once saw individuals of the two species hamering away on the same limb exactly opposite one another. Iineated Woodpeckers frequently enter pinelands, and sometimes even nest there (Agostini notes, April, 1935). Peck found a nest containing young birds on $\ddot{H a y} 31$, and Van pyne noted thet a ferrale he collected in early itarch was "about to lay." The testes of an adult that I collected on nay 16 were not enlarged.

Iineated Woodpeckers from British Honduras are 174 referable to D. I. similis, which ranges from southern Mexico to Costa Rica.

\section{Melanerpes fornicivorus (swainson)}

\section{Acorn Woodpecker}

SPECIMLNS. ISUMa: Two mi. TH Hill Bank - $\dot{7}$, Mar. 23; \% $(75.3 \mathrm{g.})$, Nov. $22 ; \%(75.0)$, Nov. 23 . Augustine $\sigma(82.9), \operatorname{Mar} .9 ; 2$ 's $(76.6,79.4)$, Mar. $19 ; \%(77.5)$, Mar. 20. One mi. N Bellerina Camp - o (76.1), Apr. 30. OTHER MUSEUMS (BM, CC, CM, CNIM, MCZ, UMDZ): Fifty-two specimens from Belize, 9 mi. "l Belize, Belize River, Manatee Lagoon area, $5 \mathrm{mi}$. N Cayo, Duck Run, Cayo, 12 mi. S Cryo, Mountain Pine Ridge, All Pines; all months except JuIy, Aug., Oct., Dec. GRITICAI PUBLISHED RECORD: Punta Placentia (Salvin and Godman, Biologia, ii, 1895: 413). 
Acorn. Woodpeckers or "black and white woodpeckers," as they are locally called, are ebundant residents of pineland and pine-oak associations in the Colony. They sometimes wander into. the semi-open and second growth that are adjacent to the pinelands. The bark of an entire pine trunk is frequently riddled with holes made by these woodpeckers and used by them as depositories for acorms, (Peck, 1921: 131). Breeding has been noted from mid-inarch to early June. In a fine series of specimens collected by Van Iyne in February and March, 1931, at localities near cayo and on the Mountain Pine Ridge, ten males ranged in weight from 68.7 to 88.7 grams (mean $78.1)$, and six females ranged from 67.4 to 76.0 grams (mean 72.6$)$.

Specimens of this species from the highlands of the Mountain Pine Ridge are not different from birds of the lowlands of British Honduras, which were described by rodd as 1 . 1 . albeolus, and I refer all specimens from the colony to that race.

\section{Centurus aurifrons (Wagler)}

Golden-fronted Woodpecker

SPACIMENS. ISUMZ: Hill Bank - $\sigma(86.4 \mathrm{~g}$.$) , Mar. 20;$ o (80.0), Nov. 20; $7(76.3)$, Nov. 27. Gallon Jug - of (81.9), Feb. 22; o, Aug. 8; $3(87.3)$, Oct. 22; o, 2 's $(82.7,74.0,75.5)$, Iov. I; o $(84.7)$, Nov. $2 ; \sigma(80.5)$, Nov. $5 ; 0(86.5)$, Nov. $1<;$ (81.4), Nov. 17 . Calabash Cay - o (84.9), Apr. 9; 2$\}^{\prime} s(78.2,81.2)$, Apr. 10; ? (63.5), Apr. 13; $9(68.7)$, Apr. 14; o (78.4), Apr. 15. Augustine $-\sigma(86.4)$, Mar. 20. OMHER MUSEUTS (BM, CC, 
CM, CNHM, MCZ, PAIS, PC, UMMZ): Pifty-three specimens from Belize, Cockroach Cay, Manatee Lagoon area, $\zeta$ mi. N Cayo, Duck Run, Cayo, Middlesex, Cemp VI, Freetown, All Pines; all months except Oct., Nov. CRITICAI PUBIISHED RECORDS: Rio ropan, San ilelipe (Hargit, 1890: 174).

The "carpenter," as British Hondurans call this woodpecker, is a common resident of the northern twothirds of the colony in tall second growth, the semiopen, and the edge of the rain forest. Peck observed this woodpecker at monkey River, the most southerly locality where it has been recorded. At coastal ard insular localities, it is especially coisnicuous in coconut Eroves. Nests containing young birds have been. noted as early as April 21 (Willis), and on July 14 Peck found a nest containing four efgs.

I have compared Golden-fronted Woodpeckers from British Ionduras with a series of $\mathrm{C}$. 2 . dubius from Yucation, and I find all mainland birds distinctly referable to that race. Specimens from Belize, the inanatee Lagoon area, fireetown, and All Pines do not approach C. a. pauper from Honduras. Conpared with specimens from the mainland, birds from the Turneffe Islands have broader white barring on the secondaries; an orange belly and pileum, not Scarlet; less scarlet on the forehead; and the breast is more Avellaneous, without Deep Olive-Buff. 


\section{Centurus pysmaeus (Ridgway)}

Red-vented Woodpeckex

SPECIMINS. UHUZ: Belize - $25 ! \mathrm{s}\left(40.2,42.2 E_{0}\right)$, Feb. 2, 1931.

Whe two specimens represent the only record of: the species from British Honduras, although it is not uncommon at Chetumal and other localities in southern Quintana koo (Paynter, 1955: 166). Van Iyne collected the birds in a pasture on the outskirts of Belize.

The specimens are siminar to Yucatán birds; so I refer them to $\mathrm{C}$. $\mathrm{p}$. rubricomus.

\section{Centurus pucherani (Malherbe)}

Black-cheeked Foodpecker

SPDCIMENS. LSUMZ: Gallon Jug - o ( 5 b.2 g•), Mar. 7; $20^{\prime} \mathrm{s}(47.0$, ?), Mar. 9; $9(49.3)$, May $31 ; \%(56.3)$, Nov. $2 ; s(51.5)$, Nov. $6 ;\}(43.6)$, Nov. 9 . Humningbird Gap - 3 (53.9), War. 26. Seven mi. $\mathbb{N}$. San Pedro. Columbia - $3(49.9)$, May 14. Two mi. NW San Yedro

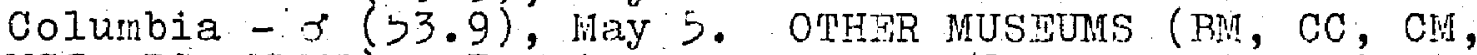
MCZ, PC, UNMZ): Fourteen specinens from lianatee River, Duck Run, Cayo, San intonio, hountain Cow, freetom, Toledo Settlement; Mar., Apr., May, Sept., Dec.

Scattered trees in plantation clearings, tall second growth, the forest border, and heavy. forest provide suitable habitats for this moderately common species. In the semi-open it is ruch less numerous than the Golden-fronted Woodpecker, but within tall forest the Black-cheeked Woodpecker replaces its 
sibling species. I have seen the Black-cheeked foodpecker near Humingbird Gap, Ballerina Gamp, and south Stann Creek in addition to the collecting localities, but it aprarently does not enter the generally lower forest and coastal scrub of the northeastern guarter of the Colony. It generally forages fairly high in the trees. Five nests found by Peck or yillis in April, May, and July were $1<, 36,40$, b5, ana 35 feet above the ground in palms or dead trees.

C. $\mathrm{n}$. perileucus, the race to which I reier the British Honduran specimens, ranges from southern Mexico to Honduras.

\section{Sphyranicus varius (Iinraeus)}

Yellow-bellied sapsucker

SPBCIMUNS. ISUMZ: Gallon Jug - ? (bl.4), Mar. 9. Silver Creek at Humingbird Hwy. - 7 (46.9), Mar. 27. Augustine - P, Dec. 12. OTHRR MUSEUS (BM, CI, MC', UNMZ): Seven specimens from Delize, Manatee Lagoon, Cayo, Ycacos Lagoon; Feb., Nar., May, Nov.

Observations of a total of 20 individuals on 14 dates from Hovember 13 to April 5 supplement the specimen records. All observations were of single birds except on November 13, when two were seen at Gallon Jug, and on March 26, when six migrant sapsuckers stopped on Half Moon Cay because of a severe storm the night before. The extreme dates for this uncommon migrant and winter visitant are November 10 and May 20 . 
Of the nine sexed specimens, eifht were females. The single male was the bird collected on May 20. Some individuals may winter on the keys, since $G$. van llets saw one bird on Half Mioon Cay ort January 1, 1961.

The five specimens that I have racially identified are all $\underline{S}$. v. varius. $180 /$

\section{Veniliorris fumigatus (d'orbigny)}

Smoky-brown Woodpecker

SPMCIMLNS. ISURz: Gallon Jug - q (33.5), Mar. 1.; $;$

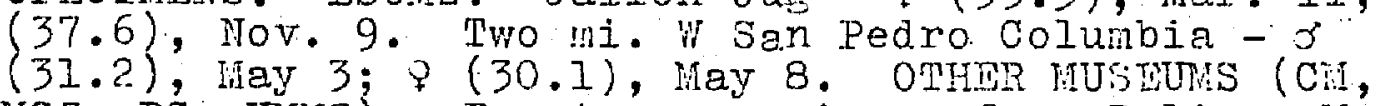
MCZ, PC, UMII ) : Pourteen specimens from Belize, Manatee Lagoon area, Duck Run, Cayo, Hountain Cow, N slope Cockscomb Mts. (1300'-1500'), Toledo Settlement; Jan., Feb., Mar., Apr., NOV. CRITICAJ PUPLISHED RECORD: Orange Walk (Hargitt, 1890: 344).

This small woodpecker is a moderately common resident of taller second growth and rain forest. . It _. is usually found in the lower level of such forested areas, especially where thickets or edge conditions exist. A male that I collected in November had fully enlarged testes, but the gonads of three other specimens collected in ilarch and May were either not enlarged or only slightly enlarged. Smoky-brown अoodpeckers were seen occupying holes 5 to 12 feet above the ground on four occasions in llay and June by Peck, Willis, or rie; but the contents of the holes is not known. In each case the hole was in a dead limb or in the tall standing trunk of a small falien tree. A 
male collected by Van Tyne at Cayo on March 15, 1931, weighed 33.6 grams.

I refer the British Honduran specimens to $\underline{V}$. sanguinolentus. 181

\section{Dendrocopus scalaris (Wagler)}

Ladder-backed woodpecker

SPECIMENS. (CM, MCZ): Manatee Lagoon area - $20^{\prime \prime s}$, oct. 1905. Al1 Pines - $x$, Anr. 23, 1935. Ycacos Lagoon - Q, llar. 9, 1907; ‘, May 29, 1907 .

The Ladder-backed woodpecker has been recorded only in the lowland pine ridges from the Sibun liver south to Ycacos Lagoon. The snecies is rare or very local, since only Blake and Agostini (who collected the specimen at All Pines) and Peck have recorded it. In his notes, leck writes that this woodpecker is "extremely shy and keeps almost entirely in the tops of the trees." The population of this species in British Honduras is an isoleted one. In Quintena Roo, Ladder-backed roodpeckers occur as far south as Carrilio Puerto (Paynter, 1952: 168), a locality lbo miles north of the Sibun River. In the Colony it was found orly in pineland, whereas in Quintana Roo it was found in coastal scrub and forest.

The British Honduran population is D. S- leucoptilurus, a race endemic to the colony. 
Phloeoceastes guatemalensis (Hartiaub)

Guatemalan Ivory-billed Moodpecker

SPECIMISRS. LSUR: Galion Jug - + , Feb. Ib; $r$, $(236.5,244.6 \mathrm{~g}$.$) , Mar. 7 ; 5(241.5)$, Nov. $1 ; 3$,? $(228.3,227.0)$, Nov. 16. Two mi. W San Pedro Columbia - P (228.0), May 7. OTHER MUSTUMS (CC, OM, MCZ, MMIZ, (WU) :.. Twenty-three specimens from Belize, fianatee Lagoon area, Duck Run, Cayo, $12 \mathrm{mi}$. 3 Cayo, Nountein (ow, N slope Cockscorib Mts. (1300'), Freetown; Jan., Ieb., Apr., May, July, Sept., Nov. CRITICAL PUBITSHHD RECORD: Orange Walk (Hargitt, 1891: 475).

This species, the largest of British Honduran woodpeckers, is a moderately common resident of tall rain forest and its edge. The species also occurs in the semi-open and tall second srowth, but there it is slightly less common than Dryocopus lineatus. Hineland in the vicinity of heavy forest is only rarely entered by the Guatemalan Ivory-billed, Woodnecker. The gonads of the three birds that I collected at Gallon Jug in November were enlarged. Peck thought that two holes he saw high in dead trees in January arld February were being used for nesting purposes by this species. No evidence indicates breeding at later dates. Agostini, Blake, and Holt collected nine specimens during April and $\operatorname{inay}(1926,1935)$. As a practice, these collectors uslally made a record of enlarged gonads, but none of the nine was so marked; thus the implication is that they were not in breeding condition. Two irldividuals of this species that I collected in march were paired; however, the gonads of these birds were not enlarged. 
Many residents of the Colony are familiar with this species and call it "father red-cap."

British Honduran specimens are referable to 183

P. E. guatemalerisis.

Family DENDROCOIAP'IIDAE

Dendrocincla anabatina sciater

Tewny-vinged Woodcreeper

SPECIMENS. LSUMZ: Hill Bank - $\gamma(36.7$ g.), Feb. 20. Gallon Jug - $\sigma(40.6)$, Mar. 7; $\sigma$ (33.6), Mar. 9; 6 (33.5), Mar. 10; $\%(30.3)$, Oct. 26; o (36.8), Oct. 30 . One mi. S Ballerina Camp - 5 (38.2), Apr. 28. Hight mi. Ww San Pedro Columbia - $5(39.6)$, Hay 16. Two mi. W San redro Columbia - $3(36.7)$, May $7 ; 3(33.3)$, Lay $8 ; \%(33.5)$, lltay $9 ; \%(36.0)$, May 11 ; $\gamma$, Nay 22 . ONHR MUSPUMS (CM, MCZ): Sixteen specimens from the hanatee Lagoon area, Mountain Cow, Freetom, Toledo Settlenent; ali months except June, Aus., Sept." URITICAI PUBLISHED RICORD: Orange Valk (Salvin and Godman, Biologia, ii, 1891: 172).

Tawny-winged Woodcreepers are common residents of rain forest, tall second growth, and the forest margins. A frequent follower of ant swarns, this species snatches insects that have been put to flight by the ants, capturing them both on tree trurks and in the air (villis, 1960a: 158). Mist nets are effective in trapping D. anabatina since it normally. forages in the lower level of the forest. Birds having fully enlarged gonads have been collected in late April and throughout May. Two newly hatched young were noted on inay 29 in a nest near 
Maratee fagoon (Peck) and Wilitis noted two adults feedins a juvenile at Gallon Tug on July 11 .

In his study of the birds of the Yucatin tininsula, Paynter (1955: 270) noted that some snecinens from southern ouintana Roo vere asoirnale to $D$. ‥ anabatina and others to D. a. typhla. Many snecimens that he examined from this area wero internediate hetween these races. As might be expected, the British Ionduran specinens are reperable to $\underline{D}$. a. enibatina..... There is little tendency toward the characteristics of In. Iyphes, even in specinens fron fallon. Jue and Hill Bank.

\section{Dendrocincle honochroa (sclater)}

kuddy loodcreener

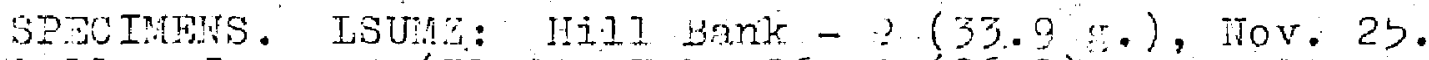
Gallon Jug - (31.2), Feb. 26; ? $(26.8)$, Mar. 14: one mi. S Ballerina Camp - $5(3 \% .3)$, Anr. 28. Jight mi. IW San Pedro Columbia - $(37.4)$, Try 16 . OTIDE

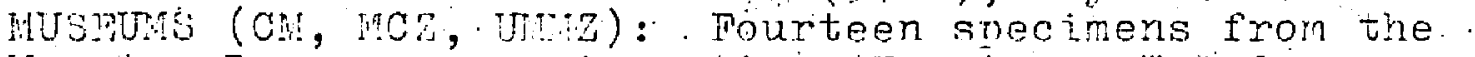
Manatee Lagoon area, Ausustine, inrectown, l'oledo Settlement; all months excent Feb., sent., oct., ivot. CRITICAL PUBLISHED RECOED: Orange "alk (Galvin and Godman, Biologia, ii, 1891: 173).

The upner slopes of the Cockscomb hountains, Honkey River, and Ycacos Iagoon are the only locelities where this resident species has been observed but not collected. It inhabios rain forest, high second growth, and "brokenpinel ridge areas of the lomlands, and is uncommon everywhere. As noted by wilis (1960a: 129), the Ruddy Hoodcreeper often follows ant swarns; in doing so it forages 
higher than the other dendrocinclid, I. anabatina. peck found two nests of this species in dune. One. was in a shell ow cuvity about 2 feet from the sround in a decayed stimn in tie "broken-nine" ridse near hanatee Lagoon. Ihis nest contained two ofss. The second rest was found in the dense rain forest near Nanatee Lagnon. It was in cavity in the base of a lead palm leaf about beet from the forest 1 foor, and it held three egris. line nominate form, 2 . n. nomochroa, ranes south from hexico to Honduras.

$\because \quad$ jittasomus rriseicanillus (vieillot)

\section{Olivaceous loodcreener}

SPACIMUS, ISUM: Ten mi. Mit Gallon Jur - $(10.6$ E.), Nov. 8. Gallon Jug -? (10.4), Mar. 4; $;(12.0)$, Lar. 7; 3 , lar. 3; 2 s's $(9.8,10.0)$, nar. 9; $2(9.4)$, Mar. $21 ;$ (10.1), liov. 9; $5(12.2)$, Nov. $10 ; \%(10.1)$, Nov. Ib. Augustine - 1 , Aug. 26. Two ni. Ni Milionario - $(11.2)$, Mar. l. . Bimt ni. Jn! San Pedro Colunbia - $-(13.1)$, May 16. Wwo mi. W San Pedro

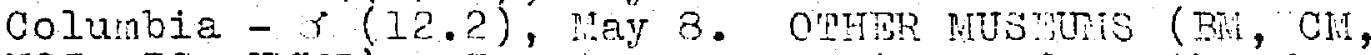
MCZ, PC, Unil ) : Twenty-one specimens from the Manatee Lagoon area, Cayo, 12 mi. S Cayo, Augustine, lountein Cov, H slope Cockscomb Mts., Freetom, Ycacos Jagoon; Feb., Mar., Apr., May, Aug., Oct. CRTTTChI PUEIISHED RICOD: Orange Walk. (Salvin and Godman, Biologia, ii, 1891: 177).

$\because \quad$ This small woodcreeper is a moderately comon resident of high, humid forest and of tall and noderately tall second growth throughout the Colony. Both van lyne and Peck collected it in pinelands (Mountain Pine Ridge, 
Ycacos Lagoon), but these bird; were probably wanderers from adjacent forests. Inlarged ronads have been noted in specimens obtained in late marci, April, and hay. specinens from the Tountain pine Fidee, litanutee Jagoon, and the area to the north of these Iocalities. are from a population intermediate in cinroters between

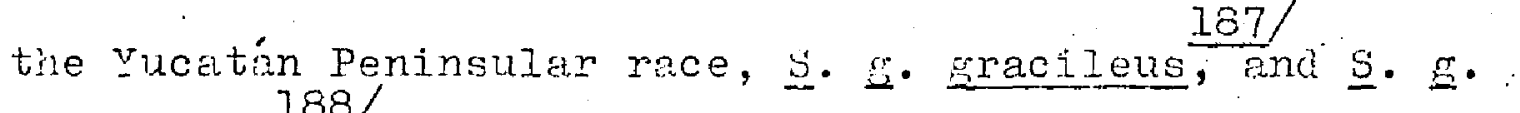
sylvioides. Some snecimens from this region are like the former race in coloration, others like the latter. Wing and tail neasurements lie between the means for the two races as given by Paynter (1950: 1.72) but are closer to those of $\underline{3}$. E. Eracileus. A majority of the specimens from the northern part of the Colony have rather yale mings and scepulars and in this respect resenble the Yucatín race. Although some syeoinens are very close to S. II. Sylioides in measurements and olumage charactors, I refer the ample from the northern area to $\mathbf{S}$. aracileus.

I assign specinens from the southern half of the colony to $\underline{\mathrm{S}} \mathrm{g}$. Sylvioides, althourh a few birds are not entirely tynical of this race. Whe individual weights of the two males from San Fedro columia are ecual to or Ereater than those of miles from the northern half of the colony. This difference in weight is in accordance with Faynter's (1957a: 260) figures, which indicate that $\underline{3}$. E. sylvioides is substantially heavier than $\underline{3}$. $g$. Erecileus. 


\section{Glyohorhychus spinurus (Viejliot)}

Vedre-billed Voodcreener

SECIRLTS. LSUT' Gallon JuE - F (14.) g.), Mar. 4;

Y (12.>), Mar. 8 ; ? (12.9), Nov. 7. Rallerina Camp(14.3), Anr. 29. Two ni. Wan Pedro Columbia - $r$, P $(16.3,14.6)$, May $>$; $>(14.2)$, May 7 . OCHR US (Cis): Three steciriens from inanatee Iaroon, Duch Run, N slope Uockscomb hts. (1600'); Mar., Hay, nov.

The fedge-billed Woodcreeper is an uncommon resident of the interior of toll rain forest. In such a nabitat it forsges through the lo:fer level of the forest, dissing into or pryirg away decayed mood, bark, or veketetion. At an elevation or 2700 feet on the main lockscomb ridge, I captured one of tinese woodcreepers in a nist net, but no others were seen there. Ihe female collected May $>$ had a sligitly enlarged ovary, and the conted of the lemale collected rovenber 7 was considerably enlarea. The conads of seven other specinens were not enlarged (no dat available for the secorid November bird). Deck found a rust or this species ir a shallow cavity in the base of a dead palm leaf on October 5 near Tolecio Settlenent. I'vo eggs vere in the nest, wich was about $B$ feet above tho fromd. G. S. pectordis is the race occunyine all of ventral America and parts of northestern south America.

\section{Xiphocolaptes pronerobirhyncins (Jesson)}

Strong-billed Hoodereeper

SPECIMEHS. ISUMZ: Gallon Jug - ? ? ( $143.8 \mathrm{~g}$. ), litar. 2 . OPHER IUSSLU: (MCZ): Two specinens from flountein Cow; 
Anr. CRIIICAL PUPLI YEWD RRCORD: unspecified locality (Sclater, 1890: 145).

All reconds of this rare woodcreeper from British nonduras are from the Gallon Jur area with the excention of the two birds collected by Austin at fountain Cow and the Iritish lluseum specimen of urspecified locality. One or two birds were observed on 12 dates between January 28 and May Is ovor four seasons by Lancaster, wilis, and me. dillia sam one bird on July 5 . All observations were made in tall fonest. Where is no evidence other than the presence of the birds in spring to indicate nesting in the colony.

I refer these specimens to $x . \underline{x}$. enirrans.

Dendrocolantes certhia (Boidaert)

Purred Toodcreener

SDECIMUNS. ISUMZ: GaIIon Jug - ? ? (58.1 g.), Iar. ?;

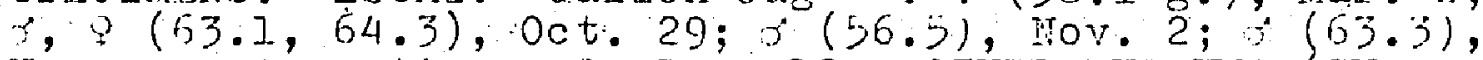

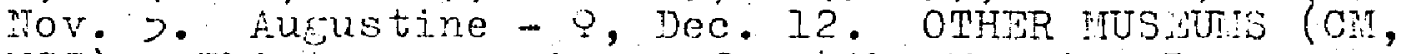
$\because \mathrm{TZ})$ : Thirteen specimens from the manatee Lacoon area, Uayo, nugustine, jountain low, A slope cockscomb lits. (1200', 1500'), Freetown, loledo Settlement; har., Apr., May, Aug., Oct., Hov., Dec. URITICAI PUTLISHDD RSCORDS: Belize (Hoore, 1859: 54), Orange Valk (Salvin and Godnan, Biologia, ii, 1891: 192).

This distinctly marked woodcreeper is a noderately common resident of tall rain forest and its margins and occasionally occurs in high second growth. Along with the two dendrociriclids, this species often feeds upon the insects that flee before army ants (Willis, 1960a: 
159). Specinens collected in Aril by solt and in hay by Agostini had enlarsed concis.

I refer the specimens to D. c. sancti-thonae.

\section{Xinhornynchus flavimaster (Swainson)}

\section{Ivory-billed Woodcreever}

SPECIMUNS. ISUMZ: Tien mi. NW Gallon Jug - r, 9 (49.2, 42.0 E.), Mov. 8. Hill Bank - ? (43.8), Nov. 20. Gallon Jug - r (49.2), Feb. 22; ? (40.7); har. ?; $29 ;-7(49.0)$, Nov. $2 ;$ if $(48.1)$, Nov. $7 ;$ i. $(4.0)$, Nov. 14. Pive mi. it Baldy Beacon - $2(42.5)$, Anr. 19. Billerina Canp - $\sigma(b 1.1)$, Apr. 2). Two ni. Nig Hilionario - $\sigma$ (49.3), Mar. 15. Seven ni. N’l San Pedro Columbia - 20 s (bI.2, 51.b), Inay 19. L'wo ni. Ni San Pedro Columbia - ;

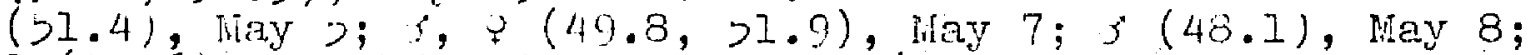

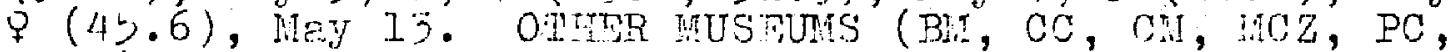
UII area, Cayo, Mountain Cow, slone Cockscomb nts. (1400', I>00'), Fretom, $\Lambda 1$ l pines, poledo settlement; every month. URITICAL PUPIIEIED RPOPDS: Crange Wajk, Southern [ = Hountain] Dine Ridge (Salvin and Godnan, Bioloria, ii, 1891: 179).

All wooded areas except the onen pinelinds and mangrove swanns are suitable habitats for this very common woodcreever. It has been noted throughout the colony (except on the keys) in moodicnds as diverse as those on the outskirts of Pelize and tize upper slopes of the Cockscomb llountains. I have collected Ivorybiljed Woodcreepers that were in breeding condition in Merch, Anril, and iiay. Peck found a recently completed but unoccupied nest on July 6 near Manatee Lagoon. the heavy female collected on Hay 7 nad an ers in the oviduct, and a $15 \mathrm{~mm}$. ovum was found in the bird collecter Hay 13 . 
I refer the British londuren popilation of this $192 \%$

species to $x$. $f$. eburneirostris. A few svecinens from Gallon Jug and belize show a slight approach to $\mathrm{X}$. f: yucatanensis but none is closer to that race than to X. . eburreirostris.

\section{Lepidocolantes soulevetii (Des Murs)}

\section{streakmheaded Woodcreeper}

SPECIMUNS. ISUMZ: Gazion Jur - g (28.I g•), lifar. II; f(30.7), Mar. 14. Two mi. NE Militionario - Y (29.7),

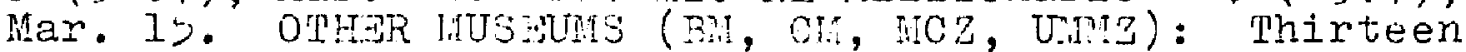
specimens from the Sibun River, hanatee Iagoon area, Cayo, Freetom, All Pines, Ycacos Lagoon, Toledo Settlement; Jan., Mar., Anr., May, Nov., Dec. CRITICAL PUBLISHED RTCORD: Belize (sclater, 1890: 1々3).

Yinhocolantes promeropiriynchus is the only British Ionduran woodcreener that has been recorded less frequently than $I$. souleyetil. The streak-headed Hoodcreeper is a resident of tall humid forest, hirh second growth, and ocosionally pineland. Although some species of dendrocolaptids are not common, all species share the taller forests. At Gelion Jug, in a few acres of tall but disturbed woodland nesr a nlantation, I have seen each of the eight species of woodcreepers recorded from the colony. Peck found a pair of atreak-headed Woodcreepers occupying an abandoned woodpecker hole in a pine tree near Ycicos Lagoon on lay 17. The hole, which was about 32 feet above the ground, contained only a few bark chips. Snecimens collected in April and May by Blake and Agostini were in breeding condition. 
The race I. S. insignis is rourd in Fritish. Honduras. In 1929, Austin described $I$. s. decoloris $\frac{195}{5}$ rom the cayo area, but the ruce wes nistakenly besed on worn specimens, as pointed out by Griscom (1952a: 244$)$.

\section{Family FURMAIIDAT}

\section{Synallaxis erythrothorax Sclater}

Rufous-bressted Spinetail

SDECIMENS. ISUEZ: Yi]l Bank - (17.j g.), Nov. 27. Gailon Jug - ? (1.7.0), Feb. 9. Ballerina Camp - p (16.6), Apr. 24; ? (16.8), Apr. 25. Kendal - ?, Aug. 31. Two mi. W San Pedro Columbia - $\because, ?(18.4,18.8)$,

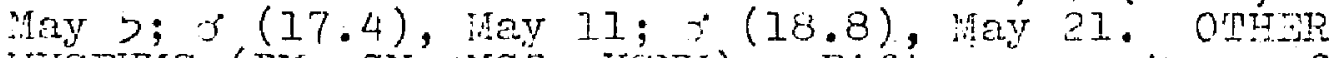
MUSDUTS (Bi, Cn, MCR, USTI!): Pifteen specimens from Orange Walk, liknatee Lasoor, Cayo, Sittee River, Toledo Settlenent; iar., Apr., June. CPITICAI JUDISHDD RZCORD: Belize (Sclater, 1890: 25 ).

In the southern one-thind of the colony, the Rufousbreasted ininetail is a cominon resident of derise thickets in abandoned plantetions and in the brushy borders of taller second prowth and forest. It is moderately comon in the central region, but in the northern sector of Pritish Ionduras it is rare end local. At Gallon Jug, the most intensively studied area in the colory, it has been seen only twice (Tebruary, October). I collected a specimen in the "broken pine ridge" at Hill Bank in Novernor, and Iay saw several individuals in thickets near Corozal during mid-Ausust. Gonads do not become fully enlarged until May. Hhe nale collected Way II was a nember of a pair that I observed nest-building. 
I refer the British Iondurm nomulation to $\underline{S}$. $196 /$

erythrothorax. I compared three fentus from the colony with a single fenale from Lake Yajoa, Honduras, and found them to be very similar.

\section{Automolus ocirolnemus (Ischudi) \\ Bufi-throeted Automolus}

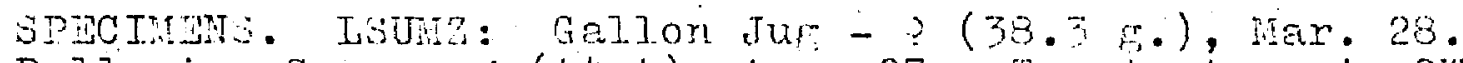
Ballerina Camp - $(44.4)$, Anr. 27. Twenty-two mi. Sit Stann Creek on jouth stann Creek - 2, Anr. 24. l'wo mi. i san redro Columbia - $\}$ (43.9), May 8 ; $(42.1)$, May $12 ; ;(45.8)$, May 23. OMHER MUSTM (BN, CC, CN, MCZ): Seventeen specimens from the Hanatee Iacoon area, San Antonio, Hountain Pine Ridge, Augustine, Camp VI, hourtain Cow, N slope Cockscomb fts. (1400'), foledo Settlement; all months excent iay, Jure, July, nug.

The vegetation vithin 10 leet of the floor in tall, humid forest and occasionaly the forost floor itself provide the preferred habit tor this secretive furnsia. It occurs wherever there is hish forest but is only noderately comon south of the Relize River ard is rare in the north. I have seen the Luff-throated futomolus fron forest at near ses level up to pyoro teet in the Cockscomb rounteins. No nests have been noted in British Honduras, but specimens possessine reproductively-active conads have been collected in late March, April, and liay.

I refer the British Honduran snecimens to $\underline{A}$. $\underline{0}$. cervinigularis. 


\section{Xenops ninutus (snerrman)}

$$
\text { plain senops }
$$

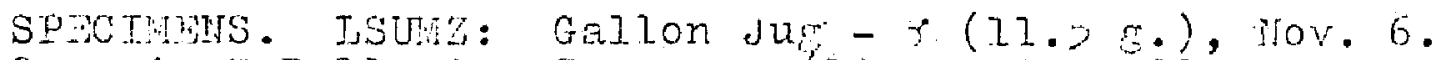

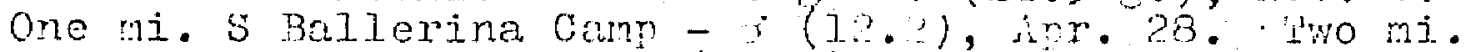
San Pedro Colmbia - (10.4), Try 8. OTH

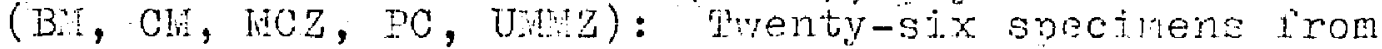
Orance Walk, inanate Laroon area, l2 ii. \& Cayo, Aurustine, hountain Cow, slone Uockscomb nts. (1500), Freetown, loledo settlenent; ieb., iar., Anr., Way, July, oct., nov.

The Flain Xenons is a moderntely comon to urcomon resident of the lower level of tali, humid forest and tall seond erowth. Tt flits about troe trunks, viner, and leaves and often pries beneath atached vereletion. As observed by ililis (1960c: 10y), the renops sometimes joins the wandering forest flocks of srall posserine birds. Some of the snecimens teken in mid-jarch, hrij, and hay had enlarged gonads.

The stecimens collected in British lomiuras bre referable to X. mexicanus. In 1919, shubb named X. $m$. cayoensis on tie basis of snecinens talen at cayo, but this race was suhsequently proven untenable (nustin, $1929: 379)$.

\section{[Sclerurus mexicanus sclater]} iany-throated Leaf-scraper

This species is listed from British Fondurus in the tables in Volume I of Salvin and Godman's Bioloria (1904: 24). The specimen could not be found by todd in 
a search in the British Museum in 1934. F.r. Podd did find, however, a specimen of S: rustemalenis taken in Cayo on April 2, 1388. As the lattor species is not recorded from the Colony in the Biolorin, rerhavs S. mexicanus vas recorded throm error.

\section{Sclerumus gutemalensis (Hartaub)}

$$
\text { Scaly-throntad Teaf-scraner: }
$$

SPECINONS. LSTAZ: Callon Jur - ; (37.I g.), Tov. 14. One ri. $\mathrm{S}$ Ballerina Camp - ? $(33.9)$, 4pr. $28 ; \%(3 ; .3)$,

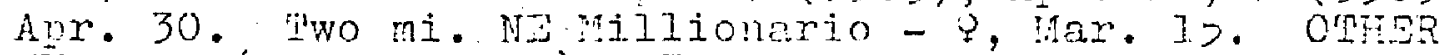
IU⿴囗十⺝ (B:, OH, ICZ): Four srecinens from cayo and Toledo settiemert; Arr., Sent., Mov., Dec.

Only a few sight reoords sunnlement the specinen datr listen above. On Hay 28 a leaf-sorarer, nrosuably this species, flew into my camn at 2900 leet on the slope of. victoria Penir. eech shot but did not preserve a bird at ilinatee lasoon in iay, and he saiv anotior on tho uprer Temash River in Deconor. Thjo rarely noted rosident prefers the floor of tall indisturbed forent. Its shyness: and the similarity of tye color of its rlumase to the Ground litter undoubted $y$ contribute to its diparert scarcity. Hone of the tiree birds thet I oollected in Farch and April had enlarged gonada, but the nle collected Hovember 3.4 did have enlarged tesies.

ihe birds residing in northerr central Anerica are 3. Euctemalensis. 
Wamizy POREICARIIDAS

laraba major (vieillot)

Great hntsinike

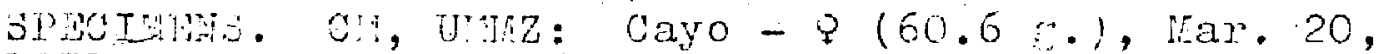
$1931 ; \sigma$, Anr. 4, 1926.

These two swecimens reprenent the orly records of the suecies from the Colony. Holt collected the. specinen on Amil 4 in a "tangle or vines in $[a]$ brusiny clearing."

I follow current practice in referring these specinens to $\underline{\mathrm{q}}$. $\mathrm{m}$. melanocrissus.

\section{1}

\section{Thamnonilus dolintus (Jinnaeus)}

Barred Antshrike

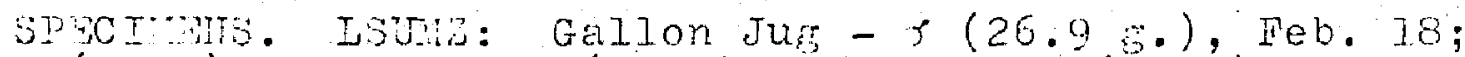
o (27.4), Feb. 19; $9(21.6)$, Feb. $21 ; \%(2.2)$, Feb. 22;

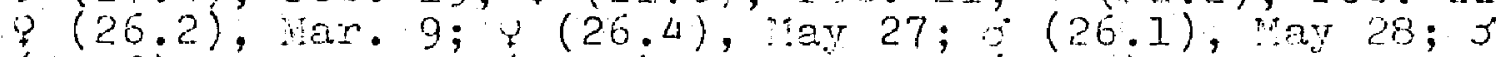
$(23.6)$, tay $29 ; 3(27.9)$, June $8 ; 0(27.4)$, oct. $27 ; 5$

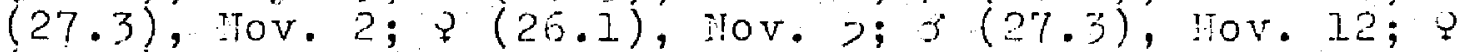
(25.0), Hov: 16. Nelinde - 5 , Sept. 2. Kendal - 3 , hur. 31. Wwo mi. Ul San Perro Colunbia - $0(26.8)$, :ay 3;

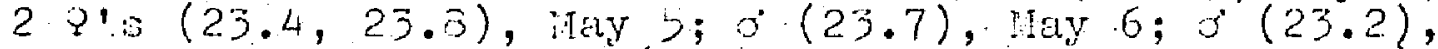

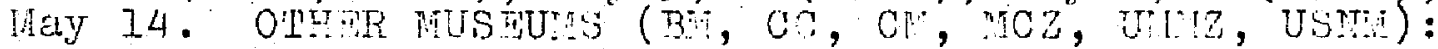
Wifteen specimens from the Manatee Lagoon area, Cayo, San Antonio, 12 mi. S Cayo, Sittee River, Toledo Settlement; Jan., Nar., Apr., Jure, July, Aug. CRIIJCAL PURIISTID RECOPDS: Vicinity of Belize (Sclater, 1890: 208); Orenge Walk (Salvin and Godman, Biolonia, ii, 1892: 203).

This antshrike occurs in low huaril ard in thickets at the edge of tall forest. The snecies is very local in its aistribution but nay be common where it is found. Like many other birds of the thickets, the Darred Antshrike is nore often heard than seen. Mist nets were 
effective in capturing nary of tile Galion Jug and san Pedro Columbia specimens. Birds in breediry; condition have been collected from Harch to early June, but lialf the specimens collected durine this period did not have enlarged conads.

Speciments from northerr retish Hordures approach 1. A. ycatianensis and specimens fron the southern nart (20) of the colony are referible to $\underline{1}$. Dr. Kennetr. Parkes is presently revisins this snecies and my desirnotinns are accordingly nnly tentative.

\section{inanononizus punctatus (Shaw)}

Slaty Antsirike

SPWCIHIT Moz: Upper Rio Grande - 3, Ioy. 25, 1906.

Reference to this specimen, which vas coljected by Peck, has been made by Ridmay (1911: pl) and others under the more seneral locality of "l'oledo District." Presumably this suecimen represents the most northern record of the species. Peck sam two or three others at the same lockity. where are no otier records from British Honduras.

The race of slaty intshrike found in Centrol America and part of nortiern jouth America is $\mathrm{T}$. atrinucha 
Tharinistes anabatinus (sclater and Salvin)

Tawny Antshrike

SIMCINAS. ISUMa: Seven mi. Tir San Dedro Colunbia -

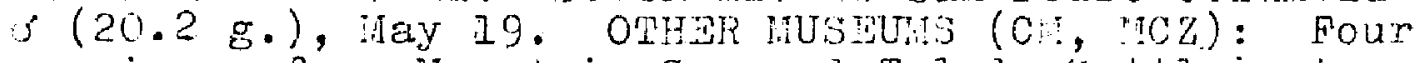
snecinens from Mountain cow and Toledo Settlement; Jàn., Apr.

In Dritish Honduras, the Tamy Antshrike is krown only from five speciuens. Three individuals coliected by peck and the one bir that I shot near isan pedro Columbia wers forateing high in the tops of trees in the tall, humid forest. The specimen collected in lay had fully enlarged testes.

These birds are referable to $\underline{I}$. 2 . andatinus.

\section{Dysithemms mentalis (Teminck)}

Slaty-canped Antvireo

SPCI GES Ch: Tive specimens from Duck kun anc dayo; Auril, 1926 .

These live specinens were coliected by Brnest $G$. Holt and constitute the only records of the species from British Honduras. Accoraing to Holt's notes, these birds had enlarged conads.

I refer the specimens to $\underline{D}$. $\underline{m}$. septentrionalis which ranges from Wexico to Panana. I have compared the five British Honduran and three fonduran specimens with four birds from Costa kica, and I believe that the costa kicun population nay be darker and possibly larger. 


\section{Microrhopjes luixensis (Cornelia)}

\section{Dot-winged Antwren}

SPECIMTS. LSUM: Gallon Jug - $\%(7.7 \mathrm{g.})$, Jar. 4; $\{$, $(7.8,7.5)$, Mer. $7 ; x(7.6)$, Oct. 25; $(8.0)$, Mov. 9. Ballerina Camn - $3(7.6), \Lambda \mathrm{mr}$. 24. Sevenmi. NW Sar-Pedro Columbia - $;(7.8)$, May $18 ; 9(9.7)$, May 19. Wwo mi. San Pedro Columbia - $\}, \psi(7.2,8.0)$,

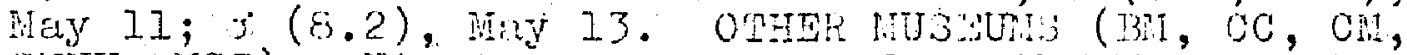
CINH,,$(I C Z)$ : Nineteen specimens from the lanetee tagoon area, Duck Run; Cayo, Niddleser, Aurustine, Cenp̈ VI, Mountain Com, Freetown, Toledo Settiement; Jan., Feb., Har., Apr., May, Aug., Sept.

Dot-winged Antwrens are moderately comon residents of tall and moderately tall forests. . There they foraee in pairs or sometimes in roups or four or even six birds in the lower story of the forest, their presence marked by an often-ropeated high, rather plaintive note. whese antwrens attain enlareed conads during harch and April and are brzedine by ilay. The female collected May 19 held an egs in the ovidict. on June 10, Villis observed a male building a nest in a trise fork about 20 feet above the ground.

The race present in British Ionduras is $\mathbb{N}$. q. boucardi.

\section{Cercomacra tyrannina (sclater)}

Dusky Antbird

SPECIMPNS. ISUA3: Gallon Jur $-\sigma(16.0 \mathrm{~g}$.$) , hay I; \sigma$ (16.9), Oct. 24. Pomona - $5(16.9)$, Apr. I. Ballerina Camp - (15.7), Apr. 25. Two mi. W San Pedro Columbia $9(16.9)$, May $5 ; x(17.2)$, May $8 ; q(17.3)$, May $9 ; x$, $(17.4,16.3)$, May $11 ; 6(18.2)$, May 18 . OTHIR MUSUUUS (BM, CC, CH, USHM): Ten specimens from the Manstee Lagoon area, Duck Run, Cayo, Preetown; Jan., Mar., Apr., May, Aug., Nov. CRITICAI PUBLISHED RICORD: Beíize (Moore, 1859: 55). 
Low humil that has grom into almost ingenetrable thickets ofters the most suitable nebitat for this shy antbird in British Honduras. The Jusky Anthird has been observed not only at the snecimen localities but also at Mill Bank (villis), Kendal snd South jtann Creek (Russell), and ycrcos Itacoon and the unper Ioho River (peck). This resident was common o:ly in the vicinity of sen pedro Colunbia, where the primitive arricultural practices produced extensive areas of suitable habitat. Ulsewhere it was unconnon. Rirds with fully enlarged sonads wero collected April 2b, May 1, and filay 8. Other specinens collected in Anril and kay had onjy slightly enlared ronads.

I assign the Pritish Horduren ponulation to $\underline{\mathrm{c}}$. $t$. crepers, wich ranges from nexico to Pananá.

\section{Gymocichln muicens (Cassin)}

Bare-cromed Antbird

SPECIMENS. ISUMZ Two mi. " San pedro Columbia - Y $(31.6$ 5.), May 13,$1956 ; \%(31.6)$, Nay $21,1956$.

Both collected birds had fully enlarsed gonads and were thion in second rrowth. Whe femile was captured in a mist net that had been suspended in extremely dense veretation about 4 feet tall in a recently abardoned hillside plantation. The male was collected as it flitted about near the ground in low huamil that had frown to a height of $12-$ to 1 feet. Wo other individuals of this species have been seen, even though a special effort was made to îna them. 
I refer these two specimens to" $\underline{G}$. $\underline{n}$. chiroleuca.

Formicarius analis (d'orbigny and Iaf'resneye)

Black-faced Antthrush

SPHCTENS. LSUMZ: Gallon Jug - ?, Feb. $24 ;$; $(60.0 \mathrm{~g} \cdot)$,

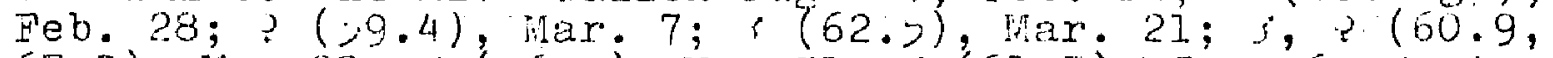
$67.8)$, inay $28 ; 3(26.5)$, May $31 ; 0(61.7)$, June $6 ; 3$, Aug. 17; 3 (66.9), oct. $23 ; j(62.2)$, oct. $30 ; \%(27.5)$, Nov. Iy. Ballerina Camp - (6.).1), Apr. 27. Seven mi. Ui San Pedro Columbia - $\sigma(60.1)$, May 14. Two mi. Nw San Pedro Columbia - o $(6,8)$, hay $4 ; j(66.9)$, they $1.1 ; 2 . \sigma^{\prime} \mathrm{s}(08.4$,

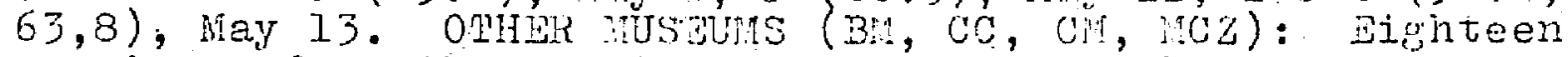
specimens from the Manatee Lagoon area, Duck Run, Cayo, Wountain Cow, Freetow, loledo Settlement; Jan., Feb., Apr., May, June, Aug., Sept., Oct.

Black-faced Anttinushes are common but secretive residents of tall rain forest wherever this habitat occurs in the colony. Their presence is usually revealed by a series ot short explosive whistles that are rathor easily imitated. If attracted to the imitation of its call, an intthrush approaches on the ground slowly, deliberately, and well-hidden. Often the bird may circle completely around a sitting observer without detection. Althoush this species rarely flies, it builds its nest in a natural cavity in a tree 4 to 6 feet above. the ground. Two or three eggs are usually laid. Iancester found an occunied nest on April 28, the earliest date. In 1957, Hillis noted four nests, the latest on July 23 . Nesting probably does not begin much before late Anril as specimens that I have collected at efrlier dates had only slightly enlarged goneds. 
I have compared the specimens of this species from British Honduris with the type and type series of $\underline{F}$. intermedius, and find all are referable to that subsnecies. There is considerable variation ariong specinens from the sane locality in respect to the rufous color of the bick. But specimens from northern British Honduras (Gallon Jug) are more like the type from the Manatee Lagoon area than birds fron the extreme south (San Pedro Colunbia); specimens from the latter locality are paler on the unrer parts than specinens from farther north. San Pedro Columbia specimens also are slightly darker on the chest.

\section{Family PIPRIDAT}

\section{Pinra mentalis sclater}

Yellow-thighed Hanakin

SPHCIMENS. LSUMz: Hill Bank - (17.1 g.), fieb. 24. Gallon Jug - $5(12.2)$, Feb. 24; 2 is (18.0, -), Mar. $26 ; \%$, Mar. 28; (16.3), Oct. 29; o (17.4), Nov. 14; $5(18.8)$, Nov. 17. Wwenty-two mi. Sw Stann Creek on. South stann Creek - 3, Apr. 26. One mi. I Victoria peak - ?, May 8. OTHMR MUSTUMS (Bh, Ch, MCz, UMnZ): Forty-four sbecinens from Urange Walk, Hanatee Legoon area, Duck Run, Cayo, San Artonio, nountain Pire Ridge, Augustine, liountain Cow, IN slope Cocksconb its. (1300'1600'), Freetown; Mar., Apr., hay, July, Aug., Oct.

This manakin is a common resident of the undergrowth of tall rain forest. There it litits noisily from branch to branch 6 to $2 b$ feet above the ground. On the crests of the very narrow ridges that extend south from the Cockscomb Nountajns, Yellow-thighed 
Manakins are the rost conspicuous birds in 3ate Arril. and iray. On one such crest, where the undererrowth was sparse and most trees were less than 12 inches in diamoter, I counted ten redconed males alone only zoo feot of trail. Fach bird in this unuslal assenblage seemed to dart about in a definite area, wille it produced many sraning noises (presumably by wing-clapoing) and mistles. Birds of this species were seen at Ycacos Lagoon, San Pedro Columbia, and Toledo settlement (Peck, Fussell) al thourh specinens more now collected. I have not noted any seasonal. wardering, but pook writes of tindin! this bird in hangrove swamps near the seashore in winter. Breodine is well under way by wron; a fentle that I collected on March 26 contained a fully formed egr. Inter nesting: is indicated b; a nest found by peck near hanatee Iagoon on Way 28 , 2006 , containing one egs. Willis noted. a fledglins at Gallon Jur on fune 26. A bird in the green Dlume of the female ma observed singing on horil es; I collected it and found thit it was a nale with fully en] arsed testes.

The rominate form of this species, ‥ ‥ nentsis, occuries northeru Central Anerica.

Inanacus cendei (Parrudaki)

White-collared llanakin

SPECIMENS. LSUnz: Hill Bank - (16.8 g.), Peb. 19. Galion Jug - (20.1), Mar. 2; (20.8), Mar. 19; ? (20.0), Apr. 5. Sizver Oreek at llumingbird Highway - 
$7(16.8)$, Mar. 27. I'wo mi. W San Pedro Columia $(15.8)$, May $5 ; z(12.4)$, thay $7 ; 2$ ? $(18.2,18.6)$, Nay $8 ; 0(18.1)$, May $11 ; 3(17.4)$, May $12 ; \%(19.9)$,

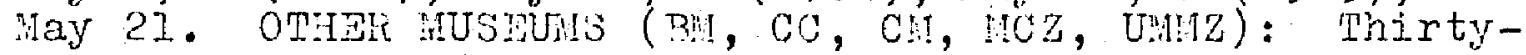
seven specimens from Orange falk, fianatee Lagoon area, Cayo, camp VI, ireetown, Toledo settlenent; all months except Jan., reb., Rov. ORIIICAL PURIISTED RECORD: Belize (Sclater, 1888: 314 ).

This snecies is a common resident in the southorn half of the colony in tall and moderately tall huamil and in the edre of heavy man forest. It occusionally occurs also in tall thickets at the edge of plantations. In the northern portion of the colory, the thite-collared hanakin occurs in the same tynes of habitat as in the south but is less cominon. The breeding season is long. I. collected a male with slighly enlarged testes on harch 2, and peck found a nest containine two esss on Aunst t. Dech of four other nests found by peck or vilis between these extreme dates contained either two esgs or two young.

\section{Schifforris turdinus (Mied)}

Ihrushlike lifanakin

SPUCINUS. LSTMR: Hill Pank - ? $(34.25$.$) , Nov. 27$. Gallon Jü - Y (35.8), Feb. 26; $(32.6)$, Mar. 8; 0 $(30.0), \operatorname{Mar} .10 ; ?(31.6), \operatorname{har} .21 ; \sigma^{*}(29.8)$, Oct. 2b; ? ? (27.2), Nov. 14. Two ni. W San Pedro Columbia- (32.6), hay 11. OPHER MUSTUMS (PM, CC, MCZ, JMAZ): Wenty-four specimens from Orinee Walk, the Manatee Lagoon area, cayo, $12 \mathrm{mi}$. S Cayo, Camp.VI, Mountain Cow, II slope Cockscumb ints. (1300'), Freetown, Toledo Settlement; all months except Hov.

In British Fonduras the Thrushlike Manakin is a common resident of mature rain forest and an occasional 
resident of tall second rowth. It foreges for insects in the lowest vegetation with cautious movements, often pausing on a vertical stem to utter its sweet, threenoted song. At Gallon JuE, on March I Jillis noted an adult incubatine two erss in a nest situated 2 feet above the ground in the stump of a palm. The nest was composed of the skeletal remains of ledves ond was lined with a thin layer of fine rootlets. Five reeks later the one young bird had left the nest. Whe same nest was relined and used in incubating two more eggs in late May. The nest was destroyed by a predator in early June. i. $t$. veree-naci $\frac{212}{5}$ is the race to which I refer the British Honduran specimens.

Tanily COPINGIDAE

Cotinga amabilis (Gould)

Lovely Cotinga

SPECIMEN, MCZ: Camp VI - P, lifar. 29, 1928.

Austin (1929: 384) collected the only specimen of this species fron British Honduras "in the extrene top of a very tall tree at the edge of the pine ridge." At Gallon Jug in 1927 , Wiliis recorded the Lovely Cotinga trice, one bird on February 27 and one on May 11. I am not aware of any other observations from the Colony. 


\section{Attila snadiceus (Gmelinn)}

Bright-rumped Attila

3PECIMIIS. LSUAz: Hill Bank - q (39.1 g.), Feb. 24. Gallon Jug - ?, Jan. 10; ? (40.5), Mar. 16; (43.9), Nov. 7. Two ni. S stann creek - ? (39.1), Inar. 30 . Two mi. W San Pedro Columbia - $7(42.1)$, Niay 12. OTISR MUSEUMS (BM, CC, CII, MCZ, PC, UMTI, UsMM): Twenty-two specinens from Belize, Manatee Lagoon area, Cayo, San Felipe, Freetown, Toledo setilenent; all months except July.

The Bright-rumped Attila is a moderstely common resident of tall forest and thickets at the forest's edge. That it is not completely sedertary is sugrested by Peck's observation that it wanders from its breeding area in fall and winter and even occurs at the seashore. The female that I collected on liarch 30 was in mangroves less than 200 yards from the becth; she was in breeding condition and accompanied by another hird. Both members of the presumed nair were singing. I suspect that the birds noted by peck were not wanderers but residents of the coastal area. At cayo, Holt found a nest containing four egss on April 9. Thus March 30 is not too early for the pair of coastal birds that I saw to be breeding. All the apecimens collected in April and hay had enlarged gonads, but data are not evilable for specinens collected later in sumner.

I refer the specimens to A. s. Plammulatus. There is considerable individual variation ariong the specinens from British Honduras, but there is only a slight approach toward the characters of $A$. S. Eaumeri. 


\section{Laniocera rufescens (sclater)}

speckled hourner

SPLCINFNS. LSUTZ: Ten ni. NW Middleser on Humingbird Hwy. - $(49.7 \mathrm{~g} \cdot), \mathrm{Mar} .26,1956$.

The only. Spockled rioumer collected in the Colony was taken by Dennett in heavy rain forest. Millis saw two singing individuals of this species at Gallon JuE on July 14, 1957.

I. r. rufescens, to which I refer the specimen, ranges throughout Central America.

Rhytipternei holerythra (Sclater and Salvin)

pufous hiourner

SPMCIMENS. LSUMZ: Two ni. TH Millionerio- - (36.3 g.), Mar. 1y. Seven mi. Ir San pedro Columbia - 5 , $(32.0,35.6)$, May 19. ONHS PUSUU:S (CM, liCZ): Five specimens from Toledo settlement and the unper iemash River; Feb., Itar., liry, Nov., Dec.

This mourner is an uncommon resident of tall, humid forest in British Honduras. Only a few additional localities of record supplement the specinen locnlities. Lancaster, Villis, and I observed $\underline{R}$. holerythra occasionally at Gallon Jug. Peck saw one near the mouth of the Nanatee River in December, and I noted one in the edge of rain forest on South stann Creek in April. The specinen collected near Millionario on March is had slightly enlarged testes, and the two birds collected in Hay near San Pedro Columbia were in breeding condition. 
I refer these birda to the nominate form, $\underline{R}$. $\underline{\text { h. }}$ holerythra.

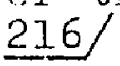

Pufous Piha

SPECTMMS. LSUR: Sixteen mi. iT Gallon Jur - i $(87.0$ g.), Mar. 4. Silver Creek at Huminebird Hwy - 3

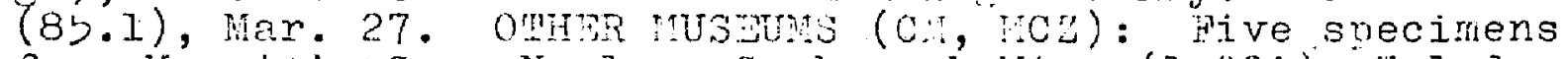
from lountain Cow, $\mathbb{N}$ slope Cockscomb its. (Is00'), Doledo Settlement; Feb., itar., Anr., Oct., Jov.

In dense undisturbed rain forest, this snecies is a moderately comon resident of the middie stratum. Ther. are sisht records from Guaca!nto, Dallemina camp, two miles northeast of blilionario, South stam Creok, the upper Rio Grande, and the uner Moho River. Undoubtediy the Rufous Piha is freruently overlooked, for it inay remain perched motionless and silent some distence above the ground. If alarmed, it sometimes emits a piercing, sinill call and flies to a distont nerch. The two nales collected in Harch near Gallon Jug arid Silver Creek had enlarged testes. On May 28 , 1959 , on the southern slope of Victoria Peak at about 3000 feet, I flushed a Rufous Piha from its nest. 'i'wo pale brown egrs were in a shallow depression about 10 feet above the ground in a crotch, between a sizable epiphytic bromeliad and a large tree. The British Honduran specimens are typical of $\underline{\text { I. }}$. unirufus. 217 


\section{Pachyramnus cinnanomeus Lanrence}

- Cinnamon Becard

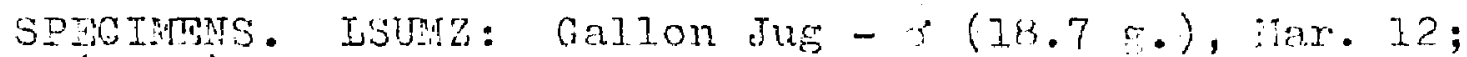
(20.1), oot. 29. Two mi. "San pedro Columbia - 9

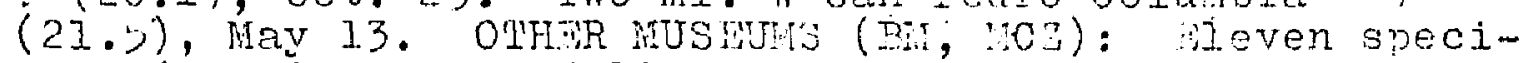
mens from Cayo, San Telipe, Camp VI, Tountain Con, upper Roho River, Toledo Settlement; Mar., Anr., oct.

This small cotinga is a morerately comon resident of tall rain forest, where it renerally forares hish ahove the cround. I have seen the spectes near the Fumningird Iighray six miles vest of yidalesex and in the rorest northeast ol :ilifinario, Milis observed it at Fill Bank. These three locolities cro the only places of: record supplenenting the specinen localiuies. The condition of the ronads is nom only for the three speciciens in the ISURz. Of these tiree birds, only the wile collected in day hed entarsed fonads. Peck found a nest in a cleming near loledo getulement on hay 13 that contained one very youn bird.

British jonduran specimens of the Cinnamon Becard $218 /$ re referable to $\underline{p}$. $c$. Fulvidior. The holotye of this race was collected by Peck in Ioledo District, ecording to iss label. Consequenty, in describing the race, Griscon used "l'oledo district" as the trpe locality. Peck's notes indicate that the specipic locality was Toledo settlenent. 


\section{Pachyrambius major (Cobanis)}

\section{Gray-collared pecard}

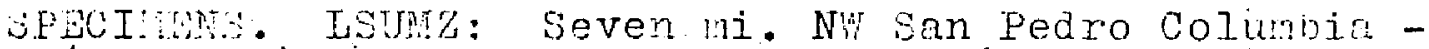

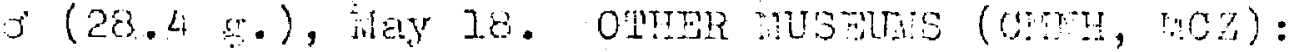
Iiddlesex - + , peb. 4, 1923; Iunta Gorda - J, Jan. 24, 1907 .

ine three suecicers listed above represent the only records of tins species in British Honduras. The male that I collectod northest or San pedro columbia was foraging in branclues ahout 30 feet above the ground in tall rain forest. This bird had tie plumage of a Iemale, but it ras actually a llale with much-enlurged testes. Peck collected a bira labeled "o, Toledo jistrict" that ras recorded by Prans and Peck (1908: 44 ). Peck's rotes supplenent inis record with the information that the bird was collected in the mancoves at funta Gorda. Paynter (19>ל: 182) recently re-exanined the seck specimen and considered it a semie. I have not seen the specimen at the Chiceo Natural Istory nuseur, wich mas collected at Middosex by scimidt and walters.

Paynter (19b5: 182) eritically examined the punta: Gorda specinen and decided that he could not with certainty assien it to eituer P. In itzensis or p. $\underline{\text { m }}$. australis. Although I have exanined good series of these two races, I have not found any specimens in a plumere comparable to the San Pedro columbia bira. Conseluently $\perp$ cannot identiry it to subspecies. 


\section{Platypsaris ilaiae (Lafresnaye)}

\section{Rose-throated Recard}

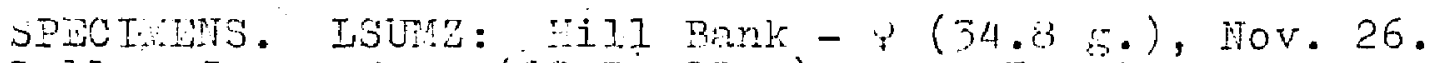

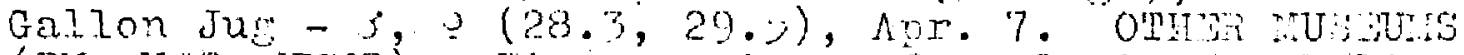

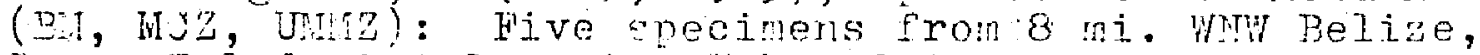
Cayo, Tolodo Settlenent; Feb., Oct., Eov., Dec.

\section{Rose-throated Eecerds are unconnon residents of} tall second rowtin, high rain forest, end the forest border and have not heen recorded at any locklitied. other than those listed as colloctine sites. Lancaster collected a nair at Gallon Jur on Aaril 7 that were in breeding condition.

J. Dan iebster has recently completed a criticsi atudy of this species and in the course of this study he exanined Britisi Jondurm srocinens. Hebster (in Iitt.) considered that we three specimens froin :ill Dank and Galion Jue could best be calied p. a- wucatinensis $\mathrm{22l}$.

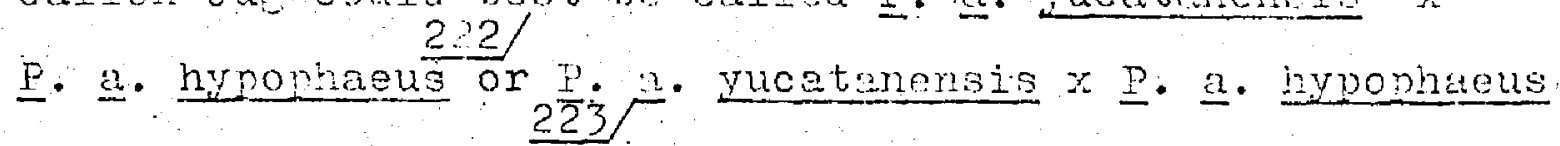
$\mathrm{x}$ ㅇ. a. sumichrasti. He concluded thit two specimens from Toledo setilement and one from an unknom specific locality were typical 로. ‥ hynonigeus.

\section{Tityra semifascieta (spix)}

Masked Tityra

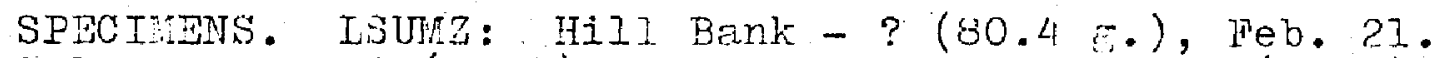
Gallon Jug - ? (77.8), झeb. 28; 7, Mar. 21;? (82.9), Ifay 7; (79.7), Nay 28; $5(78.4)$, Oct. 26; ; $(94.7)$, Nov. 16. Murustine - ?, Aur. 18; ?, Dec. 11. Ballerina Camp - $\{(84.7)$, Anr. 26. Two mi. W San Pedro Columbia $\sigma(71.8)$, May 21 . OMLIR HUSTUMS (BM, CC, CH, MOZ, UMRZ): 
Whirty-three specinens from Orange falk, Yelize, Wanatee Iasoon area, Cayo, San "eline, Il mi. S Cayo, Camp. VI, ireetow; Feb., Har. Apr., Nay, Jure, JuIy, Sent. CRI'ICAL DUBLISHT RECOD: Arenal (Helimayr, $1929: 214$ ).

This species, know locally ne the twinte woodpecker," is a comon resident off forest borders, pinelands, and open areas with scattered trees. It is sometimes seer in treetops in tall forest. The ilasked lityre is most ireruently observed in nairs or foursomes, occasionally in larger groups, foraring well above the ground or lying from ore leeding area to another. I have collected specimens in harch, April, and Way that had enlarged consds. Fect found five nests, each containing three erss, in Int, July, and Aurust. The hest noted August 3 wes in a netural cavity in a nine tree inear sanatee Iaroon and was re-used the following May. At Gallon Jug on May l6, I9s7, Willis observed a par reeding young in a hole $4 b$ fent above the ground in a tree at the edge of a cor: plantution. In a hole in the sane tren, but 23 teet hiner, a female Blackcapped rityra Iso fed young.

I assign the soecinens collected in British Honduras to $\underline{\text { I. }}$ - personata, which ranges from eastern gexico south to $\mathrm{EI}$ Salvador and Honduras. 
Erator inuisitor (Iichtenstein)

Black-capped lityra

SPICIMEMs. LSURz: Gallon Jug - p (41.9 \%.), peb. 10; \&. (43.4), June $1 ; 3(46.4)$, June 2. OpHen nưvis (BM, $\mathrm{CC}$, Un, Unz): Twolve snecimens from Belize, the Manatee Lagoon area, Cayo, Frestown; Jan., Arr., ify, Jurie, JuIy.

Winis uncomon resident has been observed only at tIill Bant, near San Pedro Colunbia, ni at the localities whe collected. The two tityra species occur in essentially the same habitats, sonetimes even resting, in the sane tree (see proedin onccies nccount). Wilits noted two nests contrining younc at callon Jug, one on ay 16 and the other on bay 19. irhe latter nest was in a cavity in a jebra trunk 4 , feet above the rround. Wacn of two nests found by Peck in 1906 near lianatee Jikgon. was in a roodpecker hole in a pine tree. The nests each held two eggs. One was l2 nd the othe: 3 feet above the Bround, and they were found hay 14 and June 4 , respectively. E. British Honduris and cuatemala to panamá.

Frmily TYMAMIDAE

Sayornis nigricans (Sminson)

Black Phoebe

SPECMMEN . ISUMZ: Caves 3ranch at Hummingbird Highway $\sigma(18.7 \mathrm{~s}$.$) , Mar. 22. O'DHER MUSTUMS (CM, lTCZ, ULTIZ):$ Pive specimens from cayo and one from the sittee River; Mar., Apr. 
The Black Phoebe is locally distributed ir central and southern British IIonduras but is unnown in the northern part of the Colony. It has been racorded only at about 200 to 400 feet above sea lovel, on tile upper parts of the Belize River (as fur wesi as Cayo), on Caves Branch, and the lifanatee, Sittee, iloho, and ienash Rivers. Rivers with steep, rocky slopes and exposed rocks in the bed seen to be preferred. It is presumably a resident, al though it his been reconded only in spring and in tovenber. Single nests conteining three ecgs were found by van lyme and Iolt on lerch 19 and April 9, respectively. Peck round a nest on spril 24 that held three nearly fledsed youns. Hen of these nests was attached to a rock ovornming a river.

filthough the British Ilonduran. specinens aro fron a lovland populstion, I see no basis for considering them

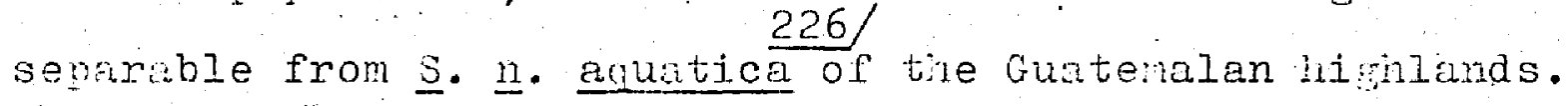
The under tail coverts of the six specimens are dinost completely sooty; the wings of the tiree males neasure 8, 88 , and 89.5 mand and the vings of the females 81 .y, 82 , and $83 \mathrm{~mm}$. In these two characters, as well as Eerieral coloration, the birds from the Colony can be natched by individuals from the mountains of Guatemala. Griscon (1932a: 246) commented on the variability of the charicters of $\underline{3}$. $\underline{\text { n. aquatica }}$ and Dickey and van Rossen

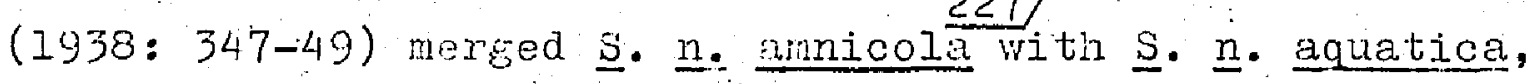
because of the great range of individual variation, 
especially in the constancy of the sootiness of the under tail coverts.

\section{Dyrocenhalus rubinus (Boddaert)}

Vermilion Plycatcher

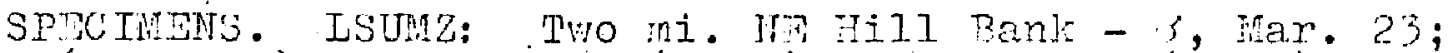
G (13.0 g. ), NTOV. $23 ; ;(13.5)$, Mov. $23 ; ?$ ? (13.2), Nov. 29. Hill Bank - $5(13.2)$, Mov. 23; $9(13.0)$,

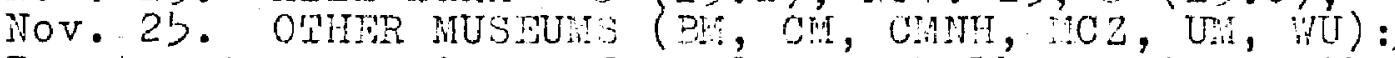
Twenty-rine specimens from Orange thalk, Belize, Sibun Piver, Manatee Lagoon, Cayo, Freetom, All Iines; Jan., Feb., Mar., Apr., May, Sent., Nov.

I'hroughout the louland nine areas of Iritish

Honduras, the Verrilion Flycatcher, or "robir red-breast," is a conspicuous and common resident. It occasionally wanders out of the ninelands, esnecially during the winter, since it has been seen at Grllon Jugr, Belize, and Cayo. In the higher Mountair fine Ridge it has been. recorded only once; I se\% one bird near Auwustine on iarch 9, 1956. Information on nesting is nearer and doubtless does not indicate the full vange of the breeding season. Feck found sevrral nests in the last week of Way and in June that container erss. Ye also noted that nests are usually nlaced 3 or 4 feet above the fround in a small palmetto, but he did find one nest 20 feet above the ground in a nine tree. The male collected by lancaster on llarch 23 near Hill Bank had only slightly enlarged testes. 
peck collected the type of $\underline{D}$. r. blatteus, the race to wich I refer all British Honduran specimens. In describing this rece, Benes refers to the trpe locality ns. "Sabune District." In his notes, Peck more precisely detines the type locality os "rear the sibune River." Since tio "Sabune District" no 7oncer exists, the latter locality is preferoble. on modern mers it is shown as tho Sibun Piver.

\section{Hucivory forficata (Gmelin) \\ joissor-tailed Flycitcier}

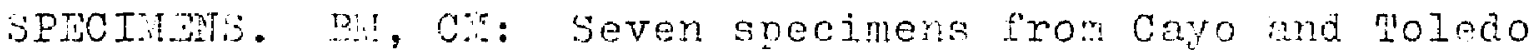
settlement; Peb., Oct., Doc.

Whis plycatcher is a rare winter resident ond probably aleo a rare fall and spring nigurt. Few sight records ounlemont the spocinens. ihe enriest fall record is renrosented hy a bird collected at cayo on votober Iy, presumbly in $18 \% 7$. Peck saw "a few" during the witer and spring of 1907 , tae last one early in April. On tiarch 17, 199\%, col. Altred Bellhouse saw several on a fence at lioom snd on warch 2y, 1920́, nolt saw one in a ralm in Belize.

\section{Muscivora tyranmus (Iinnaeus)}

Fork-tailed Flycatcher

SPICIRENS. ISUMZ: Six mi. NE Hill Bank - s, Mar. 22. I'wo mi. E Hill Bank - ? (25.2 f.), Nov. 23; $q(24.8)$, Nov, 28. OTHER MUSEUAS ( PM, CC, CM, MCZ, UIMZ): 
Pifteen specinens fron Belize, Manatee Laroon area, Wountain Pine ilige, freetom, Punta Gorda; all months except Jan.., Aur., jept., Oct. CRITTCAL PURTISHIDD RGCorDS: Sadde car and ralf hoon Gay (Selvin and Godman, Bioloria, ii, 1800: 100).

Whe fork-tailed irlotcher is an uncommon breeding bird of lowiand rrassy areas of the colon . It prefers mansin, Iou rrass but does occur in relatively dry aroas. whe species is mather locally aistributes and is absent in some anperenty suitable plnces. theme sne tro, old undeted snecinens in the aritish huseun from the Mountain Pine Ridge, but the only recent observition of the species in that area corsints of two hime I saw near husustire on isarch 11, 19,6. This flycutcher hes not been recorded in British Fon uras in eptemen or October, but this niatus is probably due to insuficient field work in the more suitable habitats at that season. Drte are not available to dotermine if the reeding birts are residents, eince birds seen in fall, winter, and sprine may be mimpnts from the nortin. Flocks of 6 to 14 or more individuals have been recorded in harch, Anril, sumst, and ilovember but possibly these vere nifments. Specimens recorded by Salvin and Godman from Half Hoon and Saldle Cars were not found in the Pritish Wuseum by llodd nor were they listed in the Catalowue of the Birds in the British Museum. The reference did not indicate dates. Unless the biris were migrants it is probable that this reference is in exror. Four nests containing eges or young have been fourd 
from March 31 to May 22. Whree of the nests were located by Peck, who stated in his notes that the nests were found 7 to 20 feet above the pround in very onen situations in the pine ridge.

The Britioh Honduran specimens are referable to $\mathrm{M}$. t. monarchus.

$$
229
$$

\section{Dyrannus tyrennus (Iinnaeus)}

Dastemn Kinnbird

SDECIMENS. ISUIZ: Calabash yay - s (46.9 E.), Apr. 9. OMISR HUSTU!S (BH, Ch): Fourtoen specimens from the hanatee Lagroon area, Cayo, All pines; Arr, Hay, hus., Oct. CRI'ICAI PURIIUTD RYOEDs: Sadale and Half foon Cays, hay 9 (Salvin, 1864: 380 ).

Whe Hestern Kingbird mi wrate: in laree numbers through British Hondures from late Ausust to Oetober and during a two-month period in spring beginning with the last thind of Harch. It is most frecuently seen on the keys and in open coastal areus, but there are a few inland records (fallon Jug, Cayo, San Pedro columbia). Peck collected an eerly autumn nigrant on August 23 and states in his notes that this species nonears from the north in late July. The latest fall date on which this species was seen was October 23 . The earliest recorded spring migrants were seen by Verner at Half Moon Cay on March 19; I saw the latest one recorded in spring on May 20. The birds were in rather sizent compact flocks (the largest consisting of 60 individuals). 
Two-thirds of the birds noted in spring were seen in the period of lnarch 27 to Anril 19.

Tyrannus melancholicus (Vieillot)

Tropical Kingbird

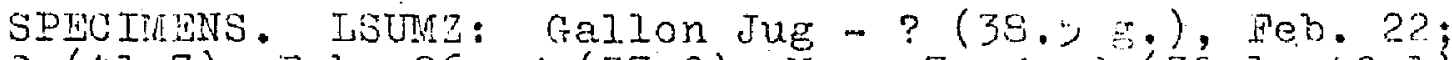
? (41.7), Feb. 26; $;(37.2), \operatorname{lar}, 7 ; 5,7(39.1,42.1)$, May 29;? (41.9), June 6; $6(41.3)$, Nov. 3. Calabash Cay - o, ₹ $(36.2,37.2), . \Lambda p r .10$. Two mi. s Aurustirie 于 (47.0), Nar. 20. Six mi. s telinda - s, Aus. 31. Two

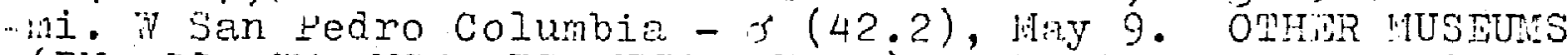
(BI, CC, CH, MCY, PC, UHIZ, USNI): Ihirty-seven specinens from Belize; Manatee Lagoon area, Cayo, San Felipe, Freetown, All ines, Toledo Settlement; all months except July. CRIIICAL PUBISSHDD RBCORD: Cockroacin Cay (Bond, 1954: 7 ).

The Tropical Kingbird is one of the most frequentiy seen residents of the onen areas of British Honduras. It has been noted in ril resions of the colony, al though it is less numerous on the keys and the dountair pine pidije. Pastures, fields, nIntntions, and open stroam banks in tive lovlands aro its preferred habitet. Westing berins in late April and continues until njd-June.

the race occupyths the region from southeastem itexico to northern South Anerica is 1 . II. chloronotus.

\section{Iegatus leucophaius (Vieillot)}

\section{piratic Flycatcher}

SPICIMINS. ISTIIZ: GaIIon Jug - o (27.b g.), ADr. 7; $\sigma(29.3)$, Hay 29. Wight mi. í Gallon dug - ó (23.9), Mar. 28. Half Moon vay - ? $(31.5)$, iar 26 . lwo mi. W San Pedro Columbia - $q(27.0)$, May 5 . OTHIR MIUS EUTS (Bir, Cir, NCZ): Siz specimens from Cayo, lireetown, and Polerlo settlement; Mar , Mar. 
The Piratic Flycatcher is a rathor local breeding bird in British Honduras. First arrivals appeared in lour different years between extreme dates of Narch 18 and harch 26. it Gallon Jus, Willis reoorded this species daily after its arrival until July 22 , the latest date on which the snecies has been seen in British Honduras. It ocours where there are tali trees in extensive clesrings and pastures, and on the edges of tall forest. occasionally it is found in small clearinge in the heart of extensive forest. Preedins rrobanly begins soon after arrival, since individuals axrive with the ronads slithty enlarged. Whe male taken on Anril 7 had fully enlarged testes, and villis noted an individual at galion Jug on April 21 near a nest about 40 feet above the around in a Sabal stub (possibly a nest built b: Hyiozetetes similis). However, the earliest date of a set of egrs is lisy 2 (Peck). Skutch (1960: 4b1-464) has described the quite unflycatcherlike practice employed by the Piretic Flycatcher of stealing nests from other species.

The populations occurring in liexico, Guatemala and British Honduras are referable to $\underline{L}$. 1 . variegatus.

Nyiodynastes iuteiventris sclater

Sulphur-bellied mlycatcher

SPLCIFENS. LSUM: Gallon Jus - $(46.0 \mathrm{~g}$.$) , May 3 ; \mathrm{t}$, Hay 28. OTHER MUSEUMS (GI, CM, MCZ): Twenty-six specimens from the Manatee Lagoon area, Duck Run, Cayo, San Antonio, 
Camp VI, Mountain Cow, Freetowr; Mar., Apr., May, June, July . CRITICAI DUPIISHW RECORD: Belize (Salvin and Godman, Riolorie, ii, 1389: 48).

The sulphur-bellied Hycatcher is an unconon breading resident in British fonduras found most often about tall trees in clearings at or near the edge of high forest. Where aro aint records from Hill Bark, Sittee River, Half Moon Cay (a migwant seen by Verner on March 26 after a storm), Ycacos Lacroon, and Toledo Settlenent. Observations made by hilis suryly the earliest record in the colony and nrovide an irdication of local abundarce. At Galion Jus, iilis first saw this species on tarch 23 and recorded an averace of four birds per day a field until July jl, when he left trat area. Iay obtained the Idtest date on Aurus 19 , men he san one bird at uoroml. Tests containingens mere found during the finst week of iny newly hatched birds mere in another nest on ituy 24 (Peck).

Biras nestine from essterr nexico south to costa Rica are referable to 1 . Inteiventris.

\section{Myodynastes maculatus (muler)}

itreaked Flycaticher

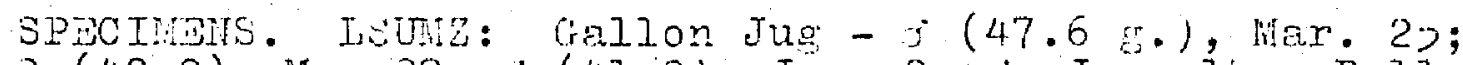
? $(42.9)$, lay $28 ; 5(4.9)$, June $2 ; \%$ June is. Balierina Camp - P $(47.1)$, Apr. 24.

The streaked Plycatcher has been recorded only at Gallon Jug and Ballerina camp, where trees in clearings 
near the edge of the tall forest provide its preferred habitat. Gontinuous field work at Gallon Jug by Willis in 1937 provides the earliest record in the colony, on March 13, and the latest, on July 20. Between tharch 19 and exry June, rillis recorded this species every day that he was in the field; most frepuently he observed two individuals.

The population in tile northern part of tine rare of trijs snecies (including British londurts) is $\underline{H}$. insolens.

\section{Megariynchus nitamma (Iinnaeus)}

$$
\text { Boat-billed Flycatcher }
$$

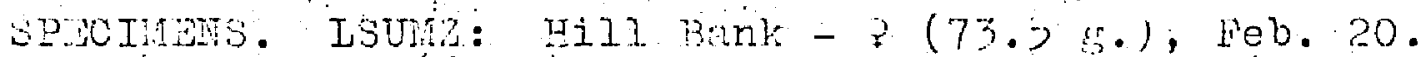

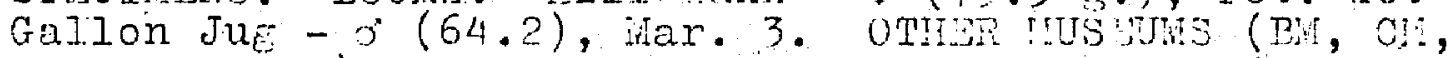
!CO,PG, Ui:Z): Hineteen specinens fron Belize, Manatee Lasoon area, Cayo, Augustine, Camp VI, Poledo settlement; Jan., Jikr., Apr., Oct., Dec.

Phis resident flycatcher is found in gritish

Eonduras ir moderate numbers nuar forost ed ses and in tall second frowth and pinelands. Counts of only one or two individuals every four days in the fiela were the experience of willis at Gallon Jur from March through May; he recorded the species more frenuently in June and July. In pinoland it is perhaps moro comon than in other habitats. Peck found four nests between Ilay 22 and June 8 that contained eggs. 
The race occupying the area fron eastern Mexico through Central America to Panama is m. mexicanus.

\section{lityozetetes similis (spix)}

Vermilion-cromed Flycatcher.

SPECIMTNS. ISUMZ: Gallon Jug $-s(29.2 \mathrm{~g}$.), War. 2);

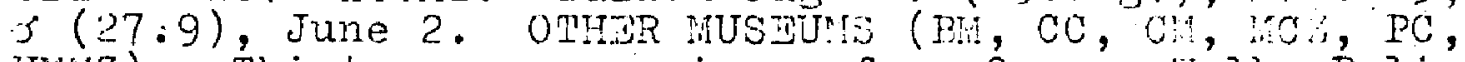
Un:z): Thirty-seven specimens from Orange irik, Belize, Ifanatee Iafoon area, Duck Run, Cayo, Camp VI, Freetown, . Toledo Settlenent; all montis excent July, sent.

This species is a common resident of tle lowlands of British Honduras, where it occupies clearings, pinelands, and riverbanks. It is less comon in the rountain Pine Ridge but does occur where the rain forest intrudes into the ninelend and it has beon recorded up to an elevation of 2700 feet in a ravine just below raldy Beacon. I did not record the vermilion-crowned Plycatcher, however, in the hountain Pine Ridge during ten days rork in December. I'en nests containing ecss were found by Peck from inay 12 to June 24 .

From eastern Mexico. southward into costa Rica, the recognized race is $\stackrel{\text { 朝. }}{-}$. texensis.

Pitancus sulphuratus (Linnaeus)

Great Kiskadee

SPECIMENS. ISUMZ: Melinda -9, Aug 30 .MHER MUSUUS (BM, CC, CWI, MCZ, PC, UMHZ, USMM, wU): Thirty-nine specimens from Ornnge Walk, Belize, Manatee Lagoon area; Cayo, All Pines, Toledo Settlement; Jan., Feb., Apr., May, June, Aug., Sept. 
The Great Kiskadee is a common resident in the cleared regions throughout the lowlands of mainland. British Honduras. It is ilso found in the pinelands and in the mangrove swamps of the coastal areas. In snall clearings or clearings recently claimed from the forest, this flycatcher is rarely present. Nests containing eges have been found in the period of liay 2 to June 8 (Peck).

I include Britisin Honduras within the rance of ․ s. guatimalensis with some reservations since I have not made a study of the porulations in southem kexico and northern Central America. vetmore (1943: 288), Brodkorb (1943: 64), Lowery and Dal auest (19\%2: 609), and paynter (1955: 143) have generaliy followed van Rossem's revision of the northerm races of the species and considered central veracruz the area of intercradation between $\underline{P}$. s. Euatimalensis and $\underline{\underline{p}}$. S- texarus. However, Miller et al (1956: 76) recognizes $\underline{\text { s. }}$. derbianus 25 the race occupying "Pacific coastal, central, and southern sections" of Mexico, without commenting on the rence- of …‥ guatimalensis.

\section{Myiarchus crinitus (Iinnaeus)}

Great Crested Flycatcher

SPECIMENS. LSUMa: Half Moon Cay - q (25.0 E.), Mar. 26. OTHOR MUSEUMS (BM, CM): Six specimens from the Manatee Iagoon area, Cayo, loledo Settlenent; Jan., Sept., Nov., Dec. 
'lhis North American Fycatcher occurs in British Honduras as a rare misrant and winter visitor. The only records for the colony in addition to the specinens listed above consist of individual birds seen at fallon dug and Cayo on five dates in the spring (Harch 12-spril 1). The specimen from Half Moon Cay was killed at niknt when it flew against the lighthouse. The earliest fall specimen was collected September 13 near Hanatee Lakoon. Kemeth C. Parkes has critically eramined the five British Honduren specinens at the Carnecie finseun for me. He notes that the bird collected september 28 near Manatee Lagoon is distinctly snall-billed and matches Pensylvania specimens of $\mathrm{H}$. $\mathrm{c}$. boreus $\frac{239}{2}$ The other four specimens ine refers to L. $\mathrm{c}$ crinitus. I refer the Hal. Woon cay bird also to $\mathrm{M}$. c. crinitus.

\section{Hyiarchus tyranmulus (Mttlier)}

Wied's Crested Flycatcher

SPACIMUS. LSUML: Gallon Jug - q $(30.8 \mathrm{~g}$. $)$, Mar. 14. Calabash Cay $-26^{\prime} \mathrm{s}$, ? $(39.2,41.6,39.0)$, Apr. 9. Augustine - 6 , Dec. 8. Pullerina Camp - ? (38.1), Apr. 26. OTHTR MUSEUAS (BM, CN, irCZ, UTH?): Twenty-four specimens from Orange Halk, Belize, Manatee Lacoon area, Duck Run, Cayo, Camp VI, Freetown, Hil Pines, Toledo Settlement; Jan., Mar., Anr., ilay, June, Dec.

This crested flycitcher is common locally in British. Honduras. At Gallon Jur four to six were seen daily from liarch through July in large clearings and second Erowth (Iillis notes). In coastal areas the 
species is also found in pinelands. That the ried's Crested Flycntcher also occurs as a migr:int is indicated by the three specinens Dennett and I.collected on Calabash Cay on April 9; I saw nine others on April 9 and 10, but none mere definitely identified at later dates. Verner noted 35 individuals of the genus Myirchus on Half Moon Cay on March 26 but was urable to identify them to species. He saw no other Myiarchus during the entire spring. Nesting has been noted at Gallon Jug, the Sibun River, Manatee Iagoon, and Toledo Settlement from April 30 to June 10. In April and lTay, birds with enlarged gronads have been taken at Duck Iiun, Ballerina Camp (on pine ridge at an elevation of 1700 feet), Treetown, and $\Lambda I I$ Pines.

I refer all racially identified specimens from British Honduras to $M \cdot t \cdot$ cooperi.

\section{liyiarchus ycatanensis Lawrence} Yucritán Flycatcher

At Gallon Jug in the spring and sumner of 1957 , Willis noted a species of lifyarchus other than the comon 1.i- tuberculifer and H. tyrannulus. He saw 26 individuals of this less common species on 21 dates from March 26 to July 14 and identified it by its call as 1 . yucatanensis: The Yucetán Flycatcher has been collected at Chetunal (7) miles northeast) in December and a specinen taken at 
Tabi, Quintana Roo (I50 miles north-northeast) on March 16 was in breeding condition (Paynter, labs: 195). Willis' observations constitute the only records of this species in British Hondures.

Wyiarchus tuberculifer (D'orbigny and Lafresnaye)

\section{Dusky-capned Flycatcher}

SPECIMINS. ISUMZ: Cne ril. Niv Corozal - 3, Aug. 16. Six mi. NE Hill Bank - (16.2 g.), Apr. l. Gallon Jug - 2 ''s $(16.4,17.1)$, Feb. 26; \&, Aug. 19; P (16.1), Nov. 6. Seven mi. NW Belize - $\}(19.0)$, Apr. $>$. Five mi. W Baldy Beacon - $Q$ (19.3), Apr. 20. Aurustine Dec. 10; 9, Dec. 12. rwo mi. T San Pedro Columbia - 3

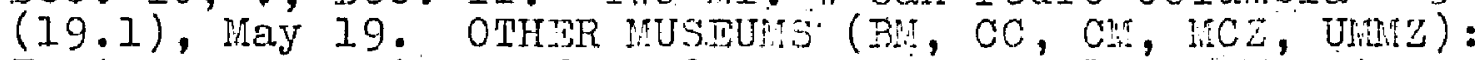
Forty-one specimens from Orance $7 a l k$, Belize, Wuntee LaEoon area, Duck Run, Cayo, Mountain cow, All Pines, Freetom, N slope Cockscomb its. (1500'), Toledo Settlement; all months except July; Aug., Sent.

The Dusky-capped Flycatcher is a cominon and almost ubiquitous resident on the British Jonduran minland. It is present in, the coastal scrub growth, trees bordering clearings and rivers, huamil, tall second growth, lowland pine ridges, and the edges of the rain forest. Wy notes indicate it is most common in the northern, drier half of trie Colony. Willis noted birds carrying "beakfuls of dry grass" to sites situated at the forest edge on April 21 and May 4. Peck found a nest with four egss on April 21 that was also near the forest edge and arother on May 10 with four eges. Whe cavities containing these nests ranger fron 1.5 to 36 feet above the ground. 
The specimen fron corozal has a greenish back and its pileum does not contrast greatly uith the back. There is no rufous in the inner webs of the rectrices. These characteristics are typical of it. $t$. platyrhynchus. I refer the specimen to this race. il. t. comectens is distinguished by a brownish back and a darker, contrasting pileum, and the inner yebs of the rectricen are sometimes rufous. Some specimens from the Gallon Jug - Hill Bank region and from coastal locilities ns far south as Belize show very little rufous on the inner webs of the rectrices and heve little contrast between the crom and a slightly olivaceous back. Ihis geopraphickl region is apparently one of intergredation between I. t. Dlatwringhus and II. $t$. comnectens. Specimens from other parts of the Colony are nore like $\mathrm{H}$. $t$. connecters then $\underline{t}$. platringehus in the color of the unper parts and in the extent of rufous in tine tail, al though perhips not wholly typical of that race.

Measurements given by Brodkorb (1943: 6y) indicate that $\underline{M}$. $t$. platyrhychus is smaller than $\mathbf{M}$. $t$. connectens. All british Honduran specinens are rather small and compare favorably with measurements given by Brodkorb for $\underline{\text { H. }} \underline{\mathrm{t}}$. platyrhynchus. Unfortunately, Erodkorb indicates neither the size of his sample nor the standard deviation; thus the comparison does not lend itself to statistical analysis. On the basis of characters discussed in the preceding 
paragraph, specimens from the southern part of the Colony are referable to $\underline{H}$. $t$. comectens and many specimens from the northern area are intermediate between the two races. The wings of 20 males frorn British Honduras ranged from 73 to $82 \mathrm{~mm}$. with a mean of $78.5 \pm 1.98 \mathrm{mrn}$; the tails of 18 males ranged from 67 to $76.5 \mathrm{~mm}$. with a mean of $73.5 \pm 2.4 \mathrm{mra}$. In 19 females the wing measurement ranged from 71 to $77 \mathrm{~mm}$. with a mean $74.2 \pm 1.72 \mathrm{~min}$. , and in ly females the tail ranged from 62.2 to $74 \mathrm{~mm}$. With a mean of $69.1 \pm 2.79 \mathrm{~mm}$. However, no clinal variation in measurements is evident in specimens taken vithin the Colony.

Paynter (1907a: 262) suggested thit If. t. platyrhynchus senerally has a rother horn-colored bill, wile if. $t$. connectens most frequently has a black bill. None of the British Honduran series has a hom-colored bill, although the lower mandible is slightly lighter than the unver one. The specimen from Corozal ( $\underline{M}$. $\underline{t}$. platyrhynchus) actually has the blackest bill in the series. This specimen is four years fresher than other specimens, so perhaps it is not comparable.

ieichts have also been suggested by paynter (1957a: 265) as possibly having subspecific significance in this species. Unfortunately, there are not yet sufficient weights available from southern Mexico, the Yucatin Peninsula, British Honduras, and Guatemala to be useful. In late winter Van Tyne collected a male at Cayo that 
weighed 17.0 rrims and four females at cayo and Belize that weighed 15.7, 1ว.9, 16.2, and 17.2 grams. Horty-four specimens of this species were critically examined from all localities in the colony where the species.has been collected except Orange Walt and Dountain Cow. British Honduran specimens are not at a11 like the darker-crowned, more greenish-backed im. t. nigricapillus of costa kica, which nay range as far north as the Caribbean coast of Honduras.

\section{Nuttallornis borealis (Swainson)}

Olive-sided Flycatcher

SPICIMBNS. ISUMZ: Gallon Jug - Q $(33.0 \mathrm{~g}$.$) , Feb. 28,$ 1957. Augustine - ?, Aug. 24, 1961 .

The Olive-sided Flycatcher has been noted only a few times in Pritish Honduras. At Corozal on Ausust 18, 1960, Lay collected one of these flycatchers but did not proserve it; and or August 26 , he saw another at Regalia. At Galion Jug, Wilis recorded one individual (two on one occasion) almost every day from february 20 to llarch 15, 1957, and Iancaster saw one bird on seven dates from January 22 to February 6, 1958. These January, Februery, and March observations may be of wintering birds, since there are apparently no spring arrival dates in Mexico earlier than April. This species is rare north of South America in winter. 


\section{Contopus virens (Linnaeus)}

Pastern wood Pewee

SPICIMTHS. LSURz: Galion Jug Calabash Cay - ? (13.5), Apr. 10. Half lifoon Cay - j, Mar. 9; $3(12.3)$, Hor. 26. Augustine - ? (13.3), May

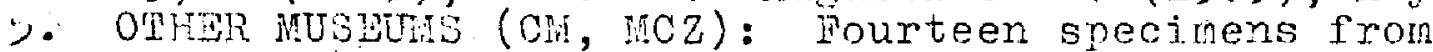
the Wanatee Ingoon area, Mountain Cow, All Pines, Freetown, lloledo Settlement; Apr., iray, sept., Oct., Nov.

This pewee is a rather uncommon migrint, occurring on the keys and in open areas throughout the colony. Fall migration dates ranfe from september 14 to November 3 ; spring dates from March 9 to hay 13, with the Ereatest number of individuals present from the last week of Warch into the first week of liey. On Half Moon Cay in 19>8, Verner noted 30 individuals on March 26 as a result of the arrival of a "norther," although he had seen only one pewee earlier in the spring (Maxch 9). Whrough April and until liny 8 , when he loft the key, Verner saw one to four of these birds nearly every day. post pewees are silent when they are in British Hondures in winter and consequently are unidentifiable to snecies in the field; conseruently the wastem wood Pewee could winter in British Honduras without being recognized.

Contopus sordidulus sclater Western Wood Pewee

SPECIMEN. RM: Ornnge Walk.

This specimen, collected by Gaumer at Orange Valk in December of 1887, is listed by Salvin and Godman in 
the Biologia (1889: 85) as Contonus richardsoni. H. not deternine its subspecific identity, since it was an immature bira.

\section{Contopus cinereus (Spix)}

Tropical Pewee

SPLCIIENS. ISUAR: Gallon Jug - 0 (11.1 G.), Feb.

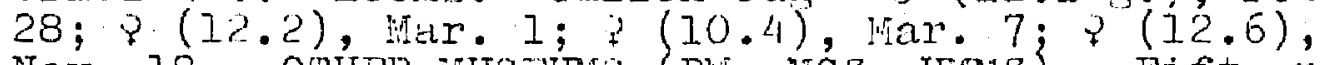
Nov. 18. OTHER MUSTUS (DII, ICZ, UMMZ): Fifteen specinens from the Belize River, Cayo, Hountain Pine Kidge, Sittee River, Toledo settlement; Jan., Mar., Apr. CRIIICAI PUDLISHID RFCORD: Orange Walk (Galvin and Godman, Bioloria, ii, 1889: 87).

This resident pewee is noderately common away from the coastal regions of the colony about clearings, Iovland pine foreats, riverbanks, and forest edges. It is not a chartcteristic species of the Nountain Pine Ridge, although it is found at the edge of this area. Nests containing two or thres egss have been found from Hay 24 to June 20 (Peck). Nesting undoubtedly begins earlier since lillis noted two young birds out of the nest on June 10. The three nests located by fillis at Galion Jugr were between 35 and 30 feet above the ground, all higher than nests noted by skutch (1960: 327). The race occupying Central America is $\underline{C}$. $c$. brachytarsus. 


\section{Contopus pertinax (Cabanis and Heine)}

Coues' Flycatcher

SPICIMENS. ISULI: Five mi. W Baldy Beacon - $q(26.4$ g.), Apr. 21. Augustine - (22.) , Mar. 9; $\}$, Dec. 11; $;$, Dec. 13. Two mi. WW Augustine - s, Dec. 13. Three mi. S Augustine - $9(21.0)$, Mar. 11. Hight mi. S Augustine - $3(22.7)$, Apr. 23. OTHSR MUSTU: (Bi, MCZ, UNMZ): Fifteen specimens from Augustine, $12 \mathrm{mi}$. s Cayo, Hountain Pine Sidge; Feb., Apr.

Coues' Flycatcher is a rosident in British Honduras, confined apparently to the liountain Pine Bidge. Its preferred habitat is the open pineland, but it cloes frequently venture as anch as one-half mile into the forest that borders the pine ridges. The female collected March II had a slimhtiy enlarged ovary and the one token April 21 contained an ege in the shell. The birds collected in December all had incompletely ossified skulls.

Austin (1929: 383) collected a single specimen at Augustine in 1928 and on the basis of its smallor measurements assigned it to $\underline{c}$. $n$. mino $\frac{246}{r}$ rather than to $\underline{c} \cdot \underline{n}$. pertinax. Additional specimens are also small and support Austin's designation. Seven males from the nountain Pine Ridge provide the following measurements in millineters: wing 94.5 to 101.b with a mean of $98.1 \div 2.3$, tail 75 to 82 with the mean $79.4 \pm 2.3$; seven females; wing 91 to 94.5 with a mean of $93.4 \pm 1.2$, tail 72 to 78 with a mean of 75.7 1.9. These measurements agree well with those of the small sample provided by Miller and Eriscom in their original description of $\mathrm{G}$. $\mathrm{p}$. minor. Seven males in the 
Camegie huseum from il Hatillo, Jonduras, have wing measurement: renging from 9 , to $10>0, \mathrm{~mm}$. with a mean of $93.4 \pm 3.4$ and tails ranging from 72 to 82 nan, with a : aean of $78.6 \pm 3.2 \mathrm{~mm}$. These birds are also c. p. minor and thus tre northern limits of this ree extend through Ionduras to British Hondures. The larger nominate form extends south into the mountains of Guatenala.

\section{Bmpidonax flaviventria (Baird and Baird) \\ Yellow-bellied flycotcher}

SPECTMENS. ISUMZ: Aurustine - ? (12.; E.), Har. 10. Two mi. Me Millionario - 3 (II.I), har. 16. Two mi. W San Pedro Columbia - 3 (13.1), Lay 3; (10.2), liay 8; $q(10.3)$, May 11 . OlHEk inUs from the lilanatee Lagoon area, Freetown, and roledo Setilement; Jan., ifay, Oct.

The Yellow-bellied Flycatcher is a moderately comon vinter resiclent in the Colony, but it is not common as a transient. Pield notes inaicate a steady decline in consecutive daily counts of this species in late Februcry and liarch without conspicuous surges in counts in April or Nay. It has not been recorded from the keys, where many migrints are detected. This empidonax flycatcher is found in forest edes, huamil, and the lower levels in tall, heavy forest.

\section{Empidonax virescens (Vieillot)}

Acadian Flycatcher

SPECINENA. ISUMZ: Calabash Cay - q, o, ? (12.9, 16.5, 14.7 g.), Apr. 10. Half hioon Cay - o (12.2), Mar. 26; 
of (10.0), Apr. 17. OTHWP MUSUM (CM): Three specimens from the Hanates Lagoon area, Cayo; Sent. 6, Oct. II, Apr. 2 .

The Acadian Flycatcher is an uncommon transient in the Colony, and its occurrence is know only from the specinen records listed above. The field notes of ali observers who have worked in British Honduras include many flycatchers called only "Emnidonax sp." It is not worthwile, however, to speculate on the identity of such birds. The two heaviest birds taken on Calabash cay were extrenely frt.

\section{Empidonax nininus (Daird and Baird)}

Lesst Flycatcher

SPTCIMENS. ISUMZ: Hill Bank - z (10.6), Mov. 20. Galion Jug - $\gamma(-9.3$ g.) , Feb. 21; 0 (9.9), Mar. 2; ? (12.5), Mar 7; $(9.9)$, Det. 22; ? (0.0), Nov. 12. Pomona - 0 (10.5), Apr. 1. OTLTR NUSEUMS (MM, GH, UWTZ, USMII): Nineteen specimens from Orange lalk, Belize, Hanatee Lagoon area, Cayo, Hounuain Pine Ridce, 12 mi. S Cayo, Freetown, All Pines, Poledo jettlenent; Jan., Feb., Mar., Apr., May, Nov., Dec.

The Least Flycatcher is a common winter visitant, but it is inconspicuous as a trarsient in British Honduras. This species is tound in clearins, second growth, and pinelands throughout the mainland of the Colony. The latest individual recorded in spring was collected on May 2. Daily totals of empidonax flycatchers in general decline in number after a peak in February, and nembers of the genus are scarce after the end of 
March. of the specimens of the Ienst Flycatcher for which weishts are provided, only the bird collected March 7 was very fat.

\section{ierenotricous erythrurus (Cabanis)}

$$
\text { Ruddy-teiled ilycatcher }
$$

SPICIMLNS. LSUMZ: Two mi. Whan Pedro volumbia - P $(7.7 \mathrm{g.})$, iray 8. :ight ni. Wi San Pedro Columbia - 5 $(7.0)$, May $1.4 ; 7(6.6)$, hay 16 . OTHER MUSUUMS (CM, HC(): Pive specimens fron polerto jottienent; Jan., Oct., Mov.

Ihis tiny flycatcher is an uncommon resinent of the lower level of tall, humid forest in extrene southern British Honduras. Farther north in the colony it has been noted only twice: in line at the head of cocirscomb Branch of South. Stann Creek (elevation about 1 yoo feet) and at Galion Jug in February. Two of the birds collected near San Pedro Columbia had enlarged conads. Whe race occurring in Central Anerica is called …‥ fulvigularis.

$$
248
$$

\section{Myiobius sulphureinygius (Solater)}

Sulphur-rumned Flycatcher

SPECIMLNS. ISUMZ: Gallon Jug - ? (8.8 ๑.), Mar. 8; $\sigma(10.0)$, litar. 10 ; 0 ; Har: $14 ; 0$ (12.1), Nov. 9. Two mi. W San Pedro Columbia - $P(10.4)$, May 3; $\$$, May 6 ; $¥(11.3)$, May 9. OTHER MUSMUMS (BM, CM, MCZ): Fifteen specimens from the Hanatee Lagoon area, Duck Run, Cayo, Mountain Pine Ridge, Mountain Cow, N slope vockscomb Wts. (1400'), Soledo Settlement; Feb., Mar., Apr., Nov., Dec. 
Within a few feet of the ground in the tall humid forests of the Colony, the Sulphur-rumped flycatcher is a characteristic resident, although it is only moderately common. It is slightly more numerous in the southern thitd of British Honduras than in the northern part. It renses high into the cockscomb nountains; I saw it in late hay in a shaded ravine just below Victoria Peak at an elevation of over 3000 feet. I have rarely seen more than one individual at once, al though the species does sonetines join the wandering flocks of small birds in search of insects. At least some birds must begin nesting in Anril, since I saw an adult on May 4 carrying food into its pensile nest attached to a liana hanging over a tributry of Cockscomb Branch. The latest nesting was recorded by fillis, who sam young being fed in the nest on June 30. Of the five individilals collected in warch for which I have date, only the one tiken on harch 25 had enlarged gonads.

The Pritish Honduren specimens fre typical of 249

M. S. sulphureipygius, which ranges from inexico south to Honduras.

Onychorhynchus mexicanus (Sclater)

Royal Fiycatcher

SPEC IMLNS. ISTRZ: Gallon Jug - $\sigma(18.6 \mathrm{g.})$, Nov. 14. Five mi. W Hiddlesex on Hummingbird Fighway - $\sigma(20.6)$, Mar. 27. Two mi. S Pomona - $\sigma(19.7)$, Mar. 31. Augustine-o, Dec. Il. Two mi. W San Pedro columbia - $\sigma$ 
(20.0), hay $5 ; \sigma(19.7)$, May $7 ; \sigma(19.7)$, May $12 ; 0$, ivay 13. OTHER MUSTUS (CA, MCZ, vU): Ten specinens from the Nanatee Lagoon area, Cayo, Camp VI, Mountain Cow, Preetomi Feb., Apr., May, Aug., Sept., Dec.

In the lower level of tall, humid forest and second erowth in the southern third of British Honduras, the Royal ilycatcher is a moderately common resident. It is infrequently seen in the northern half of the Colony. Some birds may wander northward during the rainy season, because nost observations of this species in the Gallon Jug area were made from July to November. One bird that I saw in November at Gallon Juir was perched 40 feet un in tall mahogany troe in a pasture, far from its usual forest habitat. Peck collected one on. the beach near the mouth of the Hanatee River in Decerber. Ihis species was also seen in winter in the linited growth along streams in both the rountain Pine Ridge and the Hill Bank pine ridge, habitat not occupied by this snecies in April, Way, and June, the months in which breeding usually occurs in British Honduras.

I find that British Honduran specimens are similar to Mexican and Guatemalan birds arld are assignable to o. m. mexicanus.

Platyrinchus mystaceus (Vieillot) White-throated spadebill

SPECIMENS. ISUMZ: Gallon JUg - $7(8.2 \mathrm{~g} \cdot)$, Feb. 2b;

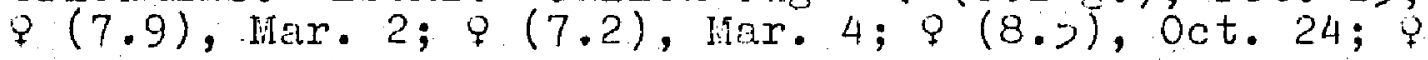


$(3.5)$, Oct. $27 ;$ ( $(8.4)$, Nov. 10. Ballerina Camp $\checkmark(9.6)$, Apr. 29. Two mi. Tan Pedro Columbia - 8 (10.4), May 20. OTHBR MUSUUS (BM, CO, CM, MCZ, UNDE): Fourteen specimens from ormge lalk, llanatee Lagoon area, Cayo, Crmp VI, ireetow, Toledo jettlement; Peb., Mar., May, Oct., Nov., Dec.

This species is a resident of the rain forest arens throughol Pritish Honduras. It prefers the understory of mature forest but is sometimes found in dense stands of cohure palm and in tall second grovth. Usually it is observed within 10 feet of the ground, where it moves about by short, abrupt flights. Thourh not shy, it may remein inconsnicuously perched for some minutes at a time, its presence indicated only by a frecuently repeated buzzy twomoted call. Because of. its unobtrusive habits, I have rarely recorded over six individuals in a day, even in the most suitable habitats. Breeding apparently begins in late Anril, es males taken on April 29 and Nay 20 hed enlarged gonads. Willis noted fledglines being fed by a parent on July 12 . Two races are distinguishable in British Honduras. Specimens from Gallon Jug have Greenish backs, poorly defined breast bands, and little streaking of the under parts. These features are characteristic of $\underline{P}$. 1 timothei. Two specimens from l'oledo settloment and one from two miles west of San Pedro Columbia are like veracruz specimens in having brownish backs, olekrly defined breast bands, and considerable streaking of the 
under parts. I refer these three birds to $\underline{D}$. $\underline{m}$. cancrominus. Specimens that I have examined from Beillerina Camp and the Manatee Iagoon area possess characters intermediate between those of $\underline{P} \cdot \mathrm{m} \cdot$ cancroninus and $\stackrel{\text { ?. }}{\mathrm{m}}$. timothei.

\section{Tolmomyias sulphurescens (Spix)}

sulphury Fletbill

SPICIMDNS. LSUMZ: TWo mi. B Hill Bank - q (I>.2 E.), M!ov. 22. Mill Bank - ? (14.1), Apr. 2. Gallon TuE-

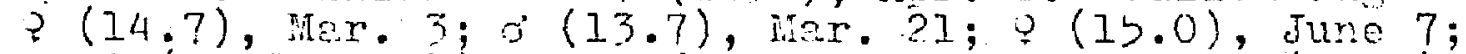
$\checkmark$, $(1>3,25.5)$, Nov. 6 . Inljerine Camp $=9(1=.9)$, Anr. 24; $2(14.2), \operatorname{pr} .29$. Two mi. NMt MillionarioY (16.b), Mar. 3.6. Two mi. W San Pedro Columbia-s

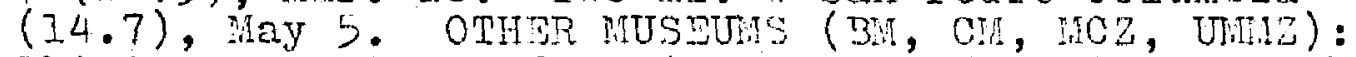
Thirteen specimens from Orange Haik, $7 \mathrm{mi}$. YNi Belize, Manktee Lagoon arca, Cayo, Toledo Settlerient; Jan., Mar., Apr., July, Oct., Nov., Dec.

This inconspicuous flycatcher is a moderately common resident of lower levels of tall forest, of high second growth, and of forest edgres; and rerely, it is found in the edge of pine ridges. It may be somewhat local in its distribution, as it seemed less common to me in the san Pedro Columbia area than in the Gallon Jue and Nanatee Lagoon regions. I swy one individual at about 3000 fret in the cockscomb lountains and others along south stam creek. Peck found nests containing four eggs in deep forest on May 19 and 28 near Manatee Lagoon. The race occupying the area from nexico to Costa Rica is $\underline{T}$. : cinereiceps. 
Rhynchocyclus brevirostris (Cabenis)

Eyé-ringed Fiatbill.

SPECIMPIS. LSUMZ: Night ni. TGallon Jug - ? (19.8 g.), War. 28. Gallon Jug - ? (24.0), Nov. 2. Nine ni. I Midaleser on Humingbird Hw . $-3(21.6)$, Max. 26. OTHER

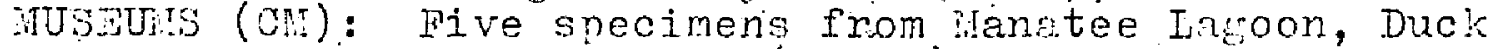
kun, N slope Cockscomb Mts. (1400'), Toledo Settlement; Jan., litar., May, Nov.

The Bye-ringed tratbill is a rather uncomon resident of tall, wet forest in the colony. In addition to the specinen localities this species has been observed only at Bullerina Camp and at spproximtely 3000 feet in the Cockscomb liountains, where I trapped one in a mist net hung at the crost of the moutin. Forest mid-levels are preferred by this slugeish and usually solitary flycatcher, a factor that contributes to the difificulty involved in seeins the bird. The ovary of the fenale taken on ifarch 26 was partially ajiargen, and the testes of the male taken on Barci 28 were greatly enlarged.

The ruce runging south tinxough Central America to

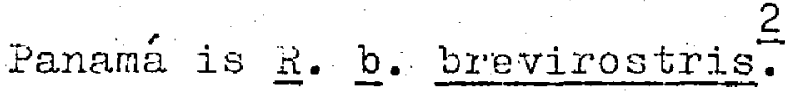

\section{Todirostrum cirexeun (Linnaeus)}

Common lody-Plycatcher

SPBCIHYNS. ISUMZ: Six mi. Ni Hill Benk - r, ifar. 23. Galion Jug - $(5.4 \mathrm{~g}$.$) , Feb. 28; (5.6)$, Apr. 2. Beven mi. NW Belize on Corozal Road $-5(3.4)$, Apr. 5 . itelinda - , Sept. 2. Two mi. J San fearo Columbia - j (b.4), MaY 1I. OTHER HUSEUMS (BM, CM, MCZ, UNMZ): Seventeen specimens from Orange Walk, Crooked Tree Lagoon, Belize: River, Cayo, Freetown, All Pines, Toledo Settlemerit; Jan., Mar., Apr., May, Sept., Dec. 
This personable little tody-flycatcher is a connon inhabitant of cleared and open regions where much scrub srowth and many thickets are present and of lake and streambanks lined with scattered trees and tall grass. I found it in greatest numbers in thickets adjacent to milpas surrounding the Kelchi village of sin pedro Columbia. Breedine berins in mid-April and continues at least into July, for Willis saw three juveniles being fed out of the nest on July 21. Of eight nests lockted by Peck, seven contained eges, and these were all found in the period of: Way 24 to june 7. Lherefore, the hejght of the breeding season is probably about the first of June. The race $\underline{\underline{T}}$. E. Enitimum rarnes from lierico to the Cancl zone.

\section{Podirostrum sylvia (Desmarest)}

$$
\text { in. Slate-headed Tody-Fiycatcher }
$$

SPECIMINS. ISUMZ: Two mi. W San Pedro Columbia - 0 $(7.2 \mathrm{~g})$, liy $4 ; \sigma(6.0)$, May $13 ; 8(8.2)$, May 21. OTHER MUSEUMS (BM, CC, CM, MCZ, USMI): Hileven specimens from Oringe Waik, Wanatee Iagoon area, cayo, Sittee River; Feb., Nar., Apr.

The Slate-headed Tody-Flycatcher has been recorded infrequently in British Honduras, probably because it is tiny and inconspicuous and inhabits the densest masses of scrubby second growth. I saw this species regularly only near San Pedro Columbia, in thickets dominated by wild plantain. In adition tothe cited collected localities, 
this species has been seen only a few times at Ycacos Lagoon, four times at Gallon Jug, and once at Hill Benk. Records are lackine in the Colony for the months of September through January, but the species is presumably a permanent resident. Snecimens collected at sur pedro Columbia had enlerged ronads (the femile contained an ovum $8 \mathrm{~mm}$. jn diameter). A nest found at $v a c o s$ Lagoon on may 9 contained two eges (Ffact).

The race occurring in Central America is $\underline{\mathbb{T}}$. $\underline{s}$. schistaceicens. $256 /$

Oncostoma cinereiguare (Sclater)

Bent-billed Plycatcher

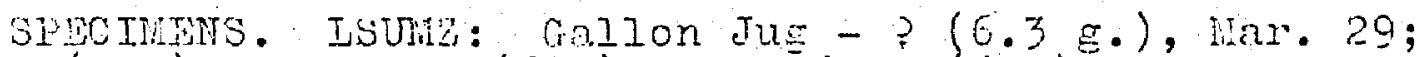
? $(7.1)$, iny $5 ; \sigma(6.9)$, June $6 ; 3(6.3)$, oct. $30 ; j$

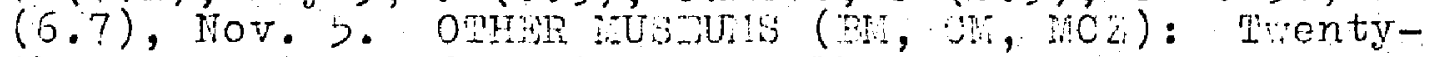

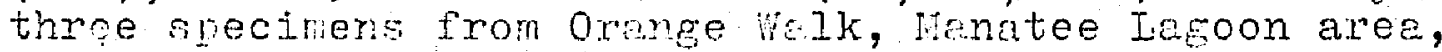
Cayo, Ser Antonio, Augustine, Mountein Cow, Freetom, All Pines, Toledo Settlement; ipl., May, July, AuE., Oct., Nov., Dec.

the Dent-billed ijucatcher is noderately common in tall second erouth and forest edges and uncomnon in the lower levels of heavy forest. In addition to the specimen records, this spocies has been seen at Ausustine, Ballerina Camp, Sittee River, Wonkey River, Ycacos Jagoon, and San Pedro Columbia. As in the case of many of the other tiny resident flycatchers, its presence is more frequently noted by ear than by sight." Breeding apparently begins in late March and contimues into June. Wizlis noted 
birds carrying nest materials on March 25 and liay 28 . Whe liarch specimen was not in breeding condition, but riost of the April, May, and tune birds had fully enlarged gonads. On June 10, Peck found a Bent-bill's nest, suspended 12 inches above the rround, that contrined one newly hatched bird and a spoiled eque

\section{Nlainea flavogtster (Thunberg)}

Yello:bellied Hlainea

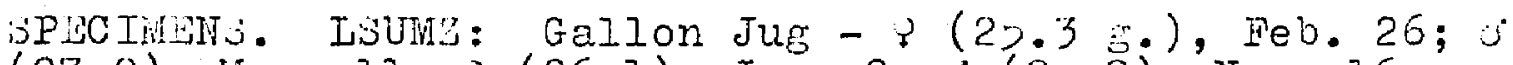
(27.2), Har. 11; 7 (26.1), June $2 ; 3(2,0.8)$, Mov. 16.

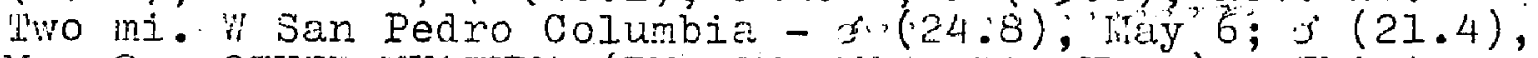

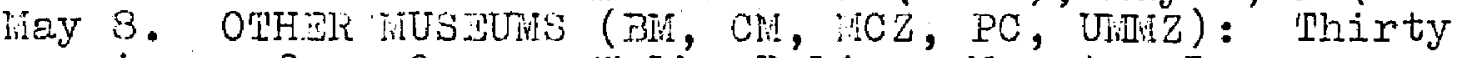
specimens from Oronge Walk, Belize, Manatee Lagoon area, Cayo, Son Felipe, sugustine, Freetown, AlI Pines, Toledo Settierent; all months except July.

Whe Yellow bellied Hainea is a locally distributed resident in British Honduras, common as far north as the drainage of the Belize siver, about extensive clearings with scattered trees and in the lowlard finelands. In the northern third of the colony it is much less comon. It is not nomally a resident of the Mountain pine kidge; the specimen collected by Austin in Anril at furrustine constitutes the only record for that region. Salvin (1864: 380) listed a specimen from Half loon Cay as Elainea subpagana, presumably the one recorded by sclater in The Catalogue of the Rirds in the British Museun (1888: 138) as Ilainea pagana. Fodd could not find this specimen in a search in the British Museum in 1934. There is, however, a specimen of E. martinica from Half Noon Cay in the British 
Nuseum; so probably the spccimen was originally misidentified. E. Elavogaster has not been otherwise recorded from the keys. Another specimen of this elainea listed by Sclater (1888: 138) from "San Pearo, British Honduras," is actually from san Pedro, Honduras, The collector, G. m. Whitely, worked in Ilonduras, not in British ilonduras. I'his sane locality error appears severnl times in Volumes X, XI, XII of The Catalogue of the Birds in the British Museum. Peck found about 20 nests of this species, most contianing two eggs or two young, but one nest contained three eggs. Nests were found from hay 4 to July 29, but "most of them [were] between Hay 20 and June 20." Peck did not state whether. the late nest on July 29 contined eggs or young. The Central American race of this species is $\underline{\underline{I}}$. subpasana.

\section{Elainea martinica (Iinnaeus)}

Caribbean Plainea

SPECIMENS. BH, CIf, UMAZ: Four specinens from Belize, Half Moon Cay, Middle Cay of Glover's Reef; Jan., May.

The Caribbean Elainea is known in British Honduras only from the specimens. The bird in the British Wuseum was collected by Salvin at Half hoon Cay in Hay 1862 . Bond (1939: 4) examined this specimen and considered it "nearly if not quite identical with" the type of $\underline{\mathrm{E}}$. $\underline{\text {. }}$. chinchorrensis. I have not critically examined two birds 
in the Carnegie fituseum taken in Nay 1935, on Glover's Reef by Blake and Arostini. l'odd compared these two birds with two specimens fron quintana Roo. that had been identified as $\underline{\text { i. }}$. remota by Griscom. Todd noted that the British Honduran specinens were paler and more injtish below and that the upper parts were less dark than in the ouintuna foo birds. This birief comparison susrests the Glover's Reef birds are $\underline{-}$. E. m. chinchorrensis is very dark above and has a dark wash on the chest. I have examined the specinen in the University of Michigan liuseum of zoology collected January 22, 1931, in Delize by Shufeldt. This bird, a fenale, does not have any indication of a bresst band. Although it is somewhat dark on the upper parts, it is more like E. . remota, and I refer it to that race. Only two individuals of $\underline{I}$. $\mathrm{m}$. chinchorrensis, the type and the specimen from Half soon cay, have been collected or even observed. In this particular case, the two birds collected on Glover's Reef do not share the characteristics of $\underline{\text {. }}$. chinchorrensis, even though they were collected in the same season on islands in the same relative position to the coast of the Yucatan Peninsula as were the two specimens of that race. In addition, the two specimens from Glover's Reef, which is south of uhinchorro Bank (the type locality of ㅍ. ㅍ. chinchorrensis) and Half Moon Cay, ure similar to specinens from islands 
to the north of Uninchorro Bank. "lhis situation is anomalous only because two specimens from the intervening area are strikingly different. I prefer to consider the two birds escribed to E. III. chinchorrensis as merely extreme variants of $\underline{2}$. $m$. remota, which is a population of the species inhabiting the islands off . the eastern coast of the Yucatán Peninsula.

\section{Wyioparis viridicata (Vieillot)}

Greenisin Lilainea

SPDCIMENS. ISUMZ: Two mi. Sil Aumustine - ?, Aur. 20. Two mi. W San Pedro Columbia - 6 (12.3 $)$, llay 4 ; (10.8), Hay 6; 7 (11.1), May 7. OTHR MUSTUS (DM, CM, ICZ, USMM): Fourteen specimens from Belize, Manatee Lagoon area, Cayo, $\Lambda 11$ Pines, Toledo Settlement; Jan., peb., Mar., Apr., May, Oct., Nov., Dec.

This small greenish flycatcher is uncommon and locally distributed in British Hondures. The only locality where this species was observed but not collected is Gallon Jug. There it was first recorded in the winter of 1958 by Lancaster, although many months of field work in the area had nreviously failed to reveal its presence. It has been noted only at forest-plantation borders and in second growth two or tinree years oid. Fenales collected in May at San Pedro Columbia had slightly enlarged ovaries ( $I$ mm. ova) and the male had fully enlarged testes.

British Honduran specimens are like those from Veracruz and are assignable to $\underline{M}$. placens. 
Camptostoma imberbe sclater

Beardless wycatcher.

SPECITENS. LSUMZ: Hill Dank - ? (6.9 g.), Nov. 27. Seven mi. NW Belize on Corozal load - $p(7.1)$, Anr. 3 . OTHDR MUSUUMS (CH, MCZ, JMTZ): Thirteen snecimens from Belize, lianatee Lagoon area, $M I I$ Pines; Jan., Feb., Mar., Anr., June, Aur., Dec.

The Beardiess Flycatcher is an unconmon resident that is confined elmost exclusively to constal scrub: growth and "broken pine ridge" in the northern and coastal regions. Peck found a nest containine two egrs in May, and G. 3. Phomas (Thayer, 1906: 460) found two nests, on hay 7 and May 16. Hach of the three nests was siturted in a low palnetto. Two males collected by Van lyne in early february at polize weined 7.4 and 8.0 grams.

The race rangine from southern lexas south to northwestern costa Rica is 1. imberbe-

Microtriccus senilevus (Sclater and Salvin)

$$
\text { Yellow-bellied Tyrannulet }
$$

SPJCInims, Bli, Ch, hoz: Seven spoctmens from lianatee. Iasoon, Cayo District, Ceyo, Treetom, Poledo Settienent; Apr., May, huE., Sept., Dec.

The Yellow-bellied Trannulet is an uncominon resident of the heavier wet forest of British Honduras. A specimen collected by Holt at Cayo vas collected in the forest. undergrowth but Peck observed that this species stays high 
in the trees. Wilis saw this tymanulet several tines in the spring and sumer of 1957 at Gallon Jug, which is the only place in the colony where it has been reported but not collected.

The race 1. s. semiflavus ran es fron southern Mexico south to Costa Rica.

\section{Lentopozon amaurocenhalus (Tschudi)}

Bro:m-capped. Ieptopogon

SPECIMLNS. ISUM: Galion Jur $-5\left(12.2 \mathrm{~g}^{\circ}\right)$, Nar. 18. Two mi. if San Pedro Columbia - -3 (12.8), fingy b. OIHER MUSEUMS (BM, .CM, MC 3 ): Six specimens from manatee Lagoon, Cayo, $\mathrm{N}$ slone Cockscomb Nts: (1300'), Toledo Settlement; Feb., Mar., Nov., Dec.

This flycatcher is a rather unconmon inhabitant of tall, wet forest, forest edges, and the vesetation over and along the benks of shaded forest streams. It is rather slow and celiberate in its actions and is difficult to observe even in areas where it is know to be present. Twenty to thirty feet above the forest floor appears to be its preferred level. The male collected March 18 had slightly enlarged gonads, and the male collected in fray was in breedins condition. The race I. a. Dileatus occurs in southern Mexico, British Honduras, and Guatenala. : 


\section{Pipronorpha oleaginea (Iichtenstein)}

\section{Oleaginous Pinromorpha}

SPECIMIENS. LSUMZ: Hill Bank - $\rightarrow(13.0 \mathrm{~m})$, Feb. 20; Galion Jug - (11.6), Mar. 28; (10.4), Apr. 7; ? (12.9), oct. $30 ; \%(13.0)$, Mov. 14. jwo ond one-half mi. SE Victoria Peak (1500') - P, May 7. 1'wo mi. I San Pedro Colunbia - $\$(11.2)$, May 6 . OHHR MUS UUS (BM, CM, MCZ): Twenty-one snecimens from Manatee Lagoon, Duck Run, Cayo, hugustine, Nountein Cow, N slope Cockscomb hits. (1.300'), I'oledo Settlement; Jan., Tar., Apr., Oct., Nov., Dec.' CRIIICAI IUPIIUHDI PCORD: Belize (Sclater, 1888: 113).

The dull-colored oleaginous Pipromorpha is widely distributed throurhout the areas of himh, wet forest in British Honduras, but it is not comon or at least not seen regularly. Occasionally it is cound in moderstely. : tall to tall. second Erowtll where there is also considexable dense, shaded undergrowth. In adition to the. areas where the bird has been collected, the olearinous Pipromorphe has been observed near nillionario, sittee River, South stann Creek, Nonkey River, and Ycacos Lagoon. Skutch (1960: 561) has described its hebit of nervously twitching its wines, a very charncteristic motion of this species: The pendent nest, with ibs coverine of Ereen mosses, is exceptionaly well concesled, but at Gallon Jug Willis found three, suspended about 4 to 6 feet above the ground. One found on April 16 contained three egrs; another located on Aurust l held only two eggs. Ihe rice in northern Central America and Hexico is $\underline{\text { P. }}$ o. assimilis. 
Tanily HIRUTDINIDAE

Progne subis (Iinrateus)

Purple Martin

SPBCIIISNS. ISUAZ: Hight ai. NU Belize - r, Aug. 23, 1960. OTHER MUSDU! (BiI): One, specific locality and date unknown.

The Purple Martin is a rerular transient through British Fondurus, aprearing inland in s.mall flocks and migruting ori the coast more abundantly. Sprine nigrents were seen as early as i'ebruary 6 , but most birds possed through in the first two weeks of march. Fall airants were noted duly 13 at Belize (Mrs. H. A. J. ivans) and rilzis sav un to $>0$ in one day during the first veek of Augtist.

The one British Honduran specimen in the british Suseum was exanined by load and is the snecinen listed in the Catalogue of sirds in the British huseun (Sharpe, 1885: 632) as prosne purpurea, specinen b'. Helladyr (1932: 13) listed this reference in tile symonony of

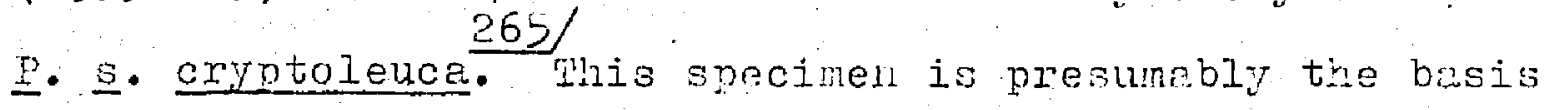
for inclusion of british Ilonduras in the rame of Prome cryptoleuca as given by the uneck-list of Worth Merican Birds (1957: 366). I have not examined the specinen critically, althourh Toud did so ard labeled it "= subis AOU." I have referred a specimen collected by lay in Aurust to the norinate form, $\underline{P}$. $\mathrm{s}$. subis. 
Progne chalybea (Gnelin)

Griy-breasted hartin

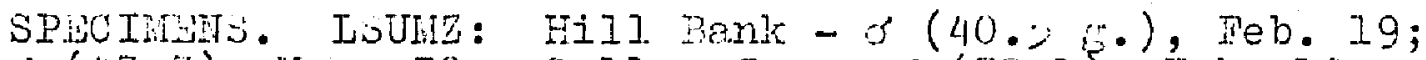
of (43.3), Mar. 30. Galion Jug - 3 (38.1), ireb. id;

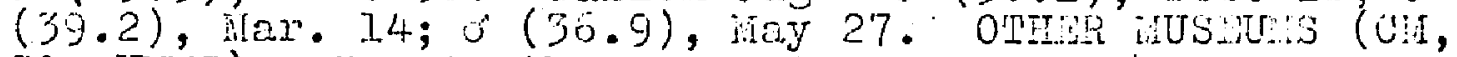
CC, JMZ): Twenty-three specimens from inanatee Iagoon area, Cayo, Freetom, All Pines; Jan., Feb., tiar., Apr., Iay, June, Dec.

The Gray-breasted Martin is a rather common broeding bird of the larger cleaxings, villages, and lorlund pine ridges, but moves about ratier erratically during the fall and vinter. At Galion Jug this pecies is a conspicuous nesting bird but I sam no metins there in october and November. Peck observed few martins during the nonths september to February. Oocupied nests have been noter between $\Lambda$ pril 4 and June 9 irl the enves of houses, in holes in derd linbs and sabal palns, and in abandoned woodpecker holes in the pine ridges.

The race of the Groy-breasted sartin ranging from Mexico into south hrepica is $\underline{p}$. c. chilybea.

\section{Petrochelidon prrrionota (Vieiliot)}

\section{Clite Swallow}

Jared verner observed a single Cliff swallow on Half hioon Cay on Mreh 10, 1958. This is the only record of the species in the Colony. 


\section{Hirundo rustica (Iinnaeus)}

Barn Bwallow

SPECIHENS. TSUTZ: Thee ni. : Belize - q (14.?.), Apr. 4. Galion Jug - ? (13.4), Nov. 12; 5 (13.0), Nov. 14. OPHER MUSWUIS (BH, CH): Geven specinens from

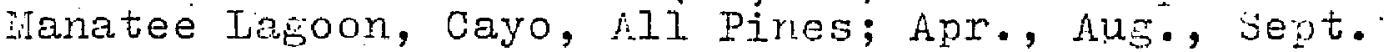

The Sarn Svallow is a rather comon tronsient through British honduras. In sutwan it has beon noted from August 20 to Hovenber 24 and in spring from inarch 28 to inay 24 . It has been Ireguenty seen or and between the keys, in wet coastal areas, and on lowland oine ridges. At Gallon. Jus in November, I often observed it with Roush-winged swallows feedirg over the clearings. The specinens are assigrable to the wide-ranging race, ‥ ․ erytirogaster.

\section{Stelgidopteryx ruricollis (Vieillot)}

$$
\text { Rough-winged Swallow }
$$

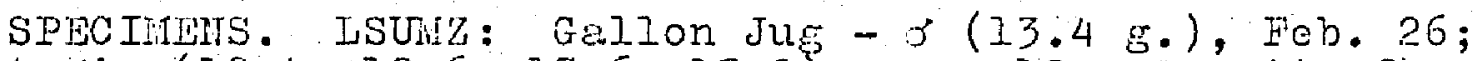
$4.5^{\prime} \mathrm{s}(12,4,12.6,13.6,13.9)$, Nov. 12. Summit of

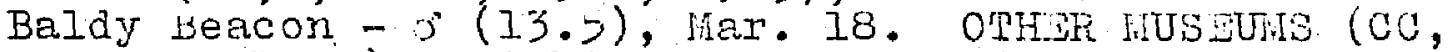
Cif, IfCZ, UMHz): bigliteen specinens from belize, líanatee Iagoon area, Cayo, Augustine, Hretom; Jan., Heb., Nar., Apr., May, June.

The Fough-winged Swallow is a noderctely comnon transient and winter visitant; it breeds locally in central British Honduras. Higration dati are not available, since it is impossible to distinguish between residert and nonresident individuals in the field. Definite 
evidence of nesting has been obtained only at ireetown, but a nest has observed in a cave occupied by this syecies near Dry Greek on the Humingbird ilighay on fpriz 2. Peok noted sevaral individuals hovering about holes in the bank of the Sittee River on April 22. At Galion Jug no indication of local nesting was noted and in spring all swallovs of this species had departed by Aoril 21. Two nated birds feeding young at a rest in a dead coconut tree on the bank of the jittee liiver at ireetown were collected on say 13 by tiake and scostini. lhese two specinens represent the only definitely breeding individuals collected in sritish Hondurss and are referable to S. I. fulvipenis wive of six other specinens ovtained at the sane locality from nay 6 to 23 had enlirged gronads, but I refer all six to $\underline{\text { S. }}$ r. fulvinennis with some loubts about each one; three of these specinens are lales with large winir aeasurements (116, 117,119 mo) and all lack a pronounced tinge of rusous on the throat. One of the specinens collected at Gallon Jug on November 12 and the one collected at Buldy seacon are sinilar to topotypical s. $\underline{\text { r. }}$ fulvipennis.

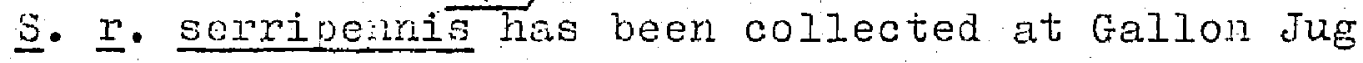
(iToverber 12), Belize (January, February, March), end Augustine (specinen collected April 2) by Austin and identified by Paynter, 1957b: 212). A fenale collected by Peck in a cave near lanatee lagoon on fiarch $\supset$ has almost 
black upper parts, very dark under parts, solidly blackti ped under tail coverts, and a wite interior loral region; I refer it to $\underline{3}$. ‥ stuarti. Paynter (19,7b: 212-13) has identified the specinen teken by Ausin at Augustine on April 23 as $\underline{\text { S. }}$. stuarti. Austin (1929: 384 believed that the birds entering a cave near suirustine in late April were possibly breeding. Peck, however, observed that wintering biras ake temporary use of caves as roosting sites.

In the process of racially identifying the koushving swallows from tritish Honduras, I hrve had to set aside several specimens as unidentifiable. lixese specimens

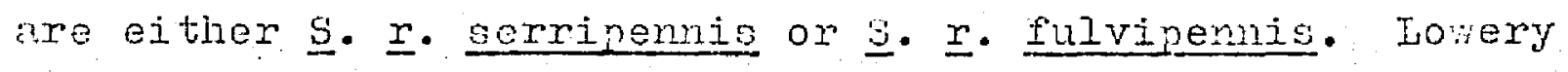
and Dalquest (1901: 616) have commented upon the similari-

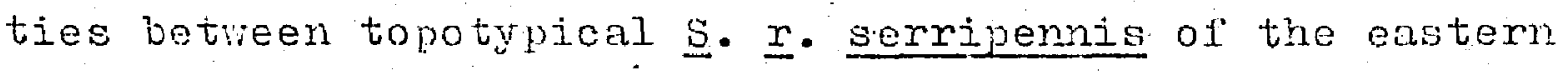

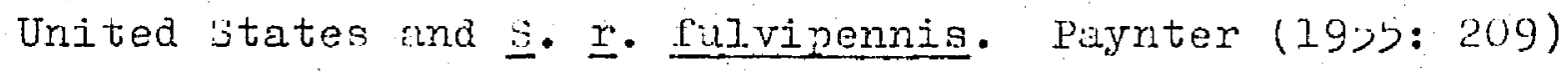
considers $\underline{\text {. }}$. fulvipenis "doubtfully distinet" from the eastern worth American population. volor changes occurring with the aging of museum specinens are notoriously diffichlt to evaluate in this species. I he not ertensively reviewed the lifexican and northern Central American populations, and consequently I follow current practice in recognizing these two races. 
Riparia riparia (Limnaeus)

Bank. Swallo:

SPECIMIT: MCZ: Toledo Settlenent - f, Sent. 21, 1906.

Whe Bank bwallow occurs in British Hondures as an uncommon tronsient in Ausust (Lay.) and september (Pecln, Ballance) and in hinril and liar. Peck collected the only specinen just a few miles inland, and lay noted a fe: individuals ut corozal, but all other observations were on the leys (principully Half Joon Cay, where verner saw ten birds on six dates from April 12 to way 6).

\section{Iridoprocne bicolor (vieillot)}

inree smallow

SPICINHS, CIA, PC, UIMZ: Six snectmens from Eelise and the wantee Lasoon area; Jan., Dec.

This swallow is an extrenely coundent winter visitant in the coastal regions of the colony. Peck estimated a flock seen on December 4 at over 100,000 birds. Phis epecies moves about considerably during ite winter stay. Gerrara vin meto say 322 tree swallows in a forty-nimute poriod noving steadily in a southwesterly direction a few miles east of Eolize on December 22. llost of the observations have been in December and January, but the extrene dates are Hovember 22 to April 4. Swallows in serleral (and occasionally swizts) are called "Christnas birds" in British Fondureis, but this species is probably nost deserving of the nane. 


\section{Iridoprocne al jilinea. (Lawrence)}

ilenerove swallow

SPHCIMUS. LSUnk: Six mi. MIT Hill Bank - 2 (14.3 g.),

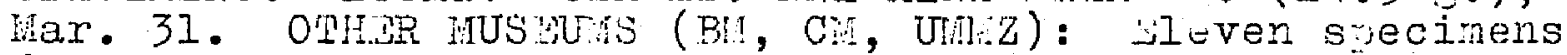
from Beize, Nianatee Lagoon area, Rio lopan, ireetown, Alz Pines; Feb., inr., Apr., liay, oct.

Whe langrove swallow is a common resident of coastal areas, wet prassy savinnahs in the coestal pine ridges, and all large rivers, often occurring far inland (Benque Viejo, Hill Benk Laroon). Lhis swallow was occasionally seen over emall ponds in the vicinity of Grilon Jug. ilests are usually constructed in cevities in stumps or trees partialiy anbrenged in water. Peck, honever, jound then occupyin: abendoned woodpecker holes in pine trees situated in very oyen areas of the lomland pine rialges. wests containing eggo have been noted in may and early June.

The noninate forn of this species, I. a. is resident in central inerica.

Panily CORVIDAE

Dsilorinus morio (vaglex) Broun Jay

SPiCIMHS. LSUHZ: Hizl Bank - ?, Feb. 16; q (216.j s.), Nov. 20; $7(201.1)$, Nov. 26; (204.8), Nov. 27 Galion Jue - s, Mar. 20; $s(209.5)$, Mar. 21; Apr. 5; (21).2), June 1. Augustine - ., Aus. 16; 3, Dec. 16. Two ni. W Jan Pearo Columbia - o (239.1), ny 3; (190.1),

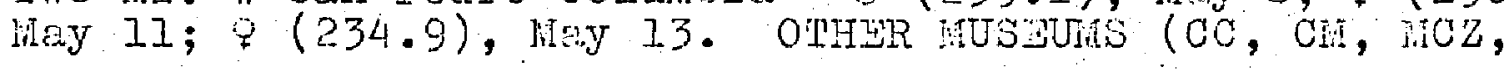


PO, UMz): Pwenty-nine snecitens from velize, Haratee Jaroon aren, Caro, Camp VI, 12 mi. s Ceyo, freetom, hl1 Pines, ioledo Settienent; all months except July, Aur., Sept., Dec.

The "pian-pian" as it is often called, is a ubiauitous re:ident of all rejichs of mainland British tonduras cxcent in extensive aroas of tull undisturbed rein sosest (such as in the coolscomb basin). It is especially abundsnt along the forest edge and in tall second rowth in the noxthem end centrel rewions of the colory but is less comion in all habit ts $j$. the southern sector. A thougit the Prom Jay normaly occurs in smill roups of cucophonous individuals, nesting birds are extrenely difficult to detect. Pocl: locrted rive resto containing esss (four of then in the pine riores and the fliftin in cn onen pastue) in tice period of April 21 to hay 29. Hales taken on tebruary 23 and ifarch 7 by Tan Tyne were breedino, as indicated by the numped testes.

Selonder (1989: 385) has shom that palorinus neicanus, the White-tipred Brom Jar, is a color phase of Psilorhinus morio, the Bro:m Jay. British Honduran specimens are nonomorplic and white-tipned; subsecifi-

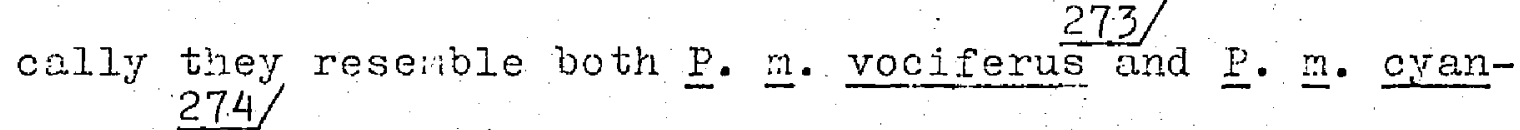

orenys. Peynter (1950: 213-214) has noted that the Rio Fondo region constitutes an area of intergration between these two races. Only three of eifht specimens from Hill Bant and Gallon Ju; have white thighs and a 
sharp Iine of Bemration between the sooty and hite areas of the breast. These three birds wre rather typical ‥ ‥ vociferus, but the other live show tendencies toward tie grojigh thigh and indistinct chest line of $\underline{\underline{P}}$. $\mathrm{n}$. cronosenys. Snecinens fron selize, the Hantee lacoon area, Cayo, Austine, freetown and Nil Pines are as a wole reforable to 2 . ayanomens, Ithough not all individuals are entirely typical. Thus the most pronounced rerion of intermadition includes whe Rio Fondo area and northern British Honduras (rill Banle and Gallon Jug). rinere is no indication of any clinkl change in weigt or linecr measurements in the epecinens from the Colony.

\section{ranthoura rncas (Rodduert) \\ Green Jay}

3PJCIMES. LSUIZ: Jill Bank - $r$, $9(7,2,2,80.8 .8$.$) ,$ Feb. $26 ; j(72.5)$, ITov. $21 ; 2$ 's $(78.3,75.0)$, Nov. 27 . Augustine - 2 , Aug. 24; $43^{\prime 3}$, Dec. $14 ; 8$, Dec. 17. Ballerina Cainp - ? (81.0), 4pr. 25; $6(34.4)$, Apr. 27. OLHER MUSUUSS (BIT, CH, NCZ, UMZ): ititeen specimens from the lianatee Iagoon nrea, Cayo, Rio Hakal, Camp VI, Freetown; Feb., Mar., Apr.. Iney, July, Bept. ORIICAI PUBIISIE RZCORD: Beline (Salvin and Godnan, Bioloria, i, 1887: 302 ).

The Green Jay is locally distributed in small numbers over much of British Hondurns. It has been nost irequentIy encountered below I700 feet where tail second growth or forest horder the pinelinds and below 
l300 feet in till, dense thickete along watercourses. only at Gucanello, south stun orook at the junction of sittee ranch, and on the kio Grande and the ho Rivar has the "cling-cling," as it.is imom locnlly, been observed but not collected. ITenr Ballerina Camp and. Guacanllo up to 30 individusls fere seen in one ary, but else:here it vas unconnon. The only breeding informetion is provided by the enlirod conda of the ienale collected on hipril $2 j$.

British Hondurn specinens are asignable to 273

$X \cdot Y$. centralis on the basis of their mina end teil neasuremonts. Eleven ales. from the colony have wings medsuring fron 11 i to $120 \mathrm{~m}$. with a nean of lIbt 2.3, and ten males have toils ronging from 12 ; to 140 n. with a nean of $133.5 \pm 2.2$. Four fenles have wings neasuring $112,112,113$, and $116 \mathrm{~mm}$. and tail measuring 127, 130, 130, nd $133 . \mathrm{bm}$. These mearuronts coincide closely with the date given for $x$. $Y$. centwalis by Pisynter (1900: 21).

A comprison of tire weints of birds of the Yucatin Peninsula witil the weigts of the British Honduran specinens indicate the latter are considerably heavier. Hileven meles of $Y \cdot I \cdot m-\frac{276}{2}$ from the Yucatán peninsula ronged from 39.3 to 79.0 grans ith an aproxinate nean of 68.3 , and rive fenales from the same rofion veiched 60.b, 60.7, 63.4, 64.6, 68.0 grans (data from Paynter, 19>5: 21>; 
Wrd fron rive aditional opecimens in the University of

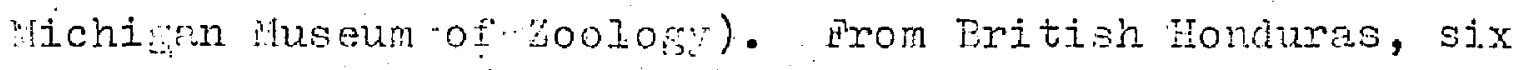
merles of $x$. chentralis ranced from 72.6 to 34.4 crans with a mean of $79.1 \pm 4.2$, and four femles weighed 75.0 , $78.3,80.8$, and 81.0 . eruns.

\section{Cissilonia yucitmica (Dubois)}

$$
\text { PInck-and-blue Jay }
$$

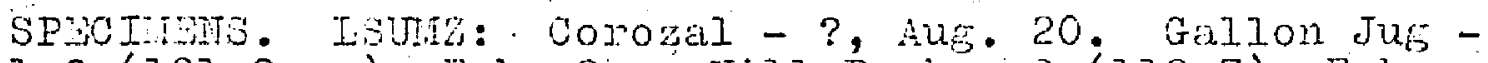
I? (121.2 ge), Feb. 2b. TIill Bank - ? (112.7), Feb.

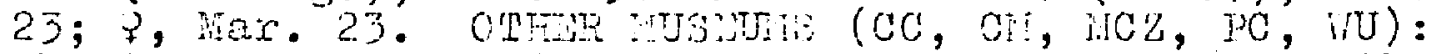
minteen specinens from the ianatee Lacroon area, sibun

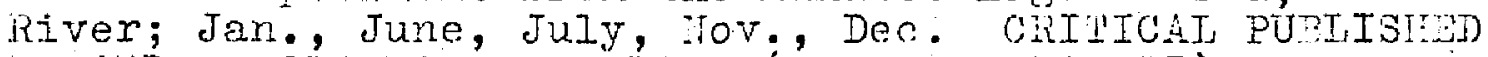
Rocokds: old River, Belize (roore, 1859: 37 ).

This jay is an uncomon resident of the lomands of the northern half of British Hondurss. Bensely oversrown "broken pine ridge" nd the swamp regions that sonetines border these pine lands are ito usual

" habitat. One specinen (Gellon Jug), however, was taken several niles from pine lunds in dense second erouth. ihe female trimen on Harch 23 had a sightly enlarged ovary. Peck found two nests in the Manatee Iacoon area on liay 20. Both were in pine trees. One nest contained f'ive egis and the other had just been completer. The specirien collected by Iny at Corozal on Aurust 20 is a juvenile.

The British Honduran population occupies the southernmost nart of the ronge of the species and is typical of

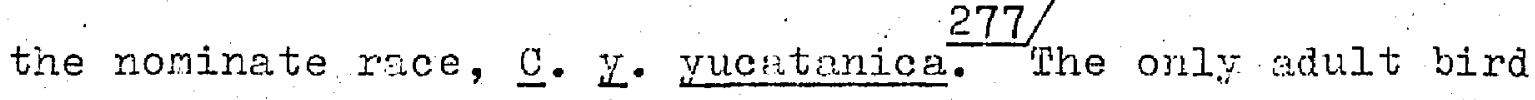


amon: the four opecinens from British Fonduras in the ISUMZ is a femle. It is smaller (wing $143 \mathrm{~mm}$, tail $174 \mathrm{~mm}$ ) than specinens fron $\mathrm{Tab}: \mathrm{sco}$ ( $\mathrm{C} \cdot \mathrm{W}$. rivularis wrd the blue of its hock is less brilliant thin that of the northern race.

\section{[Cyanolyca punilo (Stricliand)] Stricklard's Jay}

This joy is listed in the tobles in the introduction to volume I of the Piolorio Centroli-Americsna, sves

- (Salvin and God:an, 1904 : xxi) as occurring in British Honduras. Jodd could not find a secinen fron the colony in the British inselum in 1934. In the absence of ary recent substantiating evidence, the presence of the Strickland Jay in Eritish Horuurs is only Mrothetical. In Guntemala, this species occurs principally in ock forests at elevations of 7000 to 8000 feet in the western part of the country. It seerns unlikely that it would be found in British Honduras.

\section{[CYanocitta stelleri (Gmelin)] Steller's Jay}

Salvin and Gonnan (1904: xxi) recorded this species from British Ionduras in the tebles in the introduction to Volume I.of the Bioloria Centrali-Americana, Aves. 
Boird et al (1874: 362 ) include Belize within the renge of steller's Jay. I know of no specimens of Cymocitta from British Honduras. Hodd was unable to find the specimen roferred to by Salvin and Godnan. Todd secrched for it in the British Iuseum in 1934. Since no specinen is known and since this juy is nomblly a resicent of altitudes much higher then those found ir the colony, tinis species should be onitted from the list of British Honduran birds.

Tamily THOGIODVIDSE

Cistothorus platensis (Iatharn)

Short-billed Jarsh iren

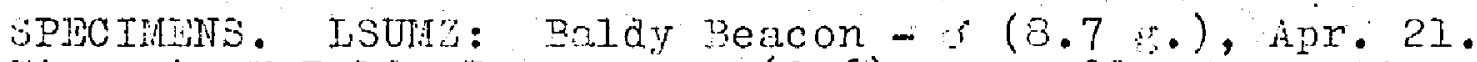
Five mi. Baldy Deacon - $j(8.6)$, Apr. 20. Ausustine -

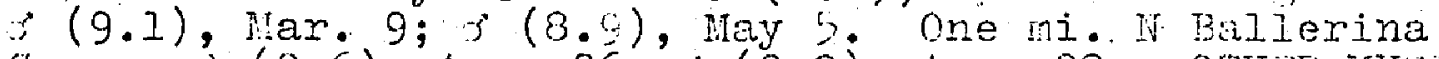

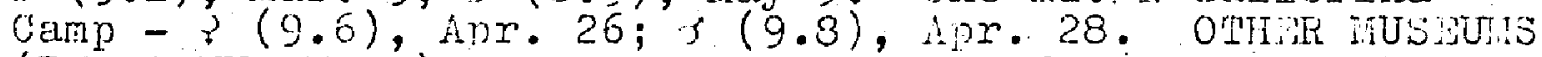
(BH, CHIH, U.RZ): Ten specimens, sII froin the mountrin Pine Ridere; feb., ipr.

The Short-bililed liarsh fren in British Eondures is confined to the mell-drained hills of tile liountain Pine Ridge. lhere it mey be found in moderite numbers In the short Grass on the open parlike sloves, siaring this habitat $\because$ th Grasshopper Bparrows. It is presumaby a resident, but I did not record it during a week's work at Augustine in December. These marsh wrens wero ratiner tame and mere observed easily. Some individuals seen 
in April were singins and behaving as if yound were nearby. A male collected by inurie on Mril 25 had enlarged testes.

Hellmayr (1934: 122) referred two specimens of the Short-billed Harsh iren fron the bountuin Pine Ridge to $\underline{\mathrm{c}}$. elesans. I heve been unhle to conpare the recently collected meterial iron British Monduras with specimens of C. 2- elefans from Iake of Dizeñas, Guktenala, the type locality. bhort-billed harsh irens from chiniss and liebusco are senarally roferred to $\underline{Q}$. $\underline{\text { e elecons. }}$ I have compred the nountain Pine idge birds with opecimens fron lhiapas and Tabasco. The British ronduran birds are decidedy darker thy the idexican nocinens. In order to satisfactorily identify the snecimens from southern Wexico and Tritish Honduras, they nust be compored with topotypical ‥ … elegans.

\section{Campylorhynchus gonatus (I,esson)}

Bend-backed "iren

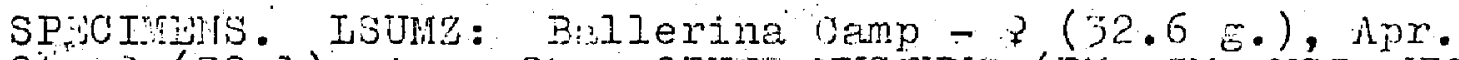

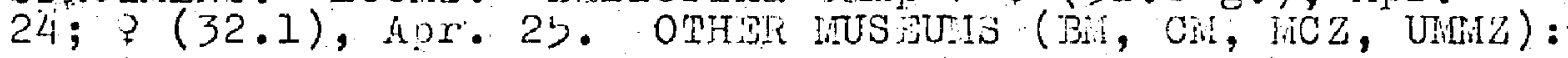
Fourteen specimens from Duck Run, Cayo, Camp VI, Jountain Con, iroledo Settlenent; Mar., Apr., Serit., Oct.

This large resident wren is local in its distribution in British Honduras. Ausustine and the dense forest ejght miles northest of San pedro Coluntia are the only points of record other then the specinen locilities. 
The habitat preferences of the Band-backed iren are varied. In the colony, it hos been found in riverside thickets ard fjo trees, tall trees bordering clewring, and in undisturbed, very hunid forests. Specimens iken in April possessed enlarged conads. Mrree females collected at Cayo on Itarch 16 by Van irne veighed, respectively, $31.2,32.4$, and 33.0 yrums.

I refer the nine British Fonduran specinens that I have examined to .. z. restrictus, tiongi they diter from typical $\underline{\text {. }}$ z. restrictus in having a lishter and redder color on the abdomen and fewer spots on the abdomen. Wing neasurements of seven fenales indicate they ma also be smaller than $\underline{C}$. $\underline{-}$ restrictus, as they range fron 79 to $02 \mathrm{~mm}$. with a mean of $80.8 \pm 1.08$. But one male hes a wing neasurement of $80 \mathrm{~mm}$, which is well. vithin the size range of $\underline{\mathrm{c}}$. $\underline{z}$. restrictus. Friedmann (in curviler and de jchauensee, 1930: 439-40) noted similar veriant characters in four specinens from Gavilan, Guatenin, a locality only 16 miles west-south"yest of Cayo. Both Friedrann and Brodkorb (1947: 242-43) heve considered the possibility that the Petén and British Honduran birds may ropresent an undescribed ree.- The Gavilan and all tritish Honduran specinens were collected in an area less than 70 miles in length on the periphery of the range of the species, without apparent isolating factors intervening. the characters described above do not impress me as significant 
enough to warrant naming these lockl birds es a distinct subspecies. The specjuens are definitely sinilar to C. z. restrictus but, as Brodkorb (1947: 242-43) sugEested, nay heve sonle charucters of $\mathrm{C}$. $z$. vulcanins.

Mryothorus modestus Cabinis

\section{Pain "iren}

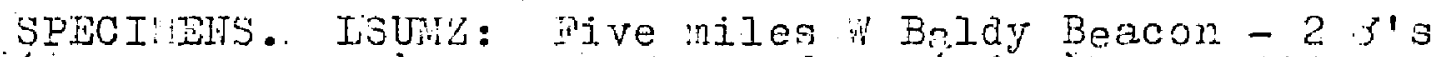
$(17.6,19.1$..$), \operatorname{Apr} 19,1956 ;$ ? $(16.0), \operatorname{Arr} .20,19=6$. Augustine - ?, Dec. $16,1956$.

This wren is an uncomion resident of the dense brush and tell grass that srows near the headwaters of streans arising in the liountain pine Ridge. Occasionaly it is noted in a uniforn habitat of 3 to 2 feet nin Eriss. On inpril 19 I observed an adult leodir: fled $\Leftrightarrow-$ Iings. Whis date is not early since in Costa pica, accordine to intutch (1960: 129), the breeding season spans a period extendins from January into september. whe British Honduran bidds ire refereble to modestus. These smecimons and a series from chiapes cind Guatema exhibit a mreat degree of individual variation that malies them indistinguisable fron costa Rican material.

\section{Phrvotiorus diculipectus Lafrennaye}

Spotted-breasted Wren 


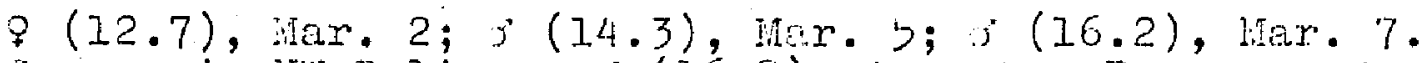
Seven ni. Wi Belize - $\}(16.3)$, Anr. y. Pomone (16.2), Apr. 1. Stem Creek - (14.7), if cr. 30. Aurustine -, Dec. 10. Znllerina Carp - $3(13.3)$,

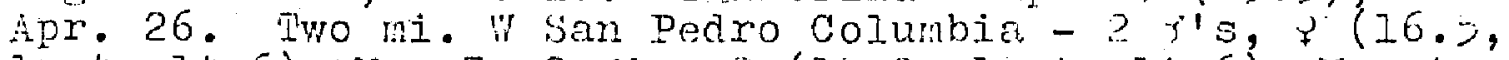

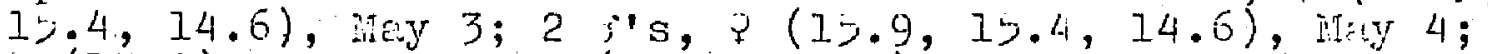

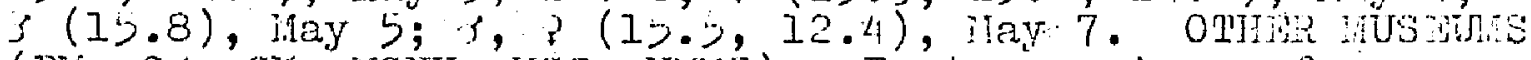

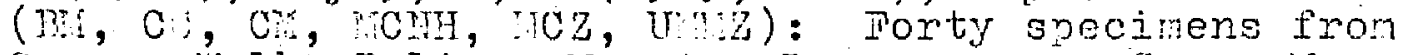
Orange lalk, Belize, Hanatee Lacoon arca, Cayo, Hountain Pine Ridge, liountain cow, Freetown, $\Lambda 11$ Pines, l'oledo Settlement; all months excent July, Aur.; Sept., Hov. CRIPICAL PUBIISHDD RECOPD: CorozaI (SaIvin and Godman, Biologia, i, 1880: 92).

Whe spotted-breasted wren is a comion resident of the undernowth and thickets in both forests and second growti. It avoids only the interior of undisturbed humid Porost and pinelands. It is also comon in thickets about plantation clecrings and pastures nond in the fringes of

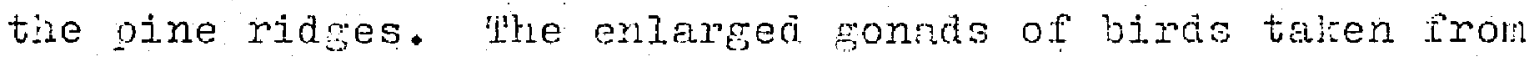
late riarch into jiay indicate tint breeding occurs it least during these nonths. Willis noted one bird carrying naterial to a nest on nay 26 , but this nest nay havo buen constructed for use as a cornitory ratier then for breeding purposes.

When British Ionduran specinens are arranged in a. series from north to south, the transition from a pale gray-brown and less intense spotting in specinens from the north to a richer brown and more intense spotting in southem specimens is especially conspicuous. Speciners from the mountain Pine Ridge, Cayo, mlanatee Iagoon, and more northern localities, I assign to 1 . nn. carobrumeus. 
Although not entirely typical of the Peninsular race, they are definitely close to it. Pirds from san. Pedro Columbia and Toledo settlement distinctly anroach 284

f. 江. umbrinus and I refer them to that race. A population intemediate between these races occupies a belt across the Colony that includes Ballerine Camp, Pomona, stann Creek, freetom sind AII Pines. The meights of the British Honduran specinens are intermediate between. those given by paynter (19>7a: 268) for $\underline{\text { T. }}$. canobrumeus (Yucatán, ouintana Roo, Campeche) and $\underline{\text { T. }}$. unbrinus. (Chiapas). There is no enpreciable difference in weight between specimens from northern British Honduras and those fron the southern part of the Colony.

\section{Iroglodytes aedon Vieiliot}

\section{House Wren}

SPICIMENS. LSUNZ: Two mi. A Hill Bank- $-5(10.3$ g.), Nov. 23. Gallon Jug - ? (10.0), Trar. 19; 9 (11.0),

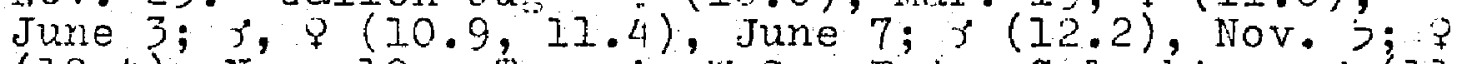
(10.4), Nov. 10. Two ril. W San Pedro Columbia - j (11.1), May 9. OTHFR WUSDUMS (CH, HCZ): Bleven specimens from Cayo, Freetown, All Pines, Sittee River, loledo settlement; Apr., lay, Sept.

Al though rather local in it occurrence in the Colony, the House Wren is comon about the buildings and houses of some villages. Occasionally this resident is found in thickets in the lovland pine ridges and in the piles of urburned limbs and logs in rilpas. It has been seen in Pomona and Augustine. The breeding period 
is lorg, for specimens talen in April, Mry, and June had enlarged gonads and Peck found a nest at toledo Settlenent on jeptember 1 that contained threo egers in an advanced stage of incubation. This nest was situated between the sash and shutters of an unoccupied house.

I refer the British Fonduran specimens to $\underline{\underline{1}}$. $\underline{\text { a }}$ $285 /$

internedius. These specimens exibit a considerable degree of individual variation, but as a series they are typical of the widejy ranging race.

Henicorhina leucosticta (Cabanis)

White-breasted "Wood "ren

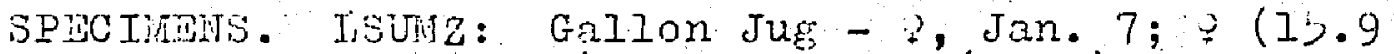
8.), Feb. 2); ? (12.7), Nar. 11; ó (17.0), Tay 28;? (1).2), Oct. 24; $;(16.8)$, Oct. 26; (14.9), IIov. 6; $3(14.3)$, Nov. 16. Wwo mi. 3 Ponona - 3 (16.2), Har. 31. Two mi. N Itllionario - (14.2), Mar. 13. Two ni. W San Pedro Colurbia - $\gamma(16.2)$, hay 11 ; $s, 2$ (i6.2, 14.6.), May 21. OTHTR iUSUUS (CO, CH, IOJ): Twentynine-specinens from the Kanatee Lagoon area, Chorro, Cayo, Cainp VT, Mountain Cov, Cockscomb Nts. (II slope, 11>0-1400'), Freetowr; ifar., Apr., May, Jurıe, Oct., Nov.

The Wite-breasted food wren is a comon resident of the undergrowth of forested areas from sea level to the uppermost slopes of the Cockscomb hountains. It even frequents dense stands of cohune paln and tall and moderately tall second frowth but avoids the relatively open pinelands. Specinens collected Harch 13 and 31 and in April and llay heve been in breeding condition. 
$A$ nest suspended 18 inches abore tise ground from a GmII puln contained three egss on Anril 30. I found a flectgling on kay 6 on the crest of the cocliscomb :ountains at about 2800 feet.

The 29 specinens from British Itonduras that I have exanined exhibit a considerable amoint of individus veriation. In exomles from the same Jocality the redaish-brom color of the back ranges from a very deep red-brown to a mach peler brom. In two specimens from San Pedro Columbia the pileum is dark-reddish like. the bock but in a third, it is slightly groyisil. since every British Honduran specimen can be notched by biras Iron ferther north (ivbsco, Veracma, San luis potosí) the colony is within the rone of 1 . 1 . prostheleuca. The two San Pedro Columia specinens may exhibit a tendency toward $\mathrm{H}_{\text {. }}$. tropaea, but even in these tmo birds the under parts (especially under tail coverts) are nore line those of $\underline{\text { H. }}$ l. prosthelenca.

\section{Uropsila leucogastra (Gould)}

White-belitied Wren

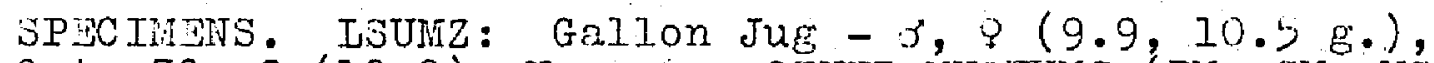

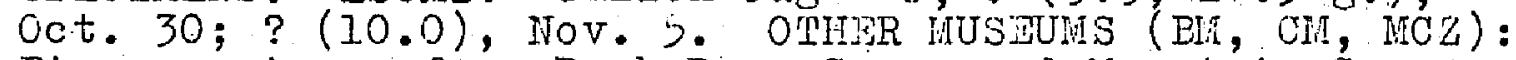
Five specinens from Duck Run, Cayo, and lountain Cow; April. CRITICAL PUDLISHED RBCORD: Orange Halk, Dec. (van Rossem, 1938a: 15).

Hill Bank is the only localjty not listed above where this resident wren was observed. It inhabits 
plantation ediges, dense, 10\% second prowth, and 10w1and pinelands, especially where the pines are crovded by oaks and otiner low extraneous veretation. At Galion Juc "fillis found it noderately comon. Iwo npril apecimens collected by Iolt had enlarged conds, and at Galion 'Jü a Mite-bellied rren ouserved by lillis was mest buildins in a bulthorn acacia on April 21 .

British Honduran specimens agree rell mith Yucetén. specinens of $\underline{U}$. 1 . brachyura and I refer them to that. form. The Gallon Jug and Cayo suecinens do heve slightly bromer backs than the Yucatán birds, but not sigrificanty so. Whe darker coloration of the back sugrests an aproach to tile dorsal coloretion of $\underline{U}$. 1 . musica. Two specinens. collected by van lyne in the Petén are paler dorsally, quite urlike U. 1. musica. Paynter and Vaurie (1960:431) are correct in placing van kossen's.rece, Nannorchilus leucoraster australis, in the synonomy of U. 1 - brachyura. It appears van Rossem aid not compere his four specimens from the Colony rith a good series from tho Yucatán Penirsula.

aamily WISTDA

Melanoptile globirostris sclater

Black Catbird

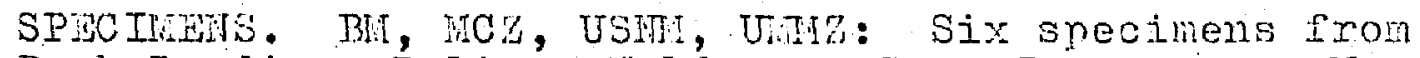
Beck-Landing, Belize, Half Ioon Cay; Jan., Apr., May. 
CRITICAL PURIISHED RECORDS: Corozal, Glover's Reef (Salvin and Godman, Biolocie, i, 1879: 27).

The Black Catbird hes not been recorded in British Honduras aince 1931, when shufeldt collectea three specimens in brushy second growth near Belize. Pornans the species was once more midely distributed, for Salvin and Godnan in the Biologia (1079: 27) nention Northern Two Cays, Long Cay, and Midde Cey (alz of Lighthouse Reef) anong the localities at which the species was seen or collected. The species io possibly no loneer present on the keys, since extensive recent investirations have failed to reveal it. Hhe Rlack Catbird is ratier local in its distribution in the Yucatin Peninsula north of the colony. I suspect it has been overlooked by collectors in British Honduris in recent yeers.

Paynter (1954: 4) referrea Pritish Fonduran snecimens to the noninate race, $\mathrm{g}$. glabrirostris.

\section{Dumetella carolinerisis (Iimaeus)}

Catbird

SPCIIHNS. ISUR: Galion Jug - ? (36.5 g.), Iar: 4; ? (33.6), Oct. 29. Calabesh Cay - (32.5), Apr. 15. Hilf

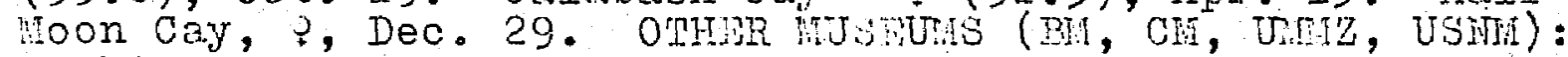
Eight specimens from Belize, Manatee Jagoon, Cayo, All Pines; Oct., Jan., Mar., Apr.

The catbird is an abundant migiant and winter resident of the mainland of British Honduras, frequenting tangled second growth and to a lesser extent, the forest 
undergrowth. It also occurs in small numbers on the keys as a minter resident and transient. Lctual dates of arrival and peak of fall migration are not lnow but this species is present in late september and becones comnon by aid-october. In tice spring tine sreatest nunber of transients are noted during mid-April and usually tine last birds have departed by hay 9 . The latest springs record was obtimed on May 18 (Villis).

\section{Iinus gilvus (Vieillot)}

Tropicel hockimgird

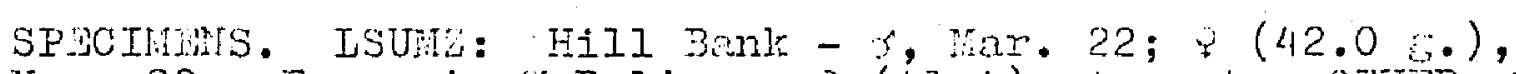
Nov. 29. Tour mi. Belize - (41.4), Anr. 4. OIHER

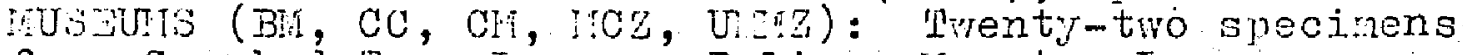
from Crooked Pree Lacoon, Belize, Wantee I,goon area, Sittee River, All Fines; Jun., Teb., Apr., July, Dec. CRITICAL PUBIISTY RECORD : Lighthouse Cey and Glover's Reef (Salvin and Godman, Biolokia, i, 1879: 36).

Fron Corozal south throush the corstal lovlands to the vicinity of All Pines, the Propical soclrinbird is a locally common resident. It penetrates inland as far as Crooked Tree Iagoon, the IIIl Bank Iasoon, Churchyard, Pomona, and Kendal, and has been found on some keys (Bendezvous point [Bond, 19;4: 7], Soldier and Calebash Cays in the Turneffe Islinds, Lighthouse Reef, and Glover's Reef.) Pire ridges, sivampy dense areas adjacent to the pine ridges, and clearings in the vicinity of dwellings are its customary habitats. It is a comon species in the towns and villages of the area that it occupies in the 
Colony, where it is lnom as the "nightingale." Peck found nests containing eggs on Way 18 and 24 and a nest containin three young birds on June 18 .

$292 /$

I- $\equiv$. leucopheus, is the race of the Propical

noclingbird to which I refor the British fondurin specimens.

\section{Family IURDIDAE}

\section{Turdus albicolis}

ifhite-throater Robin

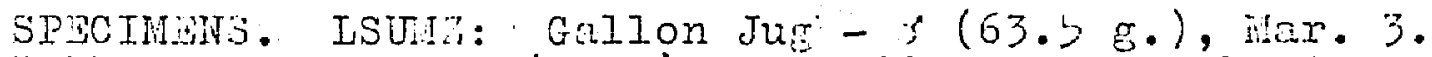
Bullerina Camp - $5(57.3)$, Anr. 23. Cockscorb its. $(3000 \%$ - 5 , Hay $6 ; 3$, liky 9 . Cubetas - $6(66.6)$, Mir. 12; o $(57.7)$, liar. 16. OTHER WUSBUS (BM, CH, CWH, ifCZ): Thelve spectinens from Belize, Ianatee Iagoon area, Duck Run, cayo, cemp VI, troledo Settlement; Mar., spr., Oct., Dec.

In the vast rain forest of the lifaya liountain region, the wite-thropted Robin is a comon breeding bird. Wear the crest of the Cockscomb Kountrins, about the shaded and very humid revines, it is both. an abundant and characteristic species. In tre drier forests of the Gallon JuE area it is present in small numbers during the breoding season. Peck thought the birds that he saw in the Manatee Lagoon area in october and at loledo Settlement in December were nigrants, since he did not find them in the spring. Anthony (Griscom, 1932a: 306) noted that in Guatemala most 
thrushes of this epecies harl departed f'ron Cobán and the ilta Verepoz region during october, November, end. Decenber. Periaps the birds noted by peck were wanderens from the mountains. Gnecimens thet I collected in nidharch, hril and liay hed enlurged gonds and were in breeding condition.

Whe six males from British Mondur.s in the LSUliz are all dark sicte on the upper parta. Three of the. . specinens have a narrom buffy edge on the greater coverts, a slight tinge of olive in the slate of the back, and sightly smaller neasurements (wins: 109.シ, II3.0, $1.7 .5 \mathrm{~mm}$ ). These three birds sre presumebly first year birds, altiough in breeding condition. The other three specinens lick the buffy edrings of the ureeter coverts, have slate colored backs without an olive tin;e, and have large ming neasurements (110.b, 119.5, 122.0 mm.); these are perhaps oldex birds. I refer these specimens to il. al. parcolor on the basis of the dark upper parts, since smaller size may not be as diagnostic as Blake (1900: 410) thought. Austin (1929: 387) noted similarities betweon British Honduren vircis arid ㄹ. a. 294 oblitus of costa fica. The slate color of the uprer parts is" the most obvious similarity; I have exaniner one Costa Rican specinen that matches the slate back of the British Honduran material. It is of interest that the two males with the extrene ring reasurements (109.5, 122.0 ma.) had practically the same weiphts ( $37.3,57.7$ grams). 
Ilurdus ereyi (Bomeperte)

Clay-colored Robin

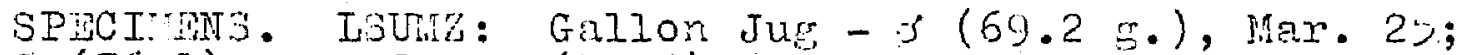

f $(76.8)$, hay $29 ; ;(71.5)$, June 8 . Stann creek - 6 (67.2), 活ar. 23. Two mi. Wan Pedro Columbia - 9 (71.3), My 6. OTH:JR IUS Seventeen specimens from Belize, Cayo, iountain Cow, Freetown, Toledo Settement; Jan., Mrr., liay, June, oct., Iov.

In and about clearines, pastures, villases, and open: streanbenls, the Olay-colored hobin my be very comnon, al though extremely shy excent during the nesting season. It is a resident throughout nost parts of the colony and is especially numerous in the lowland valleys along the coest. Occupied nests have been noted in vay and June. Pirds coljocted in late larch did not have enlarged onads. "illis noted a Clay-colored robin visiting a nest on JuIy 17 but did not see the cortents.

Specimens from Galion Jug are most like I. tamalinensis, but one of the three specimens from this

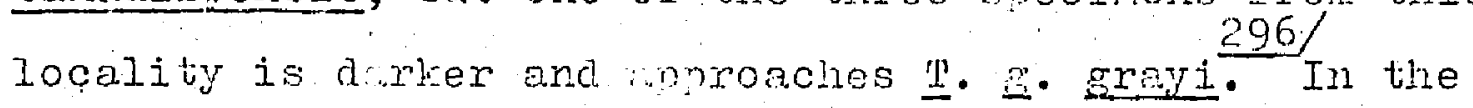
central region of the Colony (Cayo, Stam Creek, Freetomn), tie population is intemediate between these two rices, but in the extreme south (San Pedro Columbia, Toledo Settlement) three of five specimens are quite like $\underline{\underline{n}}$. grayi. 


\section{Myadestes unicolor Sclater}

Slate-colored Solitaire

SPECIIMIS. ISUTZ: Cocliscomb its. (2500-3400!) - 2 's, Inay 6,$1958 ; \%$, May 9, 1958; 7 , ray $29,1909$.

This species in British Fonduras is rostricted to the cloud-forestlike hobitat near the hishest elevations of the coclescorb lountains. There it ranges from the lichen and bryopiyte covered vesetation on the crest of the mountain dom into the deep, moicture soaked ravines, more it overlays the uner range linits of Murdus albicollis. In stay, the only nonth in wich I have been on the crests of these nountins, it is fairly comion and charactenistic of its vom limited habitat. All birds vere in song.

An isolated population such as this one in Hritish Honduras night be expected to be different subspecifically from other 1 . unicolor in Central snerica. Our four specirens are, "1ovever, not sinnicantly different from six specimens from Fondurs and Guatenala. The three females from the cockscomb inourtains erhibit considerable indivirual variation in the shedes of crey on the remiges and under parts. The one British Honduran nele is a much paler sray, especially on the broast, than birds from Fondures; but if noles ere subject to as nuch inaividual vaxiation as fenales, this difference is not significant. I refer these speciriens to I. . u . nallens. 
Wylocichla mustelina (Grnelin)

"iood Wirush

SPTCINATS. LSUIZ: GaIIon Jug - 2 , Jan. j; 3 (

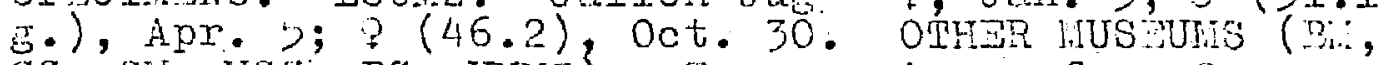
$C C$, CH, not, PC, Unz): Ten specimens from Orange Walk, Belize, lianatee Lagoon, Cayo, it slope Cockscomb Nts.; Mar., Oct., Mov., Dec.

The Hood thrush is comon in wooded areas in British londurs from october to nid-apil. Undoubtedly miny biras aro transients ne! it has not been possible to is tincuish between winter resicionts and misrints. "ullis ald notes at Gallon du sugesest that an increase in nuber took ploce betmeen Pebrung 26 and harch 14 and was follored by a sraduel decline

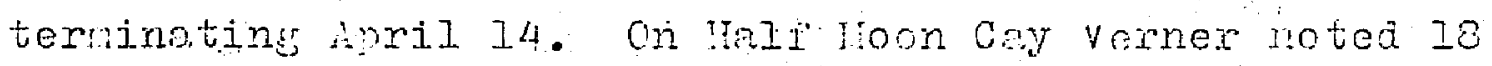
individuals on eight dates from arch 26 to ifay 7 , ten of these birds on inril 19 alone. the mie colfected on Apriz; at Galion Ju; wos vory fat.

\section{Hylocichla ustulata (Iuttall)}

Swainson's 'Phrush

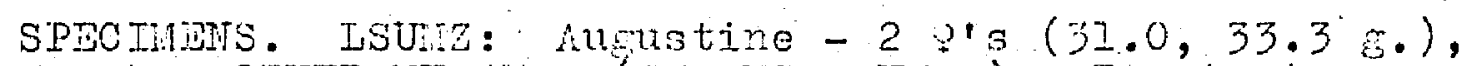

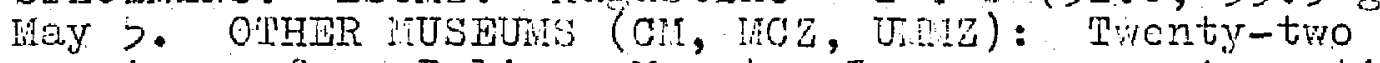
specinens from Belize, Mantee Lugoon area, Ausustine; Apr., Sept., Oct.

Swainson's Thiush has been recorded in British Fonduras only as a trinient. Pall records are linited to one specinen collected by Peck on September 23 and to a series of twenty birds obtained by shufeldt at 
Belize on October 9, 1932. Unfortunntely no notes accompanied these october speciners, but conditions mst have been renarkble since these thrushes vere only a few of the trinsinnts collected thet day. In spring, one to six birds have been seen on 16 dates from harch 26 to llay 14.

The specianen aro roferable to II. ul. Swainsoni.

\section{Hylooichla minina (Lafresnaye)}

Grov-cheeked Inrush

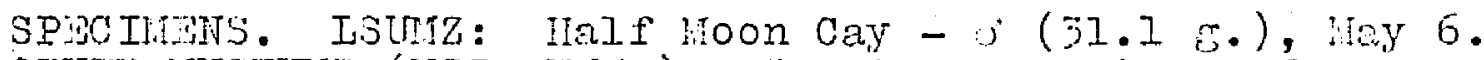
OLHAR MUSTUIS (IRCZ, VDOTZ): Fourteen snecinens from Belize and roledo öettlenent; cot., Tov. 13.

Shufeldt collected 13 of these normelly urcomon trunsichts at Belize on october 9, 1932. Verner collected a specinen on flalf foon Cay and sen two other birds of.' this species on hisy 7 and 8.

I assign sneciners to $\mathrm{H} \cdot \mathrm{m}$. Minime

\section{Bylocichla fuscescens (Stenlens)}

Veery

SPICIMNS. CH, Unz: Belize - 2, oct: 9, 1932. Hanstee Lagoon - 3, Sept. 1s, 1905.

These two specimens are the only ones from the colony. The Eelize specinen is referable to H. f. fuscescens and the bird taken by Peck in the nine ridge near Nanatee Lagoon is $\mathrm{H}$. . saliciola. 


\section{Bialia siajis (Linnacus).}

Wostern Bluobird

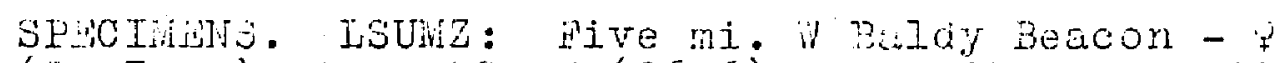
$(22.7 \mathrm{gg}), A p r .20 ; j(26.5)$, Apr. 21. Aumsine -

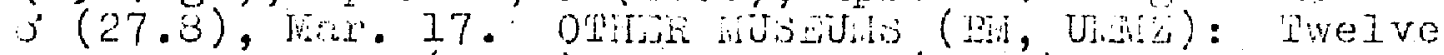
ni. S Cayo - $(20.9)$, inar. 1 ; $(27.2)$, lar. 4. soutrem $i=$ joun win] Pine ilige - i, Ant. 20.

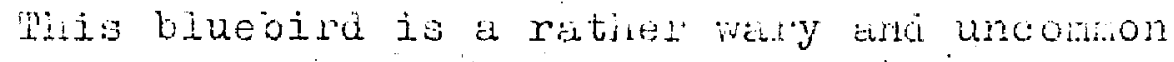
resident of Bribish Hondura, fown ory in we open

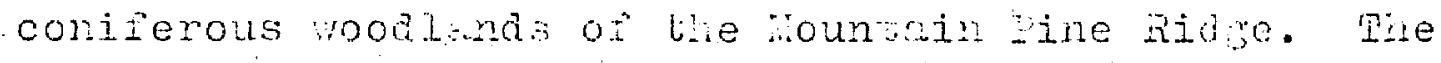
Aoril bidus wero is breeding cindition.

I an urable to roper the ive spodmon that. I

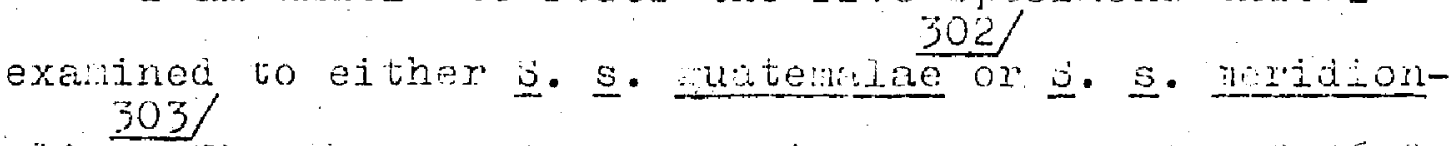

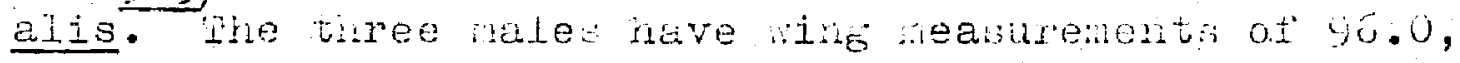

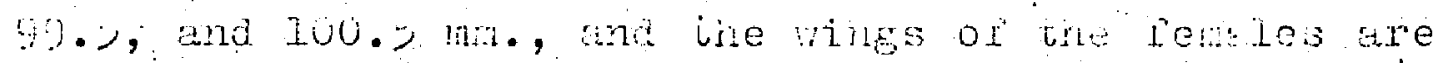
$94 .>$ and $99.0 \mathrm{~nm}$. 3 . larger (wing averuging 10,.5 nm.; Griscom, lyj2a: 313) than the Iive specinens listed here. The feniles from British Fonduras are much like cuatemalun specimens in color and patuern. The males are sinilar to Guabencian males in color and extent of color on the urder parts, but the umper parts of the houn uin Pine kidge birds are slighty paler thrm Guatenalan ones. Thus in size the British Fonduran specinens are close to $\underline{\text { s. }}$ s. meridionalis, but their colorition is more

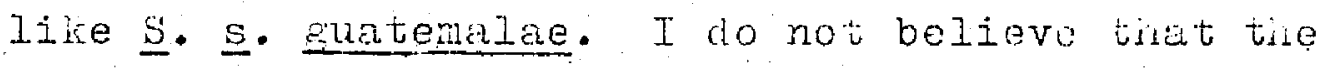
Dritish Honduran population, represented by so few 
examples, is distinct enough to warwart naming. I suspect the range of $\underline{s}$. $s$. madionalis tay be nore extensive than now recognized and my include auch of northern Honduras, since the specinens that I exanined from the latter country mere certainly not $\underline{\mathrm{S}}$. $\underline{\text {. }}$ guatemalae.

Panily SYIVIIDAE

Polioptile caerulea (Iinnaeus)

Blue-grity Gratcatcher

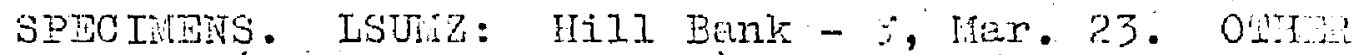

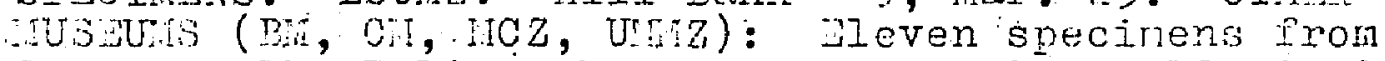
Ornne Valk, Belize, Nanatee Lagoon, Cayo; 12 ni. S Ciyo, Toledo Settlenent; Jan., Feb., liar., Sept., Dec.

No specinens of this species have been taken in British Honduras in the sumer, although villis saw ten Blue-Eray Gnatcatchers on the Hill Bank pine ricige on sugust 3. .. . dempe $i$ is a resident race of parts of liexico south into quintana Roo, and is to be exnected in the colony as a resident. The LSUIL specinen is sinall (ving and tail each $46 \mathrm{~mm}$ ) and probably is referable to this race. Todd identified a December specimen in the British Museum as this subspecies. Pive other specimens that I have eximined and three additional specinens in the British inuseun checked by lodd are referred to $\underline{\text { D. }}$. c cerulea. In addition to 305 lisis' 
hust record, this species has been noted in moderate nubers in the Colony from september 9 to Apriz

\section{Polioptila plunbea (Ginelin)}

Tropical Gnatcatcher

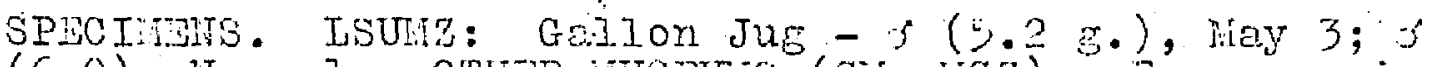

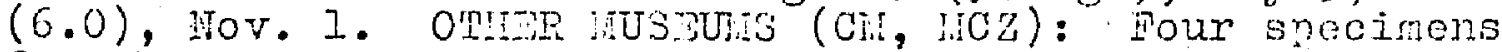
from Duck Run, fountain Con, Preotown; Apr., lity.

In British Yonduras, tire Iropical Gnatcatcher is $\therefore$ moderately comon resident of riverbarks, rantutions, pine ridge thickets (in lowlands), second srowth, and tall numid forest. In the forest it is probably more conton in the canopy, athoush it does occasionaly venture into the undergrowth. Milis saw a bird collecting nest material on jarch 12, and tpril and may specinens were ir breeding condition. The ruce $P$. p. superciliaris rences from texico to Pananá.

\section{Ramphocaenus rufiventris (Jontparte)}

Iong-bilied Antwren

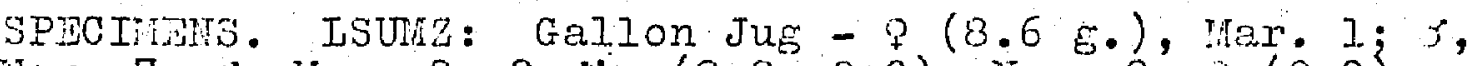
Mar. 7; 7 Mar. 9; 2 s's $(8.8,9.0)$, Mov. 2; 9.0$)$, Jov. 9. Pomona - $\sigma(8.6)$, Apr. 1. Augustine - P, AuE. 22. Two mi. San Pedro Columbia - 2.'s (9.1, 10.5), May $13 ; *(10.2)$, May 22 . Night mi. Nw san Pedro Coiumbia $-y(10.1)$, May $16 ; 2 J^{\prime} s, ?(10.1,10.6,11.0)$, Lay 18. OMHJR MUSDUAS (BM, CH, JNDZ, MCZ): Nine specimens from the Hanatee ligoon area, Cayo, llountain Cow, Freetow; Itax., Apr., May, June, July, Dec. CRITICAI PUBIISHDD RZCORD: Orange Walk. (Salvin and Godman, Bioloria, ii, 1892: 220). 
In the underronth of ts.l r rin forcst and moderately tall to tall second rroith, the Lonis-billed Antwren is locally a common resident. Almost inviciobly, male and Eemale forage very close to one another, their prosence nide known by many lon trills and churrs. In thedium second grovtin dominated by 30 -foot conune mims near jan Pedro Columbia, I found nest in the early st wes of construction on ray 11. It was mised in a tork of a small bush 18 inches above the rround in a ratirk open area. At this stage the nest was an amorbious ball of suall twigs, fine barl, lichens, and moss. Hen days. later it was a compot open boml, the cavity 2 incies deep and 1.> inches acros, but it contained no eces. The inside mas lined viti vor fine masses but the outside had wany rotruding lonse ands of thise, bark, Lenves, hra lichens. At Gizon Jur, 7ilitis foind two sinilar neste ony a flen incies above the rround one conteined two exis. June $12-20$, and the other was uderconstruction July 4 . and still eimty July 10.

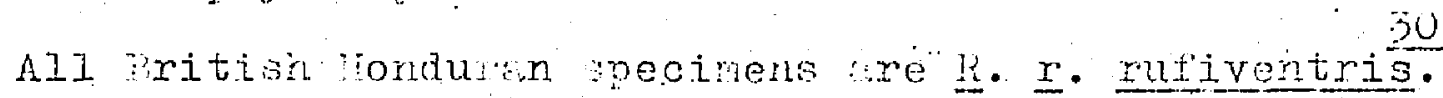
A series fron tile colony was compared with the tyoe ard tyoe series or le. ‥ ardeleo. Specinens from tailon Jug and oryo approach the peninsular povulation in paleness of tieir coloration but they are nore like the roninate form. 


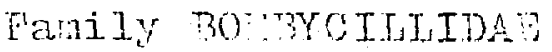

Pombycilla cedrorum (Vieillot)

Cedar irowing

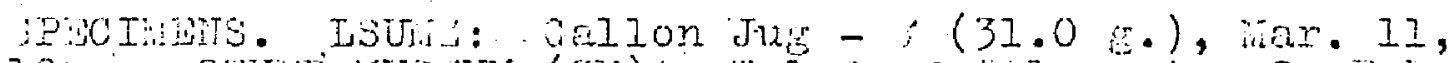

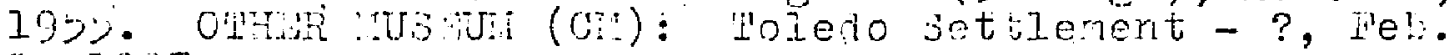
S, 1907 .

Gedar laxwirm: have been noted in only binee yeans

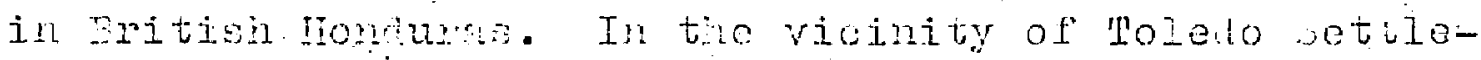
ment, Peck observed mell rlooks (less thon 12 inoividuals) fro:l abruary 9 to $2>, 1907$. is sroup of about 9 bi:ds Erequented tae village of Gallor Jur betreen j'ebruary 18 wnd tarch 11, 3.955. . Iro inotiduals no ued by vower on Half :oon Cay on lebruery 23, 1908, wert certairly transientr.

Finily arTTEATDAE

Grolarin sujonensis (Gmelin)

Rufous-browed Fepperslirike

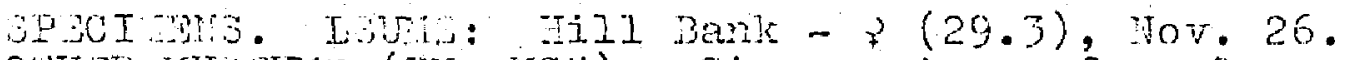

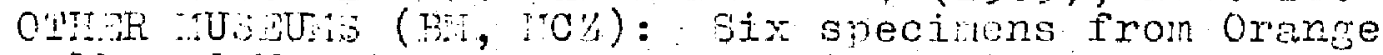
Walk and lianatee Jasoon; As., Jay, Dec.

This uncomon resident of British Honduras has been found only in dense over rown regions of the lonland pinelands and, according to Peck, in nangrove swamps. I have seen this species only at Hill Bank in wovenber and rillis observed it there in August. Peck mrites of collecting one "alons the beach near the mouth of the 
- Ianate kiver, in Harch," and seeing it at Youcos Lagoon. Ie also reporto finding an uninished nest on the edse of the ine ridre rear lanatee lagoon on April 10.

Tire back, pileum, and superciliary line of the Novenber ppecinen are listched by a bird taken at chichen Itzá in Jecenber, but the under parts of the Britiah Jonduran snecinen aro slichtiy brimter. I rofer this specimen to the peninsulur ruce, $\underline{Q}$. $\underline{x}$. rucatanensis. 309 I have not examined the other necillens froll the colory, but podd describes the four birds in the Pritisi Musen fron Orange balk as "intmmediete" between $\underline{0}$. tenensis and $\mathrm{C}$. E. Alviventris. R. A. Parnter, Jr., informs me thict tive two specimens in the auseum of do:t-

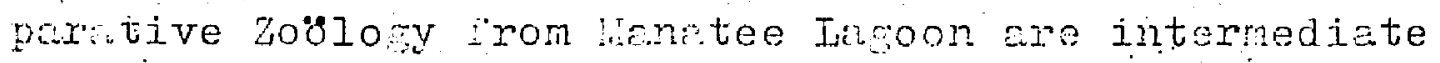
between trie two races.

\section{PariIY VIREOIJAIIDAE}

Smarasdolaniua pulchellus (Sclater and Salvin) Green jhrike-vireo

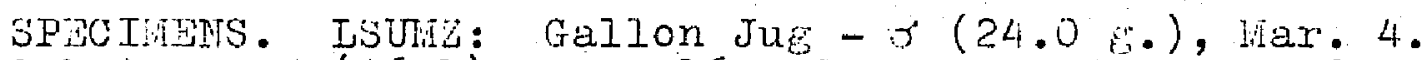
Cunetas - 0 (26.1), har. 16. Seven mi. IV San Pedro. Columbia - 5 (24.0), lay 18. OTHER MUSUUAS (BM, CHI): Two specinens from Cayo District, $N$ slope Cockscomb Mts . ; Mar.

Although tire Green Shrike-vixeo is a very colorful species, its presence in the upper level of tell humid 
forest is usulaly detected only uy its timoncelike sonr. Its nencuating rotes are ropulary repeated

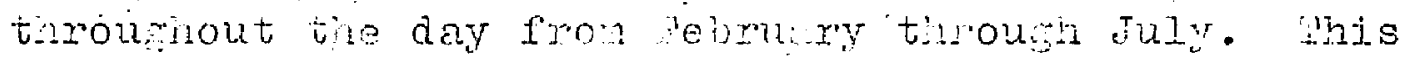
snecies is not comor, but it is chancteristic of the

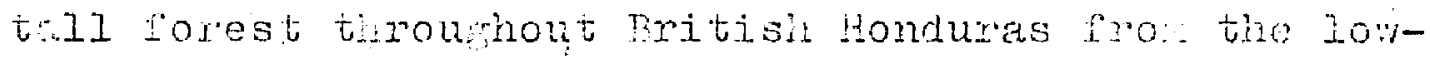
1.ans. to the unver siones of the cockscomb nountains. there ane no fall or winter records, probebly bectuse of the absence of son'" it that tine. "illis sam a : fenalo carry palo sroen lichons or loss straids into

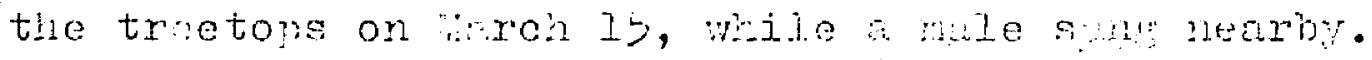
whe ha specinen vas iu breedin: contition, as vere tiree larch birds.

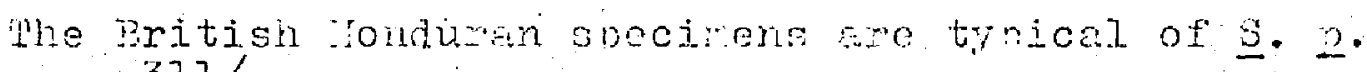
pulchellus. 311

Panily VIREONTDAE

Vireo Iriseus (roddacrt)

ihite-eired vireo

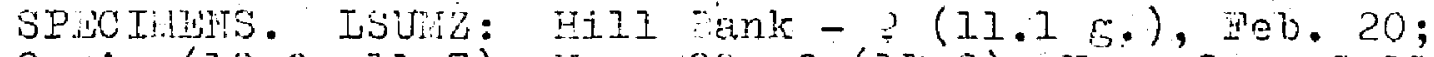
2 's $(10.9,11.7)$, Hov. 20; ? (11.2), Nov. 23. Galion JuE - ? (9.3), ireb. 2I; 0 (11.b), Irov. 9); (11.9), Nov. 10. Seven mi. IN Belize - 9 (14.7), Apr. 9. OMHR VUSUUAS (BH, CH, UIIZ, USTI): I'venty-two specinens from Orange Walk, Belize, hanatee Jagoon, Cayo, All Pines; Jan., lieb., ifer., Apr., Oct., Dec.

The wite-eyed vireo is a common winter visitant and probebly a less comon minrit throughout the colony. In luuanil and along the forest edge, this vireo is 
conspicuous fron mid-october (it undoubtedly arrives ecrlier) to about April. lo. Courts nade during the course of normal field work during this geriod total about tree to six julividuls delily. On half foon Cay, verner recorder one or two birds on four clates from liarcil 2 to hpriz g. As this enecies loes not Hinter on the jolund, these birds must have been aigrints. whe presence of trunient is aloo indicuted by an exceptional count of 50 individuals at Gallon Jug on April y, 195y. Wuch fiat was remover frow the swecinen collected April 2, 19b6. The latest sprins date in ritish Honcuras is hrril 17.

1 relier 1.1 of tio 20 specinens thit I have critically 312

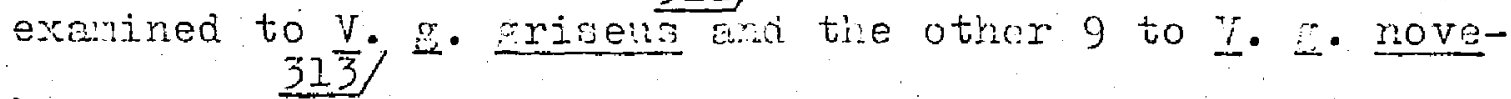
borscensis. There is ro difference in points of record or j.n cirrivel and departure dotes between the two reces except that the ony two huril specimens exanined are: $\mathrm{V} \cdot \mathbf{2}$. noveboracensis.

\section{Vireo paliene (alvin)}

liangrove Vireo

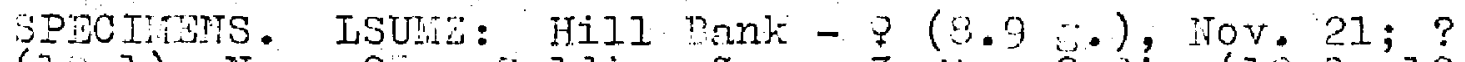
(10.1), Nov. 25. soldier day - 3 sis, 2 is. (12.0, 12.0 ,

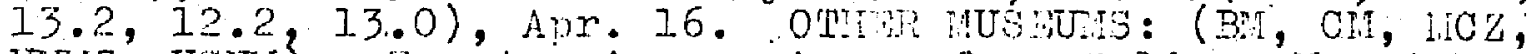
UTEY, USWh : pwenty-six specimens from Belize, manatee Lagoon, Uayo, freetown, Ali Pines, Ycacos Lagoon; Fob., Apr., Hay, Jure, hue., oct. CIITICAL PUBIISHED ROCOND: Corozal (Jalvin and Godman, Bioloris, i, 1882: 201); Rendezvous Point (Bond, I954: 83). 
Throughout the 10:1and coastal region, locally inlend along witercourses, cind on some of the inner keys, this dimutive vireo is a comon resident wherever it occurs at all. Formaly it inhabits the edge of the nugroves, lagoon borous, trickets, and low huanil. On soldior day it wis the most chracteristic specios of trie savodilla doninated nodlard, yet on nearby dalabasi cay, mere there awe no sanodillis, V. merister mas the only resident vireo. miy maly does the iangrove vireo forage mow than a few feot above the sround. peck reporte two nesta, one containing three ens found on Arril 23 and the other witil two egrs located Jusle 22 . Ihe irides of one fencle and two wie birds taken in breedin: condition vere dusky brom. I refer these iritioh Iondurm specisens to $\underline{V}$ p. senillivus Jond (19,4:8) has comented unon the distinctiveness or tire sone of tiis species in comprison with that of $V$. Iriseus, a point with which I. fully aeree.

\section{Vireo nuttoni (Oossin).}

Hutton's Vireo

SPDCIMEN, DH: Southern $L=$ Hountain 7 Pine kidse, Apr. 26,1838 .

podd has exanined this specimen and found that it is in poor condition ard not racially identiliable, except that it represents "a paler race of huttoni." 


\section{Vireo flavifrons (Vieillog)}

$$
\text { Yellow-tirosted Vireo }
$$

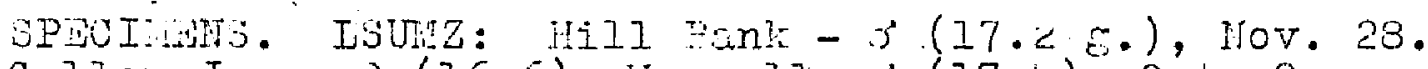
Galion Jug $-?(16.6)$, Iiax. II; $\sigma(17.5)$, Oct. 2 . O'HAr nUS Belize, Cayo, Hountain Cow, roledo Settlerent; 'Heb., Aor., Dec.

the Yellow-throated Vireo occurs in. British Hondurss as a mirront and winter resident in very salal numbers. second rrowth nay be its.poferred habitat, but it has been observed in inuamil, pinelands, and toll humid forest. verner ar itve birds on Falf idoon Gay on tarch 20, tie hiduest one-day crunt of lnown ticusients in the colony. The ourliest fall date is october 2 and the latert epring date is ipril 19. whe adul nue collected Novenoen 29 ras in full song in a pine tree.

\section{Vireo soliturius (Wilson)}

$$
\text { Solitary Vireo }
$$

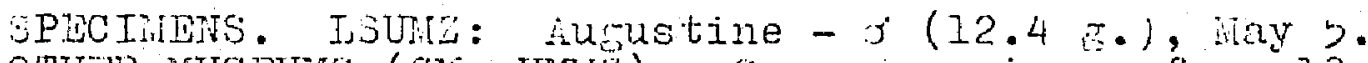

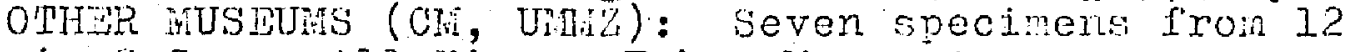
mi. 3 Cayo, All Pires; Feb., Mr., Anr.

Extensive field worlk in December near tile type locality of this rare vireo failed to reveal its. presence. Thus, it has rot been confirned as a yectrround resident. Blake and Agostini collected a pair of breeding biras on hril. 23 in a palneto thiclet in the pine ridge near All pines, evidence that this 
species $i$; not confined to the Mountain Pine Ridge. Van Tyne (1933: 2) thought that the five birds he collected between Februm 16 and jarch 4 were "about to breed." The Iray $>$ adult akle had only slinitly enlarged testes.

The endenic Rritish Fonduran population of the 315

solitary Vireo is $\underline{V}$. $\underline{S}$. notius, and all specinens fron the colony are reiorsble to it.

Vireo oliviceus (Linnaeus)

Red-eyed Fireo

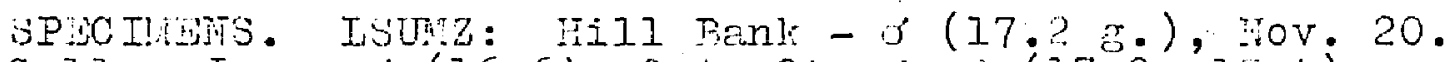
Gallon Jug - $5(16.5)$; Oet. $24 ; 3$, ? $(17.0,13.4)$,

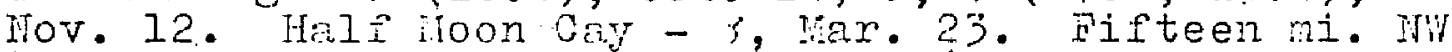
ridalesex on suminebird wy - ? (19.9), likr. 27.

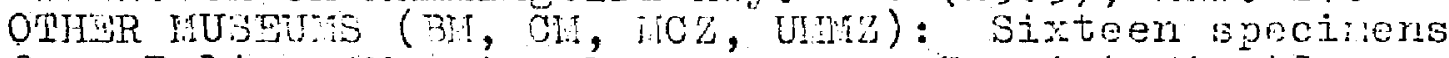
from Delize, Manatee lagoon area, san intorio, Oamp VI, liountain Co:, ireetom; lar., Apr., hy, hu, Sent., Oct.

Whe fied-eyed vireo is a moderately comon transient through British Honduras ovor an extended period in the fall and spring. Peck noted arivis fron tile north as eerly as July 2 and collected a shecinen iumst 8. whe species contimes to be yresent in numers into October and a few inatviduals huve lingered as late as lovember 26. The last week of lifarch is tine tual date of arrival of north-bound mirrants. Verner noted 30 individuals of this species on jarch 26 at Half ioon vay after a storm the nimt before. It is comon until Inte April. The latest sprine birds moro collected liay 14. 


\section{Vireo lovoriridis (Cassin) \\ Yellow-groen vixeo}

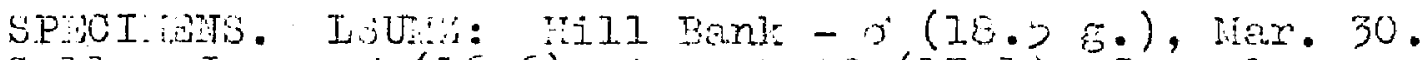
Gallon Jug - $;(16.6)$, Apr. b; ? (17.1), June 8. Ballerina Canp - 3 , $(17.3,17.0)$, ipr. 26. Two ni. In San Periro Columbia - $;(1.6 .2)$, Way 4 ; $\}(16.7)$, litay

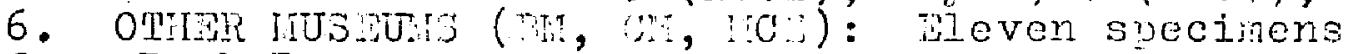
from Duck Run, Cayo, Sitlee River, Ireetown; Nen, , Apr., ilay.

Unlive nost breeding biris of the colony, this vireo mirrotes southrird for the inter. It arrives in snring in late mach (Itarch 20-30) and is comuon by the first eef of aril. the senti-open mat the forest odre provide ite fivorite nat tat. Inis species iks not been rooried above an elovation of 1600 feet or in the heart of extenive corests, althougi it hoes enter the loriand pine ridres. Only srecinens taken in late Anril, ay, wh ture were in breeding condition. Feck found a iest contajning ens in the pine ridge near frntee Lagoon on June 20, andillis noted two nests conteining roun; at Hill Bank in the first meek of Aucust. The fill deperture ate is undetermined.

The r:ce of the Yellow-green Vireo breadine from Mexico to Panami is $v$. r. Mavoviridis.

\section{Vireo marister (Iawrence)}

\section{Yucatán vireo}

SPYCIMUS. ISUMR: incrabb's Water Cay - 3, hay 17. Calabash Cay - 2 ;s $(21.0,21.0 \mathrm{~g}) ;$ f.pr.9; 3 , 


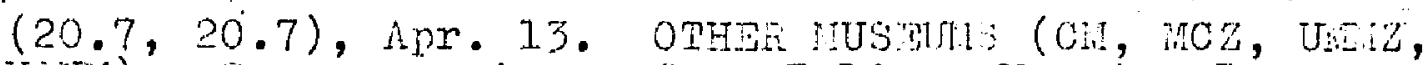
Usmi): Seven specinens from Beliee, lanatee Is;oon, South Vest Cay; ?, nay, Dec. CRI'ICAI PUPIT ITID KOCOSD: Desente Point (Bond, 19=4: 8).

In British Hondures this vireo is a looaly conmon resident of mancroves and adjacent habitats near Belize and on any of the keys. In the naniroves and thickets on Calabash Cay I noter as many as 16 individuals in a two-hour period. Peck collected one bird in December in e thicket in the pine ridge near Manatee la:oon. Four of the cight adult rirds I collected in April and ny were in breodirs condition. $I$ refer these specinens to $I \cdot m$. mister.

Vireo altilonuus (Vieillot)

Black-whokered vireo

SPCIHE, CH: Half Moon Cay -3 , March 22.

The specinen listed above was found aed by irnest G. Holt in a pool of water at tie base of: the Half foon Cay lighthouse. This bird, a mile with enlarged testes, his a well-defined submin line and is typical of $\underline{v}$. a. barbatulus.

Iireo philadelphicus (Cassin)

Philadelphia Vireo

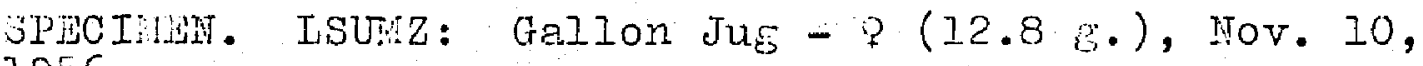
1956. 
This bird was collected as i inpently picked ariy ants from the crown of an eight-foot trumpet tree. It gell to the ground when shot and lecame black with ants in the fer seconds that elansed bofore I retrieved it.

\section{Hylonhilus ochraceicens (jolcter)}

$$
\text { many-cromed creenlet }
$$

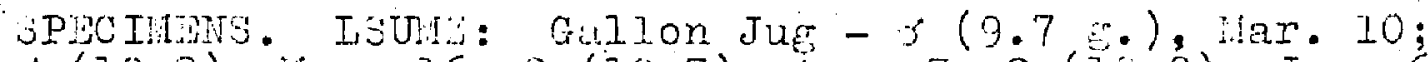
$\sigma(10.8)$, Mr. 16; $9(10.7)$, Apr. $7 ; ?(10.2)$, Tune 6 .

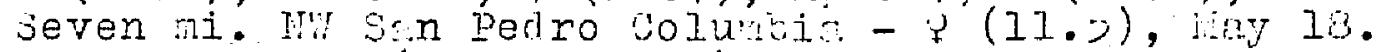

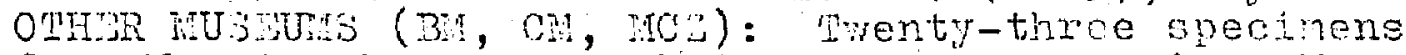
from Nanatee Laroon, Duck Sun, Gayo, Murine, lountain Con, Preetom, Toledo Settlenent; al months except Mar., June, JuIy, Sent.

In tall humid forost and occasionily tell secone? growh, the "amy-cromed Greniet is a common resident. It has been noted in the for sts (1600 reet) friming; the fountain eine fidge and high in the vockscomb Wountains ( 3000 feet). rilis found enest containing two esgs on April 1 and on July 7 he observed two nests, one containing young birds and the other under coinstruction. The tirree nesto aiscovered by iillis wero 6 , 11 , and 23 feet above the ground.

The roce of this greenlet ranging throurh Central Arerica is $\mathrm{H}_{\text {. }}$ ochraceicens. 


\section{Iylophilus decurtatus (Bonaprte)}

Groy-headed Greenlet

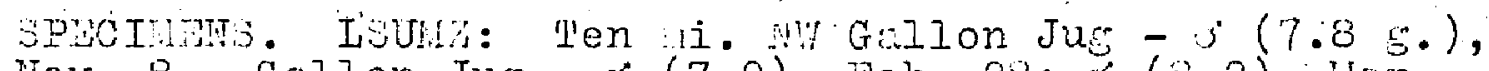
Nov. 8. Galion JuE - J (7.9), Teb. 28; J (3.2), har. 23; 8 (8.9), Hov. 5. Seven mi. Wh Belize - j (0.8), Apr. 5. Seven mi. Nu sen Pearo Colunbia - ? (10.3),

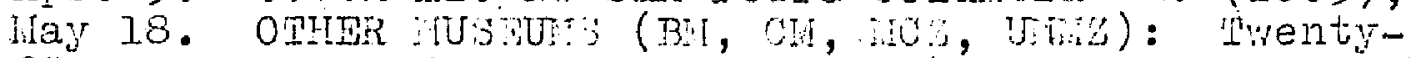
five specinens from orange welk, Belize, lian tee Lacoon area, Duck thun, San Antonio, fountain co\%, it slope Coolsscomb iits. (1300', 18>0'), Frestom, All pines, Toledo Jettlenent; Jan., har., Amr., Mhy, Sept., Oct., Nov.

The oray-cromed Greenlet sre uents neariy all forest nreas from the coast il scrub to the vory humid Forests of the dockscomb lounteins. It is most conspicuous on the forest ed os and in teller second \%orth. In tile heavior forest where $\mathrm{H}$. ochraceicens also occurs, H. decurtatus usuilly formes ach higrer. Ihis comon species may begin to rest in harch, since the four opocinens collected in harch had fully enlerged gonads. The bird collected hay 18 was a fledcling just out of the

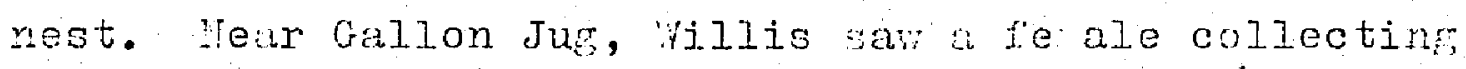
nest naterial on June 27. The population in rorthem centrel smerica is II. decurtatus. 320

Fainily covgBIDA?

Chlorophenes spiza (Iimiaus)

Green Iloneycreeper

SPEIMMS. LSUAZ: Ballerina Camp - $5(19.3$ ह. $)$, Apr.

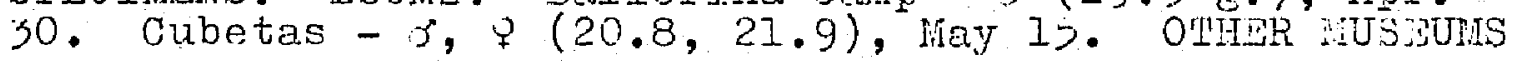




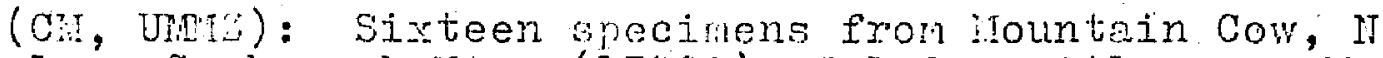
slope Cockscomb its . (1300'), Iloledo Settlenent; Mar., Ipr., Dec.

In the extensive and relatively undisturbod tall forests to the south of the jiountain pine nidge ma in the drainage of the Cockscomb hountains, the Green Foneycrencr is a noderately common imlabitant of the midale and upper forest levels. Tour the crest of tile Cockscomb range, whe the trees are not 30 tall, this snecies was frecuentiy observed. Its at:tus as a resident is open to sone question. Pecl. first sav it at. Toledo settlement in arly December and states tinat it became conmon before it completely disanpeored ir nid-pebruary, ife saw one other bird, at wanatee luasoon in December. Whese obsorvations suspest that a soasonal shift may occur in the local population from the ruin forests at elevations above 1200 feet into the lowland forests. Ihroe of the oifht marcil specinens Iron the Cookscomb iountoins had enlared consds as did all three harch and April birds from Pallesina cemp and cubotas. The specinens ate exanples of $\mathrm{G}$.

\section{Cyenerpes cyaneus (Linniteus)}

Blue Honeycreeper

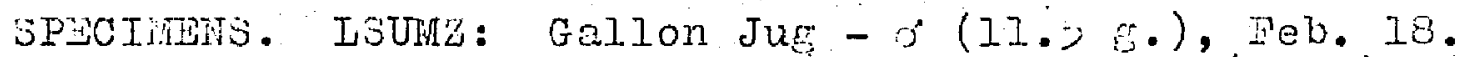
pen mi. NW Hidalesex on Humingbird IW - -5 (12.3), Iar. 26. One-half mi. B Bald Beacon $(2900)-j(12.7)$,

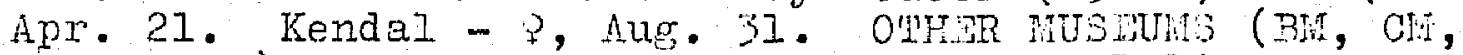
iĆ, Uiviz): Twenty-tiree specinens from Bolize, inanatee Lagoon area, Cayo, Hilountein Cow, IT slope Cockscomb hus. 


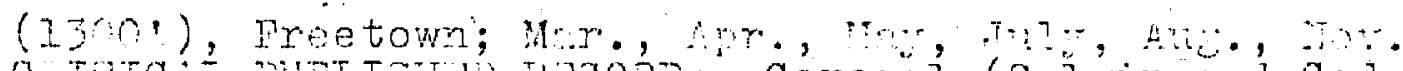

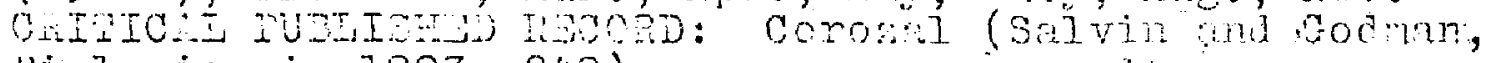
Btolorta, j., 1e8?: 240).

The p?u Honoycreoper is a fairly comton resident

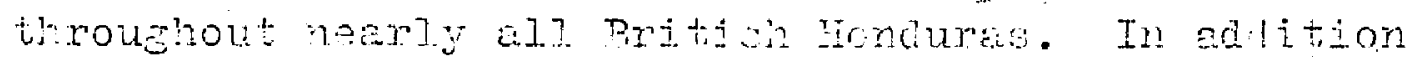
to tho ahove opedmen localities, this zodies has beer

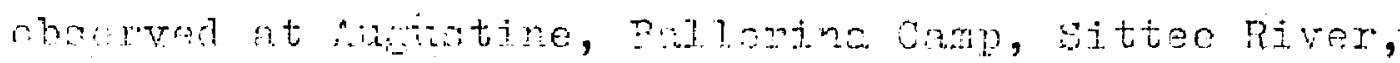

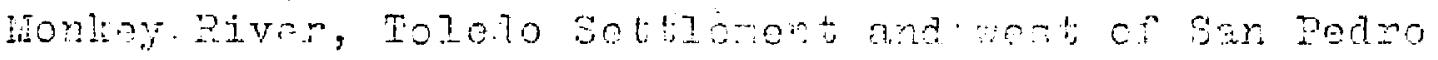

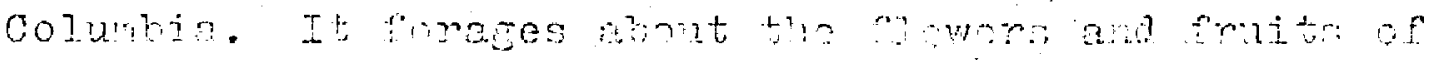

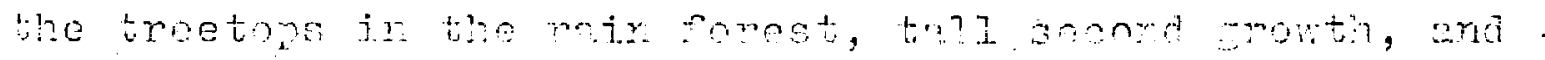

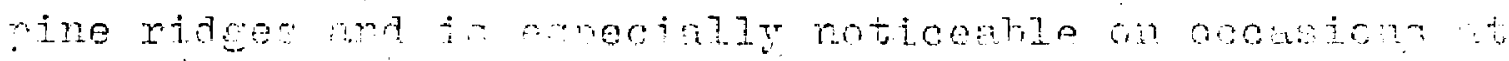

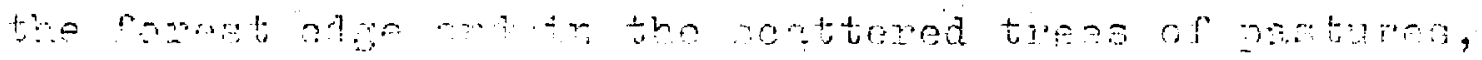

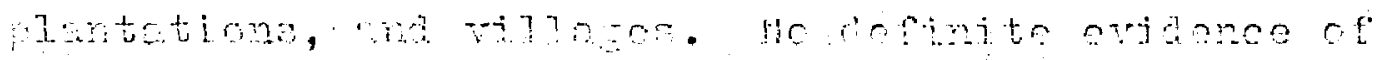

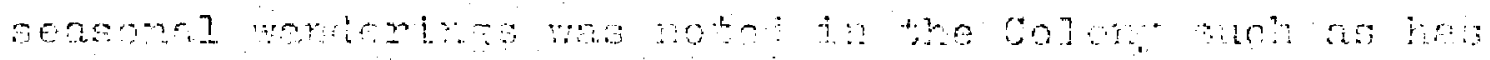

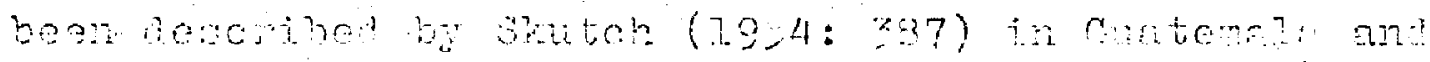

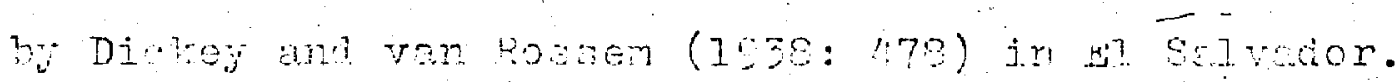

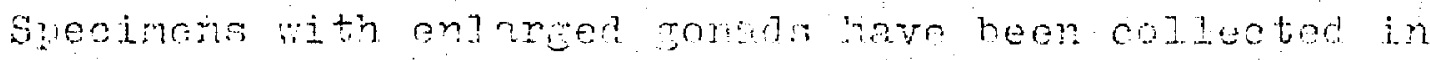
Inte karol, Aril, min May.

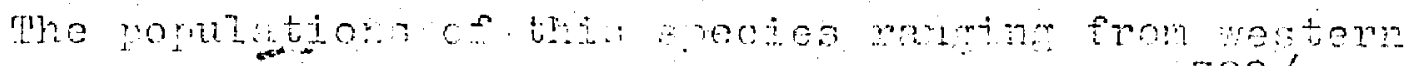

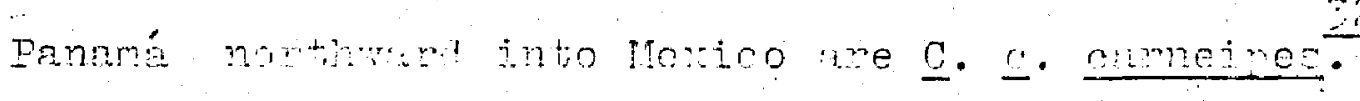

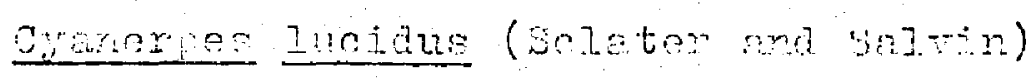
extine Honoycreeper

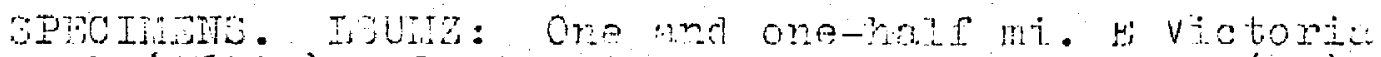

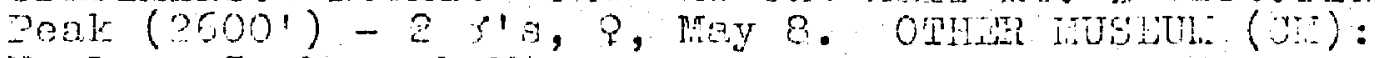
It alope Coofocomb Hts. - ?, har. ?7.

On the very namow ridge at the owat of the boolecomb hountrins, the veretation is predom nenty a mess 
of trees less than 25 feet tall "with much low undersrowth. Limbs and branches are completely covered by eriphytic bryonintos and ferns. In this habitet in hay the saining Honeycreap is tie nost comon burd. If individuls are not ictualdy in sight, ifiting shout the ends of the bronches, thoir high cricketlike zee zee nay be heard continuously. This species $x$ mes at lust from the Mignest point thrt I heve resched (3400 leet) down the slopes to 1300 fieet, altiougn not comondy below 2llo Peet. Jhe ildy spocimens had enlarged gonsds. I refer speoimens to $\underline{\mathrm{U}} . \underline{\text { I. Iucidus. }}$

\section{Qoereba flaveola (Linneeus)} snanaquit

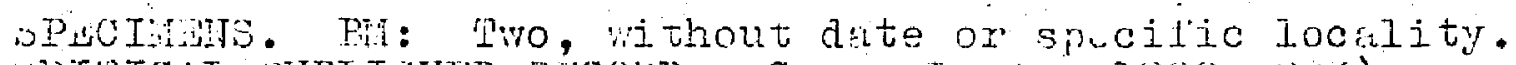

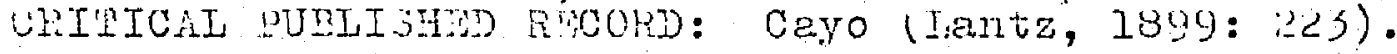

load hes examed the british ruseun speciners from an unspecified locality in pritish hondurss. lhe publisined bayo record rolers to a pair of ennanguits collected by boss. to ny knomledge trese two s!ycinens are no longer extant and this reference nay the tefore be considered with skenticism.

-resumbly the epecinens are referable to $\underline{u}$. mexicana. 324 
P.:Bily PRULIDAP

Hriotilta veirial (Iinnaeus)

Mlcol-and-white warbler

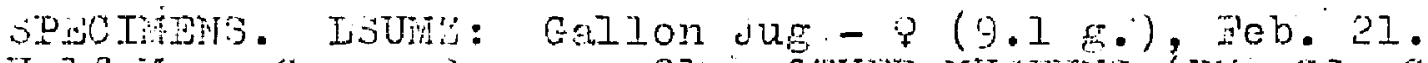

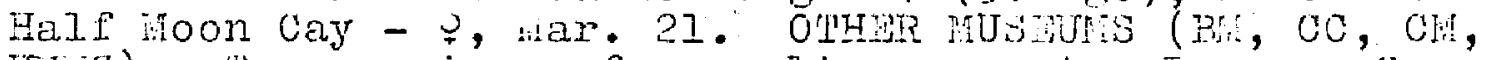
Utiz): l'en specinens from selize, ti nutee Lagoon, ceyo, Mountain rine viage, hll Pines; Jan., Apr., Aug., sept., Dec.

The black-end-mite firler is distributed troughout the country as a mignent nd uinter visutor. duly 28 is. tire errliest urrival date. 'iwo or tiree nay be seen each day regularly iuring the winter. unly five other syecies of warblers are mone numerous. The nuber of individuals observed incrases airity in early rarch, and is hignest in late larch ard vory early fipril. Practically all have departed before tire last week of April. The lidest transient was recorded by Vemer on Half moon vay on May 7 . He had not observei any riach-ind-white warblers on the island since April 19.

\section{Protonotaria citrea (Bollatert)}

Erothonotary uidiler

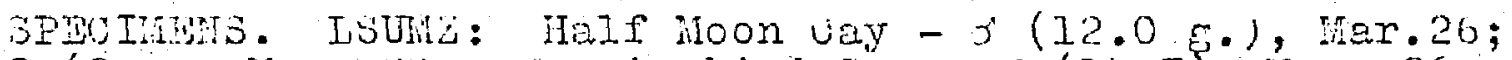
$?(9.5)$, Har. 28. Humingbird Gap - s (15.7), Mar. 26. OTHER IIUUAUS (CA, Uinz): Four specinens fron Delize, Ianatee Lagoon; har., Sept., Oct.

l'his warbler is an uncomon transient, recorded in British Honduras from augut 3 to lvovenber 22 and in the 
spring from Pebruary 28 to Apriz 19. Whe re are not sufficient records to ricrit cotection of a puak southmard moverent, but 12 of 14 spring observetions huve been in the period Harch 26 to April 11. l'he Drothonotary Warbler may be seen in any habitat during its movenent through the colony.

Li:motnlyois swainsonij (Audubon) swainson's Warbler

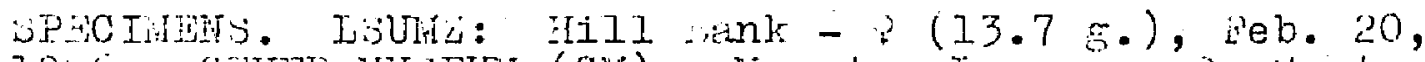

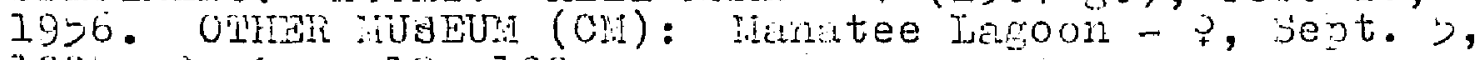
1905; 2, Lec. 13. 1907.

These three specinens and one eight record at all Banls on Noveinber $22,19=6$, constitute the only lanown data on the ocourrence of this species in the volony. The Hill Basl bird was captured in a line mist net stispunded in tall second rowth ovr a narrow dry gully. Whe manatee Lagoon birds were collected in a similir hebitat. Whe swainson's farbler that I saw wovenber 22 was in thicket on the adge of the pine ridge.

\section{Nelmitheros vernivorus: (Gmelin)}

Worm-eating varblex.

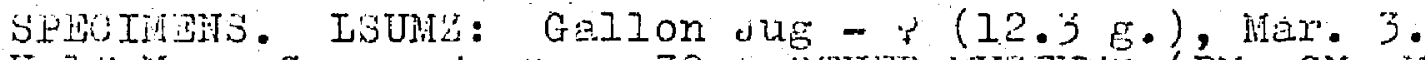

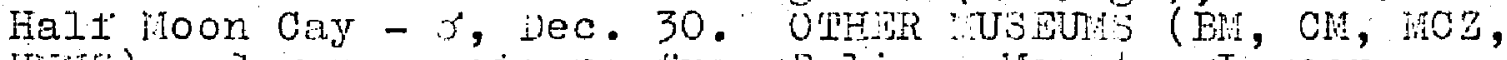
UDis : Seven specimens from Belize, Hanatee Lasoon, vayo, loledo Settlement; Jan., H'eb., lar., bept., Dec.

The Worr-eating Warbler is an uncomon migrant and winter visitant and has been recorded as early as 
Septeaber 13 and as late as Anril 19. No nore than two individuals have been seen by Isurif personrel in a day. The grecies winters on the keys, as vell as on the nainland, for ven tets captured one in a nist net in the booby colony on half noon way on vecember 50 and verner saw two there in mid-Februiry. On nine dates Pron ivarch 8 to ipriz 19, verner recorded a toul oil ten individuals; it seens lively some birds rere trensients. Horm-eating Warbleris are usuilly seen in the undorsrowtin of the main forest on tre riatintand.

\section{Vermivora cingsonterg (Linneus)}

$$
\text { Golden-winged Warbler }
$$

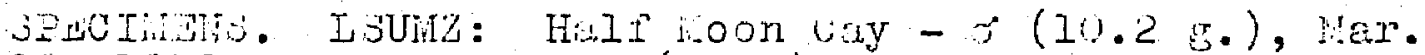

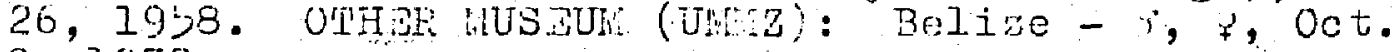
9,1932 .

Whe tolden-winged "farbler is a rare migrant and posuibly a winter visitor, for Lancaster saw one individual at Galion dus on ebruary 10. To indivaluals on Half thoon vay on March 26 (one onlected), wother there April '2, and one et Galion Jus on why 7 surply the only other records of this warblen from tine volony.

\section{Veraivora pinus (Linriaeus)}

BIuc-ringed Warbler

SPLOTHETS. LEUHz: Gallon Jug - $(7.5 \mathrm{~g} \cdot)$, har.j, 1995. UTHER irUSEUA (CM): Wratee Iagoon-3, Dec. 22 , 1905. 
In addition to the two suecimens listed above, twenty-two individuils have boen seon on as :iany dates from october 30 to Anril 24. Nost observetions of the Bine-winged Inrbler were nade in fiebruary, harch, and Aril, undoubtedly becase most of the field work by LuUn' persomel was conducted in tione wontis.

\section{Vermivore peremina (Wilson)}

i'emesse. irorber

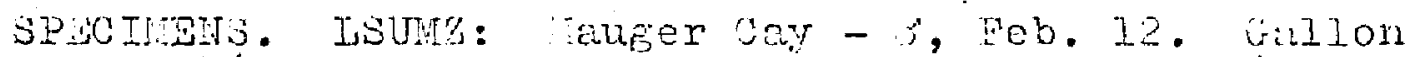

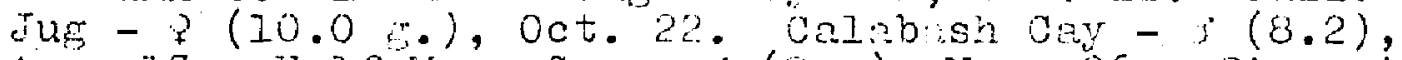
Alr. 13. Half joon cay - 3(8.2), Tar. 26. Pive di.

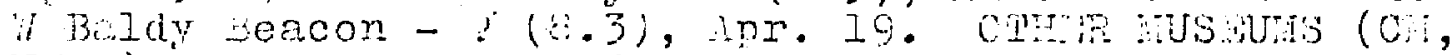
U.tu : Two specilens from Cayo and All Ines; Iar., Apr.

$$
\text { Life Hennossee varbler is an uncomon trunient }
$$

ard, on the basia of turee lebruary records, a sare vinter visitor. In the fril it as ben obsorved only i. the last third of october. In surine nost indiviauds passed throu from wareh 26 to April 20 , with a stragsler on April 27.

Vermivora ruficanille (Wilson)

Nashvilje Marbler

Lancaster observed a Nashville Marbler at Gallon Jug on February 3 and 8,1958 . "whese are the only records of the occurrence of this whrbler in British Honduras. 
Parula anericana. (Iinncteus)

Parula Farbler

SPTCIMUHS. LSULZ: Six mi. MFE Hill bank - ? (9.5 g.), Feb. 25. Gallon Jug - $3(8.1)$, Feb. 19; (6.0), Nov.

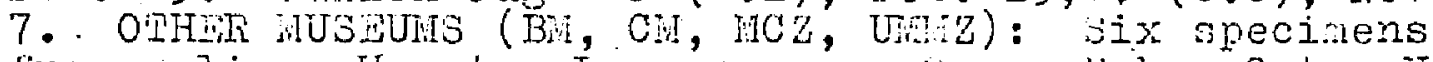
from zelize, Hanatee L goon area, layo; Heb., oct., Irov. CRIPICAI PUBLIBHSD RECOED: Turneffe (Bond, 19y4: 3).

The Parula Warbler has been recorded in the volony froil early october to hpril 18. It is uncomon as a winter resident (one January record) and only moderately common during the northward nigrution. uuring the last half of rebruary it appears in i us createst numbers, especially on the keys. Verner sam as many as five individuals in one day on Half hoon cay in ate rebruary.

Denaroica petechia (Iinnaeus)

Yello: qurbler

SPHCIMUS. Honresident races. ISURZ: Hill Benk - 3 , 7 (8.>, $9.4 \mathrm{~g}$.$) , Nar. 30 ; 7(7.8)$, Nov. $2 \%$. Gallon Jug - $6(8.6)$, Mov. 12 . soldier Cay - (9.8), Amr. 16. Calabash Cay - ? (9.4), Apr. 9. Talf ioon Cay 21. Hunting vay, $;(10.3)$, Apr. 27 . OTHSR MUS IUtï (Bid, CHi, riCz, Uiliz): Thirty-one specimens from selize, Wanatee Lagoon area, Uayo, kreetom, 111 Pines, Toledo settlement; every month excent June. Resident rice. ISURI: Six ni. Sil Belize - 2 r's (11.2, 1 1.7), ipr. 4; j, npr. 0. Calabash Cay - 2 s's (11.2, 11.3), Apr.9; (10.9), Apr. 10; $3 \mathrm{o}^{\mathrm{s}} \mathrm{s}(11.3,11.3,11.9)$, hpr. 1.; 2 3's $(12.1,13.0)$, Apr. 14. Hatchet Cay - o, May 14. OMHIR MUSHUiS (CH, CMHA, MCZ, UWLE, Usm): Thirty-six specinens from selize, All Pines, GLover's reef (Northeast, ilidale, jouthwest Cays); Jan., Apr., Hay, Dec. CRTIICAL PUIIISHID RECORD: Half' Moon Cay (saivin, 1864: 380 ). 
The Iorth fuerican races of this species are noderately common as transients and vinter visitants on the mainlond and the kuys. southward-bound individucils have been noted es enrly as July 21 and late spring wigrants were on Half foon bey on hay $a$. Too Iew specinens have been racialiy identif'ied to provide inieration dita on the various subspecies. Numbers oi minrunts have boen noted in early Musut, late jebrusy, lid-hpril, and early Nay.

specinens thet I referred to D. D. cestiva vero uaken in Jaruiry, Harch, April, and December. Other birds, collected in ipril and november, I identitied as D. . ammicola- Some liarch, April, and lovember syecinens I referred to I. w. rubiginosa, and an ipril 27 bird I as sigred to D. $\mathrm{E}$. morcomi.

the resident race of the Yellow Warbler, $D$. brvanti, is a comion inhabitart of the nangroves of the coust and islonds. Al though salvin (1864: 300) collected what was pxesumed to be the local race on Halt ioon vay, it llas not been recorded there subsequently, though it is common on the islands of GIover's Reef. Birds taken in April and hay have been in breeding condition. I) 2 . bryanti is distinguishable in the field from all wintering or transient yellow varblers of other ruces. 
Dendroice megrolis (Vilson)

Nognoli: yarblei

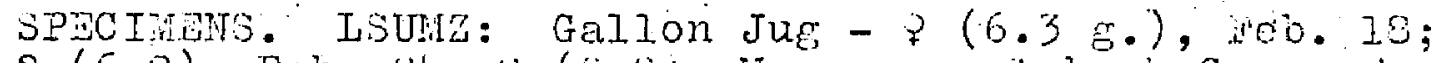
$?(6.8)$, Feb. 2h; 9 (0.0), nay 2 . velabash Cay -

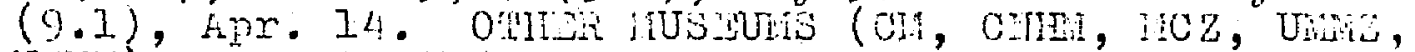
Uini): l'wenty-two spucinen from Urance valk, selize, wanatee Lagoor area, vayo, Ali rines; Jan., yleb., lar., Apr., Oct., ITov., Dẹ.

whis marbler is widely distrituted in the volony us an abundant nifrint and witer resident. Peok recorded the earliest fall risrents on jeptenber 1 . burine the minter it is the comonest mablor of the mainland and is present in all trmes of rnoded labitat. There daily counts of 10 birds are averse and 25 are the naximum. It is lese comion on the leys. ine number of individuals decreases greduaily in fipril, nd the last wagnoliat wrblers vere seen in 1956, 1907, 1998 on An 9,8 , and 7 , respectively. Suring tie gring of 19j3, verner noted one to tinee inaividuals on April 16 19 and say 2 and 7 on talf woon vay. the female collected Way $b$ hod cousiderable fat along the pterylae snd in the nesenterias, und iss ovary vas enlarged ( by 7 mn.).

\section{Dendroica tisrina (Grelin)}

Cape kny warbl ar

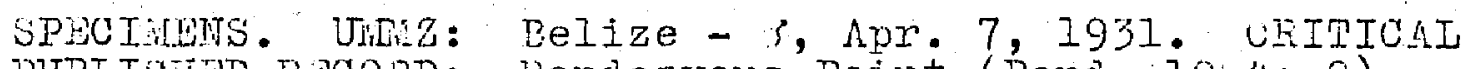
FUBLISETD RICORD: Rendezvous Point (Bond, 1924: 9).

hccording to shufeldt's notes, the specinen in the University of Michigan Museum of zoology was collected 
fron "several seen in bunch" at the boanic station on the Belize River. sond say only one lape way Viarbler - tine bird taken at Rencervous Point on January $23,19 \times 4$.

\section{Dendroica cacrulescens (Gmelin)}

filack-thronted slue iarbler

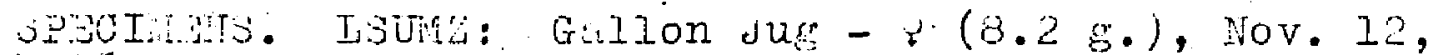

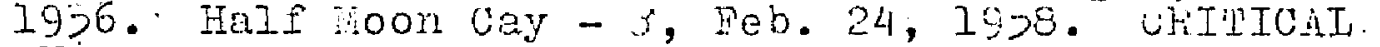
PUBLIDHED KGOLD: Keniezvous point, Jun. 23, 19,4 (Bond, 19:4: 9).

wis werbler is s rere winter viszwnt in British Fondures: I say one individunl at galion Jue on Februry 19; Villis observed nother there on narch מל; and verner found this smecies on Half hoon Cay on ivebruary 10, 19, 22, 24, and Apriz 13, 16. I refer the two Lsmin specinens to D. $\underline{c}$. caerulescens.

\section{Dendroica coronata (Limreus)}

$$
\text { inyrle varblex }
$$

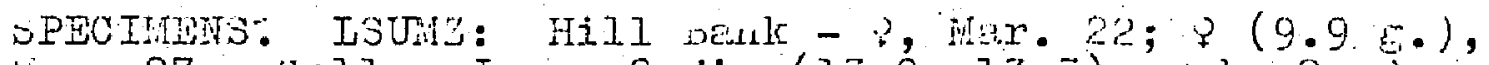
Hov. 27. Gallon Jus - $26^{\prime}$ s (13.0, 13.5), t'eb. 8;

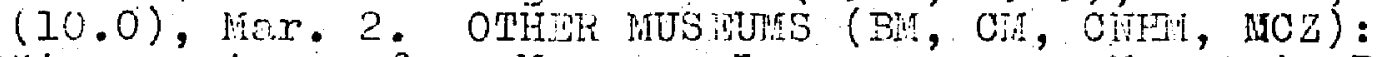
Six specimens from lanatee Lagoon, vayo, hountain Pine Ridge, Hidulesex, 'toledo bettlentnt; Jan., Heb., Nov., Dec. QRITICAI PUBIISIM RECORD: Belize (Jalvin and Godman, Bioloria, i, 1880: 127).

inytle warblers ere spordic winter visitants to the colony, appesing in flocks of up to 0 individuals in some years or as sinte individuns in others. They 
are most frequently found on the keys or lowlund pine ridges and less oiten about clocriniss at the edge of the rain forest. November 17 is the exrliest fall date. In suring, most indjviduals desart in late pebrusry and harch. April 9 is the latest spring date.

A male collected rebruary 3 has a wing gessurenent 331

of $76 \mathrm{~mm}$. and I reien it to D. c. hooveri. ill otier LSUM specimens are tynical of the nonin te form, D. $\underline{\text { c. }}$ coroneta.

עendrojca auduboni (Iomsend) Audubon's Marbler

The only individul of this species recorded fron Eritish Horduris was carefully observed by lancuster at Gallon Jue on January $21,1928$.

\section{Derdroice virens (Gneiin) \\ Plack-throated Green Warbler}

SPAIMTNS. LSUR: Hill Uank - ? (8., H.), Apr. 2;

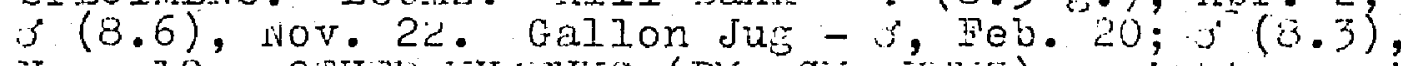

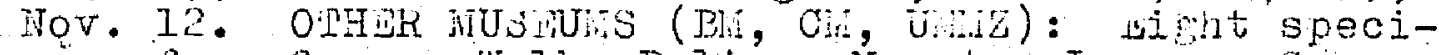
nens from Oxange fials, Belize, nantee Lagoon, Cayo, Rountain Pine Riage; Jan., reb., Apr., Sept., uct., Dec.

l'ine bidck-throated Green warbier is a noderately comon transient and winter visitant in British Honduras. lho earliest individuals in the fall were noted on September 14. Juring the dintes, birds of this species 
nay be soen in ary rooded area, but nost frequently in the pinelands. Migmatis pass nortiward fron lite february into drist, and in one yuer wasual numbers vere seen during the lest veek of npril. lhie latest spring bird was seen in the top of a tree on the amat of one of the neaks of the voctscomb roun wins on mar 9. Unlike rimy transicnte, the tuck-throuted ureen

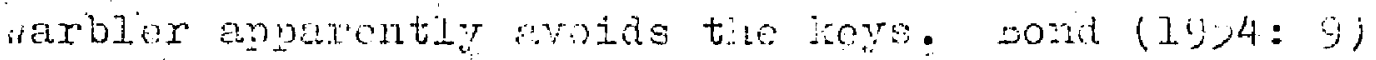
saw orie on worting 'llio vays on Januery 22 , 1944 , for the only insular record.

$$
\text { I refer the speirens from britisin tonduras to }
$$
the nominate form, ‥ $\underline{v}$ virens.

\section{Denaroica corilea (rilson)}

$$
\text { Cerulean itarblor }
$$

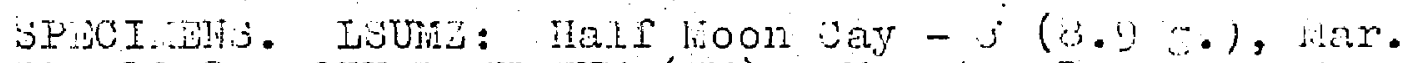

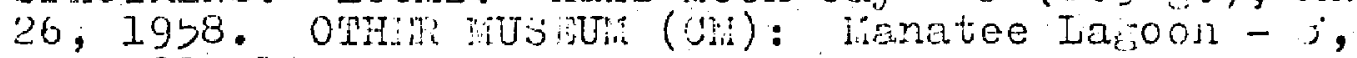
AuE. 28, $190 \%$

On Narch 26, Vornor noted tmee Uerulein Harblors on tall soon cay in edation to the syccisen listed above. He saw one othar bird on Aprill 16. Peck, who collected the other swecimen in the forest nuar mantee Lagoon, states that thjs bira was the first ho ha seen but that nore were observed during the following two weeks. 


\section{Dendroica fusca (miler)}

Blackburnian Varbler

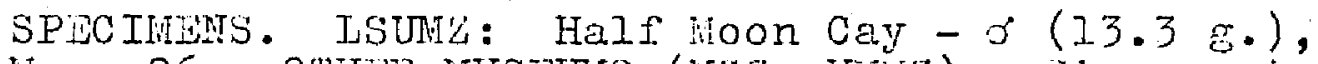

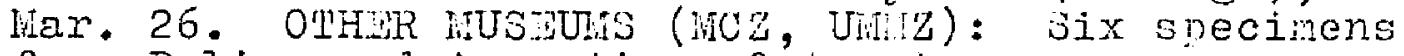
from Belize and Augustine; Oct., Apr.

The Blackburnian Werbler is a seldom recorded. inigrant in British Honduras. The only fall record is that of five specimens collected alory with many other migrants in the tom of Belize by shufeldt on october 9, 1932. On the minland in spring it was collected at Iugustine on April 21 by hustin (1929: 388), who commented that it.was "migrating in large numbers." The species was seen on the rine ridge ewst of. Hill Benk on April 1 (Iancaster), and at roledo Settlement on liay 4 (Peck). On Half Moon Cay, Verner recorded one or two birds on each of the following dates: liarch 26 , April 16, 17, 19, 20; liay 6, 8.' On English Cay on April 21, I saw one exploring palm leaves trat had fallen into the sand. It remained on the key for only a few minutes before flying off.

\section{Dendroica dominica (Linnaeus)}

Yellow-throated Warbler

SPECIMINIS. LSUNZ: Hill Bank - $\sigma$ (11.3 E.), Apr. 1; $\sigma(9.8)$, Nov. 24. Gallon JuE - $7(8.9)$, Mar. 2 ; $\sigma$ (9.3), Mar. 3. Augustine - 3 , Aug. 24; 3 , ?, Dec. 11. OTHER MUSEUMS (CM, UWIIZ, USNM): Twenty-f'ive specimens from Belize, Moho Cay, Manatee Lagoon, Cayo, l2 mi. S Cayo; Jan., Feb., Mar., Aug., Nov. 
In the rinelunds ard in the vicinity of hebitations, the Yellow-throcted Warblex is moderately common as a migrallt and vinter visitor. In the vicinity ot tald, humid forest and on the keys, this warblor does occur in small numbers during nigretion; but it is rere in winter. wurly anrivals have been noted on July 16 (nvens) and by husust tine spucies is not uncommon. foat individuls have dejarted by late narch and the Yellow-throated Warbler has not been recorded later in sprine than frril 1. Ihis species is quite tame and is orten found in toms and villages.

The gpecimens from british Hondurs are all roferublo to D. d. albilora.

\section{Dendroica graciae (Baird)}

Grace's Harbler

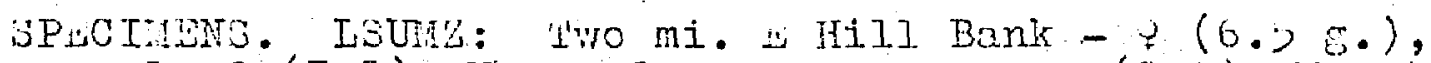
Apr. 1; ? (7.8), Jov. 20. Nugustine - (0.4), hay ; 3 , Aus. 24 One mi. II Bullerina Canp - $5(6.9)$, Apr.

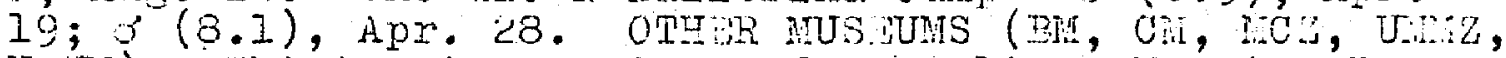
Jisilif): Ihirty-six specimens from belice, lifantee Lagoon, Duck Run, Cayo, $12 \mathrm{mi}$. S Cayo, freetom, All ilines, Ycacos Legoon; Heb., Har., Apr., May, Juine, Sept., Nov.

Grace's Warbler is a moderately common resident of the pilelands at 617 elovtions in british Fonduras. Shufeldt observed that birds were beginning to breed in mid-tebruary. Breeding certainly continues at least into Hay, since specinens collected in lay $b_{i}$ Blake end Agostini had enlarged goncids. I have heard Gruce's 
Wrblers sibein in late november. Durins the months that the rellow-throated iarlbor is jresent in the volony, these two swaies noy often be seen in the sane tree.

Sritisin Hondurn speciners aro representative of

1. 2 - decorin, rice endenic to the colony (vebster, 1961: $06 \%)$. Although the tyne locelity is selize, yll specinens so labeled nust have been token in the vine ridises a rew miles from tom. 'lo my knowledge, this species has not been oborved awy from ine trees in Iritish Honduras.

\section{Dendroica penst IVanica (Jinnaeus)}

Ghestnut-sided Warbler

BRSOTHES. ISUM: Culabash vay - 5 (9.9 8.), Apr. 14. Hali bon Cay - P (9.b), Apr. 19. Ausustire - 0 ,

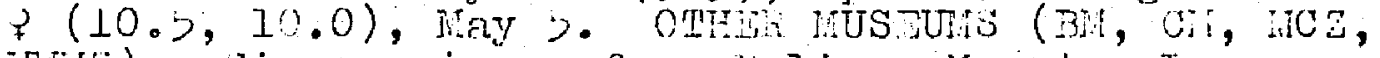

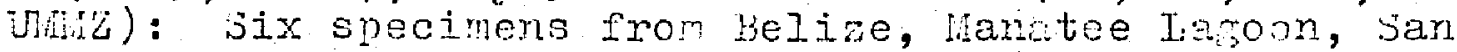
Antonio, ill. Pines, iloledo jettement; fipr., sert., oct.

Whis warbler is an uncomonly recorded tronsiont in the Colony. Fall dates rane from septembar 20 to October 12. willis saw sinile birds on tebruary 20, 27, 28 and Jarch 14; I saw one near Milionario on Mver ID. since the species is not nown to winter regularly north of Nicaragua, these birds vere probibly early niornits and not winter visitants. Fourteen birds heve been noted on eleven dates from April 10 to hrril 2) at Gellon Jus, Calabash and Half loon Lays, and the 
nountain Pine xidge. iustin (1929: 308) sem then "nigrating in large numbers" on the vountain Pine Ridge on April 27 and two or the ISUII specinens mere collected there nay $b$. Where we no other records.

\section{Dendroica cratarea (vilson)}

$$
\text { Sity-breasted farbler }
$$

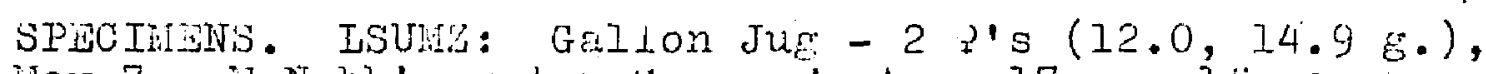

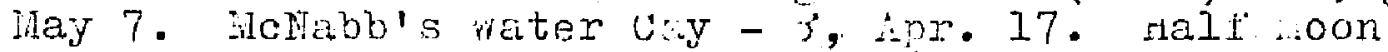

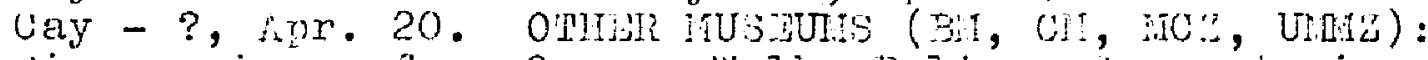
Six specimens from oringe "alk, Belize, Sas antonio, bitiee River, All Pines; Apr., Oct., Jec.

Tine nay-breasted warbler is an uncomon transient in the dolony ard has been recorded only one time in winter (Orange lalk, 1867). Shufelat collected tio in belize on October 9, 1932, for the only fall date. ihree specimens (recorded bove) tron ban fntonio, kI pines, mat stee Kiver were collected on April 24 or 2) in ifferent years. Wwenty-nina edditional intividuals hive been noted on seven occasions fron spril 17 to 27 , all but one on the keys (one at vallon dus). Birds in a flock of foul seen on mulish wey vere yery - tame and pursued elies onto the stens and porcies of the houses there withont cpperent regard lor the people present. Others persistently sough irisects atracted to the llowers of the ralns. un May 7 , Verner sam two birds on Half Moon Cay. The two females coliected on hay 7 at Gallon Jus were very fat. 
Dendroica discolor (Vieizlot)

Prairie Warbler

SPECIREN. ISUIL: Half itoon Cay - j, Apr. I, 1958.

Whe traixie Varbiex hos been recorded only on Halî hoon lay, where Vemer say thirteen individuals on as many dates from lebruary 22 to April 18 and collected one on April 1. In the vitulogue of Eirds in the British Huseum, sharge (188): 643) records a specinen trien "At sea between Janaica and british tondures" in september. Whis specinell should not be considered a sitish Honduren rocord for its exist locklity is unkrown.

The Half lioon Gy bird is typical of the nominate race, D. d. discolor.

Dendroica palmarum (Gmelin)

Dalm Tarbler

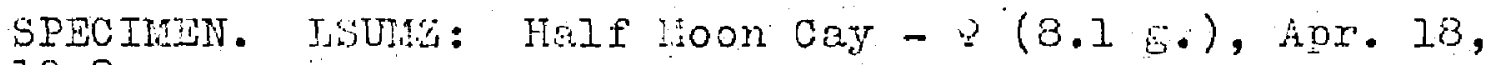
1958.

Wiis warbler is perhaps a recular late winter and spring visitant on the keys on eritish Fonduras but is not plentiful. On Hall itoon vey, verner collected a Paln flarbler und saw 20 others on 17, dates from irebruary 16 to April 22. Fond (1954:9) saw one "in nortiern "Lumeffe" about Januery 21 and $I$ saw a total of four on Calabash lay on April 8, 9, and 10. 
whe specimen is refercbly to D. . . palmamum.

\section{Seiurus aurocapilius (Linrueus)}

Ovenbird

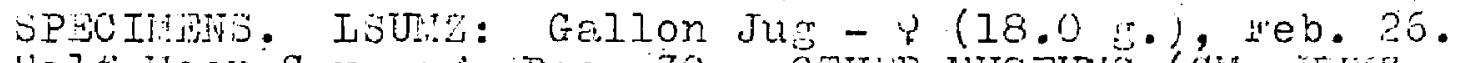

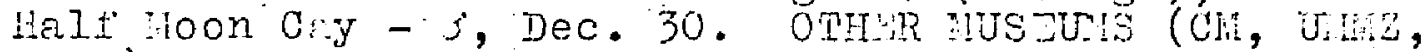
Usiol): Wight specinens from selize, ilenetee I argoon, Duck run, Uayo, Ir slope Uocksconb lits., All Pines; reb., iiter., Apr., Oct.

'the Ovenbirs is moderately common as a spring and fall misrint and also occurs, perings in moderite numers, furing; the winter. Lay sow and netted several on the outskirts of Jelize on lu ust 27; sperenty these birds were nembers of a "wave" of treneionts. iilost individuals of this species have departed by the end of harcin but a few nifrat; continue throus until early Hay. Whe latost date is may 9. wintoring biras prefer the forest floor but ure not restricted to it; the only. Decenber specinen was twken by van pets in omistnet in the boob: colony orl Hilf inoon vay.

I refer the LSUMa spoimens to the nominate forr, $328 /$

i. E- aurocapilius, in thoservations regerding the certainty of the identicication. I did not criticaly examine the other specimens.

Seiurus noveboracensis (Grnelin)

Northern Hatertirush

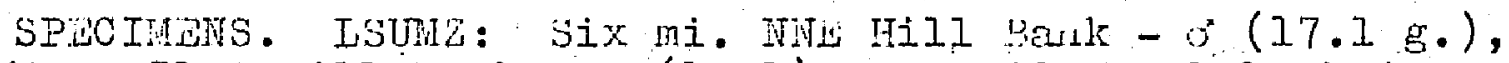
. Mar. 31. Hill Bank - p (18.1), Nov. 22. Calabash Cay - 


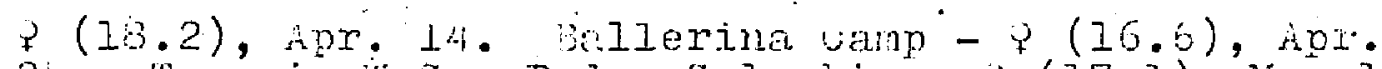
22. To mi. San Pedro Columbin-

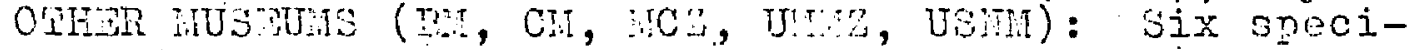
nens fron belize; Cayo, weetom; Anr., It:y, Dec.

pis varbler is a noder.tely comor migrant and winter rialtant, pueferring low wet for sted areas near the coast and on tue keys. Iay mist-netted soveral near Jeliae on inust 27 , the earliest date of record. Dond found tinis species to be comon in January on iumetie and forthorn lwo viys, al trough on the winlfond arily counts in wintry seldon exceed two birds. whe number. of individutls inccase during late larch and ronizin high until neerly tie end of April. Irsnsients continue to ns: through tine colony in reduced numbrs dunino the first week in way one specinen was obtained on the late date of iny $1 \%$. lile studies by drton (19:7: 229-239) indicate trat reconition of peouphical variation in tre fiorthem waterthusu is inriticable because of be excentiona anount of intiriand veration. AIthough I have uxarined

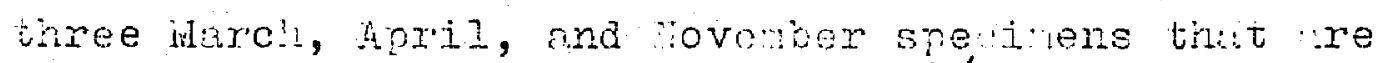
"typical" or ‥ n. noveborecensis and one kpril procian that is tpprently s. n. notubilis, thase identipicntions are posizibly in error.

\section{ocilurus motacilla (vieillot)}

Louiglane vaterthrush

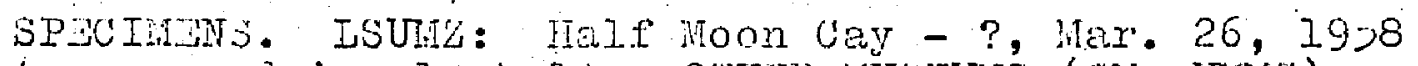

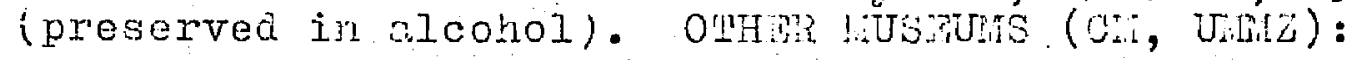




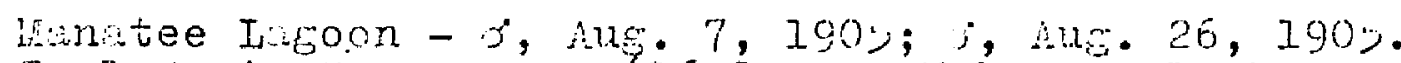
TweIve ni. 3 vayo - j (16.0 6.), lieb. 21 , 1931.

Hilis saw aigitt Louisimn waterthrushes on seven dates in the parlod or July 21 to subust 1 at Gillion Jug and rill tank. no other observations suplewent the syecimen records of this species. l'he speoinen from the Jountain Pine fiage was capwred by van lyne in a mist net suspenced over a anail stroam.

\section{Oporomis tormosus (Wilson) rentucky Varbler}

SPMCITHS. LSURz: Gallon Jur - y, Jan. 8; ? (12.6 G), Mar. $3 ;$ ? ( 12.7$)$, lar. I1. Half Mo on Uay $-j$

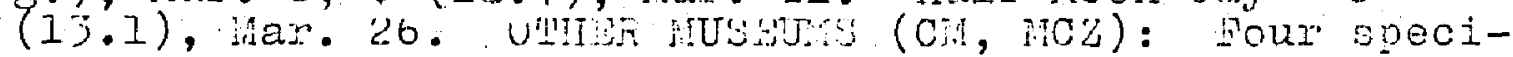
mens from hanatee rafoon, fountiin vow, and poledo Settlement; Apr., Aug., Sept., Dec.

The kentucky $\because$ arbler arrives in late August (rirst collected Aurust 31 ) ma is prosent in noderwte rubers untilmid-njil. intering individuals frequent the forest und rerowth but transients hay occur anywere, even on the keys. unusially hich daily counts, sussestinğ the passage of transients, have been mde on larch 14 and 26, April 16, anci october 24. The latest siring bird tas observed on April 18. 
Oporornis acilis (Vilson)

Connecticut Warbles

On hisy 7, 19be, vemer observed a typicul. vonneticut arblex under ineal conditions on Filf Foon cay. An effort to coliect the bird was unsuccessful. Athous the rosnibiity of misidentipation always exists, I peel that this observation is correct; the obscrver wo ware of tho rerity of this apecies and de also say a touming marbler on the sane duy wisenianr (19y0: 207) statar thit tiere "seems to be no iddale tmerican record of the connecticut harbler."

\section{Gorornis philedelohia (Hilson)}

$$
\text { nourning iarbler }
$$

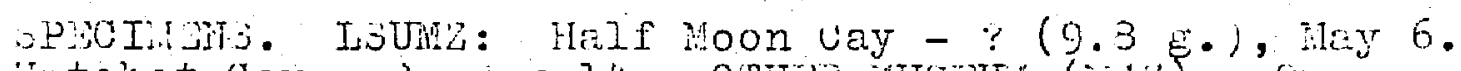

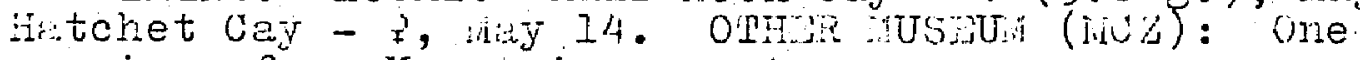
specinen from wiountain low; Apr.

The nourning forbler is threly recorded inimant

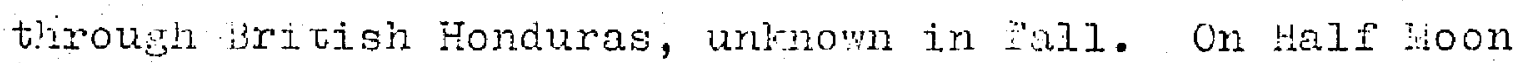
Cay, Voner saw two infividuals on hay 6 and one bird on the succeedin; two days. ithis recorded one ct Gralion Jus on may 12. In adition to the observations and specinens citad above, the only refarence to this species in the volony is thit by dustin (1929: 388) who considered it "comon everywere." this statement is misleading, for Austin was in the volony for six veelis 
and worked in several areas. I suryect his conient was the rosult of a lopsus or was nade in roference to a wave of migrants on April 14, the date on ahch he collected a specimen.

\section{Geothlyois triehas (Iinnaeus) \\ Yellowthroat}

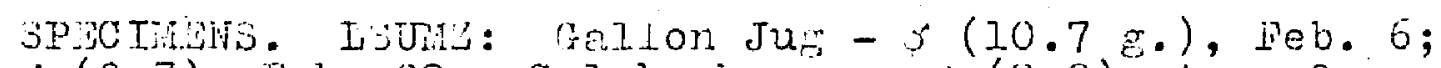
3 (9.7), Feb. 28. Calmash vay - ?(8.2), Anr. 9. Two mi. " San Pedro - $(9.4)$, Hay 11 . OMJTR (CN, Bil, Uling): Twenty-two specimens from Belize, Manatee Lasoon, 12 mi. $\$$ Cayo, Freetom, south West vsy; all months except dune - sept.

whe rellowinroat is one of the commonest of the tronsient and wintenin: warblers, outmubared only by the Nagnolia arbler. It arrives in late tugust (nuast 27 is the enriest date) and is cburdant by ootober. It is found in brusts and undergrowth on the keys and tile nainland. the numbers of individuels seen per day increase slichtly in late irebruary and eanly Marcih, then decline very eraduilly until mid-lay. We latest sprires date is fiuy 29, when a specinen was collected by Blake and LFostini on south lest Cay, Glover's reef.

I refer thirteen specimens thet I critically examined to $G$. 立. brachiductyIus. 'I'wo other specinens fre probably referable to either $G \cdot t$. buachidactylus or $G \cdot \underline{t} \cdot \underline{t r i c h a s}$. 
Uizamaethlypis poliocephela (Baird)

\section{Ground-chat}

SPECIlind, LSUM: - Two mi. E Hill Benk - 3, Mar. 23; q $(14.6$ 8.), Apr. 1 ; $\sigma(1 ; .2)$, Hov. 29. Hive Mi. W Benldy beacon - 2 : 13.9 , 14.1), Ar. 19; $(14.2)$, Apr. 20. Augustzne - 0 (14.2), liar. 19; (13.9),

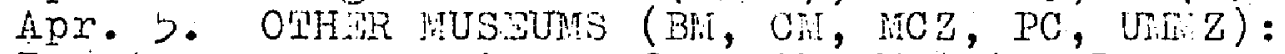
Twenty-seven specinens from the Mantee Iagoon area, 12 mi. S Cayo, rreetom, All pines; all nonths except Jan., July, עec.

line fround-chet is a comon resident in the thickets of the pine ridses at all altitudes. It is found locally in moderate nunbors in tall srass and low second growth. The species has not been recorded south of Ycacos Lagoon. I did not collect individuls with enlarged sonds before mid-April. jach of the five birds collected by rlake and nostrini in late April and wy were in breedin condition.

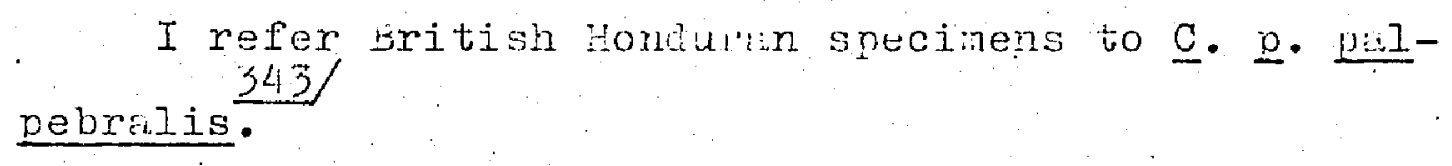

Icteria virens (Iinnaeus)

Yellow-bressted linet

SPYCIIHTS. ISUTZ: ballon Jug - ? (22.0 G.), Heb. 2I;

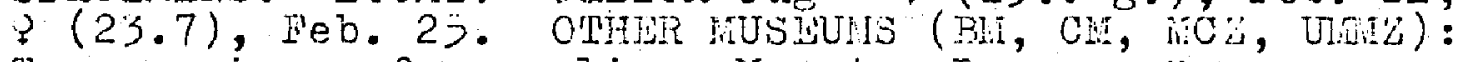
Ten specimens from belize, Inatee Laroon, Cayo, san Felipe, 12 mi. S Layo, Hountain Corr; Jan., Heb., Har., Apr., Oct., Dec.

the Yellow-breasted chet is a retiring but ratie: connon transient and winter visitant, freruenting thickets and second Erowth on the nainland. Warly fall 
migrants hive been seen on jeptember 4. In spring, most individuals have departed by early April but some have lingered until April 20. Mlthough usually shy, birds of this syecies sometines forase about houses and remain in the open for some time. One individual at Augustine was observed consuning the entire small, but exceedingly hot, fruit of a cultiveted red pepper nlant. The Yallow-breasted ulret lits never been recorded on the keys.

the nine pocinens from the volong thit 1 have critically examined are reforable to $\underline{I} \cdot \underline{v}$. virens.

\section{Granatellus sallaei (Boneparte)}

$$
\text { Gray-throeted Uhat }
$$

SPCIMins. Bh, UWH: Festern $L=$ Cayol District two undsted specinens. Cayo - j, Mar. 27, 1923.

Whis warbler is a rare resident or British Fonduras. Willis saw one or two inoividuets on a number of occasions from Feuruary through July at Gallon Jug and presuned that the species nested in the arra.

Ven l'yne exanined the cayo specumen in the U.S. Vational Huseum and referred it to $G$. $s$. boucardi. The two specimens in the British theun were reported by van rossem (1934: 404) as internediate between $\underline{G}$. and $G$. S- Brisconi. As the latter race is probably unterlable (Paynter, 19p7a: 273), it can only be assumed that the two British ifuseun specinens are not typical of $\underline{G}$. $\underline{\text { s. }}$ boucardi. 


\section{Wilsonia citrina (lodinert)}

Ilooded Warbler

SP. Wilsonia citring (rodiaert)

ONI

spt

Ilooded Warbler

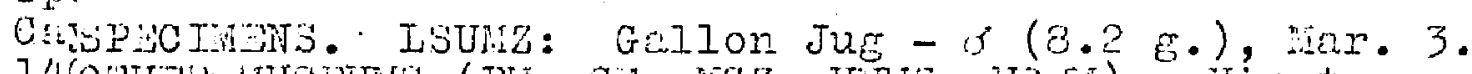

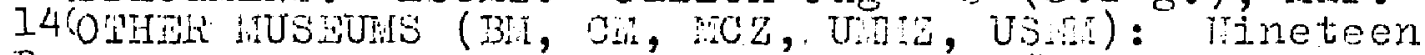
Despecimens fron belize, hanatee Iagoon, Cayo, $11 \mathrm{mi}$. S mave:yo, Loun uain uon, $N$ slope vockscomb itts. (1c00', 1400'), All Pines; Jun., iteb., har., Apr., Rur., ;ept., Dec. CHIIICAL PUPLIGHD RLCORD: Orange falk (HeI1whe Hooded iarbier becones common shortiy cifter.

the arrival of the earliest fall mismuts (earliest dite, nugust 13). It continues to be conion throushout the winter and until early hril (latest date, April 20). Daily counts of individuals rise sonewhat in late Februm and in larch with the passage of birds that wintered farther soutr. "uinter visitme ane most often seer in tile underirowth of tall forcst and second srowth on the mainland, but lond (1954: 10) noted one on Northern Two Cays on Jenuary 22 .

\section{Hilsonia pusille (Milson)}

Wilson's :arbler

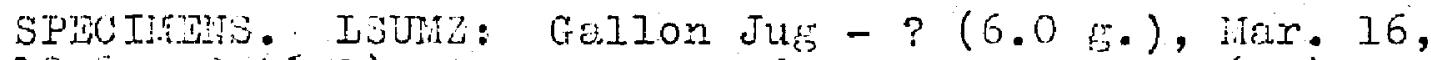

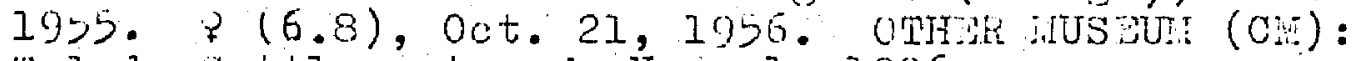
I'oledo Settlement -3 , Tov. 1, 1906.

The lilson's farbler is a rathor unconiton transient and ariter visitant in the Colony, although in the late winter in 19,7, HIIis saw four to $3 i x$ biros daily at Galion Jug from February 18 to liarch 12. In number, :illis' observations during this veriod exced ell other 
observations of the species in uritish Hondures conbined. No evidence indicates the pensine of numerous riments, unless this species begins its rortimfrd novenent very early and the birds noted by dillis newe wirsuts. linis species has not been seen earliar tran october el or

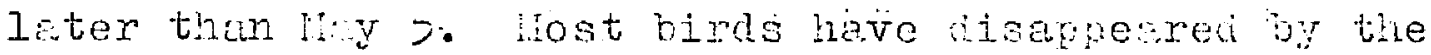
end of wroh. 'the individual seer on r.Tay, we on Halt Hoon cay and ans udoubtedly a belated misment. The specimens axe andl and have semish becks. 347

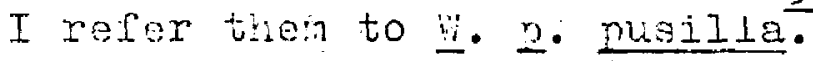

\section{Wilsonia cancdensis (Iinueus)}

$$
\text { Cansta, Wroler }
$$

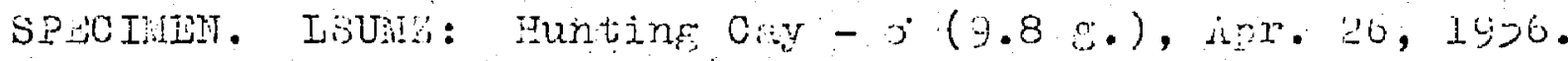

Where are tew records of tisis npecies fron Dritisi Honturos. Sing Le birds were seen at Galion Jug on Jenuary 22, Mroh 2, and Ajril 20 , ind at ubetas on harch 15. verner noted two on lialf inoon wy, one of them on February 17 and the other on tarch 26. whe Hebrukry individual is aresumably a very enly nigrant, but the bird sesn at Gallon Jug in Junuery (by Lencaster) may have been wintering.

\section{Setophage ruticilla (Linnaeus)}

American Redstart

SPECIRISTS. ISUIT: Gallon Jug - $0(7.1 \mathrm{~g} \cdot)$, Ilar. 10. OTHYR MUSWUAS (BR, CM, MCZ, UMH, USEM): Wineteen specimens from Belize, Hanatee Iagoon, Wayo, San Felipe, 
Mountain vow, Al Pines; all months except liay, June, July, sept.

In practically all habitats on tio keys and the minlend, the Anoricen ledotort is one of the comonest warblers from early anust until the following inay. Wonspicuous peaks in raly counts of individu La cour in late october and early november ard for a nonth beginning fith the last meek of narch. watrene daves are sulut 2 and iay 11. Hostert nigration is espocially noticeable on the keys.

Hot:ore (1949: 130-59) ks identified hoth …… $348 /(1949 \cdot 130-59) 349$

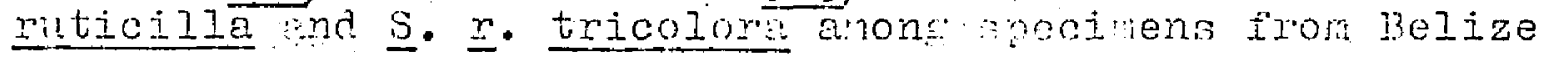
and cayo.

\section{Basileuterus calicivorus ('. Deppe)}

Golien-cromed wroler

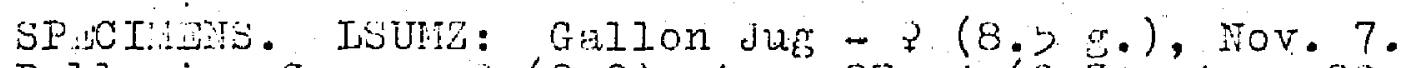
Ballerina Comp - (9.9), Apr. 27; (9.3), apr. 29.

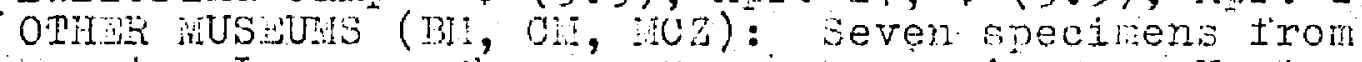
danatee Lacoon, uhorro, vayo, Hountain vow, it slope vockscomb ilts. (I8bo'); nar., Apr., sept.

lhis warblex is an uncomon and rather locally distributed resident in sritish Honduras, were in addition to the localities listed above it has been noted only near Milionario and Humingbird Gap. It has been obs rved nost frequently in tall, hunid forest, occasionally at the forest odge. bularged gonads have been noted in birds collected in late 
larch and April, and wilis noted an adult chip oing and carrying food at Gellon JuE on June 30 .

Golden-cromed Varblen from puebla south to losta rica re referred to 3 . c. culioivorus.

\section{Basjleuterus rufitrons (swatinson)}

$$
\text { Rutous-capned varbler }
$$

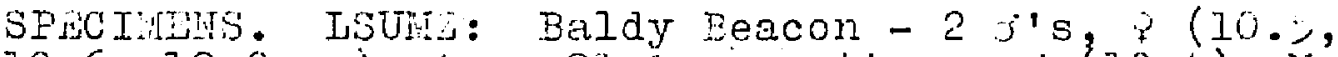
$10.6,12 . ? \mathrm{~g})$, Apr. 21. Augustine - $5(10.4)$, tar.

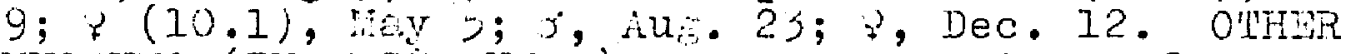

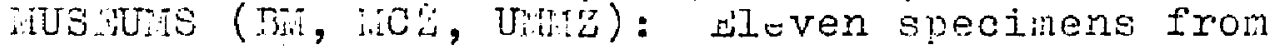
ilountain Pine kiage, 12 ni. $S$ Cayo, Austine; Peb., ipr.

In British Honduras, this resident warblur is rastricted. to tine region of the Houn vin Pine Riuge. lhero, it is found onjy in the mriss- and palnettofilled rovines and in the sorub crowtis that occurs where rain forust intruios into the pinelunds; but in suci havitat, it is hodertely comon. 'ihe ISUnz April specinene ere in breeding condition.

Snecimens from writish Hondures have completely yellow under parts, bright, oreenisi-olive backs, and an olive, not bufy, tinge on the rlanks and crissun. I refer then to $\underline{B}$. $\underline{\text {. salvini. }}$. 
Tamily ICMPIDA

Larhynchus wayleri (Gray and ritchell)

Magled oropendola

SPEUTMUS. ISUT: Seven mi. IN San redro volunbia -

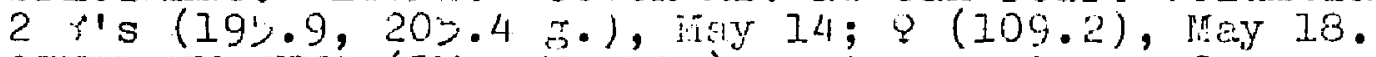

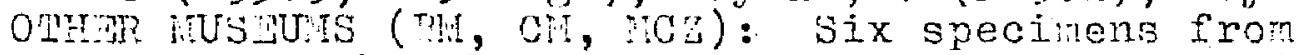
tastern orunch lelize kiver, unp vI, loledo Settlenent; War., Dec.

In British Ionduras, the Vagler Oropendola has been found only at the locelities listod above, wich are in areas of tail, humid forest in the southern cind western parts of the volony. It is a resident species - cna is much less connon than the iontezuna uropenaula. 1. found an acive colony of these birds in aid-hay near Sun iedro Colunbia: the 23 nost were suspended between 60 and 130 feet above the round fron a tree tinat was prominent because oi i us location on alioht hill. The area was one on unbroken forest some distence fro:n any strean or rivex. A fresily $r$ llen nest below the tree contained two eges and nost of the othe- nests rexe occupied.

From liexico soutr to Honduras, the populations of this species are 2 . W. agleri.

Gymostinons montezume (Lesson)

Hontezuma Oropendola

BPGCIMNS. ISUAR: Hill Bank - 2 9's (212.0, 23I.I E.), i'eb. 16; $27^{\prime} s, \operatorname{lug} .14 ; 6, ?(333.2,226.6)$, Nov. 20; 
o (301.1), Nov. 27. Bullerina isomp - P (197.3), Apr.

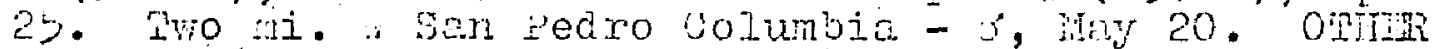

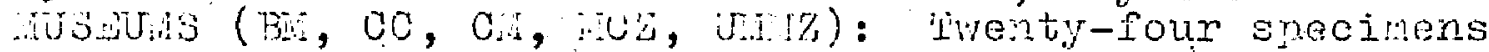
fron the binatee Iaroon area, Cavo, fountain vow, Freetow, loledo settlement; Jun. to July, inclusive.

Whe lontema oroperdols is one of the more conspicuous and charoteristic resident species of the lowlands of the colony. Test trens, sone contrining

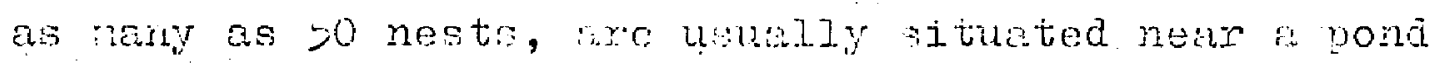
or running strean at elevstions below lpon ieet. "Yellow-tilis," as they are often cilled, forase over an extensive croa but do not sine tive prefonence of the lagler oropeniola for tall forest. wheis manderings becone nore extensive in fall and inter, as sone individuals even entor the edse of the rountirn pine aidge. llests contairins ogis have been roted from emly hpril to $j u I y$.

\section{Mnblycercus nolosericeus (i. Leppe).}

Yellow-billed cacinue

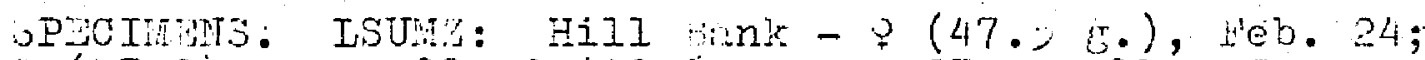
$7(27.9)$, Mov. 20; (48.6), HOV. 27. Grilon Jus - r, Jan. j; ? (62.3), tar. 4; ? ( 22.1$)$, dune 1;? (67.6),

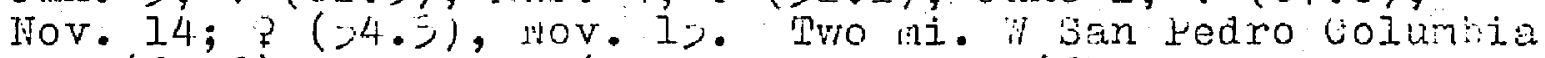

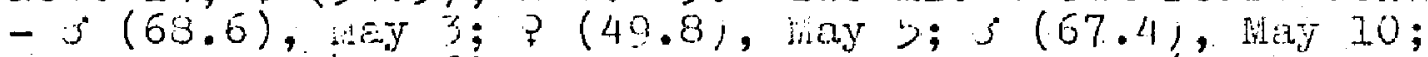

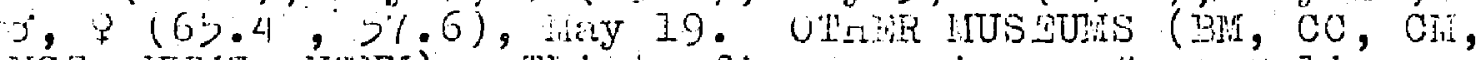
MCZ, Uiliz, USMi): Thirty-five specinens from iselize, Sibun River, Manatee Ingoon area, Ocyo, Freetow; Jan., fir., Apr., itis, June, July.

The Yellow-bilied Cacigue is a cormon resident of dense sladed uncergrowth throughout the colony. It seems to be most abundant in the more humid regions. 
Where it is found in dense cane thickets and in the low tangled growth alone streambanks, at forest edges, and and high humil. In these nabitats, daily counts may range as high as 20 inividmas. ilie sound of tenring or splittine veretation (wich has led to its local name of: "bmboo cracker") aild wistles and churrs are the most frequent indications of the bird's presence. Birds in breeding condition have been noted only in rray, althoukl jkutch (1904: 284) notes a nesting season in wosta Rica extendine from January into June. the central hinexican rece is 1 - holosoriceus.

\section{Scaphidura oryaivora (Gmelin)}

\section{Giant Cowbird}

SPACIMBHS. LSUNZ: Gallon Jug - s(2I0.; E.), ver. 3; 5 ,

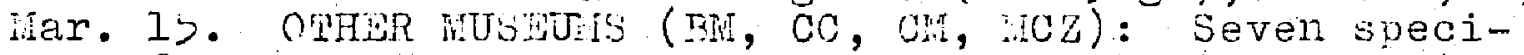
mens from nanatee liagoon area, Cayo, Jan irelipe, "reetown, l'oledo Settlement; Peb., hor., May.

The Giant Cowbird, or "tickbird," is a moderately comon resident of British Honruras, al though somewhat local in its occurrence. It is a bird of open fields and yastures, especially tinose actually occuried by livestock, at lower elevations in the vicinity of rain forost. Hill Bank and the dorth stann Creak villey are the only two adoitionel areas were this species has been observed. At Gallon Jug this cowbird was seen regularly, yet the Iontezuma oroptndola, the nests of mich are the most frequent recipients of the eggs of this parasitic 
species, did not nest in the inlediate region. The two nales collected in nerch had fuliy enlarged testes. Presumbly the reeding aeason is coincident rith thet of the oropenoles.

The northem race of the diant coubind, raning

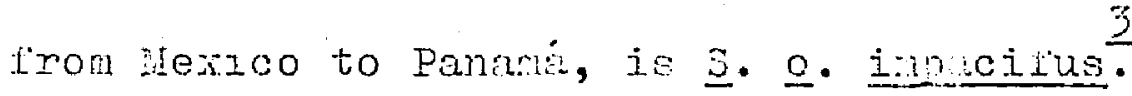

$$
\frac{\text { Tumpivius zeneus (Wa-ier) }}{\text { Red-eyed jowbird }}
$$

SPGCIMitit. Bur: Cato.

Line ched-eyed vowbird ranes from the united states to parame and is fairly comon in some areas. In british :ionduris, however, it is known pron only is shmle undated specinen in the British tuseum. mis specinen, exanined some years aro by loud, prosumbly nould be refereble to tine norinate race, ‥ a. aenens. Paynter (19y5: 262) has recorded thie combira at uhetwal, ouintan: roo, inexico. It sems likely tiat it wi.l be noted at otiner localities in Britiah Hondures.

\section{Cessidix nexicamus (Gnelin) \\ Great-tailed Grackle}

SPICIMINS. ISUM: Galabash Cay -2 rs (153.6, 214.3 g.), Apr. 8; 2 s's; $9(199.0,206.1,129.5), \mathrm{An}^{\circ} .9 ; 0$

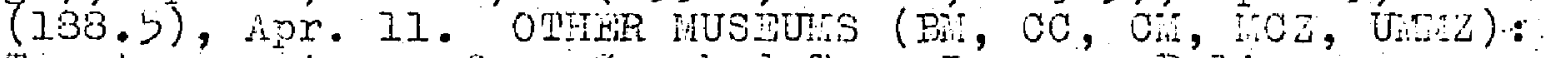
Thenty specimens from Grooked lree Lacroon, Belise, Hanntee Lagoon, Half Moon cey, ireetow, ill Pines; all nontis except Feb., July, AuE., Oct. 
In all coastel areas and on nost of the keys, the Greit-t iled Groclie is a comon and noisy resident. It is less comon inlend, although it does follo: the major watercourses and has been recorded ts fir inland as $3 a n$ Antorio in 'loledo bistrict and bill zank. Uith the excentions of Glover's heef, wher it has not been recorded, and Half Hoon Uay, were it occurs aporidicaly, this grockle is conon on alt leys wiere there wre coconut palms in wicin to aest. In Beliee wh the coastal settlenents, tis necies is probably the most characteristic bird. The fenale collected in enly hill on Vulabasi cur contwined an ese in the oviduct. willis noted a female corrying food to t nost in wn epiphyto in a bucida tree at Hill fenk on Aumst 5. The oreeding season is probably more extensive then is sursested by these few observitions.

I refor spocinens from Rxitish Honduas to $\underline{\mathrm{C}}$. in. nexicnnus. $356 /$

\section{Dives aives (Deppe)}

nelodius snclebird

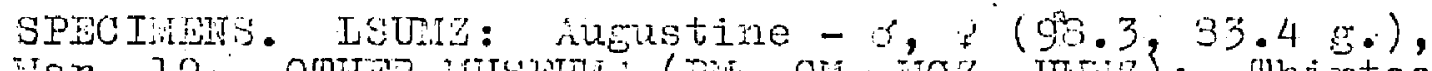

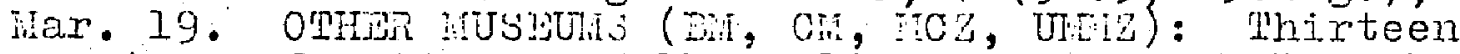
specimens Iron Orange Walk, Belize, Cayo, Duck Fun, 12 mi. is bayo, Mountain Cow, Freetom; Peb., Apr., hay.

The helodius Blackbird is a common resident of British Fonduris, occurring almost everywire except 
on the keys and in the henrt of the tall, humid forest. It is especjenly comon rear habitations in the second srowth of old clearings, and in the low brushy growth of riverbanks. when clearings are made in the rain fowest as a result of lowing oporations, tinis is one of the first suecies to populate the:.. specnens tith enlarged gorsds hove been token in spril and lay; but the two birds collected irarch ic did not heve enlarged zonads.

The centm herican form of this soecies is the 357

roninate race, D. a. nives.

Icterus sturius (Limaens)

Orohiard Oriole

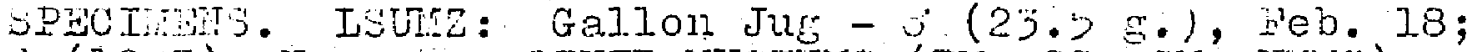

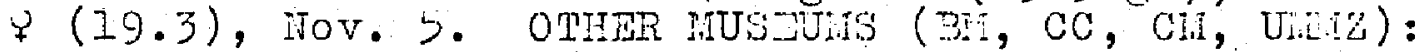
Thirty speciilens from Orance Valk, Belize, lianatee Lacoon, Cayo, San Relipe, $\Lambda I I$ Pines, Holedo jettlenent; Jan., lieb., ifar., Apr., עec.

In winter and enring this oriole is sbundant in tine vicinity of clearinge end plontations. Although Willis noted 15 individuals on Autust 6 , tho noxt carliest fall date of record in Hritish Honduras is irovember 5. Perhaps early fall niblents continue south and the winter visitants consist of tise latest micruts to leave the United States. Birds thet were definitely transients were noted on ialf Noon Cay from tharch 26 to april 20. The latter date is also the extrene spring 
date. Orchard Orioles occur in nolsy flocks, sonetines numbering as many as 70 birds, during their stay in the colony.

\section{Icterus prosthene]as (strickland)}

\section{Birch-cowled uriole}

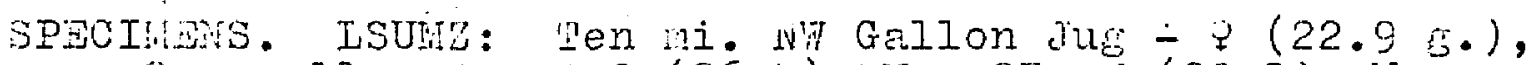
Hov. 8. irulion jug.$- ?(26.5)$, mey 27 ; $3(29.8)$, liay $30 ; ?$, Aus. 17; $(27.1)$, Oct. 26; ? (26.1), iNov. I. Hill Sark - $(29.0)$, Nov. 25. Two ni. si Hill Banle - $x$, Q (26.2, 29.1), Iiov. 23. Seven mi. W\% Belize on corosal Rd. - $3(30.6)$, Ars. 5. Stann Creek - $0(32.1)$, liar. 24. Stlierina Camp - $(29.4)$, Apr. 24. Two mi. Wan Pedro columbia - $\sigma(30.7)$, fay b; $5(28.7)$, hay il;

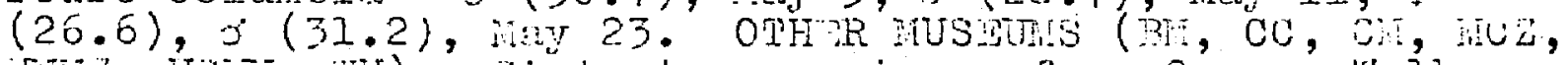

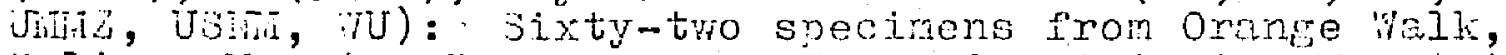
Belize, iranatee Ingoun area, Cayo, San Antonio, Mountain Pine ridge, hountin vow, Freetom, sll wines; all months

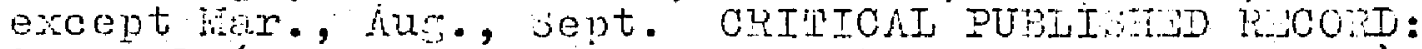
Corosal (Selvin :nd Godman, Bioloria, i, 1883: 467).

The black-cowled uriole is o com ton and widy distributed resident througlout sritish Hondurss. It is li ely to be round in coestal mancroves, lovland pi:.e. forests, toms, end in aroes once cleared by wan that are in any stafe of second rrowth. Athough not prinarily a bird of tall, unisturbed forest, it is found in and around clearings winin rin forest. It occurs in the Mountain rine Ridge only where rain forcst is present, yet it may venture a short astance into the pine lands. Gonads ö̈ birds taken in harch, April, and Niay indicate thet breeding occurs in those months and contimues at least into June. 
I. p. protheme $\frac{358 / 5}{\text { is }}$ the race to mich I refer tre British Honduran birdis.

\section{Ioterus cucialatus (Bwainson)}

Hoodea uriole

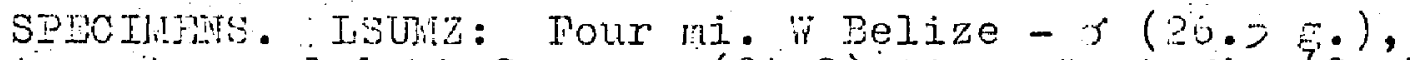
Apr. 4. Ulabash Coy - s (24.8), $1 \mathrm{pr}$. 9; 4345725.1 , $20.3,26.1,26.5)$; Apr. 10; $3 \%$ (23.2, 24.0, 24.1), Apr. 11; $7,6(--, 2,3)$, Apr. $13 ; 9(27.5)$, Apr. 14.

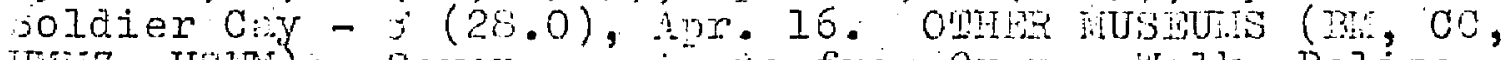
U:IIZ, USmi): Seven specinens from Ortnre valk, Belize, Cayo; Jan.; H'eb., Mar., Apr., Dec. CRITICRI PUDLISHAD ACC:DS: Ranetee (Griscon, 1926: 18), Turmeffe Cays (Bond, 19,4: 10).

On the larcer of the llumeffe vays, uspecially those rith extersive coconut "walks," the Ioodel Oriole is common. Griscom (1926: 19) observed a "flock" on Anberfris cay. On the nainland this oriole has been noted in noderate numbers in the constal scrub rowth near belize ard it lias been collected at orcinge Wolk and cayo. Nost of the individuals talen on thrmeffe inad fully enlarged gonads.

paynter (1955: 268) ho reported on the variability of the nomlation of this species occuryins the Yucatin Peninsula and its islunds. He was oble to recognize only one rece from the peninsula, I. $c$. isneus, and ne considered I. c. masoni a synonym of I. c. igneus. A critical examination of the Belize and tumeffe specinens confirms Payntex's convictions. Iritish Honduras birds are highly: variable, but mat be matched by specinens 
from Chichén Itzá. Insular ma mainland rpecimens from the Colony are similar. Oonse uently, I refer all British honduren specinens to $I$. c. imeus.

\section{Icterils mesumeles (Vagler)}

Yellow-tailed oriole

SPWCILAS. LSUIS: Gallon Jug - ; (44.9 g.), Mar. 7; $\sigma(43.0)$, inay $6 ; 3(47.7)$, oct. 23. rour ni. Belize - 2, Apr. 4. Augustine - (4\%:3), livy b; 5 , iug. 13.

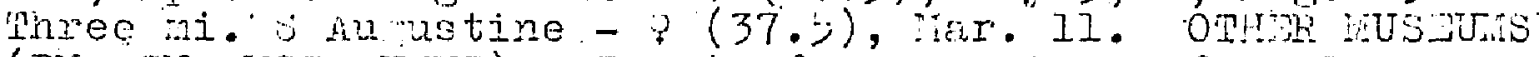

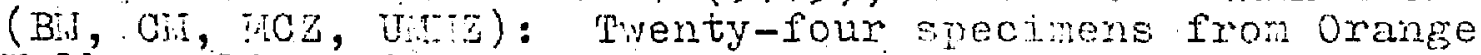
Walk, Belize, Cayo, lc mi. S Cayo, Camp VI, kio Grende; Jan., Feb., iiar., Apr. CRITICAI PUNISHW ROCOD: Corozal (Sclater, 1836: 379).

I have seen this resident oriole only at Ballorina conp and rendal in adition to tise localities listed above; Peck say it on the loho nd liemsh Rivers. flthough it ney be seon regularly in the suitible habitats where it does occur, it is somemat local in its distribution, being sosent from many mparently uable areas. Ihe Yellow-tailed oriole prefers riverside tengles, the second growth tilckets that sping up in an-mae clearings, and the edge of the rain forost that borders the Mountain Pine Ridge. It is not very abuedant in any habitat. the conads of some of the birds taken in llarch, April, and ifky more at least slighty enIarged.

The ruce of this species of oriole in the northern part of Centrsl Americe is I. $\underline{\text { m. mesomelas. }}$ 


\section{Icterus chrysater (Jesson)}

\section{Yellow-backed Oriole}

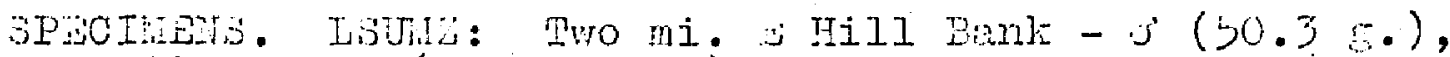
Mov. $22 ; 2$ s's $(48.1,>0.6)$, Jov. 29 . Five mi. it Bulay Beacon - ? (50.1), Apr. 19; (46.2), spr. 20. Augustine - . (45.8), Mar. 19; 3 (5.9), Vay ; 3 , Dec.

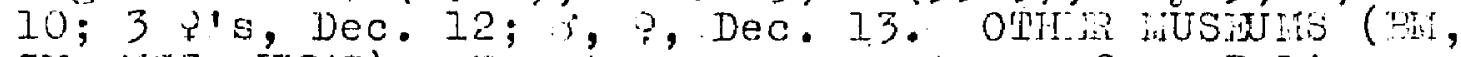

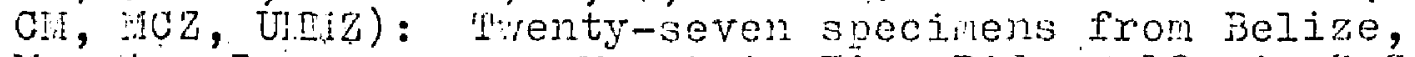
Hisnatee Ls,oon area, Jountain Dine Fidge, la mi. S Cayo, Nugustine, Cimp VI; all nontiss except JuIy, Oct., Dec.

Yellow-bisced rioles fre moderntely comon residents of the pinel nds at all alevions thronhout the Colory, and occasionaldr ther nay waer into thickets thet adjoin the vine ridns. In the foll and minter, especiely, tireso orioles bun into noisy grouns of sire to eight individuels, edilos and imatures,

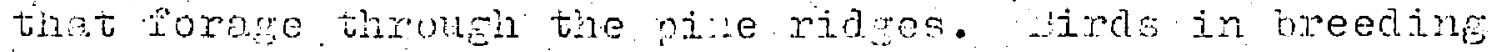
coldition have been collected as enrly as harch, and Peck reports tro nests conteining youn thet were found in hoy and June. These nests vero attroched to the underside of: palnetto leaves about 3 to 10 reet sbove the ground in the pine ridge.

I refer tive Britisn Fonturm population of tris species to the nominote fom, I. c. chrysater. populstion of the Yucatín Eeninsule ilas been nened I. C. Mayensis by van fossem, solely on the bosil: ot the ameler size of the vacatin birds in comprison with all other races. vin Rossem (1938b: 137) eives the range of the wing neasurenente of eight adult males 
of I. c. meyensis as $90-90$ rare, but coes not state tise near. Seven adult nales fron sritin Hondu.s havo

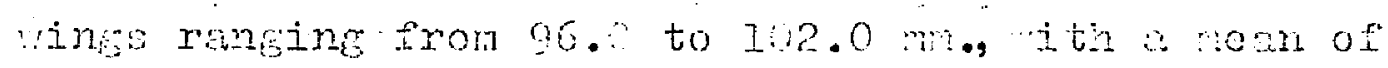

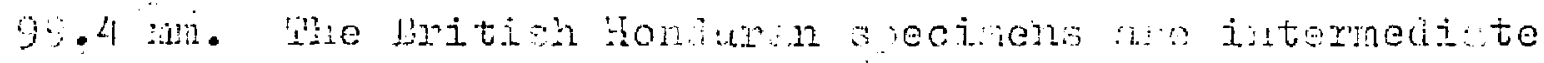
in size botwen the tro roos, hor a suies os eirit

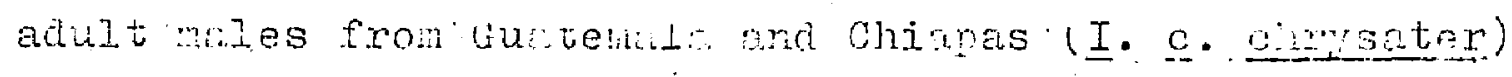

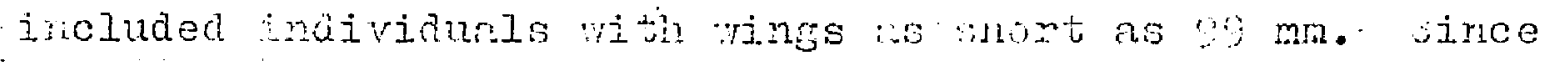
Iive of the soven mies from the colony buve and nearare-

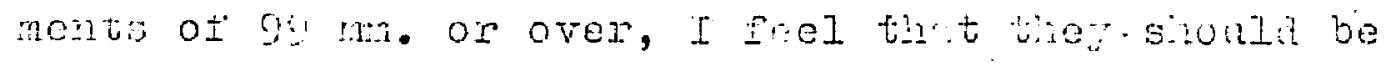
ussigned to tre noninaic race. An adilt nilo oollected

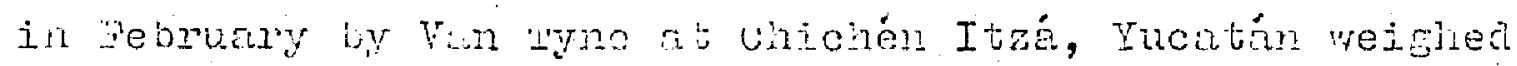
onIy 40.8 mens. Whe rict jut the minimur weignt of

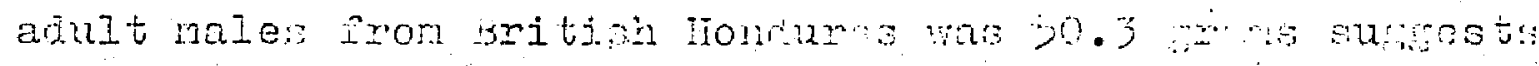

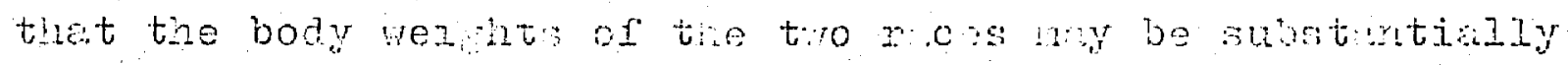
difierent.

Ieterus gularis (

:Hach-tinoster oriole

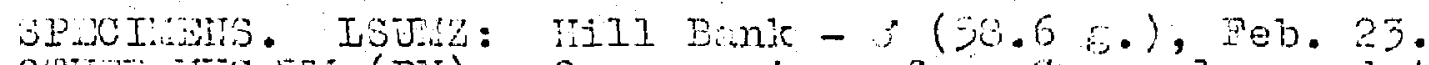

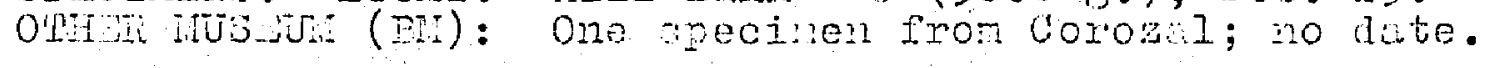

Iay obsorved several BIcol-throsted oriolos et Corozal in Aucust 1960, Iancastor an one individual at Galion Jus in Januery, and I san two others cone collected) at Hill junt in pebruary.

I refor the male from Hill sent: to 1 . E. yucatanensis and Griscon (fide Iodd) considred the lenale from Corozal "close to yucetinensis." 


\section{Icterus givila (Iinnaeus)}

\section{Ealtirure Oriole}

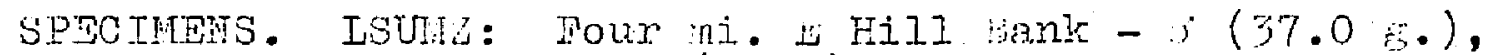
Feb. 28. Crallon Jug - $3(32.4)$, Tov. 10. Hali jioon

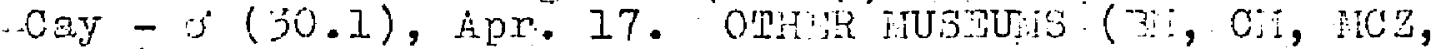
UHz): I'en specinens from Helize, Cyo, Hountuin Cow, All Pirres; dart., Feb., ipr., sept., llov.

lhe sitinore oriole is an unconion trunsient and winter visitunt in the volony. It has been obsonved most frequenty in the open pine riaces and in scttered

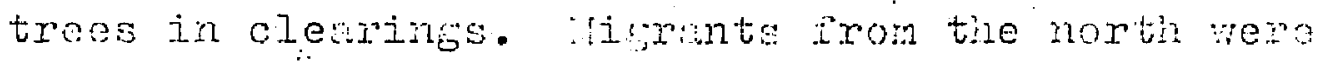
recorded as early as jepterber 29 (Eeck) and nave beon noted on tine return filint as late as May $>$, when I say six on the rountain Pine Riage. Pech's notes surgest thet this species is mors comon in the souturn third of British Honduras tian elsemere in the Colony.

\section{Melgius phoeniceus (Jimnaeus)}

$$
\text { Red-winged Blackbird }
$$

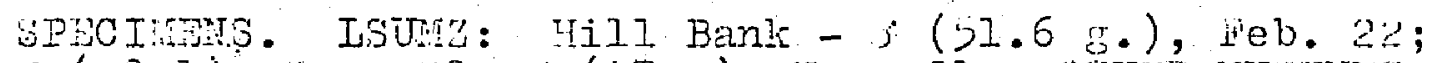

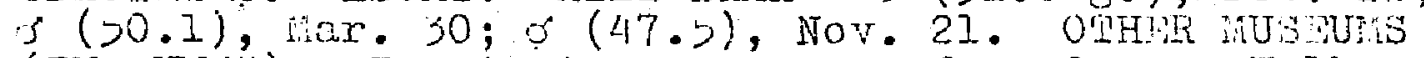
(BHI, UnU): Twenty-two specinens from Oringe Walk, Crooked Tree Lisoon, Lelize; Jin., rieb., vec.

The Red-winged Blaclbird, or "soldier bird" as it is orten called, is extrenely local in its distribution in British Honduras and has been recorded orly at the localities listed above. I have seen this species only in the narshes borderine the Hill bank Iagoon, where a flock of less than 2 individuals is resident. No data 
are available to indicate the breediug season excent tinat the specimen collected harch 30 had only slightly enlarged ronads.

I refer the British Honduran specimens to $A$. $\underline{D}$. richnondi with miscivings and the conviction that populations fron southern hexico and northern ventral America are in need of a nore thorough study. A. D. richuondi has a neavier bill than the Yucatán race, A. p. pelnioulus. paynter (19\%: : 270) found that this character is the only orto useful in distingushing between tie two races. I an mabls to note any inuication of consistently slcrder ilis in the series fro:t the Colony tiat wolld ariliate these oirds with $\mathrm{f}$. pallidulus. Whe race A. n. matidae describer by Brodkorb fro: the Usunacinta valley of Mexico is not narked distinctiy enough to be distingished from A. p. richmondi and is considered a symony by ietrore (194): 326), by the hexican Check list (Miller et al, 1927: 293), and by Paynter (195: 269).

\section{Sturnelia magna (Linnaeus)}

Eastern weadowlark

SPECIMAIS. LSUH: Lwo mi. H Hill benk - ?, Har. 25;

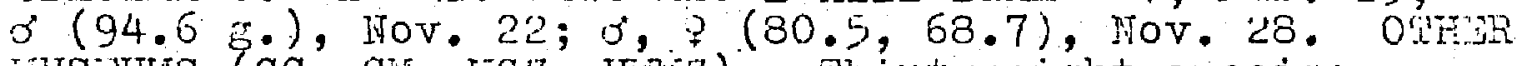

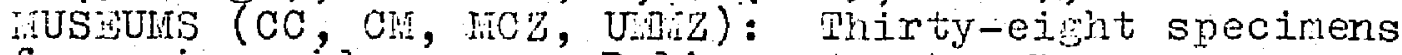
from pine riages near Belize, danatee Lagoon, t'reetown, All Pines, Monkey hiver, ycacos Lagoon; all months except July, Sept., Dec. 
Dastem veadomlarls are rather uncomon but widely distributed residents of the Erassy areas in the lowland pine ridges from till Bark and Maskalls south to Ycacos Lagoon. They are usually wary and dificult to approwch and are vore silent thm mesdowlants in the eastern United States. Bxanination of the gonads of birds collected reveals that breeding begins in late narch. Whe breeding season continues into June, for feck reports a nest containing tiree egss found Tune.29. British Honduran specimens are typical of tire small 368

race $\mathrm{s}$. $\mathrm{m}$ - inexpecta inhabiting pinelunds at low elevations from thu Petén, Guatemala, to northeastern ivicardrua.

\section{Wolichonyx orrzivorus (Linnaeus)}

Bobolink

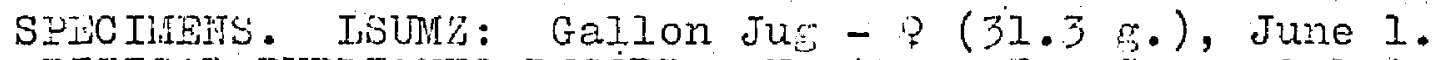
URIIICAI, PUBIISHED ROCOR: Morthern rwo Cays (Salvin, 1864: 386).

Whe Bobolink is a rather rare transient through sritish Honduras. Salvin collected a pair on Northern Two Cays on May. 20; Peck noted a flock flying overhead on April 28 or 29; and Verner saw single indiviauals on Ialf Moon Cay on April 18 and 19: 
Pamily THRATIIDAE

Tamarra musica (Bonaporte)

B.tue-hooded Iuphonia

HPTOMHA. HCZ: liount:in Cow - r, Apr. I2, 1928.

Austin (1929: 391) collected the only specinen

of this species from British Fonduris. The population rancine from sineloa and l'aneulipas south to Penamá is $\underline{\text { I. }}$. elegantisaima.

pancisre minuta (Cabanis)

Write-vented Euphonia

SPECIFHM, CH, ICA, UMm: Four specimens from Delize, fountrin Con, Cockscomb nts. (nvprox. 1400'); Heb., iiar., Apr.

the wite-vented suphonid is rare in british Honduras, and its occurrence in the Colony is known only from the specinens listed ebove. According to tile notes of Shufeldt wo collected two birds in an old pasture on the outskirts of Belize, one wis foeding on the fruit of the trumpet tree and the other vas eatins mistletoe berries in compiny with other euphonias. The nominate form has a wide distribution in south anerica, and the race I. m. humilis rones from Ecuador north to Guatemala and British Honduras. 
Ponagra affinis Lesson

Scrub tuphonia

SPICITEMS. LSUR: Seven mi. IN Belize on Corozal

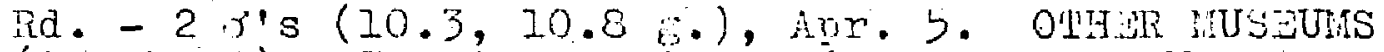
(cr, Udz): iwenty specinens from Belize, inanatee Lagoon area, Juck hun, Cayo; Jan., Feb., hpr., Jurle, iug., s'ept.

ihe few sidht recorde in addition to tile specinens listed above indicate that this biyd is a rather uncomon resident of tie lom 1 nds of British Honduras. host observations of this syecies have been mede in the . 10*: dense grontin along the cosst and in 10\% second erowtin further inland. Like othat eupionies, it trequently feeds upon ristletoe berries. riłe two ault anles taken on April were not ir breeding condition but folt noted that the two specinens he collected (Cryo, Duck Run) on Anril 7 and 19 hed enlarged sonads. The sritish Honduren hirds ase asigneble to the

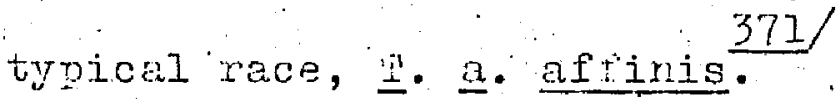

\section{Pencigra laute Pangs and Penard}

Yeliow-throuted supionia

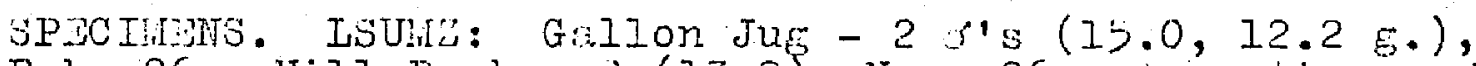
Feb. 26. Hill Bank - 7 (13.8), Nov. 26. Augustine - 5 , , iug. 18; 5 , AuE. 27. I'wo mi. W San Pedro Volumbia -

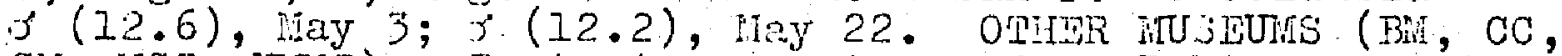
Ch, IfC, UMIZ): Forty-two specirens from Belize, inatee Lagoon area, Duck Run, Camp VI, Nountain Cow, Freetown, AII Pines; Jan. - Jure, hug. CRITICAL PUELISHED RECORDS: Corozal (Salvin and Godman, Biologid, i, 1883: 261).

This resident species occurs in all parts of British IIondures except on tre keys. Mistletoe in the taller 
trees of abundoned nilvas and cecropia trees are favorite haunts, is are also hijh second rrowth and forest edges. Somtimes tile necies is found in lowland pine forest aress. whe vello:-throsted zuphonia is porlups the connont ronben of the cenus in the Coloni Groups of tiro or four cun be noted daily in the field, altiourh the guiet nature of tis euphonia may result in its boing overlooled. ureedin has been iraicuted by tro enlarped roneds of mecinens tuken

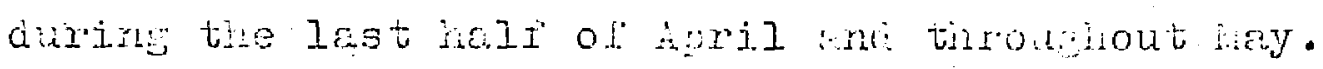
At Gallon Juk, Uilis noted birds constructins nests in mia-June. Pecr found a nest of the iroyl fycotcher occupied by this trubger in tune. Inis nest, contrining five enphonis eges, was suenonded by a lintiover a strean in dense forest. jeutch (19,4: 200) described nests constructed in the tops of decrying ance posts, in covities in banls, and in the axil of a coonut paln Ielif.

The populstions of this spocies north oi Nicaragua aro roferable to I. I. liuta.

Ifanlere gouldi (Soleter)

Gould suphonia

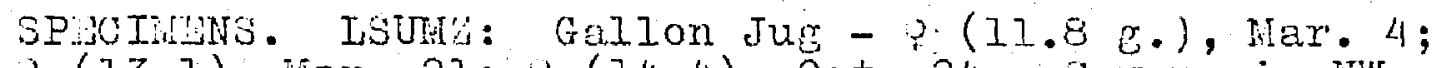
f $(13.1)$, Max. $21 ; q(14.4)$, Oct. 24 Seven mi. WW

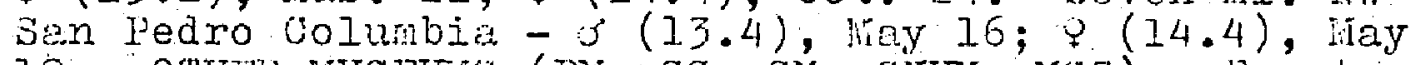

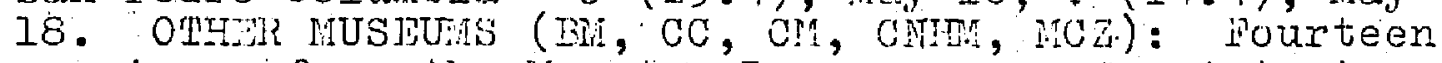
specimens from the Manatee Lagoon area, jan hntonio, Hountain Cow, Twelve ule station, Cocksconb lts. (i300!), 
'l'oledo Settlement; al sonths except Jan., Nay, June, Sert. CRILICAI PUPLISHD ROCOD: Belize (salvin and Godrlan, Bioloiza, i, 1883: 273).

Whis inconspicuous resident euphonia is distributed tiroughout the nanlmni of the volony except in the extrene northenstirn comer. It is nost frenuently found in the lower level of. trill porest and hirh second crowth. In such hebitats one or tro uicirs niy be acen newry every day in the field. boci ens uthenlurged conuda have been taken in lote varch, und in way a doned rest was found oupended fron the tin of a brench abont 6 feet above the forost floor. It contrined no eses bit two sdult birds yele close by

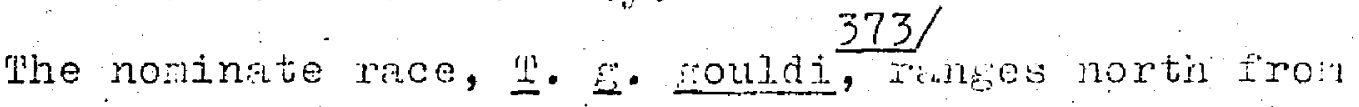
voste ilice into kexico.

$$
\therefore \quad \frac{\text { lengara nimro-cincte (Bonenrte) }}{\text { Golden-noked tinser }}
$$

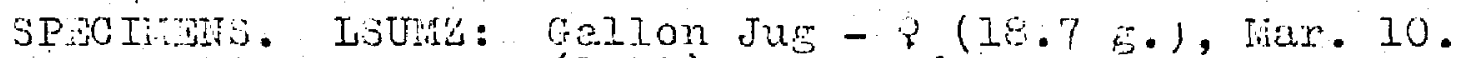

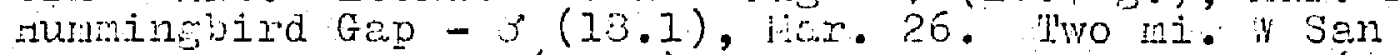
ledro Columbia - 7 (18.9), May b. OMlPR NUSUUS (DM,

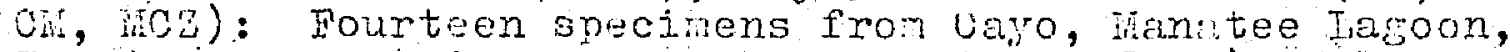

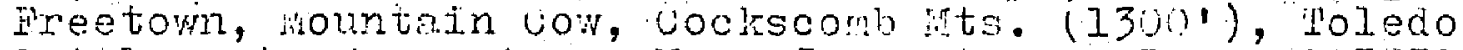
Setulenert; har., hpr., itay, June, sept., Dec. CRIIICAL PUiLISHED RuOro: Belize (Galvin and Godman, Bioloria, i, 1883: 274).

The Golden-maked Honger is a resident fros the Gallon Jus area in northestern British Ionduras southeast to the vicinity of Belize and then southward tirroughout the volony. Rarely singly, freuenty in 
prirs or groups of several individuls, they forage high in the trees of forest clenings, t:ll and noderately lall second srowth, and occasionally in the scattered urees of pastures and cultivated land. In tall forest, these mall tanmers ro almost unnoticed in the canopy. His species is not frequently seen in the rorthern part of its range in the colony. It is most mumerous in the humid regions of lolea District, binds in beediner condition have been taken froh early harch to lote hay. Whe northern race in central Arerica, to wich these birds ure referable, is $\underline{i}$. $\underline{n}$. lorvats.

\section{Threunis Virens (Iinnaeus)}

$$
\text { 3lue-sroy Tankger }
$$

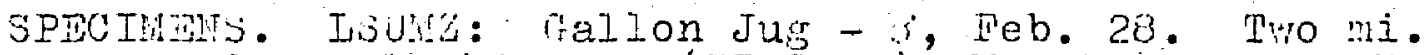

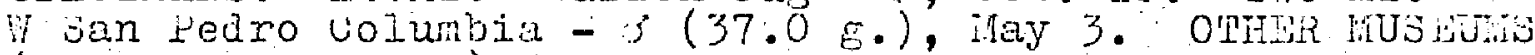
(Bu, CC, CH, UilC: : Wineteen specimens fron telize, Mantee Ingoon, Cayo, Ireetown, All Pilles, f'oledo jettlenent; Jan., Heb., Apr., hay, June, July, jec.

mis resident tanager, Iocally. Jnown as the "bluebind," is found throughout he lowlands of 3ritish

liondures. It is nost often seen in the trees of villases and lurge cle ringe,more rarely in the rorest edee ad pinelands. It is not nunerous in the northern third of the Colony, but in the extreme southern and central coastal areas, it is common and ohracteriztic species of the semi-open. Nesting has been noted in Amil, May, and June. At other seasons several individunls may forsare together in the treetops over a wide area. 
The race of the Blue-6roy llantegr reconized in ventral inejica is $\underline{\text { I. }}$ diaconus.

$$
\text { inrupis sbas (w. Depre) }
$$

Yellow-minged lranger

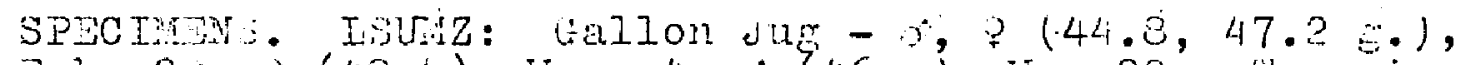

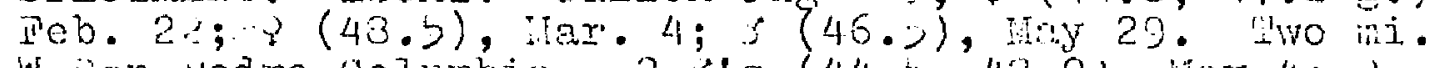
$w$ san redro columbia - 2 's $(44.5,48.9)$, hay 4; (54.3), : 12 . OHy

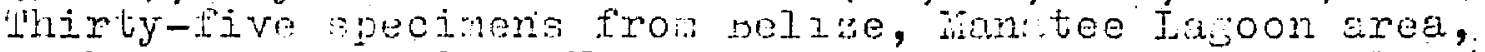
Wuck kun, velyo, Canp VI, Jountain con, reotow, All Pines, iloledo settlerlent; all montis ercept July, sent., Oct.

$$
\text { Yellow-winged fancore aro moro frequenty seen }
$$
than Blue-gray fangers and occuny more diverse habitats and areas. villases, river banks, ole rinis, tril second rrowth, 10wlend pinelunds, wh the edse of the rain iorest are suitable habitats wever they occur belo: an elevation of about 1200 feet. At Gallon Jue, fillis saw birds carryino nest buidine neterial as early as late February and Found a prent bird leedine a nearly from juvenile on April 28. it litl bank on August 4 , ie noted juveniles Plutiorine after their purents. A nest found by Peck on lny 29 contained two egis.

\section{Vamphocelus passerinii Bonapurte}

Scarlet-rumped l'angerer

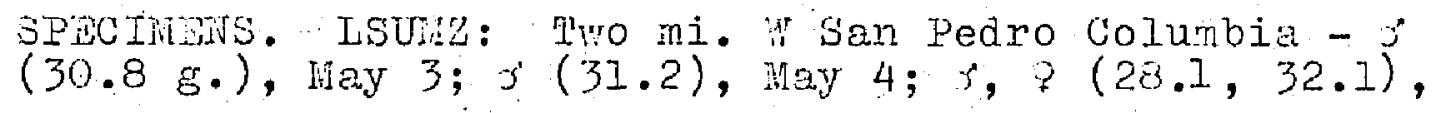




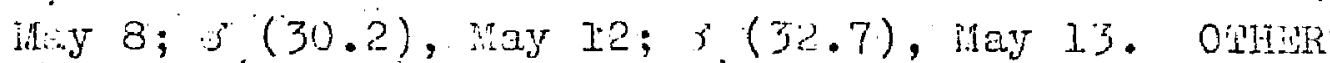

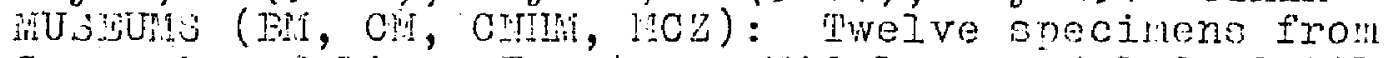
Ceyo, San relipe, Dreetown, jikilesex, loledo settlenent; Jan., Feb., Max, lay, sept. ChInICA PULIHID ReCrDs: Duck Run (Hoore, 1859: 59), Belize River and Belize (Ssivin and Godran, Diolosia, i, 1883: 281).

Whis vivid tanger js a resident of the lom tend valleys of the humid tivo-thirds of the colony. It ranges norta as an abundent and conspicuous inhabitant of Iow, dense growth of riverbanks, roedsides, brushy pestures, and abond tiejds only to North stani creek. In the arminge of the selige hiver it is less conmon. In 1907 at least one yir nested at Gullon Jug, a loc:lity here intensive fiold mork in the groceding two yeare hitd not rovouled the progence of this spocies. pourteen years exlin the Galon Ju grea ma unbroken rein forest wit. no larse atreams in the vioinity nd i.t.sti.l. rencins surrounded w forest. Binco this tan a does not frequent tall forest, its presence at Gallon Jus mey be interpreted as the result of a northward eienersal into a hebitat nade avalnble strictly trough the clauring done by man.

Shutch (19:4: 123-16), in his excellent ascussion of the life history oî this species, has indicnted a breeding season in costa Rica besiming with the first rains in late February or March. In British Honduras, nesting has been noted only in llay, when the rains usualy begin in thet country. Tomevor, this difference may be attributable to limited obsarvations rsther than to a 
correlation with the start of tire rimy season at a later date.

The short. song is repeated over and over fron a low but exposed perch, often ath tre rings held down at the sides, extosing the fuorescent brilliance of the lower back, rum, ent uppor wil coverts. Whe sone consists of an ascending bizzy zweet rollowed after a slicht. nuse by a sichtly desconding te $\bar{e}-\bar{u}$.

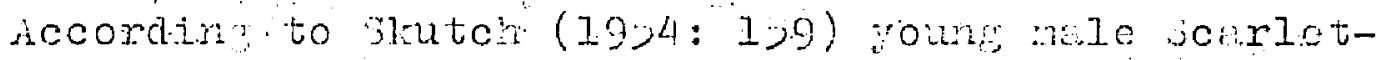
rumped tringen's actuire the noturo lunde as a result of tile postjuveral molt. in iudult male that. I collected on Nay 4 mas in alume like that of tie fenale. Its gonds were very simhty enlurgod and its plunage wa: fresh. British Fondurun specinens are not different frou tiose of the nowinate rce, $\underline{R} \cdot 0$. nesserinit.

\section{Phlogotrimuis sancuinolenta (Lesson)}

\section{Crimson-collsred Panciger}

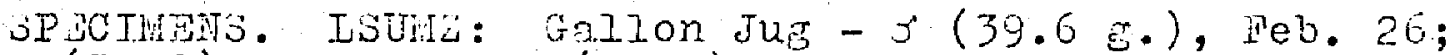
$\checkmark(39.2)$, Mar. 2); $3(37.2)$, June 1. Two Mi. V San Pedro Columbia - $5(38.0)$, May $4 ; \%(38 . \%)$, llay $9 ; 3$ (34.7), Iey I2; $0(40.2)$, May 18; (43.1), Hy 20; 3

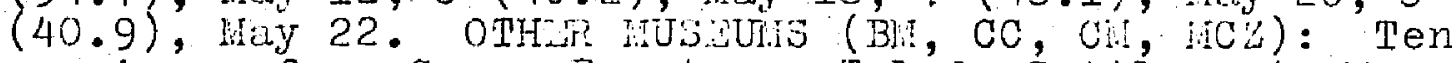
specinens from Cayo, Freetown, Toledo Settienent; lar., Apr., May, sept., Oct., Dec. CRITICAI PUBIISHED RECORDs: Belize and Belize River (salvin and Godnan, Biolosia, i, 1883: 285).

This rather uncomon resident occurs throushout lowland wooded areas but prefers tire inigh second growth of the more humid regions and the edges of tall rain 
iorest. Thus, it is nore irequenty seen in the soution part of the colony. I have found tire Crimson-collared linager in June in tipe tul ress bordering the jitteo

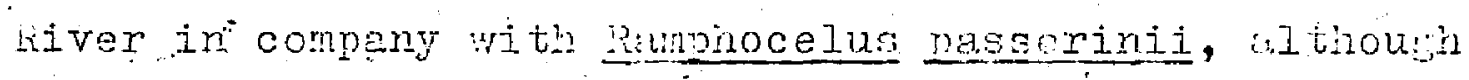
usually the present secies in not aen fur fron shded

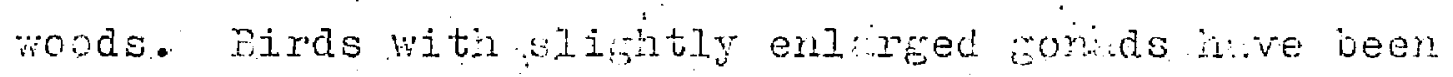
teken in eirly lay, but full propoductive activity io apperenty not attained until late rey, when nests have been found. Wew tancers possese a som thet cen surpes that of thin socies. It nuy wisted pineses, some sinilar to tipose of a Cutbid, are ntered with an oriclelibe quality. Wrored prcles ar upon erosed linos renging to jo seet above the pound.

Pritish Honurur specinens are typical of the rece ‥ S. Sanginolenta.

$$
377
$$

\section{Pinene rubri (Iinnates)}

sumer inneer

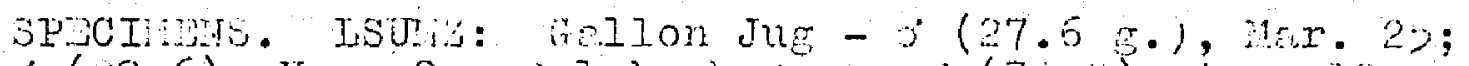

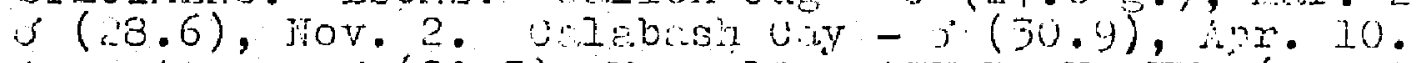

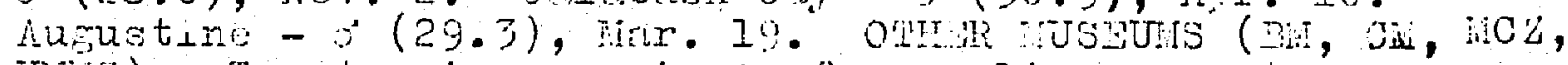
Uliz): Twenty-nine specimens from selize, fan tee Iacoon, Cayo, fountrin Pine lidae, hountain vo\%, w slope Cockscomo ints. (1301'), All Pines, roledo Settlement; Jan., lifar., Apr., hue., Sept., Oct., Dec.

Hell migrants of this species huve been collected in British honduris as early as August 24, but most sumier Tanagers anparently do not arrive uitil octobor. Althodgh nost individuals winter farther south, this 
tansger is present in smel numbers during the winter nonths. On the basis of trunsients noted on ralf loon Oay by verner, the bulk of the sprine migretion passes northward betweer late larch and tie last week of hpril. like latest spring date is nay 1 . do nojtat nreference has been noted; the biras occur wherever there are troes. All specinens thot I criticaliy examed aro referablo to $378 /$ referable to the noninate race, $\underline{p}$. r. muma.

\section{Pirunge flave (Vieillot)}

Heputic ranaper

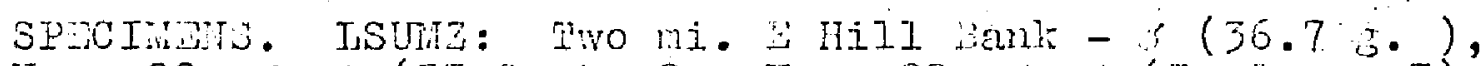
Tov. $22 ; 3, ?(3) .0,32.2)$, Tov $23 ; 4,7(32.0,32.7)$, Nov. 29. Five mi. "B.ldy leacon - s, $(36.6,30.1)$, Apr. $19 ;(47.4)$, hpr. 20; $3(30.7)$, Anr. 21. Augustine

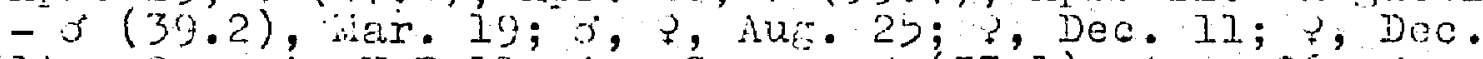
14. One mi. N Bellerina Camp - $(37.1)$, Apr. 26; 5

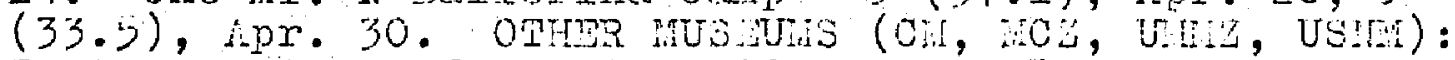
Forty specinens from pine ridres necr Belize, wantee Lasoon area, 12 mi. s Gro, surustine, Freetom, All Pines, Ycacos Iagoon; all months except June, Aug.

In the pinelunds of Lritish Hondurs at al elovotions, the Hepatic Tanaser is a moderately comon reaident. Usually it foraes in wirs or in groups ot pour or six over extensive areas in the pine ridges. At lugustine I have seen it consume the tiny not red fruit of donestic red peppers that grow about some houses. Porhaps this habit has led to the colloquial name of "peoper bird." Breeding begins by mid-March and continues at least. into August, for willis roted a fenale building a nest in a 
pine east of IIII Eank on urust 3 . 'the oxception lly heavy f̈enale collected on April 20 was veished men an ę̆ was ready for laying.

is specinen collected on the wantee River is tho

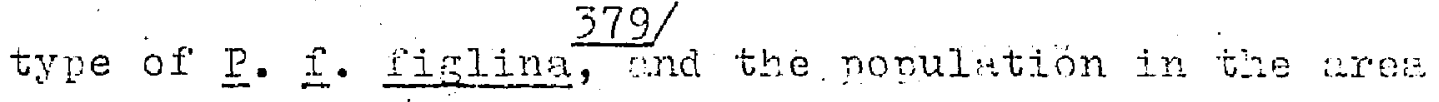
fron the Feter south to licarogud is jenerdly reperred to this roce. The extensive aries fron Brition ancurus entibs considerable renge in the degrep of renress. in tre mies, altioun the rednoss does rot overlap the colorvtion of the other rices. Since the color of the niles is an imporiant taromonic crit:rion in this necies, a lew coments concorun the colox varistion in the Britich Horduan Tules seers pertinent, sone we pinkisin (Brazil Red $x$ urecons-blood ped) and others sre d doep brick red (Snozil Red s srick hed) or Burnt Sienia. oolor ney intensiry with the naturity of tile bird, older birds

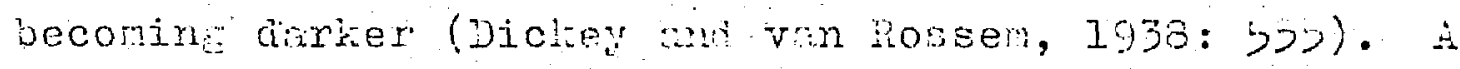
male collected april al hol fully enlerged onads but wes attired in the yeliow plumase of a female.

\section{Diransa roseo-gularis (Cabot) Rose-throated Nanajer}

No specimens of thits tanger have been taken in British Honduras, athough Paynter (1925: 275) recorded severol specinens from chetumal, duintana Roo. On July 14, alilis oaw a taneger almost certainly a female of 
this species forkging in the undergrowth and saplings at the edge of the rin forest near Galion wus. He. particularly noted itis typically rimes notivities ad ite pale yellow throat and uniler tail-coverts. Willis had been studying tonvers during the roceding several nonths and wo especially well prepred to recognize unusual spacies in the Gallon Jug sroa.

\section{Piranga oliveces (Gmelin)}

\section{scarlet lanacer}

SPRCInTs. LSUH: Geven mi. Nit Belize on vorozal Ra. -

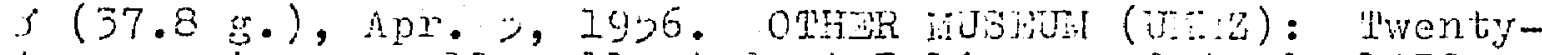
two specimens, ell collecter st Delize on oct. 9.1932.

Scarlet inagers are rure trunsients through vritish Honduras. Their occurrence in the colony is Enown only bJ the ppecinens listed sbove and by Verner's. observations of single inaividuals on peli roon cay on April 13 and $13,19>8$. The phenomencl nimoer of specinens collected on October 9 in velize by hufeld is probably due to unfavorable clinatio conditions at the tine. Since this tanerer hos bern recorded only rarely in any part of nexico in rall, the possibility exists that individuals nay not only fly across the Gulf of liexico, but also across the Yucatín Peninsula and Gulf of Honduras in one ronstop flifht. The speciren collected in April was rither fat. 
Pizanga leucopteria irudeau

white-winged Tantger

SPECINUNS. ISUR: Gellon Jug-G (Is.6 g.), hi.y I. Ten mi. IV liddalesex on Iumingoird HWy $-y(14.4)$, har. 26. Two mi. Tis Iillionario - 8 , $(14.1,19.4)$, Har. 13. OMHR MUSUTS (Bi, NCZ): Ten specimens fro: Hountain Pine lidage, turrustine, Iountain Uow; Jan.,

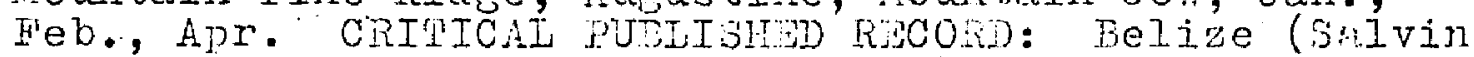
and Godmen, Biolosia, i, 1883: 295).

To the ast of the liaya nountains, this vivid little tanager is a moderately comnon resident of the tall forest and clearings within the forost. In this region it also occurs in the hardwood forest un to the elge of the pines of the ifountain pine Rirge. In the cocksconb countains, I found this species only on the high upper slopes above 2000 feat. wlsemhre in tine volony the white-winged l'anagey is an unconon resident, occurring in rain forest. It is mdoubtedy often overlooked in tall trees, for it tends to forege high in the treetops and its inconspicuous sone is hioh-pitched ari wriblerlike. Whe specinens collected in nerch possessed rreaty enlarged conads but the testes of the male obtained on iñy 1 vere only slibhtly enlarged.

I refer these syecinens to $\underline{D}$. I. Ieucontera.

Iabia rubica (vieillot)

. Red-crovned Ant-Panaser

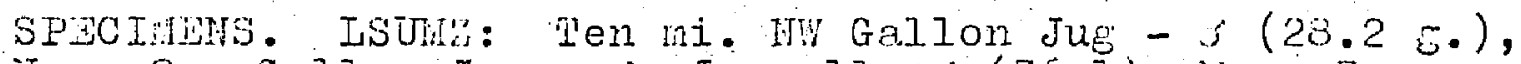
iJov. 8. Gallon Jug - 9 , Jan. $17 ; \%(36.1)$, Har. 3 ; (30.2), hay 23; 2 , hay 26 ; $5(30.4)$, litay 28 ; $(29.0)$, 
May 29; $6(31.8)$, June $6 ; ?(30.0)$, Hov. 2. Two mi. WW Lusustine - 3 , Dec. 12. Seven mi. Niw San Pedro Columbia - ? (33.1), jitay $14 ; 25^{\prime} \mathrm{s}(37.3,37.4)$, jiay 18; $5(32.0)$, liay 19. Two mi. NW San Pedro Columbia $3(34.3)$, lay $3 ;$; $(33.1)$, Hay $21 ; 0(36.3)$, liay 22.

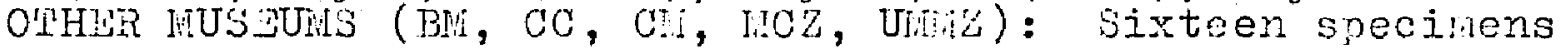
from ifanatee ikiver, Cayo, 12 mi. S Cayo, Jount:in vow, $\mathrm{T}$ slone Cockscomb Mts. (1300-1400'); Feb., Nax., Apr., inizy, June.

Whis noderately comon unt-tanager is a resident at all altitudes in the interior of tall, humid forest and nore rarely the forest edce sud tall second ;rowth. one specimen fron an unknom locslity on tile ifanteo River is the only record of the occurrence of this srecies in the area fron sittee aiver north to suintuna koo and west to Hill Bank. Peck dia not record it during nany months york in the Manatee Lagoon nroa. I presume tinis. hiatus is due to the absence of extensive areas of unisturbed rain forest. Willis $(19,8 ; 1960 a, b, c$; I961) has conducted detailed sirdies of the two species of Habia in British IIonduras, especially of various aspects of their behavior. hocording to his observations, nest building comences in lote march and nesting continues into nurust.

The series of Red-cromed Ant-magers from British Ionduras is tentatively referred to $\mathrm{H}$. I. rubicoides. It lacks consistency of charccters that would definitely affiliate it with this rece. Actualy the British Honduran population exhibits a combination of tire characters of

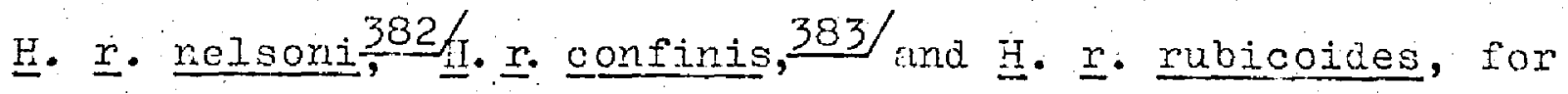
there are specinens that resemble each of these races. 
In general, hovover, the series is reither as light in

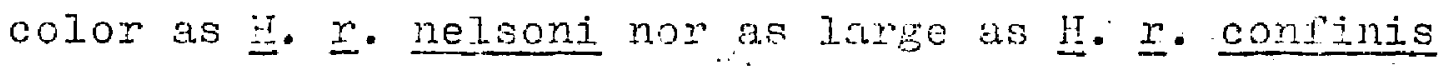
but is near $\underline{\text { r. }}$ mubicoides in size and color. Equnter (I955: 278; 19>7a: 277) has sug ested that veighomay vary weograpilcally knd presents dat:. indicating inat H. I. Pubicoides may be heavior then $\underline{H}$. I. nelsoni. Eirds. from the colony al intrmediate with rospect to shis criterion, elso.

\section{Trbia muturalis (Scleter)}

\section{Red-tliroeted Ant-Tenerer.}

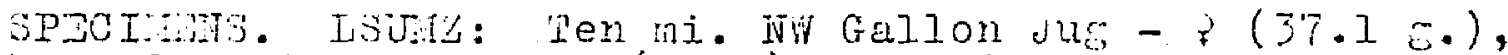
Nov. 3. Hill bank - $5(39.9)$, Nov. 27. Gallon Ju - ?, Jan. II; $\mathrm{g}(39.2)$, ieb. 13; $(30.0)$, Feb. $2 ;(3,5)$, ireb. $24 ; 2$ 1' $(32.3,33.3)$, web. $26 ; 3(40.2)$, nay $23 ;$ 2 is $(31.4,42.4)$, iky $29 ; s(39.2)$, $40.9)$, Juine $; ;(36.1)$, June $6 ; \%$, $39.4,33.4)$, 0ot. $29 ;(30.9)$, Oct. $30 ;(34.0)$, Hov. o; $(37.6)$, llov. 7 ;

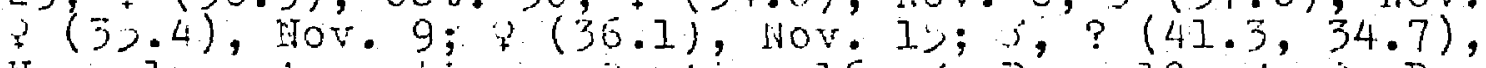

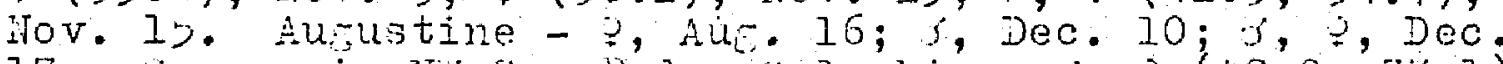
17. Seven ni. Min Sin Pedro Columoie - it (12.9, $3 \% .1)$, irey $14 ; 3(40.9)$, ney $13 ; 3,2(40.7,35.1)$, lezy 19. rimo mi. M San Pedro Columbir -2 is, $7(40.2,40.5,33.9 \%$, Lay $7 ;$; $(39.8)$, lity $14 ; 2$ is $(40.1,43.8)$, May 22 .

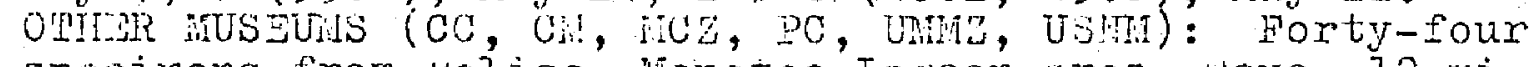
speoinens from belize, hanctoe Lagoon area, wayo, $12 \mathrm{mi}$. ¿ Caro, vanp vI, ireetom, loledo Settlenent; all months

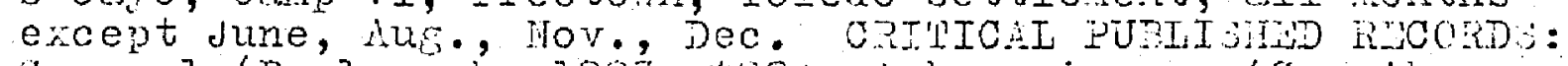
Corozal (Berlepech, 1335 : 438 ); Ambersis Uy (Carriker ind de ichauensee, 1930: 401); Urange walk j)ist. (Hellmayr, 1936: 310$)$.

Red-throeted int-lanager roide in rooded ereas throughout sritish londuras. Ercent in the neart di und isturbed tall forest, this species of wht-taraser is nore freruently seen than Habia rubica. fillis (19,8, 1960a) 
has presented evidence thet Habia gutturilis not only Forages throum the rorest border and humil of various heights (which Red-cromed Int-langgers do not) but slso occupies alintly lower stratun of the forest then does its sibling species. led-throdted hintienacers ore the habitual followers of the insects that flee before ant swarns; hed-crowned Ant-Pwngers wre aliont constrnt nowbors of the wandering flocks of mall insoctivorue forest syecies, and rely follo: int smarns (wilis, 1960c: 10,). nesting begins in late haril and extends into August. The weight of the hervy fenale collected ray 29 irncludes two Iarge ova (ll and $13 \mathrm{me}$ ).

Few species exibit as auch veriation in lexico and Central Amrica as labie putturelis. Yet these variations are lughly inconsisterit geopronically the British Honduran population is redged between the hunid Gutenelan lowands and tie nore arid Yucatán peninsula. Forost tyos chenge cradualy in this area. The internediacy of the generohical position of the colony is reflected in tile ereat mount of individual variation in the semple. I do not monder that Griscom rocognized the bjods ju British Honduros and ouintana 1300 by name, I. 2. pooensis, especielly since he based the race on only six specilens. Dayuter (19by: 279)

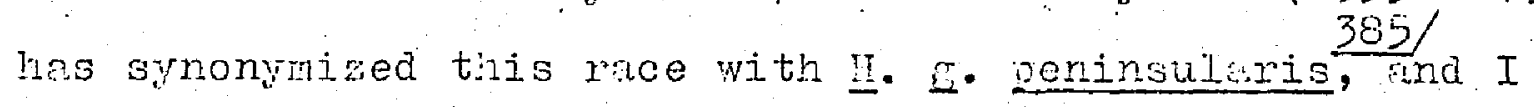
agree nith hin in considering …․ rooensis anteneble. 
I refer specimens from all sections of the colcry to I. E. littoralis. In seneral, males from British Eorduns are sinil $\cdots r$ to males of H. Salvini, but some have a distinct purplish cust, a charseter subosedly typical of 1. . Iittoralis. Eenales fron the colony are not so dark as II. E. Blvini, especielly on the under parts, and have a less conspicuous broast band than I. S. Salvinit. Bots males and fenales from the Colony are less jele and roy then color chericters oi the fonles in particular relate the

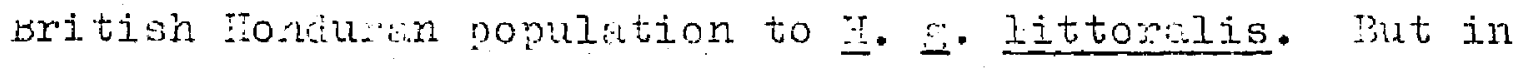
tise sizeable sories fror the colony are shecinens that matcin topotyrical material of an of the three ourrently reconnized races mentionea dibove.

\section{Ianio arintius Lafresneye Shrire-ienaser}

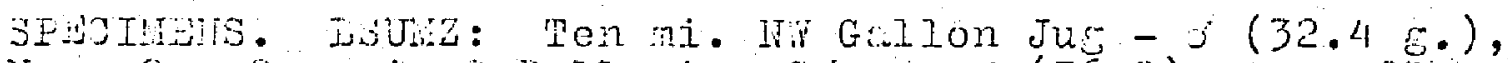
Hov. 3. One rni. S Mallerina Comp - 36.0$)$, Ans. 28. Two ni. Ne ililionario - $r(29.8)$, nar. 16 . jeven mi. Nat San Pedro volumbia -3 , ? $(40.6,40.1)$, Maty 13.

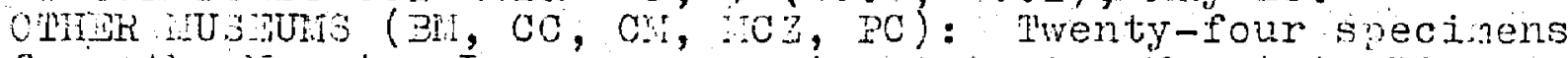
fron the Tanate Iagoon area, San Antonio, fountain Pine Ridee, Nowtain low, nt slono vockscomb !ts. (1300'), Toledo Settlenert; all nontis except June, July, Aü.

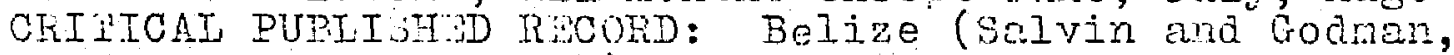
Bio103id, i, 1883: 304 ).

The lower and middle levels of tall rain forest are preferred by tho shrike-Tanager. Thers, it is a not urcomon resident, esnecially in the southorn half of 
the colony . Itais species is easily calarmed and its notes often arouse mary othem "bush" birds. specimens in breeding condition have beer taken on duril 28 and Tay 15.

ilie race occupting the area from yexico to urib-

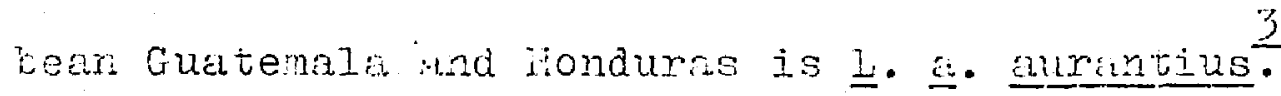

Eucontis penicillata (spix)

Gruy-inended lianager

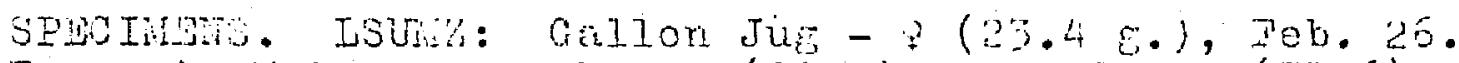
Pour mi. $\because$ stan Creek - ; $(29.0)$, nif. $23 ; 9(31.6)$,

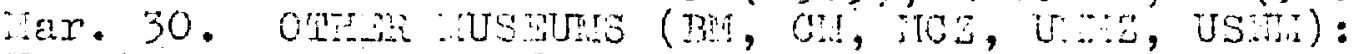
pourteen soechrens from the ancte Ingoon area, Duck thon, layo, jittee River, mrectom; :ar., lor., iroy, JuIy, Aure C?ITICAL PUIISEDD RCORDS: Belize (von Berlepsch, 1938: 4:2).

In British izonduras this tanagor is conerally anconmon resident ma rether lockl in its distribution. In adition to the locklities listed ibove tils apoies has been seen at Corozal, Pomona, south stann Creek, Conkey Rivr, end the upger lono niver. It his been Iound ju rin rorest, sorust alge, and in lall second. eroutil. In the Horth stann creek vajley, it was seen several tinos in rense wronth on tils edse of cultiveted fields and atream beds, sone distunce from donse forest. As noted by various euthors, the Griy-headed theneser frecuently fulows ant swrms (skutch, 1954: 183; Payruor, 195b: 282; Wilis, 1950a: I>9). Whe rale collected harch 30 had enl red tostes, although one collected two 
days earlier in the same lockity did not. A nest with two ens contuinine vell-devoloped enbryos ma found on April 26 by peck. british tondures lies within the rence of Ė. $\mathrm{D}$. 389 vallida.

Qhlorosningue ophthalmicus. (DuBus)

$$
\text { From-hecded vilorosninus }
$$

SPECIMY LSUL: phe and one-helf ni. Hictorin Peak $\left(2600^{\prime}\right)-2, \because a y \cdot 3,1956$.

I. found this tanger on tire crost of tire dookeonb rountins. The ferale (collocted), her me and their fieduling young were the only julviducid seen.

It is dificult to roper tis somewhet wom specinen to any of the reces that I have exurined. It nost neariy resenbles throe females from Gan Jumeito, Ionturos. the under purts of the looksonb lountin bird are a bit peler and ita bick is slidtzy darken and pyer. 1, therofore, tenutively rofer this bird to $\mathrm{C}$. $\mathrm{o}$. honduratius. Whe Eritish Honduran spocinen differs from two tenles taken eight niles northest of vountian, sacana, Guatenla, in havine a smalor, less wite, postoculir streale, a lisiter throst, and no latoral black line along either side of tise pileum. Mluse Guteman specinens any be topotypical naterial of $\underline{\mathrm{C}}$ o o richardsoni 391 the nost adjacent populction to the looksond nountains. The type locality of the latter race is not precisely imown. 
Family HZITGIUIDA

Sultator atricens (Lesson)

Blok-hended, saltetor

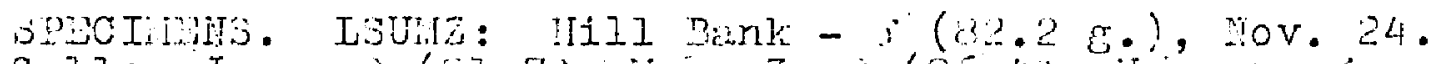

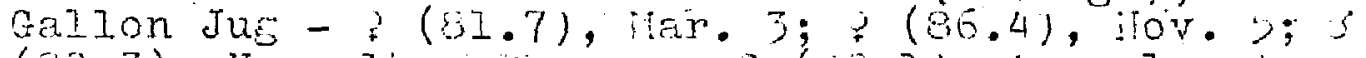

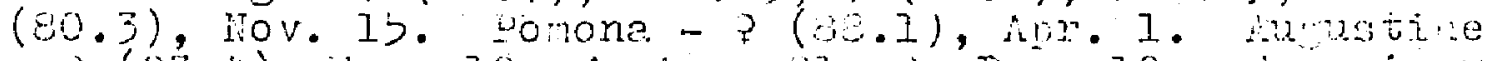
- $(93.4), \ldots r .19 ;$, Aug. 21; 2 Dec. 10. LWo ni. "

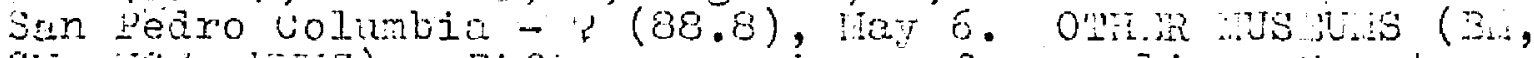

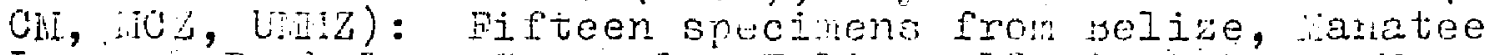

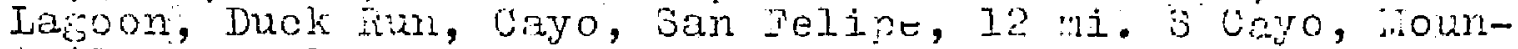
tail Com; all :lonths except jan., jent., Oct.

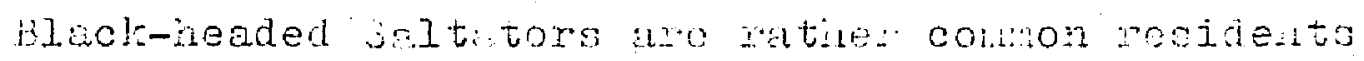

of dense nuamil, bal second fromti, ant tho edre oi

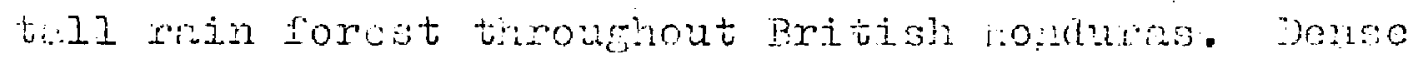
bushy vegetation alon; rivorbes also movides

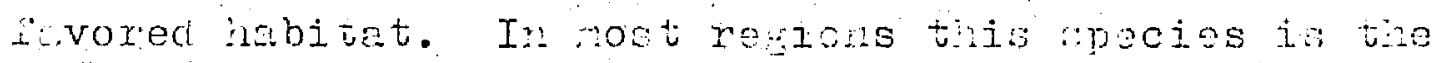
nost frententy observed nember of the renus, yet it is

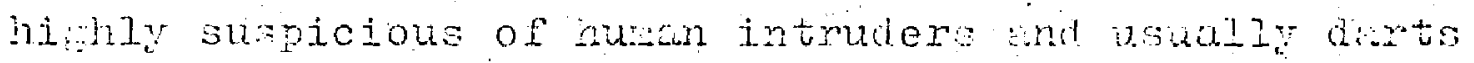
into a derse thicket wen alurnes. Birds rith enlarred

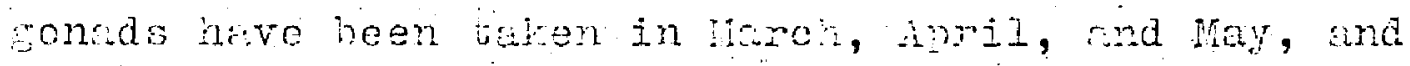
Peck found two ess in a nest on July 26.

I refer tire Ixitish Ionduran specimens to $\underline{\text { S. }}$. atricess. One secinen from Galion Jue cha notner fron Belize a.e altost devoid of diry olivaceous tine

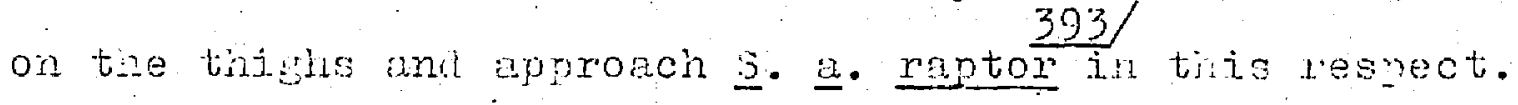

Siltator maxinus (D.I.S. MuIer)

Buff-throated seltator

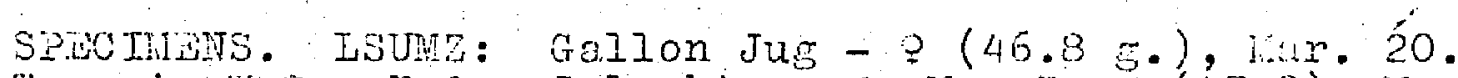

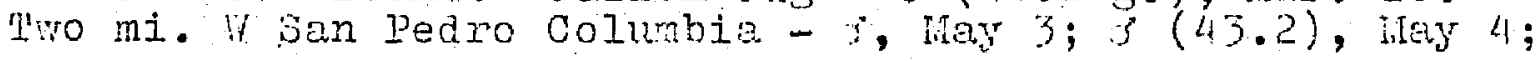




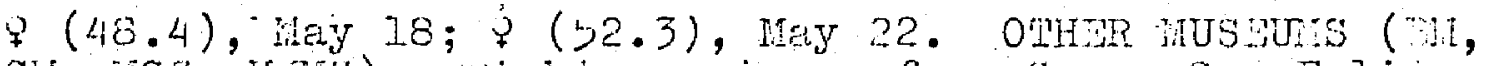
Cll, iCz, Uar : vight specimens fron Cayo, san Felipe, Sittee River, 'ioledo jettlement; Jan., Nr., Apr., Oct. CRIICAL PUSIBHD ROCOUD: Belize (jolater, 1886: 28\%).

A rather uncomon resident of sritish Hondurs, the ratiring zuff-throster saltator hes been found only whore toll tilickets occur nesp extonsive in forest and in the nor in of heavy forest. Only ner jan pedro Colunbif heve I seen it in numbers. Here it frenented the brushy border between nlantetions or humiz ard the nerrow strips of original for st thet pasist in the nonerable velleys. Ballarina Gen is the only locklity where the species has been observed but not collucted. A Cemale collected in farci had a slighty ellared ovary and one obtinged on lay 13 contaned an ege in the oviduct. Females turen at duyo Meroh 16 and 20 by van lyne rejencd 43.2 and

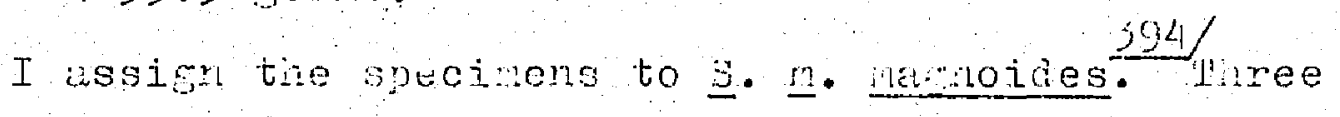

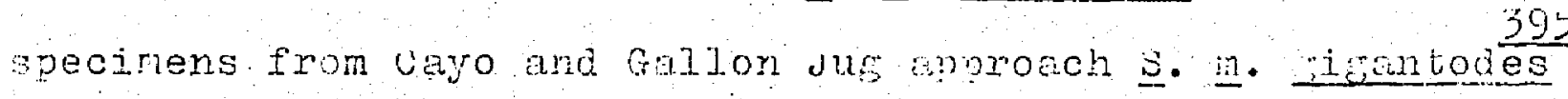
in having o considerable chount of blek on the pileun.

\section{siltetor coerulescens (Vieillot)}

\section{Grayisin saltator}

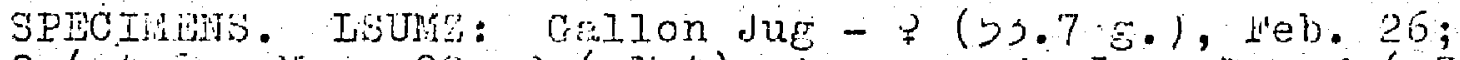

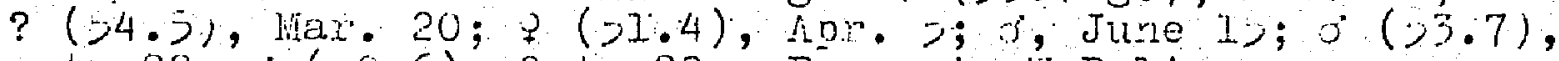
uct. 22; $f(29.6)$, oot. 29. Four mi. it Belize on Vayo Ra. - (b8.7), Apr. 4. Tyomi. San Pearo Colurbia $\sigma(36.3)$, May 6 . OLFTR ITUSUHS (MH, CH, IICZ): HIeven specinenis from layo, San Felipe, Sittee kiver; Apr. 
Huanil, tilickets alons the edge of fields and pastures, and densely overmrown riverbanks offer suitable hebitats for the locally distributed Grotyish Saltator. Whis resident svecies has been recorded only at the locsities listed above ma it ill Bank and ponona. Bven in these areas romer than four individuals are ordinarily noted in a doy in the field. 'lre start or the breeding season is indicated by tile slimlity enlurced gonads of snecinons tanen in ecrly April. A nest and two eges were found by Peck on April 27 near the sitten river.

I refer all British :onduran s ecinens to $\underline{3}$. $396 /$

arandis, though nany exhivit is depreo of paleness that 397

approaches $\underline{S} . \underline{c}$ wucatanensis. The northern half of the Colony should be considered en area of intercradation between twe two races. The dakest bird is fron the southernmost locality (San pedro Colunbia).

\section{Caryothreustes polionaster (DuBus)}

31 ack-faced irosbeak

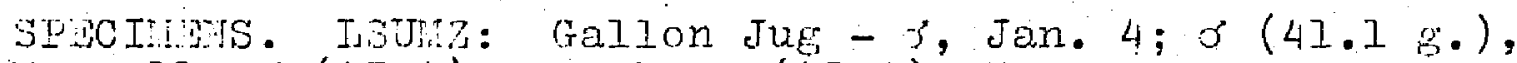
Mar. $11 ; S(43.4)$, Nay $I$; i $(43.8)$, Nov. 17. Ten mi.

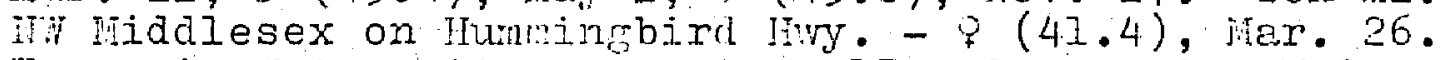
Four ni. Aurustine - 5 Aug. 17. Sever mi. Nim san cedro Columbia - i $(46.7)$, my $18 ; 9^{\prime}(41.3)$, lay 19. Tro mi. San Pedro Columbia - $(44.7)$, May 12; $3 .(38.9)$, hay $20 ; 3$, ? $(34.9,-)$, May 22 . OH Ch, licz, Uifu): Twenty-six specimens from the ifmatee Lagoon area, (Eyo, nountain Pine Ridge, Augustine, lireetown, vockscomb its. (about 1400'), Toledo Settlement; all months excent Heb., June, July, oct. CRITTCAI PUBIISIID RTCORDS: Belize (Salvin and Godncin, Biologia, i, 1883: 333). 
Whe black-faced Grosbeal is a common resident of the tall rain forest throughout British Honduras. It is nost compon in the luxuricint eorest of tile centrel and soutiern areas, and in the Cocksconb lountains it is an abundant bird at all elevations to 3200 fert. It prefers midule and upper levels of the forest but injreguonty cones as low as 10 reet. Only rarely does it leave the dense forest to porane in secon! mowth. It noves nout in snell froups of four to ei ht individals, repeatediy uttering a short buzz folzo:ec by a wistled tweet-tweet. Wenrly all specinens taken from early farcu to late hay were in breeding condition, as indicuter by enlarmed gonticis.

Racially, tilese specinens are exmples of the noninate fort, $\mathrm{Q}$. D. polio aster.

Richiondene cordinilis (Limaeus)

Cordinal

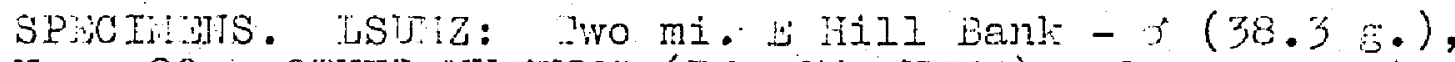

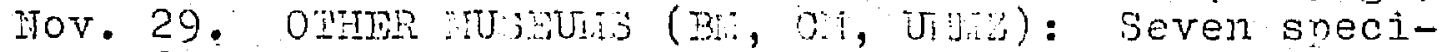
mens from Corozel, Orange ialk, Crooked Tree Lagoon, Belize, Nanatee Lasoon area; June, Mus, Hov.

In northeastern British fonduras as far south as nanate Lagoon, the cardinal is a shy and uncomon resident. The sonetimes wet thiclets that border the pine ridges and second growth that occurs in a irregular fashion in old n ntations provide favored 


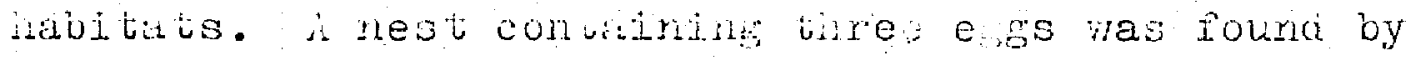

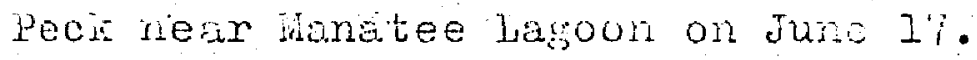

I refer the Britin Fondun population of this 399

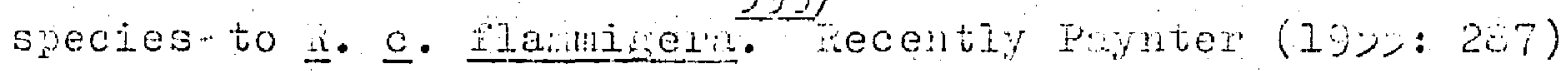
cribically examinea hile race and foma sarat it is

"slishtiy daiken, nore vermilion" tian tie Iucalín lace, R. ․ ruceunessis. Kcopen, tie rye locilit; of $\underline{\text { n. }}$.

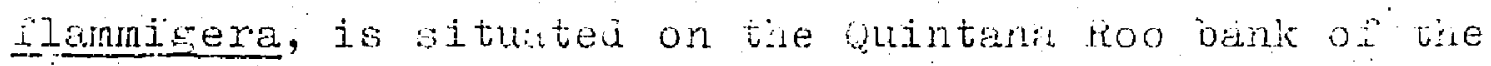
Rio Tondo.

\section{Phedoucus lurovicimis (Itriateus) \\ rose-wreasted Grobeak}

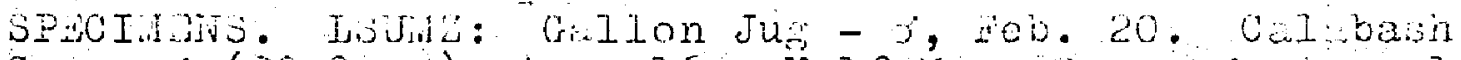
Cay - S (29.2 8.), Apr. 16. Talf ioon oay - s, Apr. 10.

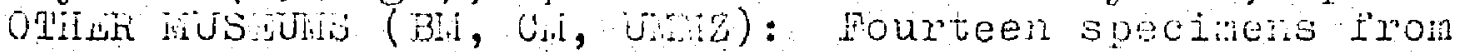
Belize, wanete lakoon area, cryo, san relipe; ilar., oct.

Whough it is infrequenty roconde, tho nose-wreasted Grosbeal is a migrent und winted loitant. phe endiest faII arrival date vas ootainea oy frupelat in 1932 when ile collected seven grosbeals : lont wi wany other worth American migrants on october 9 . One to six bitds nuve been recorded in a day's fiela wori spordically throughout the winter montis. There is no noticcable increase in numbers in the spring, and nost birds hive departed by the first week of ipril. It is notevorthy taat the three observations after April 2 have been of mirrants seen on shill keys. Verner, wo kept a daily record of migrants 
on Half Hoon cay in the spring of 19ye, sam this species only on hpril 18 (two bixds, one collected) andiliay 8 , the latest date of yecord for the Colony. I capturea a male in a mist net on Calabasin Cay on april 16. In winter tile hose-breasted Grosbeak sems to prefer aburdoned inilpas and the edges of cletrings.

\section{Guiraci ćcierulea (Limnaus)}

BIue Grosbear

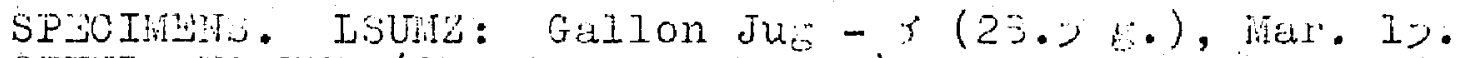

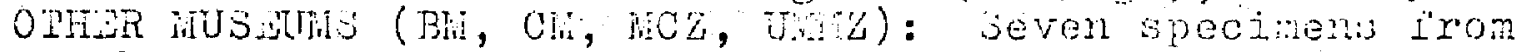
Crooked Iree Lagoon, Cayo Dist., Cayo, I2 mi. i Cayo, Ioledo settlenent; Feb., har., hr., Oct.

Darly fall visitants have beon noted in lite.

september, but Blue crosbenis are uncomon until early

Decerber. They are then rodertitely comon unt 1 the end of inaros, occurring in looks of 4 to 30 birds. one spring trunsient has been noted as late as horil I7 (Hale soon cay). Inush pields and potues and low, second growth offer preserrod habitats.

Whee mies that I critically exanines bre presumbly referble to G. c. cocrulea on the busis of color ard measuremonts. Whis species does not oxed in the Colony. Van Pyre collected two males (Feb. $2 \%$, Har. 4) tilat weighed 26.0 and 27.6 grams. 


\section{Gyanocompsa cysnoides (Iifresnaye)}

Blue-bleck Grosbeal

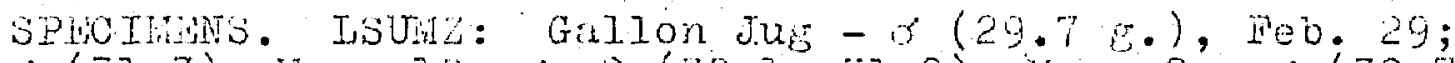

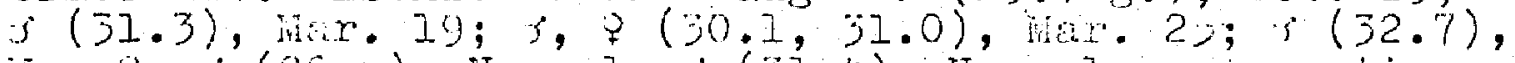
way 8 ; $5(29.2)$, Nov. 1 ; $3(31.4)$, Jov. 12. Kugutine t, Dec. 10. 1'mo ni. ism Dedro Colmbia - ? (32.1),

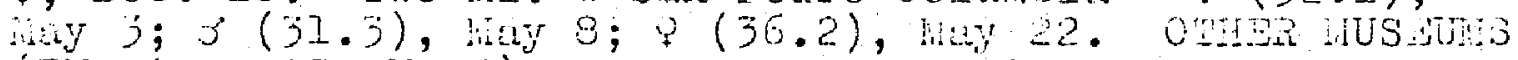
(BH, CA, ACZ, UnL ): lwenty-one epeciners from Orknge ifalk, ilantee Lasoon area, Cayo, Sar intonio, 11 mi. is Cayo, Camp VI, Freetom, loleà Settle lent; Jal., liar., Apr., itov, June, July, Dec.

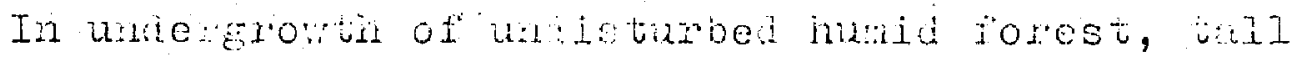
second eronti, the forest pripe, and often oditivited plantetions, thie grosteak is a modertaly comon rosident.

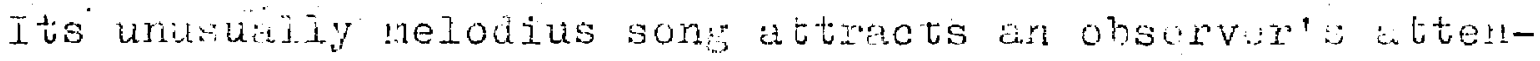
bion, altoun the singer is often hiden in i dense wicket and no easiy seen. Blue-black Grosueals ire partial to spine-bearing polms for oupport or thepr nests, which nay be occupied durine the period extending rron nid-iarch until July. The oviduct of tiro fenale collected ikay 22 encioseà an ovuar.

The majority of the specinens collected in sritisi Hondures are ratior dar blush-black whout conplcuously brigit tiroats op roreieads an consequentily bie population

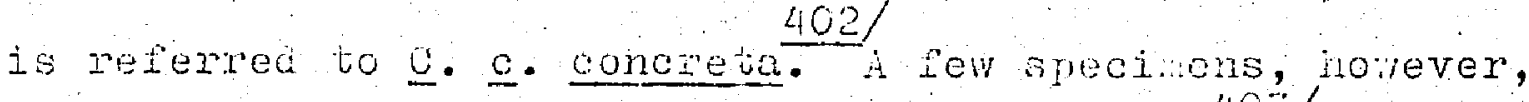

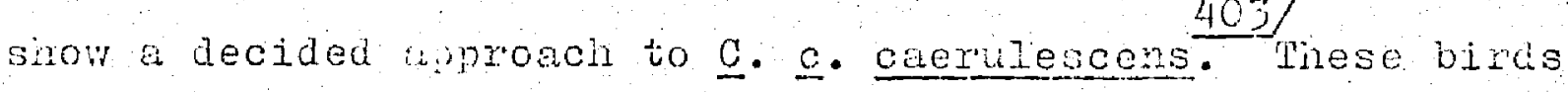
are much bxishter than C.c. concreta, and the orightest spocimen from the colony is very sinilar to the type of Q. c. caerulescens. Fodd (1923: 61), wi h a melier series, noted that ". Britisi Honduras birds ure not typical" 
of $\underline{\mathrm{G}}$. $\mathrm{c}$. concreta. The intergrdation between these two ruces does not hpear to be clinel. A Feck spociaen from the extrene aoutiern portion of the Colony wh of

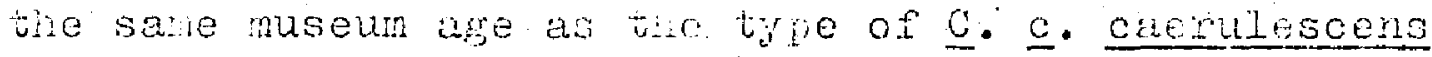
is distinotly darker thin the latto spocinen.

\section{Oyunocompsa parelline (Donapirte)}

\section{Blue Bunting}

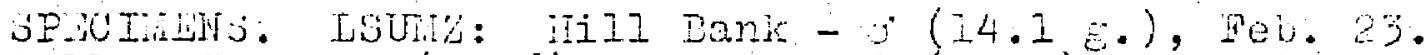

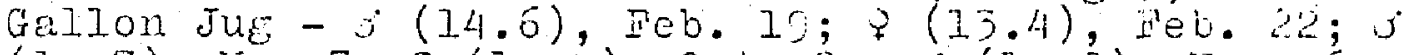

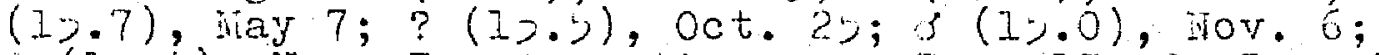

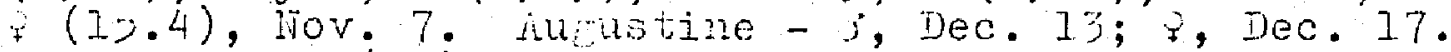

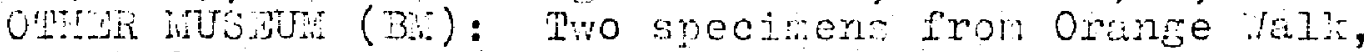
Crooked Iree Lasoon; no dates.

Blue Bunting are urcomon restants in Britist Fonduras and have been recorded only from the localiiles listed bove rine are biras of hubil we tre undergrowtin of till corest and its eage. at Gullon Jug thein nobit of foreing into smal rice plantations

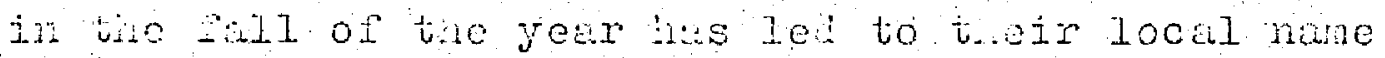
"rice bird." The ppecinen collected in ina had enlurged gonads tha was in breeding conation.

I refer these specinens to o. p. parelina, el thonoh sone speciners in this snall and viriable beries are similar to $\mathrm{C} \cdot \mathrm{p}$. dearborni. Two adult mies fron the Colony are darker tin males of the latter race. I am unable to distinguish satisfactorily betreen females of the two races with the material I have examined. Van 
iyne (1932: 39) assigned four mules front the petén, Guateiala, to C. 2. Uecrborni; wid trodkorb (1943: 8D) thought specinens from tabasco wero similar to $\mathrm{G}$. detrborni, al thoush he called them $\mathrm{C}$. 2. pirelina.

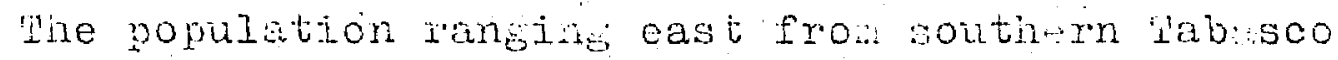

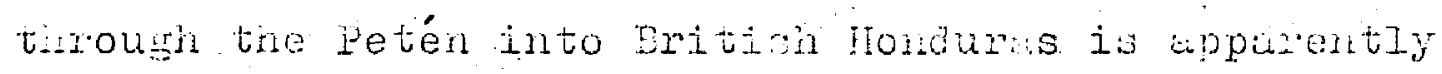
lifgily variable whe intomediate between the two races.

\section{Passerina cyinea (Iinneus)}

\section{Indiggo Runting;}

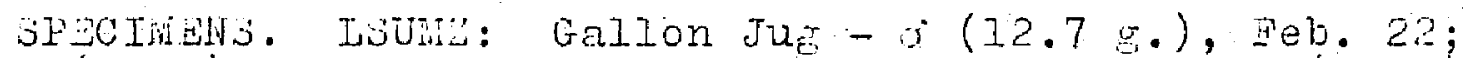
T (13.I), ieb. 2y. Tive mi. Baldy Becicon- - (17.7),

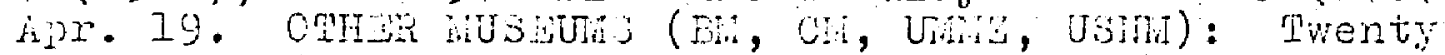
spocinens from iianatee Lafoon, Cayo, San Felipe, San Artorio, 12 mi. S Cayo, $\#$ slope cockscombinta. (1500), All Pines; Jan., Feb., har., Apr., oct. CnIIICAL

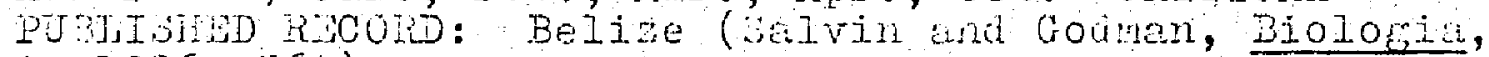
i, $1836: 364)$.

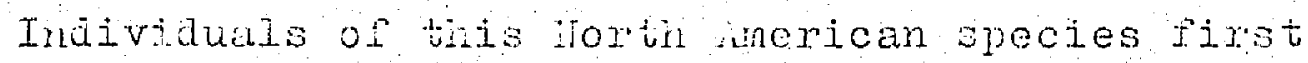
arrive in aideptenber ana by late october tiney are comon. Itumorous Indigo Zunting romain as anter visitunte. Grassy ereas, low humil, and brushy lantation edces throughout the Colong provide its selected habitet and there flocis of 10 to 30 biras are oiten found. Un the nathland winter visitunts wha mants are difficuit to ajstingush. Bxtrewely fat individuls (such as the one obtained April 19) collectea in nontypical habitats aro ikely to be mirunts. Bute obtained by verner on Half hoon Cay during the spring provide userul inioxnation, since tile spectes does not 
winter there. Verner noted nubes of trinsionts

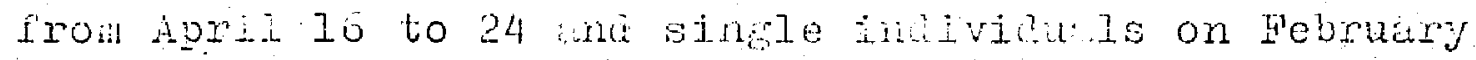
20 nd lifars 26 . :ost Indipo butines itve departed

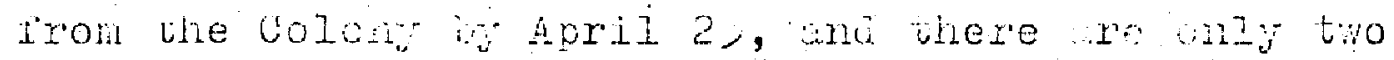
Iote: recoras (furil a, Marb).

\section{Passering ciris (Iimineus)}

\section{Painted matime}

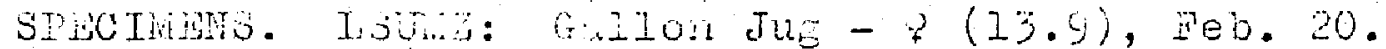

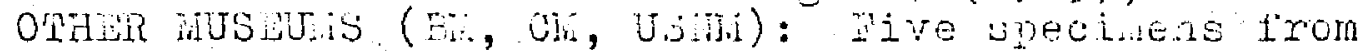
Belize, Cayo, l'oledo Settletrmt; Feb., Kor., Dec.

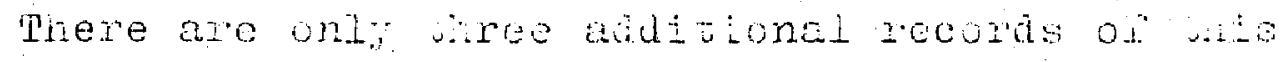
species from Britsoh Honduras. Wil is saw two birds

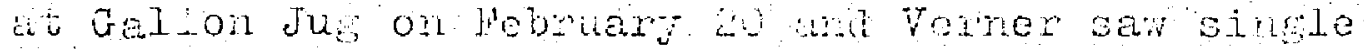

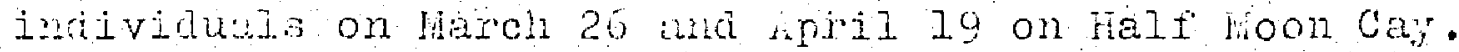

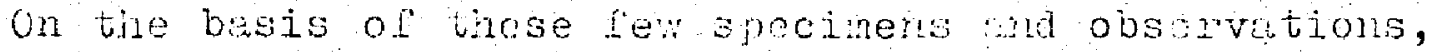
I consider santed suntigs mare winter visituts and tranients.

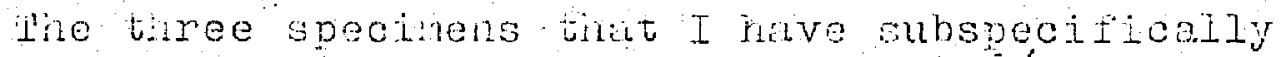
identilied are refermbe to 1 - e ciris.

\section{Soiva americuna (Gmelin)}

Dickcissel

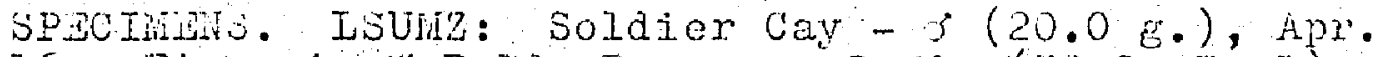
16. Pive mi. Jaldy Seacon $-20^{\prime} \mathrm{s}(30.9,35.1)$, Apr. 20. Ballerina Camp - $(22.6)$, Apr. 27. OLARR hUs SUMS (BH, CC, Ch, MCZ): Twelve specimens from San ilelipe, liantee Lagoon area, dugustine, southern. $[=$ liountain] Pine Ridge, All Pines, south hest Cay; Har., Apr. CRILICAI PUBIISHD RUCORDS: Half Hoon Cay, hay 9 (salvin, $1364: 380)$. 
the Dickcissel has been observed in writish Honduras only from the end of. F'ebruary to 1 ay 14 with the majority of the observations occurring in the period of April 12 to 27. Wirrants mit stop in ciny open dxea, es ecially on the keys and tine rasiland of pise ridses at all elevations. Flocks o: 15 to 30 inriviands of thio conmun transiont are of ten seen. sone birats are extremely fai (compire leights woove). líp gonads of biris taken in late April were slitrity enlarbea ana Peck states ilut in hay nany Dickcissels were sirejing.

\section{Sporophila borqueola (Bonaperte)}

\section{Wite-collared sedenter}

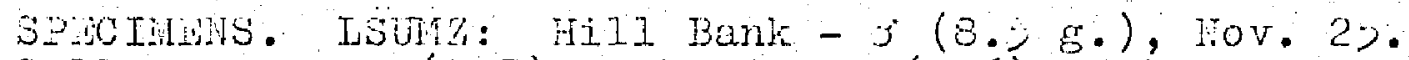
Gallon Jug - ? (5.7), Feb. 21; $5(7.6)$, Feb. 22; $(0.6)$, oct. 26. Two ni. is San Perro Columbia -

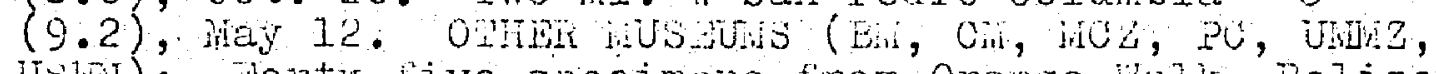
Uswil): jorty-ive specimens from orange talk, Delize, ifenatee Iagoon area, Cayo, Jan Felipe, 12 mi. S Cayo, Freetown, All pines, ioledo jettlenent; alI montis except July, hug. CirITICAS PUBI.ISISI RTCORD: 'Corozal (Salvin and Godnan, Siolokia, i, 1802: 353).

Wherever grass or wead patches occur on the nainland of the colony - in or near villages and plantations, on stream banks, and in pinelinds - the gregarious Wilte-collared seedeaters are usualli ratier comon residents. Nesting bejins in nid-foril and continues at least until septeriber 10, when the latest nest was recorded. Skutch (1954:36) reports that two nests out of five found on the Pacific slope of Gutenala 
contained sets oi three egss, but allother nests that he found contahned sets of two egrs. In British Nonduras sets of 'two eges are normal, but both peck and iillis hove each found at least one set of tiree eses. I refer the suecineins to $\mathrm{S}$. $\mathrm{t}$. norelleti.

\section{Sporopilic aneriomi (Gmelin)}

Varieble seedeter

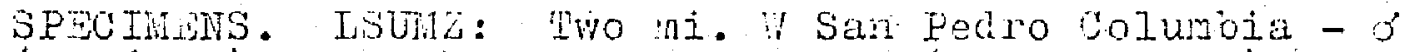

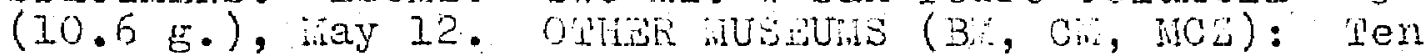
specimens from Cayo, Frectom, ioleao settlement; Jan., jiay .

In British Tonduras, Variabie segleaters have

been recorded only at the localities where spocinens

- were collected. Tho speciaen from cayo is an old undated skin in the British useun. The species hos not been observed at Cajo in rocent yens. This secdeater vas ratier uncomon in tis low vege tion of abanconed plantations near sar pearo soiubla we malo collected In hay nad enlorged tester, an peck tound a nest containing one ebe on sentember 4 . 403\%

s. a. corvina is the distinct race of the Vapiable Seedeater to wich I reier the Britioh Tonturan specimens.

\section{Oryzoborus funereus Sclater}

Lesser Kice Grosbeak

SPICIMENS. ISUMZ: Wwo mi. E Hill Bank - $s$ (13.9 g.),

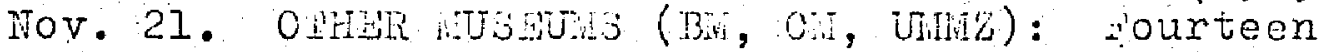


specimens from ifmatee Iagoon area, san Pelipe, f'reetom, All Pines; Feb., Mrr., Apr., May, June, July, oct.

This snall foch is rether local in its occurence in the colon and $m y$ be consid rod comon orly in the vicinity of ianstoe Lagoon, ill pinos, and folocio sectlemert. Galion Jug and Ycacos Ingoon we abiziont localitieo where it has been seen. lnis secies renuents brushy pintation edses, low husil, an dickete on the edge of the lowl ind ine nides. Peck pond nuerous hesos of the Lesser hioe Grosben betweon hebrum 20 end tugust 2 . Some indiving mo noot even liter, row the nale I collected on hovenber 21 had fully enicrged

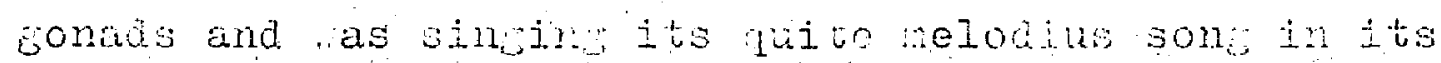
entirety.

\section{Volatinie Jearins (Iinmaeus)}

Blue-black Grissquit

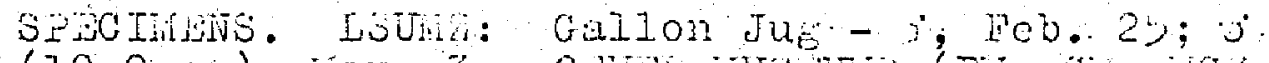

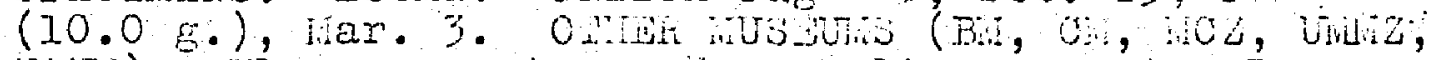
Uinii): Heven specimens from Belize, hanated Lagoon area, Cajo, $12 \mathrm{mi}$. S Cayo, Augustine, hountain Pine Ridge, All pines; Peb., har., hpr.

Blue-blick Grassquits are moderately comon residents of grass and weed patches in clenribs ana of low second growth, trrouginout tive Colony. Whey frequently associate with sporomila torqueola but are. less abundant than the latter species. Peck found three rests, one in April and two on June I, at l'oledo 
Settlenent; and Fillis observed cencle incubating two eggs on dugust 2 at Galion Jur. Lach of these nests wis within 4 feet of the crourd. the Central Anericon raco of this suectes is

V.: j. splenaens.

$$
409
$$

\section{Spinus notatus (DuBus)}

$$
\text { Black-redea jiekin }
$$

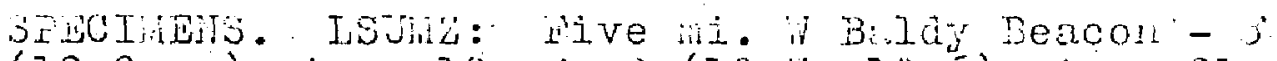
(10.0 E.), Apr. 19; $;, \quad(10.3,10.6)$, Arr.21. One mi. N. Ballerina Camp - S (11.4), Apr. 23. 0nin

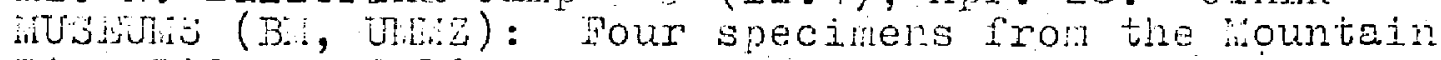
Pine Ridge and te mi. is Cayo; Feb., hpr., itay.

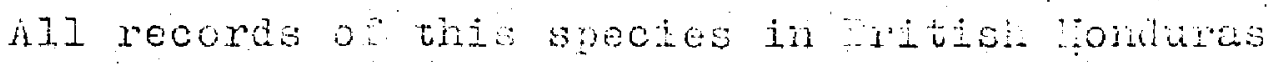
are from tire rountain pire iase. In the acutered pines of this area, 3lack-headed siskins are way and uncomon, occuring sinely and in flocks of four to ten individuels. Ho of the four spechens at trio luvin that were collected in Aor I Ha marged gonas. Van lyne securea tro fenales in lute rebran. Ono possesseà an enlared ovary and weighed 3.9 grams. I did not see siskins in Decenver auring two weeks spent on the mountair pine Riagre.

I have criticaly exminen the six ritish fondurin specinens in the museums in tis counto phis series resembles specinens of $\underline{\mathrm{S}} \cdot \underline{n}$. olenceus fron fonduras and is unlike liexican and Guatenalan indiviouls of $\underline{\mathrm{g}}$. $\underline{\text {. }}$ notatus. Birds from the colony do aifler from llonduran 


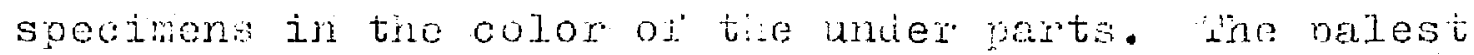

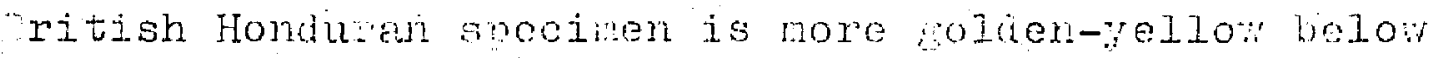

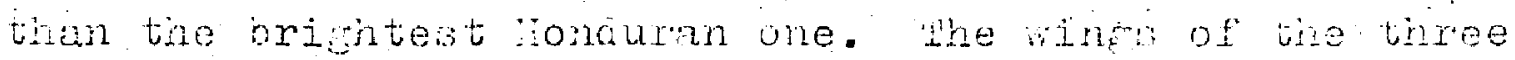
males from Britisli Fonduras are biont, measuriy, 62, 62,

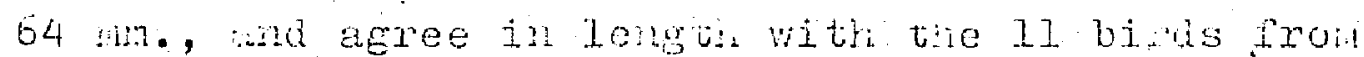

Honduras (63-64.\%, one 6\%.0 mn.). Griscon's (1932b: 61) aescription of the race from londurs includes hio

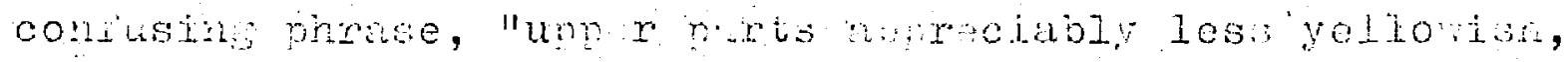
moxo olive-gred", in congreon nat

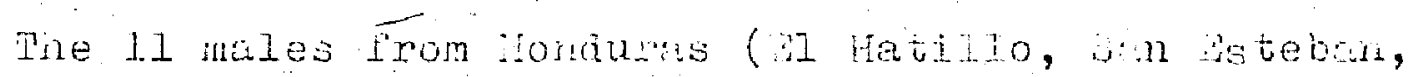

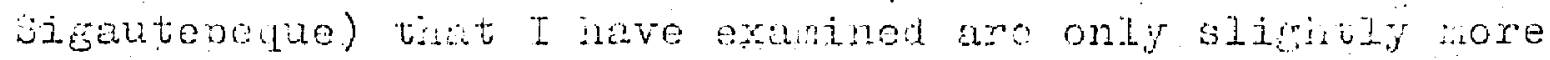

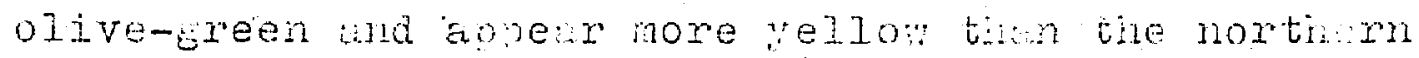
birds.

\section{Loric curvicostrin (Ininaeus)}

\section{hea irossbil1}

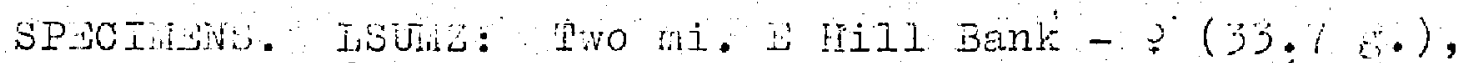

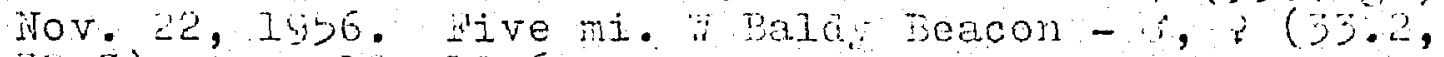
$30.2), \quad 1 p r .19,1906$.

Crossilis anve been noted only in prelunds. ine specinens listed above anc single individuals observed in tie nountain pine riage on larch 20 and horil 20 constitute the only definite records of lins upecies Iron the bolony. Hellnayr (1930: 304$)$ lists two specimens fron Brithsh jondu:as in the Chicaso itatureil nistory inseun. These two biras rede collected in worenber, 1030, at Irumilaca by je fithugel. I hove been unele to 
iocate a loculity by this liake. Jr. James A Maight, Director of urveys ir British Tondums, wh has been most helpial in checking virious loc liuies for we,

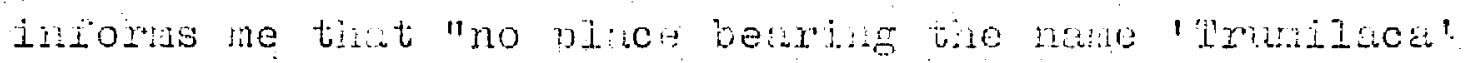
is lnow in arizisi tonduris, wh the rane does not

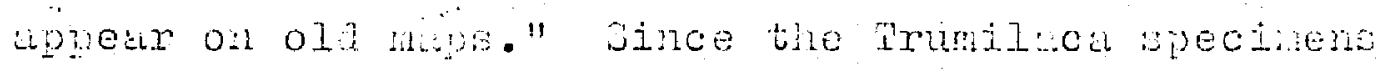

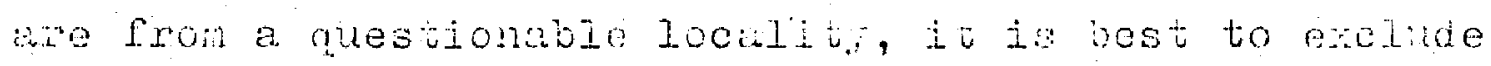
then from the list of sectimens.

The rembe collected Apwi 19 mo in weenim condition, but the nale coliected or we same day hai only slifgity enlugeri ondas.

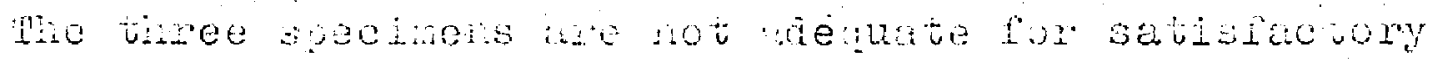
racind determation of the Eritian rondun population.

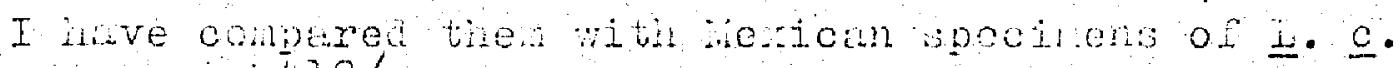
I 412 / 413

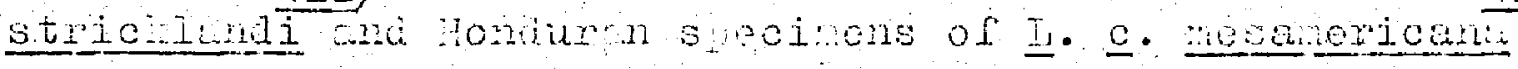
fnd rovisionalif reler the to the latur race he

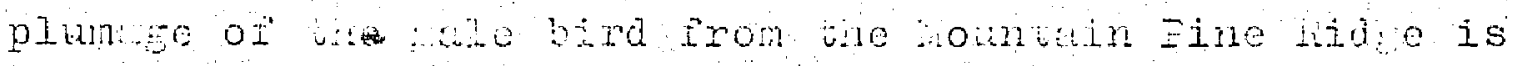

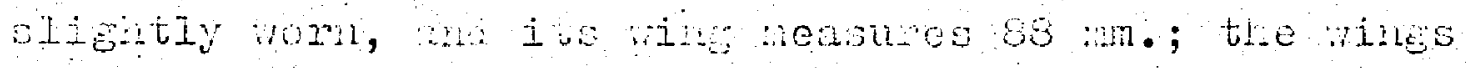

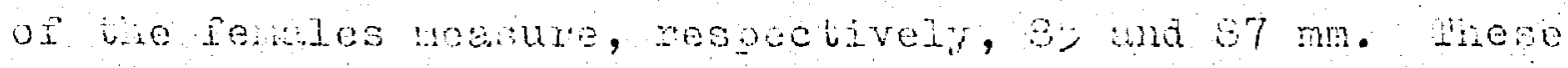

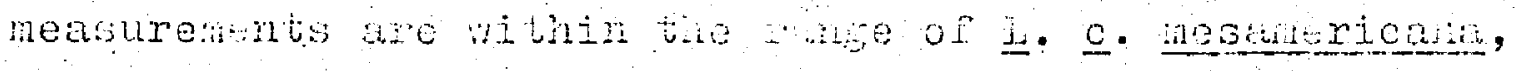

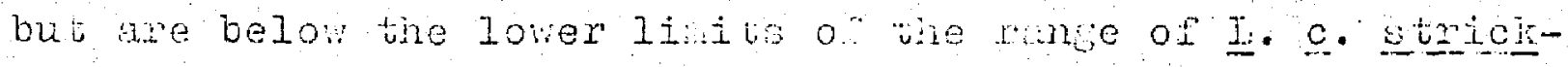

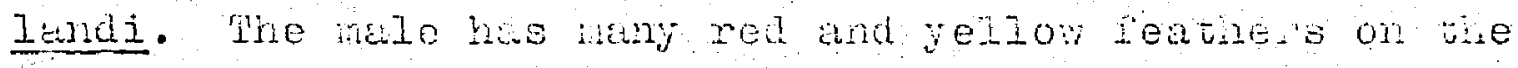

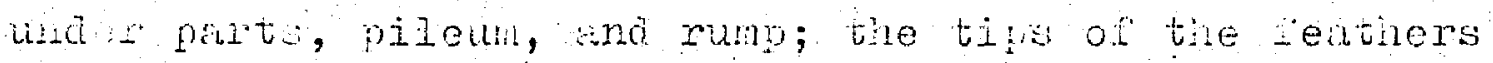
of the back are eaged with yellow or red, nu the back

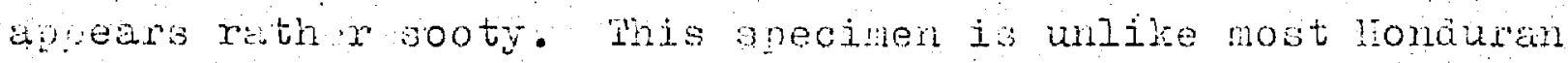
biras, which are deep rich red, but one fordu nale 


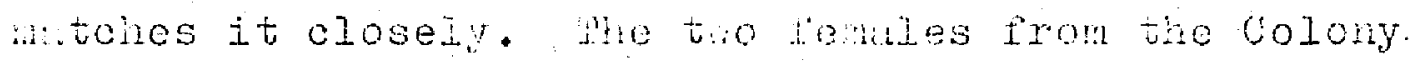

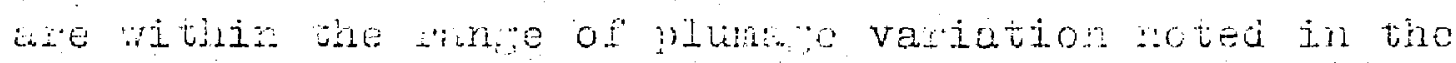
Honduran maverial.

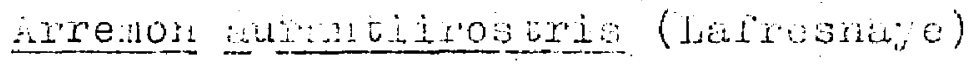

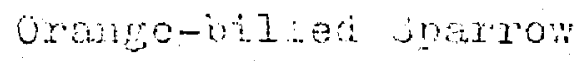

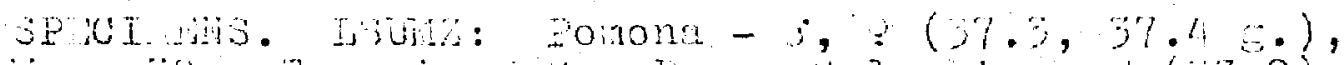

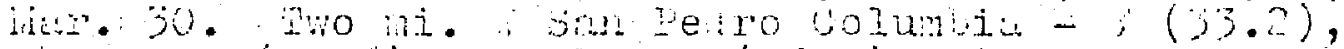

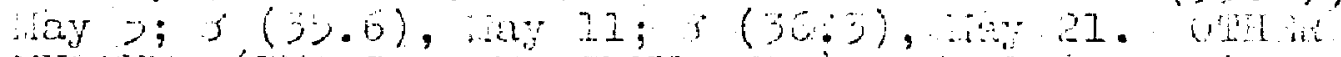

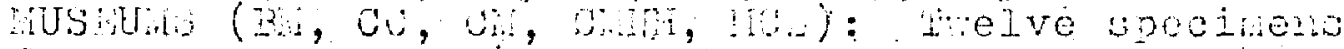

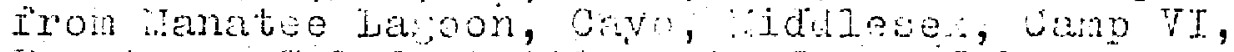
freetom, loledo settlonert cin., seb., ner., inay,

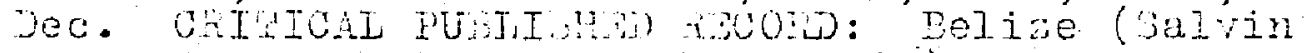
atc sodman, Biolugia, i, 1364: 324$)$.

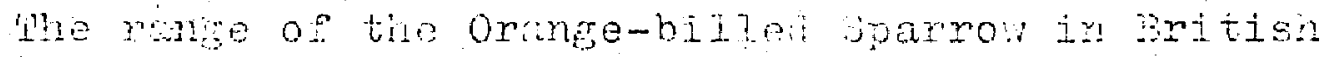
Fonduras lies to the soutin of tre belize kiver in dense,

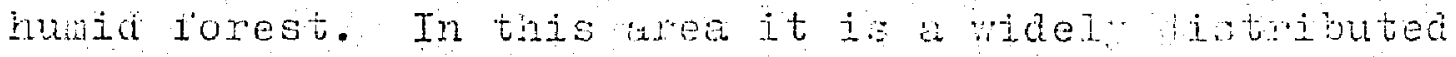

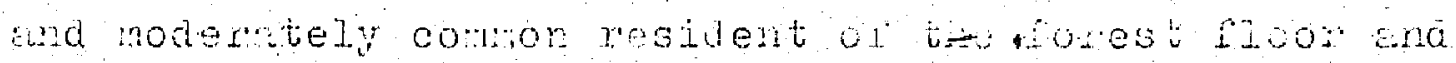
its low unengronth. I havereen tin poting snocies

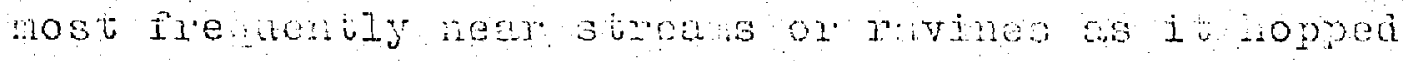
about in tho dam round liture. The nale collected on

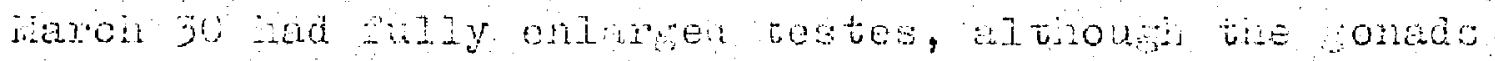

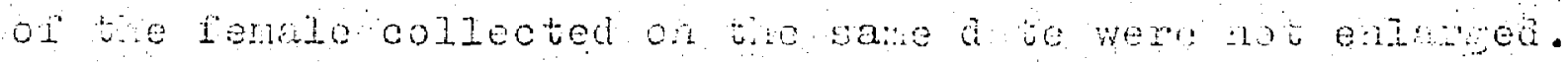

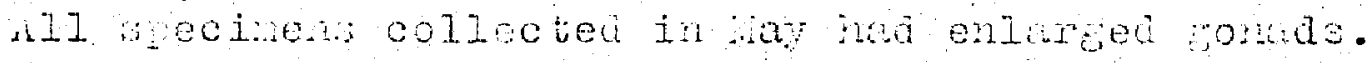
Peck round a nest on far $1 / 4$ am moting on June 1 , edcis

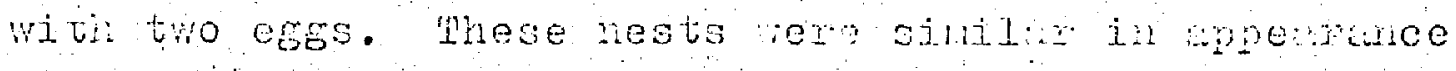
Ha conposition to those described by jhatci (1904:9y-96)

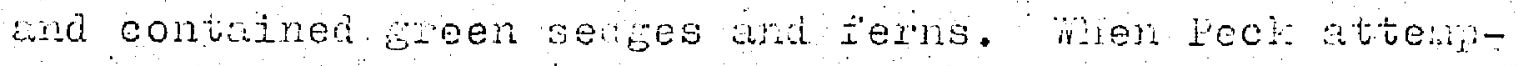

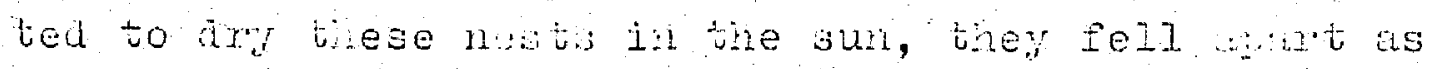
vise resilt of tire curling or the nest natuials. 


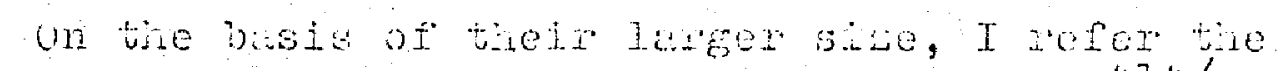

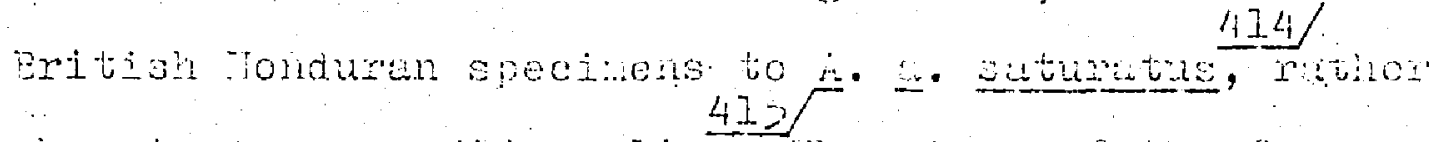

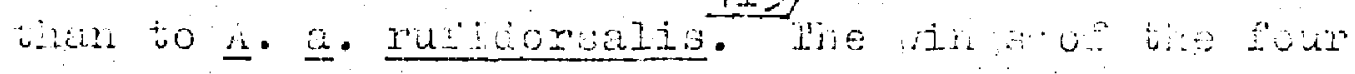

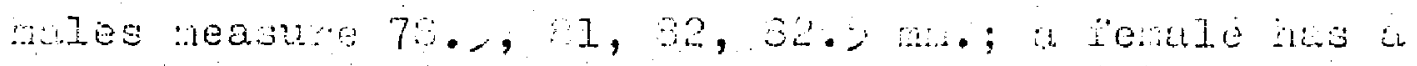

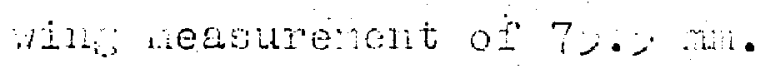

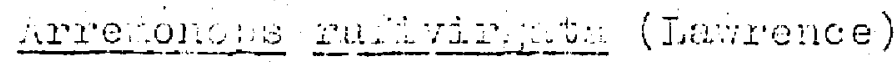

\section{․ Ulive siarro:}

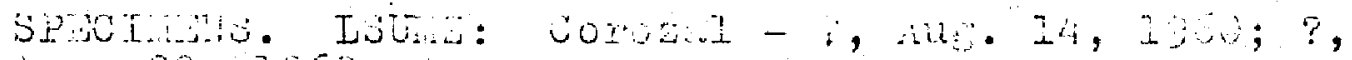
sus. $20,2960$.

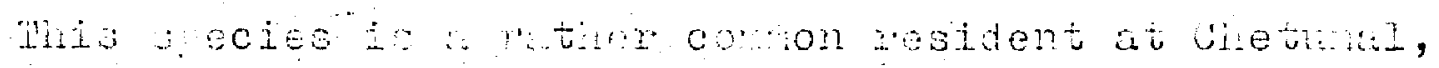

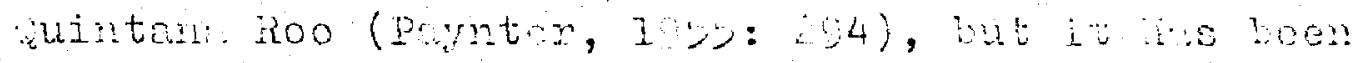

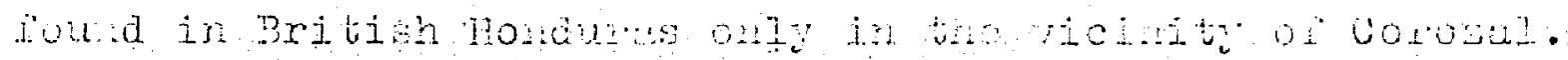

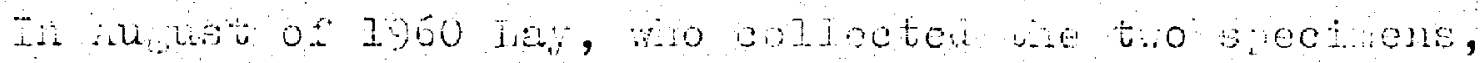

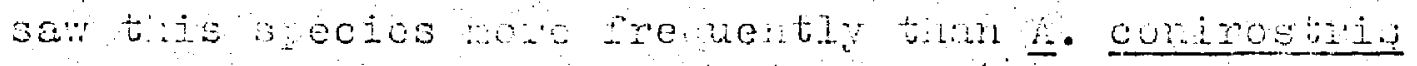

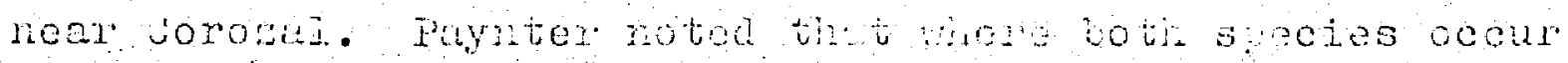

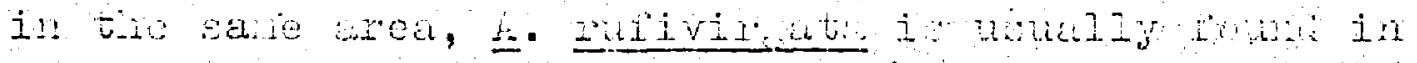

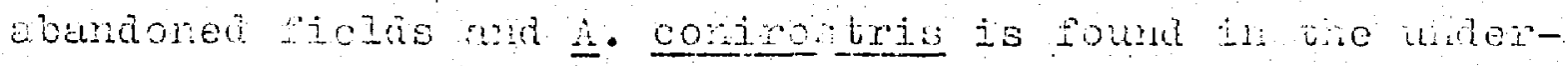

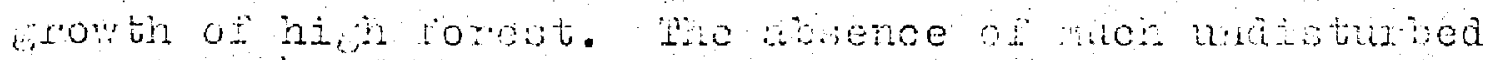

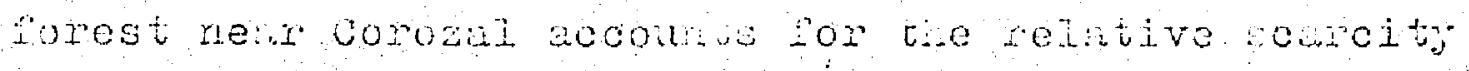

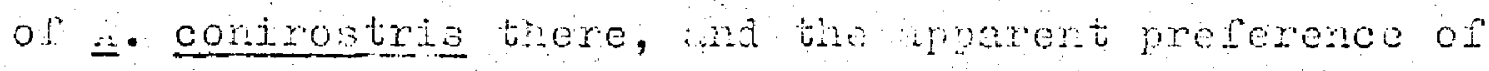

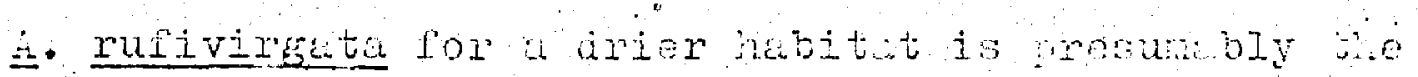
ictor but confines to to the northon tip os tae colong. I plice we tro specimens in tire rice endenic to tise Yucatar peninsula, $\underline{A}$. 


\section{Aruenuons controgtria (Bomante)}

\section{Grean-bached sparrom}

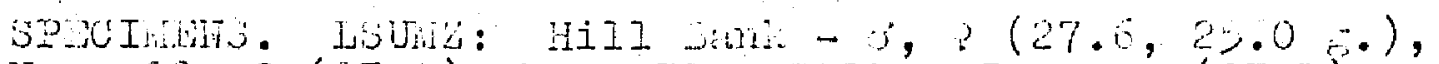
Nov. 20;? $(27.4)$, Nov. 30. Gallon Jug - (27.1),

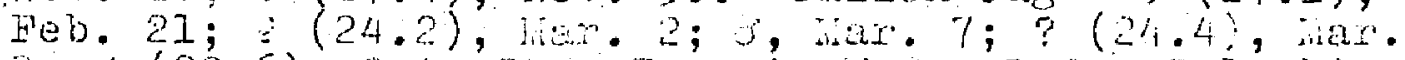
8; $0(29.6)$, oct. 29. Tivo ni. ¿ jm zedro columis-

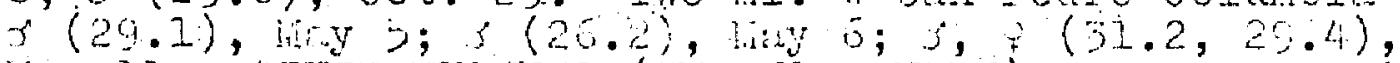

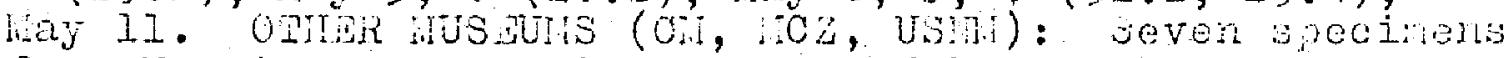
fron hantee Lacoon, Caỹo; Jan., Feb., Mar., Anr.

Green-bucked sparrows heve beon weorden in

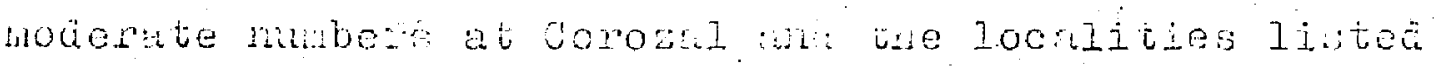

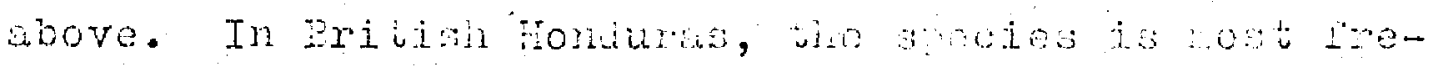

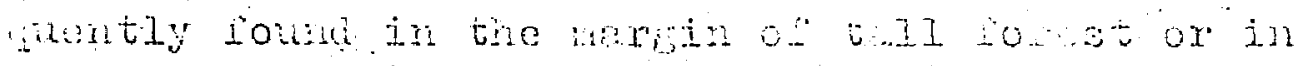

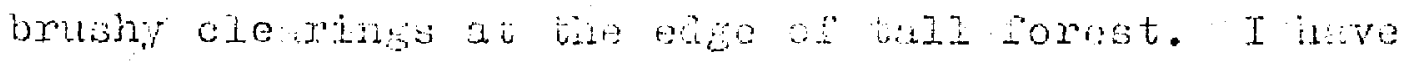

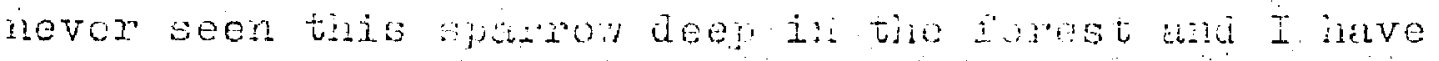

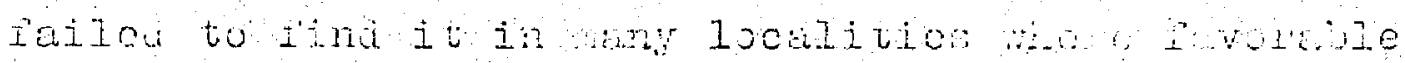

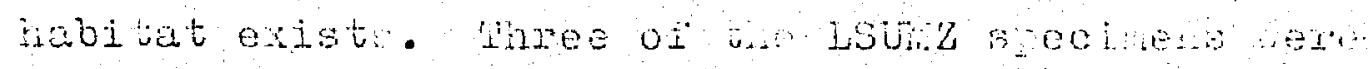

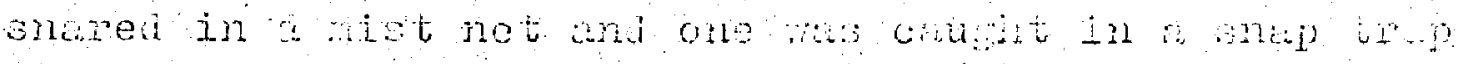

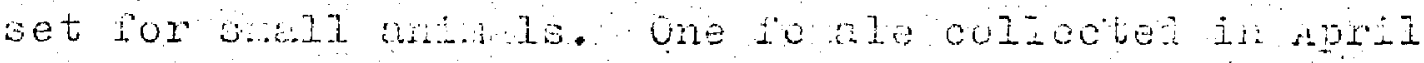

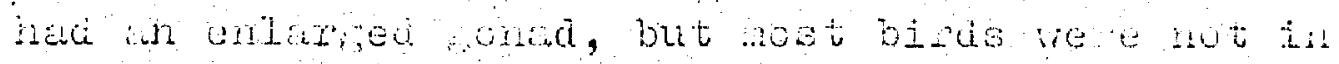
breading condition wetil hay at Gilon Jus, nilis nobej fonles rest building between wy 24 and oun 00. I assigr the ropulation of this aneies that inhabis British nondures to 1 . c. chioronotus.

\section{Eusserculus squdichonge (Gnelin)}

Bavangar brartom

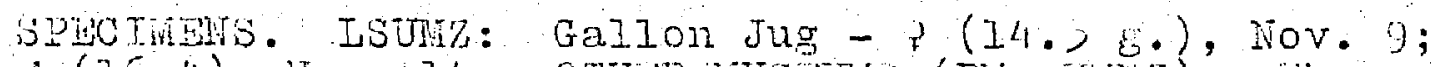

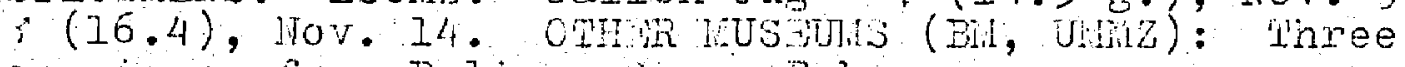
specinens from Belize, vayo; reb. 
'this species occurs in jritish nonduras as en occusional winted" visitant. vily one observation supplenenus the records renesented by lie opecimens listed above. On xurch 20, 1906 , I say four inaividuis in a frassy fiela near the beach at jtun oreak. I reler the tro specinens from Gallon iur to

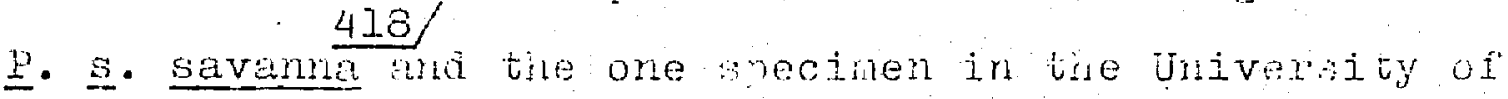
Michigan inseun of zoolosy, whici wat collected by

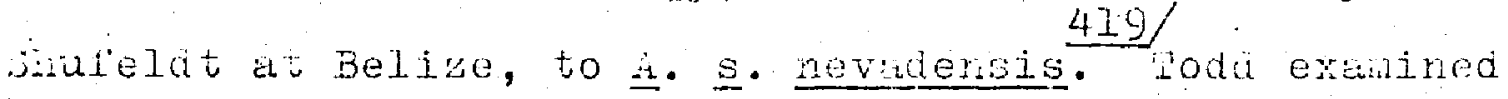

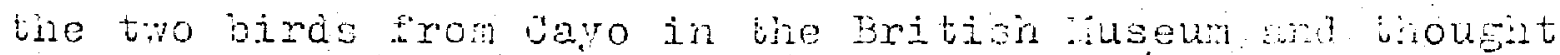
that they were probably A. S. untimus.

\section{Amodians savingarum (Greinn)}

\section{Grisshoppes jparrow}

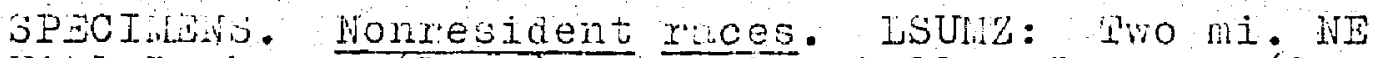

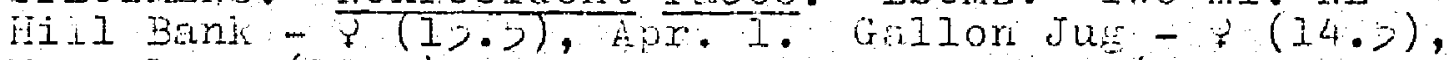

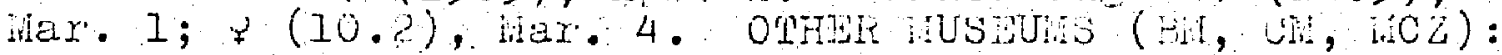
Five spectinens from Orange walk, hinetee Jateon anea, All Pines, Noledo setilenent; Apr., Dec. Kesident réce.

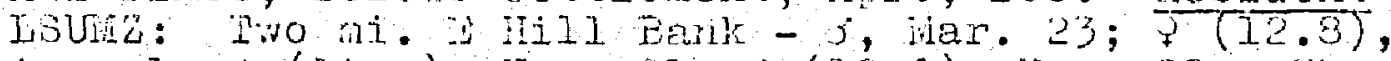
Apr. 1; f (14.2), Nov. 21; $7(12.9)$, Nov. 20. Mree ni. (ii Baidy zeacon - ? (14.9), Mar. 17. Mustine - 5 .

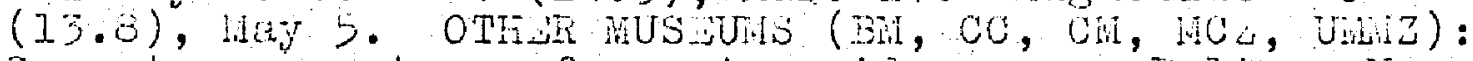
Seventeen specinens from pine ridges newr belize, Manatee Lagoon, $12 \mathrm{mi} .3$ Cayo, itountain Pine riage, frreetom; All Pines, Ycuoos Lagoon; lieb., Max., Arr., hay, June, Aus.

Northern populations of the Grassiopne spurrows wre regulas winter visitarts in pritish fonduras and are resent in small numbes from an undetermined ate in the fall until late April. A single bird noted by Vernew on April 18 on Hall foon Cay sugests that this 
species diso occur: in the Colong da transient.

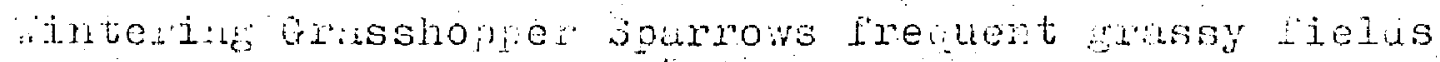
and the grastand of the pine ridges where tho lock ace resides, loda considered tie wo Mritish luseun

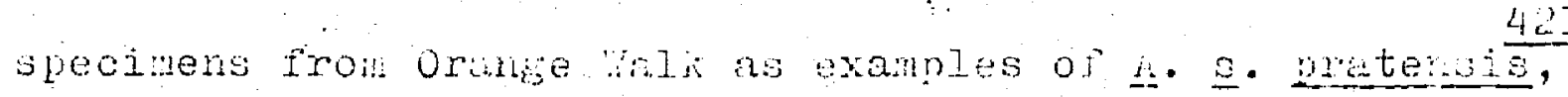

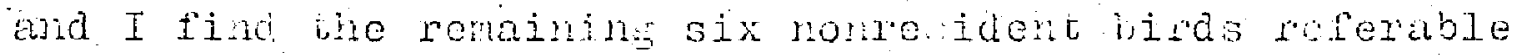
to tinis race ulso.

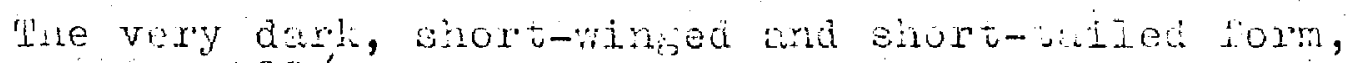

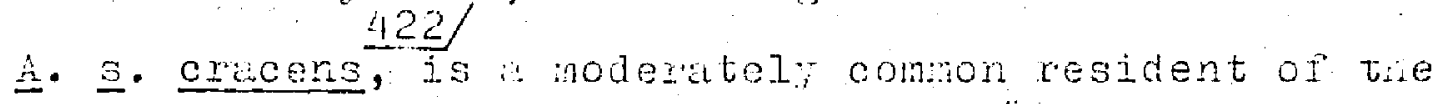
short grass in the pinelumb thromout the British contum lowiands wh is residert but less comon ir the nountain pine kideo. Like otron "grass surrono, it is shy wha rasnes ony hon an roached to within a lew feet. Itrer it files away low ore the eruss, arops wo the grounc, and mo some distance. Gonda endere in late

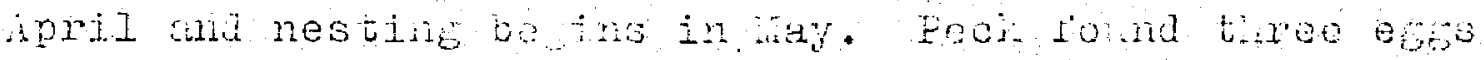
in a rest nem halding hiver on hay 27 . un the pine ridoe east of rill Bork, ilizis roted nestoondinin one egg attended by ar aduli on hums 3 .

\section{Minopilin ruescens (swanson)}

nusty Snarow

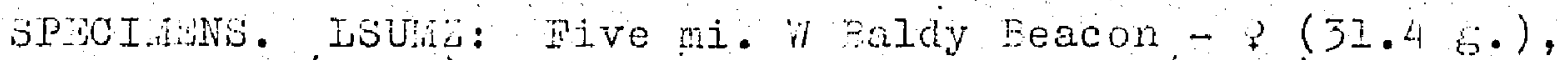
Apr. 19; $(28.2)$, Apr. 20. Augustine - $3(30.9)$, ihtr.

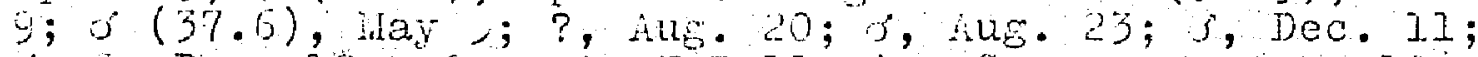
3 , Dec. 12. One ni. I Beillerina Cmp - j, Apr. 19; 3

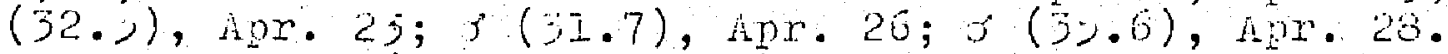

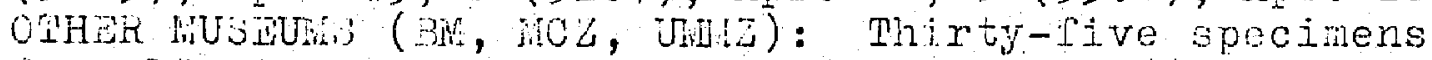

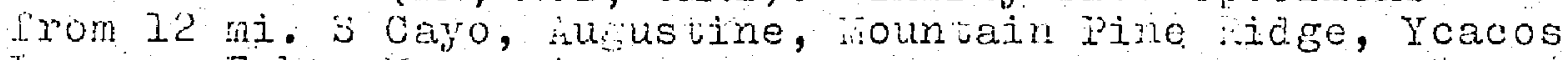
Lagoon; Feb., iar., Apr. 
In the extensive srassy areas of tile pinelinds of the Hountain Pine lidge, especially near brush filled ravines and suall thickets, Fusty jparrows are comon, consuicuous residenta. I have never seen this sparrom in the lowlond pinelunds, but Peck raported then in this habitat at Monkcy Riven and at Ycacos Lesoon, where he collected three pecinnas ihe concis of only one-half the birds collected in late April and hay were enlarged.

I refer the specinens of the Rusty sperrow fron British Hondures to $A$.. pyritoides Pans and Peck (igos: 46) assjgned the tiroe syecinens from Ycucos Gagoon to is. ‥ discolor on southern Honduras, on the basis of their snell size and plumage characters. I nave not soen epecinens of the latter race and emmot coment on its vilidity. I heve however, compared the British Fondurin specinens with a series of $\underline{A}$. $\underline{\text {. }}$ pyratoides from eastom letico (Verucrus, san luis potosí) and I do not find them different. Furteen mele birds fron the hountrin Pine Ridgo have ing measurements in millineters ringing from 66 to 72 with a nean of $70.0 \pm$ 2.14. The tirils of these snecimens range from 72.5 to 80.5 with a mean of $73.8 \pm$ 2.3ל. Ihese newsurements are not significutly shorter than those of seven males from eastern liexico, which have wings ranging in milineters from 67 to 73 with a mean of $71.4 \pm 2.0$, and tails ranging 
from 71.2 to 79 with the ach $79.4 \pm \cdot 3.0$. Where are no

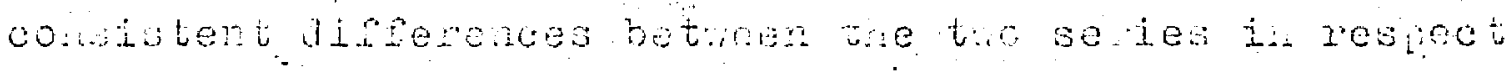

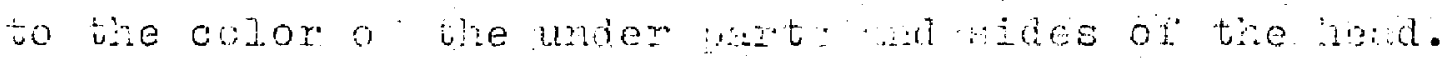

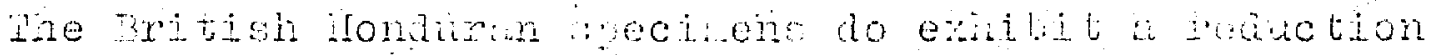

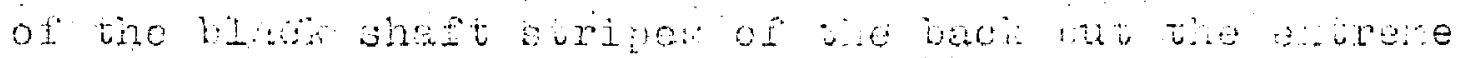

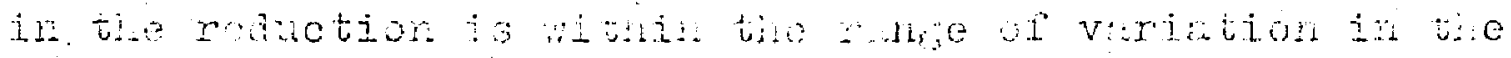

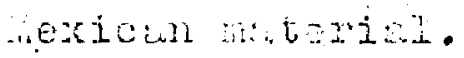

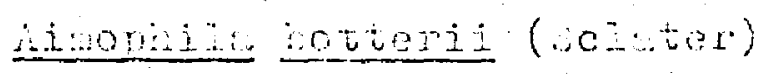

roturiss sarrow

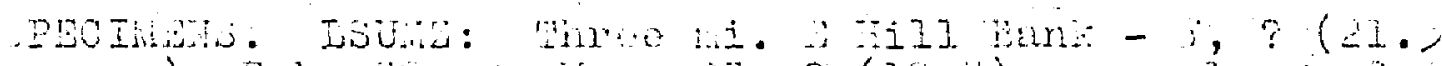
(20.1, 20.4), nov.

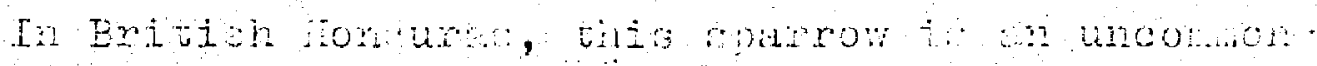

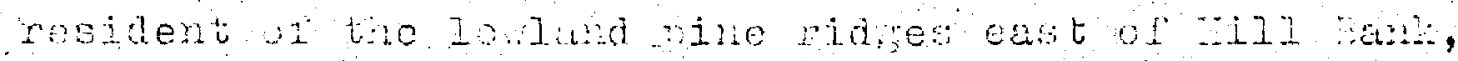

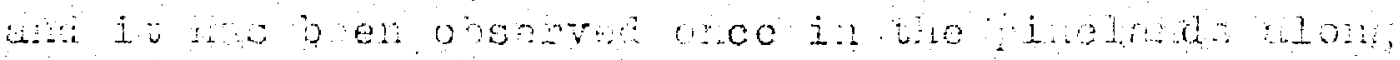

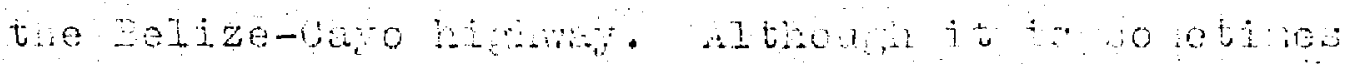

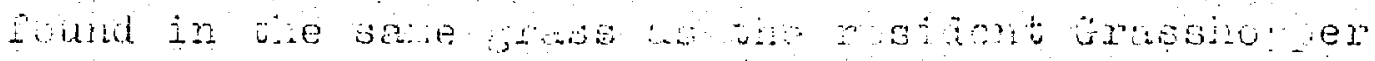

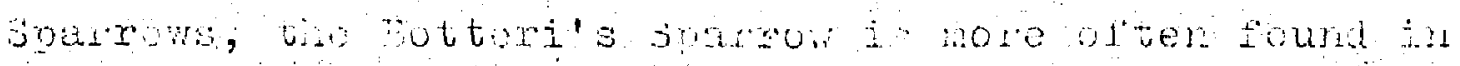

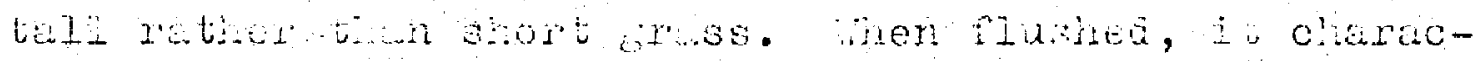

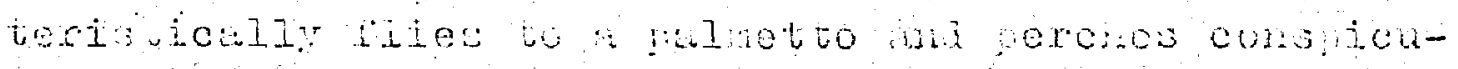

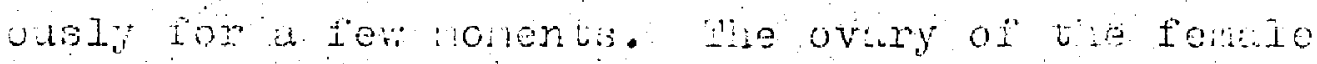
collocted in late warch was slightl enlined. On aroust 3, 19,7, 7illis obsorved a sureul-brensted juvelile

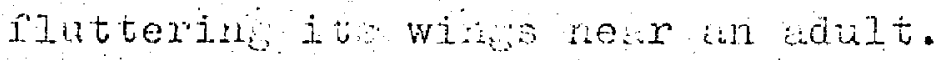

the extreably durr population of tid: a arrow resiang in the petén, dxitenala, and oriphatiy described 


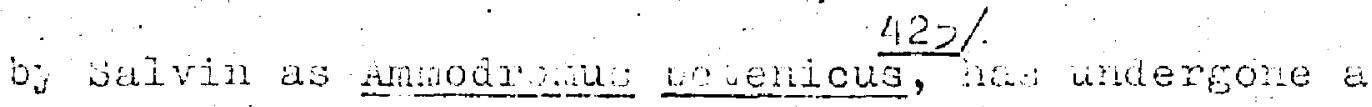
sepies of nonenclatorial cinmes. - In loge, Ridgray. trinsferrod it to vie sems inomlia, and in 1901

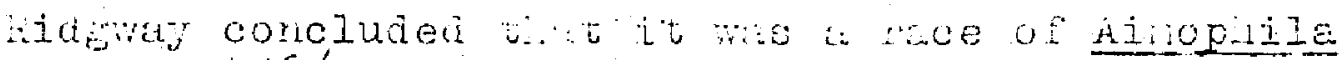

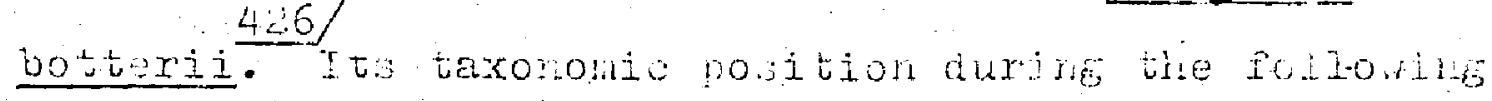

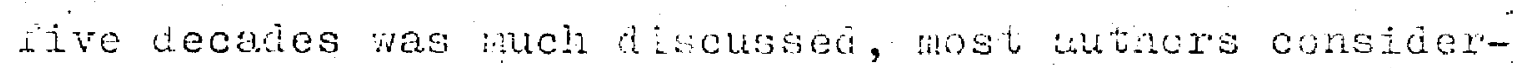

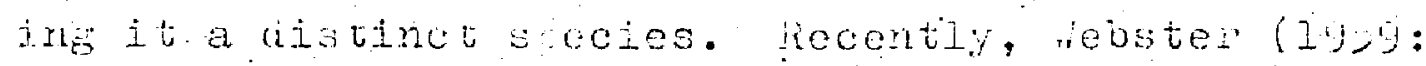

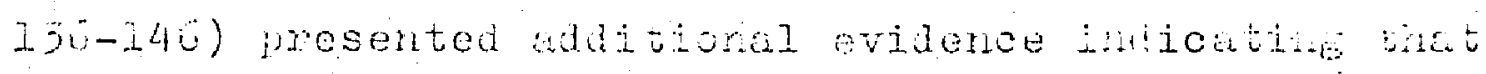
4. Dotenios and

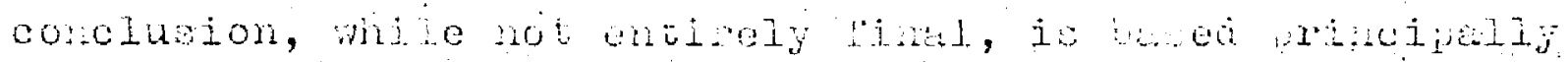

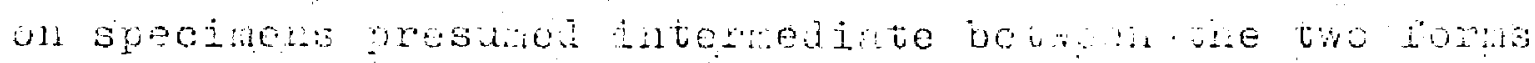

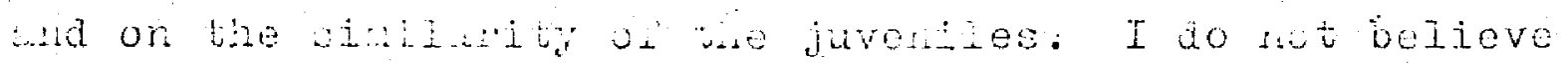

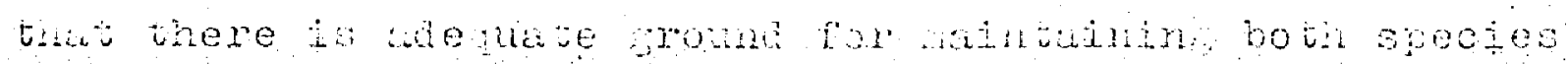

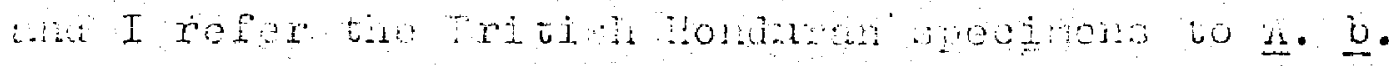

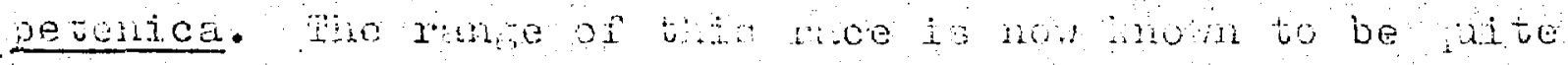

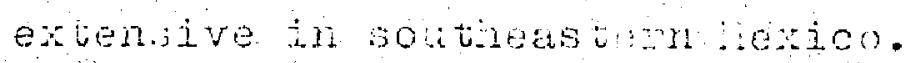

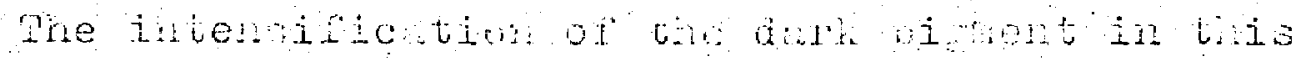

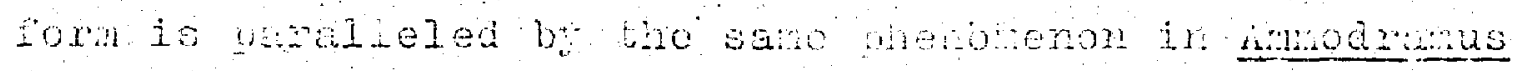

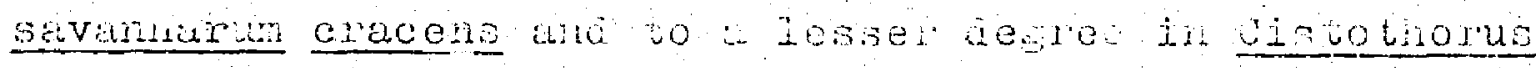

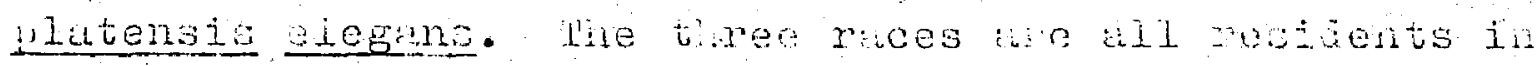

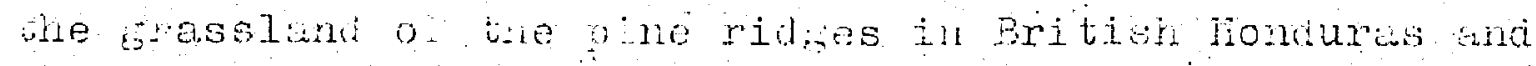
cadjuent aress, tron hot occurrins in exactly tad sane areas. 


\section{Bojellit passorina (Nechetoin)}

\section{Uising ingron}

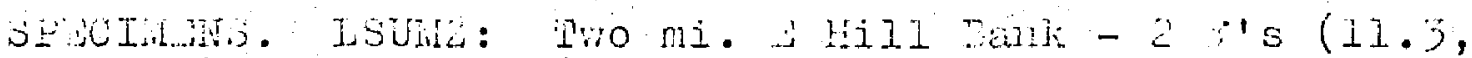

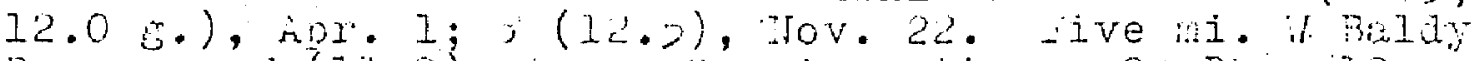

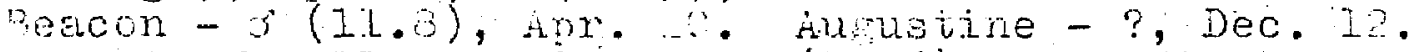

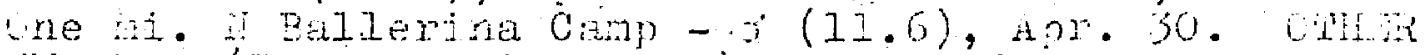

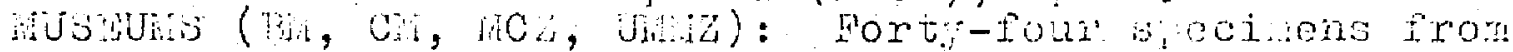

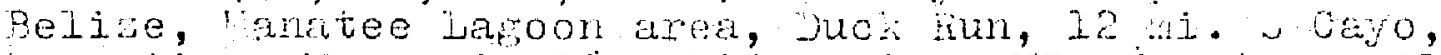

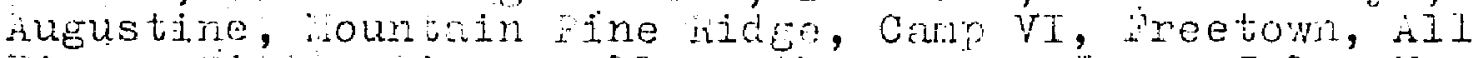
Pines, sibtee Rivex; all wontis excent dune, July, Hov., Dec.

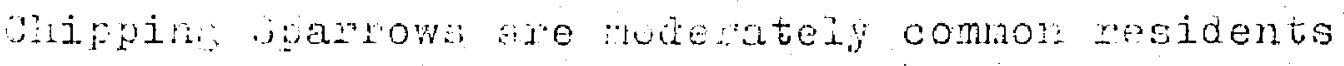
of the binel nas at all eievations throughout british Fionduras. Intrequenty, trey are found in closwincs in tall ruin torest adacent to the pine ridres. specimons in breoding condition have been when in armi and May, and Peok fount a nest contuinin three efrs in a pine troe nesr wanted lab;00n on hay Is, I006.

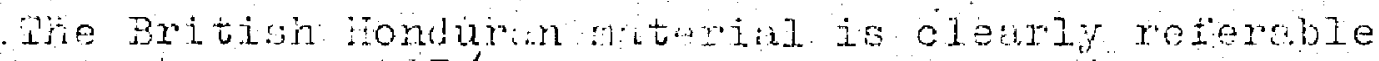
427

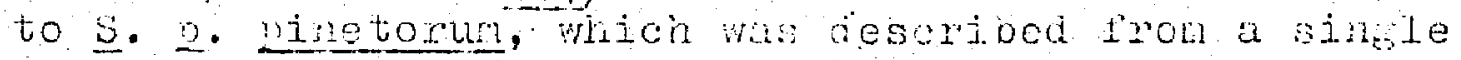
specimen collected at poctur, intentia, a locility about 40 mies southest of the hountain pine Rilge. "the trpe, an adult nele, hats aing neasureitert of 71 and osil measurenent of 62 m. the sucimens from the colony agree vith it in plunte chureteristics but are sailer. iffeen males have angs whing fron 66 to $69 \mathrm{~mm}$. with an averge of $67.7 \pm 1.20$. The trils of these moles range trom $y$ to $29 \mathrm{~min}$. wis a inean of $20.3 \pm 1.90$.

On April 3, 19ye, Jared Femes identified a sparrow on Falf joon Cay as s. passerih. since thip bira was not collected, its suospecilic identity is not known. 


\section{Lelospiét lincolnit (Audubon)}

\section{Lincoln's Buaxro"}

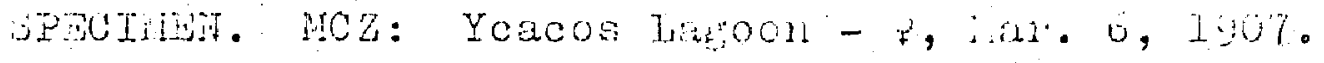

This smecinen, wioh was collected bo peck, has

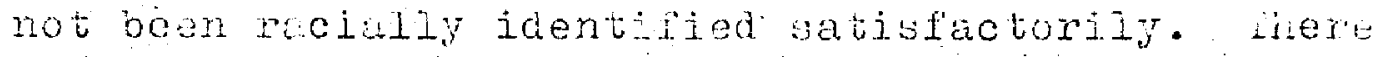
are no other roopds of the spectes from Eritisin ilondiris. 


\section{DISCUSSION AND CONCLUSIONS}

Four hundred and sixty-three species of birds have been definitely recorded from British Honduras. of this total, 308 species definitely or probably nest in the Colony and another 20 species may possibly nest. Winter visitants and transients amount to 126 species, of which 50 are predominantly transients. Another four spectes are stragglers. Five forms are present throughout much of the year but do not breed.

The rain forests of the Colony are continuous with the forests of the Caribbean slopes of Central America to the south and with those of Guatemala and southern Mexico to the west. The birds that inhabit the tall, humid forests in British Honduras are consequently typical of the forests of the Caribbean lowlands of northern Central America.

The avifauna of the tall forests of the Colony is rather uniform from south to north. This uniformity is surprising, for rainfall ranges from an annual 175 inches in the south to only 59 inches at Gallon Jug, a locality less than 20 miles from the state of Quintana Roo, Mexico. A total of 216 breeding species are associated in or near rain forest habitats in 
Britîsh Honduras. Only 13 of these species (Table 1 , Sect. A) have not been recorded in the vicinity of Gallon. Jug and in other more northerly parts of the Yucatan Peninsula (Quintana Roo, Campeche, or Yucatan). Seven other species are listed in. Table 1, Sect. B; that have been recorded fewer than four times at Galion Jug, but are more common to the south and unrecorded farther north on the Peninsula. Ciccaba nigrolineata, Dysithamnus mentalis, Pachyramphus major, and Campylorhynchus zonatus are the only rain forest species in the Colony that have not been recorded at Gallon Jug but are known from Quintana Roo, Campeche, or Yucatan. On the other hand, 24 species (Table l, Sect. C) occur at Gallon Jug but are unrecorded from the Mexican portion of the Peninsula. I believe rainfall, per se, is less of a limiting factor to bird distribution than is commonly believed. The forests at Gallon Jug are. scarcely less tall or luxuriant than the forests in southern British Honduras. While at Gallon Jug, I always felt that the humidity was high, even in the dry season, and I suspect the humidity has much to do with maintenance of the forest. The birds are undoubtedly there because no barriers have prevented their spread. Some response has occurred to the drier conditions in the northern part of the Colony, and it can be noted in an analysis of the endemic element shared by British Honduras and the northern Peninsula. Two hundred and 
TABLE 1

SPECIES RECORDED IN RAIN FOREST OR ASSOCIATED HABITATS

A. Occurring in southern British Honduras but unrecorded at Gallon Jug and in Quintana Roo, Campeche, and Yucatan.

Leptotila cassinii Thalurania furcata Heliothryx barroti Electron carinatum Taraba major

Thamnophilus punctatus

Thamnistes anabatinus
Gymnocichla nudiceps Zarhynchus wagleri Tanagra musica Tanagra minuta Sporophila americana Arremon auranticostris.

B. Occurring in southern British Honduras and rarely at Galion Jug but unrecorded in Quintana Roo, Campeche, and Yucatan.

Phaethornis superciliosus Campylopterus hemileucurus Florisuga mellivora

C. Occurring at Gallon Jug but unrecorded in Quintana Roo, Campeche, or Yucatsn.

Leucopternis albicollis Pulsatrix perspicillata Phaeochroa cuvieril

Malacoptila panamensis Centurus pucherani Glyphorynchus spirurus Xiphocolaptes promeropirhynchus Automolus ochrolaemus Laniocera rufescens
Colibri delphinae Cotinga amabalis Terenotriccus erythrurus Ramphocelus passerinii 
thirty-eight species nest on the mainland in both British Honduras and more northern parts of the Peninsula (Quintana Roo, Campeche, and Yucatan). Four of these species are endemic to the Feninsula: Meleagris ocellata, Otophanes yucatanicus, Myiarchus yucatanensis, and Dumetelle glabrirostris. Forty-six of the 238 species have endemic subspecies on the Peninsula, and of these endemic races, 32 occur in British Honduras, or show their influence in birds from the Colony (Table 2). Endemic Peninsular races are generally paler and smaller than contiguous races.

Only five forms collected in British Honduras have close affinities with the west Indies. Columba leucocephala and Elaenia martinica occur in British Honduras, the islands of the northeastern part of the Yucatan Peninsula, and in the West Indies. Vireo altiloguus has a similar distribution but has been recorded in the Colony only once. Pelecanus o. occidentalis and Pandion haliaetus ridgwayi are races represented by breeding birds in British Honduras and also various parts of the Antilles.

The keys are small and numerous and are situated close to one another. Many are near the mainland. Nonpelagic spectes found on the keys are not different from those on the mainland. The 31 species that have nested on the islands are listed in Table 3 . Seven of these species have not been recorded nesting since 
TABIE 2

RACES ENDEMIC TO THE YUCATAN PENINSUIA THAT OCCUR IN BRITISH HONDURAS OR WHOSE CHARACTERISTICS ARE APPROACHED BY BRITISH HONDURAN BIRDS.

Buteo magnirostris conspectus

Ortalis vetula intermedia

Caprimulgus salvini badius

Campylopterus curvipennis pampa

Amazilia jucatanensis yucatanensis

Pteroglossus torquatus erythrozonus

Centurus aurifrons dubius

Centurus pygmaeus rubricomus

Sittasomus griseicapillus gracileus

Xiphorhynchus flavigaster yucatanensis

Thamnophilus doliatus yucatanensis

Attila spadiceus gaumeri

Platypsaris aglaiae yucatanensis

Myiarchus tuberculifer platyrhynchus

Platyrinchus mystaceus timothei

Psilorhinus mexicanus vociferus

Cissilopha san-blasiana yucatanica

Thryothorus maculipectus cannobrunneus

Uropsila leucogastra brachyura

Mimus gilvus leucophaeus

Ramphocaenus rufiventris ardeleo

Cyclarhis gujanensis yucatanensis

Granatellus sallaei boucardi

Icterus chrysater mayensis

Icterus gularis yucatanensis

Icterus cuculiatus igenus

Habia rubica nelsoni

Habia gutturalis peninsularis

Saltator atriceps raptor

Saltator coerulescens yucatanensis

Richmondena cardinalis flammigera

Arremonops rufivirgatus verticalis 
TABLE 3

SPECIES BREEDING ON THE KEYS

Pelecanus occidentalis

Sula sula

Phelacrocorax auritus *

Fregata magnificens

Leucophoyx thula *

Cochlearius cochlearius

Eudocimus albus *

Pandion haliaetus

Rallus longirostris

Charadrius wilsonia *

Sterna dougalili

Sterna anaethetus. *

Sterna fuscata

Sterna albifrons *

Thalasseus sandvicensis *

Anous stolidus

Anous tenuirostris

[Columba leucocephala]

[Crotophaga sulcirostris]

Anthracothorax prevostii

Amazilia rutila

Centurus aurifrons

Tyrannus melancholicus

[Elaenla martinica]

[Melanoptila glabrirostris]

Mimus gilvus

Vireo pallens

Vireo magister

Dendroica aestiva

Cassidix mexicanus

Icterus cucullatus

* breeding based on records made by Salvin; brackets indicate nesting is presumed. 
Salvin found them in 1862. Four species are presumed to be nesting birds. In addition Rallus longirostris belizensis, a race known from one specimen, occurs in the mangroves of the mainland and on many keys. I am skeptical of the validity of races named from only one specimen, but the species is a highly polymorphic one and many geographic races have been described in its range.

Four species (Myadestes unicolor, Cyanerpes lucidus, Chlorospingus ophthalmicus, and Eupherusa exima) occur in the Cockscomb Mountains but not elsewhere in the Colony. Only Chlorospingus ophthalmicus has a number of distinctive races in the various parts of its range. It is possible that the Cockscomb Mountain population is subspecifically distinct, but the one specimen that I collected is not adequate evidence. The area of the unique habitats in the highest mountains is not extensive enough to support additional isolated species.

The pinelands constitute the only extensive areas that are isolated to any degree from other similar regions in Central America. The lowland pine ridges in British Honduras are separated. from the pines of the Mountain Pine Ridge by rain forest. Pines do occur in southeastern Guatemala but rain forest intervenes there also. Twenty-four species of birds are found in the pinelands but not in other habitats in the colony 
(Table 4). Additional species reside in pinelands but elsewhere in the Colony as well. The only subspecies other than Rallus longirostris belizensis that are endemic to British Honduras are limited to the pinelands. These birds are Dendrocopus scalaris leucoptilurus, Vireo solitarius notius, and Dendroica graciae decora. They represent highly plastic species, divided into many subspecies, ranging from the United States south to northern Central America. Thryothorus modestus and Basileuterus rufifrons are the only species in the list of birds limited to the Mountain Pine Ridge that Griscom (1932a: 66-67) does not include in his list of Temperate Zone species in Guatemala. These two species are characteristic of brushy or grassy areas in Guatemala, and it is this habitat that they frequent in the pinelands of British Honduras. Vireo solitarius and Ammodramus savannarum are the only species occurring in pinelands at all elevations in British Honduras that are not included by Griscom among Guatemalan Temperate Zone species. Only one species, Sturnella magna, of the seven restricted to lowland pine areas in the Colony is considered a temperate zone species by Griscom. Thus 14 species, which are considered Temperate Zone forms in Guatemala; also occur in British Honduras and there they reside only in the pine ridges. These factors suggest that the majority of the pine ridge birds are 
TABLE 4

SPECIES OCCURRING IN PINELANDS BUT NOT IN
OTHER HABITATS IN BRITISH HONDURAS

A. Species occurring in pinelands at all elevations.

Amazilia cyanocephala

Melanerpes formicivorus

Vireo solitarius

Dendroica graciae

Icterus chrysater
Piranga flava

Loxia curvirostra Ammodramus savannarum Aimophila rufescens

Spizella passerina

B. Species occurring only in the pinelands at low elevations.

Colinus nigrogularis

Columbina minuta

Amazona xantholora

Dendrocopus scalaris

Pyrocephalus rubinus Sturnelia magna

Aimophila botterii.

C. Species occurring only in pinelands of the Mountain Pine Ridge.

Buteo Jamaicensis Contopus pertinax Cistothorus platensis Thryothorus modestus
Sialia sialis

Basileuterus rufifrons

Spinus notatus 
derived from the avifauna of greater elevations in Guatemala. However, Contopus pertinas and Spinus. notatus bear a greater resemblance to subspecies occurring in the mountains of Honduras than to races in the Guatemalan highlands.

The birds that are confined to the lowland pine ridges of British Honduras are species that are typical of low elevations in parts, if not all, of their ranges. Colinus nigrogularis and Columbina minuta are species common in the coastal lowlands of the Yucatan Peninsula and regions to the south. Amazona xantholora is usually considered a Peninsular endemic, but a specimen has been collected in Honduras. Dendrocopus scalaris ranges from the United States to Honduras, usually in light forest. Pyrocephalus rubinus occurs in open areas from the United States to Argentina, but it is absent in some parts of Central America. Sturnella magna ranges from the United States to Brazil in open grassy areas. The race present in the Colony is found also in Honduras and Nicaragua. Aimophila botterii is a grasslands species occuring in Mexico, Guatemala, and British Honduras. 
APBPENDIX A

PRIMARY CITATIONS MENTIONED IN THE TEXT

1. Tinamus major percautus Van Tyne, Misc. Publ. Univ. Michigan, Mus. Z001., 27, 1935: 8 (Uaxactun, Petén, Guatemala):

2. Tinamus meserythrus sclater, Proc. zool. Soc. Iondon, 27, 1859 [1860]: 392 (Playa vicente, Oaxaca, Mexico).

3. Tinamus boucardi Sclater, Proc. Zool. Soc. London, 27, 1859 [1860]: 391 (Teotalcingo, Oaxaca, Mexico).

4. Crypturus sallael goldmani Nelson, Proc. Biol. Soc. Washington, 14, 1901: 169 (Chichén Itzá, Yucatán, Mexico).

5. Colymbus dominicus brachypterus Chapman, Bull. Amer. Mus. Nat. Hist., 12, 1899: 256 (Lomite Ranch, Lower Rio Grande, Texas).

6. [Colymbus] Podiceps Linnaeus, Syst. Nat., ed. 10, 1, 1758: 136 (in America septentrionali [= South Carolina]).

7. [Pelecanus] occidentalis Iinnaeus, Syst. Nat., ed. 12, 1, $1766: 215$ (in America [= Jamaica $]$ ).

8. [Pelecanus] carolinensts Gmelin, syst. Nat., 1, pt. 2, 1789: 571. (in sinu urbis Charlestown $[=$ Charleston Harbor, South Carolina]).

9. [Pelecanus] Sula Linnaeus, Syst. Nat., ed. 12, 1, 1766: 218 (in Pelago indico [= Barbados, Iesser Antilies]).

10. Pelecanus Leucogaster Boddaert, Table Pl. enlum., 1783, 57, no. 973 (Cayenne). 
11. Carbo floridanus Audubon, Bds. America (folio.ed.), 3, 1835, pl. 252 (Florida Keys).

12. Carbo mexicanus Brandt, Bull. Sci. Acad. Imp. Sci. St. Petersbourg, 3, 1837, col. 56 (Mexico).

13. Plotus leucogaster Vieillot, Nouv. Dict. Hist. Nat., 1, 1816: 545 (Florida).

14. Fregata minor rothschildi Mathews, Bds. Australia, 4, 1915: 280 (Aruba, Dutch West Indies).

15. [Ardea] Herodias Linnaeus, Syst. Nat., ed. 10, 1, 1758: 143 (in America [= Hudson Bay]).

16. Cancroma maculata Boddaert, Table Planch. snlum., 1783: 5 (Martinique).

17. [Ardea] virescens Linnaeus, Syst., Nat., ed. 10, 1 , 1758: 144 (in America [= coast of South Carolina]).

18. [Ardea] caerulea Linnaeus, Syst. Nat., ed. 10, 1, 1758: 143 (in America septentrionali [= South Carolina $]$ ).

19. Ardea caerulescens Latham, Index Orn., 2, 1790:690 (Cayenne $[=$ French Guiana $]$ ).

20. [Ardea] Egretta Gmelin, Syst. Nat., 1, pt. 2, I789: 629 (in insula S. Dominici, insulis Falkland et America australi ad Louisianam usque L= French Guiana]).

21. Ardea Thula Molina, Sagg. Stor. Nat. Chili, 1782: 235 (Chili).

22. [Ardea] Ibis Linnaeus, Syst. Nat., ed. 10, 1, 1758: 144 (Egypt).

23. Egretta ruficollis Gosse, Bds. Jama1ca, 1847: 338 (Burnt Savanna River and Bluefields Creek, Jamaica). 
24. [Ardea] Hoactli Gmelin, Syst. Nat., 1, pt. 2, 1789: 630 (in novae Hispaniae lacubus [ = Valley of Mexico]).

25. [Ardea] violacea Linnaeus, Syst. Nat., ed. 10, 1, 1758: 143 (In America septentrionali [= South Carolina]).

26. Tigrisoma mexicana Swainson, in Murray's Encl. Geog., 1834: 1383 (Real del Monte, Hidalgo, Mexico).

27. [Ardea] exilis Gmelin, Syst. Nat., 1, pt. 2, 1789: 645 (Jamaica).

28. Cancrome zeledoni Ridgway, Proc. U.S. Nat. Mus., 8, 1885: 93 (Mazatlan, [Sinaloa,] Mexico).

29. Dendrocygne autumnalis fulgens Friedmann, Condor, 49, 1947: 190 (Lomita Ranch, Texas).

30. [Anas] discors Linnaeus, Syst. Nat., ed. 12, 1, 1766: 205 (in America septentrionali [= South Carolina]).

31. [Vultur] Aura Iinnaeus, Syst. Nat., ed. 10, 1, 1758: 86 (in America calidiore [= Veracruz, Mexico $]$ ).

32. Elanus leucurus majusculus Bangs and Penard, Proc. New England Zool. Club, 7, 1920: 46 (Sen Rafael, California).

33. Milvus yetapa Vieillot, Nouv. Dict. Hist. Nat., 20, 1818: 564 (Paraguay).

34. Falco uncinatus "Illiger" Temminck, P1. Col., livr. 18, 1822, pls. 104, 105, 115 (Bahia, eastern Briazil).

35. Chondrohierax uncinatus aquilonis Friedmann, Jour. Washingtion Acad. Sci., 24, 1934: 314 (Tamaulipas, Mexico).

36. Rostrhamus sociabilis major Nelson and Goldman, Proc. Biol. Soc. Washington, 46, 1933: 193 (Catemaco, Veracruz, hexico). 
37. Sparvius bicolor Vieillot, Nouv. Dict. Hist. Nat., 10, 1816: 325 (Cayenne [ French Guiana]).

38. Buteo hypospodius Gurney, Ibis, 1876: 73 (Medellin, Colombia).

39. [Buteo borealis] var. costaricensis Ridgway, in Baird, Brewer, and Ridgway, Hist. N. Am. Birds; 3, 1874: 258 ( no locality $[=$ Costa Rica $]$ ).

40. Sparvius platypterus Vieillot, Tabl. sncyo. Méth., 3, 1823: 1273 ( $\mathrm{L}^{\prime}$ Amerique septentrionale $[=$ Philadelphia, Pennsylvania]).

41. Rupornis magnirostris conspecta Peters, Auk, 30, 1913: 370 (San Ignacio, Yucatán, Mexico).

42. Rupornis magnirostris direptor Peters and Griscom, Proc. New kngland Zool. Club, 11, 1929: 46 (Finca El Cipres, near Mazatenango, Pacific Slope, Guatemala).

43. Buteo fuliginosus Sclater, Proc. Zool. Soc. London, 1858: 356 (Sțate of Tamaulipas, Mexico).

44. Asturina plagiata, Schlegel, Mus. Pays-Bas, 2, 1862: I (Veracruz, Veracruz, Mexico).

45. Buteo ghiesbreghti DuBus, Esq. Orn., livr. 1, 1845: pl. I (Hacienda Mirador, several leagues from Veracruz [Mexico]).

46. Leucopternis ghiesbreghti costaricensis Sclater, Bull. Brit. Orn. Club, 39, 1919: 76 (Carrillo, Costa Rica).

47. Falco nigricollis Latham, Ind. Orn., 1, 1790: 35 (Cayenne [= French Guiana]).

48. Falco anthracinus Iichtenstein, Preis-verz. Suug. V8gel, - Mexico, 1830: 3 (Veracruz, Hexico). 
49. Urubitinga ridgwayi Gurney, List Diurn. Birds Prey, 1884: 148 (Guatemala).

50. Spizaetus ornatus vicarius Friedmann, Jour. Washington Acad. Sci., 25, 1935: 45$]$ (near Manatol $[=$ Manateel Lagoon, British Honduras).

51. Spizaetus tyrannus serus Friedmann, Smith. Misc. Coll., 111, No: 16, 19>0: 1. (Rio Indio, near Gatún, Canal Zone, Panamá).

52. Ischnosceles niger DuBus, Bull. Acad. Roy. Sc1. Belg., 14, 1847: 102 (Mexico).

53. Pandion Ridgwelr [sic] Anonymous $[=\mathrm{C}$. J. Maynard], Am. itxch. and Mart., no. 3, 1887: 3 (Andros Island, Bahamas).

54. [Falco] carolinensis Gmelin, Syst. Nat., 1, 1788: 263 (Carolina).

55. Herpetotheres cachinnans chapmani Bangs and Penard, Bull. Mus. Comp. Zo81., 62, 1918: 37 (Santa Iucia, Rio Hondo, Quintana koo, Mexico).

56. [Falco] cachinnans Iinnaeus, Syst. Nat., ed. 10, I, 1758: 90 (in America. meridionali [= Surinam]).

57. Carnifex naso Lesson, scho du Monde Savant, 6, sec. 2, 1842, col. 1085 (Reale jo, Nicaragua).

58. Micrastur guerilla Cassin, Proc. Acad. Nat. Sci. Philadelphia, 4, 1848: 87 (Jalapa, Veracruz, Mexico).

59. Falco anatum Bonaparte, Geogr. and Comp. List, 1838: 4 (Egg Harbor, [New Jersey]).

60. Falco albigularis Daudin, Traité d'orn., 2, 1800: 131 (Cayenne $[=$ French Guiana $]$ ). 
61. Falco femoralis Temminck, Planches Col., i, 1823, pls. 121,343 (Paraguay).

62. [Falco] sparverius Linnaeus, Syst. Nat., ed. I0, I, I758: 90 (in America $[=$ South Carolina $]$ ).

63. [ㄷaㅁ] rubra Linnaeus, Syst. Nat., ed. 10, 1, 1758: 157 (in America [ $=$ western scuador]).

64. Penelope purpurascens Wagler, Isis von Oken, 1830, col. 1110 (Mexico [probably Veracruz]).

65. Ortalis vetula intermedia Peters, Auk, 30, 1913: 371 (Camp Mengel [= Alvaro Obregón], Rio Hondo, Quintana Roo, Mexico).

66. Ortalida plumbiceps Gray, List Gallinae Brit. Mus., 1867: 11 (Honduras [= Omoa], Guatemala).

67. Ortyx nigrogularis Gould, Proc. Zool. Soc. London, 1842 [1843]: 181 (Mexico [= Honduras]).

68. Aramus pictus dolosus Peters, Occ. Papers Boston Soc. Nat. Hist., 5, 1925: $144^{\prime \prime}$ (Bolson, Costa Rica).

69. Rallus longirostris belizenzis oberholser, Proc. U.S. Nat. Mus., 84, 1937: 335. (Ycacos Lagoon, British Honduras).

70. Iimnopardalus maculatus insolitus Bangs and Peck, Proc. Biol. Soc. Washington, 21, 1908: 43 (Ycacos Lagoon, British Honduras).

71. Corethrura Guatemalensis Lawrence, Proc. Acad. Nat. Sci. Philadelphia, 15, 1863 [1864]: 106, 107 (Guatemala).

72. Aramides albiventris Lawrence, Proc. Acad. Nat., Sci. Philadelphia, 19, 1867: 234. (British Honduras). 
73. [Fulica] americana Gmelin, Syst. Nat., 1, pt. 2, 1789: 704 (in America septentrionali $L=$ North America]).

74. [Fulica] spinose Linnaeus, Syst. Nat., ed. 10, 1, 1758: 152 (in America australi [= Panamá]).

75. [Charadrius] vociferus Iinnaeus, Syst. Nat., ed. 10, 1. 1758: 150 (in America septentrionali $[=$ South (arolina]).

76. Charadrius Wilsonia Ord, in Wilson, Amer. Orn., 9, 1814: 77 (shore of Cape Island $[=$ Cape May], New Jersey).

77. Numenius hudsonicus Latham, Index Orn., 2, 1790: 712 (in sinu Hudsonis [= Hudson Bay $]$ ).

78. Tringa solitaria Wilson, Amer. Orn., 7, 1813: 53 Pocano Mt., Pa., Kentucky, and New York [= Pocono Mountains, Pennsylvania]).

79. Symphemia semipalmata inornata Brewater, Auk, 4, 1887: 145 (Larimer County, Colorado).

80. Scolopax semipalmata Gmelin, syst. Nat., I, pt. 2, 1789: 659. (New York).

81. [Mringa] Morinella Linnaeus, Syst. Nat., ed. 12, 1, 1766: 249 (ad maris littora Americae septentrionalis; and Europae [= coast of Georgia]).

82. Scolopax delicata Ord, Wilson, Amer. Orn., Ord reprint, 9, 1825: 218 (Pennsylvania).

83. Larus Smithsonianus Coues, Proc. Acad. Nat. Sci. Philadelphia, 14, 1862: 296 (wastern and Western coasts of North America).

84. [Sterna] surinamensis Gmelin, Syst. Nat., I, pt. 2, 1789: 604 (in Surinam). 
85. Sterna aranea Wilson, Amer. Orn., 8, 1814: 143 (Cape May, New Jersey).

86. Melanosterna anaethetus recognita Mathews, Birds Australia, 2, pt. 4, 19I2: 403. (Bahama Islands).

87. [Sterna] fuscata Iinnaeus, Syst. Nat., ed. 12, I, 1766: 220 (in Insula Dominicensi [= Hispaniola, West Indies]).

88. Sternula Antillarum Lesson, Descr. Mamm. Ois., Récemnent Decouverts, Suppl. Oeuvres Buffon, ed. Levêque, 20, 1847: 256 (Guadeloupe [Island, West Indies]).

89. Sterna maxima Boddaert, Table Planch. Enlum., 1783: 58 (Cayenne [= French Guiana]).

90. Sterna acuflavida Cabot, Proc. Boston Soc. Nat. Hist., 2, 1847:257 (Tancah, Yucatán $L=$ Quintana Roo, Mexico]).

91. [Sterna] stolida Linnaeus, Syst. Nat., ed. 10, 1, 1758: 137 (in Americae Pelago [= West Indies]).

92. Megalopterus minutus americanus Mathews, Bds. Australia, 2, pt. 4, 191<: 423 (British Honduras).

93. Columba flavirostris Wagler, Isis von Oken, 5, 1831 , col. 519 (Mexico [= Veracruz, Mexico $]$ ). .

94. Columba pallidicrissa Chubb, Ibis, 1910:60 (Costa Rica).

95. [Columba] macroura Linnaeus, Syst. Nat., ed. 10, 1, 1.758: 164 (in Canada $[=$ Cuba $]$ ). 
96. Chamaepelia passerina ? var. pallescens Baird, Proc. Acad. Nat. Sci. Philadelphia, 11, 1859: 305 (Cape St. Lucas [= Cape San Lucas, Baja California, Mexico]).

97. Chamaepelia minute interrupta Griscom, Amer. Mus. Novitates, No. 379, 1929: 4 (Secanquim, Guatemala).

98. Chamaepelia rufipennis Bonaparte, Coimpt. Rend. Acad. Sci. Paris, 40, 1855: 22 (Cartagena, Colombia).

99. Leptotila fulviventris Lawrence, Ann. New York Acad. Soi., 2, 1882: 287 (Yucatén, Mexico).

100. Leptotila plumbeiceps Sclater and Salvin, Proc. zool. Soc. London, 1868 [1869]: 59 (Vera Paz, Guatemala).

101. Leptotila cerviniventris Sclater and Salvin, Proo. Zool. Soc. London, 1868 [1869]: 59 (Vera Paz, Guatemala).

102. [Columba] montana Linnaeus, Syst.. Nat., ed, 10, I, 1758: 163 (Jamaica).

103. Conurus astec, Souancé, Rev. Mag. Zool. 9, 1857:97 (Mexico).

104. Pionus haematotis Sclater and Salvin, Proc. Zool. Soc. London, 28, 1860 [1861] : 300 (Choctum, Vera Paz, Guatemala).

105. Psittacus senilis Spix, Av. Bras., 1, 1824: 42 (Veracruz, Mexico).

106. Pionus senilis decoloratus Griscom, Amer. Mus. Novitates, No. 379, 1929: 6 (Pozo Azul de Pirris, Costa Rica).

107. Amazona albifrons nana Miller, Bull. Amer. Mus, Nat. Hist., 21, 1905: 349 (Calotmul, Yucatán, Mexico). 
108. [Psittecus] autumnalis Linnaeus, Syst. Nat., ed. 10, 1, 1758: 102 (in America [= southern Mexico]).

109. A[mazona]. oratrix Ridgway, Man. N. An. Birds, 1887: 587 (Petapa, Oaxaca).

110. Chrysotis guatemalae Sclater, Ibis, 1860: 44 (Guatemala and Honduras).

111. C[occyzus]. americanus occidentalis Ridgway, Man. N. Am. Birds, 1887: 273 (Western United States .. [= Santa Rita Hountains, Arizona]).

112. [CucuIus] americanus Iinnaeus, Syst. Nat., ed. 10, 1, 1758: 111 (in Carolina [= South Carolina]).

113. Coccyzus minor continentalis van Rossem, Bull. Mus. Comp. Zo81., 77, 1934: 389 (Volcán de Santa Ana, Dept. Sonsonate, El Salvador).

114. Piaya thermophila Solater, Proc. Zool. Soc. London, 1859 [1860]: 368 (Jalapa, Veracruz, Mexico).

115. Crotophaga sulcirostris Swainson, Philos. Mag. (n.s.), 1, 1827: 440 (Temascaltepec, Mexico).

116. Strix pratincola Bonaparte, Geogr. and Comp. List, 1838: 7 (no locality $[=$ Pennsylvania $]$ ).

117. Scops guatemalae Sharpe, Cat. Birds Brit. Mus., 2, 1875: 112 (Guatemala).

118. Bubo virginianus mayensis Nelson, Proc. Biol. Soc. Washington, 14, 1901: 170 (Chichén Itzá, Yucatán, Mexico).

119. Pulsatrix perspicillata saturata Ridgway, Bull. U.S. Nat. Mus., 50, pt. 6, 1914: 758 (Santo Domingo, Oaxaca, Mexico). 
120. Glaucidium griseiceps Sharpe, Ibis, 1875: 41 (Guatemala).

121. Glaucidium ridgwayi Sharpe, Ibis, 1875: bs (Central America $[=$ Mexico $]$ ).

122. Strix hypugaea Bonaparte, Amer. Orn., 1, 182b: 72 (Western United States $[=$ Plains of the Platte River]).

123. Ciccaba virgata centralis Griscom, Bull. Mus. Comp. Zoo\%1., 69, 1929: 159 (Chivela, Oaxaca, Mexico).

124. Asio stygius robustus I. Kelso, Auk, 51, 1934: 522 (Mirador, Veracruz, Mexico).

125. Nyctibius jamaicensis mexicanus Nelson, Auk, 17, 1900: 260 (Metlaltoyuca, Puebla, Hexico).

126. Chordeiles texensis Lawrence, Ann. Lyc. Nat. Hist. New York, 6, 1857:167 (Texas [= Ringgold Barracks near Rio Grande City]).

127. Chordeiles acutipennis micromeris Oberholser, BuIl. U.S. Nat. Mus., no. 86, 1914: 16 (Xbac, Yucatán, Mexico).

128. Caprimulgus minor Forster, Cat. Anim. North Amer., 1771: 13 (no locality [= South Carolina]).

129. Chordeiles Henryi Cassin, Illustr. Birds California, Texas, etc., pt. 8, 1855: 239 (Fort Webster, New Mexico).

130. Nyctidromus albicollis yucatanensis Nelson, Proc. Biol. Soc. Washington, 14, 1901: 171 (Tunkas, Yucatán, Mexico). 
131. Antrostomus badius Bangs and Peck, Proc. Biol. Soc. Washington, 21, 1908: 44 (Toledo District $[=$ Toledo Settlment], British Honduras).

132. Caprimulgus vociferus Wilson, Amer. Orn., 3, 1812: 71 (Pennsylvania [= Philadelphia, Pennsylvania]).

133. Streptoprocne zonaris mexicana Ridgway, Proc. Biol. Soc. Washington, 23, 1910: 53 (Rio Seco, near Cordova, Veracruz, Mexico).

134. Hemiprocne albicincta Cabanis, Jour. fifr Orn., 10, 1862: 165 (Guiana).

135. Chaetura richmondi Ridgway, Proc. Biol. Soc. Washington, 23, 1910: 53 (Guayabo, eastern Costa Rica).

136. Aeronautes saxatalis nigrior Dickey and van Rossem, Condor, 30, 1928: 193 (Los L'sesmiles, Dept. Chalatenango, El Salvador).

137. Ornismya Iongirostris DeLattre, Echo du Monde Savant, 1843, no. 45, col. 1070 (Guatemala).

138. Phaethornis adolphi saturatus Ridgway, Proc. Biol. Soc. Washington, 23, 1910: 54 (El Hogar, Costa Rica).

139. Phaethornis adolphi Gould, Monogr. Trochil., 1, 18ל7, pl: 35 (Cordoba, Veracruz, Mexico).

140. Aphantochora roberti Salvin, Proc. Zool. Soc. London, 1861 [1862]: 203 (Vera Paz, Guatemala).

141. Ornismya pampa Lesson, Hist. Nat. Colibris, Suppl. Ois. - Mouch., 1832: 127, pl. 15 (Interior of la Plata [ = Guatemala]).

142. [Trochilus] mellivorus Iinnaeus, Syst. Nat., ed. 10, 1, 1758: 121 (in Indiis[= Surinam]). 
143. Trochilus prevostii Lesson, Hist. Nat. Colibris, Suppl. Ois.-Mouch., 1832: 87 (South America).

144. Anthracothorax prevosti nigrilineatus Bond, Proc. Acad. Nat. Sci. Philadelphia, 88, 1936: 359 (Bonacca Island, Spanish Honduras).

145. Ornigmya canivetii Lesson, Hist. Nat. Colibris, Suppl. Ois.-Mouches, 1832: 174 (Brazil l= Jalapa, Veracruz, Mexico]).

146. Thalurania townsendi Ridgway, Proc. U.S. Nat. Mus., 10, 1887 [1888]: 590 (Segovia River, Honduras).

147. Trochilus candidus Bourcier and Mulsant, Ann. Sci. Phys. et Nat., d'Agric. et d'Ind., Soc. roy., etc., Lyon, 9, 1846: 326 (Cobán, Guaternala).

148. Cyanomyia guatemalensis Gould, Intro. Trochil., 1861: 148 (Dueñas, Guatemala).

149. Ornismya rutila DeLattre, Echo du Monde Savant (2), 7, 1843, col.1069 (Acapulco, Guerrero, Mexico).

150. Trochilus yucatanensis Cabot, Proc. Boston Soc. Tat. Hist., 2, 1845: 74 (Yucatán, Hexico).

151. Trochilus tzacatl De la Llave, Registro Trimestre, 2, no. 5, 1833: 48 (Mexico).

152. Ornismya eximia Delattre, Echo du Monde Savant, 1843, col. 1069 (Cobán, Guatemala).

153. Trogon massena Gould, Monog. Trogonidae, pt. 3, 1838, pl. 16 (Mexico).

154. Trogon melanocephala Gould, Monog. Trogonidae, 1835, pl. 6 (State of Tamalipas, Mexico). 
155. Trogon puella Gould, Proc. Zool. Soc. London, 13, 1845 [1846]: 18 (Escuintla, South America [= Guatemala]).

156. Aganus braccatus Cabanis and Heine, Mus. Hein., I, 1863: 184 (Mexico [= Vale Real, veracruz]).

157. [A]cedo] torquata Linnaeus, Syst. Nat., ed. 12, i, 1766: 180 (Martinique and Mexico).

158. [Alcedo] Alcyon Linnaeus, Syst. Nat., ed. 10, I, 1758: 115 (in America [= South Carolina]).

159. Chloroceryle amazona mexicana Brodkorb, Auk, 57 , 1940: 5.43 (Barra de Cahuacán, Chiapas, Mexico).

160. Geryle americana isthmica Goldman, Smithsonian Misc. Coll., 56, no. 27, 1911: I (Rio Indio, (near Gatun), (anal Zone, Panamá).

161. Ceryle septentrionalis Sharpe, Cat. Birds. Brit. Mus., 17, 1892: 134 (no locality $[=$ Teapa, Tabasco, Mexico]).

162. Ceryle superciliosa stictoptera Ridgway, Proc. Biol. Soc. Washington, 2, 1884 [1885] : 95 (Sisal, Yucatán, Mexico).

163. Hylomanes momotula Lichtenstein, Abh. Akad. Wisss. Berlin for 1838 [1839]: $449^{\circ}$ (Valle Real [=Veracruz?], Mexico).

164. Prionites carinatus DuBus, Bull. Acad. Roy, Sci. Belg., 14, 1847: 108 (Guatemala).

165. Momotus Lessonii Lesson, Rev. Zool., 1842: 174.(Realejo, Nicaragua). 
166. Galbula melanogenia Sclater, Jardine's Contrib. .0rn. for 1852, 1853: 61 (no locality [= Veragua, Panamá]).

..167. Bucco hyperrhynchus Sclater, Proc. Zool. Soc. Iondon, 23, 1855: p1. 105, p. 193 (upoer Amazon).

168. Monasa inornata DuBus, Buli. Acad. Roy. Sci. Belg., 14, 1847: 107 (Guatemala).

169. Aulacorhynchus prasinus virescens Ridgway, Proc. Biol. Soc. Washington, 25, 1912: 88 (Chasniguas, Honduras).

170. [Ramphastos] torquatus Gmelin, Syst. Nat., 1, pt. 1, 1788: 354 (Mexico [= Veracruz, Mexico]).

171. Pteroglossus torquatus erythrozonus Ridgway, Proc. Bio1. Soc. Washington, 25, 1912: 88 (Temax, Yucatán, Mexico).

172. Ramphastos sulfuratus Lesson, Traité d'orn., livr. 3, 1830: 173 (Mexico).

173. Picus Yucatanensis Cabot, Proc. Boston Soc. Nat. Hist., 1, 1844: 164 (Yucatán [= Yalahau, Quintana Roo, Mexico]).

174. Picus similis Lesson, Descrip. de Mamm. et d'Ois. récomm. decouvert., 1847: 204 (San Carlos, Central America [= IaUnion, sil Salvador $]$ ).

175. Melanerpes formicivorus albeolus todd, Proc. Biol. Soc. Washington, 23, 1910:153 (near Manatee, British Honduras).

176. Picus dubius Cabot, Proc. Boston soc. Nat. Hist., I, 1844: 164 ([Uxmal], Yucatán). 
177. Centurus santacruzi pauper Ridgway, Proc. U.S. Nat. Mus., 10, 1887 [1888]: 582 (Truxillo, Honduras).

178. Melanerpes rubricapillus rubricomus Peters, Checklist Birds World, 6, 1948: 164 (Mérida, Yucatán).

179. Melanerpes pucherani perileucus Todd, Proc. Biol. Soc. Washington, 23, 1910: 154 (near Manatee, British Honduras).

180. [Picus] varius Iinnaeus, Syst. Nat., ed. 12, 1, 1766: 176 (in American septentrionali $L=$ South Carolina]).

181. Chloronerpes sanguinolentus Sclater, Proc. Zool. Soc. London, 27, 1859 [1860]: 60 (Omoa, Honduras).

182. Dryobates scalaris leucoptilurus oberholser, Proc. U.S. Nat. Mus., 4I, 191I: 141, 146 (Pine Ridge, near Manatee Lagoon, British Honduras).

183. Picus guatemalensis Hartlaub, Rev. Z001., 1844: 214 (Guatemala).

184. Dendrocincla anabatina Sclater, Proc. Zool. Soc. London, 27, 1859 [1860] : 54 (Omoa, Honduras).

185. Dendrocincla anabatina typhla Oberholser, Proc. Acad. Nat. Sci. Philadelphia, 56, 1904: 452 (Puerto Morelos, Yucatán [= Quintana Roo], Mexico).

186. Dendromanes homochrous Sclater, Proc. Zool. Soc. London, 27, 1859 [1860]: 382 (Teotalcingo, Oaxaca, Mexico).

187. Sittasomus griseicapillus gracileus Bangs and Peters, Bull. Mus. Comp. Zo8̛l., 68, 1928: 392 (Chichén Itzá, Yucatán, Mexico). 
188. Sittasomus sylvioides Lafresnaye, Rev. Mag. Zool., 2, 1850: 590 (Mexico [= Veracruz, Mexico]).

189. Glyphorhynchus pectoralis Sclater and Salvin, Proc. Zool. Soc. London, 28, 1860 [1861] : 299 (Choctum, Vera Paz, Guatemala).

190. Xiphocolaptes emigrans Sclater and Salvin, Ibis, 1859: 118 (no locality [ = San Geronimo, Vera Paz, Guatemala]).

191. Dendrocops Sancti-Thomae Lafresnaye, Rev. Mag. Zool. 4, 1852: 466 (In insula Sancti-Thomae [= Santo Tomas, Guatemala]).

192. Dryocopus eburneirostris Des Murs, Icon. Orn., 1847, pl. 52 (Realejo, Nicaragua).

193. Xiphorhynchus flavigaster yucatanensis Ridgway, Proc. Biol. Soc. Washington, 22, 1909: 73 (Temax, Yucatán, Mexico).

194. Picolaptes compressus insignis Nelson, Auk, 14, 1897: 54 (Otatitlán, Veracruz, Mexico).

195. Lepidocolaptes souleyetii decoloris Austin, Bull. Mus. Comp. Z081., 69, 1929: 380 (E1 Cayo, British Honduras).

196. Synallaxis exythrothorax Sclater, Proc. Zool. Soc. London, 23, 1855 [1856], pl. 86, p. 75 (Cobán and Honduras).

197. Anabates cervinigularis Sclater, Proc. Zool. Soc. London, 24, 1856 [1857]: 288 (Cordova, Veracruz, Mexico).

198. Xenops mexicanus Sclater, Proc. Zool. Soc. London, 24, 1856 [1857]: 289 (Cordova, Veracruz, Nexico). 
199. Xenops genibarbis cayoensis Chubb, BulJ. Brit. Orn. club, 39, 1919: 52 (Cayo, British Honduras).

200. Tinactor guatemalensis Hartlaub, Rev. Zool., 7, 1844: 370 (no locality [= Guatemala]).

201. Thamnophilus melanocrissus Sclater, Proc. Zool. Soc. Iondon, 27, 1860 [1861]: 252 (Santecomapam, Orizaba, Veracruz [= Cobán, Guatemala]).

202. Thamnophilus doliatus yucatanensis Ridgway, Proc. biol. Soc. Washington, 21, 1908: 193 (Temax, Yucatán, Mexico).

203. Thamnophilus intermedius Ridgway, Proc. U.S. Nat. Mus., 10, 1887 [1888]: 581 (Truxil1o, Honduras).

204. Thamnophilus atrinucha Salvin and Godman, Biol. Centr-Amer., Aves, 2, 1892: 200 (Panamá).

205. Thamnistes anabatinus Sclater and Salvin, Proc. Zool. Soc. Iondon, 27, 1860 [I86I]: 299 (Choctum, Vera Paz, Guatemala).

206. Dysithamnus mentalis septentrionalis Ridgway, Proc. Biol. Soc. Washington, 21, 1908: 193 (Choctur, Vera Paz, Guatemala).

207. Formicivora boucardi Sclater, Proc. Zool. Soc. London, 26, 1858 [1859]: 300 (Acatepec, Oaxaca, Mexico).

208. Cercomacra crepera Bangs, Auk, 18, 1901: 365 (Divala, Chiriqui, Panamá).

209. Gymnocichla chiroleuca Sclater and Salvin, Proc. Z001. Soc. London, 37, 1869.[1870]: 417 (Tucurriqui, Costa Rica). 
210. Formicarius moniligex intermedius Ridgway, Proc. Biol. Soc. Washington, 21, 1908: 194 (near Manatee Lagoon, British Honduras).

211. Pipra mentalis Sclater, Proc. Zool. Soc. London, 1856 [1857]: pl. 121, p. 299 (Cordova,..Veracruz, Mexico).

212. Heteropelma verae-pacis Sclater and Salvin, Proc. Zool. Soc. Iondon, 28, 1860 [1861] : 300 (Choctum, Vera Paz, Guatemala).

213. Attila flammulatus Lafresnaye, Rev. Zool., 11, 1848: 47 (Columbia [= Veracruz, Mexico $]$ ).

214. Attila gaumeri Salvin and Godman, Biol. Centr.-Amer., Aves, 2, 1891: 134 (Tizimin, [Yucatán,] Mexico).

215. Lipaugus rufescens Sclater, Proc. Biol. Soc. Iondon, 25, 1857 [1858]: 276 (Cobán, Guatemala).

216. Lipaugus holerythrus Sclater and Salvin, Proc. Zool. Soc. London, 28, 1860 [1861] : 300 (Choctum, Vera Paz, Guatemala).

217. Lipaugus unirufus Sclater, Proc. Zool. Soc. Iondon, 27, 1859 [1860]: 385 (Playa Vicente, Oaxaca $[=$ Playa Vicente, Veracruz]).

218. Pachyramphus cinnamomeus fulvidior Griscon, Bull. Mus. Comp. Zo81., 72, 1932: 357. (Toledo district $[=$ Toledo Settlement $]$, British Honduras).

219. Pachyramphus major itzensis Nelson, Proc. Biol. Soc. Washington, 14, 1901: 173 (Chichén Itzá, Yucatán, Mexico). 
220. Pachyrhampus major australis Miller and Griscom, Amer. Mus. Novitates, no. 159, 1925: 3 (San Rafael del Norte, Nicaragua).

221. Platypsaris aglaiae yucatanensis Ridgway, Proc. Biol. Soc. Washington, 19, 1906: 120 (Yucatan, Wexico).

222. Platypsaris aglaiae hypophaeus Ridgway, Proc. U.S. Nat. Mus., 14, 1891: 467 (Sañ Pedro Sula, Honduras).

223. Platypsaris aglaiae sumichrasti Nelson, kuk, 14, 1897: 52 (Otatitlán, Veracruz, Mexico).

224. Tityra personata Jardine and selby, IIlus. Orn., I, 1827, pl. 24 (Real del lifonte, Hildalgo, Mexico).

225. Ps[aris]. Fraserii Kaup, Proc. Zool. Soc. London, 19, 1851: pl. 47, pls. 37 and 38 (no locality $[=$ Veracruz, Mexico]).

226. Sayornis aquatica Sclater and Salvin, Ibis, 1859: 119 (Dueñas, Guatemala).

227. Sayornis amnicola Bangs, Proc. New England Zool. club, 3, 1902: 37 (Boquete, Panamá).

228. Pyrocephalus rubineus blatteus Bangs, Proc. Biol. Soc. Washington, 24, 1911: 189 (Sabune District [Sibun River], British Honduras).

229. Tyrannus (Milvulus) monarchus Hartlaub, Rev. Zool., 7, 1844: 214 (Guatemala).

230. Tyrannus chloronotus Berlepsch, Ornis, 14, 1907: 474 (Temax, Yucatán, Mexico).

231. Elainea variegata Sclater, Proc. Zool. Soc. Iondon, 24, 1856 [1857]: 297 (Cordọa, Veracruz, Mexico). 
232. Myiodynastes luteiventris Sclater, Proc. Zool. Soc. Iondon, 27, 1859 [1860]: 42 (Vera Paz, Guatemala).

233. M[yiodynastes] audax insolens Ridgway, Man. N. Amer. Birds, 1887: 332 (Hacienda "Mirador" [Veracruz, Mexico]).

234. Scaphorhynchus Mexicanus Lafresnaye, Rev. Mag. Z001., 3, 1851: 473 (Mexico).

235. Muscicapa texensis Giraud, Sixteen New Species Texas Birds, 1841: pl. I (Texas [= probably Veracruz, Mexico]).

236. Saurophagus guatimalensig Lafresnaye, Rev. Hag. 2001., 1852: 462 (Guaternala).

237. Pitangus sulphuratus texanus van Rossem, Trans. San Diego Sco. Nat. Hist., 9, 1940: 82 (Brownsville, Texas).

238. Saurophagus Derbianus Kaup, Proc. Zool. Soc. Iondon, 19, 1851: 44 (Zacatecas, Mexico).

239. Myiarchus crinitus boreus Bangs, Auk, 15, 1898: 179 (Scituate, Ihassachusetts).

240. [Turdus] crinitus Linnaeus, syst. Nat., ed. 10, 1, 1758: 170 (in America [= South Carolina]).

241. Myiarchus cooperi Baird, Rept. Expl. and Survey R.R. Pacific, 9, 1858: 180 (Mexico).

242. Myiarchus platyrhynchus Ridgway, Proc. Biol. Soc. Washington, 3, 1885 [1886]: 23 (Cozumel Island, Quintana Roo, Mexico). 
243. Myiarchus lawrenceii connectens Miller and Griscom, Amer. Mus. Novitates, 159, 1925: 6 (Las Cañas, Matagalpa, Nicaragua).

244. Myiarchus nigricapillus Cabanis, Jour. für Orn., 1861: 250 (Costa Rica $[=$ Bonilia, Costa Rica]).

245. Empidonax brachytarsus sclater, Ibis, 1859: 441 (Cordova, Veracruz, Mexico).

246. Wyiochanes pertinax minor Miller and Griscom, Amer. Mus. Novitates, 159, 1925: 5 (between San Rafael del Norte and Jinotega, Nicaragua).

247. Contopus pertinax Cabanis and Heine, Mus. Hein., 2, 1859: 72 (Jalapa, Veracruz, Mexico).

248. Myiobius fulvigularis Salvin and Godman, Biol. Centr.Amer., Aves, 2, 1889: 58 (Santa Fé [Veraguas, Panamá]).

249.. Tyrannula sulphureipygia Sclater, Proc. Zool. Soc. London, 24, 1856 [1857]: 296 (Cordova, Veracruz, Mexico).

250. Muscivora mexicana Sclater, Proc. Zool. Soc. London, 24,1856 [1857]: 295 (Cordova, Veracruz, Mexico).

251. Platyrinchus mystaceus timothei Paynter, Postilla, Yale Peabody ins., no. 18, 1954: 2(24 km. NW Xtocomo, Quintana Roo, Mexico).

252. Platyrhynchus cancrominus Sclater and Salvin, Proc. Zool. Soc. Iondon, 28, 1860 [1861] : 299 (Choctum, Vera Faz, Guatemala).

253. Cyclorhynchus cinereiceps sclater, Ibis, 1859: 443 (State of Oaxaca, Mexico). 
254. Cyclorhynchus brevirostris Cabanis, Arch. Naturg., 13, 1847: 249 (Jalapa, Veracruz, Hexico).

255. Todirostrum cinereum finitimum Bangs, Proc. Biol. Soc. Mashington, 17, 1904: 114 (San Juan Bautista, Tabasco, Mexico).

2b6. Todirostrum schistaceiceps Sclater, Ibis, 18b9: 444 (State of Oaxaca, Mexico).

257. Plainea subpagana Sclater, Ibis, 1860: 36 (Dueñas, Guatemala).

258. Elaines chinchorrensis Griscom, Amer. Mus. Novitates, No. 236, 1926: 3 (Great Key, Chinchorro Bank, Quintana Roo, Mexico).

259. Elainea martinica remota Berlepsch, Ornis, 14, 1907: 396 (Cozumei Island, Quintana Roo, Mexico).

260. Elainia placens Sclater, Proc. Zool. Soc. London, 27, 1859: 46 (Cordova, Veracruz, Mexico).

261. Camptostoma imberbe Sclater, Proc. Z0ol. Soc. London, 25, 18.57 [1858]::203 (San Andres Tuxtla, Veracruz, Mexico).

262. Pyramulus semiflavus sclater and Salvin, Proc. Zool. Soc. London, 28, 1860 [1861]: 300 (Choctum, Vera Paz, Guatemala).

263. Leptopogon pileatus Cabanis, Journ. far Orn., 13, 1865: 414 (Guatemala).

264. Mionectes assimilis Sclater, Proc. Zool. Soc. Iondon, 27, 1859: 46 (Cordova, Veracruz, Mexico).

265. Progne cryptoleuca Baird Rev. Amer. Birds, sign. 18, 1865: 277 (Remedios, Cuba). 
266. [Hirundo] Subis Linnaeus, Syst. Nat., ed. 10, 1, 1758: 192 (ad sinum Hudsonis [= Hudson Bay $]$ ).

267. [Hirundo] chalybea Gmelin, Syst. Nat., I, pt. 2, 1789: 1026 (in Cayenne [= French Guinea]).

268. Hirundo erythrogaster Boddaert, Table Planch Enlum., 1783: 45 (Cayenne [= French Guinea]).

269. Cotyle fulvipennis Sclater, Proc. Zool. Soc. Iondon, 27, 1859 [1860]: 364 (vicinity of Jalapa, veracruz, Mexico).

270. Hirundo serripennis Audubon, Orn. Biogr., 4, 1838: 593 (Charleston, South Carolina).

271. Stelgidopteryx ruficollis stuarti Brodkorb, Condor, 44, 1942: 217 (Finca Panzamalá, Alta Verapaz, Guatemala).

272. Petrochelidon albilinea Lawrence, Ann. Lyc. Nat. Hist. New York, 8, 1863: 2 (Panamá).

273. Corvus vociferus Cabot, Proc. Boston Soc. Nat. Hist., 1, 1843: 155 (Yucatán, Mexico).

274. Psilorhinus cyanogenys Sharpe, Cat. Birds Brit. Mus., 3, 1877: 140 (Peaxl-Bay Lagoon, Mosquito $[=$ Pear 1 Cay Lagoon, Nicaragua $]$ ).

275. Xanthoura luxuosa centralis van Rossem, bull. Mus. Comp. Lo81., 77, 1934: 397 (Secanquim, Alta Yera Laz, Guatemala).

276. Xanthoura Iuxuosa maya van Rossem, Bull. Mus. Comp. Z0811., 77, 1934: 397 (Rio Lagartos, Yucatán, Mexico).

277. Cyanocitte yucatanica Dubois, Bull. Acad. Roy . Sci. Belg., ser. 2, 40, 1875: 797 (Yucatán). 
278. Cissilopha yucatanica rivularis Brodkorb, Auk, 57, 1940: 547 (Balancán, Tabasco, Mexico).

279. Cistothorus elegans Sclater and Salvin, Ibis, 1859: 8 (Lake of Dueñas, Guatemala).

280. Heleodytes zonatus restrictus Nelson, Auk, 18, 1901: 49 (Frontera, Tabesco, Mexico).

281. Heleodytes zonatus vulcanius Brodkorb, Auk, 57, 1940: 547 (Aquacaliente, volcán de Tacaná, Chiapas, Mexico).

282. Thryothorus modestus Cabanis, Jour. ftr Orn., 8, 1860: 409 (San José, Costa Rica).

283. Thryothorus maculipectus canobrunneus Ridgway, Man. N. Amer. Birds, 1887: 552 (Temax, Yucatán).

284. T[hryothorus]. maculipectus umbrinus Ridgway, Man. N. Amer. Birds, 1887: ל52 (Guatemala).

285. Troglodytes intermediug Cabanis, Jour. fur orn., 8, 1860: 407 (San José, Costa Rica).

286. Scytalopus prostheleucas Sclater, Proc. Zool. Soc. Iondon, 24, 1856 [1857]: 290 (Cordova, Veracruz, Mexico).

287. Henicorhina prostheleuca tropaes, Bangs and Peters, Bul1. Mus. Comp. Zo8l., 67, 1927: 480 (Lavijagua, Costa Rica).

288. Troglodytes brachyurus Lawrence, Ann. New York Acad. Sci., 4, 1887: 67 (Temax, Yucatán, Mexico).

289. Hemiura leucogastra musica Nelson, Proc. Biol. Soc. Washington, 16, 1903: 159 (Teapa, Tabasco, Mexico). 
290. Nannorchilus leucogaster australis van Rossem, Bull. Brit. Orn. Club, 54, 1938: 15 (Orange Walk, Belize, British Honduras).

291. Melanoptila glabrirostris Sclater, Proc. Zool. Soc. Iondon, 2b, 1857 [1858]: 27) (Omoa, Honduras).

292. Mimus gilvus leucophaeus, Ridgway, Proc. U.S. Nat1. Mus., 10, 1887 [1888]: 506 (Isla Cozumel, Quintane Roo, Mexico).

293. Turdus assimilis parcolor Austin, Bull. Mus. Comp. 4087., 69, 1929: 386 (Camp 6, Cayo District, British Honduras).

294. Turdus assimilis oblitus Miller and Griscom, Amer. Mus. Novitates, 184, 1923: 13 (Tenorio, Costa Rica).

295. Merula tamaulipensis Nelson, Auk, 14, 1897: $7 \mathrm{~b}$ (Ciudad Victoria, Tamaulipas, Mexico).

296. Turdus Grayi Bonaparte, Proc. Zool. Soc. London, 5, 1837 [1838]: 1.18 (Guatemala).

297. Myadestes unicolor pallens MIler and Griscom, Amer. Mus. Novitates, 183, 1925: ל (San Rafael del Norte, Nicaragua).

298. Turdus Swainsoni Tschudi, Fauna Peruana, Aves, 1845: 28 (Carlton House, Saskatchewan, Canada).

299. Turdus minimus Lafresnaye, Lafresnaye, Rev. Zool., 11, 1848: 5 (ad Bogotam in Nova-Grenada [= Bogotá, Colombia]).

300. Turdus Fuscescens Stephens, in Shaw, Gen. Zool., 10, 1817: 182 (Pennsylvania). 
301. Hylocichla fuscescens salicicola Ridgway, Proc. U.S. Nat. Mus., 4, 1881 (1882): 374 (Rocky Mountain district $[=$ Fort Garland, Colorado $\rfloor)$.

302. Sialia sialis guatemalae Ridgway, Proc. U.S. Nat. Mus., 5, 1882: 13 (Guatemala).

303. Sialia sialis meridionalis Dickey and van Rossem, Condor, 32, 1930: 69 (Los Esesmiles, Chalatenango, El Salvador).

304. Polioptila caerulea deppei van Rossem, Bull. Mus. Comp. Zo81., 77, 1934: 402 (Rio Largartos, Yucatán, Mexico).

305. [Motacilla] caerulea Linnaeus, Syst. Nat., ed, 12, 1, 1766: 337 (Pennsylvania $[=$ Philadelphia, Pennsylvania]).

306. Popioptila superciliaris Lawrence, Ann. Lyc. Nat. Hist. New York, 7, 1861 [1862]: 304 (New Grenada, Isthmus of Panama $L=$ Iion Hill, Panamá.l).

307. Scolopacinus rufiventris Bonaparte, Proc. Zool. Soc. London, b, 1837 [1838]: 119 (Guatemala L= San José, Guatemala]).

308. Ramphocaenus rufiventris ardeleo Van Tyne and Trautman, Occas. Papers, Univ. Michigan Mus. Zool., no. 439, 1941: 9 (Chichén Itzá, Yucatán, Mexico).

309. Cyclorhis flaviventris yucatanensis Ridgway, Proc. U.S. Nat. Hus., 9, 1886 [1887]: 519 (Mérida, Yucatán, Mexico).

310. Cyclaris flaviventris Lafresnaye, Rev. Zool., 5 , 1842: 133 (Santa-Cruce in Mexico $t=$ probably, Veracruz, Mexico]). 
311. Vireolanius pulchellus sclater and Salvin, Ibis, 1859: 12 (Guatemala).

312. Tanagra grisea Boddaert, Table Planch. Finlum., 1783: 45 (Louisiana [= New Orleans, Louisiana]).

313. [Muscicapa] noveboracensis Gmelin, Syst. Nat., I, pt. 2, 1789: 947 (Noveboraco [= New York ]).

314. Vireo semiflavus Salvin, Proc. Zool. Soc. London, 1863 [1864]: 188 (Petén, Guatemala).

315. Vireo solitarius notius Van Tyne, Occas. Papers, Univ. Michigan Mus. Zool., no. 256, 1933: 2 (12 mi. south of El Cayo, British Honduras).

316. Vireosylvia flavoviridis Cassin, Proc. Acad, Nat. Sci. Philadephia, 5, 18bl: 152 (Panamá,...., and San Juan de Nicaragua $[=$ San Juan de Nicaragua, Nicaraguaj).

317. Vireosylvia magister (Baird Ms.) Iawrence, Ann. Lyc. Nat. Hist. New York, 10, 1871: 20 (Belize, British Honduras).

318. Phyllonanes barbatulus Cabanis, Jour. far Orn., 3 , 185b: 467 (Cuba).

319. Hylophilus ochraceiceps Sclater, Proc. Zool. Soc. Iondon, 27, 1859 [1860]: 375 (Playa Vicente, Oaxaca, Mexico):

320. Sylvicola decurtata Bonaparte, Proc. Zool. Soc. Iondon, 5, 1837 [1838]: 118 (Guatemala).

321. Chlorophanes guatemalensis Sclater, Proc. Zool. Soc. London, 1861 [1862.): 129 (Guatemala $[=$ Choctum, Vera Paz, Guatemala]). 
322. Caereba carneipes Sclater, Proc. Zool. Soc. London; 27, 1859 [1860]: 376 (Playa Vicente, Oaxaca, Mexico).

323. Caereba lucida Sclater and Salvin, Ibis, 1859: 14 (Guatemala).

324. Certhiola mexicana Sclater, Proc. Zool. Soc. London, 24, 1856 [1857]: 286 (Cordova, Veracruz, Mexico).

325. [Motacilla] aestiva Gmelin, Syst. Nat., 1, pt. 2, 1789: 996 (in Gujana, aestate in Canada $[=$ City of Quebec, (anada]).

326. Dendroica aestiva amnicola Batchelder, Proc. New England 2001. Club, 6, 1918: 82 (Curslet, Newfoundland).

327. Motacilla rubiginosa Pallas, Zoogr. Rosso-Asiatica, 1, 1811: 496 (in insula Kadiak $[=$ Kodiak Island, Alaska]).

328. Dendroica aestiva morcomi Coale, Bull. Ridgway Orn. Club, No. 2, 1887: 82 (Fort Bridger, Utah [= Myoming $]$ ).

329. Dendroica Vieillotii, var. Bryanti Ridgway, Amer. Nat., 7, 1873: 606 (no locality [= Belize, British Honduras]).

330. LMotacilla] caerulescens Gmelin, Syst. Nat., 1, pt. 2, 1789: 960 (in insula s. Dominici [= Hispaniola]).

331. Dendroica coronta hooveri McGregor, Bull. Cooper Orn. Club, I, 1899: 32 (Palo Alta, California).

332. [Motacilla] coronata Linnaeus, Syst. Nat., ed. 12, 1, 1766: 333 (in Pensylvania [= Philadelphia, Pennsylvania]). 
333. [Motacilla] virens Gmelin, Syst. Nat., l, pt. 2, 1789: 985 (in Pensilvania [= Philadelphia, Pennsylvania]).

334. Dendroica Dominica var. albilora Baird Ms. in Ridgway, Amer. Nat., 7, 1873: 606 (Belize, [British] Honduras /.

335. Dendroica Graciae, var. decora Ridgway, Amer. Nat., 7, 1873: 608 (Belize, [British] Honduras).

336. Sylvia discolor Vieillot, Hist. Nat, Ois. Amér., 2, 1807: 37 (Etats-unis et les grandes Iles Antilles [ = New York $]$ ).

337. [Motacilla] palmarum Gnelin, Syst. Nat., 1, pt. 2, 1789: 951 (in insula s. Dominici [= Hispaniola]).

338. [Motacilla] aurocapillus Linnaeus, Syst. Nat, ed. $l<, 1,1766: 334$ (in Pensylvania $L=$ at sea, apparently off Haiti]).

339. Hotacilla noveboracensis Gmelin, Syst. Nat., I, pt. 2, 1789: 958 (in Iouisiana, et Noveboraci sepibus $[=$ New York $]$ ).

340. Siurus naevius notabilis Ridgway, Proc. U.S. Nat. Mus., 3, 1880: 12 (Black Hills $l=$ shores of Como Lake, Carbon County], Wyoming).

341. Irichas brachidactylus Swainson, Anim. Menag., 1838: 295 (northern provinces of the United States).

342. [Turdus] trichas Iinnaeus, Syst. Nat., ed. 12, 1, 1766: 293 (in America septentrionali $[=$ Maryland $]$ ).

343. Chamaethlypis palpebralis Ridgway, Man. No. Amer. Birds, 1887: 526 (Mirador, Veracruz). 
344. [Turdus] virens Linnaeus, Syst. Nat., ed. 10, 1758: 171 (in America [ = South Carolina, 200 or $300 \mathrm{miles}$ from the sea]).

345. Granatellus sallaei boucardi Ridgway, Proc. U.S. Nat. Hus., 8, 1885: 23 (Yucatán, Mexico).

346. Granatellus sallaei griscomi van Rossem, Bull. Mius. Comp. Zo81., 77, 1934: 403 (Cobán, Guatemala).

347. Muscicapa pusilla Milson, Amer. Orn., 3, 1811: 103 (Southern States, . . Iower parts . . of New Jersey and Delaware [= Southern New Jersey $]$ ).

348. [Motacilla] Ruticilla Linnaeus, Syst. Nat., ed. 10, 1758: 186 (in America [= Virginia]).

349. Motacilla tricolora P.L.S. Miller, Natursyst. Suppl., 1776: 175 (Cayenne $[=$ French Guiana]).

350. Sylvia culicivora Lichtenstein, Preis-Verz. Salig., V8gel, . Mexico, 1830: 2 (Mexico [= Jalapa, Veracruz]).

351. Basileuterus salvini Cherrie, Proc. U.S. Nat. Mus., 14, 1891: 342 (Cobán, Vera Paz, Guatemala).

3b2. Cacicus wagleri Gray and Mitchell, Genera Birds, 2, 1844: 342 (ro locality $[=$ Cobán, Guatemalaj).

353. Sturnus holosericeus Lichtenstein, Preis.-Verz. Saug., Vögel, . . Mexico, 1830: 1 (Alvarado, Veracruz, Mexico).

354. Psomocolax oryzivorus impacifus Peters, Proc. Biol. Soc. Washington, 42, 1929: 123 (Pasa Nueva, Veracruz, Mexico). 
355. Ps[arocolius] aeneus Wagler, Isis von Oken, 22, Heft 7,1829, col. 758 (Mexico [= Laguna, Veracruz]).

356. [Corvus] mexicanus Gmelin, syst. Nat., 1, pt. 1, 1788: 375 (Mexico $[=$ Veracruz]).

357. Icterus dives Iichtenstein, Preis-Verz. saug., Vögel, -. Mexico, 1830: 1 (Mexico).

358. Xanthornus prosthemelas Strickland, Contr. Orn., 1850: 120, pl. 62 (Guatemala).

359. Icterus cucullatus igneus Ridgway, Proc. U.S. Nat. Mus., 8, 1885: 19 (Yucatán).

360. Icterus cucullatus masoni Griscom, Amer. Mus. Novitates, no. 23ל, 1926: 18 (Manatee, British Honduras).

361. Ps[arocolius]: mesomelas Wagler, Isis von Oken, 22, Heft 7, 1829: col. 755 (Mexico).

362. Xanthornus chrysater Lesson, Echo du Monde Savant, $11,1844: 204$ (Mexico).

363. Icterus chrysater mayengis van Rossem, Bull. Brit. Orn. Club., 58, 1938: 136 (Peto, Yucatán, Mexico).

364. Ioterus gularis yucatanensis Berlepsch, Auk, 5 , 1888: 454 (Yucatán, Mexico).

365. Agelaius phoeniceus richmondi Nelson, Auk, 14, 1897: 58 (Tlacotalpan, Veracruz, Nexico).

366. Agelaius phoeniceus pallidulus van. Tyne and Trautman; Occas. Papers Univ. Michigan Mus. Zool, , no. 496, 1946: 1 (3 km. south of Progreso, Yucatán, Mexico). 
367. Agelaius phoeniceus matudae Brodkorb, Auk, 57, 1940: 548 (Palizada, Campeche, Mexico).

368. Sturnella magna inexspectata Ridgway, Proc. U.S. Nat. Mus., 10, 1887 [1888]: 587 (Segovia River, Honduras).

369. Pipra elegantissima Bonaparte, Proc. Zool. Soc. Iondon, 5, 1837 [1838]: 112 (Mexico).

370. Phonasca humilis Cabanis, Jour. fllr Orn., 8, 1860: 334 (Costa Rica).

371. Tanazra [Euphonia affinis] Lesson, Rev. Zool., 5, 1842: 175 (Realejo, Nicaragua).

372. Tanagra lauta lauta Bangs and Penard, Bull. Mus. Comp. 2081., 63, 1919: 35 (Guatemala).

373. Euphonia Gouldi Sclater, Proc. Zool. soc. London, 25,1857 [1858]: 66, pl. 124 (Guatemala).

374. Calliste larvata DuBus, Esq. Orn., Iivr. 2, 1846, pl. 9. (Tabasco, Mexico).

37b. Tanagra diaconus Lesson, Rev. ZooI., 5, 1842: 175 - (Realeijo, Nicaragua).

376. Ramphocelus passerinii Bonaparte, "Antologia, 1831, no. $130,3 "$; Isis, 1883: 755 (in insula Cuba $L=$ Mexico]).

377. Tanagra (Tachyphonus) sanguinolenta Jesson, Cent. Z001., 1831: 107, pl. 39 (Mexico).

378. [Fringilla] rubra Linnaeus, Syst. Nat., ed. 10, 1, 1758: 181 (in America [= South Carolina]). 
379. Pyranga figlina Salvin and Godman, Biol. Centr.Amer., Aves, 1, 1883: 293. (Manati [= Manatee] River, British Honduras).

380. Pyranga leucoptera Trudeau, Jour. Acad. Nat. Sci. Philadelphia, 8, 1839: 160 (Mexico).

381. Saltator rubicoides Lafresnaye, Rev. Zool., 7, 1844: 41 (Mexico):

382. Phoenicothraupis rubica nelsoni Ridgway, Bull. U.S. Nat. Mus., 50, pt. 2, 1902: 142, 145 (Peninsula of Yucatán [Puerto Morelos] including Campeche [Apazote]).

383. Phoenicothraupis rubica confinis Bangs, Proc. Biol. Soc. Washington, 18, 190ל: 156 (Yaruca, Honduras).

384. Phoenicothraupis salvini rooensis Griscom, Amer. Mus. Novitates, no. $235,1926: 17$ (Chunyaxche, Quintana Roo, Nexico).

385. Phoenicothraupis salvini peninsularis Ridgway, Proc. Washington Acad. Sci., 3, 1901: 130 (Izalam, Yucatán, Mexico).

386. Phoenicothraupis littoralis Nelson, Auk, 18, 1901: 48 (Frontera, Tabasco, Mexico).

387. Phoenicothraupis salvini Berlepsch, Ibis, 1883: 488 (Vera Paz, Guatemala).

388. Ianio aurantius Lafresnaye, Rev. Zool., 9, 1846: 204 (Guatemala).

389. Eucometis spodocephala pallida Berlepsch, Auk, 5, 1888: 451 (Yucatán). 
390. Chlorospingus honduratius Berlepsch, Verh. 5th Int. Orn. Kong., 1912: 1088 (Voicán de Puca, Honduras).

391. Chlorospingus ophthalmicus richardsoni Griscom, Ibis, 1935: 816 (Sierra de las Minas, Guatemala).

392. Tanagra (Saltator) atriceps Lesson, Cent. Zool., 1832: 208 (Mexico [= Veracruz $]$ ).

393. Pyrrhula raptor Cabot, Jour. Boston Soc. Nat. Hist., 5, 1845: 90 (Yucatán, Mexico).

394. Saltator magnoides Lafresnaye, Rev. Zool., 7, 1884: 41 (Mexico [ G Guatemala]).

39b. Saltator gigantodes Cabanis, Mus. Hein., 1, 1851: 142 (Mexico).

396. Tanagra grandis Lichtenstein, Preis.-Verz. Satig., VBsel, - . Hexico, I830: 2 (Jalapa, Veracruz, Mexico).

397. Saltator grandis yucatanensis Berlepsch, Verh. Sth Int. Orn. Kong., 1912: 1114 (Mérida, Yucatán, Mexico).

398. Pitylus poliogaster DuBus, Bull. Acad. Roy. Sci. Belg., 14, 1847: 105 (Guatemala).

399. Cardinalis cardinal is flammiger Peters, Auk, 30, 1913: 380 (Xcopen, Quintana Roo, Mexico).

400. [ [ardinalis]. cardinalis yucatanicus Ridgway, Man. N. Am. Birds, 1887: 443 ([Mérida,] Yucatán, [Mexico]).

401. [Loxia] caerulea Linnaeus, Syst. Nat., ed. 10, 1, 1758: 175 (America [= South Carolina]). 
402. Lyanoloxia concreta DuBus, Bull. Acad. Roy. Sci. Belg., 22, 18ל5: 150 (Playa Vicente, Veracruz, Mexico).

403. Cyanocompsa cyanoides caerulescens Todd, Auk, 40, 1923: 61 (Esparta, Costa Rica).

404. Cyanoloxia parellina Bonaparte, Consp. Gen. Avium, I, 1850: 502 (AIvarado, Veracruz, Mexico).

405. Cyanocompsa parellina dearborni Miller and Griscon, Amer. Mus. Novitates, No. 184, 1925: I (San Rafael del worte, Nicaragua).

406. [Emberiza] Ciris Linnaeus, Syst. Nat., ed. 10, 1, 1758: 179 (in America [ South Carolina]).

407. Spermophila morelleti Bonaparte, consp. Gen. Avium, 1, pt. 2, 1850: 497 (Guatimala [= Petén, Guatemala]).

408. Spermophila corvina Sclater, Proc. zool. Soc. London, 27, 1859 [1860]: 379 (Playa Vicente, Oaxaca, Hexico).

409. Fringilla splendens Vieillot, Nouv. Dict. Hist. Nat., nouv. ed., 12, 1817: 173 (Cayenne [= French Guiana]).

410. Spinus notatus oleaceus Griscom, Proc. New England 2001. Club, 1), 1932: 61. (Cerro Cantoral, District of Achaga, Honduras).

411. Carduelis notata DuBus, Bull. Acad. Roy . Sci. Belg., 14, 1847: 106 (le Mexique [= Jalapa, Veracruz, Mexico]).

412. Loxia curvirostra stricklandi Ridgway, Proc. U.S. Nat. Mus., 8, 1885: 354 (Mexico [= City of Mexico]). 
413. Loxia qurvirostra mesamericana Griscom, Proc. Boston Soc. Nat. Hist., 41, 1937: 136 (Rancho Quemado, South central Honduras).

414. Arremon aurantiirostris saturatus Cherrie, Proc. U.S. Nat. Mus., 14, 1891: 345 (Choctum, Dept. of vera Paz, Guatemala).

415. Arremon rufidorsalis Cassin, Proc. Acad. Nat. Sci. Philadephia, 1865: 170 (Turrialba, Costa Rica).

416. [Embernagra rufivirgata] verticalis Ridgway, Proc. U.S. Nat. Mus., 1, 1878: 248-49 (Merida, Yucatín, Mexico).

417. Embernagra chloronota Salvin, Proc. 2001. Soc. London, 1861 [1862]: 202 (Choctum, Vera Paz, Guatemama).

418. Fringilla Savanna Wilson, Amer. Orn., 3, 1811: 5. (Atlantic coast, from Savannah Georgia, to Great Egg Harbor, Wew Jersey [ = Savannah, Georgia]).

419. Passerculus sandwichensis nevadensis Grinnel, Univ. Calif. Publ. Lool., 5, 1910: 312 (Soldier Meadows, Humboldt County, Nevada).

420. Passerculus anthinus Bonaparte, Compt. Rend. Acad. Sci. Paris, 37, 1853: 920 (Kadiak [= Kodiak Island, Alaska]).

421. Passerina praterisis Vieillot, Nour. Dict. Hist. Nat., nouv. ed. 25, 1817: 24 (New York).

422. Coturniculus savannarum cracens Bangs and Peck, Proc. Biol. Soc. Washington, 21, 1908: 45 (Ycacos Jagoon, British Honduras). 
423. Embernagra pyrgitoides Lafresnaye, Rev. Zool., 2, 1839: 97 (Mexico [= Jalapa, Veracruz]).

424. Aimophila rufescens discolor Ridgway, Proc. U.S. Nat. Mus., 10, 1887 [1888]: 587 (Segovia River, Honduras):

425. Aminodromus petenicus Salvin, Proc. Lool. Soc. London, 1863 [1864]: 189 (Petén, Guatemala).

426. Zonotrichia botteri Sclater, Proc. Zool. Soc. London, 25, 1857 [1858]: 214 (vicinity of Orizaba, Veracruz, Mexico).

427. Spizella pinetorum Salvin, Proc. Zool. Soc. Iondon, 1863 [.1864]: 189 ([Poctum,] Petén, Guatemala). 
Figure 1. Map of British Honduras showine the localities that are nurbered in the Gazetteer. The numerical sequence of localities is an arrangenent whereby north takes precedence over south and west over east. 1. Corozal. 2. Orange Walk, 3. Rio Hondo. 4. Ambergris vay. b. Wew River. 6. Haskalls. 7. Crooked Tree Lagoon. 8. Cay Corker. 9. Hill Bank J dgoon. 10. Spanish Creck. 11. Hick's Cays. 12. Mauger Cay. 13. Isabella. 14. Hill Bank. 1). Boom. 16. Rendezvous Point. 17. Gallon Jug. 18. Belize River. 19. Belize. 20. Worthern Two Cays. 21. Sibun Kiver. 22. Sergeant's Cay. 23. KcHabb's Water Cay. 24. I'urneffe Islunds. 25. Iighthouse Reef. 26. -tnglish vay. 27. Soldier Cay. 28. churchyard. 29. Orange Halk, 30. Saddle Cay. 31. Middle Ions Cay. 32. Calabash Cay. 33. han-of-welr Cay. 34. Chorro. 3〉. Duck Run. 36. iranatee Bar. 37. Half Hoon Cay. 38. lianatee Lagoon area. 39. i.anatee River. 40. Caves Branch at Humingbird Hirhway. 4.I. Western Eranch of the Belize River. 42. Cayo. 43. sibun River at Hummingbird Highway 44. San Felipe. 4j. Jiullins River. 46. Senque viejo. 47. san Antonio. 48. Dry Ureek at Humingbird Highway. 49. Baldy Teacon. 50. Humingbird Gap. Li. iridalesex. 22. Arenal. 33. Pomona. 54. Cay Dolores Chamel. b5. Horth Stann Creek. 26. Stann Creek. 27. Augustine. b8. Camp VI. 59. Guacamallo. 60. Tobacco Cay. 61. Lastorn Branch of the Belize River. 62. Fillerina Camp. 63. Sittee River. 64. Freetown. 65. Regalia. 66. Southemilater Cay. 67. Kendal. 68. All Pines. 69. Sittee Eranch of South jtann Creek. 70. Victoria Peak. 71. Hountain Cow. 72. Curlew Cay. 73. litilionario. 74. North wast Cay. 75. Long Cay. 76. Middle Cay. 77. South Vest Cay. 78. Glover's Reef. 79. South Stann Creek. 80. Point Placentia. 81. Hatchet Cay. 82. Round Cay. 83. Deep River. 84. Dompion Cay. 85. Honkey River. 86. San Pedro Columbia. 87. Rio Grinde. 83. Tom Owens Cay. 89. Holedo Settlenent. 90. Punta Gorda. 91. Hunting Cay. 92. Moho River. 93. Temash River. 


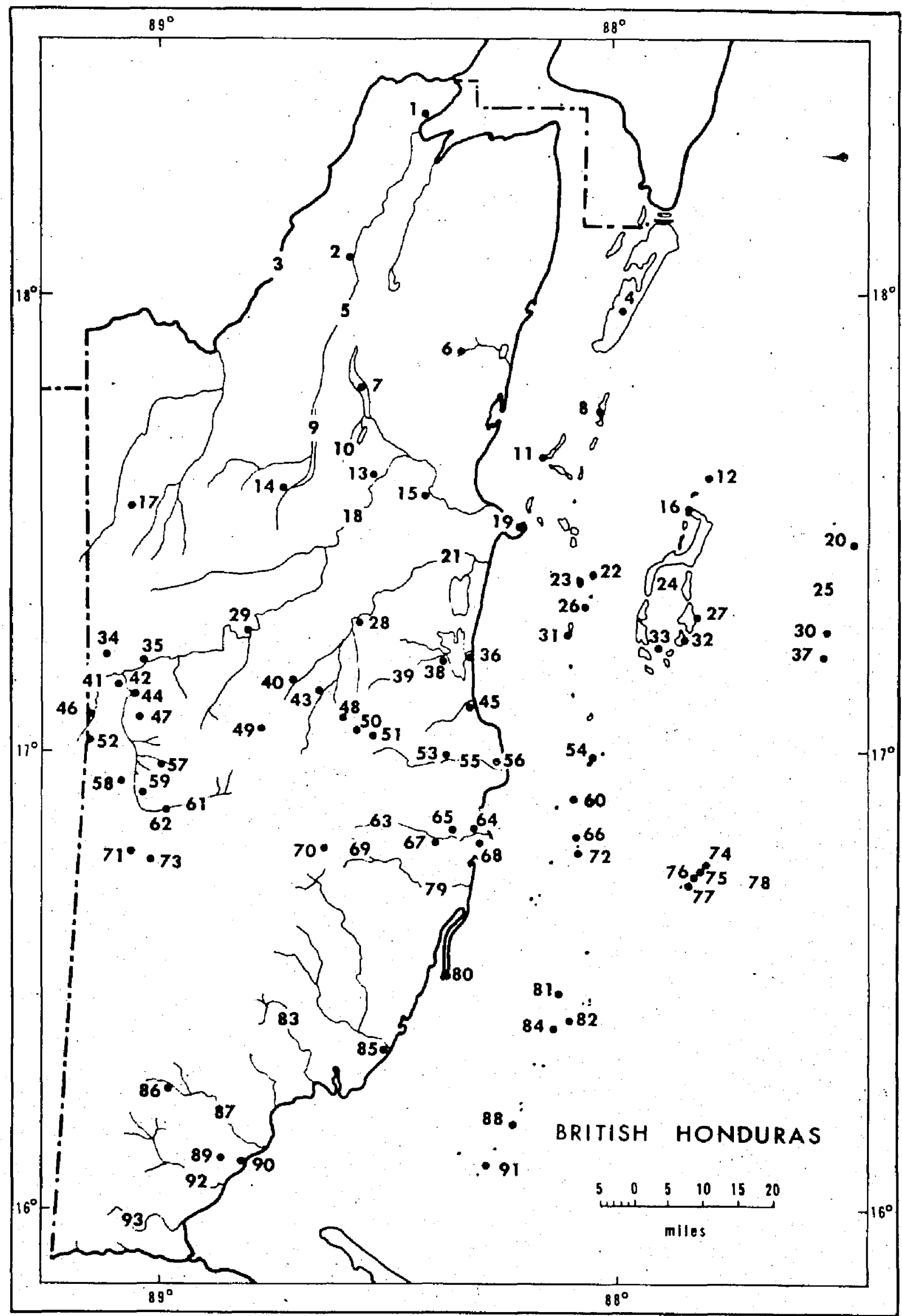




\section{APPENDIX B}

\section{GAZTPTEIR OF LOCAIIMINS}

Place names and seogrephic features to grich reference is :ade in the text are listed here. Names are followed by co-ordinates to the neavest minutes of, first, north latitude, and, second, west lonitude. Most of the looalitios are to be found on the inerican Georraphical Society's "jap of Hispanic Anerice on the Scale of 1:1,000,000 (1:illionth liap)," Provisional edition, H.E-16. Spellings conforn to usage in British Honduras. Numbers in brachets idertify the position of a locality on the map irl Figure 1 .

Al1. Pines. - $16^{\circ} 48^{\prime}, 88^{\circ} 18^{\prime}$. A village on the coast south of the nouth of the sittee River. Important Blake and Asostini locality [68].

Ambergris Cay - Between $17^{\circ}>4^{\prime}, 88^{\circ} 03^{\prime}$ and $18^{\circ} 09^{\prime}$, $87^{\circ}$ y'. Iarge key south of the boundary between British Honduras and ouintara Roo, Mexico. Visited by Griscom $\lfloor 4\rfloor$.

ArenaI. $-17^{\circ} 02^{\prime}, 89^{\circ}$ og'. Village about 10 miles southwest of Cayo on the boundary between British Honduras and Guatemala $[52\rfloor$. 
Augustine. - $16^{\circ} 58^{\prime}, 88^{\circ} 00^{\prime}$. Village at the restern edge of the pinelands of the fountrin Fine Ridise. Important collecting locality. Elevation I>>0' LD7J.

Back Landing. - I did not find this locality on any maps. Probably near coast on Belize river. A specinen in British inseun fron this locslity.

Baldy Beacon. - $17^{\circ} 031,88^{\circ} 47$. The hichest point in the Mountain Pine Ridge. slevation 3000 ' [49].

Ballerina Camp. - $16^{\circ} 53^{\prime}, 88^{\circ} 59^{\prime}$. A Lancaster and Russell collecting locality on the sastern Brinch of the Belize River. Pine ridge to north, tall forest to south. Hilevation about lyoo' [62].

Belize. - $17^{\circ} 30^{\prime}, 88^{\circ} 12^{\prime}$. City on const. Nany old specimens labeled "Belize" were collected inland. The city is surrourded by nangroves, but pinelinds and tall forest are "ithin Io miles [19].

Belize River. - From $17^{\circ} 10^{\prime}, 89^{\circ} 04^{\prime}$ to the sea at $17^{\circ}$ $33^{\prime}, 88^{\circ} 17^{\prime}$. Fornerly the usual route from Delize to vayo. Mlso called Old River [18].

Benque viejo. - $17^{\circ} 04^{\prime}, 89^{\circ} 08^{\prime}$. Village 6 miles southwest of cayo on boundary between British Honduras and Guatemila [46].

Boom. - $17^{\circ} 34^{\prime}, 88^{\circ} 24^{\prime}$. Village on Belize River 14 miles north-nortiwest of Belize LIjJ.

Calabash Cay. - $17^{\circ} 14^{\prime}, 87^{\circ} 51 !$ Key on east edge of 'lurneffe Islands. Mangroves and coconut palms. Important Dennett and Russell locality L32].

Camp VI. - $16^{\circ} 56^{\prime}, 89^{\circ} 04^{\prime}$. Formerly a mahogany camp. An Austin locality. Also written Canp 6 [58]. 
Ceves Branch at Hummingird Highway. - $17^{\circ} 09^{\prime}, 88^{\circ}$ 42'. Area formerly forested, now : cricultural $[40]$.

Uay corker. - $17^{\circ} 4{ }^{\prime}, 88^{\circ} 03^{\prime}$. Key 20 miles nortweast of belize 1.81 .

Uay Dolores Chanilel. - $16^{\circ} 29^{\prime}, 83^{\circ} 03^{\prime}$. Hast of Stann creek. A jalvin locality L54J.

vayo. - $17^{\circ} 08^{\prime}, 39^{\circ} 06^{\prime}$. Town at the union of the wastern and iesterm Branches of the Belize River. f'ormerly calied

Cayo District. - An adninistretive division in British Honduras. It now includes all of the area west of the crest of the haya iountains (including the Nountain Pine Bidge) and wuch of the valley of the Belize River. Once called "Western District, "and sone specinens in the British museun are so labeled.

Chetumil Bay. - Situated at northeastern border of mainland British Honduras. Also called Bahia de thetunel. Chorro. $-17^{\circ} 13^{\prime}, 89^{\circ} 07^{\prime}$. Village, niles northwest of Cayo [34].

Churchyard. $-17^{\circ} 17^{\prime}, 88^{\circ} 34^{\prime}$. village on jibun River โ28」.

Cockroach vay. - In the northeastem part of the inuefe Islinds. I did not find it on luaps.

Cockscomb Nountains. - Highest mounvains in British Honduras. Part of maya llountains. Victoria Peak, which is the highest point (elevation $3700^{\circ}$ ), is identified on the map as locality no. 70 . 
columbia kiver. - A tributary of the kio lrende in southein British Honduras. Identified on nap as river nearest locality no. 36.

Corozal. - $18^{\circ} 24^{\prime}, 88^{\circ} 24^{\prime}$. Tow in extrene northern sritish Honduri..s [I].

Urooked 'iree lragoon. - In norihern British Honduras [7]. curlew cay. - $16^{\circ} 46^{\prime}, 88^{\circ} 03^{\prime}$. Key esst of 211 pines. A salvin locality [72].

Deep hiver. - Hrom $16^{\circ} 28^{\prime}, 10^{\circ} 47 \cdot$. Soutieast into the sea $[83\rfloor$.

Dry Creek at Humingbird Highway. - $17^{\circ} 04^{\prime}, 88^{\circ} 36^{\prime}$. A. Dennett and Russell locality in tall forest 448].

Duck Run. - Formerly a chicle stotion on the belize river below Cayo. I was unable to determine its precise location. Also called Ienue veiba L35J.

Hastern Brmch of the Belize hiver. - One of tre two mein tributaries of the Belize liver. Mlso called Hakal River [6I].

melish Cay. - $17^{\circ} 19^{\prime}, 88^{\circ} 02^{\prime}$. Tiny key 1 ) miles southerst of Belice [26].

i'rectown. - $16^{\circ} 49^{\prime}, 88^{\circ} 18^{\prime}$. A villase on the sittee River near the coast. An important blake and hostini locility [64].

Galion Jug. - $17^{\circ} 33^{\prime}, 89^{\circ} 02^{\prime}$. A village in northwestern British Honduras. Not established until about 194b. Ornithologically, it is the most thoroughly studied area in the Colony. Flevation $400^{\prime}[17]$. 
Glover's heef. - A group of smal keys :ituated between $16^{\circ} 42^{\prime}, 87^{\circ} \supset 1^{\prime}$ and $16^{\circ} 4>^{\prime}$ and $87^{\circ} 47^{\prime} \cdot$ inlso spelied Glover heef [78].

Grassy Cay. - I was unble to rind this locality on haps. A salvin locality niturted someriere in the rurneffe Islands.

Guicamallo. - $16^{\circ}$ > $y^{\prime}, 89^{\circ} 02^{\prime}$. Abchdoned cimp situcted 570 feet above the tastern Branch of the Belize kiver at an elevation of $1700^{\prime}$ [D9]. Ihe river crossine near tis point is the in comllo urossing.

Herly noon Cay. - $17^{\circ} 13^{\prime}, 87^{\circ} 34^{\circ}$. Key 48 miles enstsoutheast of Beline. Test lnown lor its booby colony ‘37].

Hatchet Cay. - $16^{\circ} 27^{\prime}, 80^{\circ} 07^{\prime}$. Key 17 rilles east of Point Placentia [81].

Hick's Cays. - A number of keys a fey niles northeast of Belize [II].

Hill sank. - $17^{\circ} 35^{\prime}, 88^{\circ} 4^{\prime}$. A village at the south end of the Hill sanl Eacroon. Both tall forest and pinelands in the vicinity. An important collecting locality [14].

Hill Bank Lagoon. - Between $17^{\circ} 3 y^{\prime}, 88^{\circ} 44^{\prime}$ and $17^{\circ} 46^{\prime}$, $88^{\circ} 39^{\prime}$. Heir the source of the New River. Also called New River Jagoon $49 \mathrm{~J}$.

Fumingbird Gap. - $17^{\circ} 03^{\prime}, 88^{\circ} 34^{\prime}$. Highest noint on the Funningird Highway. pall forst. Jlevation about $900^{\circ}[50]$.

Iunting Cay. - $16^{\circ} 07^{\prime}, 88^{\circ} 16^{\prime}$. Key 3y miles east of Punta Gorda [91]. 
Isabella. - $17^{\circ} 37^{\prime}, 88^{\circ} 32^{\prime}$. Village on Delize Kiver [13].

Kendal. - $16^{\circ} 48^{\prime}, 88^{\circ} 24^{\prime}$. Plantation on sittee river [67].

Lighthouse Reef. - 1 groul of keys between $17^{\circ} 13^{\prime}, 87^{\circ}$ $34^{\prime}$, and $17^{\circ} 23^{\prime}, 87^{\circ} 28^{\prime}$ L2.1.

Ionk Gay. $-16^{\circ} 44^{\prime}, 87^{\circ} 48^{\prime}$. A key in Glover's Reef [75.1.

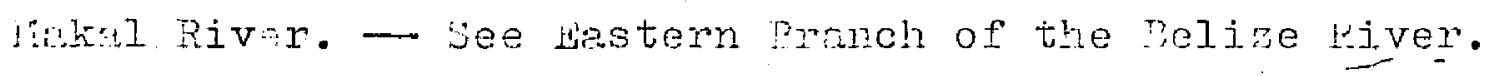
han-of-werr vay. - About $17^{\circ} 1 \% 1,87^{\circ}$ 5. A tiny key in the lurnefte I3lcinds [33].

Nanatee Dan. - $17^{\circ} 13^{\prime}, 88^{\circ} 18^{\circ}$. At the nouth of the hanntee Kiver. i Peok locality [36].

Whintee Lazoon area. - About $17^{\circ} 12^{\prime} ; 88^{\circ} 23^{\prime}$. Pock collected rany specinens athin à ratius of five iniles of the point on the nap [38].

Hanatee River. - From $17^{\circ} 08^{\prime}, 83^{\circ} 33^{\prime}$ to Hanctee Lacoon and the sea [39].

Haskalls. - $17^{\circ} \mathrm{3} 3^{\prime}, 88^{\circ} 20 \%$. Village in nortieaste Bratish Monduras $[6]$.

Whuger Cay. $-17^{\circ} 36^{\prime}, 87^{\circ} 47^{\prime}$. Small key at northern end of the Iurneffe Islands L12].

Laya Hountains. - Whe hich nountains in tine interior of the colony. Whey include the cocrscomb litountains and the nountain pine ridge. Whe area southwest of localities no. 49 and 70 . 
KoNeibb's Mater Vay. - $17^{\circ} 23^{\prime}, 88^{\circ}$ 05'. Small key 10 miles southeast of Belize [23].

Felinda. - $16^{\circ} 59^{\prime}, 88^{\circ} 20^{\prime}$. A village in the valley of the worth 3 tann Creek about 3 miles fro:n the coest.

iidale cay. $-16^{\circ} 43^{\prime}, 87^{\circ} 49^{\prime}$. is key in Glover's Reef $[76]$.

Middle Lons Cay. - $17^{\circ} 17^{\prime}, 88^{\circ} 06^{\prime}$. A key 16 miles south-southeast of Belize L3IJ.

Midcilesex. - $17^{\circ} 02^{\prime}, 38^{\circ} 32^{\prime}$. A village near the head of the Nortil stann Creek valley [jI].

Milionario. - $16^{\circ} 46^{\prime}, 89^{\circ} 01$ '. A canp in tall forest soutin of the wastern Branch of the Belize hiver. silevation about 2000 ' [73].

Woho River. - From about $16^{\circ} 131,89^{\circ} 0 \%^{\prime}$ southeast to the sea. [92].

nonkey River. $-16^{\circ} 211,83^{\circ} 30^{\prime}$. A village in southern British Honduras situated at the mouth oi a river of the sarle nane [85].

Inorgan Cay. - I did not find this locality on inaps. Berry collected Anous tenuirostris on this key in April 1907. I suspect that it is east or southeast of the nouth of the liranatee River.

Wountain Cow. - $16^{\circ} 47^{\prime}, 89^{\circ} 03^{\prime}$. An Austin site southwest of the Mountain Pine Riage L7IJ.

Mountain Pine Ridge. - $\Lambda$ part of the Haya Hountins. It includes the area on the nap from localities no. 7 , 59, and 62 east to no. 49. Wuch of the srea consists of hilly pinelards between elevations of 1,00 and $3000^{\prime} \cdot$ 
Wullins River. $-17^{\circ} 06^{\prime}, 83^{\circ} 13^{\prime}$. A village on the coast of central British Honduras at the mouth of a river of the same nalile [4D].

New kiver. - irom about $17^{\circ} 29^{\prime}, 08^{\circ} 45^{\prime}$ nortin-northeast to lhetumal gay $[>]$.

North kast Cay. - $16^{\circ} 4 \mathrm{y}^{\prime}, 37^{\circ} 48^{\prime}$. A key in Glover's Reef [74].

North stann creek. - inrom about $17^{\circ} 001,88^{\circ} 32^{\prime}$ eestward to the sea. Uitrus treos are extensively cultivited in the valley [s

Northern wo Cays. $-17^{\circ} 23^{\prime}, 87^{\circ} 23^{1}$. Weys in the northern part of Lighthouse Reef [20].

Old River. - see Belize iiver.

Orange Walk. - $18^{\circ} 05^{\prime}, 88^{\circ}$ 3. $42 \mathrm{~J} \cdot 17^{\circ} .17^{\prime}, 88^{\circ} 48^{\prime}$ [29]. Several specimens in the fritish Heum, wich were collected late' in 1887, berr the name "Orange Walk." I suspect these opecimers were talien at the more northern of the two tows, mich was the nore inportant place. However, Goss reconded observations of ducks on the selize liver near orange valk, which is the nore southern locality.

Point Placentia. - $16^{\circ} 30^{\prime}, 88^{\circ} 23^{\prime}$. On the southern coast $[80]$.

Pomona. - $17^{\circ} 00^{\prime}, 88^{\circ} 22^{\prime}$. A villare in the villoy of the Iorth stam Creek [>3].

Pompion Cay. $-16^{\circ} 24^{\prime}, 88^{\circ}$ 09\%. A swall hey about 23 miles east of Honkey River [84]. 
Punte Gorda. - $16^{\circ} 06^{\prime}, 88^{\circ} 49^{\prime}$. The largest tom in soutliem ritish Ionduras. - Go stal [90].

Regalia. - $16^{\circ} \cdot 49^{\prime}, 88^{\circ} 22^{\prime}$. A village on the sitted river [6>].

Rendezvous 2oint. - $17^{\circ} 32^{\prime}, 87^{\circ} 50^{\prime}$. A part of the Purnefie Isiands L16].

Rio Gronde. - Pron $16^{\circ}$ I', $88^{\circ} 26^{\prime}$ southeast to the sea $[87]$.

Rio Hondo. - Forns the northern boundary between British Fonduras and quintans Roo, Mexico. Howing sortireast into cinetuml try L3].

Rio inopan. - Seo "iestern kranch of the Belize liver. Round Cay. - $16^{\circ} 24^{\prime}, 88^{\circ} 06^{\prime}$. Key about 26 niles east of Monkey hiver L82」.

Saddle Cay. - $17^{\circ}$ I', $87^{\circ} 32^{\prime}$. A key in Ligintiouse Reef $[30]$.

San Antonio. - $17^{\circ} 04^{\prime}, 89^{\circ} 03^{\prime}$. A village 6 miles south-southeast of cayo. A number of epecinens ir the sritish iluseun vere collected at this locality. There are other villarges called san Artonio in the Colony [47].

San Felipe. - $17^{\circ} 07^{\prime}, 89^{\circ} 04^{\prime}$. A village 3 miles southcast of layo. A number of specimens in the British ifuseum were taken at this locality. [44].

San Pearo Columbia. - $16^{\circ} 16^{\prime}, 88^{\circ} 38^{\prime}$. A village on tine volumbia diver in southern british londuras. An important Dennett and Russell site ves situated two ailes west of San Pedro Columbia at the point where a large spring formed the Columbia River [86]. 
Serjeants Cay. - $17^{\circ} 23^{\prime}, 88^{\circ} 03^{\prime}$. A anall ley 13

miles soutinenst of belize [2?].

Sibun River. - Plowing northeast fron the rountain Pine lidere to tire sea L2IJ.

sibun River it the Humingbird flimhway. $-17^{\circ} 08^{\prime}, 88^{\circ}$ 38'. Firested area $[43]$.

Silver Creek at the Humingird Sifway. - silver ureek is a tributary of the sibun inves this crossing is betireen localities $43 \mathrm{ma} 48$ on the map.

isittee brinch of South Stann Ureek. - Fron $16^{\circ} 4 \mathrm{~d}^{\prime}, 83^{\circ}$ 39' east and southeast to vouth jam ureel. Draining the northern slope of the coobsconb lountains [69.].

Bittee River. - Hron $16^{\circ}$ j0', $83^{\circ} 34^{\prime}$ east to the sea [.63].

soldier cay. $-17^{\circ} 17^{\prime}, 87^{\circ} 49^{\circ}$. A key on the eastern edse of the lumerfe $I$ indas $[27\rfloor$.

south stan creek. - Hron the vocksconb houndains custsoutileast to the sea $[79]$.

south West vay. - $16^{\circ} 42^{\prime}, 37^{\circ}$ 5]'. A key in Glover's Reef. Also called southwest Cay, Bouthmest-of-all Cay [77].

Southern Mountein Pine Ridge. - See nountain Fine Ridge. Southern Pine Ridge. - See rountain Pine Ridge. Southern Water Cay. $-16^{\circ} 48^{\prime}, 88^{\circ}$ O'. A key 13 miles east of the nouth of the sittee River $[66]$. 
Spanish ureek. - Prom $17^{\circ} 32^{\prime}, 88^{\circ} 16^{\prime}$ north into Crooked Tree Lazoon [10].

Stann Creok. - $16^{\circ}$ b8', $38^{\circ}$ I5'. Wown at the noutil of North stann Creek $L>6 j$.

Iemash River. - From the Guatemalan bonder in extreme southern British Hondur:ts to the sea 493. .

Hobacco Cay. - $16^{\circ}$ b4', $88^{\circ}$ 06'. A leey 11 miles southeast of stenn Creek [60].

Toledo District. - An adrinistretive division of British Honduras. It includes nost ruts or the Colony south of point lacentia. Districis in the volony undereo freaut boundary chames.

Ioledo settlement. $-16^{\circ} 07^{\prime}, 88^{\circ} 33^{\prime}$. Formerly a viliage 4 niles vest of punte Gorde [89i.

Hom Owens oay. - $16^{\circ} 11$ ', $88^{\circ} 14^{\prime}$. A key 39 miles east nortileast of Funta Gorda [33].

Turneffe Isturis. - a Eroin of small islinds cbout $20-$ 2) niles east of Belize. Appear on mary naps as a single islend [24].

Twelve Mlie station. - Twelve miles up North stan Creek, A railroad owce run throuch trie villey. A schild locality.

Twenty-two rile station. - Twenty-two miles up rorth Stinn Creek. A Schnidt locality.

victoria Peak. - $16^{\circ} 47^{\prime}, 88^{\circ} 36^{\prime}$. In the Cocksconb iountains. The highest point in the Colony. Hlevation $3700 \cdot[70]$. 
Western Branch of the Belize River. - One of the two main tributaries of the Belize River. Also called kio hopan [4I].

\#iestern District. - See Cayo Jistrict.

Hild Cane Cay. - A sall key situated about lo niles soutic of the tom of ronkey River. A Peck lockility.

Ycacos Iagoon. - $16^{\circ} 17^{\circ}, 88^{\circ} 37^{\prime}$. A coastal lacoon in southern. British Honduras. A peck locality eigit miles couthre:t of locelity no. $6 \%$ 
IITERA EUEE UILED

AVERICAN ORNITHOIOGISTS' UNION CCHWT"LA.

1957. Check-1ist of Nurth American birds. 5th ed. Amer. Orn. Union, Baltimore. 691 p.

ANDERSON, A. Fi.

1954. A brief sketch of British Honduras. Government Printing Office, Belize. $80 \mathrm{p}$.

AUSIIN, O. I., JR.

1929. Birds of the Cayo District, British Honduras. Bull. vius. Comp. Zoöl. 69: 353-394

AUSTIi, O. I., SR.

1953. The migration of the Commor Tern (Stterna hirundo) in the western Hemisphere. $\bar{B} i \mathrm{r}$ banding 24: 39-54.

BAIRD, S. F., T. IN. BREWLR, AND ROBERE RIDGWAY.

1874. A history of North anerican birds. Land birds. Vol. 2. Little, Brown, and Co., Bostion. $590 \mathrm{p}$.

BANGS, OURRAM, AND H. E. PECK.

1900. On some rare and new birds from British Honduras. Proc. Biol. Soc. Washilfton $21: 45-46$.

BARTLELT, H. H.

1935. A method of procedure for field work in tropical American phytogeography based upon a botanical reconnaissance in parts of British Honduras and the Peten forest of Guatemala. Carnegie Inst. Washington Publ. 461: $1-25$.

BEARD, J.S.

1944. Climax vegetation in tropical America. Ecology 25: 127-158.

BENT, A. C.

1940. Life histories of North American cuckoos, goatsuckers, hurningbirds and their allies. Bull. U. S. Nat. Mus. 176, 506 p. 
BERLEYSCH, G. H. VON.

1883. Descriptions of six new species of birds from South and Ceritral America. Ibis Ser. 5, $1: 487-494$.

1888. Descriptions of new species and subspecies of biras from the Neotropical Region. Auk 5: $449-460$.

BLAKE, E. R.

1950. Report on a collection of birds from Caxaca, Mexico. Chicagc. Nat. Hist. Mus. Hieldiana, Z001. 31: 395-419.

1958. Birảs of Volcán de Chiriquí, Panama. Chicago. Hat. Hist. Ilus. Fieldiana, Zool. 36: 499-577.

BOND, JAMES.

1939. Notes on birds from the west Indies and other Caribbean islands. Acad. Nat. Sci. Philadelphia, liotulae Naturae lic. 13,6 p:

1954. Birds of Turneffe and Northern Two Cays, British Honduras. Acar. Nat. Sci. Philadelphia, Notulae vaturae No. 2io, 10 p.

BRODKORB, FIERCH.

1943. Birds of the Gulf lowlands of southern inexico. Misc. Fubl. Mus. Zool., Univ. Michiean, No. $55,88 \mathrm{p}$.

1947. The barded wrens of northern viddle America. condor 49: 242-243.

CAREIKER, M. A., AND R. M. DE SUHAUENSEE.

1935. An annotated list of two collections of Guatenalan biras in the Academy of Natural scierces of Filiadelphia. Iroc. Acad. Nat. Ści. Ehiladelphia $87: 411-455$.

COOKE, M. T.

1938a. Returns of banded birds: recoveries of banded marsh birds. Bird-banding 9: 80-87.

1938b. Some interesting recoveries of banded birds. Bird-banding 9: 184-190.

1946. The winter range of the Great Blue Heron. Auk 63: 254.

1950. Returns from banded birds. Bird-banding 21: $11-18$.

COUES, EILIOTL.

1864. Notes on certain Central American Laridae. collected by Mir. Osbert Salvin and Mr. F. Godman. Ibis 6: 387-393.

DARLIVGTON, F. J., JR.

1931. Notes on the birds of Rio Frio (near Santa Marta), Magdalena, Colombia. Bull. Mus. Comp. 
Z0001. $71: 349-421$.

DAVIS, I. I., AND BIIL GUION.

1961. Breedirg bird censuses. Humid tropical forest, upland savania, lowland savanna. Aud. Field potes 15: 510, 512-513.

DEVAS, R. P.

1953. Birds of Eritish Honduras. Yuille's Prirterie Ltd., Fort-of'-Spain, Triridad. 79 p.

DICKEY, D. R., AND A, J. VAN ROSSEM.

1933. The birds of El Salvador. Chicago. Field Mus. Nat. Hist., Zool. Ser. 23(406), $612 \mathrm{p}$.

DIXOH, C. G.

1956. Geology of southern British Honduras with notes on adjacent areas. Government printer, Belize. $94 \mathrm{p}$.

EATCN, S. W.

1957. Variation in Seiurus noveboracensis. Auk 74 : $229-239$.

EDWARDS, E. P.

1959. Nesting of the Lesser Swallow-tailed Swift, Fanyotila cayennensis, in Guatemala. Auk 76:

EISENMANN, EUGENE.

1955a. The species of Midale American birds. Trans. Linnaean Soc. New York 7, 128 p.

1955b. Status of the Black-polled, Bay-breasted, and Connecticut Warblers in Widdle America. Auk 72: 206-207.

FORBE's, H. O., AND H. C. ROBINSON.

1899. Catalogue of the charadriomorphic birds... in the Derby Museum. Bull. Liverpool Museums 2: $51-75$.

FRIEDIMANN, HWRBER'T.

1949. The status of the Spotted Rail, Pardirallus maculatus, of Chiapás. Auk $66: 8 \overline{6}-\overline{37}$.

1950a. The birds of North and Middle America. Bull. U. S. Nat. Pius. 50(11), 793 p.

1950b. The forms of the Black Hawk-Eagle. Smithsonian Misc. Collections $111(16), 4 \mathrm{p}$.

GOSS, N.S.

1891. History of the birds of hansas. George W.
Crane and Co., Topeka. 692 p. 
GRISLONI, IUDIOW.

1926. The ornithological results of the MasonSpinden expedition to Yucatan. Pt. 1 . Introduction; Birds of the mainland of fastern Yucatan. Amer. Mus. Novitates No. $235,19 \mathrm{p}$.

1932a. The distribution of bird-life in Guatemala. Bull. Amer. Mus. Nat. Hist. 64, 439 p.

1932b. New birds from Honduras and Mexico. Proc. New England zool. Club 13: 55-62.

HARGITT, EDVIARD.

1890. Catalorue of the birds in the British Museum. Vol. 18. London. $598 \mathrm{p}$.

HARTERT, ERINST.

1892. Catalogue of the birds in the British Museum, by Osbert Salvin and Ernst Hartert. Vol. 16. London. $703 \mathrm{p}$.

HEILMAYK, C. E.

1929. Catalogue of the birds of the Americas and the adjacent islands. Chicago. Field Wus. Wat. Hist., Zool. Ser. 13(6), 258 p.

1934. Catalogue of the birds of the Americas and the adjacent islands. Chicago. Field Mus. Nat.

Hist., Zool. Ser. 13(7), 531 p.

1935. Cataloque of the birds of the Americas and the adjacent islands. Chicago. Field Nius. Nat. Hist., Zool. Ser. 13(8), 541 p.

1938. Catalopue of the birds of the Anericas and the adjacent islands. Chicago. Field Mus. Nat. Hist., Zool. Ser. 13(11), 662 p.

HELIMAYR, C. E., AND BOARDMAN CONOVER.

1942. Catalopue of the birds of the Americas and the adjacent islands. Chicago. Field Mus. Nat. Hist., Zool. Ser. 13(1), No. I, 636 p.

1949. Catalogue of the birds of the Americas and the adjacent islands. Chicago. Field Nius. Irat. Hist, , Zool. Ser. 13(1), No. 4, 358 p.

HOLDRIDGE, L, R.

1947. Determination of world plant formations from simple climatic data. science 105: 367-368.

HOW BII, T. R.

1957. Birds of a second-growth rain forest area of Nicaragua. Condor 59: 73-111.

IANCAS'TER, D. A.

1960. Behavior of Boucard's Tinamou, Crypturellus boucardi, in the breeding season. Unpublished Ph.D. Thesis. Louisiana State Univ. 151 p. 
LANT2, D. E.

1899. A list of biras collected by Col. N. S. Goss in Mexico and Central America. Trans. Karsas Acad. Sci. 16: 218-224.

LIHCOLN, F. C.

1928. Banded Fintail recovered in British Honduras. Condor 30: 359 .

1936. Returns of banded biras. Bird-bandite 7: 139-148.

LOWEIY, G. H., AND W. W. DAL GUEST.

1951. Birds from the state of Véracruz, Mexico. Univ. Kansas tub1., Nus. Nat. Hist. 3: 531-649.

LUNDEIL, C. I.

1940. The 1936 Michioan-Carnegie botanical expedition to British Honduras. Carnegie Inst. Washington Publ. 522: 1-57.

liATHLNS, G. M.

1912. Birds of Australia. Vol. 2. Witherby and Co., Iondon.

MIILER, A. H. , HERBERT FRIEDHANI, IULLOW GRISCOM, AND R. T. MOORE.

1957. Distributional check-list of the birds of Mexico. Pacific Coast Avifauna 33, $436 \mathrm{p}$.

MOORE, T. J.

1859. Iist of mammals and birds collected by Mr. Joseph Leyland in Honduras, Belize, and Guatemala. Proc. Zool. Soc. Iondon 27: 50-65.

MURIE, ADOLF.

1935. Manmals from Guatemala and British Honduras. Misc. Fubl. Mus. Zool., Univ. Michigan, No. $26,30 \mathrm{p}$.

OATES, E. N.

1901. Catalogue of the collection of birds! eggs in the British Museum (Natural History). Vol. 1. London. $252 \mathrm{p}$.

OBERHOLSER, H. C.

1914. A monograph of the genus chordeiles Swainson, type of a new family of goatsuckers. Bull. U. S. Nat. Mus. $60, \cdot 123 \mathrm{p}$.

OGILVIE-GRANT, W. R.

1892. Catalogue of the birds in the British Iuseum, by R. B. Sharpe and $W$. R. Ogilvie-Grant. Vol. 17. London. $522 \mathrm{p}$. 
1893. Catalogue of the birds in the British Museum. Vol. 22े. London. $585 \mathrm{p}$.

1898. Catalogue of the birds of the British viuseum, by R. B. Sharpe and $W$. R. Ogilvie-Grant. Vol. 26. London. $687 \mathrm{p}$.

PAYNTER, R. A., JR.

1954. Three new birds from the Yucatán Peninsula. Yale Peabody Mus., Postilla, No. 18, 4 p.

1955. The ornithogeography of the Yucatán Peninsula. Peabody Mus. Bull. 9, 347 p.

1957a. Biological investigations in the Selva Lacandona, Chiapas, Mexico. Bull. Mus. Comp. Zoöl. 116: 191-298.

1957b. Rough-winged Swallows of the race stuarti in Chiapas and British Honduras. Condor 57: $212-213$.

FAYNTER, R. A., JR., AND CHARIES VAURIE.

1960. Family Troglodytidae, p. 379-440. In Ernst Mayr and J.C. Greenway, Jr., [ed.], Checklist of the birds of the world. Vol. 9. Mus. Comp. Zoöl., Cambriage, Mass.

PECK, M. E.

1908. Protective adaptations in the nesting habits of some Central American birds. Froc. Iowa Acad. Sci. 15: 177-182.

1910. The effects of natural enemies on the nesting habits of some British Honduras birds. Condor 12: $53-60$.

1921. On the acorn storing habit of certain woodpeckers. Condor 23: 131 .

PEIERS，J. L.

1929. An ornithological survey in the Caribbean lowlands of Honduras. Bull. Mus. Comp. Zoöl. 69 : $397-478$.

RAIN , A. L.

1960. Races of the Short-tailed Hawk, Buteo brachyurus. Auk 77: 448-459.

RIDGWAY, ROPERT.

1911. Birds of North and Middle America. Bull. U. S. Nat. Mus. 50(5), $859 \mathrm{p}$.

1912. Color standards and color nomenclature. Fubl. by author. Wastington. 44 p. 53 color plates.

1916. Birds of North and Middle America. Bull. U. S. Nat. Mus. $50(7), 543 \mathrm{p}$.

ROGERS, C. H.

1939. The swifts of Panama. Auk 56: 81-83. 
SALVADORI, TOMIVASO.

1891. Catalogue of the biras in the Britisn Huseum. Vol. 20. London. $658 \mathrm{p}$.

1893. Catalogue of the birds in the British Viuseum. Vol. 21. London. $676 \mathrm{p}$.

SALVIL, OSBERT.

1864. A fortuight anongst the sea-birds of British Honduras. Ibis 6: 372-387.

1866. A further contribution to the ornithology of Guatemala. Ibis 8: 188-206.

1889. A list of the birds of the islands of the coast of Yucatan and the Bay of Honduras. Itis Ser. $6,1: 35,-379$.

1892. Catalorue of the birds in the Fritish Museum, by Osbert Salvin and Ernst Hartert. Vol. 16.

SALVIA, OSBTRT, AND F'. D. GODMAH.

1870-1904 Biologia Centrali-Americana. Aves. Taylor and francis, London. 3 vols. of text issued in 74 dated parts. Vol. 1, 512 p. Vol. 2, $598 \mathrm{p}$. Vol. 3, $510 \mathrm{p}$.

SAIVIN, OSBERT, AND P. L. SCLATER.

1860. Contributions to the ornitholosy of Guatemala. Ibis : $396-402$.

SAUNDERS, HOWARD.

1896. Catalogue of the birds in the British Museum, by Howard Saunders and Osbert Salvin. Vol.

25. Iondon. $475 \mathrm{p}$.

SCIATER, Y. L.

1886. Catalogue of the birds in the British Wuseum. Vol. II. london. $431 \mathrm{p}$.

1888. Catalogue of the birds in the British Huseum. Vol. 1.4. London. $494 \mathrm{p}$.

1890. Catalogue of the birds in the British Museum. Vol. 15. London. $371 \mathrm{p}$.

1891. Catalogue of the birds in the British Museum, by P. L. Sclater and G. E. Shelley. Vol. 19. London. $484 \mathrm{p}$.

SCLATER, P. L., AND OSBERT SAIVIN.

1859. On the ornithology of Central America. Iois: $1-22,117-138,213-234$.

1868. Synopsis of the American rails (Rallidae). Proc. Zool. Soc. Loridon: 442-470.

SELANDER, R. K.

1959. Polymorphism in viexican brown jays. Auk 76: 385-417. 
SHARFE, R. B.

1835. Catalopue of the birds in the British Museum. Vol. 10. London. $682 \mathrm{p}$.

1892. Catalogue of the birds in the. British Museum, by R. B. Sharpe and H. R. Orilvie-Grant. Vol. 17. London. $871 \mathrm{p}$.

1894. Catalowue of the birds in the British Miseum. Vol. 23. liondon. $353 \mathrm{p}$.

1896. Catalogue of the birds in the trritz:h Miseum. Vol. 24. London. $794 \mathrm{p}$.

1898. Catalogue of the birds in the British ivuseum, by R. B. Sharpe and W. R. Ogilvie-Grant. Vol. 26. $687 \mathrm{p}$.

SHELIEY, G. H.

1891. Cataloove of the birds in the British Museum, by 5 . I. Sclater and. G. E. Shelley. Vol. 19. London: $484 \mathrm{p}$.

SKUTCH, A. F.

1954. Life histories of Central American birds. 1. Frineililidae to Coerebidae. Pacific Coast Avifauna $31,448 \mathrm{p}$.

1960. Iife histories of Central American birds. 2. Vireonidae to Tyrannidae. racific Coast Avifauna $34,593 \mathrm{p}$.

SLUD, PAUI.

1960. The birds of Finca "La Selva," Coasta Rica: a Tropical Wet Forest locality. Bull. Amer. Mus. Nat. Hist. 121: 49-143.

STANDLEY, F. C., AND 3. J. RECORD.

1936. The forests and flora of Britisn Horiduras. Chicago. Field Mus. Nat. Hist., Bot. Ser. $12(350), 432 \mathrm{p}$.

STORER, R. W.

1961. Two collections of birds from Campeche, Mexico. Occas. Papers Mus. Zool., Univ. Michigan, No. 621, 20 p.

THAYER, J. E.

1906. Nests and efgs of the Beardless Flycatcher. Auk 23: 460-461.

THOMAS, G. E.

1908. The Mexican Elack Hawk. Condor 10: 116-118.

TODD, W. E. C.

1923. Arrevision of the gerus Cyanocompsa. Auk 60: 58-69. 
1942. List of the hummingbirds in the collection of the Carregie Mus. Ann. Carregie Mus. 29: $271-370$.

1943. Critical remarks on the toucans. Proc. Biol. Soc. Washington 56: 153-162.

VAN ROSSEMY A. J.

1934. Critical notes on Hidale American birds. Bull. Mus. Comp. Zoöl. 77: 387-490.

1938a. Notes on some Mexican and Central American wrers of the genere Heleodytes etc. Bull. British Orn. Club. 59: 10-15.

1938b. Descriptions of 21 new races of Fringillidae and Icteridae from Mexico and Guatemala. Bull. British Orn. Club 415: 124-138.

VAN TYNE, JOSSEIYM.

1933. A new Solitary Vireo from British Honduras. Occas. Fapers Mus. Zool., Univ. Michigar, No. 256,2 p.

1935. The birds of northern Peten, Guatemala. Misc. Publ. Mus. Zool., Univ. Michigan, No. $27,46 \mathrm{p}$.

VERNER, JARED.

1959. Behavior of the lied-footed Booby. (Sula sula) in British Honouras. Unpublished H. S. Thesis. Louisiara State Univ. 91 p.

1961. Nesting activities of the Red-footed Booby in British Honduras. Auk 78: 573-594.

WEBSFER, J. D.

1959. A revision of the Botteri Sparrow. Condor 61: $136-146$.

1961. A revision of Grace's warbler. Auk 78: 554566 .

WEBSTER, J. D., AND R. T. ORR.

1958. Variation in the Great Horned Owls of Middle America. Auk 75: 134-142.

WETIVORE, ALEXANDER.

1943. The birds of southern Veracruz, Mexico. Proc. U. S. Nat. Mus. 93: 215-340.

1949. Geographical variation in the Anerican Redstart (Setophaga ruticilla ). Jour. Washington Acad. sci. 39: 137-139.

WILIIS, EDWIN.

1958. The foraging behavior of ant-tanagers in British Honduras. Unpublished M. S. Thesis. Louisiana State Univ. 93 p. 
1960a. A study of the foraging behavior of two species of ant-tanagers. Auk 77: 150-1.70.

1960b. Voice, courtship and territorial behavior of ant-tanagers in British Honduras. Condor $62: 73-87$.

- 1960c. Red-crowned Ant-Tanagers, Tawny-crowned Greenlets, and forest flocks. Wilson Bull. $72: 105-106$.

1961. A study of nesting ant-tanagers in Eritish Honduras. Condor 53: 479-503.

ZIMIMER, J. T.

1945. A new swift from Central and South America. Auk 62: 586-592. 


\section{AUTOBIOGRAPHY}

Stephen M. Russell was born on September 16, 1931, in Hot Springs, Arkansas. He graduated in 1953 from Virginia Polytechnic Institute in Blacksburg, Virginia, with the degree of Bachelor of Science in Biology. Since September 1958, he has been a member of the faculty at Louisiana State University in New Orleans. He became a candidate for the degree of Doctor of Philosophy in 1959. 


\section{EXAMINATION AND THESIS REPORT}

Candidate: Stephen lilims Russeli

Major Field: $\quad$ Zoology

Title of Thesis: A Distributional study of the Birds of British Honduras

Approved:

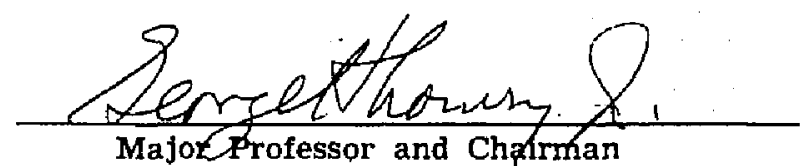
Majo Professor and Chpirman

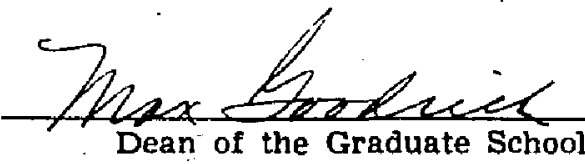

EXAMINING COMMITTEE:

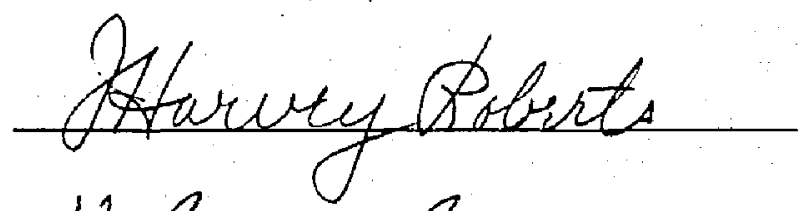
A1. Brme Bondreane
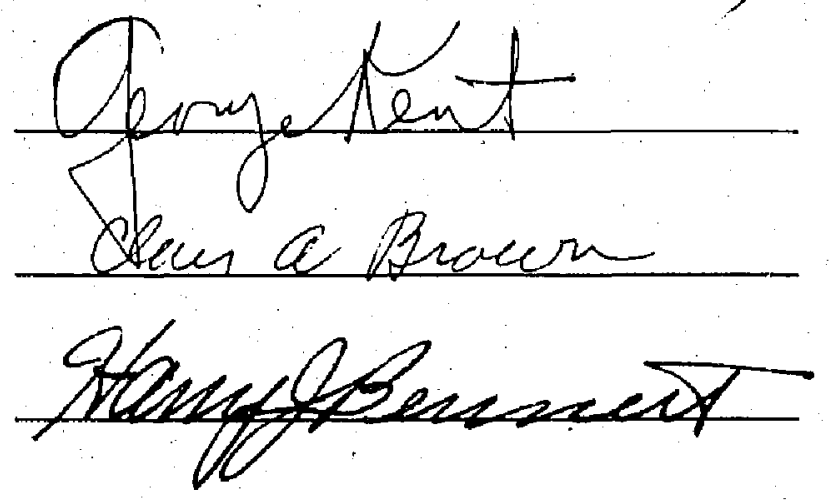

Date of Examination:

1) January 1962 